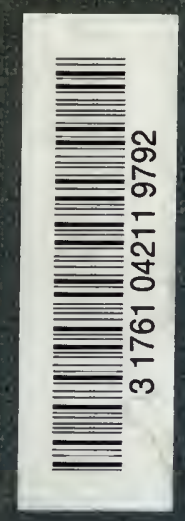

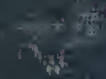

IWV of opguro Hisnogy 



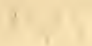


Digitized by the Internet Archive in 2007 with funding from Microsoft Corporation 
-

i 



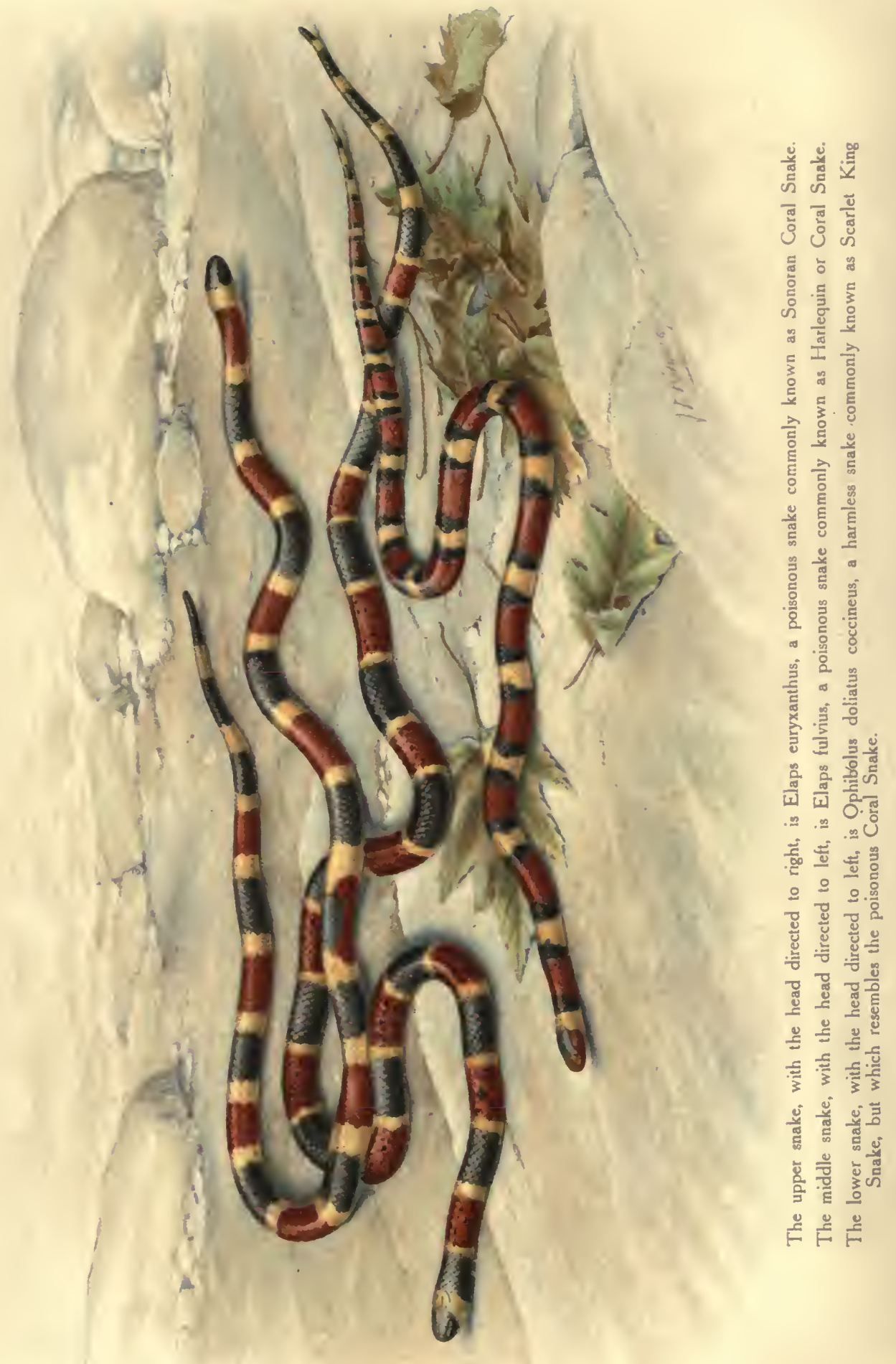




\section{AN INVESTIGATION OF VENOMOUS SNAKES}

WITH SPECIAL REFERENCE

TO

THE PHENOMENA OF THEIR VENOMS

BY

HIDEYO NOGUCHI, M.D., M.Sc.

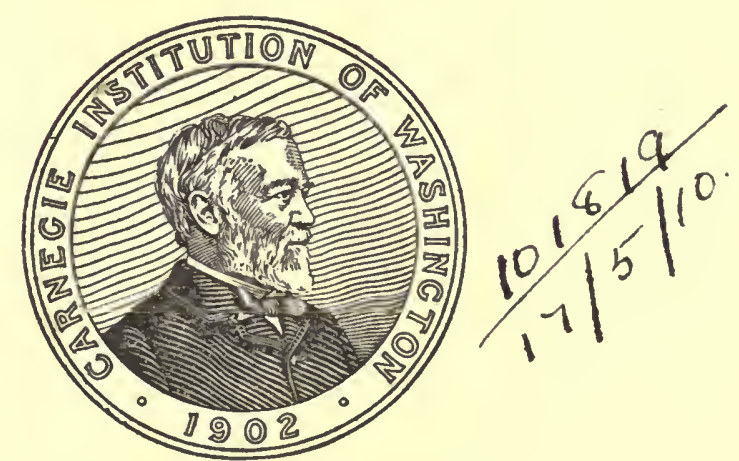

WASHINGTON, D. C.

Published by The Carnegie Institution of Washington 


\section{CARNEGIE INSTITUTION OF WASHINGTON}

Publication No. iII

Copies of this Book

were first issued

SEP 81909

The Plimpton Press Norwood Mass. US.A. 


\section{PREFACE.}

My interest in an opportunity to study the subject of snake venom I owe to certain peculiar and fortunate circumstances. After my graduation in medicine, I was for several years connected with the Institute for Infectious Diseases, in Tokio, where I came under the instruction of Professor Kitasato. In the autumn of the year I900 I became assistant in pathology at the University of Pennsylvania, where I remained until Professor Flexner resigned his post to assume the directorship of the laboratories of the Rockefeller Institute. It was soon after my arrival in Philadelphia that Dr. S. Weir Mitchell expressed his great desire that the scientific study of snake venom should be resumed and prosecuted along the lines of the new biological conceptions of toxication and immunity, which had become at that time so promising a field of pathological investigation. I had, therefore, the good fortune thus early to become associated in carrying out the studies (which extended over several years), relating to snake venom, which were issued from the pathological laboratory of the University of Pennsylvania. The expenditure involved in the execution of the researches of snake venom was met first by Dr. Mitchell himself, and later, chiefly through his recommendations, by means granted from the Bache Fund of the National Academy of Sciences and by specific grants from the Carnegie Institution of Washington.

During the several years of my connection with the University of Pennsylvania, I was the recipient of many courtesies from the other members of the staff of the Pathological Department, and from Provost Harrison, Dr. John Marshall, the professor of chemistry, and many others, to whom I wish to express my appreciation. In the interval between my leaving the University of Pennsylvania and resuming my connection with Professor Flexner at the Rockefeller Institute, I spent a year of study on snake venom at the Statens Serum Institute, in Copenhagen. The expenses incurred were defrayed by the Carnegie Institution of Washington. For the opportunity to continue my work in the Serum Institute I am indebted to Dr. Madsen, who has also placed me under many obligations by his constant aid and kindness. I am also indebted for many courtesies to Professor Salomonsen and to Dr. Walbum of the Institute.

The present monograph on snake venom was projected a number of years ago, and at first it was intended that it should be devoted to a collection of the studies on venom in which I was more or less directly concerned. The 
Carnegie Institution generously undertook to defray the expenses connected with the preparation and the publication of the monograph. However, as the work of preparation progressed, it seemed more desirable to present a fuller and more balanced exposition of the subject of venom than was at first proposed. No single work in the English language exists at this time which treats of the facts of zoological, anatomical, physiological, and pathological features of venomous snakes, with particular reference to the properties of their venoms. During the interval of the preparation of this monograph there appeared in French the excellent work on snake venom by Professor Calmette, which covers a part of the ground gone over in my monograph. I have availed myself of the opportunity offered by Professor Calmette's book to complete and improve my own. In this connection I desire to thank Professor Calmette for his generosity in supplying me with cobra venom on several occasions, and Dr. George Lamb also for liberal gifts of cobra and daboia venom. I am also indebted to Director William T. Hornaday, Dr. Raymond L. Ditmars, and Mr. E. R. Sanborn of the New York Zoological Park for permission to consult their collection of skulls and photographs of snakes and to reproduce certain of the specimens.

Finally, it is my very pleasant duty to acknowledge the great advantages which I have gained from the long connection with Dr. Flexner, and the many acts of friendship which he has shown me.

Hideyo Noguchi.

ROCEEFeller INSTItUte FOR MEdical Research. New York, November, I908. 


\section{CON'TEN'TS.}

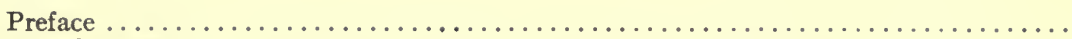

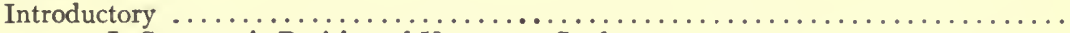

I. Systematic Position of Venomous Snakes.

II. Morphology of Venomous Snakes

Family Colubridx

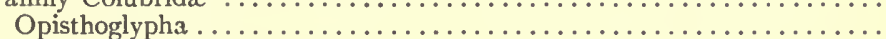

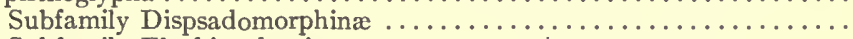

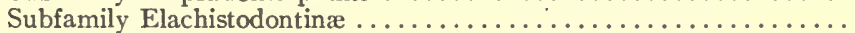

Subfamily Homalopsinæ . . . . . . . . . . . . . . . . . . .

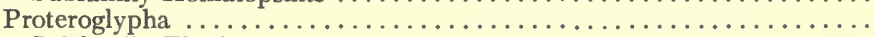

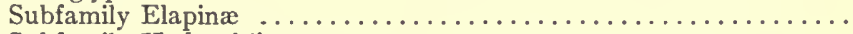

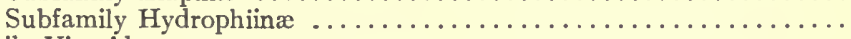

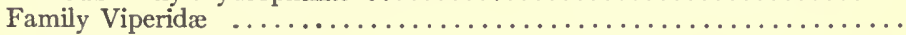

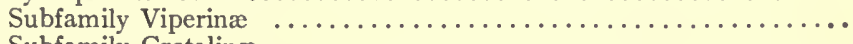

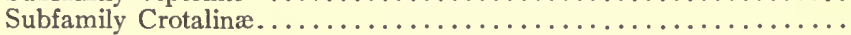

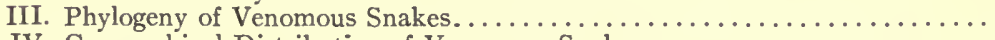

IV. Geographical Distribution of Venomous Snakes $\ldots \ldots \ldots \ldots \ldots \ldots \ldots \ldots$

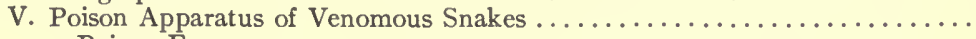

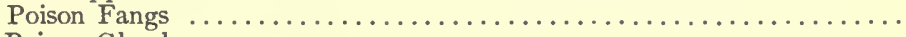

Poison Glands . . . . . . . . . . . . . . . . . . . . . . . . . . .

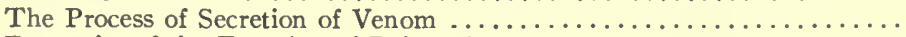

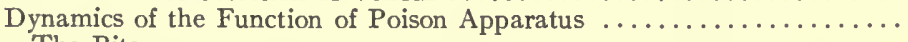

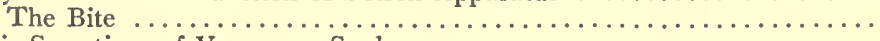

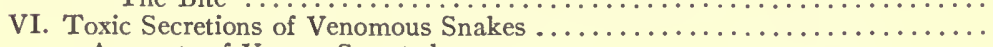

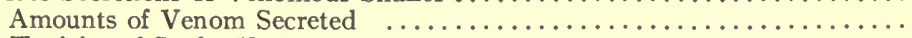

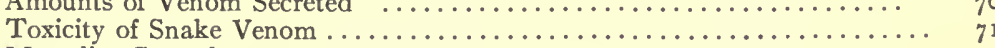

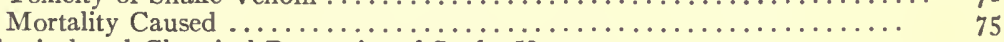

VII. Physical and Chemical Properties of Snake Venom............... 77-93

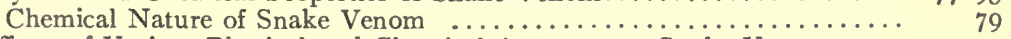

VIII. Effects of Various Physical and Chemical Agents upon Snake Venom ....

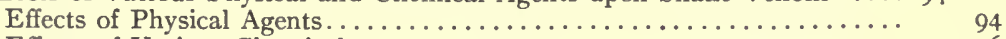

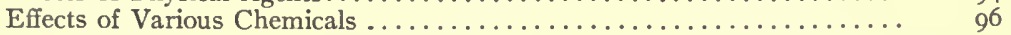

IX. Effects of Ferments upon Snake Venom ...................... I03-105

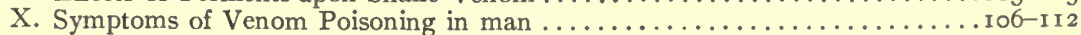

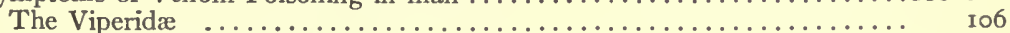

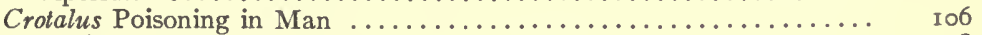

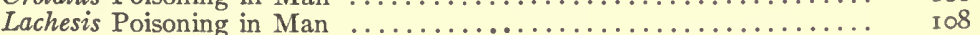

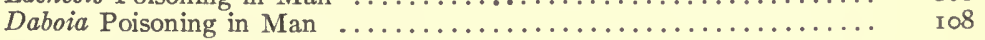

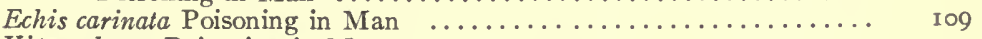

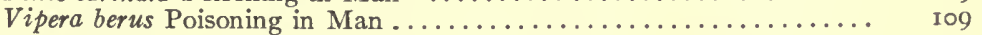

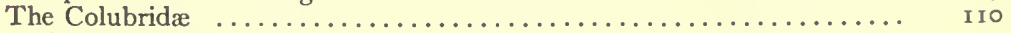

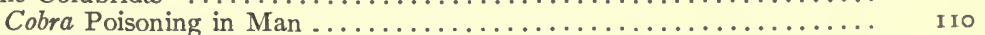

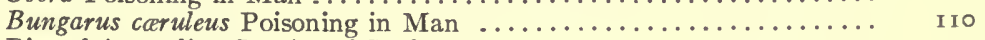

Bite of Australian Species of Snakes....................... I 10

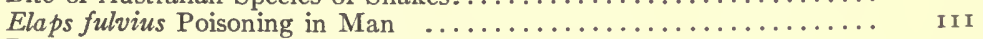

Post-mortem Examination............................. I I

Various Symptoms of Snake Poisoning Encountered in Man ......... I 2

XI. Experimental Venom Poisoning in Animals $\ldots \ldots \ldots \ldots \ldots \ldots \ldots \ldots \ldots \ldots \ldots$

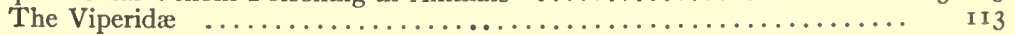

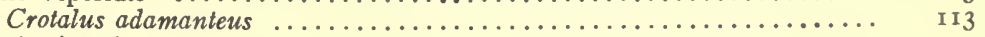

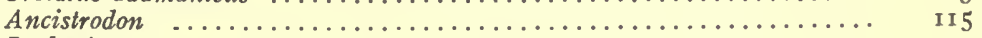

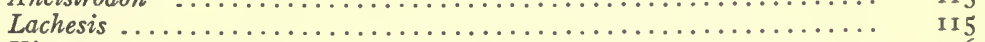

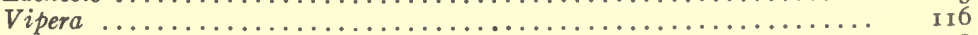

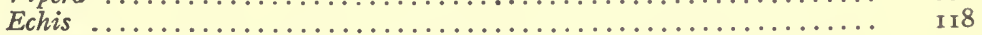

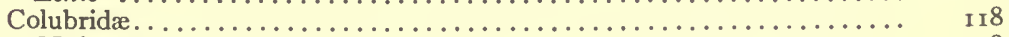

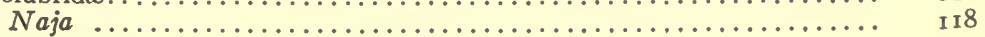


$\begin{array}{ll}\text { Page. } & \text { Pa. }\end{array}$

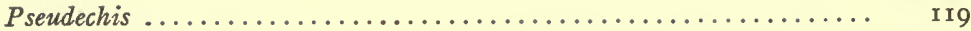

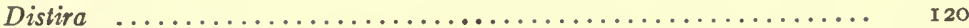

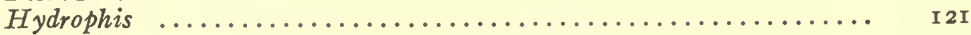

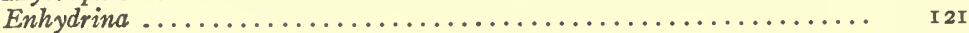

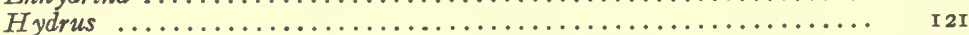

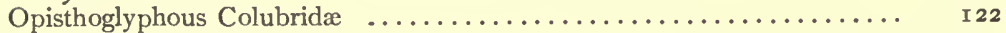

XII. Effect of Snake Venom upon the Nervous System and Effect of the Sequelæ upon the Respiratory and Circulatory Functions ....... I24-132

Crotalinæ.................................. I 24

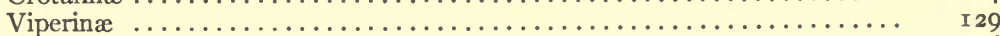

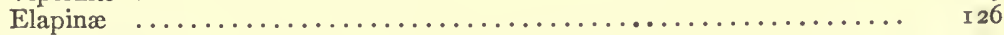

Hydrophiinæ ............................... I 3 I

XIII. Effects of Snake Venom upon the Coagulability of the Blood ......... I33-I42

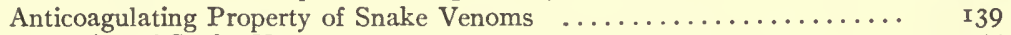

XIV. Neurotoxins of Snake Venom ........................... 143-1 55

Histological Changes Caused by Neurotoxins of Snake Venom........ I 50

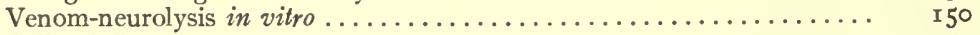

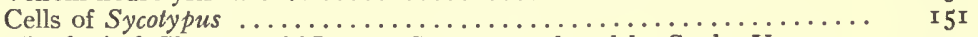

Histological Changes of Nervous System Produced by Snake Venom .. I I 2

XV. Hæmorrhagins of Snake Venom $\ldots \ldots \ldots \ldots \ldots \ldots \ldots \ldots \ldots \ldots \ldots \ldots \ldots \ldots \ldots$

Histological changes caused by Venom Hæmorrhagins $\ldots \ldots \ldots \ldots \ldots \ldots$ r6

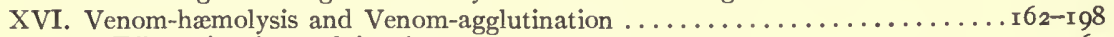

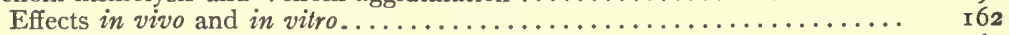

The New Era of the Study of Venom Hæmolysis .............. r69

Mechanism of Venom Hæmolysis .......................... 185

Antihæmolytic Properties of Cholesterin.................. I94

XVII. Cytolysins in Snake Venom . . . . . . . . . . . . . . . . . . . . . . 199-205

Effect of Venom on Cells of Warm-blooded Animals ............ I99

Effect of Venom on Cells of Cold-blooded Animals ............. 201

Cytolytic Action of Snake Venom on Micro-organisms ............ 205

XVIII. Histological Changes produced by Snake Venom on various Organs and

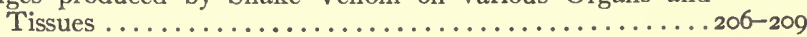

Action of Snake Venom upon the Liver..................... 207

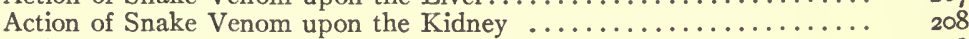

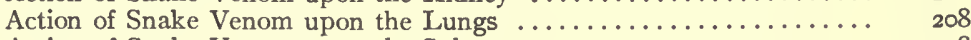

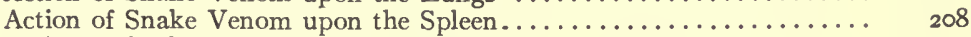

Action of Snake Venom upon the Heart................... 209

Action of Snake Venom upon the Muscles ................. 209

XIX. Ferments in Snake Venom .......................... 210

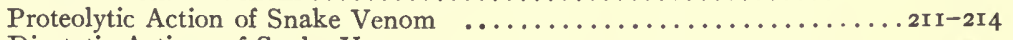

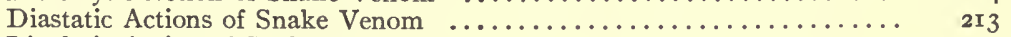

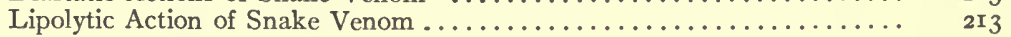

XX. Antibactericidal Properties of Snake Venom $\ldots \ldots \ldots \ldots \ldots \ldots \ldots \ldots \ldots 5^{-218}$

XXI. Toxicity of the Tissues of Venomous Snakes .................. 2 r9

XXII. Effects of Snake Venom on Mucous, Conjunctival, and Serous Membranes and Alimentary Tract ...................220. 222

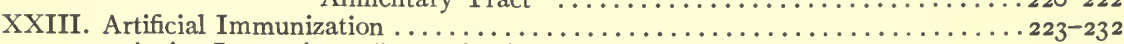

Active Immunity - Prophylactic Inoculation $\ldots \ldots \ldots \ldots \ldots \ldots \ldots \ldots . \ldots \ldots$

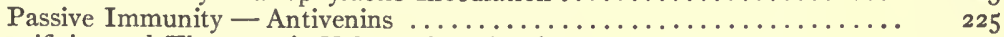

XXIV. Specificity and Therapeutic Values of Antivenins $\ldots \ldots \ldots \ldots \ldots \ldots \ldots \ldots . \ldots \ldots 233^{-245}$

Specificity of Antivenins as a whole ........................ 233

Specificity of Antivenins due to differences in the characteristic toxic principles of the venom of each species .........................

Specificity of Antivenins due to differences in individual cytotropic toxins

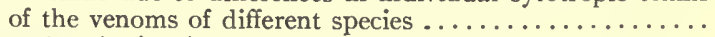

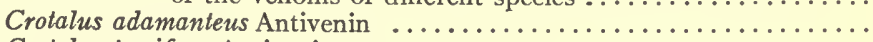

Crotalus terrificus Antivenin . . . . . . . . . . . . . . . . . . . . .

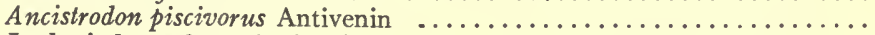

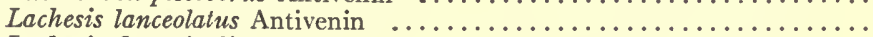

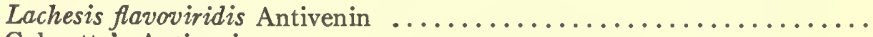

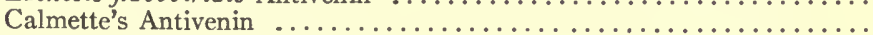

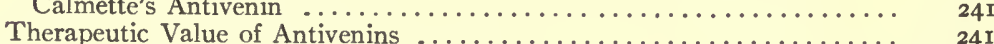

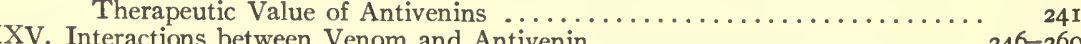

Establishment of the Chemical Nature of Venom-antivenin Reaction ....

Regeneration of Venom and Antivenin from their Neutral Combination ... . 248 
The Ehrlich-Madsen partial Saturation Phenomenon in Venom-antivenin

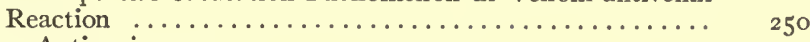

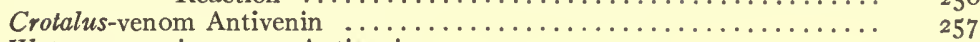

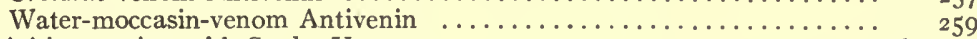

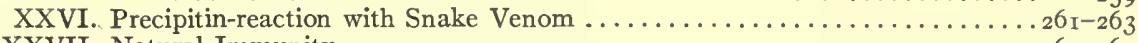

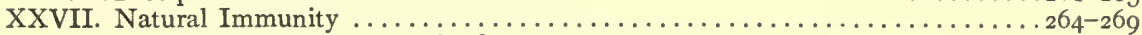

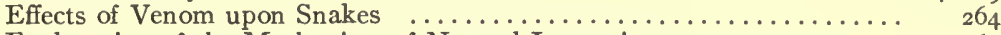

Explanation of the Mechanism of Natural Immunity ............. ${ }_{2} 65$

Natural Immunity of Certain Animals from Snake Venom.......... 268

XXVIII. Effects of Snake Venom upon the Blood of Cold-blooded Animals and upon

the Nerve Cells, Nerve Fibers, Ova, and Spermatozoa...270-284

Action of Snake Venom upon Cold-blooded Animals ............ $27 \mathrm{r}$

Effects of Snake Venom upon the Blood Corpuscles of Cold-blooded Ani-

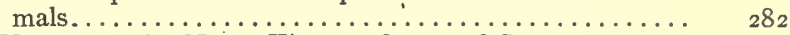

Effects of Snake Venom on the Nerve Tissues, Ova, and Spermatozoa .. ${ }_{284}$

XXIX. Effects of Snake Venom upon Plants and the Process of Germination of

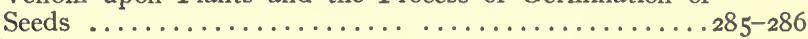

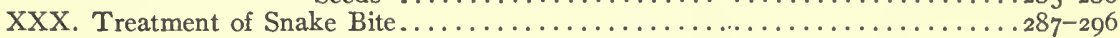

Non-specific Treatment. Immediate Ligature and Dissection ......... 287

Local Treatment ...................................... ${ }_{28} 88$

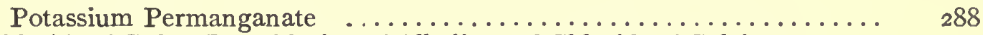

Chloride of Gold, Hypochlorites of Alkalies and Chloride of Calcium...... 29r

General Medicamentation ............................ 291

Certain alleged Antidotes for Snake Poisoning $\ldots \ldots \ldots \ldots \ldots \ldots \ldots . \ldots . \ldots . \ldots$

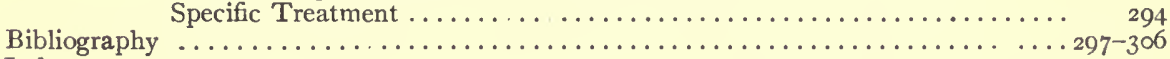

Index ............................................ 



\section{LIST OF PLATES.}

Frontispiece. Elaps euryxanthus, Elaps fulvius, and Ophibolus doliatus............ Title

Plate I. A, B, C, Skull of Homalopsis buccata. D, E, Skull of Distira stokesii......... Io

2. A, Skulls of a Harmless Snake and of a Boa Constrictor. B, Skull of Naja bungarus. C, Skull and Skeleton of Naja tripudians............

3. A, B, C, Skull of Naja tripudians. D, E, Skull of Bungarus candidus.......

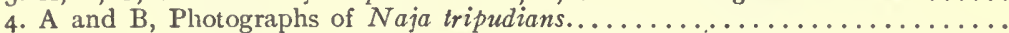

5. A and B, Photographs of Head of Naja bungarus (King Cobra), C, Photo-

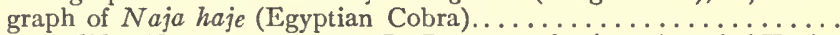

6. A, Bungarus candidus (Common Krait). B, Bungarus fasciatus (Banded Krait).

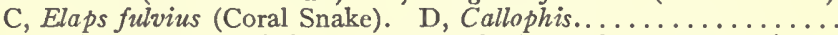

7. A, B, C, Skull of Glyphodon tristis. D, E, F, Skull of Elaps marcgravi.....

8. A, Pseudechis porphyriacus. B, Notechis scutatus. C, Acanthophis.........

9. A, Distira cyanocincta. B, Enhydrina valakadien. C, Hydrus platurus......

I0. A and B, Hydrophis. C, Enhydris curtus. D, Platurus laticaudatus. .........

II. A, B, C, Skull of $H y d r u s$ platurus. D, E, Skull of Platurus colubrinus.........

12. A, Vipera berus. B, Cerastes cormutus. C, Cerastes vipera. D, Vipera rus-

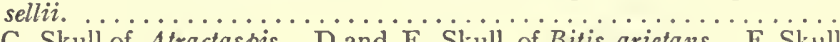

13. A, B, and C, Skull of Atractaspis. D and E, Skull of Bitis arietans. F, Skull

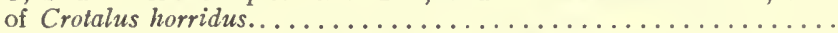

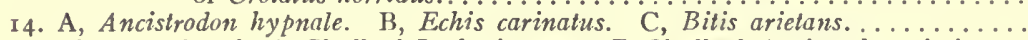

I5. Photographs of: A, Skull of Lachesis mutus; B, Skull of Ancistrodon piscivorus; C, Skull of Ancistrodon contortrix; D, Skull of Crotalus adaman-

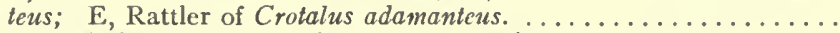

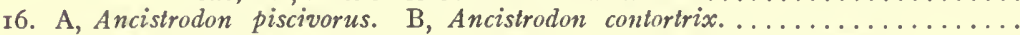

I7. A, Lachesis mutus. B, Lachesis flavomaculatus. C, Lachesis gramineus. $\quad \mathrm{D}, \mathrm{La}$ -

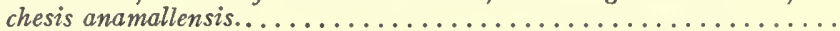

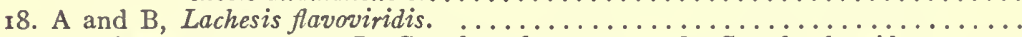

I9. A, Sistrurus catenatus. B, Crotalus adamanteus. C, Crotalus horridus .......

20. Venom gland of Crotalus adamanteus: A, Longitudinal section; B, Crosssection, showing Tubular Raminous Structure; C, Cross-section; D, Portion of Tabular Acinus, showing Columnar Epithelial Cells with Nuclei near Base of Cell Body......................

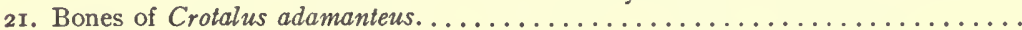

22. Musculature of the Poison Apparatus, Head of Ancistrodon piscivorus.........

23. A, Normal Preœsophageal Ganglia of Sycotypus canaliculatus. B, The Ganglia

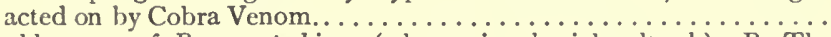

24. A, Medulla oblongata of Rana catesbiana (4 hours in physiol. salt sol.) B, The same, kept 2 hours in Cobra Venom solution. C, The same, kept

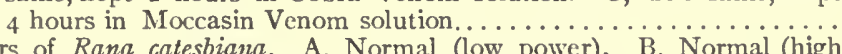

25. Nerve fibers of Rana catesbiana. A, Normal (low power). B, Normal (high power). C, Acted on by Cobra Venom for 2 hours (low power). D,

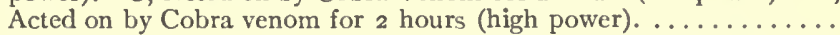

26. A, Hæmorrhages from Capillary and Small Vessels of the mesenterial membrane of Rabbit, under the influence of the venom of Crotalus adamanteus. B, Hæmorrhagic and Softening Effects of the venom of Crotalus adamanteus upon $\mathrm{M}$. pectoralis of Pigeon .............

27. A, Hæmorrhage caused by venom of Crotalus adamanteus on the mesentery of Guinea-pig. Showing one larger and two smaller ruptures of Capillary Vessel. B, Hæmorrhage caused by venom of Crotalus adamanteus on the mesentery of Rabbit. Showing defect of Capillary Vessel wall caused by disappearance of an Endothelial Cell. C. Hæmorrhage in mesentery caused by Crotalus Venom in Rabbit ........

28. Effect on White and Red Corpuscles of Rabbit. A, Normal rabbit blood; 5 minutes at $37^{\circ} \mathrm{C}$. B, Normal; 24 hours in normal saline at $37^{\circ} \mathrm{C}$. $\mathrm{C}$, Crotalus Venom, 0.5 per cent; 6 hours at $37^{\circ} \mathrm{C} . \ldots \ldots \ldots .$. 
Plate 29. Effect on White and Red Corpuscles of Rabbit: A, Crotalus Venom, 0.5 per cent; 24 hours at $37^{\circ} \mathrm{C}$. B, Cobra Venom, 0.5 per cent 5 minutes at $37^{\circ}$ C. C, Cobra Venom, 0.5 per cent; 20 minutes at $37^{\circ} \mathrm{C} \ldots \ldots \ldots$. I 70

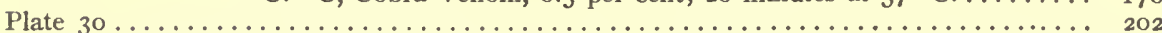

Figs. I to 4. Eggs of Arbacia punctulata: I, Normal. 2 to 4, Different stages of Ovolysis caused by I per cent Cobra Venom in sea-water.

Figs. 5 to 8. Eggs of Lepidonatus squamatus: 5, Normal. 6 and 7, Different stages of Ovolysis caused by I per cent Cobra and 2 per cent Crotalus Venom, showing no real Ovolysis, but peculiar Retraction of Deutoplasm.

Figs. 9 to I I. Pluteus stage of Arbacia punctulata: 9, Normal, active pluteus. Io, Pluteus under the effect of 2 per cent Cobra Venom. II, Disintegration under the effect of same venom.

31. Ovolysis, Eggs of Asteria vulgaris: I, Normal unfertilized egg. 2, Action of I per cent Cobra or 2 per cent Moccasin Venom. 3, Result of complete Ovolysis by these venoms in 6 hours. 4, Action of 2 per cent Crotalus Venom in 6 hours. 5, Normal egg with polar body formation. 6, Ovolysis by venom. 7 to 15 , Ovolytic effects of venom

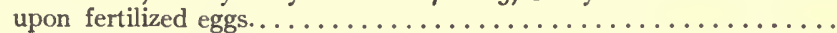

32. A, Young Agar Culture of Bacillus anthracis. $\ddot{B}, \ddot{C}$, and $\ddot{D}$, Young Cultures

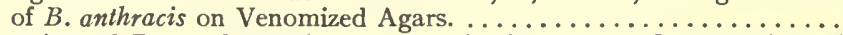

33. A, Cross-section of Pectoral Muscle of Normal Pigeon. B, Cross-section of Pectoral Muscle of Pigeon which died from effect of venom of Crotalus adamanteus. C, Longitudinal section of Pectoral Muscle of Pigeon which died of Crotalus Venom poisoning. D, Cross-section of Normal Muscle of Thigh of Frog. E, Cross-section of Venomized Muscle of Thigh of Frog. 


\section{INTRODUCTORY.}

At a certain stage of the evolution of our modern knowledge of snake venom the action of the venom was attributed to the presence of microscopical animalcules in the poison. According to this theory the animalcules, introduced through the bite of the snake, multiply rapidly and bring about death. Dr. S. Weir Mitchell first disproved this hypothesis through the experimental basis and established the chemical nature of the fatal principles of snake venom. Lucien Bonaparte recognized a little earlier the protein nature of the venom and called the toxic constituent echidnin, while Dr. Mitchell gave the term crotaline to the active principles of rattlesnake venom. While Bonaparte failed to overthrow the germ theory, Mitchell succeeded in doing so, and finally, in his further pursuit of the subject, so thoroughly cleared up the chemistry of snake poisons that the analysis made by him and his associate Reichert, in I886, stands to-day with but little modification by later investigators. The exhaustive and extensive investigations of Mitchell and Reichert taught us that snake venom is no simple substance, but consists of several different active principles, each with its characteristic properties; that these toxic principles are of a proteid nature and can be separated into three main groups: globulins, venom peptone, and venom albumen, the latter being without poisonous property.

While the work above referred to revealed for the first time the complex nature of snake venom, a little over a score of years has since passed and in the meanwhile our knowledge of venom has greatly increased, especially through the influence of biological methods of study.

While Mitchell, Fayrer, Brunton, Lacerda, Calmette, and others were actively engaged with the researches upon venom, modern microbiology was inaugurated by Pasteur and Robert Koch, and through the efforts of their followers immunology and toxinology have been instituted.

Ehrlich, Behring, Roux, Kitasato, Brieger, Metchnikoff, and their pupils have demonstrated by their investigations the existence of a group of substances whose characteristics are thermolability, chemiolability, toxicity and unknown chemical constitution, and, above all, their capability to stimulate in the animal body the formation of specific antisubstances. These substances are known as toxins and are elaborated by the activity of animal as well as plant cells. Bacteria often produce powerful toxins, but many toxin-like substances are produced in the higher plants. Thus, Rudolph Kobert and his pupils, notably Stillmark, studied carefully the properties of the active toxic principle, ricin, of the castor bean, Ricinus communis. The 
protein nature of ricin and abrin, another toxic principle from the jaquirity bean, was then established. Flexner, who made the most minute pathological study on these phytalbumins, called attention to the close resemblance between some forms of toxalbumoids and snake-venom poisonings. Ehrlich finally succeeded in preparing antiricin and antiabrin serums by immunization, and confirmed their toxin-like nature.

Strong evidences exist, however, that it is possible to separate pure toxic agents from the protein molecules to which they attach. The work of $\mathrm{L}$. Mendel approaches this end, while peptic digestion has been shown by M. Jacoby to remove much of the protein with the toxicity well preserved.

Turning our attention now to the toxin-like products of animal origin, we find that suitable examples are not lacking. Thus, many insects, worms, fishes, amphibia, reptilia, and even mammalia are provided with glands that secrete toxin-like principles of varying power. As proven by Calmette, Phisalix and Bertrand, Fraser, and others nearly twelve years ago, snake venom is placed among toxalbumoids by its apparent protein nature and capability of antitoxin formation. To the category of toxins we may assign various ferments, inasmuch as both are labile and antitoxin or antiferment forming in the alien animal body, and having the antigenous property. It may not be out of place, therefore, to make a brief comparison among the physiological products elaborated by the specified cell groups and snake venom.

Of all physiological products elaborated by diverse groups of specified cells of animal body none is so complex as the venom of serpents. Any glandular secretion is more or less polytropic in its action, but the secretion of the poison gland of snakes takes the first rank in polytropism. It is well known that the gastric juice contains at least three active ferments, namely, pepsin, rennet, and lipase, and in the pancreatic secretion there are trypsin and lipase. In the saliva we find pthyalin. In the leucocytes, as shown by the interesting work of Opie, there are two kinds of proteolytic ferments and one fibrin ferment. The multiplicity of these active principles becomes, however, almost insignificant when compared with snake venom. This particular product is found to be a remarkable polytropic one, and to-day we recognize in it a large number of constituents which impart to the venom the powers of proteolysis, lipolysis, plasma coagulation, and, above all, of dissolving the nerve cells, blood cells, endothelia, liver cells, kidney cells, testicle cells, egg cells, spermatozoa, protozoa, bacteria, and muscle fibers. In short, snake venom contains (besides proteolytic ferments, lipase, and fibrin ferments) a group of cytolysins of extreme activity, and, indeed, upon these cytotoxins depend the lethal properties of nearly all kinds of snake venom. The venom fibrin ferment has also been identified with the lethal principle of certain viperine or colubrine venoms.

Besides these directly injurious agents, venom contains a certain principle which destroys the bactericidal property of the normal blood and causes eventual secondary septicemic infection. That these cytolytic properties of snake venom have nothing to do with the proteolytic or lipolytic ferments 
in an ordinary sense has been conclusively proven by various experiments. In fact, the majority of venom cytolysins are thermostabile in contradistinction to the ordinary ferments and are of immense activity, while pepsin or trypsin has but little cytolytic property upon the cells freshly taken out of a living animal body. Thus, snake venom contains a set of toxic agents entirely different from the physiological ferments of other glands.

Do we, then, have a class of bodies whose mode of action is comparable with that of the venom cytotoxins? To this question we answer in the affirmative. The presence of cytolytic agents is by no means restricted to snake venom, but the phenomena of cytolysis have been constantly observed with normal and especially immune serums. The investigations of Landois, Buchner, Nuttall, Metchnikoff, Ehrlich, Morgenroth, Bail, Pettersson, Bordet, Dungern, Moxter, Schattenfroh, Gruber, Sachs, Landsteiner, Flexner, Noguchi, and others are sufficient to prove the wide occurrence of normal and immune cytolysins in the blood serum.

Through the classic works of Bordet, Erhlich, and Morgenroth the mechanism of cytolysis occasioned by normal or immune serums has been shown to be due to two constituents, which must cooperate to produce this effect. Serum cytolysins are specific, and the specificity has been shown to be caused by one of the constituents concerned in cytolysis and is capable of being increased through artificial immunization. This is Ehrlich's amboceptor and Bordet's substance sensibilisatrice. The second constituent taking part in cytolysis is increased with difficulty by the immunization and is present in all normal as well as immune serums. This is Ehrlich's complement and Bordet's alexine. Its function is to inflict injury upon the cells already treated with the specific ambocepter or substance sensibilisatrice.

What, then, is the relation between the mechanism of serum cytolysis and that of venom cytolysis? Many differences have been noted to exist in these two sets of cytolysis.

Flexner and Noguchi first demonstrated that venom cytolysis bears a general resemblance to serum cytolysis, as the mechanism of solution of cells is of a dual or complex nature, though this apparent parallelism has later been found to be only partial.

In venom cytolysis the complementary substances are sometimes inherent to the cell itself, thus setting forth examples never met in the case of serum cytolysis. The amboceptor or substance sensibilisatrice of snake venom is much more thermostabile than that of serum, and many amboceptors in venom retain their activity even after brief boiling.

While a finer analysis of serum cytolysis has become a matter of extreme difficulty and has added little to that which was brought out by the investigations of Ehrlich and Bordet several years ago, the nature of venom cytolysis has been much more profitably studied in recent years. It may be considered safe to say that our knowledge concerning the venom cytolysis has broken through the boundary of pure biological-physiological domain and is now wandering in the biochemical realm. This advance has been the fruit 
of the works of Flexner and Noguchi, Calmette, and Ehrlich, Kyes, and Sachs, but the new field was directly opened by the three investigators last named. Thus Preston Kyes, in part with Sachs, succeeded in Ehrlich's laboratory in preparing a compound of the hæmolytic principles of snake venom and lecithin, and the effect of this discovery on toxicology in general has been very important and far-reaching. The hremolytic compound, which was designated venom lecithid, is highly thermostabile and it differs from its original venom or lecithin in various physical and chemical properties. Although the lecithid formation represents one of the phases leading to the destruction of certain cells, there is no reason to assume that venom cytolysis in general is always produced in the same mechanism.

Quite recently Faust succeeded in obtaining from cobra venom a constituent of considerable toxic value with a chemical constitution falling to the group of glucosides. This he calls ophiotoxin and shows it to contain no nitrogen. Nothing so far has been mentioned as to its capability of forming its antibody in the animal body. While the hæmolytic constituent is completely separable from the neurotoxic by means of lecithid preparation, it is noteworthy that ophiotoxin acts not only upon the nervous system, but also upon the blood corpuscles, no complementing substance being required to produce hæmolysis.

Faust may be quite right in placing ophiotoxin in the group of sapotoxins, yet ophiotoxin is not shown to represent all the cytolytic principles characteristic of the native venom; hence we may not be justified in classifying the latter among these derivative substances.

It is quite interesting, however, that among the Amphibia some genera are provided with certain forms of venom-secreting glands. The amphibian venoms are not so complex in composition or behavior as the reptilian venoms. Thus the genus Bufo secretes from the dermal glands bufonin and bufotalin, both having definite chemical structure. The genus Salamandra also secretes from its skin-glands two alkaloids of known chemical composition, namely, salamandarin and salamandridin. Numerous fishes possess certain poison glands. The order Sauria seems to contain only one poisonous genus, Heloderma, which secretes a venom from the sublingual glands. Among the mammalia there is only one animal which is provided with a venomous gland and venom apparatus. This, Ornithorhynchus paradox, has in its hind legs a grooved spur connected through a long subcutaneous duct with a venom gland situated near the thigh. The action of its venom is described as resembling that of snake venom.

The phylogenic position of the poison gland of Ophidia has been cleared up through the exhaustive studies of Leydig, Duvernoy, Ranvier, Gracomini, Flemming, Cholodkowsky, Stannius, Meckel, and others. It corresponds with the glandula oris of the birds and the glandula parotida of the mammalians.

Histological and anatomical studies have revealed that the oral cavity of the Amphibia contains only mucous glands, while that of the Reptilia, besides 
the pure mucous, also contains a united gland of serous and mucous secretion. The venom-glands of the serpents belong to the mixed structure. This relation gradually passes to the opposite direction and finally all find in the parotid of the mammalia a pure serous gland.

The proportion of the mucous and serous parts of the venom-glands is quite variable, according to the kind of snake, but the serous portion, which occupies the rear of the gland, is much larger than the mucous-secreting front portion. The only secretory duct is provided for the serous or venomsecreting portion, while the front portion has several smaller ducts.

That the venomous serpents differ from the non-venomous kinds only by the presence of a specific poison-conducting fang in the upper jaw, but not by the presence or absence of the venom-gland, has been shown by Leydig, Duvernoy, Stannius, and others.

Phisalix, Bertrand, Jourdain, Alcock, Rogers, and others found that the innocuous serpents possess venom-glands of a primitive stage of evolution.

Having briefly defined the position among the physiological secretions, its polytropism, its biological place in zoological sense, its probable chemical composition, and the phylogenic views and facts on the venomous snakes in the system of nature, I propose to define snake venom in relation to immunity.

Since the monumental discovery of diphtheria antitoxin by Behring and Kitasato and of tetanus antitoxin by Kitasato in 1890 , the solution of the problems of immunity has been laid open to experimental investigations. With fluctuating success and failure, pharmacologically active and inactive biological products of almost every kind have been tried for the possible production of specific antibody. There have resulted Pfeiffer's bacteriolysin, Carbone-Belfanti's hæmolytic serum, Ehrlich's antiricin and antiabrin serums, and many other preparations of specific nature. Numerous attempts, some futile and some successful, have led to the conclusion that all alkaloids and similar simple substances of definite chemical constitution are not capable of producing their antibodies when injected into the animal bodies. Agglutinins, precipitins, and various antiferments have also been produced by means of injecting cells, proteins, or ferments, each highly specific to the antigen concerned.

It was found that bacterial toxins, various somatic cells and their constituents, phytotoxins, blood cells and ferments are responded to by the formation of their corresponding antisubstances, and that in each instance the interaction is specific.

Calmette, Phisalix and Bertrand, and somewhat later Fraser, have shown that the blood serum of the animal repeatedly inoculated with snake venom counteracts the action of the venom very effectively. This was done in I894, and extended by various investigators. Sewall was, however, the first (in I887) to show that the repeated inoculations of a snake venom into susceptible animals render the latter more resistant to the action of the same poison. 
The introduction of snake venom into the domain of immunity has been quite fruitful in obtaining various facts which served to increase our knowledge of the nature of immunization in general. On its practical side we all know that Calmette was the first to recommend his antivenin for the treatment of snake poisoning, and, despite much protest and dispute as to its value as a therapeutic, it has no doubt saved many victims from death. This assertion requires no advocate, because the antitoxic property of the antivenomous serum has long been established on the purely experimental basis, and this alone is enough to encourage the use of the antivenin in as large doses as practicable in all cases of snake bites.

Many lives must have perished through the minute excess of venom beyond the limit of human toleration, whereas the removal of that excess by the injection of a few vials of antivenin would have spared them from the grip of death. There are to-day at least several different specific antivenins that can be employed in combating snake bites. These are of comparatively feeble strength, yet we may reasonably expect some benefit from these preparations.

I do not believe that the limit of antitoxic units attainable by these immune serums has been reached, but I am convinced that in the future much more potential antivenins will be obtained through the employment of various methods and improvements in the modes of immunization.

The importance of a thorough consideration of the specificity of antivenomous serums was recognized in the earlier work of $\mathrm{C}$. J. Martin and the later investigations of George Lamb and also of the present writer. While Calmette once erred as to the specificity of antivenin - although not without possible grounds for his assumption - C. J. Martin keenly observed that the action of antivenin is specific in the sense that the physiological actions of the venom of different species of snake are the work of different constituents of each specimen; hence the antivenin capable of counteracting the lethal principle A fails or may fail against the lethal principle B or C of other venoms. Here Martin openly regards the venom as a polytropic poison and sees the necessity of securing a polytropic antitoxin. This line of thought is in perfect harmony with the early views of Mitchell and Reichert and the later treatise of Flexner and Noguchi.

The question of specificity did not, however, remain long without another and still more urgent modification - the question of individual specificity. Lamb and Noguchi investigated another problem, as to whether or not the individual toxic constituents of the venoms belonging to the different species are identical. That the physiological and pathological effects do not reliably indicate the principles that produce them, hence disclose no identity of the active agents, is well understood. But, when we come to deal with such substances as snake venoms - so closely related to each other both in action and origin - there is but little reason for one to doubt their complete identity. It is most extraordinary that the hæmolytic or neurotoxic or hæmorrhagic constituents of one kind of snake venom should differ from the similar constituents of another kind; yet this was found to be the case. In its infinite 
complexity snake venom takes the highest rank among the serum cytolysins. Through the exhaustive investigation of various biologists and pathologists we know how intricate the amboceptors and complements of various normal and immune serums are. Apparently, accepting the interpretation of Ehrlich, these molecules possess similar toxophore atom complex but different cytophilic groups. It is only by respecting this delicate specificity that we can accomplish the preparation of antivenins and employ them effectively. It may be superfluous to mention that the differentiation of these closely allied toxic principles was made possible through the immunization reactions only.

On the more theoretical side, snake venom has again been largely instrumental in defining the chemical nature of the interaction of the antigen and antibody. C. J. Martin and Cherry, later also Calmette (the former opponent to the chemical theory), and many others have contributed much to the establishment of the chemical nature of the action. Madsen and Noguchi found the reaction between snake venom and antivenin to be reversible and follow the law which Arrhenius and Madsen applied to other toxins and antitoxins.

The regeneration of the hæmolytic principle from the neutral mixture of venom and antivenin has been accomplished by Morgenroth by means of dilute acid. This discovery received confirmation from the recent work of Calmette and Massol.

Returning to the more familiar immunization phenomena a few words may be added as to the precipitin reaction of snake venom. Lamb and Flexner and Noguchi have demonstrated that the proteins contained in the venoms of different species of snake are not quite identical so far as the precipitin reactions with specific immune serums are concerned. Like other immune reactions this was found to be only relative.

As to the practical application of the facts gained by innumerable struggles and enormous labor, it must be admitted that the crop is not yet fully garnered, yet the study of venom has brought and is constantly bringing to science and humanity great benefits, of a direct and indirect character. 


\section{SNAKE VENOMS.}

AN INVESTIGATION OF VENOMOUS SNAKES WITH SPECIAL REFERENCE TO THE PHENOMENA OF THEIR VENOMS. 



\section{CHAPTER I.}

\section{SYSTEMATIC POSITION OF VENOMOUS SNAKES.}

The order Serpentes Linnæus ${ }^{1}$ or Ophidia Brongniart ${ }^{2}$ had experienced repeated reclassifications by systematists before it was brought into an intelligible and a logically conceived system, mainly by the labors of Oppel (I8II), Wagler (1830), J. Müller (I83I), Gray (I849), Duméril and Bibron (1852), Stannius (I856), Günther (I864), Cope (I864, I887, I.898), Boulenger (I896), and Stejneger (1895, 1907). From Linnæus to Oppel and Merrem the term was applied to a heterogeneous assemblage of various species, including the snake-like lizards and the batrachian Cœciliidæ. Laurenti (I768) added no improvement. Wagler eliminated improper members from Serpentes, while Müller divided it into two divisions, the Microstomata (= Angiostomata) and Macrostomata (= Eurystomata), basing them on the proportion and position of the paroccipital bone or suspensorium of the quadrate. Duméril and Bibron then divided the order according to the dental structures into Opoterodonta, Aglyphodonta, Opisthoglypha, Proteroglypha, and Solenoglypha. The first is angiostomatous and the last four eurystomatous. The Angiostomata were divided by Stannius into Typhlopina and Tortricina, and the Eurystomata into Peropoda (with rudiments of pelvis), Asinea, and Thanatophidia, the last including all of the venomous snakes. Gray created two suborders, the Colubrina and Viperina, while Günther distinguished between Ophidii colubriformes, O. colubriformes venenosi (Elapidæ and Hydrophidæ) and O. viperiformes. Cope laid stress upon the modification of the squamosal, ectopterygoid, and endopterygoid bones, the condition of the vestigial limbs, division or nondivision of the anal scutum, lungs, hemipenis, and also upon the grooved and non-grooved characters of the posterior teeth. In Cope's system the snakes are divided into several divisions, which stand above the rank of families in most of the classifications. Thus there are Catodonta, Epanodonta, Tortricina, Peropoda, Colubroidea, and Solenoglypha. The term Asinea of Stannius is employed by Cope to cover Peropoda and Colubroidea. Cope finally dropped the term Asinea and broadened Colubroidea superfamily by adding all members of Thanatophidia except the viperine snakes, and subdivided Colubroidea into Aglypha, Glyphodonta, and Proteroglypha. ${ }^{3}$ Peropoda was separated from Colubroidea entirely on account of the rudiments of pelvis. In other words, Cope's Colubroidea contains three or four eurystomatous families of Duméril and Bibron, leav-

1 Linnæus, Systema naturæ, Ioth ed., I 758 , I96, I, 214.

2 Brongniart, Bulletin, Academy of Sciences, I800, Nos. $35,36$.

3 Peropoda with rudiments of pelvis, and Platycerca containing Hydrophidæ, are added to this suborder Colubroidea in his latest work. 
ing out the Solenoglypha, which is also eurystomatous. Peropoda is not in Duméril's system, although a Eurystomata.

Finally, Boulenger succeeded in formulating a more natural and rational classification of these animals, which is accepted by most systematists as by far the best proposed. His phylogenetic system stands as follows:

5. Uropeltidæe<smiles></smiles>

I. Typhlopida
6. Xenopeltidæ

3. Boidæ
8. Amblycephalidx

7b.C. Proteroglypha

7. Colubridae Aglypha

I. No ectopterygoid; pterygoid not extending to quadrate or to mandible; no supratemporal (squamosal); prefrontal forming a suture with nasal; coronoid present; vestiges of pelvis................

Maxillary vertical, loosely attached, toothed; mandible edentulous; a

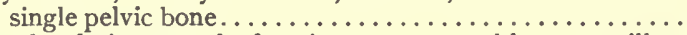

Typhlopida.

Maxillary bordering mouth, forming a suture with premaxillary, [prefrontal and frontal, toothless; lower jaw toothed; pubis and ischium present, latter forming a symphysis..........

Glauconiida.

II. Ectopterygoid present; both jaws toothed.

A. Coronoid present; prefrontal in contact with nasal.

r. Vestiges of hind limbs; supratemporal (squamosal) present.

Squamosal large, suspending quadrate $\ldots \ldots \ldots \ldots \ldots \ldots \ldots$

Squamosal small, intercalated in cranial wall ...............

2. No vestiges of limbs; squamosal absent $\ldots \ldots \ldots \ldots \ldots \ldots \ldots$

B. Coronoid absent; squamosal present.

r. Maxillary horizontal; pterygoid reaching quadrate or mandible.

Prefrontal bone in contact with nasal $\ldots . \ldots \ldots \ldots . . . .$.

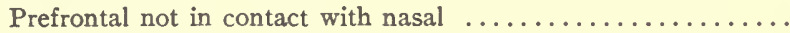

2. Maxillary horizontal; pterygoid not reaching quadrate or mandible .................................. Amblycephalida.

3. Maxillary vertically erectile, perpendicularly to ectopterygoid; pterygoid reaching quadrate or mandible........... .

Boida.

Ilysiida.

Uropeltida.

Xenopellida.

Colubrida.

Viperida.

Apart from these anatomical characters the following synopsis will serve better for ordinary practical purposes:

Typhlopide: Eyes vestigial; no teeth in lower jaw; without enlarged ventral scales.

Glauconiida: Eyes vestigial; teeth restricted to lower jaw; without enlarged ventral scales.

Uropeltida: Eyes very small; head not distinct; ventral scales scarcely enlarged; tail extremely short, ending obtusely and covered with peculiar scales.

Ilysiida: Eyes functional and free; claw-like spurs of vestiges of the hind limbs on each side of vent; ventral scales scarcely enlarged.

Boida: Eyes functional and free; claw-like spurs of vestiges of hind limbs on each side of vent; ventral scales transversely enlarged.

Xenopeltida: Eyes free; no vestiges of limbs or of their girdles; maxillary typical, horizontal, not separately movable, with a series of teeth; mandible toothed, but no coronoid bone. Dentary movably attached to tip of articular bone of mandible; skin beautifully iridescent.

Amblycephalida: Like the Xenopeltidæ, but ends of pterygoids free, not reaching the quadrates. No mental groove.

Colubrida: Like the Xenopeltidæ in main characters, but squamosal horizontally elongated and movable; pterygoid reaches the quadrate. Median longitudinal line between shields of chin.

Viperida: Eyes free; pair of poison fangs in front part of mouth, carried by the otherwise toothless, much shortened, and vertically erectile maxillaries. Ventral scales transversely enlarged. 
Thus the order Ophidia is represented in the following synopsis, the venomous snakes being given in italics:

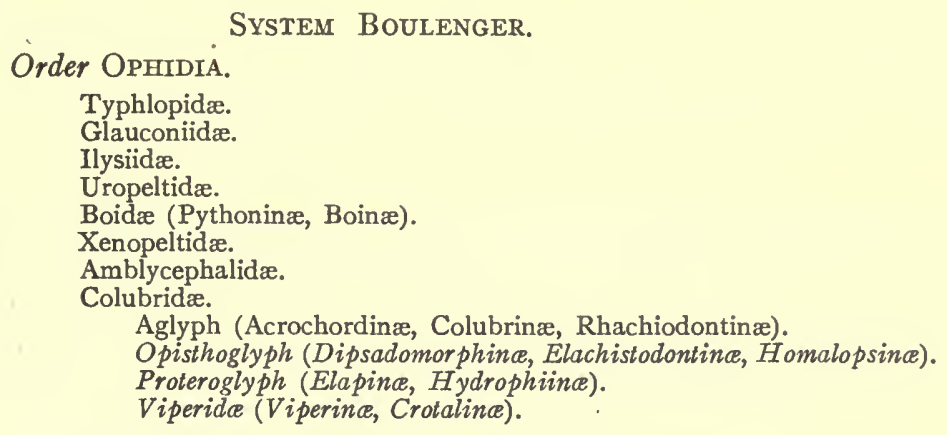

As the great work of Cope is indispensable to a student of classification of Serpentes, a concise form of his system, which was arranged with reference to the penial structure as well as many other characteristics, is given below, the venomous snakes being given in italics.

\section{System Cope. ${ }^{1}$}

\section{Order SERPENTES.}

Superfamily. Family and Subfamily.

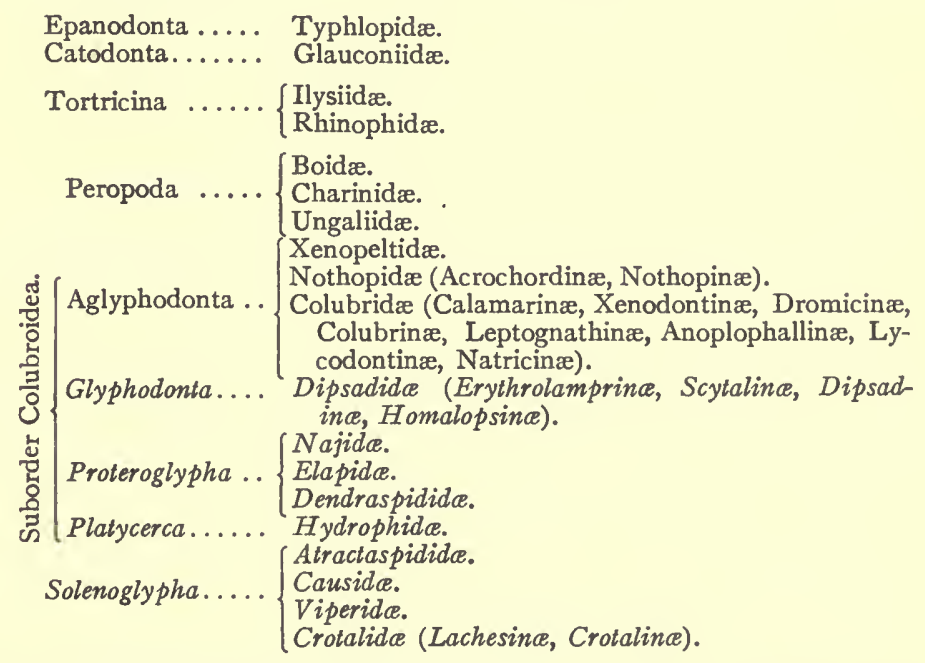

1 Cope, Ann. Rep. Smithsonian Institution, Washington, U. S. National Museum, 1898. 


\title{
CHAPTER II.
}

\section{MORPHOLOGY OF VENOMOUS SNAKES.}

That mere external general appearances are not sufficient to distinguish a poisonous snake from an innocuous kind has long been known. Indeed, our natural instinct to fear every form of snake, notwithstanding the beautiful coloration of some species, may have had its origin in a series of accidents resulting from a reckless approach to the innocent-looking poisonous snakes. A brief description, therefore, of various individual superfamilies, families, subfamilies, genera, and species of the venomous snakes may be useful.

In describing the poisonous snakes the zoological order has been adopted, commencing with the Opisthoglypha. For the purposes of this work it has not been found advantageous to follow any one authority as to nomenclature and classification, but no confusion need arise from this, as in most instances the authority is indicated. The system of Boulenger is more often employed in the Asiatic, African, and European snakes, while Cope's classification is more frequently used in the American varieties. The exact description of various Oriental snakes is derived from the excellent work of Stejneger.

\section{Family COLUBRIDE Boulenger. OPISTHOGLYPHA.}

\author{
Plate $\mathbf{r}, \mathrm{A}$ and $\mathrm{B}$.
}

This is Cope's equivalent. Superfamily Glyphodonta; family Dipsadidæ.

Dryophidæ of authors must be included under this heading. Tragops prasinus Wagler and perhaps Dryophis prasina of authors, which comes under Dryophidæ, inhabits East India and has a powerful venom; it is Opisthoglyphous. Dryophis Boie and Dryinus Merren are identical and have no elongated median maxillary teeth anterior to the elongated posterior grooved teeth. Dryophis Boie is not identical with Dryophis Wagler.

Family characters: One, or more, of the posterior teeth of the maxillary bone have a groove or furrow running frontally from base to apex, and conduct the secretion of the modified supralabial gland. Their zoological position is between the harmless and the powerfully venomous members of Colubridx. The venom is usually trifling in amount, but powerful, often killing lizards in a very short time. Their comparative inoffensiveness must largely be due to the situation of the poison fangs, which is unfavorable for inserting them into a victim. The family includes 79 genera and about 300 species.

This family contains forms of very varied habits, arboreal, terrestrial, subterranean, and aquatic. Cosmopolitan, excepting New Zealand.

\section{Boiginæ Stejneger. Dipsadinæ Cope.}

\section{Subfamily DIPSADOMORPHIN $A E$ Boulenger.}

Teeth well developed, nostrils lateral.

Some forms are arboreal, others terrestrial, and all have a long tail. The coloration of the arboreal is green above, often with white or yellow longitudinal bands, and white or yellow underneath. Their food consists chiefly of lizards, birds, and eggs. The following genera represent their corresponding types: 
Boiga Fitzinger and Stejneger.

Genus DIPSADOMORPHUS Fitzinger.

The maxillary bone carries Io to $\mathrm{I}_{4}$ teeth with 2 or 3 elongated, grooved teeth in the rear. Pupil vertical. Body and tail very long. Arboreal. The median or vertebral row of smooth scales is enlarged; ventral scales broad, forming an obtuse lateral angle which facilitates climbing. Subcaudals divided. This genus contains 22 species.

Dipsadomorphus trigonatus.

Pale gray or yellowish-olive above, with a white band or spots with black edge along the back. The band is zigzag. Inhabits India and grows to 3 feet in length. Dipsadomorphus cyaneus.

A beautiful arboreal snake, with green above and greenish-yellow underneath; black between the scales and along the dorsal side. Inhabits northern India and Assam, and reaches the length of 4 to 5 feet.

Dipsadomorphus kræpelini Stejneger.

Color in general rather dusky gray, with brownish spots and bands. Inhabits Formosa.

Genus DIPSADOBOA Günther.

Maxillary teeth 16 to 18 , followed, after a short interspace, by a pair of enlarged grooved fangs situated below the posterior border of the eye. Head distinct from neck; eye rather large, with vertically elliptical pupil. Subcaudals single. Only one species. West Africa.

Genus RHINOBOTHRYUM Wagler.

The only species $R$. lentiginosum inhabits tropical South America.

Genus HIMANTODES Duméril and Bibron.

Seven species are known. Tropical South America and Central America.

Genus CHAMATORTUS Günther.

The only species, C. aulicus, inhabits east and central Africa.

Genus GEODIPSAS Günther.

Two species, infralineata and boulengeri, are found in Madagascar. Length abcut $\mathrm{I} .5$ to 2.2 feet.

Genus HOLOGERRHUM Günther.

Only species, philippinum, has 40 caudals in single row and reaches about a foot. Genus ITHYCYPHUS Günther.

Two species, goudoti and mineatus, abound in Madagascar. $\quad 2.5$ to 3.5 feet long.

Genus LANGAHA Brugnière.

Three species, nasuta, intermedia, and crista-galli, inhabit Madagascar. Dryiophis Schlegel is a synonym of this genus.

Genus ALLUAUDINA Mocquard.

It has only one species, bellyi. Madagascar.

Genus ETEIRODIPSAS.

This is contained in Dipsas Schlegel. The only species, colubrina, inhabits Madagascar.

Genus STENOPHIS Boulenger.

Eight species are known. Madagascar.

Genus LYCODRYAS Günther.

The only species, sancti johannis, reaches a length of 2.5 feet. Madagascar. 
Genus PYTHONODIPSAS Günther.

Only one species, which inhabits tropical Africa.

Genus DITYPOPHIS Giinther.

Only one species, which inhabits tropical Africa.

Genus TARBOPHIS Fleischmann.

Eight species inhabit southeastern Europe, southwestern Asia, tropical and northeastern Africa.

Genus LYCOGNATHUS Duméril and Bibron.

Two species are known, both inhabiting tropical South America.

Genus TRYPANURGOS Fitzinger.

One species. Tropical South America.

Genus OXYRHOPUS Wagler.

Seventeen species, all inhabitants of Central and South America.

Genus RHINOSTOMA Fitzinger.

Two species are known, both from South America.

Genus THAMNODYNASTES Wagler.

Two species are known, both from South America.

Genus TACHYMENIS Wiegmann.

Two species are known. Bolivia, Peru, Chili.

Genus HEMIRHAGERRHIS Boettger.

One east African species grows less than a foot.

Genus TOMODON Duméril and Bibron.

Two species are known; inhabit South America.

Genus AMPLORHINUS Smith.

Two species are known in tropical and South Africa.

One species is known.

Genus PSEUDABLABES Boulenger.

Genus PHILODRYAS Wagler.

Thirteen species are known, all South American inhabitants.

Genus IALTRIS Cope.

One species is known; inhabits Santo Domingo.

Genus TRIMERORHINUS Smith.

Three species in Africa south of the Equator, East Africa.

Genus RHAMPHIOPHIS Peters.

Five species are known; inhabits Africa.

Genus DROMOPHIS Duméril and Bibron.

Two species are known; inhabits Africa.

Genus TAPHROMETOPON Brandt.

One species is known; found in central Asia and Persia.

Genus PSAMMOPHIS Boie.

The skull of this genus, as well as that of the two preceding genera, is remarkable for the wide vacuity between 'the frontal and sphenoid bones, a condition which approaches that of the Lacertia. Seventeen species are known, all inhabitants of Africa and southern Asia.

Genus MIMOPHIS Günther.

This genus is known from Madagascar. 


\section{Eight species. Southeastern Asia. \\ Genus DRYOPHIS Dalman. \\ Genus CCELOPELTIS Wagler.}

Behind the row of numerous small maxillary teeth are I or 2 much larger, grooved fangs at a level below the posterior border of the eye. Anterior 6 teeth on the mandible much larger than the rest. Pupil round. The scales of the adult have more or less longitudinal groove and are in $\mathrm{I}_{7}$ to $\mathrm{I} 9$ rows. Ventrals laterally round, indicating their terrestrial habit. Subcaudals divided. Two species in the Mediterranean district and in southwestern Asia. This genus is also called Malpolon.

Colopeltis monspessulana s. lacertina.

This snake exceeds all the European snakes in length, reaching 6 feet. The tail alone takes up about a quarter of the whole length. Dorsal olive-brown or yellowish or reddish, with small, dark, light-edged spots in some instances; lateral color often blackish, with whitish spots; ventral color yellowish-white, with or without brownish markings. There are some very green specimens with a dull blackish neck. The concave shape of the head is responsible for its specific name lacertina. They are found around rather dry localities with shrubs, and lizards, birds, and mice furnish their prey. When disturbed they make a loud hissing, but seldom bite. The bite, when effected, produces a certain paralytic effect upon the small animals, and its action is rapid. This species is also called Malpolon insignitus.

Cœlopeltis moilensis.

Northern Sahara, Nubia, Arabia, Western Persia.

\section{Genus MACROPROTODON Boulenger. ${ }^{1}$}

Macroprotodon cucullatus.

Dentition peculiar. Examining from the anterior to posterior, there are 3 small teeth and the fourth and fifth are elongated, followed by an interspace. Several small teeth and lastly 2 enlarged, grooved teeth then complete the remaining rear space. Dorsal side pale brown or gray with small spots or streaks on the body, and with a larger black patch semicircularly around the neck; ventral side bright red or yellowish, sometimes with blackish spots. It inhabits Andalusia, the Balearic Islands, and North Africa. Total length under 2 feet.

\section{Genus PSAMMODYNASTES Günther.}

Psammodynastes Günther, Cat. Brit. Mus., Colubr. Sn., I40.

Anisodonies Rosén, Ann. Mag. Nat. Hist.' (7), I905, XVI, I 28.

Third and often fourth maxillary teeth much enlarged. Scales without pits. Anal undivided, distinguishing by this from Dipsasmorphus Fitzinger.

Psammodynastes pulverulentus Boie.

Psammophis pulverulenta Boie, $1827=$ Psammodynastes pulverulentus Günther, Cat. Colubr. Sn., Brit. Mus., I858, I40, 25I. Boulenger, Cat. Sn. Brit. Mus., I 896.

Size small. Brownish-gray densely spotted with dusky and pale ochraceous, forming a very obscure pattern. Several V-shaped narrow bands on head. Under side brownish-gray with two narrow dusky bands, one on each side of median line. The grayish ground-color is produced by innumerable dusky specks powdered all over the surface. Coloration is, however, variable. Eastern Himalaya, Malay peninsula and archipelago, Indo-China, Philippine Islands, and Formosa.

\section{Genus TRIMORPHODON Cope.}

Trimorphodon Cope, Proc. Acad. Nat. Sci. Phila., I86I, 297.

Posterior maxillary teeth elongate, grooved; anterior teeth of both jaws elongate; intermediate teeth of maxillary series shorter. Pupil vertical. Head triangular

1 The following Opisthoglyphous genera enumerated in Cope's work have elongated middle maxillary teeth; posteriors grooved: Passerita Gray, Gephrinus Cope, Tragops Wagler, Tropidococcyx Günther. 
and very distinct from the narrow neck. Two loreals, one anterior to the other. Anal scutum divided, subcaudals in two series. Scales smooth and subequal. Coloration pale, with darker blotches. Chiefly Central American and Mexican genus, with one exceptional species which ranges within the United States northwardly. All of the species are of moderate size, reaching a length of 3 feet and the thickness of a man's forefinger. They live on lizards, young snakes, and batrachians. Their disposition is rather vicious.

Trimorphodon lyrophanes Cope. "Jewsharp Snake."

Coloration, light gray; about twenty pairs of deep brown blotches along the back to base of tail; the tail also blotched; an irregular row of blotches on sides; ventral side white. Total length 2.5 to 3 feet. Found in southern Arizona and lower California.

Trimorphodon upsilon Cope $=$ Trimorphodon vilkinsonii Cope.

(I) Top of head brown, with a small Y-shaped mark; dorsal spots transverse diamonds, more or less transversely divided by paler spots; brown collar.

(2) Top of head white, with 3 round black spots, a few transverse undivided black rhombs, with pale edges.

Other species of this genus are Trimorphodon lambda Cope, Trimorphodon tau Cope, Trimorphodon collaris Cope.

\section{Genus SIBON Fitzinger.}

Sibon Fitzinger, Neue Class. Reptilien, $1826,29$.

Heterurus Duméril and Bibron, Erp. gén., VII, 1854, II70.

Leptodira Günther, Cat. Brit. Mus. Col. Snakes, 1858,165 .

Eteirodipsas Jan, Elenco sist. ofidi, 1863 , 105.

An elongate grooved tooth on the posterior part of the maxillary bone; other teeth subequal. Pupil vertical. This genus is distinguished from Dipsas by the subdivided preanal plate; from Himantodes by the double scale pits, that genus having but one; from Trimorphodon by the equality of the solid maxillary teeth and the single loreal plate. In some of the species the head is less distinct and forms a gradual transition to the more fusiform types. Size moderate. Nine species constitute this genus and inhabit Central American and Mexican districts. One species ( $S$. annulatum) extends its range throughout tropical South America and northward into southern Texas.

Sibon septentrionale Kennicot.

Body slender, with gradually tapering tail, which is about one-fifth of total length. Head ovoid, depressed, very wide, and swollen at temporal regions. Neck slender, about half as wide as head. Coloration of body light-yellowish ground with broad, lustrous, brownish-black half rings; abdominal surface uniformly light-yellowish. Oviparous. Southern portion of Texas, New Mexico, Panama, Arizona, Mexico.

Other species of this genus are Sibon yucatanense Cope, Sibon annulatum ${ }^{1}$ L., Sibon personatum Cope, Sibon rhombiferum Günther, Sibon frenatum Cope, Sibon nigrofasciatum Günther, Sibon pacificum Cope.

Scolecophis æmulus Cope.

Genus SCOLECOPHIS Cope.

Groove of posterior maxillary teeth shallow. Coloration of body exactly similar to Elaps fulvius. It is surrounded by wide black rings, broadly bordered with yellow and separated by red interspaces of twice their width. The scales of the red spaces have each a central black spot which is more distinct than in Elaps fulvius, on the anterior part of the body, above the sides; posteriorly they are weaker. The coloration of the head differs from Elaps fulvius in having merely a large black spot covering the parietal, superciliary, and frontal plates, and extending round the eye, but not reaching edge of lip. Muzzle and chin unspotted. The tail has

${ }^{1}$ Dipsas annulata Duméril and Bibron. Leptodra annulata Günther. 
a peculiar tubercular carination and distinguishes this species from a very closely allied Scolecophis atrocinctus. Size rather small. It inhabits a rocky, mountainous region. Three species are known.

Genus TANTILLA Baird and Girard.

Tantilla Baird and Girard, Cat. N. Amer. Rep., Pt. I, Serp., r853, I31.

Homalocranium Duméril and Bibron, Mém. Acad. Sci., 1853, XXIII, 490.

Posterior maxillary tooth grooved. Head depressed and continuous with neck No loreal. Eyes below medium size. Body subcylindrical, tail short. Scales smooth. Subcaudal divided. Most of the species belonging to the genus are small, have a pale brown body and a black head, and lead a secretive or burrowing life. They inhabit especially the Central American, Mexican, and South American districts and the southern portions of the United States. About I6 species comprise this genus. From the hygienic standpoint the Tantilla are non-dangerous poisonous snakes. 23 species are described by Boulenger.

Tantilla coronata Baird and Girard.

A yellow or white ring at base of head. Yellow ring followed by a broader ring of black. South Carolina, Florida, and westward to Mississippi.

Tantilla eiseni Stejneger.

Yellow ring followed in rear by black dots. California.

Tantilla nigriceps Kennicot.

No yellow ring at base of head. Texas, New Mexico.

Tantilla gracilis Baird and Girard.

Coloration like preceding species, but six supralabial plates instead of seven. Missouri to Texas.

\section{Genus MANOLEPIS Cope.}

Manolepis Cope, Proc. Amer. Phil. Soc., I885, 76.-Boulenger, Cat. Brit. Mus. III, I896, I 20.

Maxillary teeth equal anteriorly to grooved teeth, which are enlarged; anterior mandibular teeth longer than posterior. Head distinct from neck. Pupil vertical. Scales smooth, pitless. Anal and subcaudal undivided. There are discrepancies in the descriptions of different authors.

\section{Manolepis putnamii ${ }^{1} \mathrm{Jan}$.}

Anterior maxillary and mandibular teeth longer than median. Pupil round. Body cylindrical, stout; neck but little constricted; muzzle protruded beyond labial margin, oblique, truncate in profile; head acuminate and oval.

\section{Genus CONOPHIS Peters.}

An elongated, grooved tooth separated from others by an interspace. This genus is rather an isolated American variety, and it is quite similar to and probably allied to the African genus Rhamphiophis Peters. Both genera have decurved muzzle and claw-like rostral plate, designed for scooping a cavity in the soil by a downward movement. Three species are recorded, all Mexican.

Genus CONIOPHANES Hallowell.

Erythrolamprus Cope, Bull. U. S. Nat. Mus., 1887, 55.-Boulenger, Cat. Brit. Mus., Snakes, III, r895, 199 .

Posterior maxillary teeth elongate and grooved. Pupil round. Loreal present. Scales smooth and pitless. Anal and subcaudal divided. Typical species are brown or red, with black stripes and delicate and handsome tints. Nine species described, with one exception confined to Central America and Mexico.

Coniophanes imperialis Baird.

Erythrolamprus imperialis Boulenger, Cat. Brit. Mus., Snakes, III, I896, 206.

Scales in nineteen rows. Sides dark; a median dorsal band of varying width; ventral red. According to the number of labials it is divided into two subspecies.

\footnotetext{
In many respects this may be an Aglyphodont colubrine belonging to Dromicus putnamii Cope.
} 
Coniophanes imperialis imperialis Baird.

Eight labials. Body above deeply purplish-black, with two dorsal yellowishbrown stripes from head to tip of tail, and separated by a narrow vertebral line of ground-color; head above black, with two narrow yellow lines from nostrils to occiput crossing upper angle of orbit; ground-color of the back extends into end of abdominal scutella; middle of abdomen uniformly bright red.

Coniophanes imperialis proterops Cope.

This species is distinguished from Baird's species by having 7 labials instead of 8 .

Coniophanes lateritius Cope.

Erythrolamprus lateritius Boulenger.

Erythrolamprus melanocephalus Cope, I887, U. S. Nat. Mus., 78.

Tachymenis melanocephalus Peters, Mon. Ber. Akad. 1869, 876.

Whole body bright vermilion, punctulated with brown, passing through orange to golden on the belly. Head broad posteriorly with acute prominent muzzle. Io scales posteriorly black, labials bordered and transversed by yellow lines, and occiput dotted with the same; throat and chin black-spotted. Anal divided. Small in size with a rather slender body and long tail. Head and neck not very distinct. Central America and Mexico, northward into southern Texas.

The remaining genera of the subfamily Dipsadomorphinæ are as follows:

$\begin{array}{lll}\text { Thelotornis, } & \text { Xenopholis, } & \text { Micrelaps, } \\ \text { Oxybelis, } & \text { Apostolepis, } & \text { Elapotinus, } \\ \text { Dryophiops, } & \text { Amblyodipsas, } & \text { Miodon, } \\ \text { Chrysopelea, } & \text { Calamelaps, } & \text { Polemon, } \\ \text { Dispholidus, } & \text { Rhinocalamus, } & \text { Brachyophis, } \\ \text { Hydrocalamus, } & \text { Xenocalamus, } & \text { Macrelaps, } \\ \text { Ogmius, } & \text { IElapomoius, } & \text { Aparallactus, } \\ \text { Stenorhina, } & \text { Elapomorphus, } & \text { Elapops. }\end{array}$

\section{Subfamily ELACHISTODONTIN E Boulenger.}

Only a few teeth, both on posterior part of maxillary and dentary bones and on palatines and pterygoids. Some of the vertebræ in the thoracic region have highly elongated unpaired hypapophyses which are so protruded as to pierce the dorsal wall of the gullet in forward direction. Only one species is known, Elachistodon westermanni. Brown above, with yellowish stripe; below yellow. Inhabits India.

\section{Subfamily HOMALOPSIN $\mathbb{E}$ Boulenger.}

One or more posterior maxillary teeth grooved. Eyes small, vertical pupils. Nostrils on upper surface of snout and provided with valves which can be closed. Some species have very narrow ventral scales, recalling the burrowing or Hydrophine snakes; none of these snakes use their ventral scales for locomotory purposes. One genus, the Herpeton, has a vegetable diet, while the rest are piscivorous. This subfamily is absolutely aquatic, and embraces the fresh-water snakes of all countries. Head usually small and thick, scarcely distinct from neck. Many of the East Indian species are semimarine and inhabit the tide-water or coast. Habitat, southeastern Asia, including India, Malay Archipelago, Philippines, southern China, New Guinea, and northern Australia.

\section{Genus HOMALOPSIS Kuhl.}

Maxillary teeth II to $\mathrm{I} 3$, decreasing in length posteriorly, followed after an interspace, by a pair of slightly enlarged, grooved teeth; anterior mandibular teeth much longer than the posterior. Head distinct from neck; eye small, with vertically elliptic pupil. Body cylindrical; tail moderate, 2 subcaudals in two rows. Southeastern Asia. 


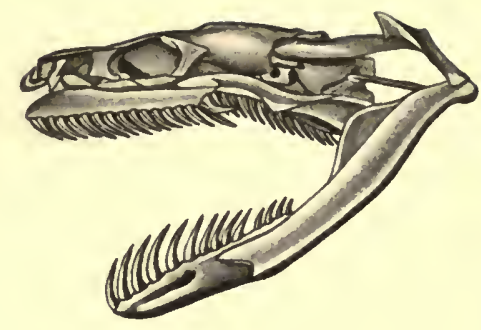

A

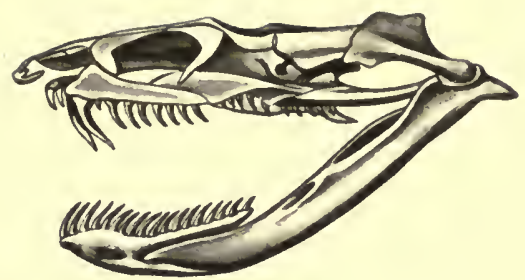

D
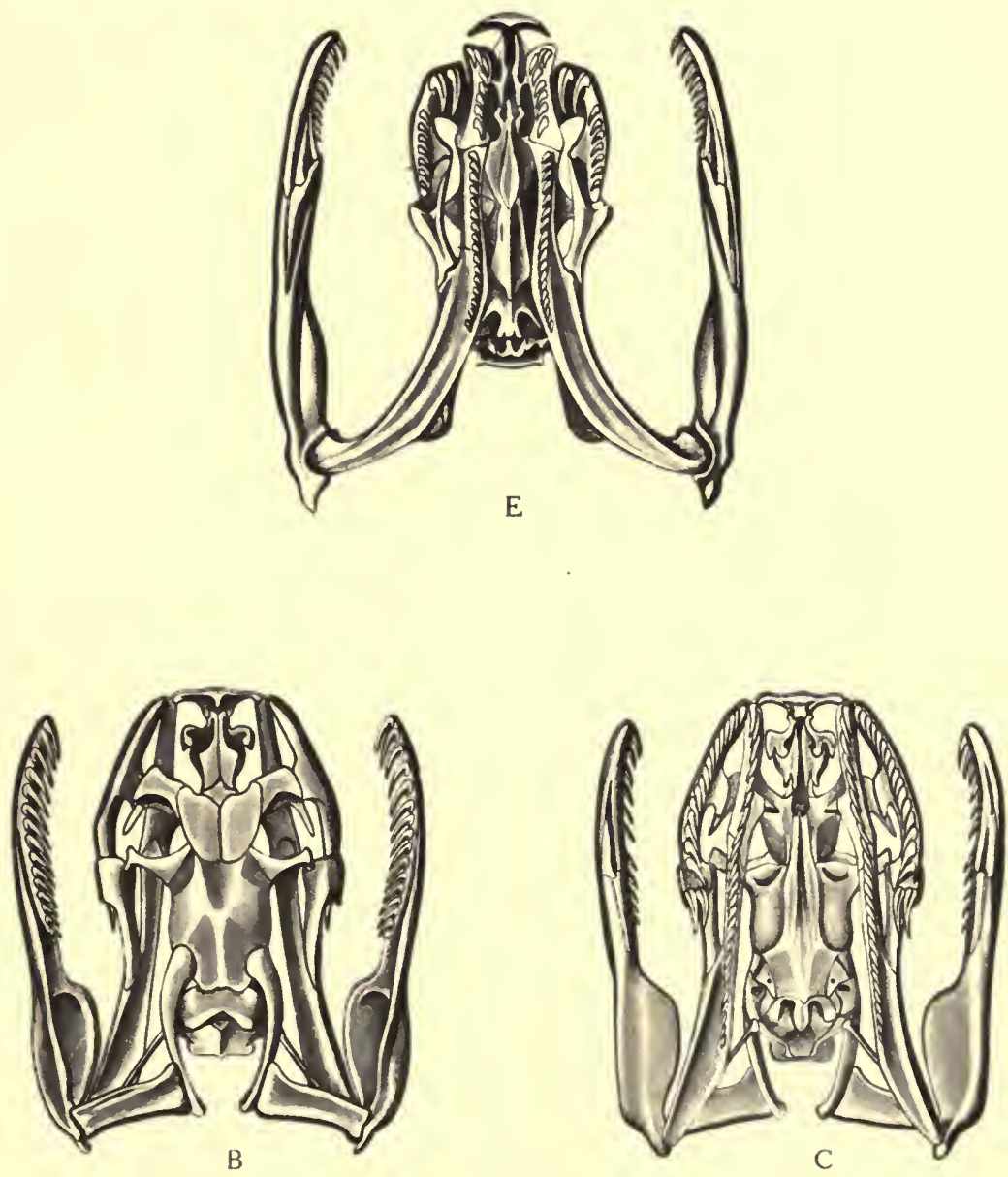

A, B, and C, Skull of Homalopsis buccata. D and E, Skull of Distira stokesii.

(Drawings from Boulenger's Book.) 



\section{Homalopsis buccata.}

Scales in 37 to 47 rows. Ventrals 160 to 171 ; anal divided; subcaudals 70 to 9o. Total length about 3 feet. Bengal (?), Burma, Indo-China, Malay Peninsula, Sumatra, Borneo, Java.

\section{Genus CERBERUS Cuvier.}

Cerberus rhynchops and 2 other species.

Genus HYPSIRHINA Wagler.

Hypsirhina plumbea and $\mathrm{I}_{4}$ other species.

\section{Hipistes hydrinus.}

\section{Genus HIPISTES Gray.}

Head covered with small scales, scales of body smooth, excepting the very narrow ventrals, which have double keels. Body laterally compressed, resembling in general appearance the Hydrophinæ. It is piscivorous and swims far out into the sea. It inhabits Siam.

\section{Family COLUBRIDE Boulenger. PROTEROGLYPHA.}

Corresponds to Cope's two superfamilies Proteroglypha and Platycerca and Stejneger's Elapidæ.

This family contains all snakes with a permanently erect grooved poison fang in the anterior portion of the horizontal maxillary bone. Boulenger and Stejneger divide the members of this family into subfamilies Elapinæ and Hydrophinæ. ${ }^{1}$ As a rule, smaller, solid teeth are carried by the maxilla behind the grooved fangs. Shape of pupil variable, some being round, some vertical. Elaps and Acanthophis have vertical pupils, while the famous Cobra has a round one. Although their poison apparatus is inferior to that of Viperidæ in Boulenger's term or Solenoglypha of the usual nomenclature, the Elapine snakes are the deadliest and often the most dangerous of all snakes. ${ }^{2}$ Their general appearance is not essentially different from that of most harmless colubrine snakes and the presence of the fang is the only reliable difference in these species. Most Proteroglypha are viviparous, but the famous cobra de capello and certain marine snakes are oviparous. Some are terrestrial, others marine.

The Elapine snakes are tropical. The whole Australian, Palæotropical and Neotropical regions, with exception of Madagascar and New Zealand, are inhabited by them. They extend northward into the warmer parts of North Africa, and range over a great part of the Palæarctic subregion, being found in North Africa and southwestern Asia. They also inhabit the southeastern Asiatic islands and mainland.

\section{Subfamily ELAPIN $\mathbb{E}$ Boulenger.}

All are terrestrial, and the general feature is that of the harmless colubrine snakes. The comparatively small eye with vertical pupil, frequent absence of loreal, and indistinctness in width of head and body are often of differential value in determining the species, but the presence of the grooved fangs is the last and reliable criterion. The most remarkable feature of some of the Elapine snakes is that they can dilatc certain cervical ribs, assuming a hood-like or fan-formed shape when the snakes are excited. This, together with the conditions of median dorsal scale rows and subcaudals, serves to divide them into several genera. According to Cope the presence or absence of a postfrontal bone draws the line between Naja and Elaps. ${ }^{3}$ They live on small vertebrates: lizards, birds, rats, frogs, snakes, and occasionally

\footnotetext{
1 Hydrinæ Stejneger.

The most dreaded species are Naja, Ophiphagus, and Bungarus in India, and Acanthophis and Pseudechis in Australia. They all possess very powerful venom and have courage and are often rapid in action. The Ophiphagus elaps of India reaches 12 feet and is the longest venomous snake.

Cope gave them the rank of families, Najidæ and Elapida.
} 
fishes. Their fondness for rats makes some of them extremely dangerous, as they often invade the human abode for their prey. There are about 150 species, grouped into a large number of genera.

Genus NAJA Laurenti.

Naja Laurenti, Synops. Rept., p. 90, 1768.

The pair of large and grooved poison fangs are separated by an interspace from one to three small, faintly grooved teeth near the posterior end of the maxillary bone. Pupil round. Head but slightly distinct from neck. Neck covered with more numerous scales, and can be expanded into a hood by the spreading and forwarding motion of the ribs. Scales are smooth and pitless; vertebral row not enlarged. Anal entire, subcaudal divided. No loreal. Postfrontal bone present.

Naja tripudians. (Plate 2, C; plate 3, A, B, C; plate 4, A, B.)

This dangerous tropical snake is known as the Cobra di capello and is much dreaded on account of its powerful venom and its audacity. Oviparous, producing about twenty elliptical soft-shelled eggs of the size of a pigeon's egg. Coloration varies much. The typical form is yellowish to dark brown with a black-and-white spectacle-like mark on dorsal side of hood and a black-and-white spot on each side of the corresponding under surface. Other specimens are uniform pale brown to blackish-gray, without the spectacle pattern on the hood. Length usually 4 to 5 feet, or even over 6 feet, the tail 9 inches or more. It resorts to places affording easy retirement, such as heaps of stones, stacks of wood, ruins, and deserted hills of termites, and loves the neighborhood of streams. It visits inhabited houses to catch rats.

The range of habitation is very wide, from Trans-Caspia to China, including all southern Asia, and to Formosa and the Philippines. Many observations show that cobras live in pairs, but otherwise do not take much notice of each other or of other kinds of snakes. They avoid the hot sunshine and hunt late in the afternoon or evening. There are many varieties of this species, of which several will be described below.

Naja tripudians typica: A spectacle-shaped white imprint on the most dilated portion of the dorsal surface of the hood; ventral side transversely banded with one or more dark lines. India, Bengal, Ceylon.

Naja tripudians caca: Uniform pale brown to deep gray color, without pattern on the hood, and one or more dark bands across the anterior ventral surface. TransCaspian region, India, Bengal, Java.

Naja tripudians fasciata: Brown, black, or olive color, with more or less light transverse bands; a ;white spectacle bordered with black is on the neck, and a black spot on each side, above the mark. Bengal, India, Cochin China,-southern China, Hainan, Cambodia, Siam, Malay Peninsula.

Naja tripudians sputatrix: Black or deep brown with a yellow white-rimmed spectacle on the side of the head and neck. Southern China, Burma, Malay Peninsula, Chusan Islands, Sumatra, Formosa, Indo-China.

Naja tripudians leucodira: Brown or black without mark on the hood

Naja tripudians miolepis: Brown or black; around the head and neck yellowish; no mark on the head. Sarawak, Labuan, Borneo.

\section{Naja samarensis.}

Black above, sometimes yellowish-black; pale brown to yellow on ventral surface; neck black. Grows to 3 feet. Philippine Islands.

Naja bungarus s. Ophiophagus elaps s. Hamadryas. "Sunkerchor" or Skull-breaker." (Plate 2, B; plate $5, \mathrm{~A}, \mathrm{~B}$.)

This is the king cobra or snake-eating snake, or hamadryad. It has a wellexpanding hood. Coloration variable, from yellowish to black, with - or without an olive gloss. More or less distinct dark bands or rings may be seen in some 
specimens, while others are olive above with black-edged scales, and still others are very dark above and beneath. The distinctive, specific character is the small number of scales. It has only $r_{5}$ rows on the middle of the body and 19 to 21 on the dilatable neck, where in the typical tripudians 29 to 35 rows are found. It reaches the length of even 15 feet, and its venom is very powerful. It is said to kill an elephant within 3 hours by one bite and is liable to attack man. Perhaps this is the most dangerous snake of India. It lives exclusively on other snakes. It haunts the rivers and streams, lives in forests and jungles, and is a very agile climber.

Naja haje. (Plate 5, c.)

The common hooded cobra of Africa, the "Aspis," so called on account of its shield or hood. Spectacle-marks on the neck absent or indistinct. General color varies brown to dark brown or blackish above, with or without spots of brown or yellow; below yellow, dark brown, or blackish; head blackish; the neck with black or brown band on the uniform dark olive or yellow ground-color. It inhabits the border of the Sahara, Egypt, southern Palestine, east Africa to Mozambique. It is very common in central Africa and along the basin of the Nile and the Soudan. In Egypt it is often seen near ruins, under heaps of stones or among bushes. When chased it stops to defend itself. It lives in captivity for 6 or 8 months, but remains wild and vicious. It may reach a length of 6 feet or more.

Naja flava.

Very similar to the foregoing species. Has a dilatable neck, which is surrounded by a black band in some specimens. Color very variable, uniformly yellowish, reddish, brownish, or blackish, with a light spectacle-mark. Averages about 5 feet in length. South Africa.

Naja melanoleuca.

Sides of head brown or whitish, labial plates bordered black posteriorly. Reaches nearly 8 feet in length. Tropical Africa.

Naja nigricollis.

Coloration variable, with a black transversal band under surface of neck. Senegambia, upper Egypt to Angola and Transvaal.

\section{Naja anchietæ.}

Black or brown above; muzzle yellowish; abdomen yellow or light brown, with or without a black band across under surface of neck. Scales on the neck or body $I_{5}$ to $I_{7}$ rows. Grows to 6 feet. Angola.

\section{Naja goldii.}

Eyes large; 5 rows of scales on neck and body. Color uniformly black or with transversal series of small whitish marks; abdominal surface white anteriorly, black posteriorly; subcaudal scales black. Grows to 5 or 6 feet. Lower Niger.

\section{Genus SEPEDON Merrem.}

Maxillary bone more prolonged than palatal bone, and carries one pair of enormous fangs, but no other teeth, differing thus from Naja. Neck dilatable. Head not distinct from neck. Eyes moderate in size with round pupil. Body cylindrical; scales keeled, in I9 rows.

Sepedon hæmachates Merrem. "Spy-slange" or "spitting snake."

Known in South Africa as Ringhals or banded neck. This is another hooded snake of Africa. The general description of the genus applies to this species. General color bluish-black with many narrow undulatory and zigzag crossbands of yellow or yellowish-white color; under side of neck black or deep red with one or two white bands around lower portion of neck; belly grayish. This snake is very well known because of its peculiar habit of spitting the venom to a distance 
of more than 3 feet. This was primarily stated by the African natives, who believe that if the venom gets into the eye the sight will be lost. This seems to be partly corroborated by subsequent observations of some European travelers and settlers. It seems quite conceivable that if the projected venom gets into the eye there will be severe conjunctivitis. Calmette states, however, that he never observed such faculty in Sepedon during its captivity in his laboratory.

Boers call it Spy-slange or spitting snake, meaning that it spits out its saliva when excited.

\section{Genus BUNGARUS Daudin.}

Bungarus Daudin, Bull. Soc. Philom. Paris, 1803, 187 .

The two large, grooved poison fangs are followed by one or two smaller teeth. Eyes small, with round or vertical pupils. Head not distinct from neck. Dorsal ridge prominent and covered with a row of much-enlarged scales. Scales in 13 to 17 rows. Body moderately thick, with comparatively short tail. Subcaudal in one or two series. Bungarus is closely allied to Naja, but has an undilatable neck. About half a dozen species inhabit southeastern Asia.

Bungarus candidus ${ }^{1}$ s. cæruleus. (Plate $3, \mathrm{D}, \mathrm{E}$; plate $6, \mathrm{~A}$.)

Bungarus candidus var. coruleus, or often $B$. caruleus so called, is one of the most dreaded venomous snakes of the whole of India and adjacent regions. It is known as common krait; has a habit of invading houses in search of rats. It is comparatively small in size, reaching about 3 feet; lives on lizards, rats, and young snakes. It is known to penetrate to a veranda, bathroom, or even a pillow, but usually hides in old trees or walls. Scales smooth, dark brown or bluish-black with narrow crossbars or white specks, or alternately barred brown and yellow; under part uniform white. Krait is the next most dangerous snake to the cobra.

Bungarus fasciatus. (Plate 6, B.)

General color bright yellow, alternating with blackish bands. About 5 feet long. Fangs comparatively small. Known in northwestern India under the name Koclia-krait, it inhabits Bengal, Coromandel, and Burma. A bite of this species, also called the banded krait, is fatal to a dog within a few hours.

Other species of Bungarus are multicinctus, ${ }^{2}$ which reaches 3 to 4 feet in length and inhabits South China, lower Burma and Formosa; ceylonicus, the Ceylon krait, and lividus, which has less-pronounced median dorsal scales and inhabits Assam.

\section{Genus HEMIBUNGARUS Peters.}

Hemibungarus Peters, Mon. Ber. Berliner Akad. Wiss., r862, 637 .

In contradistinction to the genus Callophis, this one has several small solid teeth behind the poison fang. The pupil is round. Head and neck less distinct. Body rather slender and cylindrical. The poison extends sometimes down to the abdominal cavity. Scales in 5 rows. Tail short. Subcaudals in two rows.

Hemibungarus colligaster.

Head purplish with black crossbars separated with narrow white bands; abdominal surface and tip of tail red; nose yellow, with black band around the upper lip near eyes. Grows to a length less than 2 feet. Philippine Islands.

Hemibungarus collaris.

Black on back; black and red bands on belly; yellowish collar on back part of head. Philippine Islands.

\footnotetext{
1 Boulenger divided Bungarus candidus into two varieties, caruleus and multicinctus. Stejneger is inclined to consider Bungarus candidus s. caruleus as not so closely allied as to be ranked as subspecies, but deserving full specific rank as Bungarus multicinctus - not as Bungarus caruleus multicinctus.

2 Boulenger's subspecies of Bungarus candidus, and corresponds to Bungarus semifasciatus Günther, not of Boie, 1827.
} 
Hemibungarus nigrescens.

Scales in 13 rows. Inhabits western India, Bombay to Travancore.

Hemibungarus japonicus Gïnther. "Hai."

Callophis japonicus Günther, Ann. Mag. Nat. Hist., 1868, 428.

Hemibungarus japonicus Boulenger, Cat. Snakes, Brit. Mus., III, r896, 396.

Scales in 13 rows. Red above, with one to five black bands crossed by other black bands with yellow margin; muzzle and chin black; ventral surface yellowish with black specks and black transverse bands. Oshima in Riu Kiu Islands.

Hemibungarus bœttgeri. "Hai."

Callophis battgeri Fritz, Zool. Jahrb., Sept., r895, VII, 86r. See also Kat. Schl. Mus. Senckenberg, I 898, I 23.

Hemibungarus japonicus Boulenger, Cat. Snakes, Brit. Mus., I896, III, 395. Stejneger, Herpetology of Japan, $1907,3^{89}$.

Almost identical with the preceding species except in coloration. Color above iridescent blackish blue with four longitudinal light bands, being reddish in the two median and white in the two outer ones. Across these longitudinal lines are about If transverse, irregular bands of bluish-black edged with white. These black crossbands are carried across the belly on a single ventral; under side whitish with numerous large and irregular blackish-blue blotches. Okinawa Island in Riu Kiu Islands.

Genus CALlOPHIS Giinther. (Plate 6, D.)

Callophis Gray, Ind. Zool., II (C. fig.).

In many respects this genus resembles Sepedon. The maxillary bone is longer than the palatine, and carries a pair of very strong poison fangs, without any other teeth. Eyes small, with a round pupil. Body cylindrical and slender. Neck not dilatable. The scales are smooth instead of being keeled as in Sepedon, imbricated in 13 rows. The head is small and not distinct from the neck. Length not more than 2 feet. All the members of Callophis are elegantly and variedly colored, hence are called by this generic name, which means "beautiful snake." They live exclusively on other snakes belonging to Calamarida, and do not inhabit any region where no calamarine snakes are to be found; for example, Ceylon. They are essentially terrestrial and hide around old logs or trunks of trees; they are slow and lazy, being more of a nocturnal nature. While their venom is by no means weak, no fatal accident from the bite of the snakes of this genus has been recorded.

Callophis gracilis.

Red or pale brown, with three longitudinal black lines indented with black and brown specks, the lateral marks alternating with the vertebral ones; black and yellow bands along under side of abdomen and tail. Total length about 2 feet. Malay Peninsula and Sumatra.

Callophis trimaculatus.

Head and muzzle black with a yellow speck on each side of occiput; belly uniformly red. Total length about a foot. Burma and India.

Callophis maculiceps.

Head and muzzle black with two yellow bands on each side; belly red. Total length about I.5 feet. Inhabits Burma, Cochin China, Malay Peninsula.

Callophis macclellandii.

Elaps macclellandii Reinhardt, Calcutta Journ. Nat. Hist., IV, 532. Günther and Boulenger grouped it in Callophis.

Head and neck black with a yellow crossband in rear of eyes; back reddishbrown with regular and equidistant black rings; belly yellow with bands and quadrangular marks of black. Total length about $x_{.5}$ to 2 feet. Inhabits Nepal, Assam, Burma, southern China. 
Callophis bibronii.

Head black anteriorly, reddish posteriorly; body purplish-brown to the tail, with transverse-irregular bands. Grows to 2 feet. Found by Bedhome at the altitude of 3,000 feet in Malabar.

\section{Callophis univirgatus Gïnther.}

Callophis univirgatus Günther, Proc. Zool. Soc. London, 1859, 83.

Callophis macclellandii var. univirgatus Boulenger, Cat. Snakes, Brit. Mus., III, I896, 399.

Coloration alone separates this from the macclellandii, it having a narrow black line down middle of back, and no regular crossbars. It inhabits Sikkim and Nepal, Assam, Burma, southwestern China, Formosa. In the province of Fokien it is found at an altitude of 3,000 to 4,000 feet.

\section{Adeniophis Meyer.}

\section{Genus DOLIOPHIS Girard.}

Doliophis differs from Callophis chiefly on account of the presence of an enormously developed poison gland in the former. It is not restricted to the head, but extends along the anterior third of the body, gradually thickening and terminating in front of the heart with club-shaped ends. Owing to the extension of these glands, which can be felt through the skin as thickenings at end of first third of body, the heart has been shifted farther back than in any other snake.

Doliophis bivirgatus.

Color purplish-red or black above, red on head, tail, and belly. Total length 4 to 5 feet. Burma, Cochin China, Malay Peninsula, Sumatra, Java, and Borneo.

Doliophis intestinalis.

Back brown or black with longitudinal rings of lighter or darker shade. Tail red; belly red with intersections of black. crossbars. Total length about 2 feet. Burma, Malay Peninsula, Sumatra, Java, Borneo.

Doliophis bilineatus.

Back black with two white bands along entire length of body; muzzle white; the belly striated with white and black bands; tail orange. Total length a little over 2 feet. Philippine Islands.

Doliophis philippinus.

The back carries two longitudinal brown bands, which are intersected by the transverse black bars of the belly; the interspaces of the bands are again annulated with yellow and red; head brownish with small yellow specks. Total length about 18 inches. Philippine Islands.

\section{Cacophis Günther.}

\section{Genus BOULENGERINA Dollo.}

The maxillary bone has a length equal to that of the palatine; carries a pair of comparatively large fangs, then a series of three or four small teeth behind the fangs. Eyes small with round pupil. Body cylindrical; scales soft, in 2 I rows; the ventral scales are rounded off. Moderate tail. Subcaudal double. It is a small snake, about 7 inches long. The head and neck indistinct in width.

\section{Boulengerina stormsi.}

The only known species of this genus is of brown color with black rings on neck, black tail, the belly anteriorly white, posteriorly brown. Inhabits the region around Lake Tanganyika.

\section{Genus ELAPECHIS Boulenger.}

The length of the maxillary and palatine bones is equal. A pair of enormous poison fangs is followed by two or four small teeth. Head and neck indistinct. Eyes small with round pupil. Body cylindrical. Scales soft, oblique, and in $I_{3}$ to $\mathbf{I}_{5}$ rows; ventrals rounded off. Tail very short. Subcaudals in two rows. 


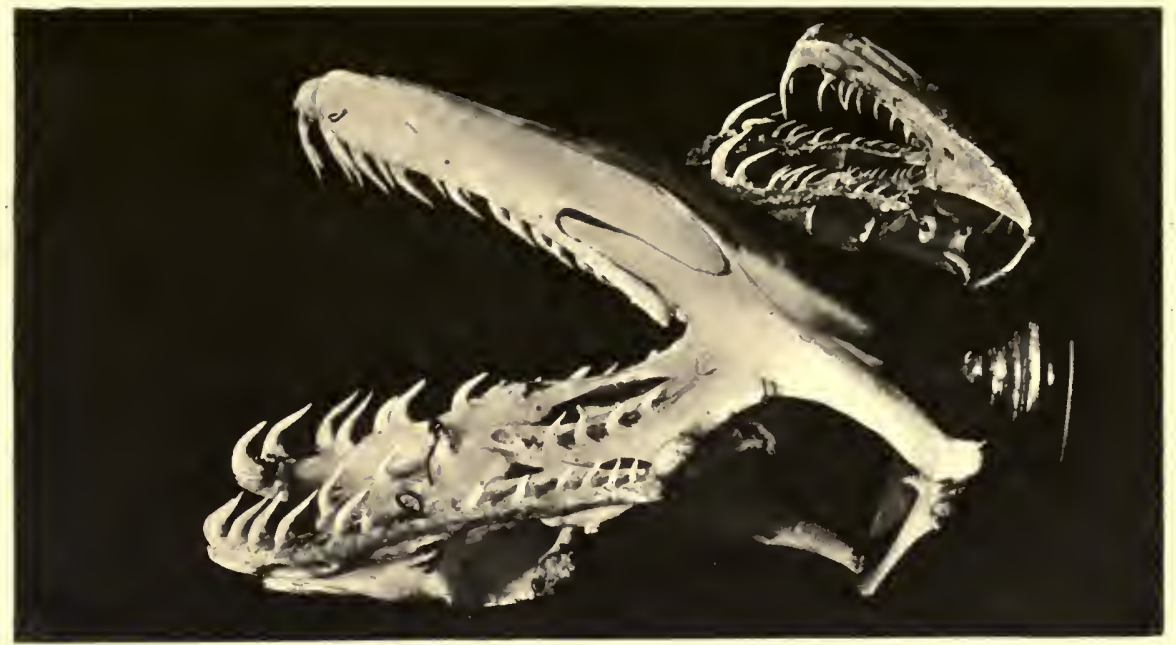

A

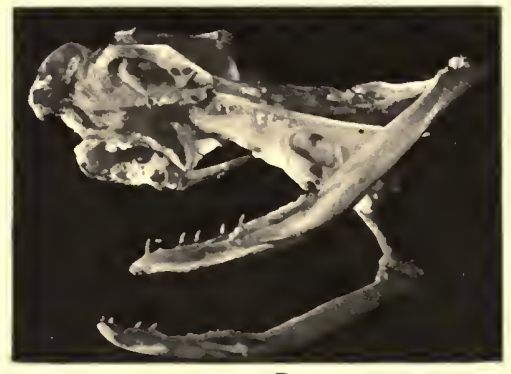

B

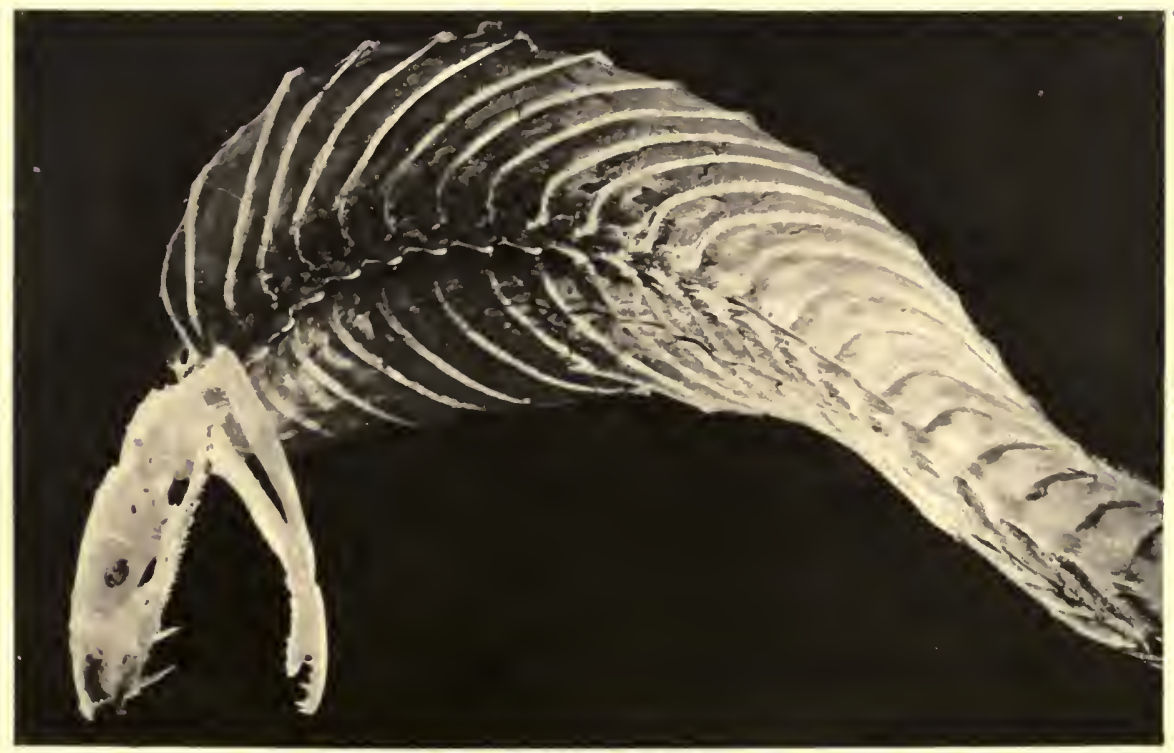

C

A. Skulls of a Harmless Snake and of a Boa Constrictor.

B. Skull of Naja bungarus. (From Photograph.)

C. Skull and Skeleton of Naja tripudians. (From Photograph.) 



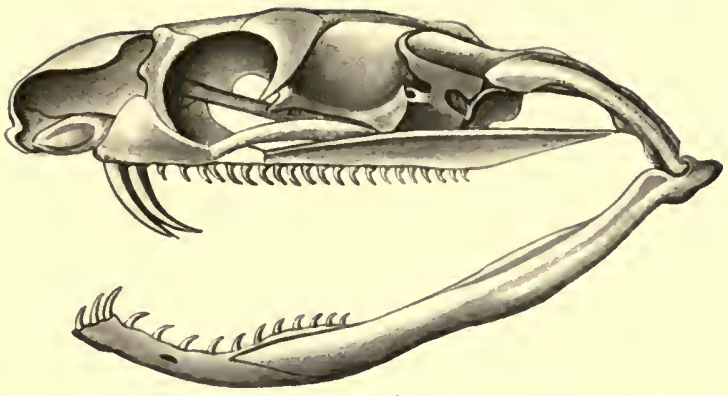

A
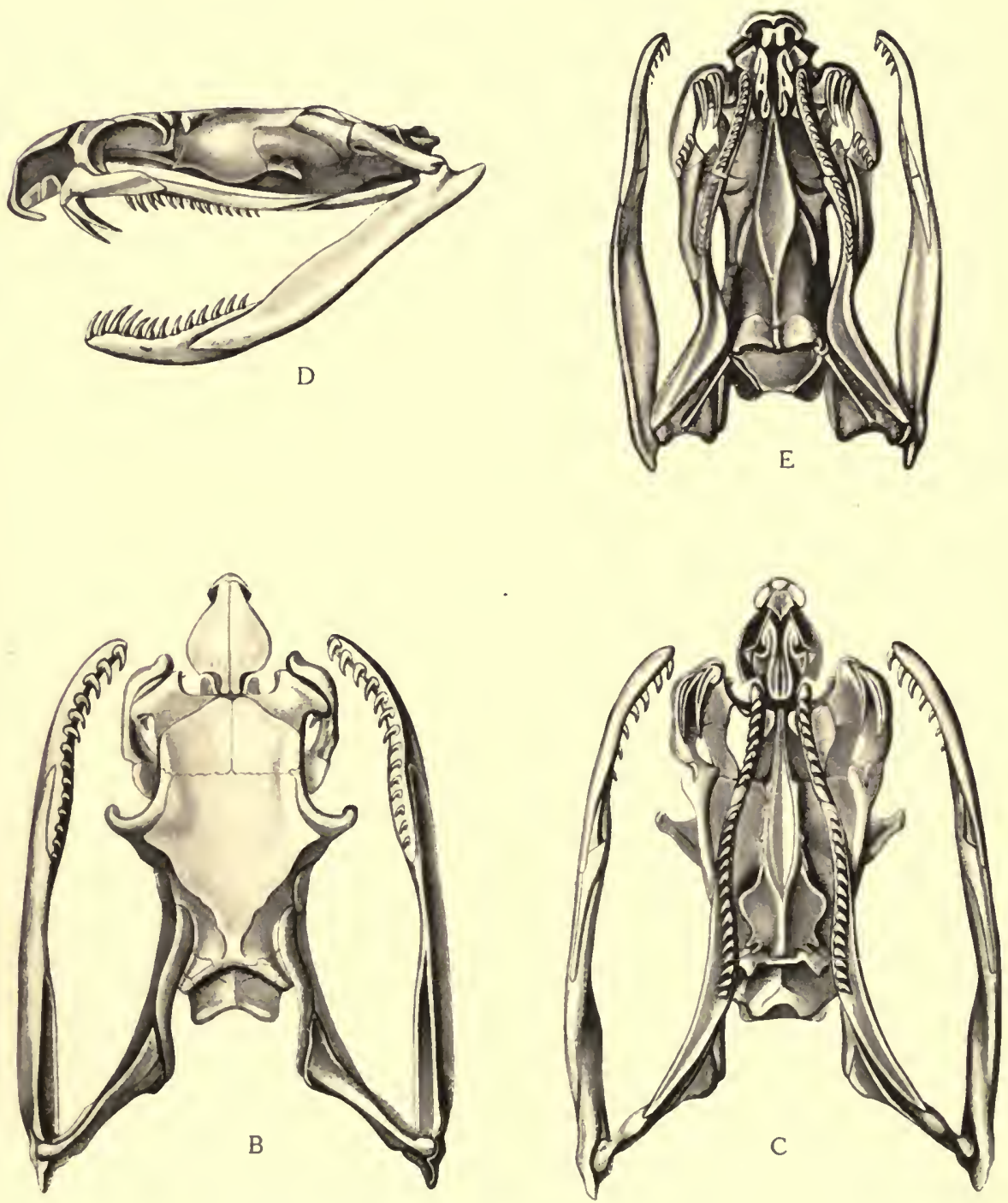

A, B, and C, Skull of Naja tripudians. D and E, Skull of Bungarus candidus. (Drawings from Boulenger’s Book.) 


$$
\text { . }
$$


Noguchi

Plate 4

A 


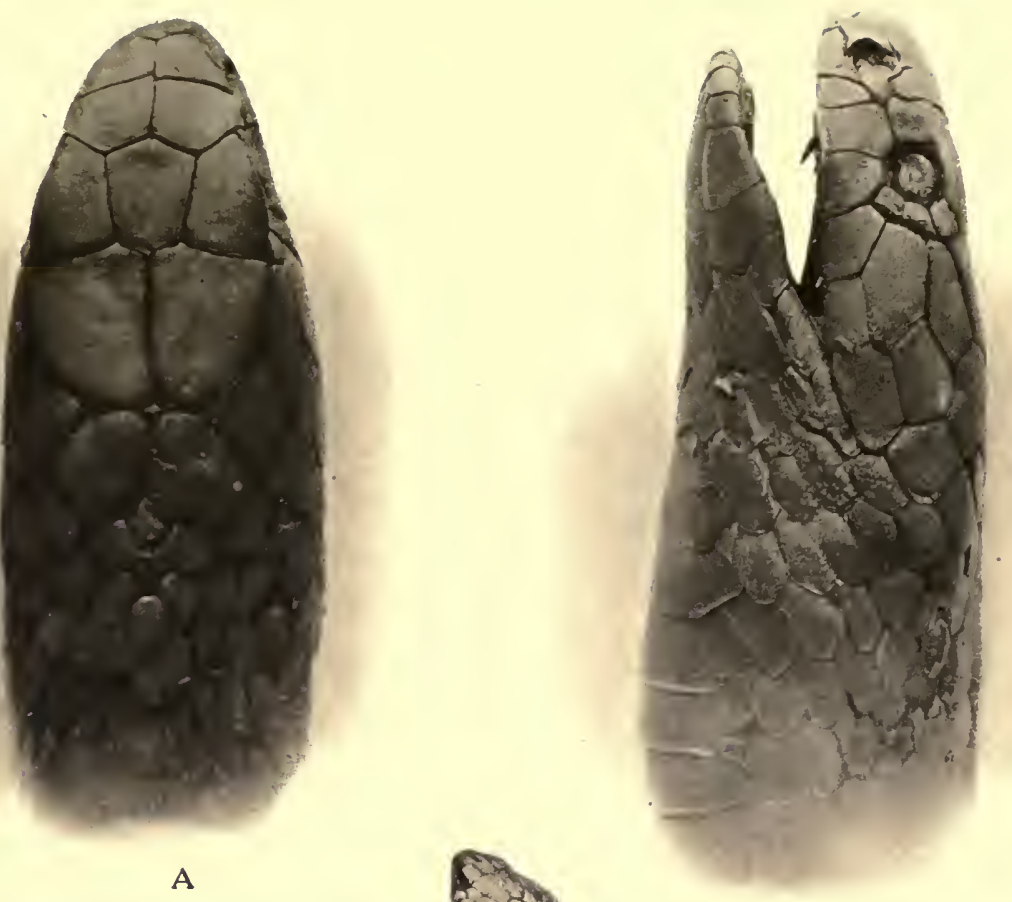

A

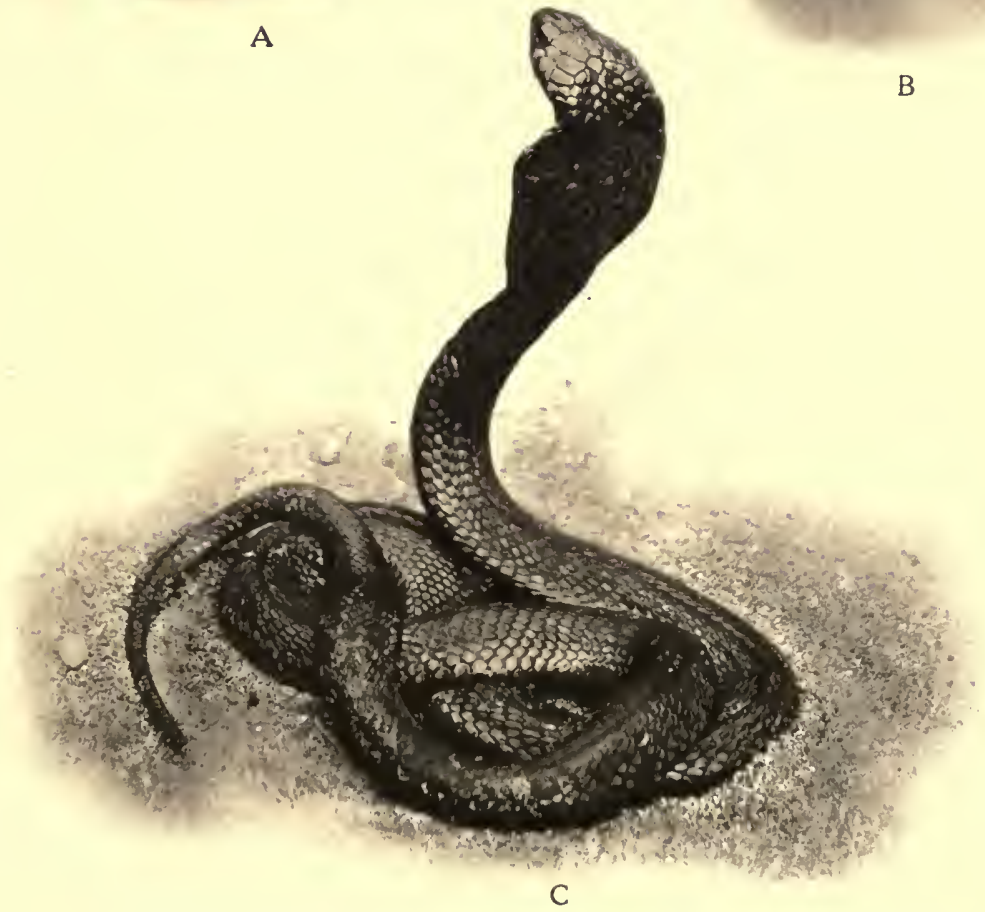

A and B. Photographs of Head of Naja bungarus (King Cobra), from Dead Specimen. C. Photograph of Naja haje (Egyptian Cobra), from Live Specimen. 
Elapechis guentheri.

Color whitish or gray above, with black crossbars; belly whitish or brownish, or gray. Total length about I.5 feet. Gaboon, Congo, Angola, central Africa.

Elapechis niger.

Whole body black. Not over 1.5 feet in length. Inhabits Zanzibar.

Elapechis hessii.

Color gray with black crossbars; belly white. Total length about 5 inches. Congo.

Elapechis decosteri.

Color dark gray; each scale has a black margin; belly white. Total length about I foot. Delagoa Bay.

Elapechis sundevallii.

Reddish color with yellow transverse bands; scales bordered with brownish red margin; upper lip and belly yellow. Total length $I .5$ to 2 feet.

Elapechis boulengeri.

Back black with tiny white crossbands; head white, belly grayish-black. Total length only 5 to 6 inches. Inhabits Zambesia.

\section{Genus ASPIDELAPS Fitzinger.}

The maxillary bone is farther advanced than the palatine bone, as in Sepedon, with a pair of very large poison fangs, besides which there are no teeth on maxilla. Head slightly distinct from neck. Moderate-sized eyes with round or vertical pupil. Body cylindrical. Scales oblique and keeled in 19 to 23 rows. Ventrals rounded off. Tail short and obtuse. Subcaudals in two rows.

Aspidelaps lubricus.

Orange or red with black rings; top of head sometimes completely black. Total length about 2 feet. Cape and Namaqualand.

Aspidelaps scutatus.

Pale gray with black specks or crossbars; head has a black curved ( ) mark; black collar around neck; belly whitish. Total length about I.5 to 2 feet. Natal, Delagoa, Mozambique.

\section{Genus WALTERINNESIA Lataste.}

The maxillary bone surpasses the palatine bone in length. It carries a pair of very powerful poison fangs, but no other maxillary teeth. Head and neck distinct. Eyes very small, with a round pupil. Body cylindrical. Scales somewhat keeled and in 23 rows; the subcaudals in two series. The tail is short.

Walterinnesia ægyptia.

Dorsal side blackish-brown; belly light in degree. This snake may grow 3.5 to 4 feet long. Egypt.

\section{Genus DENDRASPIS Schlegel.}

The maxillary bone is curved at the base, and carries a pair of strong poison fangs. No other maxillary teeth. A long terminal tooth on each mandible. Head narrow, elongate; eyes moderate in size, with round pupils. Body slightly compressed; scales narrow, and very oblique, in $\mathrm{I}_{3}$ to 25 rows. Tail long; subcaudals in two rows.

\section{Dendraspis viridis.}

Color uniform olive green; head black; lip yellow; belly and tail yellow, with scales and plates bordered black. Total length about 6 feet. Western Africa, Senegal, St. Thomas Island. 
Dendraspis jamesonii.

Same coloration, with I $_{5}$ to I9 rows of scales; tail sometimes black. Total length somewhat over 6 feet. Western Africa, Guinea to Angola, central Africa.

Dendraspis angusticeps.

Color uniform green, olive, or blackish; belly yellowish or light green. Total length 6 to 7 feet. Western Africa south of Congo; central Africa; eastern Africa; Transvaal; Natal.

\section{Dendraspis antinorii.}

Color olive above, yellowish beneath. Total length 8 to 9 feet. Abyssinia.

\section{Genus OGMODON Peters.}

The maxillary bone, which is more prolonged than the palatine bone, carries, beside the poison fangs, 6 to 7 grooved reserve teeth. Eyes very small, head not distinct from body. Body cylindrical with smooth scales in I7 rows. Tail short. Subcaudals in two series.

Ogmodon vitianus.

Pointed snout. Color dark brown, lighter on sides; belly white or slightly spotted with black; tail black. Total length about I.5 feet. Fiji Islands.

Genus GLYPHODON Günther. (Plate 7, A, B, c.)

The general character like Ogmodon. Snout rounded off. The poison fangs are followed by small posterior maxillary teeth with an interspace between them. Head and eyes small; pupil round or slightly vertically elliptical. Body cylindrical, the scales in 17 rows. Tail short, subcaudal in two series.

Glyphodon tristis.

Color dark brown above, occiput yellowish or pale brownish-red, belly yellow. Total length about 3 feet. Northeast of Australia, southeast of New Guinea.

Genus PSEUDELAPS Duméril and Bibron.

Maxillary bone is longer than palatine bone and carries a pair of large poison fangs, which, after an interspace, are followed by 8 to i 2 small teeth towards rear. Anterior mandibular teeth almost as large as the poison fangs. Head and neck not very distinct. Eyes small, vertical pupil. Body cylindrical. Scales smooth, in $I_{5}$ to 17 rows. Tail moderate or short, subcaudals in two rows.

Pseudelaps muelleri.

Color brown with a light vertebral line; the clear band of each side of head crosses over the eyes; belly yellowish or coral-red, with or without black specks. Total length about I.5 feet. Malay Archipelago (Dutch), New Guinea, New Britain.

Pseudelaps squamulosus.

Color brown with yellowish band around snout and between the eyes; belly whitish with black specks, which join and form blackish line on each side. Total length about I.5 feet. New South Wales.

Pseudelaps krefftii.

Color dark brown with a longitudinal line on each scale; yellow transverse band on occiput, passing over to another yellow band around muzzle; belly whitish anteriorly and black in posterior portion. Total length about 8 inches. Queensland.

Pseudelaps harriettæ.

Color brown with a longitudinal black line on each scale. Total length about I.5 feet. Queensland. 


\section{Pseudelaps diadema.}

Color pale brown with a brown net on each scale and a yellow transverse band on occiput; belly uniformly white. Total length about 2 feet. North, East, and West Australia.

\section{Pseudelaps warro.}

Same characteristics as diadema, but with large black collar around neck; top of head black, but not so black as collar. Port Curtis, Queensland.

\section{Pseudelaps sutherlandii.}

Same characteristics as above, except certain color variations. This also has a spectacle-shaped collar on neck. Norman River, Queensland.

\section{Genus DIEMENIA Gray.}

The maxillary bone surpasses the palatine bone and carries a very well-developed pair of poison fangs, behind which are 7 to ${ }_{5} 5$ smaller teeth with wide interspaces between them and the fangs. The anterior mandibular teeth are elongated and present the appearance of poison fangs. Head and neck slightly distinct. Eyes quite large with round pupil. Body cylindrical with I $_{5}$ to I9 rows of scales on back. Tail is moderate, subcaudals usually in two rows. Color very variable, yellowish, olive, brownish-red, and brown. Medium length about 3.5 to 5 feet. Southeast of New Guinea and Australia.

The following species of Diemenia exhibit the characteristics noted: psammophis, torquata, and olivacea have I5 rows of scales; modesta has I9 rows, as have also textilis, the "Brown" snake, and nuchalis.

\section{Genus PSEUDECHIS Wagler.}

The maxillary bone surpasses the palatine bone markedly, and carries a large pair of poison fangs, followed by two to five smaller solid teeth in the rear. Anterior mandibular teeth long. Head more or less distinct from neck. Eyes rather small, with round pupil. Body cylindrical. Scales smooth, in 17 to 23 rows, having a few more rows on the neck, though the latter is not, or only slightly, dilated. Tail moderate, the subcaudals partly in double, partly in single series. Total length about 6 feet or even longer. Australia and. New Guinea. Eight species in this genus.

Pseucechis porphyriacus. (Plate 8, A.)

Back black with anterior row of red scales; belly reddish with black edges.

Pseudechis cupreus.

Color copper above, brown or orange beneath; all the plates and scales blackrimmed.

\section{Pseudechis ferox.}

Muzzle greatly rounded off. Scales on body in 25 rows. Dorsal color black, yellowish on under side.

Besides the above named, the following species of Pseudechis have the color characteristics noted:

$P$. australis, back pale brown; belly yellowish.

$P$. darwiniensis, brownish-red; head pale brown; belly light yellow.

$P$. papuanus, uniformly black, but chin white.

$P$. scutellatus, dark brown above; muzzle pale brown or yellowish; belly yellow.

P. microlepidotus, dark brown above; belly grayish-yellow; head blackish.

\section{Genus DENISONIA Krefft.}

Maxillary bone projecting beyond palatine bone, with a pair of large poison fangs followed by 3 to 5 smaller teeth. Anterior mandibular teeth pretty well 
developed. Head distinct from neck. Small eyes, usually with round pupil; some pupils vertical. Body cylindrical. Scales smooth, in 15 to I9 rows. Tail moderate or short. Subcaudals in one single row except one species. Boulenger enumerates 2 I species of Denisonia.

\section{Denisonia superba.}

Brown or salmon color, belly yellow or olive-gray. Length about 3.5 feet. New South Wales, central Australia, Tasmania.

\section{Denisonia coronata.}

Olive color with black band on each side of head; belly yellow or pale olive. I.5 feet long. Western Australia, New South Wales.

Denisonia coronoides.

Color brown; yellow lip; belly olive-gray or salmon. Length about I.5 feet. southern Australia; Tasmania.

Danisonia muelleri.

Color brownish-gray; lip and chin yellow; belly gray. Length about a foot. Queensland.

\section{Denisonia frenata.}

Scales in I9 rows. Color olive-brown; upper lip yellow; belly white. Length about I.5 feet. Lake Elphinstone and Queensland.

Denisonia ramsayi.

Color olive-green; belly yellow; subcaudals black. Length about a foot. New South Wales.

Denisonia signata.

Color greenish-brown; head brown; belly gray or white. Length 2 to 2.5 feet. Queensland and New South Wales.

Denisonia dæmelii. land.

Color olive; head more intense; belly yellow. Length about I.5 feet. Queens-

\section{Denisonia suta.}

Pale olive color; head deeper brown; belly yellow. Length about 7 inches. Middle Australia.

Denisonia frontalis.

Light brown color; black vertebral line; belly pearl-white, with bronze-colored median band. Length about I.5 feet. New South Wales.

Denisonia flagellum.

Color pale brown; occiput and neck black; belly white. Length about I.5 feet. Victoria.

\section{Denisonia maculata.}

Color brownish-gray or brown; head covered with large dark olive-green or brown speckles; belly grayish. Length about I.5 feet. Queensland.

Denisonia punctata.

Pale brown color; head and neck orange; lower lip and belly yellow. Length about a foot. Northwestern Australia.

Denisonia gouldii.

Color brownish-yellow; neck white; head covered with large greenish-blue speckles from nose to neck; lower lip and belly yellow. Length I.5 feet. Southwestern Australia. 
Denisonia nigrescens.

Color deep olive; head black; belly yellow. Length about 1.5 to 2 feet. New South Wales and Queensland.

Denisonia nigrostriata.

Yellow color with black stripes; head dark brown; upper lip and belly yellow. Length ahout I.25 feet. Queensland.

Denisonia carpentariæ.

Brown color; upper lip and belly yellowish-white. Length 8 inches. North Queensland.

Denisonia pallidiceps.

Color deep brown-olive; head usually very light; belly yellow. Length about 2 feet. North Australia.

Denisonia melanura.

Dark brown color; head and side of body red; tail black; belly yellow. Length about 3.25 feet. Solomon Islands.

Denisonia par.

Color brownish-red in large bands over body, with white intervals; head brown; belly white; tail with red bands. Length about 2.5 feet. Solomon Islands, Straits of Bougainville, and neighboring islands.

Denisonia woodfordii.

Color light brown, with reticular pattern; head dark brown; belly white. Length about 2.25 feet. New Georgia, Solomon Islands.

\section{Genus MICROPECHIS Boulenger.}

Maxillary bone extending forward as far as the palatine, with a pair of large poison fangs followed by three small solid teeth; anterior mandibular teeth longer. Head distinct from neck; eyes very small and with round pupil. Body cylindrical; smooth scales, in $5_{5}$ to I $_{7}$ rows. Tail short; subcaudals in two rows.

Micropechis ikaheka.

Color yellow and black on transverse bars; head and tail black; belly yellow. Length 4.5 to 5 feet. New Guinea.

Micropechis elapoides.

Color cream, with 22 black bands which are larger than the white interspaces which separate the former. Length about 2.5 feet. Florida Islands, group of Solomon Islands.

\section{Genus HOPLOCEPHALUS Cuvier.}

Same characters as Micropechis. The scales in 2I rows. Ventrals angulate and notched laterally. Tail moderate, subcaudals in one row.

Hoplocephalus bungaroides s. variegatus.

Color black above with yellow speckles forming irregular crossbands on body; upper lip yellow; belly whitish-yellow, and yellower on sides. Length about 6 feet. New South Wales.

Hoplocephalus bitorquatus.

Ventral scales very angular. Color olive-green; head pale olive with bright yellowish occipital speckle, and two black spots and some smaller spots between and around the eyes; belly olive-gray or brown. Length about I.75 feet. Queensland, New South Wales.

Hoplocephalus stephensii.

Alternative transverse bars of white and black, the black twice larger than white. Head dark, a yellowish W-spot on neck. Length 2.5 feet. Port Macquarie, New South Wales. 


\section{Genus TROPIDECHIS Gïnther.}

Same characters as Hoplocephalus and Micropechis. Scales of trunk more keeled in 23 rows. Tail moderate; subcaudals in one row.

Tropidechis carinata.

Dark olive with darker transverse bands; belly more or less olive-green or yellow. Length about 2.5 feet. New South Wales, Queensland.

Genus NOTECHIS Boulenger. (Plate 8, в.)

Maxillary extending forward as far as the palatine, with a pair of large, grooved poisoned fangs followed by 4 or 5 small, feebly grooved teeth; mandibular teeth, anterior longest and feebly grooved. Head distinct from neck, with distinct canthus rostralis; eye rather small, with round pupil; nasal entire; no loreal. Body cylindrical, but scales of trunk are smooth and oblique, in $I_{5}$ to $\mathrm{I}_{9}$ rows. Lateral scales shorter than dorsal. Tail moderate, subcaudals in single row.

Notechis scutatus s. Hoplocephalus curtus.

This famous snake, known as "Tiger snake," has dark-olive color; belly yellow or olive; scales have often dark rim, in I5 to I9 rows, which are smooth. The olive color of the body is often crossed with dark bands.

\section{Genus RHINHOPLOCEPHALUS F. Müller.}

Dentition same as Hoplocephalus. Head and neck little distinct. Eyes small with round pupil. No internasals. Body cylindrical, rigid, and smooth scales in ${ }_{5}$ rows. Tail is short, subcaudal in one single row.

Rhinhoplocephalus bicolor.

Olive-gray color above, whitish-yellow on belly; white tongue. Length about I:25 feet. Australia.

\section{Genus BRACHYASPIS Boulenger.}

Same characteristics as above, but head distinct from neck; eyes small and have a vertical pupil. Body stout and cylindrical. Scales smooth, slightly oblique, in rg rows. Tail short, subcaudals in one row.

Brachyaspis curta.

Uniform brown-olive color, with yellowish belly. Length about 1.5 feet. Western Australia.

Genus ACANTHOPHIS Daudin. (Plate 8, c.)

The "death adder" has a maxillary bone equaling the palatine in length, and the former carries a pair of large poison fangs, followed by a series of two or three small teeth in the rear. The anterior mandibular teeth are so elongated as to appear like the fangs. Head distinct from neck. Eyes small with vertical pupil. Body short and thick, covered with 2I to 23 rows of keeled scales. Anterior caudals in one and the posterior in two rows. Tail peculiar in form, being laterally compressed, with a thin, horny, terminal spine. This snake is viviparous.

Acanthophis antarcticus.

This is the real "death adder," the type of this genus. The colors of the upper parts are a mixture of brown, reddish, and yellow, often spotted with black or brown. End of tail yellow, reddish-brown, or black. Length under 3 feet. Moluccas, New Guinea, Australia.

\section{Genus ELAPOGNATHUS Boulenger.}

The maxillary bone surpasses the palatine bone, with a pair of fairly developed poison fangs, but no other teeth; mandibular teeth of equal length. Eyes moderate, the pupil round. Body cylindrical and covered with ${ }_{5}$ rows of smooth scales. Tail moderate, the subcaudal in one row. 


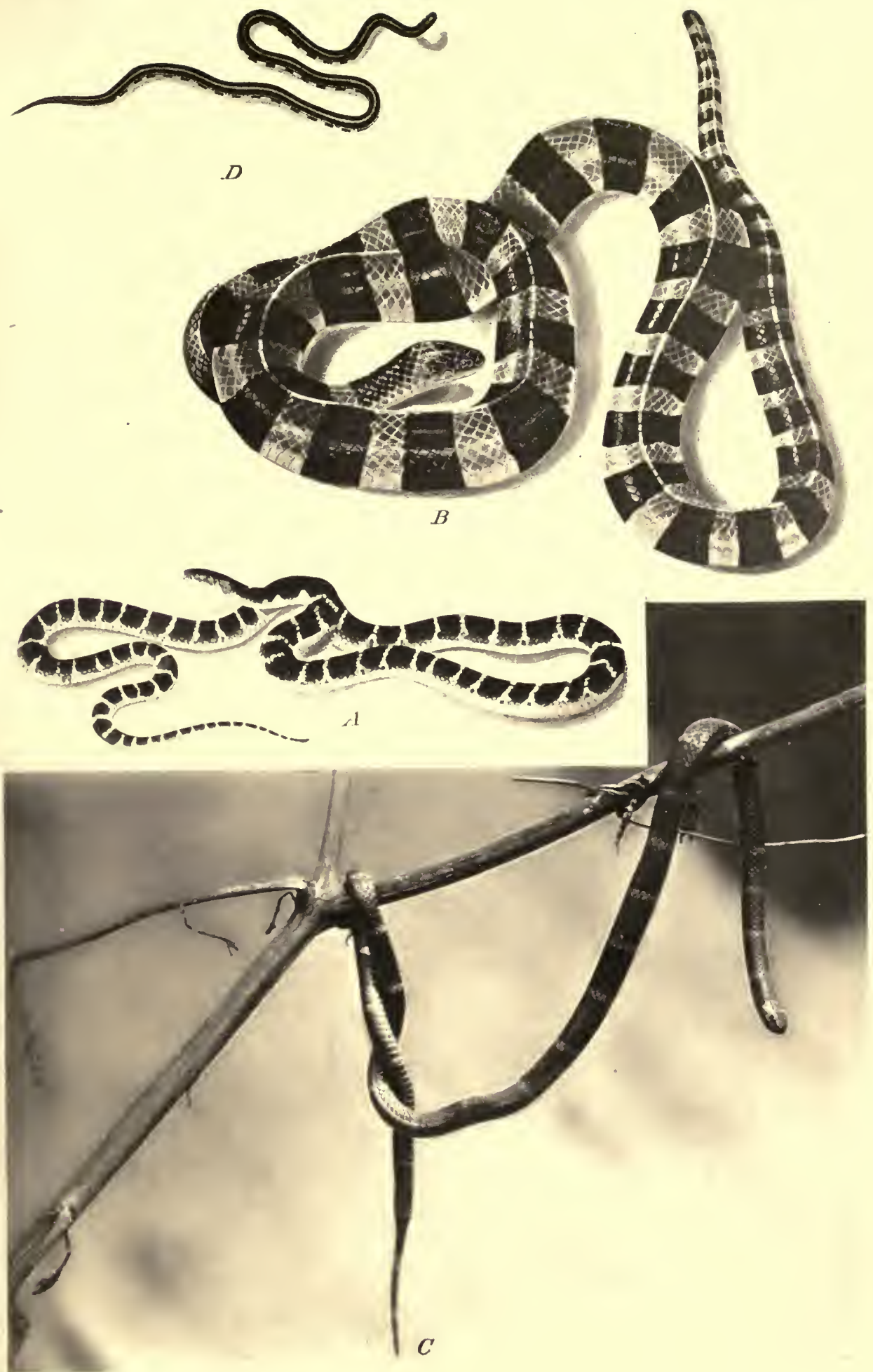

A, Bungarus candidus (Common Krait). B, Bungarus fasciatus (Banded Krait). C, Elaps fulvius (Coral Snake). D, Callophis.

(A, B, and D, Photographic Reproductions from Fayrer's Thanatophidia; C, Photograph from Live Specimen.) 



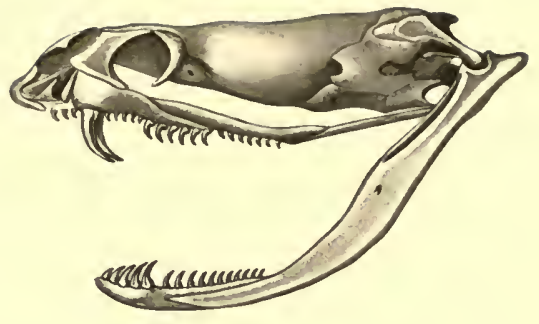

A
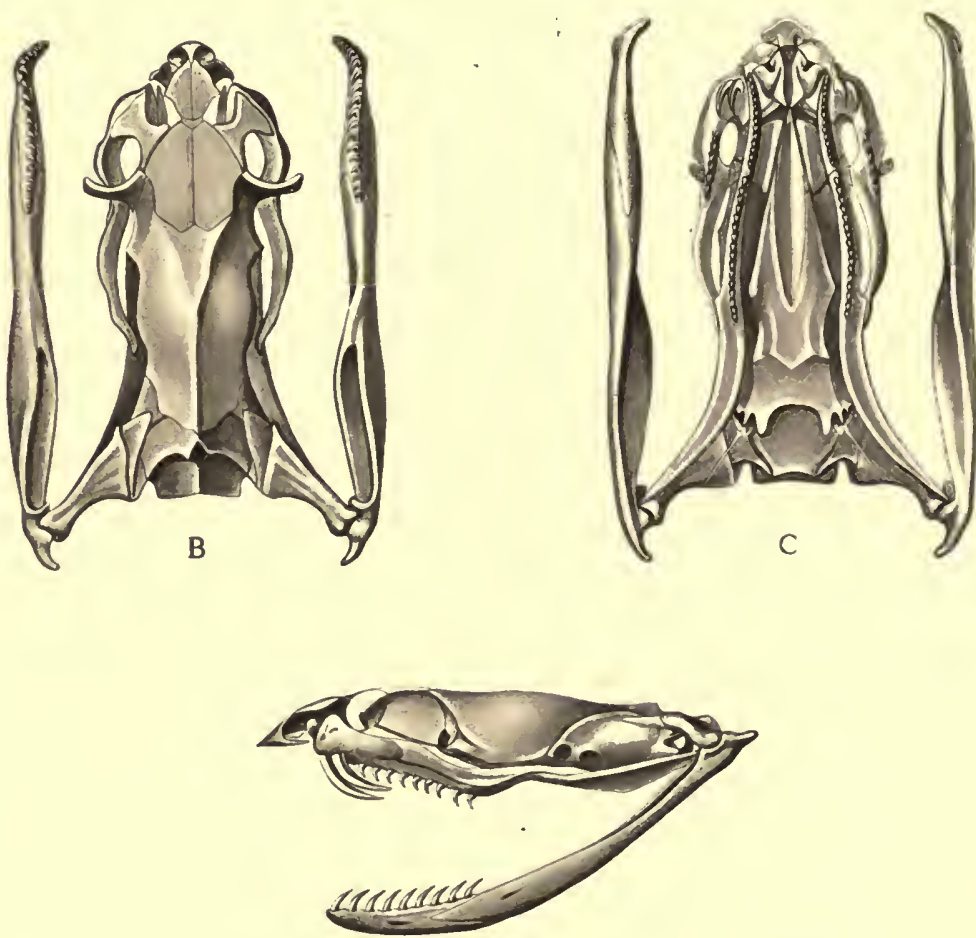

D
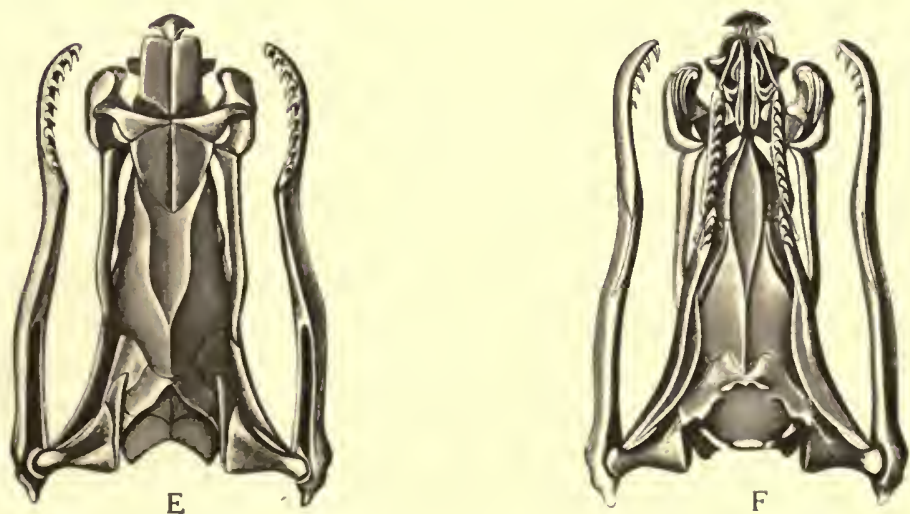

A, B, and C, Skull of Glyphodon tristis. D, E, and F, Skull of Elaps marcgravi.

(Drawings from Boulenger's Book.) 


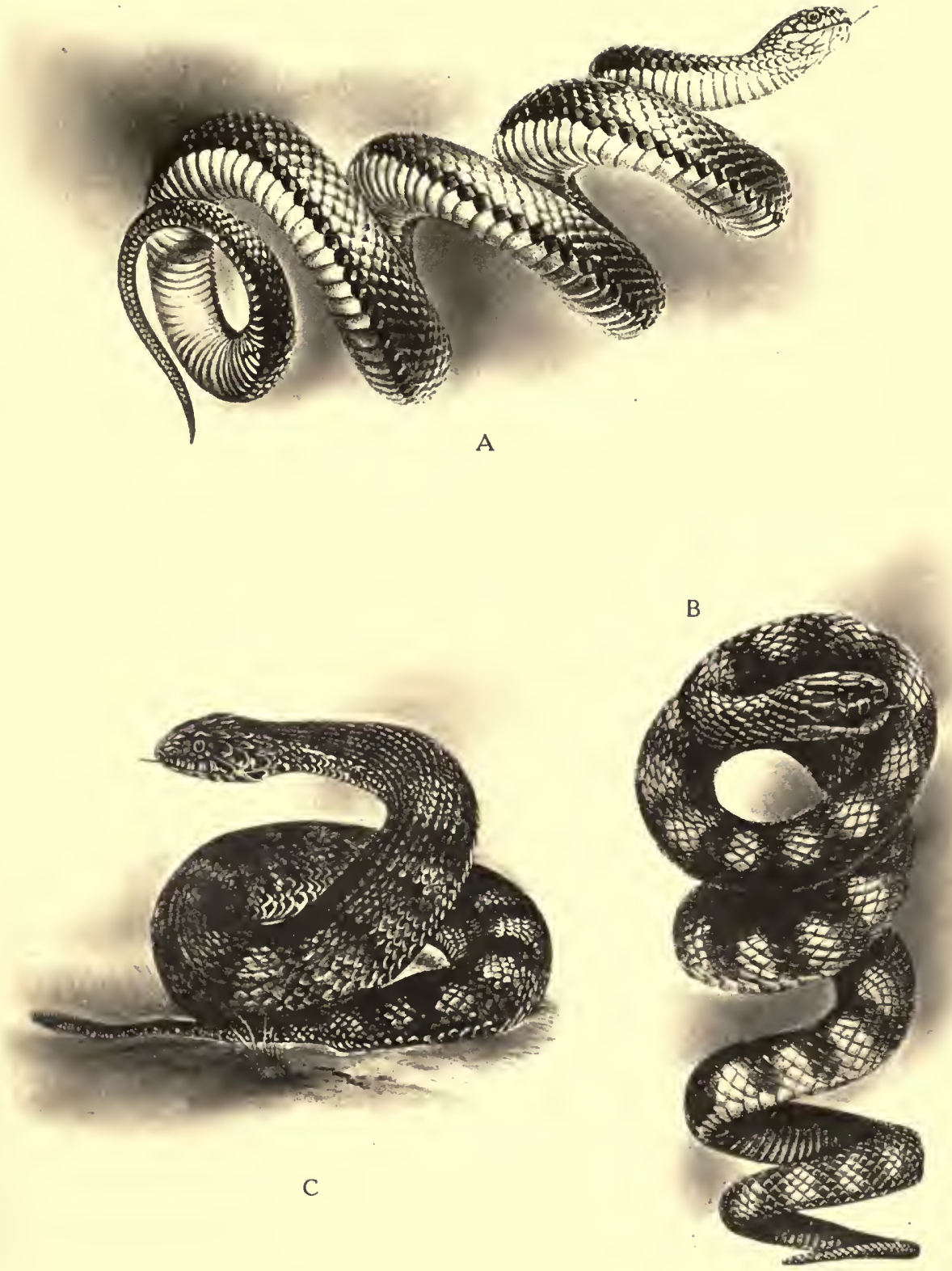
A, Pseudechis porphyriacus.
B, Notechis scutatus.
C, Açanthophis.

(Photographic Reproductions from Krefft's Book.) 



\section{Elapognathus minor.}

Dark olive color with a black occipital spot in young specimens; belly yellow or greenish-gray. Length about I.5 feet. Southwestern parts of Australia.

\section{Genus RHYNCHELAPS Jan.}

Maxillary bone surpasses palatine, with a pair of poison fangs of medium dimension, followed by a wide interspace as far as the two small teeth at extremity of bone. Anterior mandibular teeth longer than posterior. Head small and indistinct from neck. Eyes small with vertical pupil. The short, cylindrical body has 15 to I 7 rows of smooth scales. Tail very short. Subcaudals in two rows.

\section{Rhynchelaps bertholdi.}

Yellow, with ig to 40 ordinary black rings narrower than interspaces. The head is more of a brown color and has one large black spot.

\section{Rhynchelaps australis.}

Color red above with irregular transverse bars consisting of black-rimmed yellow scales; belly white. Length about a foot. Queensland.

\section{Rhynchelaps semifasciatus.}

Color yellow above with brown crossbands; large brown speckle on head; belly white. Length about a foot. Western Australia.

\section{Rhynchelaps fasciolatus.}

Color red above with numerous black-brown crossbands; large brownish-black speckles on head. Length about a foot. Western Australia.

\section{Genus FURINA Duméril and Bibron.}

The maxillary bone surpasses the palatine, carries a pair of medium-sized poison fangs and one or two small teeth near posterior end of bone. Mandibular teeth almost equal in length. Head is small and indistinct from neck. Eyes very small with a round pupil. Cylindrical body, covered with ${ }_{5}$ rows of smooth scales. Tail very short; subcaudals in two rows.

Furina calonota.

Color yellow, with black vertebral ray; black bar crosses extremity of muzzle; a large black spot covers top of head; belly white. Length about 7 inches. IVestern Australia.

\section{Furina bimaculata.}

Color yellow, with large black spots on nose, on middle of head, and the occiput; belly white. Length about I.25 feet. Western Australia.

\section{Furina occipitalis.}

Black and white bands all over body, narrower on belly; head black with wide white band on occiput and narrower white band on muzzle; nose black. Length about 2 feet. Australia.

\section{Genus ELAPS Schneider. ${ }^{1}$ (Frontispiece; Plate 7, D, E, F.)}

The maxillary bone is rather short and protrudes beyond the palatine, carrying a pair of large poison fangs; only a few or no pterygoid teeth; mandibular teeth of equal length. No postfrontal bone; the prefrontals unite on the median line. Head small, not distinct from neck. Eyes small with vertical pupil, which is elliptical or semi-elliptical. Body cylindrical, with 15 rows of smooth scales. Subcaudal scales partly in one, partly in two, or throughout in two rows. The rather elongate body, short tail, and small eyes render it difficult to discriminate these from the calamarine snakes without examining the dentition. The scutellation 
of the head is exactly that of Tantilla. Coloration bright, consisting of red and black, with some yellow, arranged in rings or parts of rings. The red is generally the ground-color, and the black rings are either single or in sets of three. The latter may be much narrower than ground-color, or may be so wide as to reduce it to very small proportions (Elaps semipartitus). Epidermis beautifully iridescent, especially in the black spaces. The colors are much like those of the mineral labradorites, and are probably due to the same physical cause, namely, a microscopic lamination of the surface (Cope). On direct antero-posterior view the color is peacock purple; on transverse view it passes from brassy yellow through brassy green to maroon and brown. The colors do not appear if the scales are wet. As to the dangerous character of the coral snakes, all suspicion of doubt has been removed by the many fatalities arising from careless handling of these snakes. The alleged non-dangerousness or even innocuousness of the coral snakes has its origin in the mistaken identity of the snake, as their general appearances are hardly distinguishable from many truly non-poisonous American snakes - for example, Ophibolus ("scarlet king snake," O. doliatus; "red king snake," O. coccineus; O. annulatus, "ringed king snake," etc.), and Osceola elapsoidea; the "scarlet snake," Cemophora coccinea; Rhinochilus lecontei. One fundamental difference in the color-arrangement seen in the species of Elaps within the United States boundary and that in Ophibolus, Osceola, and Cemophora, is that in our Elaps black rings are bordered on each margin by a yellowish ring, while in the others the yellow rings are bordered on each side by a black ring.

Red - yellow - black - yellow - red (Coral snake).

Red - black - yellow - black - red (Ophibolus and the like).

Elaps fulvius. ${ }^{1}$ (Plate 6, c.)

This species is known as the "harlequin snake." Color above, red; yellow and black rings; tail yellow and black rings; nose black. Length 3.25 feet. Eastern parts of Southern States of North America, boundary of Ohio and of Missouri down to Rio Grande, Mexico, Central America.

Elaps euryzanthus.

This is known as the "Sonora coral snake." Color red with II yellow-rimmed black rings. Length about 1.25 feet. Arizona and Colorado, northwestern parts of Mexico; in Arizona even at an altitude of 5,500 feet.

Elaps marcgravii.

Six to ro black rings, the middle ones being larger. Muzzle yellow, nose black; occipital black. Length about 3.5 feet. Tropical South America.

Elaps heterochilus.

Like E. marcgravii. Length I.6 to 2 feet. Brazil.

Elaps surinamensis.

Seven or 8 series of tricolored rings. Length 2 to 3 feet, but can attain a length of 6 feet. Venezuela, Guiana, northern part of Brazil, northeast of Peru.

\section{Elaps gravenhorstii.}

Seven series of tricolored rings. Length under 2 feet. Brazil.

Elaps langsdorfii.

Dark-brown color with 63 cross series of cream spots, each occupying one scale; belly yellow with red crossband. Length about I foot. Upper Amazon.

\footnotetext{
1 An account of the dangerous effect of the bites of this species was given by Einar Loennberg, Proc. U. S. Nat. Mus., I 894 , XVII, 334. See also Cope, I898, I I23. The habits of the coral snake are admirably described by Ditmars, The Reptile Book, 1907, 397.
} 
Elaps buckleyi.

Orange color with yellow spots; head black; temple yellow. Length about 1.6 feet. North Brazil and East Ecuador.

Elaps anomalus.

Fifty-five black rings separated by narrow yellow bands; belly reddish; tail yellow or red with four black rings. Length about a foot. Colombia.

Elaps heterozonus.

Red or brown color with 17 to 25 black rings which are narrower than intermediary spaces; the black band on the head transverses the eyes. Length about 3.6 feet. Eastern Ecuador; eastern Peru; Bolivia.

Elaps elegans.

The black rings of the tricolor series are separated by yellow spaces; 12 to 17 series; head black with yellow spots. Length about 2.5 feet. Mexico and Guatemala.

Elaps annellatus.

Black color with 4 I to 49 white rings on body, including 4 to 7 on tail; white ring on head. Length about r.6 feet. Eastern Peru.

Elaps decoratus.

Fifteen to 16 series of the three black rings on red; the liead yellow with black crossband over eyes. Length about 2 feet. Brazil.

Elaps dumerilii.

Eight to 9 series of black rings on red and yellow; head black with one yellow crossband over occiput.

Elaps corallinus.

The "serpent corail." The black band is separated by a red space with yellow edge; head bluish-black, and a blue line from rear of eye to lower jaw; tail white. Length about 2.6 feet. Tropical South America; St. Thomas, St. Vincent, Martinique.

Elaps hemprichii.

Black with red and yellow rings, a large ring between two narrow ones; occiput, upper lip, and temple yellow. Length about 2.5 feet. Guiana, Colombia, and Peru.

Elaps tschudii.

Black rings with larger spaces in series; the interspaces red and yellow; muzzle black. Length about I.5 feet. Peru.

Elaps dissoleucus.

Same coloration. Length 3.25 feet. Venezuela.

Elaps psyches.

Alternative rings of black and brown with 48 to 52 narrow yellow rings: head black with yellow spots. Length about 1.6 feet. Guiana.

Elaps spixii.

Twenty to 38 black rings of the tricolor series; an occipital collar of black is followed by a spacious red band. Length about 5 feet. Venezuela, North Brazil. Elaps frontalis.

Coloration regular; red, yellow, black series; head spotted yellow on black. Length about 5 feet. Central Brazil, Paraguay, Uruguay, and Argentine Republic. Elaps lemniscatus.

Eleven to I4 series of black on red and yellow ground; head yellow, nose black; a white band on middle of head crosses the eyes. Length 3.5 feet. Guiana and Brazil. 
Elaps filiformis.

Almost the same as Elaps lemniscatus, this species is characterized by the black muzzle and black band over the yellow head. Length about 2 feet. Amazon and Colombia.

Elaps mipartitus.

Black with 40 to 60 narrow white rings; head black between the eyes, the rest yellow. Length about 2 feet. Central America, tropical South America.

Elaps fraseri.

Black with 75 narrow white rings. Length about 2.5 to 3 feet. Ecuador. Elaps mentalis.

Body black with $5^{8}$ to 70 narrow white rings; tail annulated black and yellow. Length about r.6 feet. Colombia and Ecuador.

Elaps ancoralis.

Sixteen black rings of series; the middle ring of a series is larger; black spots; the head has an anchor pattern. Length 2.5 to 3 feet. Ecuador.

Hydrinæ Stejneger.

Subfamily HYDROPHIIN E Boulenger.

In adopting the aquatic or marine life these sea snakes have undergone considerable morphological changes. The most remarkable features are the highly compressed, oar-blade-like tail and the narrowly tapered upper part of body, which is in some cases strongly compressed laterally throughout the entire length. As a rule the posterior part of the body is enormously enlarged and presents rather a characteristic appearance in contrast with the tiny anterior part. Head not wider than neck. Eyes small with round pupils. The nostrils are situated on top of the snout and are provided with valves. The tail is prehensile and can keep the body afloat by seizing a polyp. The scales of the body are polygonal and are juxtaposed with short keels or knobs or spines, sometimes in pairs, and totally unlike the scales of other snakes. The ventrals are so reduced in width that they can hardly be recognized as such. The above-mentioned features are typical of the absolutely marine snakes, but in some species still partially terrestrial the ventrals are broader and keeled, and the snakes live near the shores, and occasionally or temporarily climb among the rocks or go ashore considerable distances from the landing-places. The tropical marine snakes can not crawl easily on the land, although agile in water. They survive in an aquarium only two or three days, mostly dying shortly after captivity. Owing to the large capacity of the lung they can dive very deep.

The Hydrophiinæ snakes are proteroglyphous and their poison is extremely powerful. They live on fish and are viviparous.

The geographical distribution of the sea snakes is not easily established, owing to the absence of definite boundaries and to the occasional conveyance from the native to a foreign place by currents. In general it may be stated that outside of the Atlantic Ocean all the tropical and subtropical seas are inhabited by the representatives of Hydrophiinæ. About 50 species are known.

Genus DISTIRA Lacépède. (Plate I, D, E.)

Poison fangs are large and followed by 4 to to small grooved teeth. Head is larger than Hydrophis. Body more or less flattened. Scales imbricated on anterior part of body, less distinct on ventral side, always small. The catalogue of the British Museum enumerates 18 species distributed in the Indian and Pacific Oceans, including from the Persian Gulf to Japan and around New Caledonia.

Distira ornata.

Uniform dorsal color gray; belly whitish. Length 3 to 4 feet. Persian Gulf, India, Ceylon, and Malay Archipelago and northern part of Australia. 
Distira subcincta.

Forty-one dark bands, separated by spaces the width of the bands. The bands stop in the middle of the side of the body; series of small black spots on sides. Length 3.2 feet. Indian Ocean.

Distira cyanocincta. (Plate 9, A.)

Greenish-olive with quite large black or dark rings on back; the belly has a black longitudinal band. Length 5 feet. Persian Gulf, India, coasts of China and Japan, Papuasia.

Distira jerdonii.

Olive above with black rings; between the rings black spots. Length 3 feet. Gulf of Bengal, Strait of Malacca, and Borneo.

\section{Genus ACALYPTUS Duméril and Bibron.}

The maxillary bone is longer than ectopterygoids, the head covered with scales behind. Body elongated. Western tropical Pacific Ocean.

Acalyptus peronii.

Gray or pale olive above, with white belly and dark bands. Length 3 feet. Hong Kong, western Pacific tropical zone.

\section{Genus HYDROPHIS Daudin. (Plate IO, A, B.)}

Maxillary longer than the ectopterygoid, not extending forward as far as the palatine; poison fangs large, followed by a series of 7 to 18 solid teeth. Head small; nostrils superior, pierced in a single nasal shield, which is in contact with its fellow; head-shields large; præocular present; loreal usually absent. Body very long, often very slender anteriorly; scales on the anterior part of the body, imbricate; ventrals more or less distinct; very small.

Indian and Pacific Oceans, from the Persian Gulf to Southern China and northern Australia.

\section{Hydrophis obscurus s. stricticollis.}

Dark olive-green with yellow bars which form rings in the compressed posterior part of body; yellow spots on muzzle and yellow bars on each side of head. Length about 3 feet. Gulf of Bengal; Malay Archipelago.

Hydrophis spiralis.

Olive above, yellowish beneath, with black rings; head black, with a horseshoeshaped yellow spot whose convexity rests upon prefrontal scales. Length 1.5 feet. Hydrophis cærulescens.

Color gray with coarse black bands, forming complete rings or interrupted annules on ventral surface; head uniformly black. Length about 2 feet. Coast of Bombay, Gulf of Bengal, Strait of Malacca.

\section{Hydrophis nigrocinctus.}

Pale olive above, yellowish on belly, with black rings which are larger beneath. Length 3 feet. Gulf of Bengal, Strait of Malacca.

\section{Hydrophis elegans.}

Pale yellow above, with black rhomboid cross-speckles separated by a black spot; black spots on belly; head covered with black, crossed by a light line from nose and eyes. Length about 2.5 feet. From Malay Islands to northern Australia.

\section{Hydrophis gracilis.}

Olive or bluish back with clear crossbands anteriorly, and rhomboid speckles reaching the belly or interrupted on the sides. Length 3 feet. Persian coasts, India, Ceylon, Malay Archipelago. 
Hydrophis cantoris.

Dark olive body, with yellowish bands above; posterior part of body olive above, yellow on sides; tail with vertical olive bands; blackish line throughout wholelength of belly. Length about 3.5 feet. Gulf of Bengal.

Hydrophis fasciatus.

Head and neck black; yellow crossbands on neck, body pale with black rings, which are wider near the back. Length 3.2 feet. Coasts of India, Cochin China, and Malay Archipelago.

Hydrophis leptodira.

Black with yellow streaks on neck, yellow rings on body. The streaks and rings number 77. Length about 1.6 feet. Delta of Ganges.

\section{Genus ENHYDRINA Gray.}

Two vigorous poison fangs are accompanied by 4 solid teeth. Body moderately compressed. Scales imbricated and distinct, but very small on belly. Color olive or gray with black crossbands; sides of belly white. From the Persian Gulf to New Guinea.

Enhydrina valakadien s. bengalensis. (Plate 9, B.)

Length about 3.5 feet. The male has stronger scales, keeled or tubercular. Gulf of Persia, coasts of India, of Cochin China, Malay Archipelago and Papuasia.

\section{Genus HYDRELAPS Boulenger.}

Muzzle short, scales of head large. Poison fangs are followed by 6 rear teeth. Body slightly compressed. Scales imbricated; ventral scales small, but well marked. North coast of Australia.

Hydrelaps darwiniensis.

Black and yellowish white rings, narrower near the belly; head dark olive with black spots. Length I.5 feet. Northern Australia.

\section{Genus HYDRUS Schneider.}

The maxillary bone of this genus is longer than the ectopterygoid and situated somewhat behind the palatine bone. The poison fangs are cannulated and rather short, followed by 7 or 8 solid teeth with a wide interspace between the fangs and the latter. Snout long. Body rather short; scales hexagonal or squarish, juxtaposed; no distinct ventrals. Indian and Pacific Oceans.

Hydrus platurus s. Pelamis bicolor Daudin. (Plate 9, C; plate Ir, A, B, C.)

Anguis platurus Linnæus, Syst. Nat., I 2 ed., I, 39r.

Hydrophis platurus Latreille, Nat. Hist. Rept., IV, 1802, 197.

Hydrus bicolor Schneider, Hist. Amph., I, 242.

Color black and yellow, with crossbands bordered with black. Length 2.5 feet. Indian Ocean, tropical and subtropical Pacific.

\section{Genus THALASSOPHIS Schmidt.}

Poison fangs followed by 5 small teeth. Snout short. Body rather elongate. Scales hexagonal and juxtaposed, ventral scales indistinct. Coast of Java.

Thalassophis anomalus.

Body with black bands, which are wider near back. Length about 3 feet. Java.

\section{Genus ENHYDRIS Merrem.}

Not Enhydris Latreille $=H y p$ sirhina Wagler.

Enhydris Merrem = Lapemis Gray, Ill. Ind. Zool II.

Lapemis hardwickii, type, Stejneger.

Two poison fangs and 2 to 4 slightly grooved small teeth; body short and thick; the scales, which are hexagonal or squarish, have almost completely disappeared from the belly. Coast of India to the Chinese Sea and New Guinea. 
Enhydris curtus. (Plate ${ }_{\lambda}^{\pi} 10, \mathrm{C}$.)

Dark crossbands, broader at middle of body; tail black. Length 2.5 feet. Coasts of India and Ceylon.

Another species of this genus is Enhydris hardwickii Gray.

Genus PLATURUS Latreille.

Laticauda Laurenti, Syn. Rept., rog.

Two large poison fangs and one or two small solid teeth near end of maxilla. Body very fringed. Scales united and imbricated on body, large on belly and tail. Four species along the eastern parts of Indian Ocean and west Pacific.

Platurus laticaudatus s. fischeri. (Plate $\mathrm{IO}, \mathrm{D}$.)

Olive with yellow belly; 29 to 48 black rings. Length 3.5 feet.

Platurus colubrinus. (Plate II, D, E.)

Olive color with 28 to 54 black rings. Length 3.5 to 4 feet.

Platurus muelleri.

Sixty-two rings. Only in subtropical central Pacific to New Hebrides and Tasmania.

\section{Genus AIPYSURUS Lacépède.}

Aipysurus Lacépède = Emydocephalus Krefft, type annulatus, Proc. Z. S. London, 1869, 321 .

Maxillary slightly longer than pterygoids; the poison fangs and 8 to to hollow teeth are separated by a short interval; the anterior mandibular teeth slightly longer. Body moderate, scales imbricated, ventrals large, and keeled at middle.

\section{Aipysurus australis.}

Brown or cream color, with brown spots forming more or less distinct crossbars. Length about 3.5 feet. New Guinea and Australia.

The species: Aipysurus eydouxii, annulatus, and lavis ${ }^{1}$ may be found along the coasts of Singapore, of Java, of the Philippines, and of Loyalty Islands.

\section{Family VIPERID $\approx$. Boulenger. ${ }^{2}$}

The maxillaries are very short, movably attached to the prefrontals and ectopterygoids, so that they can be erected together with the large poison fangs, which with the reserve teeth are the only maxillary teeth. The prefrontals are not in contact with the nasals. The squamosals are very loosely attached. The poison fangs are perforated, having a wide hole on the anterior side of the base, in connection with the large venom gland; the hole leads into a canal which opens gradually as a semicanal on the anterior surface of the distal third or quarter of the fang. As usual in poisonous snakes, several reserve fangs are stored away behind the acting fang. When the latter is broken off or has served its time it is cast off at the base, and the next reserve tooth takes its place. The supply of reserve fangs is indefinite, half-developed teeth down to mere germs constantly growing.

All of the Viperidæ are very poisonous, and all of them, except the African Atractaspis, are viviparous. They include the terrestrial, arboreal, semiaquatic, and burrowing types.

The family is found in every country except Madagascar and Australia.

1 This is Emydocephalus annulatus Krefft. Stejneger describes Emydocephalus ijima, which Boulenger thinks to be identical with Krefft's Emydocephalus annulatus. See Stejneger, Herpetology of Japan, 1907 .

${ }^{2}$ Includes Cobridæ and Crotalidæ of Stejneger and Atractaspididæ, Causidæ, Viperidæ, and Crotalidæ of Cope. 


\section{Subfamily VIPERIN $Æ$ Boulenger.}

Stejneger's Cobridæ. Cope's Atractaspididæ, Causidæ, and Viperidæ together.

There is no fossa in the external side of the maxillary bone, between the eye and the nose, as in Crotalinæ. The vipers are entirely restricted to the Old World, ranging over the whole of Europe, Africa, and Asia, except Madagascar. Their northern extension is limited only by the permanently frozen condition of the ground. Nine genera with about 40 species are known. The head and neck are distinct, covered with small scales, with or without frontal plates and parietals. Eyes small with vertical pupils. Body cylindrical. The scales keeled, with apical fossa, in from $\mathrm{I} g$ to $3 \mathrm{r}$ rows. Tail short, subcaudals in two rows.

\section{Genus VIPERA Laurenti.}

Vipera berus S. Pelias berus. (Plate I2, A.)

This is the common European viper. The upper jaw not turned at the end; scales of body form $2 \mathrm{I}$ rows. The coloration is very variable. Usually the gray, yellowish-olive, brown or red ground-color is set off by a dark zigzag band along the back. The belly is gray, brown, or black, or speckled. The end of the tail is usually yellow or red. Some males are black, through extension of the black marking or through darkening of the ground-color. Males usually are darker and deeper in black markings, with the ground-color lighter, and are mostly somewhat smaller than the females.

The viper prefers heaths, moors, and mixed woods with sunny slopes. Brambles, clumps of nettles, hedges, the edge of small copses, and heaps of stones, are favorite places of retreat, affording shelters, and being also the resorts of mice, which form its chief sustenance. At harvest time it is often found in cornfields, and it frequently hides in the sheaves of grain. Vipers are fond of basking on certain spots: on the top of stones, the stump of a tree or a strip of sand; a shower of rain or even passing clouds driving them back into their holes. They are nocturnal and a fire attracts them. They can not climb, and, if they can avoid it, do not go into water. They hibernate for about six months, and a number in the same place.

This species reaches a length of about 2 feet. It has a wide range, from the British Isles to Saghalien Island and from Caithness to the north of Spain, and the intermediary countries and districts. It ascends the Alps to an altitude of $6, \infty 00$ feet. In captivity it refuses to eat. Its food consists of small birds, frogs, lizards, and sometimes fishes. Its bite is sometimes fatal to human beings, and especially to children, but is not often so.

\section{Vipera aspis.}

The asp of the Mediterranean is a more southern and western European viper. The muzzle is slightly turned upwards. The top of the head is usually covered with small scales. The coloration is very variable: gray, yellowish, brown, or red above with zigzag band, usually a $U$ mark on the occiput, and longitudinal black bands from back of eyes; belly yellow, white, gray, or black, with a somewhat lighter space. Length 2 to 2.5 feet. France, southern parts of England, Pyrenees, Alsace-Lorraine, Black Forest, Switzerland, Italy and Sicily, Tyrol.

\section{Vipera ursinii.}

Color yellow or pale brown above, gray or dark brown on the sides, sometimes uniform brown, with more or less regular oval, elliptical, or rhomboid speckles; white stripe along vertebral column; two or three longitudinal series of speckles, dark brown or black on sides; chin and throat yellow; belly black with grayish or white cross series of spots. No sexual difference in coloration. Length about r.3 to r.6 feet. Southeastern parts of France, Italy, Istria, Bosnian mountains, plains of lower Austria, Hungary. 


\section{Vipera latastii.}

Gray or brown above, with a longitudinal zigzag band, usually speckled with white; head with or without speckle on top; black stripe behind eye; belly gray, spotted with black and white; tail yellow with yellow spots. Length about 1.6 to I.8 feet. Spain and Portugal, North Africa.

\section{Vipera ammodytes.}

The upper jaw turns up into a horny appendix. Color gray, brown, or reddish above, with a zigzag dorsal band, ordinarily spotted with white; black stripe from rear of eye; belly gray or violet; end of tail yellow, orange, or coral red. Length about I.6 to I.8 feet. Tyrol, Carinthia, Styria, Hungary, Danubian districts, Turkey. Not farther than $48^{\circ}$ north latitude. North Africa.

Vipera russellii. (Plate I2, D.)

Known best as the "Daboia"; another synonym is Vipera elegans. The scales form about 30 rows on back. Top of head covered with small, imbricating, usually keeled scales. General color pale brown above, with 3 longitudinal series of black, light-edged rings, which sometimes encircle reddish spots; belly yellowish-white, uniform, or with small crescent-shaped black spots. Length up to 5 feet. ${ }^{1}$ Hindustan Peninsula, Bombay, Bengal, Ceylon, Burma, and Siam. The species ascends the Himalayas to an altitude of 5,000 feet. Its food consists of small vertebrates, frogs, mice, rats, and birds. It invades the inhabited house to hunt the rat. Its poison is extremely powerful.

Vipera superciliaris.

Snout round. Body is covered with 27 rows of strongly keeled scales. Coloration pale reddish-brown or orange, with blackish crossbands which are intersected by a yellowish longitudinal band on each side; belly white with black speckles. Length 1.8 to 2.5 feet. Mozambique coasts.

\section{Vipera lebetina.}

Upper jaw obtuse and rounded off with marked prominence. Coloration very variable, gray or pale brown above, with a series of large dark speckles; a large $\tau$ of brown is found on the top of the head; belly is whitish and dotted with brownish-gray; end of tail yellow. Length $\dot{3}$ feet, but the female may attain 3.5 feet. Cyprus, Galicia, Asia Minor, Persia, Beluchistan, Morocco, and northern India.

\section{Vipera renardii.}

Resembles Vipera berus, but with the upper jaw more pointed. The coloration is like Vipera ursinii of Europe, with slight variation. Length about 2 feet. Central Asia, Turkestan.

\section{Vipera raddii.}

Coloration pale brown or gray, with a series of small reddish dots in pairs along the back; $\wedge$ on head and black band behind the eye; belly yellow, punctulated with black and white. Length 3.5 feet. Armenia.

\section{Genus CAUSUS Wagler.}

Head distinct from neck; eyes moderate, round pupils. Body cylindrical, scales smooth or keeled, oblique on the sides; ventrals rounded off. Tail short, subcaudals in one or two rows. Four species in this genus.

\section{Causus rhombeatus.}

Snout obtuse, slightly prominent; the scales in $\mathrm{I} 7$ to $2 \mathrm{I}$ rows. Coloration olive or brown, often with a series of $\mathrm{V}$-shaped brownish speckles, which are rimmed 
with a white edge, and a large $\wedge$-shaped mark on the back of head; lips bordered black; belly yellowish or gray. Length 2 to 2.5 feet. Tropical and central Africa, Gambia, Cape.

Causus resimus.

Snout prominent and more or less turned upward. Color olive-gray above, uniformly white on belly. Length I.5 feet. Central and eastern Africa, Angola.

Causus defilipii.

Snout prominent, more or less turned upward. Color gray or pale brown above, with a series of $\mathbf{v}$-shaped, brownish-black, rhomboid speckles; large $\Lambda$-shaped speckle on rear of head; dark oblique line from rear of eye; belly yellowish. Length about I.2 feet. Central and eastern Africa, Transvaal.

Causus lichtensteinii.

Snout obtuse; scales in 15 rows, the subcaudals in single row. Color dark gray with indistinct marks. Western Africa, Gold Coast, Congo.

\section{Genus BITIS Gray. ${ }^{1}$}

Head very distinct from neck, covered with imbricate small scales; eyes rather small, with vertical pupils. Nostrils directed upward or upward and outward, pierced in a single or divided nasal, with a deep pit or pocket above, closed by a valvular, crescentic supranasal. The postfrontal bone is much larger than that in Vipera. Scales keeled, in 29 to $4 \mathrm{I}$ rows; subcaudals in two rows. Tail very short.

Bitis arietans. (Plate $13, \mathrm{D}, \mathrm{E}$; plate $\mathrm{r} 4, \mathrm{C}$.)

The "puff adder" has the nostrils on the upper surface of snout. Body very thick, tail short. Head large and triangular. Color yellow or orange with chevronshaped, large, oblique, black crossbars and an oblique band from rear of eye; belly either all yellow or speckled with small black points. It is hard to see this viper when it is lying on sand, or stony ground; the under parts are sometimes whitish. It is very slow, and trusts to not being discovered when lying in the dry grass; when approached it inflates the body and hisses loudly with a puffing sound, watching the enemy with raised and characteristically bent head and neck; but it bites only when actually touched or attacked. The effect of the bite is very dangerous. $^{2}$ Its prey consists chiefly of small mammals, which it hunts during the night. Length about 4 to 5 feet. The whole of Africa, excepting northern coasts, from southern Morocco, Kordofan, and Somaliland to the Cape of Good Hope, and southern Arabia.

Bitis peringueyi.

Color olive-gray, with 3 longitudinal series of blackish or gray speckles. Length about I foot. Angola and Damaraland.

\section{Bitis atropos.}

Color brown or brownish-gray, with 4 longitudinal dark series of black and white dots; belly gray or brown. Length up to r.5 feet. Cape of Good Hope.

\section{Bitis inornata.}

Eyes smaller than in atropos. Length up to I.5 feet. Cape of Good Hope.

Bitis cornuta.

Nostrils high and outward. Head covered with small imbricated scales, strongly keeled; 2 to 3 scales alongside the eyes become so elevated as to appear like horns at upper inner corner of eye on each side. Color gray or brownish-red with black

1 Echidna.

2 The natives of southern Africa claim that this viper can jump so high as to reach a man on horseback. The Hottentots hunt it to get its head, which is used by them to prepare a poison for arrows, by mixing the pulp of the crushed head and a certain plant juice. 

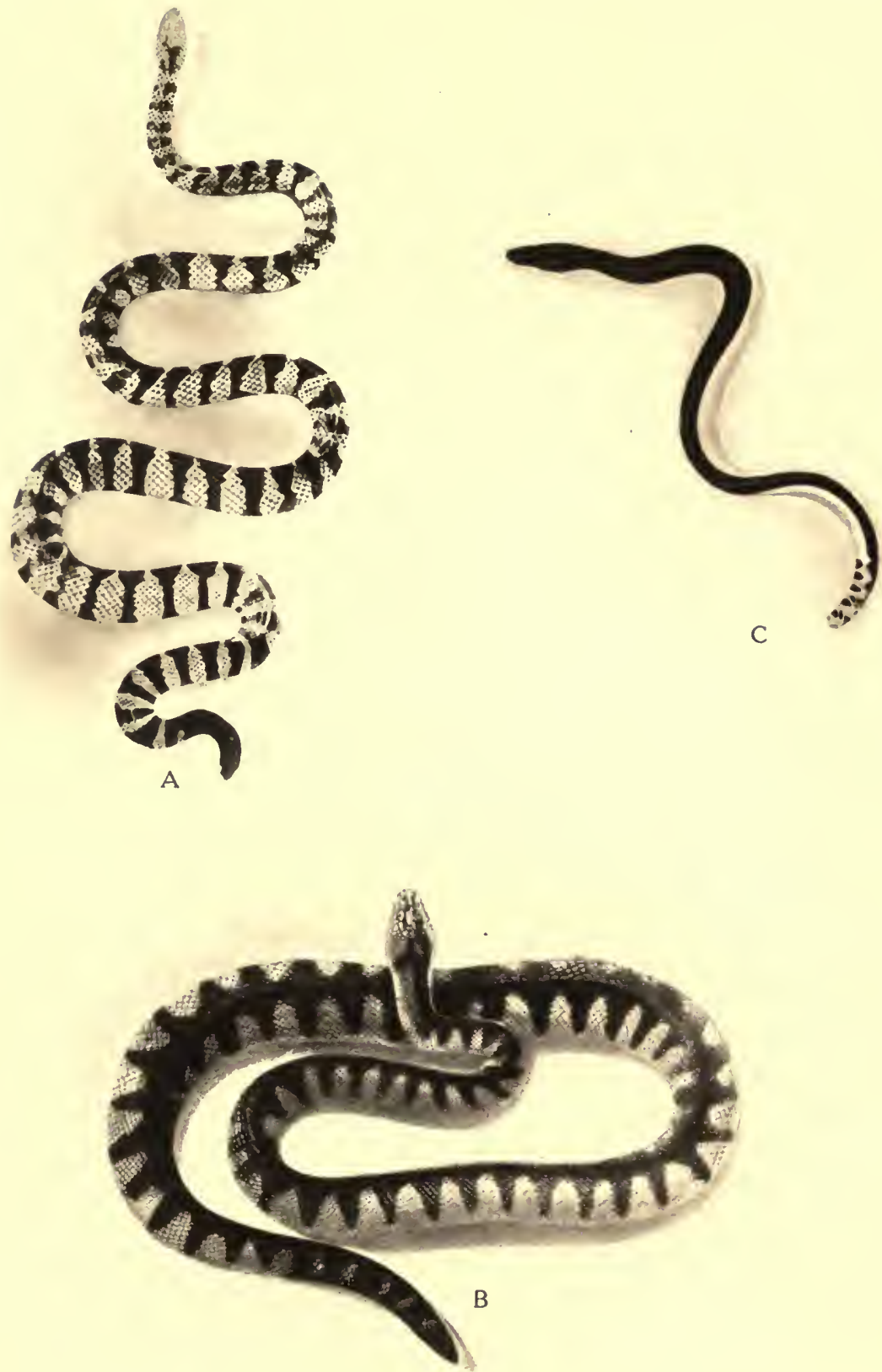
A, Distira cyanocincta.
B, Enhydrina valakadien.
C, Hydrus platurus.

(Photographic Reproductions from Fayrer's Thanatophidia.) 



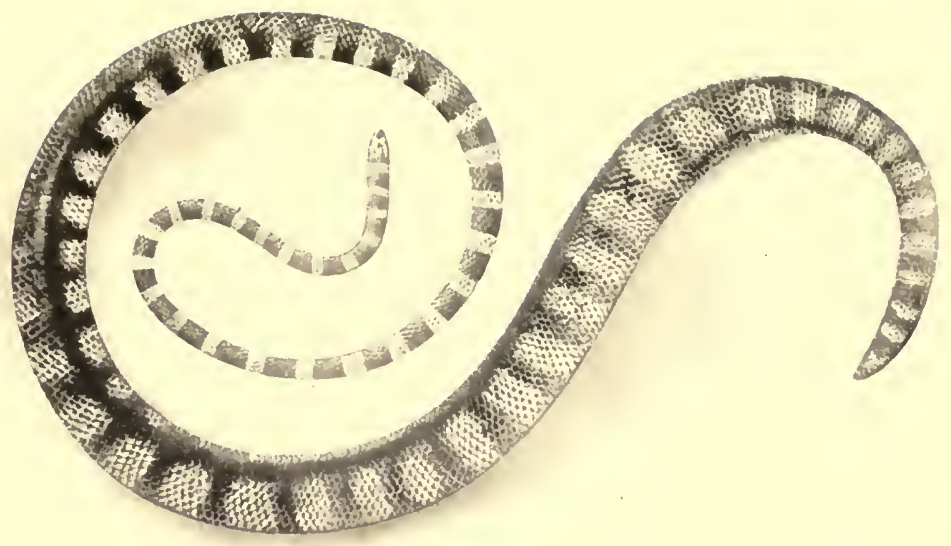

A
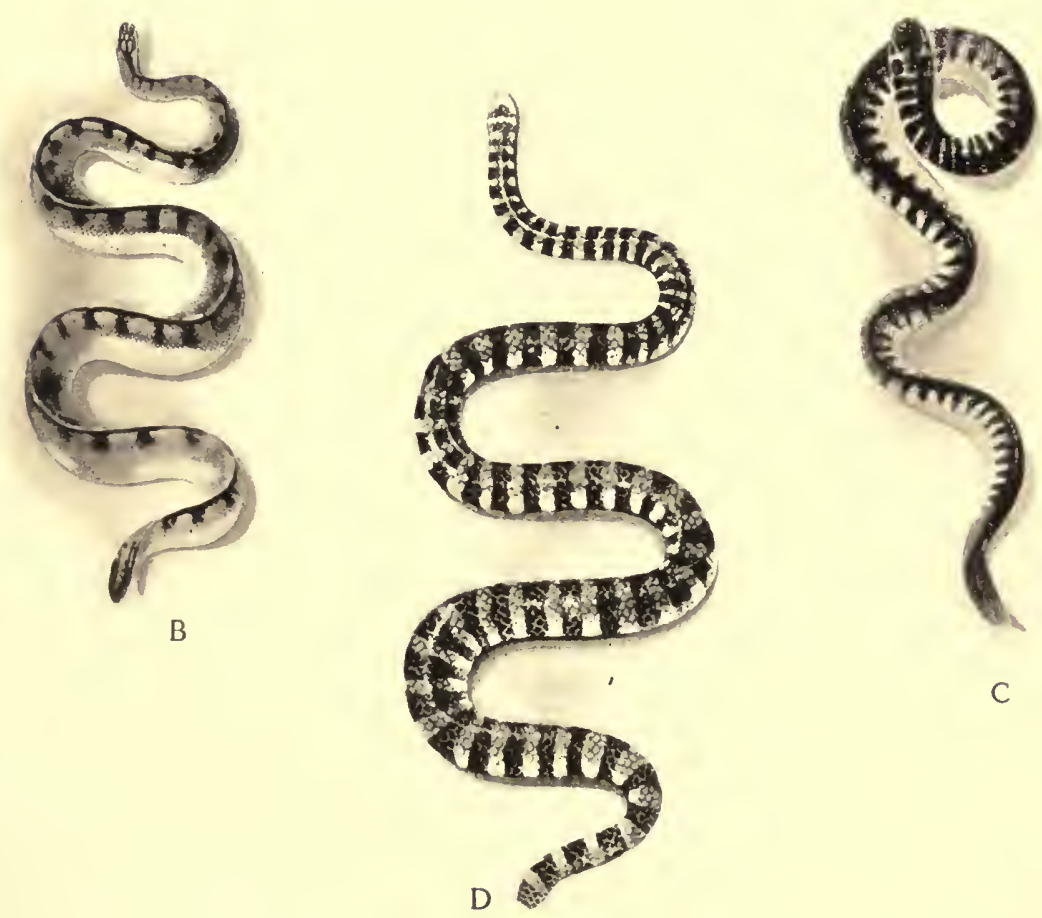

A and B, Two species of Hydrophis.

C, Enhydris curtus.

D, Platurus laticaudatus.

(Photographic Reproductions from Fayrer's Thanatophidia.) 

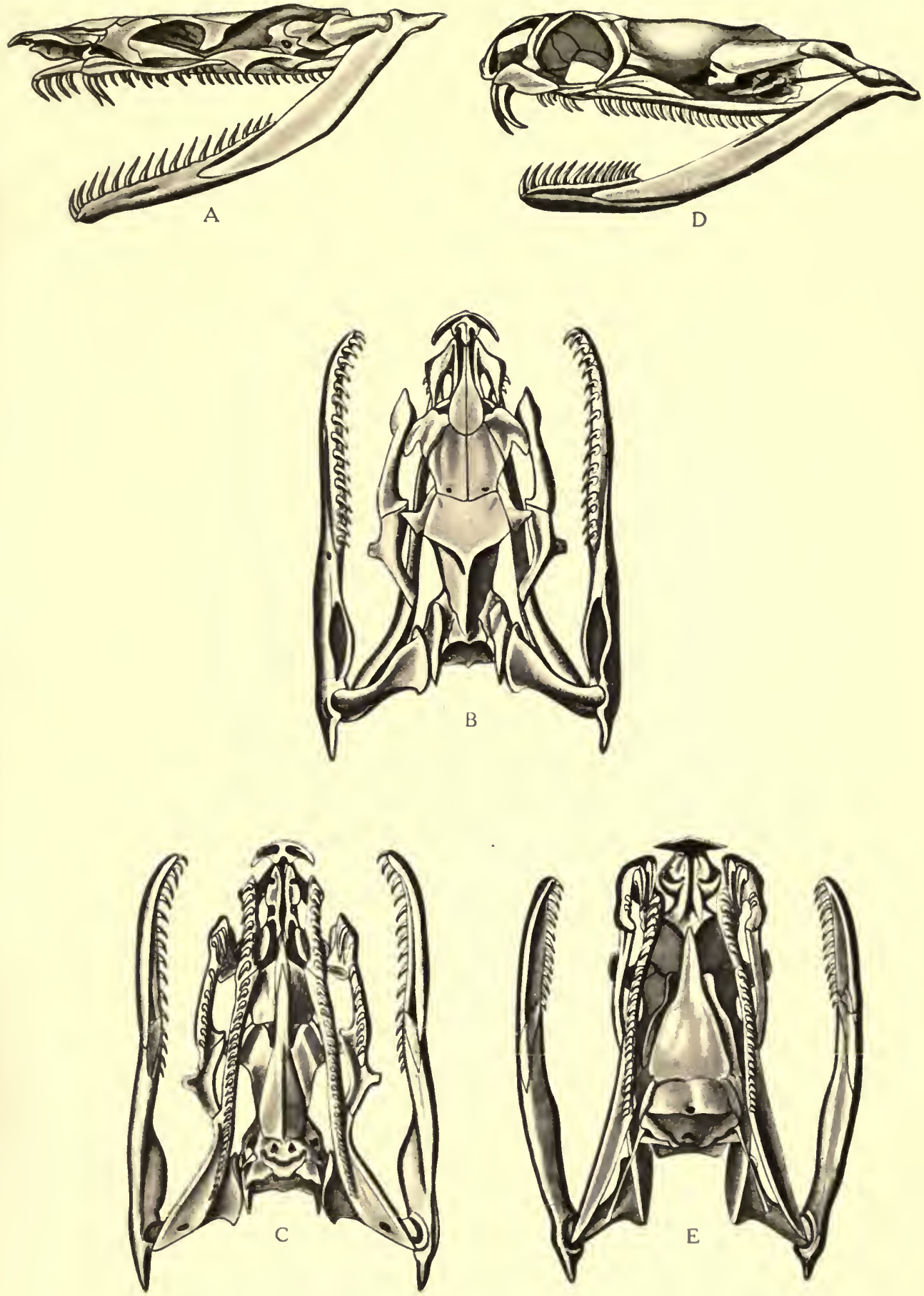

A, B, and C, Skull of Hydrus platurus. D and E, Skull of Platurus colubrinus.

(Drawings from Boulenger's Book.) 

Noguchi

Plate 12

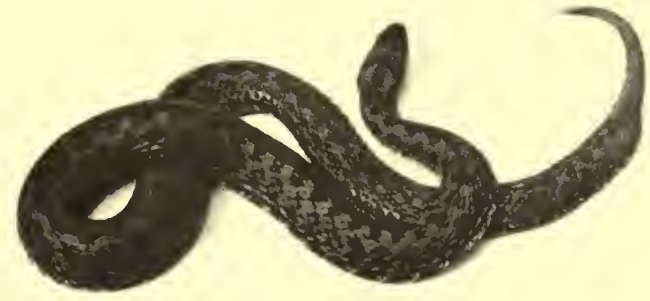

A
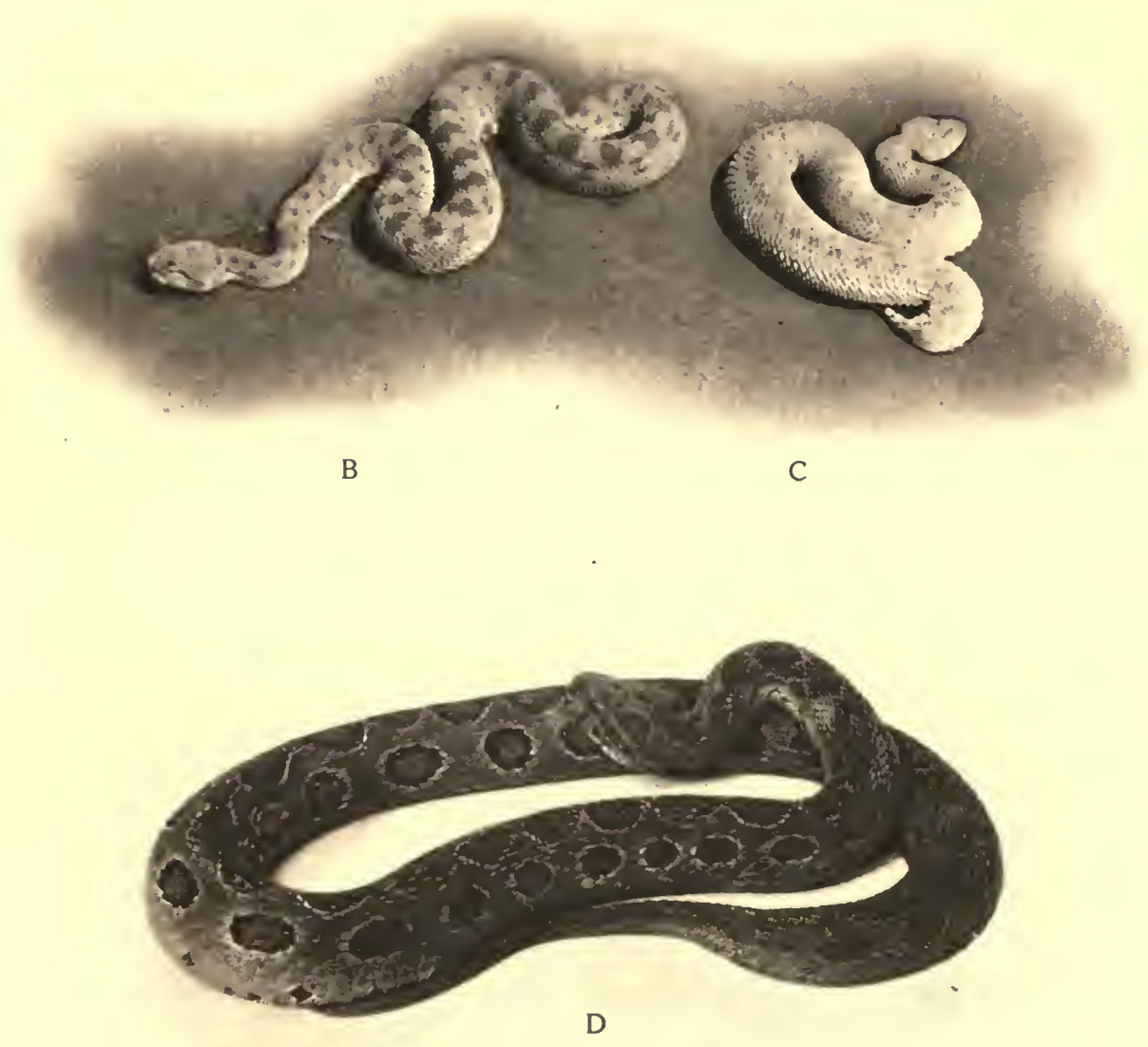
A, Vipera berus.
B, Cerastes cornutus.
C, Cerastes vipera.
D, Vipera russellii.

(Photographs from Live Specimens.) 

spots rimmed with white in 3 or 4 longitudinal series; belly yellow or brown, uniform or speckled. Length about 2 feet. Cape, Namaqualand, Damaraland.

Bitis caudalis.

The prominent keeled scales near the eyes take the form of a single horn. Color reddish or grayish-red, with 2 brownish series of spots; belly yellow, uniform or black-spotted on sides. Length about I.5 feet. South Africa, Angola to Namaqualand.

Bitis gabonica. "Rhinoceros Viper," or "Gabonian Viper."

Nostrils directed upward and outward. Between the eyes the inter-supranasal scales are so prolonged as to form a pair of horns, which are erect and triangular or sometimes even of a tricuspid form. This viper may grow about 4 feet long and is vicious. Color brown, with a single longitudinal vertebral series of black speckles; belly yellow with many small brown or black dots. Head very large and triangular. Body very stout with a small tail ending abruptly in a point. Nocturnal, and during the day appears to be very lazy and inactive. Its venom is very powerful, but it bites only when molested.

\section{Bitis nasicornis.}

The nostrils directed upward and outward. Supranasals form two triangular, erect horns of 3 or 4 keeled scales. Between the horns are small scales separating them. Color purple or red-brown above, with pale-olive or dark-brown speckles; the vertebral series is of brown spots rimmed white and each speckle assumes rhomboid shape; belly olive with black or yellow spots. Length about 4 feet. Western Africa, from Liberia to the Gaboon.

\section{Genus PSEUDOCERASTES Boulenger.}

This genus is represented by only one species, $P$. persicus of Persia.

\section{Pseudocerastes persicus.}

Head very distinct from neck, covered with small imbricate scales. Eyes small, vertical pupils. Upper jaw very short, and rounded off. Coloration gray or brown, with four series of large black speckles; the head carries two longitudinal black streaks behind the eyes; belly is whitish, spotted with black. Length 3 feet.

\section{Genus CERASTES Wagler.}

Head very distinct from neck, covered with scales, small, juxtaposed, and lightly imbricate. Eyes small, vertical pupils. Body cylindrical with imbricate scales with apical pits, in 23 to 25 rows. Tail short; subcaudals in two rows.

Cerastes cornutus.1 "Horned Viper." (Plate I 2, в.)

Upper jaw short and large. Two erect horns above the eyes. Color brownyellowish or gray, with or without 4 to 6 series of brown speckles. Black bands run obliquely behind the eyes; belly white; end of tail black or white. Length 2.5 feet. North of Sahara, Egypt, Nubia, Arabia, and central Palestine; Asiatic side of Suez Canal.

Cerastes vipera. (Plate I2, c.)

Snout very short and broad. No "horns." Color yellowish, pale brown or reddish, with or without black speckles; end of tail often black above and white beneath. Length I foot. North of Sahara, from Algeria to Egypt.

\section{Genus ECHIS Merrem.}

Head very distinct from neck, covered with small imbricate scales; eye moderate, with vertical pupil; nostrils directed upward and outward, in a single or

\footnotetext{
1 The "Horned Viper," or C. vipera, is supposed to be the species which has become famous through the suicide of Cleopatra. In the daytime the horned viper is invisible, being buried in the sand with only the eyes, nostrils, and horns appearing above the surface. This attracts small birds, which mistake the horns for insects and, approaching the viper, are themselves caught.
} 
divided nasal. Body cylindrical; scales keeled, with apical pits, in 27 to 37 rows, dorsal scales forming straight longitudinal series; ventrals rounded. Tail short; subcaudals single. Africa, north of the Equator, southern Asia.

Echis carinatus. (Plate 14, B.)

"Phoorsa" 1 is characterized with a single row of subcaudal scales. It is ferocious and aggressive, ready to strike at any time. The body is of more or less dark grayish color and is patterned with stripes and with speckles and dots of blackishbrown; the back is marked with long whitish-yellow undulatory lines, on each side of the vertebral line; the head has Y-shaped speckles. The scales produce a peculiar noise, when the snake rubs them together by folding the body. Length reaches 2 feet. India, Persia, Beluchistan, Arabia, Palestine, and Africa, north of Equator. Echis coloratus.

The scales on the muzzle are convex and smooth or slightly keeled. No Y mark on head. Length 2.5 feet. Arabia, Socotra, Palestine.

\section{Genus ATHERIS Cope.}

Head very distinct from neck, covered with imbricate scales. Eyes large, vertical pupils. Body slightly compressed. Scales keeled, with apical fossa. Tail moderate and prehensile, subcaudals in one row. Arboreal habits. Tropical Africa.

\section{Atheris chlorechis.}

Color greenish with small yellow dots, end of tail yellow. Length about 1.5 feet. Western Africa, from Liberia to Ogowe.

\section{Atheris squamiger.}

Color olive, with yellow, narrow, more or less regular $\mathrm{Y}$ bands, or with green spots; belly dark olive with black spots. Length about $\mathrm{r} .8$ feet. Western Africa, from Cameroon to Angola.

\section{Atheris ceratophorus.}

Many erectile superciliary scales. Body highly keeled. Dark olive color, with cross-shaped black spots; belly pale olive. Length only 7 inches. Western Africa.

Genus ATRACTASPIS Smith. ${ }^{2}$ (Plate ${ }^{3}$, A, B, C.)

Enormously developed poison fangs. A few teeth on palatine, but none on pterygoid bones characterize this genus. The mandible edentulous, with 2 or 3 small teeth in middle of dentary bone. Head small and indistinct from neck. Eyes minute, round pupil. No postfrontal bone. Body cylindrical; scales smooth, in I 7 to 37 rows. Ventrals rounded off. Tail short, subcaudals in one or two rows. General coloration brown, brownish-black, and black. This genus is remarkable as presenting the most extreme specialization in the viperine direction, the poison fangs being as large in proportion as in any other form and the solid teeth on the palate and mandible, which are much reduced in number in many of the Crotalines, having almost disappeared.

The habitats of the several species of Atractaspis and the variations in length are shown in the following list:

$A$. hildebrandii, length $\mathrm{I} .5$ feet; eastern Africa.

A. congica, length I.5 feet; Congo, Angola.

A. irregularis, length r.66 feet; central and western Africa from;Gold Coast to Congo.

A. corpulenta, western Africa, from Liberia to Gaboon.

$A$. rostrata, length 2 feet; central and eastern Africa. 
A. bibronii, length 2 feet; east of Cape Colony, Natal, Namaqualand, Angola.

A. aterrima, length about 2 feet; central and western Africa.

A. dahomeyensis, length about I.5 feet; Dahomey.

A. micropholis, length about I.2 feet; Cape Verde.

A. leucomelas, length about 2 feet; Somaliland.

A. microlepidota, length about 1.75 feet; western and central Africa.

\section{Subfamily CROTALINÆ Boulenger.}

The essential difference of this subfamily from the Viperinæ is the presence of a deep cavity or pit between the eye and the nose, lodged in the hollowed-out maxillary bone. This pit is lined with a modified continuation of the epidermis, and is amply supplied with branches from the trigeminal nerve. It is undoubtedly sensory, but we do not know its function. ${ }^{1}$ All snakes belonging to this group are called "Pit-vipers."

The maxillary bone, into the lower end of which the large hollow fang is immovably fastened like a knife in a handle, is extremely shortened and higher than long, so as to appear to be in a vertical position. On the other side of this bone there is the deep cavity which separates two articular surfaces. The upper surface of the maxillary forms with the corresponding concave face of the prefrontal (lachrymal) bone, which projects from and articulates with the frontal bone, a hinge-like joint allowing considerable freedom of motion. The lower articular surface receives the flattened anterior end of the external pterygoid bone (transversum). If the ectopterygoid be moved forward or backward, the maxillary hinges on the prefrontal, and if the same is pushed forward the fang is erected.

The Crotalinæ are divided into two groups according to whether the snake has the "rattle" or not. The rattleless snakes fall into two genera, Ancistrodon and Lachesis; the rattlesnakes are divided into Sistrurus and Crotalus. About 60 species are known.

The rattlesnakes are restricted to America, but the rattleless Crotaline snakes are found in North and South America and the southeastern half of Asia. No pitviper is found in Africa, Australia, the southwestern corner of Asia, and Europe, except one species which enters the extreme southeastern corner.

\section{Genus ANCISTRODON Beauvois.}

Originally transliterated as Agkistrodon, a $\gamma \kappa \iota \sigma \tau \rho o \nu$, hook, $\delta \delta \omega \nu$, tooth.

Without a rattle. Sensory pits between nose and eye. Surface of head covered with 9 large shields, sometimes broken into small scales. Body cylindrical, covered with smooth or keeled scales which have special fossa. Tail moderate or short, subcaudal scales in one or two rows. From northern borders of the Caspian Sea, throughout most of the Asiatic mainland and in North and Central America. In the Asiatic mainland to Himalaya in the south and to Lake Baikal in the north. Japan (Formosa and adjacent islands) has some representatives.

\footnotetext{
Ancistrodon piscivorus Lacépède. (Plate 15, B; plate r6, A.)

Trigonocephalus piscivorus Holbrook.

Crotalus piscivorus Lacépede.

Cenchris piscivorus Gray.

Toxiophis piscivorus Baird and Girard.

Coluber aquaticus Shaw.
}

The water-moccasin or "cotton mouth" has a round muzzle. Scales of body keeled, in 25 rows, subcaudals in one row, ending in two rows towards the point. General color dark chestnut-brown, with darker markings. Head above purplishblack. On each side a series of 20 or 30 narrow, vertical, purplish-black bars I or 
2 scales wide. Of these, sometimes two contiguous to each other form a space darker than the ground-color. Sometimes corresponding bars, from opposite sides, unite and form a ring encircling the body. Sometimes there is a lighter shade bordering the dark bars. Beneath, black, blotched with yellowish-white. No loreal plate. The water-moccasin is a water-snake and is found about damp, swampy places or in water, but never far from it. In summer, numbers of these snakes are seen resting on the low branches of such trees as overhang the water, and they plunge into the water at the slightest alarm. They are also found in the ditches of rice fields, especially on the dry bank, where they bask in the sun. It is said that the water-moccasin attacks everything that comes within his reach, erecting his head and opening his mouth for some seconds before he bites, which habits are not observed with other pit-vipers. This snake is very much dreaded, although records of fatal issues are not numerous. Unlike the other pit-vipers the watermoccasin is easily kept in captivity, as it takes food in the cage. Effelds once had a pair so tame as to take fish, cold or warm-blooded animals, or even raw meat, from the forceps in the hand of the keeper. It is said that the bite of the watermoccasin, curiously enough, is more dangerous to other venomous snakes than to itself, and that this snake is very fierce towards other snakes. Length 4 to 5 feet.

Eastern states of North America, including North Carolina, Indiana, Florida, and Texas.

Ancistrodon contortrix. (Plate 15, C; plate 16, B.)

The "copperhead" is more slender than the water-moccasin. A distinct loreal plate is present. Above light hazel-brown, rather brighter on top of head, and everywhere minutely marked with fine dark points. On each side is a series of I 5 to 26 darker chestnut-colored blotches resting on the abdominal scutellæ, and suddenly contracting about the middle of the side so as somewhat to resemble an inverted $Y$. These blotches extend to the vertebral line, where they may be truncated or end in a rounded apex. Generally those of the opposite sides alternate with each other, but frequently they are confluent and form continuous bands. Color beneath dull yellowish, with a series of distinct large, dark blotches, 35 to 45 in number, on each side; chin and throat unspotted; side of head cream color; labials yellowish-white. Length about 3 feet.

The copperhead is called "upland moccasin," "chunk head," "pilot snake," or "deaf adder," according to different localities, and is much dreaded on account of the absence of warning before the bite and of its aggressive nature. However, only very few cases of fatal poisoning have been recorded. These snakes are easily kept and fed in captivity. Like all Crotaline snakes the copperhead produces living young, 7 or 9 in number.

North America. From central Massachusetts to Texas, and from Florida to Kansas, including Illinois, Louisiana, Indiana, and Mississippi. Michigan, Wisconsin, and Nebraska are said not to be inhabited by this species.

\section{Ancistrodon bilineatus.}

Snout pointed; scales less carinated. Subcaudals single in front, divided in posterior. This "Mexican moccasin" has a general coloration similar to but deeper than that of the other two species, of which the copperhead is the fairest and most vivid. Length about 3 feet. Mexico, Guatemala, and Honduras.

\section{Ancistrodon halys.}

Snout somewhat upwardly turned, with a rounded end. Coloration yellowishgray, red, or pale brown above, with dark crossbars; belly whitish, more or less marked with gray or brown. Length I. 5 feet. Border of Caspian Sea, Ural mountains, and Yenisei Highland, Turkestan. 


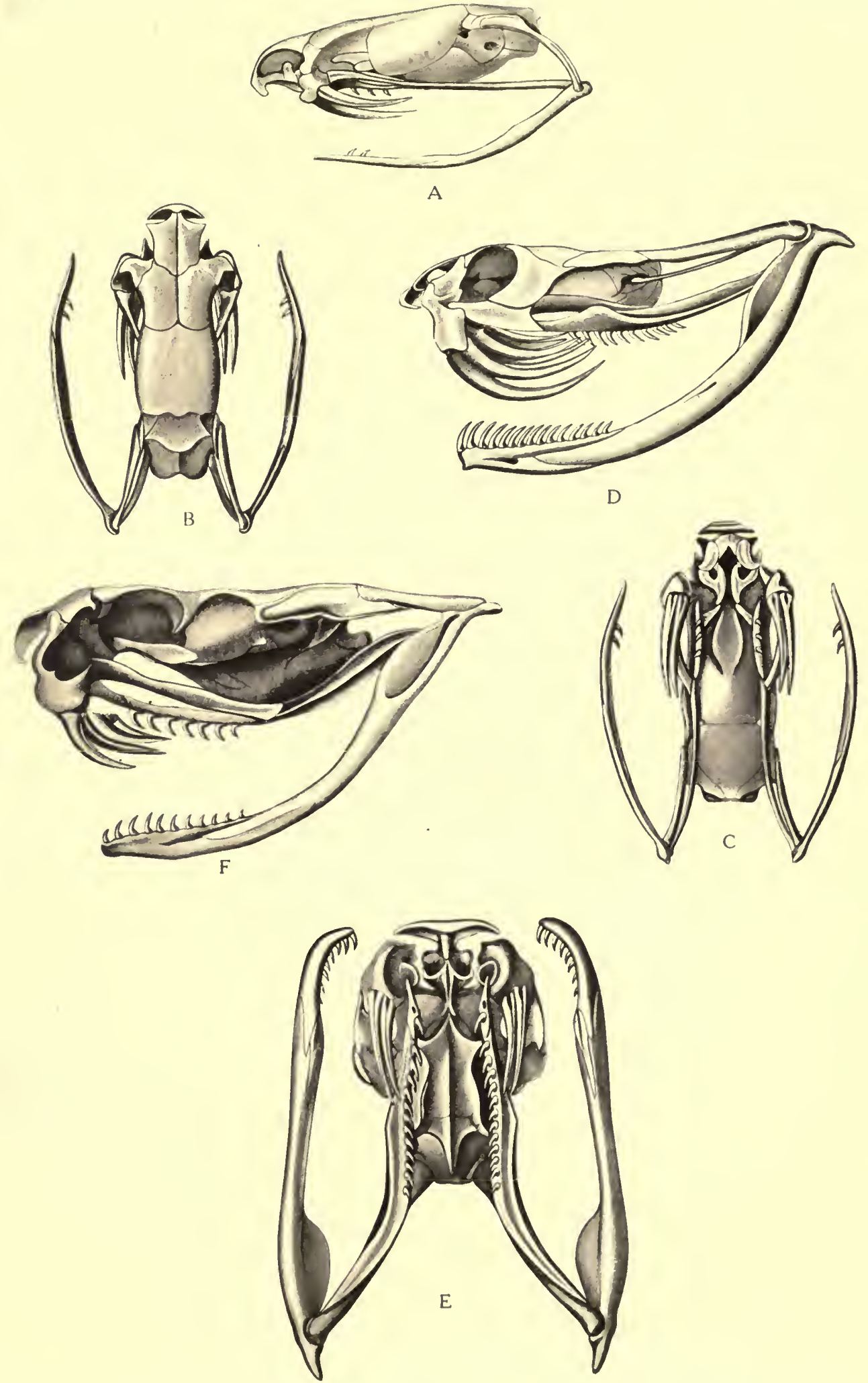





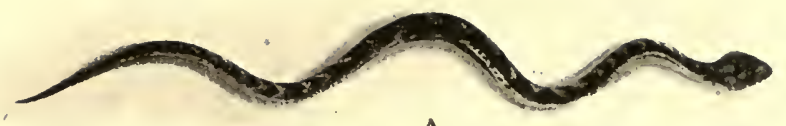

A

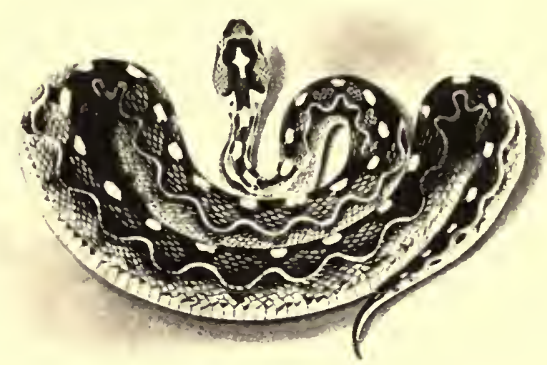

B

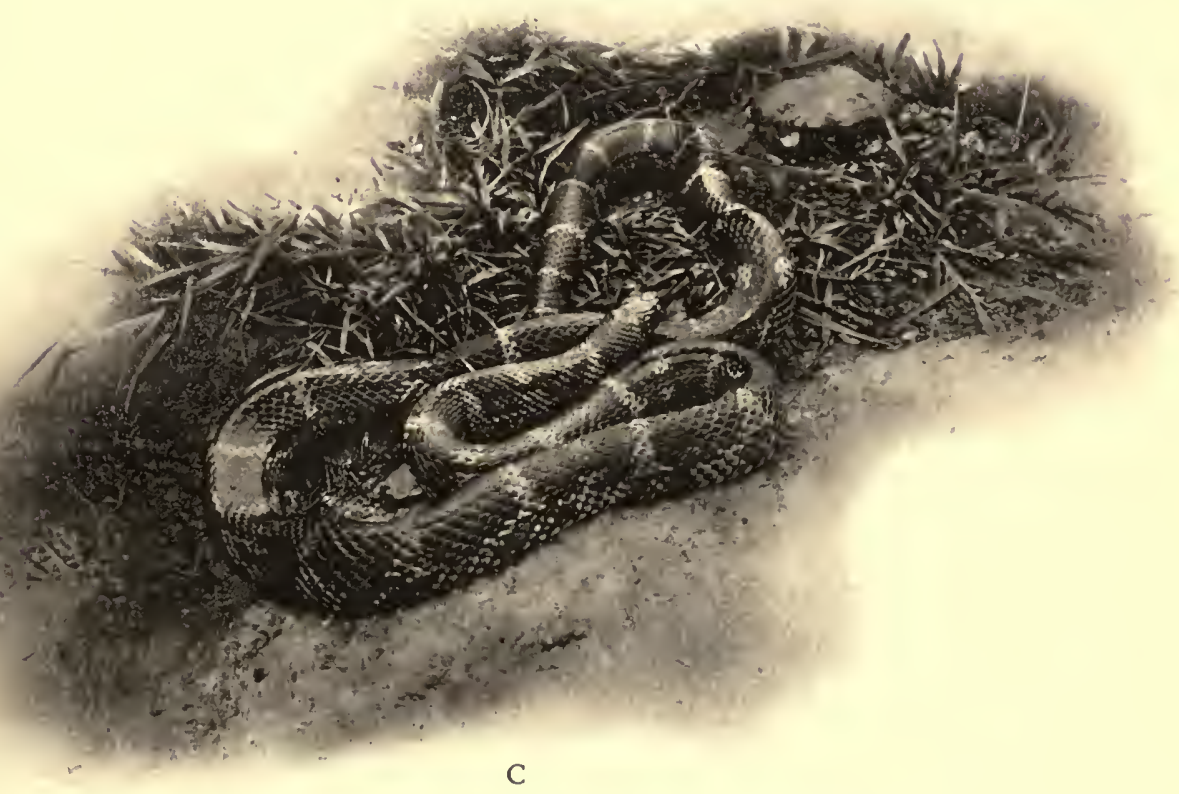

A, Ancistrodon hypnale. B, Echis carinatus. C, Bitis arietans.

(Photographic Reproductions: A and B, from Fayrer's Thanatophidia; C, from Live Specimen.) 


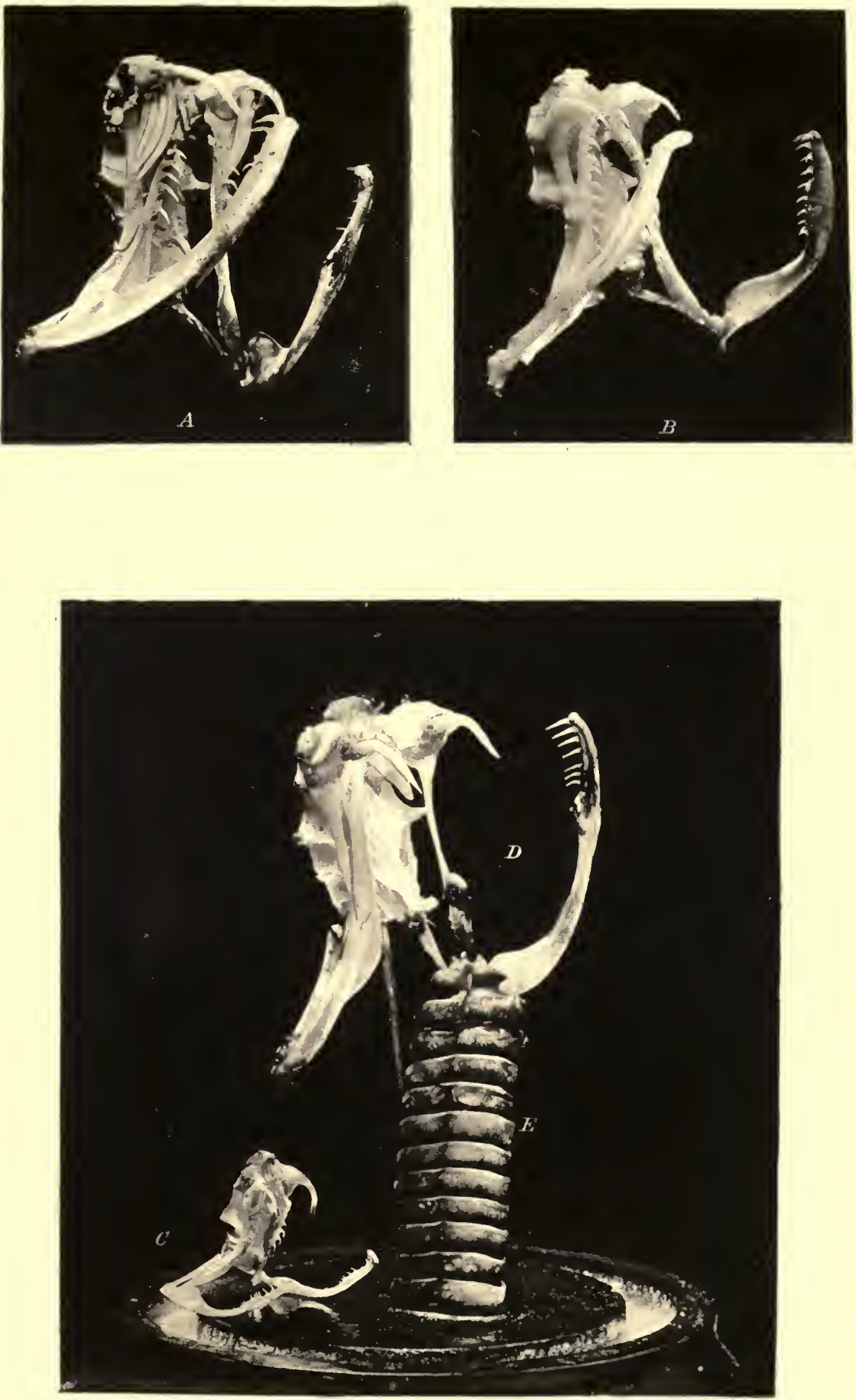

Photographs of : A, Skull of Lachesis mutus; B, Skull of Ancistrodon piscivorus ;

C. Skull of Ancistrodon contortrix; D. Skull of Crotalus adamanteus; E, Rattler of Crotalus adamanteus. 



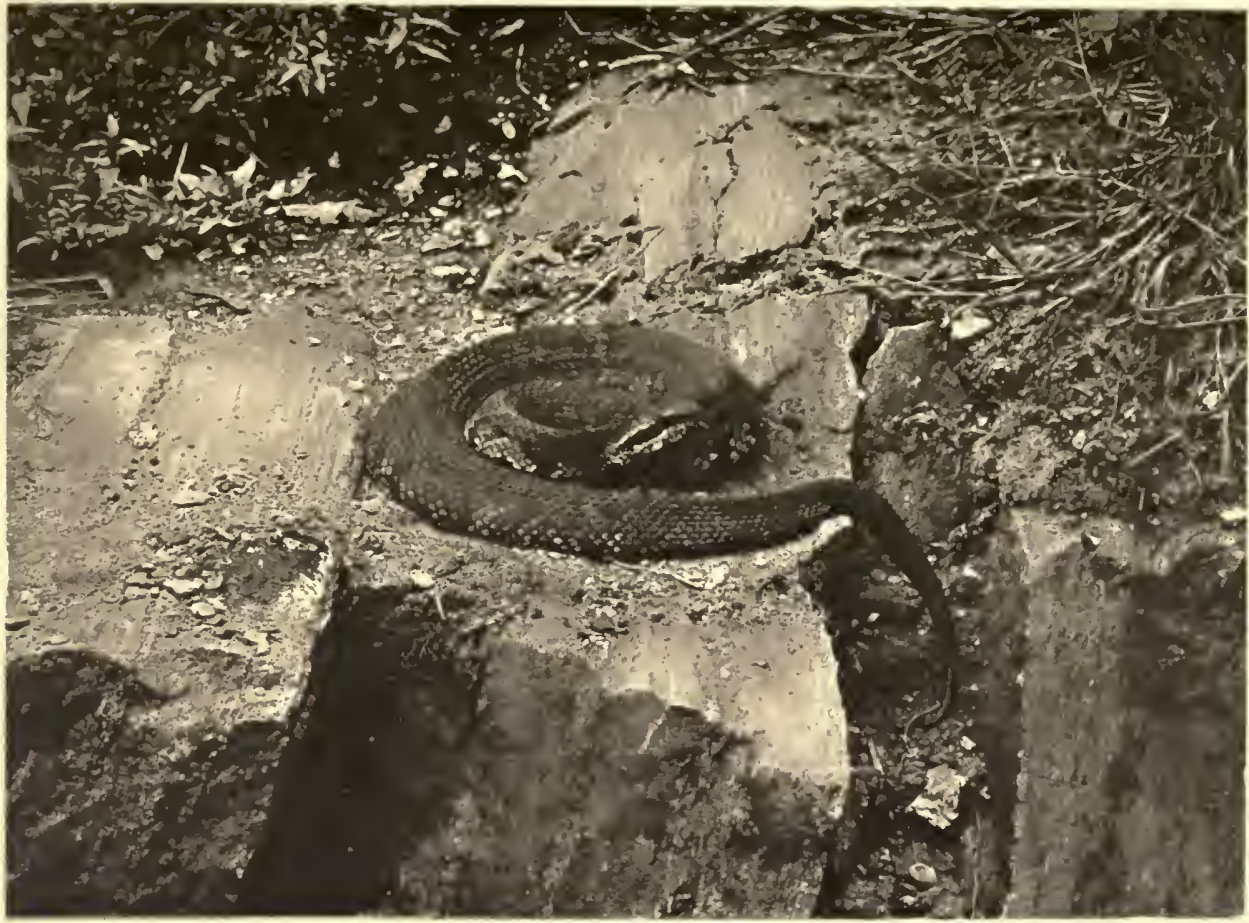

A

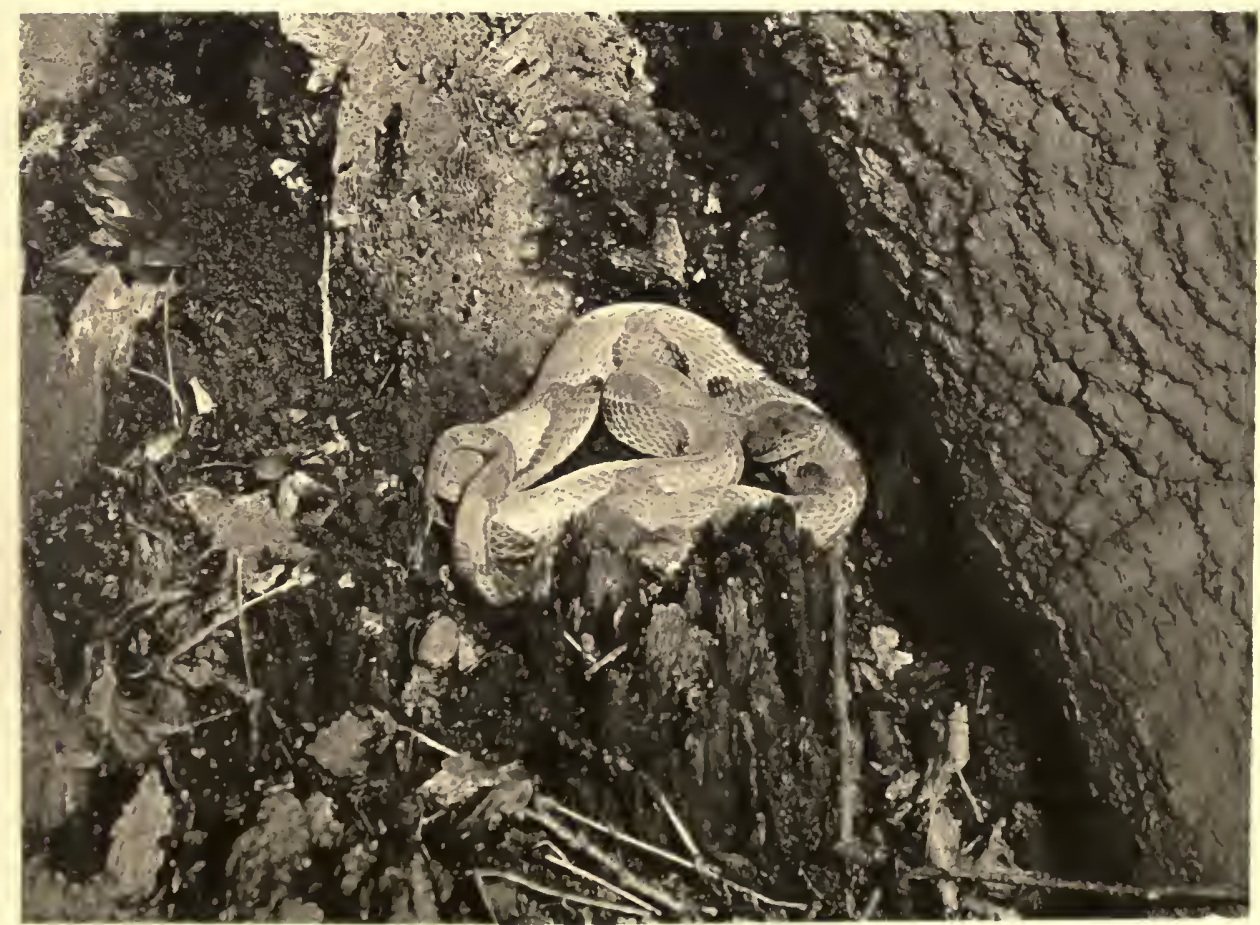

B

A, Ancistrodon piscivorus.

B, Ancistrodon contortrix.

(Photographs from Live Specimens.) 



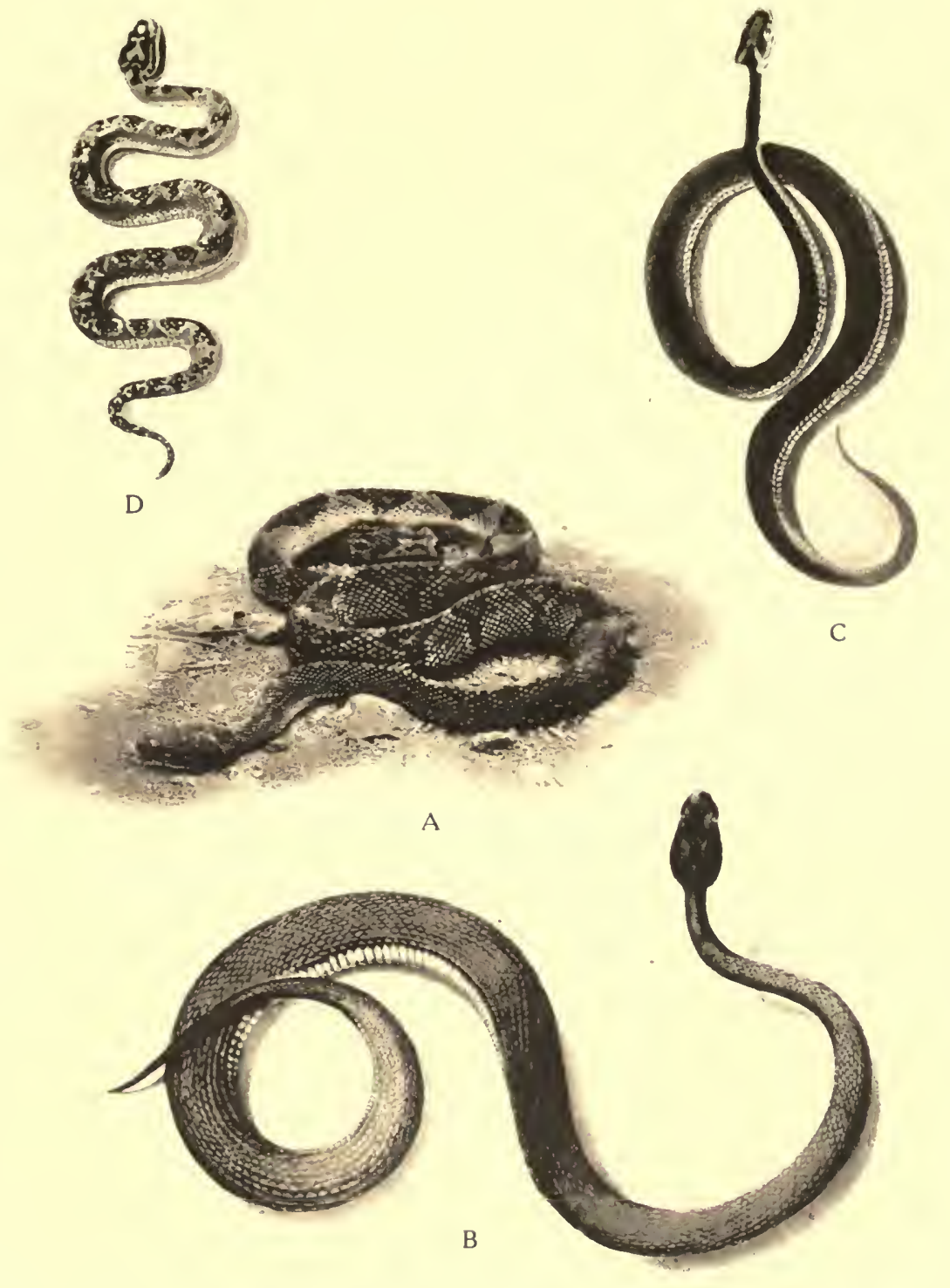
A, Lachesis mutus. B, Lachesis flavomaculatus. C, Lachesis gramineus. D, Lachesis anamallensis. (Photographic Reproductions: A, from Live Specimen; B, C, and D, from Fayrer's Thanatophidia.) 


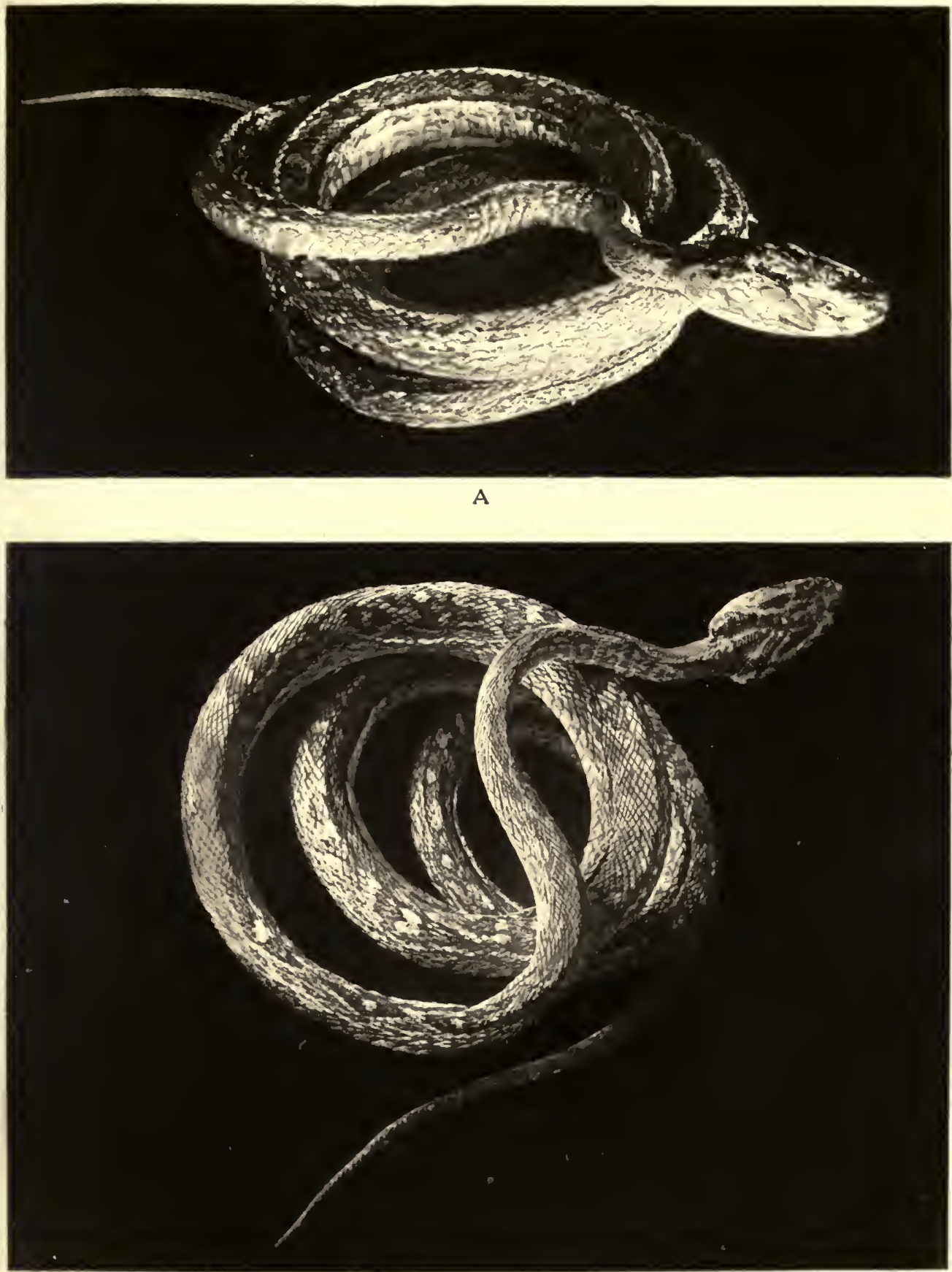

B

Lachesis flavoviridis.

Two views are given to show more completely the characteristics of this snake. 



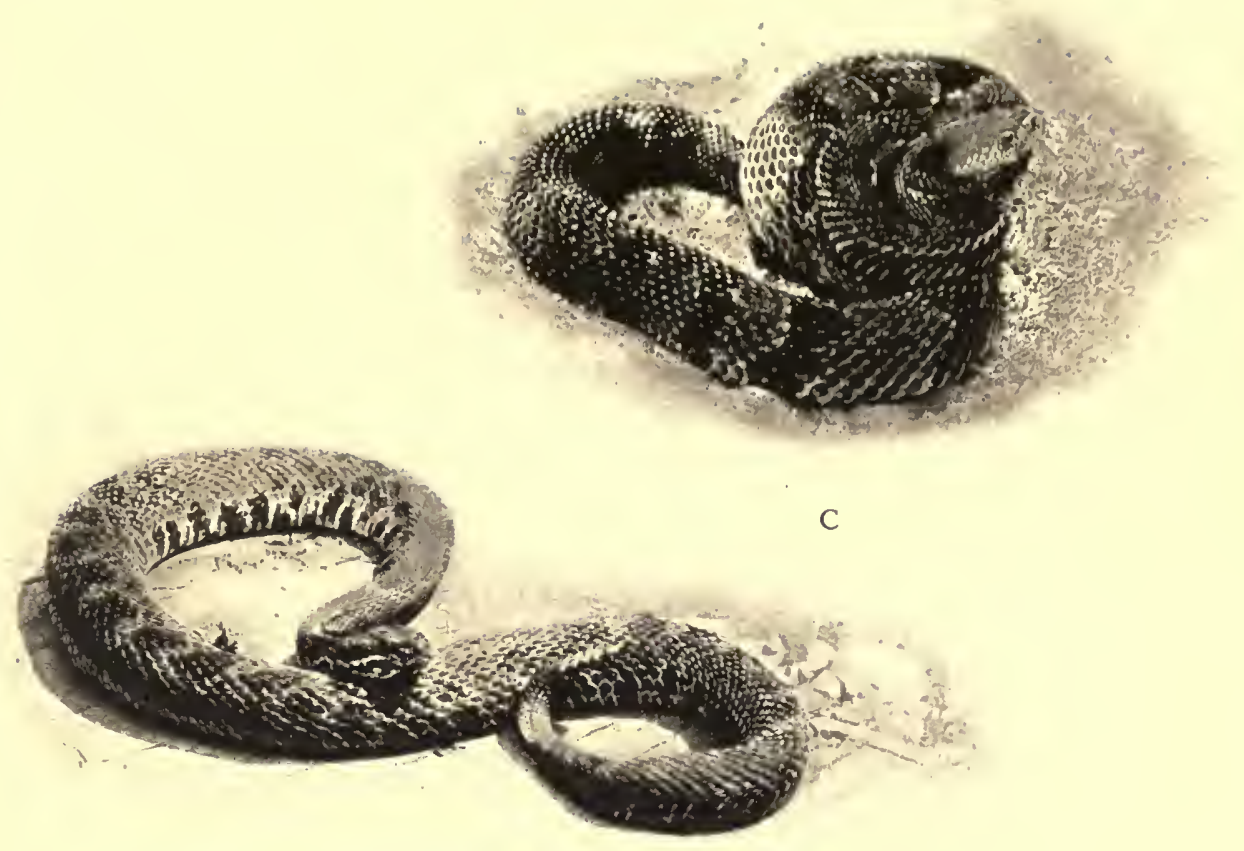

A

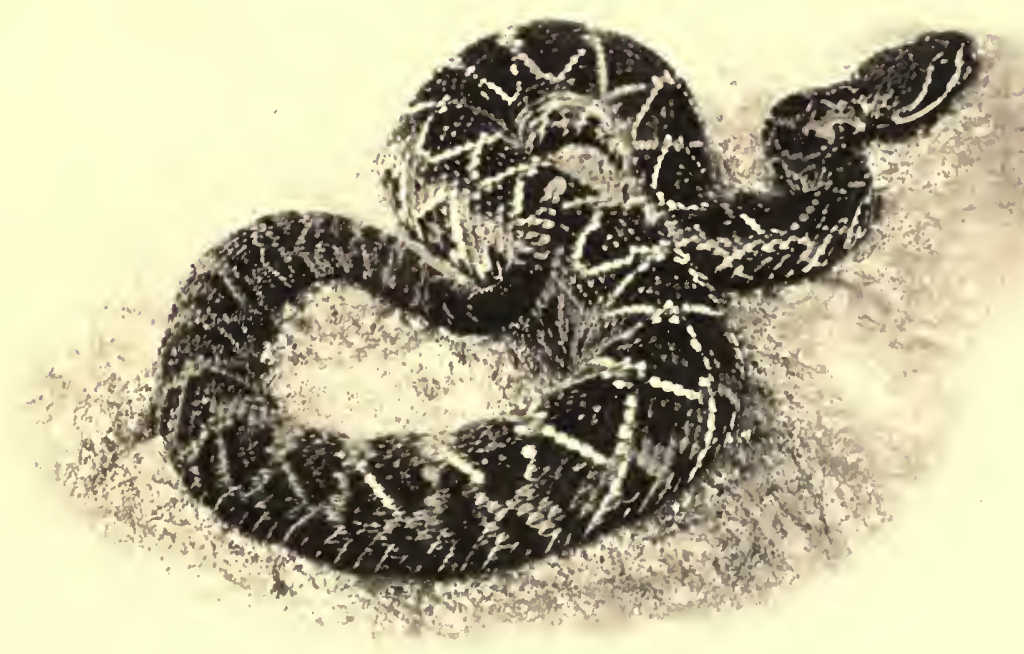

B
A, Sistrurus catenatus.
B, Crotalus adamanteus.
C. Crotalus horridus.

(Photographs from Live Specimens.) 
. 
Ancistrodon intermedius.

Ancistrodon blomhoffi intermedius Stejneger.

About same as halys except that the snout is not turned at the end. Length about 2.5 feet. Central Asia, eastern Siberia, Mongolia, and Japan.

\section{Ancistrodon blomhoffi. ${ }^{1}$}

Resembles the halys, but not turned up on end of snout. Coloration variable: gray, brown, or red above, with large black-rimmed blotches in pairs; black bands with red margin; belly yellow or reddish, more or less spotted black. Length about 2.5 feet. Japan, Mongolia, eastern Siberia, central Asia.

Ancistrodon blomhoffi brevicaudus 2 Stejneger.

Much like Ancistrodon blomhoffi of Japan, but is distinguished from it by absence of white spot at anterior angle of crescentic lower postocular, and by the fewer number of subcaudals. Length about 2 feet. Eastern China, Korea, and Formosa.

\section{Ancistrodon himalayanus.}

Snout hard, markedly turned upivards. Color brown with black crossbars or points; a light-margined black band from eye to the angle of mouth; belly dark brown or more or less whitish. This snake lives chiefly on mice. Length about 2 feet. Himalayas up to ro,000 feet, especially in the northwest.

Ancistrodon acutus.

The snout is so prolonged as to protrude. Length about 5 feet. Upper Yangtse, China.

Ancistrodon rhodostoma.

Snout pointed, sometimes directed upwardly. Length about 3 feet. Java.

Ancistrodon hypnale. (Plate I4, A.)

Snout more or less curved, with a hard-pointed end. Scales in I7 (most of the Ancistrodon species 2r) rows. Length about 2 feet. It is known as "carawalla" in Ceylon, where it is dreaded. Ceylon, western coasts of India to Bombay.

\section{Genus LACHESIS Daudin. ${ }^{3}$ (Plate I 5, A.)}

Without a rattle, but the tail has a series of Io to I 2 rows of spinous scales sharpened at end. Head covered with plates or small smooth or carinated scales, with or without special fossa. Maxillary bone much reduced in dimensions, but ectopterygoid is well developed. The absence of the regular shields on top of head makes it easy to differentiate this genus from Ancistrodon. Many species of Lachesis of Asiatic origin are called Trimeresurus. Stejneger points out that it has not been conclusively demonstrated that they are generically identical with the numerous American pit-vipers of a similar head scutellation, which are usually known as Trigonocephalus or Bothrops. The South American Lachesis is sufficiently characterized by the peculiar scutellation of the tail.

The American representatives of Lachesis are as follows:

\section{Lachesis lanceolatus.}

Known as Fer de lance of Martinique, "Jararacussu" of Brazil, and Bothrops lanceolatus of various authors. Snout obtuse, slightly elevated; scales of top of head are small and imbricated, more or less strongly carinated. Subcaudal in two rows. Coloration very variable: gray, brown, yellow, olive, or reddish, uniform or

\footnotetext{
1 Mamushi. According to Stejneger this species is restricted to Japan, including the small southern islands.

Ancistrodon blomhoffi affinis Gray was described, but its locality is uncertain; it is supposed to come from Yaeyama Island of Riu Kiu, Japan.

3 Bothrops, Trigonocephalus, and Trimeresurus are synonyms for this genus.
} 
with more or less distinct dark crossbands or speckles; black band from eye to corner of mouth; belly uniformly yellowish or spotted brown. Length about 6 feet.

This is one of the most dreaded venomous reptiles in America, and establishes itself everywhere - in swamps, plantations, forests, in the plains and in the hills. During the daytime it hides quietly, but is ready to cause death at any moment. Its motion is exceedingly rapid. It swims easily. The bite of the Fer de lance is extremely dangerous and causes numbers of deaths in Martinique, especially among the sugar-planters, or coffee-cultivators.

Tropical America; Mexico, Martinique, St. Lucia, from Bequia Isle towards St. Vincent, Venezuela, Guiana, Rio de Janeiro.

Lachesis mutus. "Bushmaster." (Plate r7, A.)

The "Surucucu" of the Brazilians is another large venomous snake of tropical America. Color yellow or rose on back with a series of rhomboid brown speckles or indented black speckles; a black band extends from eyes to corner of mouth. Length about 6 feet. Central America and the tropical zone of South America.

Lachesis atrox.

Laboria is another name for this snake. Resembles the Fer de lance, but the body is stouter, the head larger, with more vigorous poison fangs. Length of the fang may reach $\frac{1}{3}$ inch. Color brown with crossbands or triangular speckles. Dark band from eye to corner of mouth. Belly whitish-yellow with brown spots. Length about 3.5 feet. Central America; from Peru to the north of Brazil.

\section{Lachesis pulcher.}

Color olive with brownish crossbands with white rim. Belly covered with fine confluent brown speckles. Length 2 feet. The Andes of Ecuador.

\section{Lachesis microphthalmus.}

Snout short and rounded, eyes very small. Length 2 feet. Peru and Ecuador.

Lachesis pictus.

Snout obliquely truncated. Length I foot. Peru.

Lachesis alternatus.

Head narrow and elongated. Length 3.5 feet. Southern Brazil, Paraguay, Uruguay, Argentine.

\section{Lachesis neuwiedii.}

The Bothrops urutu of the Brazilians has obtuse snout. Scales highly carinated, as in the foregoing species. Color yellowish or pale brown with brown speckles rimmed black; the dorsal speckles form a single or double series alternately; belly more or less powdered with brown. Length 2.5 feet. Brazil, Paraguay, Argentine.

\section{Lachesis ammodytoides.}

Turned-up snout. Color brownish with large white-rimmed black speckles, or zigzag alternative crossbands; belly yellowish with brown speckles. Length $\mathrm{x} .6$ feet. Northeast of Chile and Argentine.

\section{Lachesis xanthogrammus.}

Length about 5 feet. Long snout. Ecuador and the Andes of Colombia.

\section{Lachesis castelnaudii.}

Length 3.5 feet. Long snout. Brazil, Ecuador, eastern Peru.

\section{Lachesis nummifer.}

Snout large and rounded; subcaudals mostly in one row. Length 2.8 feet. Mexico and Central America.

\section{Lachesis godmani.}

Snout large and rounded; subcaudals in one row. Length 2 feet. Guatemala. 


\section{Lachesis lansbergii.}

Snout turned up somewhat as in Vipera aspis. Subcaudals in one row. Length 2 feet. Southern Mexico, Colombia, Venezuela, Brazil.

Lachesis brachystoma.

Snout turned up. Length I.5 feet. Southern Mexico and Central America. Lachesis bilineatus.

Snout rounded; subcaudals for most part in two rows. Tail prehensile. Color greenish, in contrast to most of the enumerated species, which are mostly brownish, grayish, or dark yellowish, with or without black speckles; belly white; end of tail red. Length 2.5 feet. Brazil, Bolivia, Peru, Ecuador.

Lachesis undulatus.

Snout short and round. Color olive or brown, sometimes with black speckles. Tail prehensile. Length about 2 feet. Mexico.

\section{Lachesis lateralis.}

Snout rounded, subcaudals in one row. Tail prehensile. Color greenish with yellow line on each side. Length . 6 feet. Costa Rica.

\section{Lachesis bicolor.}

Much like foregoing. Green with yellow belly. Length I.2 feet. Guatemala. Lachesis schlegelii.

Subcaudals in one row. Tail prehensile. Coloration very variable: Green is predominant, with speckles or bands of black, rose, or red; belly yellow, with green or red; end of tail red. Length 2 feet. Central America, Colombia, Ecuador.

Lachesis nigroviridis.

Subcaudals in one row. Tail prehensile. Color greenish or olive with black speckles; belly yellow; head black. Length r.6 feet. Costa Rica.

Lachesis aurifer.

Snout short and rounded; subcaudal in one row. Tail prehensile. Color green with yellow speckles; black band on temple. Belly greenish-yellow. Length about 2.5 feet. Guatemala.

The Asiatic representatives of Lachesis are characterized by the shorter tail, which is often prehensile and enables the snake to climb or grasp the trees during the hunt for its prey. The subcaudals are in two rows. On account of the more general characteristics peculiar to this group, these snakes, though undoubtedly belonging to the common genus Lachesis, are divided into two main groups. As was mentioned previously, the term Trimeresurus is used by Stejneger in lieu of Lachesis, because the character of the tail is considered by him to be sufficient reason to group the Asiatic pit-vipers under the former designation.

\section{A. The first supralabial scale is in conlact with its neighbor.}

I. Scales in $2 \mathrm{I}$ to 25 (seldom 27 ) rows; 129 to 158 ventrals; 2 I to 27 subcaudals; 5 to 9 series of scales between supraocular

Lachesis monticola. plates. Tail non-prehensile.

Snout obtuse. Color brown or yellow above, pale yellow or brown on sides, with a brown temporal band; belly white, with brown spots. Length 2.5 feet. Tibet, Himalaya (up to 7,500 feet), Burma, Malay Peninsula, Singapore, Sumatra. Lachesis okinavensis.

Trimeresurus okinavensis.

End of snout pointed and raised. Color brown above with dark crossbands and a light temporal band; belly brown with black spots, especially along side of body. Length about r.25 feet. Okinawa, Riu Kiu Islands, Japan. 
Lachesis strigatus.

Length I.5 feet. Vicinity of Bombay, Deccan, Anamallays, and Nilgherries.

II. Scales in 27 to 37 rows; 174 to 231 ventrals; 54 to 90 subcaudals; tail non-prehensile.

Lachesis flavoviridis. "Habu." (Plate I8, A, B.)

Trimeresurus riukiuamus Hilgendorff.

Trimeresurus favoviridis Boulenger; later, Lachesis flavoviridis Boulenger.

Bothrops flavoviridis Hallowell.

Scales in 33 to 37 rows; 222 to 231 ventrals; 75 to 90 pairs subcaudals; 8 to 9 supralabials. Coloration pale brown or yellowish-green on the back with black marblings; the head has the longitudinal black streaks disposed symmetrically; belly yellow or greenish with darker speckles. Length about 4 feet.

This snake is much dreaded by the natives and occasions many fatalities every year. Oshima and Okinawa subgroups of the Riu Kiu Islands, Japan.

Lachesis cantoris.

Color pale brown to greenish with small black speckles; side whitish; belly white or greenish. Length about 3 feet. Andaman and Nicobar Islands.

III. Scales in 21 to 27 rows; 160 to 218 ventrals; 54 to 92 subcaudals; the tail is slightly or not at all prehensile.

Lachesis jerdonii.

General coloration greenish-yellow with some black markings. Length about 3 feet. Habitat, Assam, Tibet, Yang-tse.

Lachesis mucrosquamatus.

Trimeresurus mucrosquamatus Günther.

Trigonocephalus mucrosquamatus Cantor.

Not Lachesis mucrosquamatus Wall.

General coloration brownish or gray, with blackish speckles. Length about 3.25 feet. Formosa.

Lachesis luteus.

Trimeresurus elegans Gray.

Very much like the foregoing species, but this has somewhat keeled temporal scales. It lives in the crevices of stone walls, or in hollow trees, etc. It is more sluggish than the L. flavoviridis. Length about 3 feet. Yaeyama Islands, Riu Kiu, Japan.

Lachesis purpureomaculatus.

Color, back purplish-black, sometimes variegated with pale green; sides pale green; belly olive or whitish-green, uniform or with black spots. Some specimens are completely green. Length about 3 feet. Himalaya, Burma, Malay Peninsula, Andaman and Nicobar Islands, Pinang, Sumatra, India.

IV. Scales in 2 I (occasionally I9 or 23 ) rows; 7 to $I_{3}$ series of scales between supraoculars; tail more or less prehensile.

Lachesis gramineus. "Green pit-viper." (Plate $17, \mathrm{c}$.)

Trimeresurus gramineus.

Snout more or less prominent. Color bright green, seldom olive or yellowish. with deeper crossbands; end of tail yellow or red; belly green, yellow, or white. Length about 2.8 feet. Southeastern Asia, Darjeeling, Himalaya, delta of Ganges, Siam, South China, Hong Kong, Formosa, Java, Sumatra, Timor.

Lachesis flavomaculatus. (Plate $\mathrm{r} 7, \mathrm{~B}$.)

Snout is prominent and obliquely truncated. Color bright green or olive, sometimes with reddish-brown bars; belly green, olive, or yellowish-green; end of tail usually red. Length about 3.2 feet. The Philippine Islands. 


\section{Lachesis sumatranus.}

Color bright green with or without black crossbands; yellowish band on each side; belly yellow or green with or without black speckles; end of tail red. Length about 3.5 feet. Singapore, Sumatra, Borneo, Palawan.

Lachesis anamallensis. (Plate $\mathrm{I} 7, \mathrm{D}$.)

Color green, olive, yellow or reddish-brown; black temporal band; belly pale green; tail usually black or yellow. Length 2.5 feet. Anamallay and Nilgherries, southern India.

\section{Lachesis trigonocephalus.}

Coloration similar to preceding. Length about 2.5 feet. Ceylon.

\section{Lachesis macrolepis.}

Color bright green or olive. Belly pale green. Length about 2 feet. Southern parts of India.

\section{B. First infralabial plate is divided; the separated portion forms a pair of small supplementary dental plates; 144 to 176 ventrals; 38 to 57 subcaudals; tail prehensile.}

\section{Lachesis puniceus.}

Scales in $2 \mathrm{I}$ to 23 rows. General coloration gray, brown, or red; belly spotter brownish; end of tail red. Length 2 feet. Java, Borneo.

\section{Lachesis borneensis.}

Length about 2.2 feet. Borneo, Sumatra.

\section{Scales in 19 to 27 rows; ventrals 127 to 156 , subcaudals 45 to 55. Tail prehensile.}

\section{Lachesis wagleri.}

Color green with lighter or deeper black and yellow speckles. Length about 3 feet. Malay Archipelago and Peninsula.

\section{Genus SISTRURUS Garman.}

Head very distinct from neck, covered with 9 large symmetric plates. ${ }^{1}$ Eyes rather small, with vertical pupils. Body cylindrical; scales carinated, apical fossa. Tail short, terminated by a horny appendix which produces a peculiar sound (the rattle); subcaudals for the most part in one row.

Sistrurus miliarius. "Southern Pigmy Rattlesnake."

A very small species with stout body and distinct, flattened head. Tail thin, minute rattle. Dark ashy gray, with a series of large, black blotches on the back, these irregularly rounded and separated by reddish spaces; on the sides are several series of black spots, smaller and less distinct than those on the back; tail unusually reddish; belly white, thickly marbled with black spots or blotches. Length about 1.8 feet. Florida, central North Carolina, coastal region along the Gulf of Mexico to Texas. Along the Mississippi valley to Arkansas and central Oklahoma.

Sistrurus catenatus. "Massasauga." (Plate 19, A.)

Large and comparatively stouter snake than S. miliarius. Tail shorter, rattle better developed. Ground-color grayish-brown, with a series of large, rich-brown blotches on the back, these faintly bordered with white; tail ringed with dark brown; belly dull gray marbled with black or entirely black; throat paler. The maximum number of joints of the rattles examined by Ditmars was eight. Length about 2.5 feet, but reaches 3.5 feet. 
It is a snake of swampy localities, and eats cold-blooded animals, unlike Crotalus; in this and in the presence of the large shields on the head the pigmy rattlesnake resembles the copperhead or water-moccasin. It can be kept in captivity, as it readily becomes tame and takes food.

Sistrurus catenatus var. edwardii.

Coloration much paler and more yellowish than the typical form. Habitat, from Ohio to Nebraska, Minnesota, Wisconsin, and Michigan, and even some districts in Canada and south to Mexican borders. The Edwards massasauga extends farther south than the regular massasauga.

\section{Sistrurus ravus.}

General coloration yellowish-brown with a dorsal series of dark-brownish blotches, and a series of crossbars; belly yellowish with brown spots. Length about 7 inches. Vera Cruz, Mexico.

\section{Genus CROTALUS Linnæus. (Plate 15, D, E.)}

This genus is provided with the rattle as in the Sistrurus, but may be distinguished from the latter by the scutellation of the head; this being small and granular. A few varieties may be covered with some enlarged shields in the front of the eye. The genus comprises I 5 distinct species and several varieties; I I of these species and 2 varieties are found in the United States. The rattle consists of a number of thin, but dry and more or less elastic, hollow, horny cones of successive sizes. These horny cones have a stricture in the middle and are divided into an upper smaller cone and a lower larger cone. The base of the lower cone is inwardly turned and its diameter is smaller than that of the smaller upper section of the next proximal cone, which is constructed in a similar manner. Thus the upper globular portion of the horny cone serves to hold the next cone by means of the inwardly turned edge of the latter. Of course the diameter of the base opening of the second cone is longer than that of the strangulated part of the first cone, but shorter than that of the upper globular part of the latter. The articulation of the rattle-cones is very loose and a slight shaking is sufficient to cause the well-known sound.

The number of the cones or "buttons" does not agree with the number of years the snake has lived, as is commonly believed, but increases irregularly irrespective of the age of the snake; it seldom surpasses 18 to 20 cones.

Rattlesnakes live in all kinds of ground, but prefer rocky regions, where they have abundant places of concealment. They are not of quick movement and do not bite quickly unless trodden upon or attacked. It is hard to induce them to take food when in captivity.

\section{A Chain of Large, Dark, Pale-Bordered Rhombs or "Diamonds."}

(a) Diamond markings closed on sides:

Dark olive; rhombs with yellow borders. (Southeastern United States). Crotalus adamanteus. Grayish; rhombs with whitish borders. (Texas to southern California) ..... Crotalus atrox. Reddish; rhombs with whitish borders. (Southern and lower California)

Crotalus atrox var. ruber.

Dull white or pinkish, with very obscure, rhomb-like markings. (Southern

California, lower California, and Arizona) $\ldots \ldots \ldots \ldots \ldots$..............

(b) Diamond markings narrowly open at sides and continued downward as narrow bands:

Yellow or greenish. Two paler blotches within each rhomb. (Arizona, New

Mexico, and Mexico) ......................................... molossus. 


\section{A Row of Rounded, Dark-Bordered Blotches, Weli, Separated.}

(a) No horn over the eye:

A pale band, one scale wide, in front of eye. (Central United States, Canada

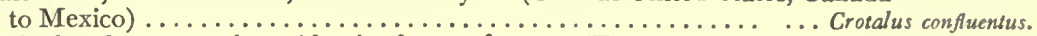

A pale band, two scales wide, in front of eye. (Extreme western United

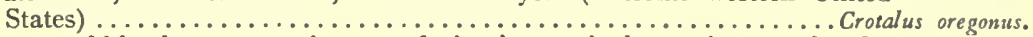

Two rows of blotches on anterior part, fusing into a single row in rear of body.

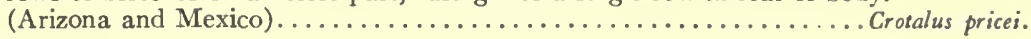

(b) A horn over each eye:

Yellowish; square, dull blotches on back and black spots on sides. (Deserts of Arizona, Nevada, and California) .............................. Cras cerastes.

\section{Markings in the Form of Dark, Transverse Bands.}

(a) Bands angular:

Bands regular in the rear - sometimes broken into three blotches - the central the largest. (Eastern United States, Vermont to Florida; westward to the

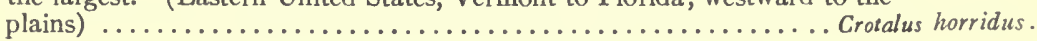

(b) Bands even:

Yellowish or gray; three series of blotches on anterior portion of body. On latter two-thirds of body bands closely situated. (Desert mountains of southern California, Arizona, Nevada) ...................... Crotus tigris. Greenish; narrow and regular black bands at a considerable distance apart. (Region of the Mexican boundary, from western Texas to western

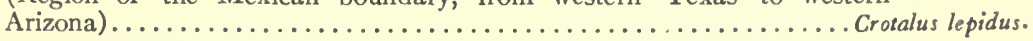

\section{Crotalus adamanteus Beauvois. "Diamond-back Rattlesnake." (Plate 19, B.)}

Crotalus durissus Linnæus.

This is the largest species of the whole fanily and grows over 6 feet and even up to 8 feet in some specimens. Body stout and heavy. Head broad, flat, and distinct from the neck. Scales in 25 to 29 rows, the dorsals highly carinated; 169 to I8I ventrals; 24 to 32 subcaudals. The poison fangs are of highest efficiency both in structure and in dimension. Coloration olive or grayish-green, with a chain of large, diamond markings of a darker hue, these with bright yellow borders about the width of a single scale; toward the tail they become obscure and fuse into crossbands; the tail on top is olive, ringed with black; belly dull yellow. Southeastern United States, from North Carolina to Florida and along the mouth of the Mississippi.

This reptile is said to be very bold and alert. A diamond rattler seldom glides for cover, if disturbed. Pine swamps and hummock lands are its favorite haunts. It is mostly of a nocturnal nature and hunts its prey after twilight. Wild rabbits, rats, birds, and the like constitute its food. It swims well, but seldom climbs trees.

Crotalus horridus Linnæus. "Banded Rattlesnake" or "Timber Rattlesnake." (Plate 13, F; plate 19, c.

The general scutellation is similar to the Crotalus adamanteus. The most familiar coloration is that of a sulphur-yellow ground-color, with wide, dark-brown or black crossbands, these usually wavy or sharply pointed in the rear; tail black. Another common phase is olive. On the anterior portion of the body are three series of dark blotches, margined with yellow; these fuse into wavy, yellow-edged crossbands on posterior two-thirds of body; belly uniformly yellow or spotted with black on yellow. Length about 3.5 to 4 feet.

Central Vermont to the northern portion of Florida, thence westward to Iowa, Kansas, Indian Territory, eastern Texas. Abundant in the coastal regions of the Atlantic and the Gulf (variety cane-brake rattlesnake). The mountains of southern New York, Massachusetts, and eastern Pennsylvania. 
This species lives in mountainous regions where they find many ledges, cleft with many fissures and large shelving rocks. During the hibernating season they gather together, coiling closely, and thus pass the winter. In the spring, during the mating season, they linger on the main ledge in large numbers, but finally scatter to the timber for the warm months. This is the most mild-tempered species and becomes so docile that it can be handled like the harmless snakes.

Crotalus atrox Baird and Girard. "Western Diamond Rattlesnake."

Next to the diamond-back rattlesnake of the Southeastern States, this species is the largest of the genus. It attains a length of 7 feet. Color-pattern similar to the preceding species, except the tail, which is white with jet-black rings. The ground-color may be yellowish-gray, pale bluish-gray, or pinkish, according to the localities. General color-pattern much duller than the eastern species. Some specimens from the desert region of Arizona are of distinct pinkish ground-color with vividly white-rimmed rhombs. Tail chalky white with jet-black rings. It mainly inhabits the sub-arid and desert regions of Texas and southwestern United States. Common in central and western Texas, southern New Mexico, Arizona, and southern California. In Mexico the coloration and scutellation of the head differs from the original type. This is one of the wildest and most vicious species.

Crotalus atrox var. scutulatus. "Mountain Diamond Rattlesnake."

Crotalus scutulatus Boulenger.

Irregular plates cover anterior portion of head, resembling Crotalus oregonus. It is, however, maintained to be a subspecies of Crotalus atrox, which in the Mexican Tablelands has undergone variation in some of the typical forms. Length about 3 feet. Arizona, New Mexico, Texas, northern part of Mexico.

Crotalus atrox var. ruber Cope. " Red Diamond Rattlesnake."

Differs from the typical atrox in having a more reddish hue. Length about 4.5 feet, but can grow up to 5 feet. Arid regions of California, and the peninsula of lower California; southwestern Arizona.

Crotalus confluentus Say. "Prairie Rattlesnake."

Body not so stout as most rattlesnakes, and the snake seldom reaches a length of 6 feet. Greenish-yellow, or olive, with a row of large, round, and well-separated blotches of brown upon the back. Toward the tail the blotches fade into obscure bands. The head marking differs from the Pacific rattlesnake. In the prairie rattlesnake a dark band starts from beneath center of eye to angle of mouth, while the Pacific rattlesnake has the dark band commencing behind center of eye. The dark band is bordered with yellow strips - the front strip being narrow, the width of one scale row, whereas the pale strip of the Pacific species is of the width of two scale rows.

This species is rather vicious and irritable, but becomes very tame in captivity. In the prairie this snake often prowls into the burrows of prairie dogs, but instinctively it seeks the deserted burrows. Sometimes the snake may be hunting in the burrows to devour some of the young.

Western parts of North America, from British Columbia ( $46^{\circ}$ north latitude) to the southern parts of California, Dakota, Nebraska, Kansas, southwestern Texas, northern Mexico.

Crotalus oregonus Holbrook. "Pacific Rattlesnake."

Crotalus lucifer Baird and Girard.

Rather smaller than the prairie rattlesnake, but resembles it in most other characters except head markings, of which mention has been made above. Habits similar to the Prairie rattlesnake. Length under 4 feet. The Pacific region, from southern British Columbia to southern California; also in Idaho, Nevada, and Utah. It occurs in altitudes as high as I I,000 feet. 
Crotalus tigris Kennicott. "Tiger Rattlesnake."

This snake seldom attains more than 3.5 feet. The general features not essentially different from prairie and Pacific rattlesnakes. Yellowish-gray, with a series of small and not very distinct blotches on back and on each side, for the anterior third of body; on the latter two-thirds, these blotches fuse into regular crossbands, producing a strongly barred effect. It becomes docile in captivity. Desert mountains of Arizona, Nevada, and southern California.

Crotalus molossus Baird and Girard. "Black-tailed Rattlesnake."

Head large and quite blunt at snout. On the upper part of snout are 3 pairs of enlarged scales. Body fairly stout and attains a length of 3.5 to 5 feet. The uniform jet-black tail distinguishes this snake from the other southwestern species. Its range is not farther north than the central portion of Arizona. Its range into Mexico is not definitely known.

Crotalus cerastes Hallowell. "Horned Rattlesnake" or "Side Winder:"

One of the smallest species of Crotalus. It has a horn-like projection over each eye. Body stout, with strongly keeled scales. Pale brown, yellow, or pinkish, with a series of dull blotches, generally separated by white interspaces; irregular rows of small black or brown spots on sides; several black bars on tail. Maximum length about 2.5 feet. Desert areas of Arizona, southern Nevada, southwestern Utah, and eastern California.

Crotalus lepidus Kennicott. "Green Rattlesnake."

The smallest species of the genus. Body quite slender. Greenish-gray or rich, dark green above, crossed at wide intervals by narrow jet-black bands; the bands are usually bordered with pale greenish-yellow; belly pinkish, or yellowish-white Just behind the head is a black blotch forked in the front. Length about 2 feet. This species inhabits mountainous areas, on both sides of the Mexican boundary.

Crotalus pricei Van Denburgh.

Rare and very small, resembling Sistrurus catenatus in general appearance. Length about 2 feet. Southern Arizona to northern part of Mexico.

\section{Crotalus triseriatus.}

Length about 2 feet. Mexico.

Crotalus polystictus.

Length about 2 feet. Tableland of Mexico.

Crotalus mitchelli Cope. "White Rattlesnake."

The head squamation differs from the other rattlesnakes. The large anterior nasal plate is separated from the rostral plate by small scales. With other species of Crotalus the anterior nasal shield is in contact with the rostral plate. Grayishyellow or pinkish, the body profusely sprinkled with brown dots; upon the back these dots assume the form of a series of blotches, which imparts much the same effect as the pattern of the western diamond rattlesnake. A bright-red specimen has been taken in Canyon Prieto of Arizona and was named Crotalus pyrrha by Cope, but no more of the same variety have since been encountered. Length about 3.5 feet. Desert mountains of lower California, southern California, southern Arizona, and extreme northeastern Mexico.

Crotalus terrificus. "Dog-faced Rattlesnake."

Length 4 to 4.5 feet. Northern part of Brazil and northern Argentine. 


\section{CHAPTER III. \\ PHYLOGENY OF VENOMOUS SNAKES.}

The distinction between the non-poisonous and poisonous snakes is the presence in the venomous species of a special poison apparatus, consisting of a poison gland and poison fangs - teeth especially adapted for injecting the venom into the tissue of the victim. The poison gland is in communication with the poison fang through an excretory duct which originates in the former. The poison fang is distinguished from ordinary maxillary teeth by the presence of a longitudinal groove or a canal running along the axis of the fang on the frontal side. The canal ends in a slit-like orifice on the frontal surface near the apex. A mere presence of the poison gland alone does not, however, entitle a snake to the rank of Serpentes venenata, but it requires the simultaneous presence of the poison fang and the poison gland. The composite and complex nature of the poisonous apparatus creates conditions which directly or indirectly influence the degree of danger from a bite of a poisonous snake. The efficiency of a venomous bite depends to a considerable extent upon the size and position of the poison fang, the nature and amount of the venom, and also the habit of the snake. These factors decide the degree of danger of the poisonous snakes and render it convenient to group them into dangerous and non-dangerous species.

The evidence that the poison apparatus is the result of progressive evolution is made clear in the morphology of the maxillary teeth alone. In the innocuous species the maxillary teeth are small, uniform, and solid, and are designated Aglyphodont. The next group of species has one or more grooved teeth in the rear of the maxilla, but no grooves in the anterior teeth. This group has received the name of Opisthoglyph, and must be considered as the primitive form of the venomous snake. The next step of advancement is shown in certain species in which the anterior maxillary tooth or teeth are grooved in varying degree. The groove may be so deep that the edges protrude forward to fuse together and inclose a complete canal. In such case the junction line of the edges is easily recognizable. Behind the grooved or canaliculate teeth there may be some small solid teeth in some species. This group is known under the name of Proteroglyph. Here the grooved teeth attain a larger size than the rest of the maxillary teeth. The last and highest stage of evolution of the poison fang is, however, seen in the group called Solenoglyph, in which all maxillary teeth embrace a longitudinal tubular duct. Only in the newborn specimens a faint fusion mark along the frontal median line of the fang is visible, while no trace persists after maturity. The size of the fang reaches large proportions, and the fang is erectile through the movable joint of the maxillary bone with the prefrontal bones.

A systematic inquiry into the relation between the poison fang and poison gland in their evolutional chronology is not without certain bearing on the question of the origin of poisonous snakes, and on the evolutional relation of 
the poisonous to the non-poisonous species. The question may be raised as to whether the poison gland and fang came into existence at the same time, or whether one antedates the other. If not of simultaneous appearance, which of the two came first? Through elaborate work of various investigators it was made clear that the poison gland does exist in the group of snakes which possesses no grooved or perforated teeth, and the presence of the grooved tooth is always associated with a much more developed venom gland than the rudimentary form of the aglyphous species. The poison gland of the snake is a modified form of the glandula labialis superior and in all probability is equivalent to, if not identical with, the parotid of the mammalia.

In the Urodelia and the Anura the oral cavity is provided with the mucussecreting glands which are located in the internasal and lingual regions, and also in the pharyngeal area in the latter order. In the Chelonia the medial and lateral palatine glands take the place of the internasal, and the sublingual appears anew. In the Crocodilia no sublingual gland is present. First in the Sauria, comprising both the Lacertia and the Ophidia, the glandula labialis, superior and inferior, are added to the sets already mentioned. For the Ophidia no palatine gland is present, but there is sometimes the poison gland. Phylogenetically considered, the salivary glands appear first in the Amphibia, in which the mucus-secreting glands are the only kind. In the Pisces no salivary gland is found. The majority of the Reptilia possess the mucous gland with a fairly high, clear cylindrical epithelium, which contains more or less granules in the protoplasm (Wiedersheim, I886). In this class, however, not only the number of glands, but also their shape, arrangement and structure, become more abundant and variable, with acquisition of certain new functions at the same time. In certain Sauria, for example, the Lacertia and Anguis fragilis, a serous and a mucous gland are formed in the area of the sublingual gland, a fact which shows that the condition is gradually approaching the mammalian class.

The poison gland of snakes has occupied the minds of many great anatomists for solution of its origin and its relation to the salivary glands, both in the same order and in the orders next to it. Comparative studies of Carus (1834), Tiedemann (I810), Meckel (I829), Stannius (1846), Ellenberger and Hoffmeister (188I), and others demonstrated that in the mouth of birds of prey there are at least four to five sets of glands, corresponding to the submaxillary, sublingual, lingual, parotid, and a group of glands (follicle) near the side of and behind the posterior nostrils, which, together with a large group around the Eustachian tube, was held for the tonsils by Rapp (I843). Rapp's interpretation was shown to be incorrect by the work of Kahlbaum (I854), Leydig (I857), Stöhr (I884), Gadow (I89I). The peculiarity .of the avian mouth is in the presence of a pair of glands over the maxillary joint. Carus (I834) was not able to decide whether it is to be considered an analogue of the parotid of the mammalians or the poison gland of snakes. Ranvier (I884, I887) held that the cells of the gland erroneously called the submaxillaris are mucus-secreting, which is not the case with the gland of the labial commissure. Battelli and Giacomini (I889) described two types of cells, 
a typical mucus-epithelium and a granulated cell, but considered them to be identical only in different stages of function. They considered the gland in the corner of the mouth not identical with the parotis of the mammalian, and named it glandula angularis oris. Cholodokowsky (1892, I893) declared that the salivary glands of the birds are purely mucus-secreting. Wiedersheim (1898) hesitated to conclude the identity of the gland of the mouth corner of birds with the posterior supralabial gland or the poison gland of snakes, while Gadow (1879) recorded the occurrence of the parotids in various species of birds. As mentioned before, snakes possess the supralabial glands throughout all families. It was also remarked that only certain snakes have well-developed poison glands. The question may be asked whether the poison gland may be phylogenetically related to the parotid of the mammalia or the glandula angularis oris of the birds. What relation has it to the supralabial glands in general? The situation and the serous character of the secretion and the single excretory duct of the poison gland suggest strongly a possible homology with the mammalian parotid. The histological and the anatomical examinations of the supralabial glands of many innocuous snakes brought out certain interesting facts which seem to help to trace back the origin of the poison gland. The accounts of the anatomical studies of various glands of the oral cavity by the early investigators are mostly macroscopic. Meckel (I826) stated that the non-poisonous snakes possess far larger salivary glands than the poisonous ones. A similar finding is in Stannius's work (I846). The supralabial gland (glandula labialis superior, Leydig; glandula maxillaris superior, Oppel) has been exhaustively examined by Tiedemann (I8I3), Meckel (I826), Cuvier (I8Io), Cloquet (I821), Dugès (I827), Duvernoy (1832), Schlegel (I837), and Leydig (I873). Leydig made the important discovery that the glandula labialis superior of non-poisonous snakes is composed of two distinct parts. The anterior part is reddish-gray in color and consists of many minute glandular grains, with numerous excretory ducts. The posterior part appears yellowish-white and is of coarser glandular grains. It possesses only one excretory duct and is homologized with the poison gland of the venomous species. Reichel (I882) demonstrated an exactly similar condition of the gland with Tropidonotus natrix, one of the harmless, solid-toothed colubrine snakes.

According to Leydig ( 1873 ) the poison gland is not a proper gland; but a modification of one of the lobes of the supralabial gland, and may be present in non-poisonous snakes. It may be here stated that, prior to Leydig, Meckel (I826) announced that the poison gland originates in an enlargement and development of the yellowish portion of the supralabial gland. As early as I833 Duvernoy demonstrated the occurrence of the poisonous gland in many species hitherto considered non-poisonous, and declared thereby that the simultaneous presence of the poison fang is one of the essential characteristics of the poisonous snakes. Phisalix and Bertrand (I894) look upon the toxic property of the adder blood as deriving from the supralabial gland through the internal secretion, and the natural immunity of the same animal against the viperine venom as the result of constant immunization by the same prin- 
ciple as echidnin. Jourdain (1894) found that Tropidonotus viperinus, Elaphis asculapii, Coronella levis and Rinachis scalaris enjoy the same immunity against the viper's venom as Tropidonotus torquatus. He held it certain that these snakes have the venom-producing apparatus and contain its product in the blood. Jourdain ventured a still more far-reaching generalization, that every snake is provided with the venogenous gland.

While the experimental data concerning the toxic property of the posterior yellowish portion, alleged to be homologous with the real poison gland by Leydig, are strikingly meager, a mere anatomical investigation into the extent in which that particular portion of the supralabial gland comes into existence among the non-poisonous species seems to warrant enough interest to be briefly dwelt upon in this place. Several species of the Aglyphous snakes have been studied by some investigators. Of the subfamily of Natricinæ (or Colubrinæ) some species of the genus Natrix (or Tropidonotus), of the subfamily Coronellinæ, some species of the genus Elaphe (s. Coluber), Ptyas (s. Coryphodon) and Herpetodryas, ${ }^{1}$ and of the subfamily Rhachiodontinæ, the genus Daspeltis have been studied.

Tropidonotus natrix s. Natrix torquatus Fleming: the glandula labialis superior consists of a grayish and a yellowish portion. The glandular grains are made of aggregates of tubules. The cellular elements of the yellowish portion are filled up with granules, and appear like the rennet cells. The epithelium of the excretory duct is a high, clear cylinder cell. The entire yellowish part is provided with one single duct, while the anterior parts have many small ducts opening near the teeth. Leydig (1873) drew an analogy between the yellow portion and the parotid of the mammalia. The posterior part of the yellowish portion is described by Leydig as having the dark, granulated epithelium. Reichel described a similar character of the cell and added that the nucleus is situated basally. The examination of the grayish part reveals many tubules with clear cylindrical cells, which show transverse striation when treated with osmic acid. The reddishgrayish portion contains transparent, non-granulated cells, which are cylindrical and have basal nuclei. Sometimes there are smaller, highly granulated cells with nuclei dislodged. These are usually met with in the edge of the acini. Some alveoli may consist entirely of this type, others chiefly of the first-named kind, and still others of a mixture of the two types. Reichel considered these varying types of the epithelia as the representatives of different stages of cellular activity, the first type being the resting state.

Tropidonotus subminiatus Reinwardt: Niemann (1892) has described the supralabial and the yellowish gland separately. He found four smaller excretory ducts in the former and one larger for the latter. The yellowish gland is surrounded by a strongly developed connective tissue capsule, which has a circular cleft to allow the entrance of the blood-vessels. The long-oval tubules of the gland are surrounded by a thin, delicate connective tissue membrane. The glandula labialis superior is wrapped up in a layer of strongly developed connective tissue, within which a lymphatic space is also present. 
Tropidonotus tesselatus Laurenti: In the glandula labialis superior, which is somewhat smaller and narrower than that of the natrix, there is present the yellowish portion with large follicles.

Coronella levis Merrem: This species possesses the glandula labialis superior, consisting of one grayish and one yellowish portion.

Coluber viridiflavus var. carbonarius Schreiber, or Coluber flavescens s. asculapii: The Æsculapius snake has a less-developed supralabial gland, which has, however, two distinct portions, one grayish and one yellowish portion. The cells forming the tubules of the yellowish portion are highly granulated. The only duct is lined with high, clear, cylindrical cells greatly differing from those present in the glandular tubules. The rest of the gland, composed of smaller acini, has clear, epithelial cells. Leydig (I873).

Elaphis virgatus Schlegel: In the rear part of the supralabial gland is formed the yellowish portion, which is distinguished, by its firner consistency, from the glandula labialis superior proper. Three excretory ducts are provided for the latter, but only one for the yellowish portion. The structure of the yellowish part is briefly stated here. This portion (yellow) is surrounded by a scantily developed connective tissue, beneath which lies the lymphatic space with small, irregular, compressed meshes, from above to below, which contain some lymphatic cells. The gland consists of small, mostly tubular spaces, which, while rather narrow, are quite regularly built and often present a flattened form. Each of these tubules is inclosed in an extremely delicate, soft connective-tissue layer. The interior of the tubule is lined with epithelia of cubic shape. The connective-tissue capsule of the glandula labialis superior is weaker than that of the yellowish portion.

Ptyas korros Schlegel s. Coryphodon korros Jan: In this species the glandula labialis superior consists of a grayish and a rear yellowish portion, but the transverse sections of the two are described as similar.

Herpetodryas carinatus Boie: No yellowish part is found in this species, although the glandula labialis superior is regularly developed and surrounded by a poorly developed layer of connective tissue in which a lymphatic space is noticeable. In the place of the yellowish portion, which is missing even in a rudimentary form, the glandula membran. nictitant. is enormously developed.

Liophis merremii Wiedersheim: This is another example in which no yellowish part is observed in the rear of the glandula labialis superior.

Daspeltis scaber Wagler: Kathariner (1898) described in this species, besides other sets of oral glands, an independent poison gland, which, according to his judgment based upon the anatomical characteristics, can not be considered as a specialized part of the supralabial gland. This gland is a tubular, branched, and compact gland by itself and has one single central duct, which opens at the corner of the upper jaw in a pocket of the mucous membrane of a definite tooth. On the other hand, the glandula labialis superior is composed of numerous alveolar glands which secrete their product into the groove between the maxilla and the upper lip through 
their respective ducti excretores. Among these different Aglyphous species only two seem to lack the rudimentary venom gland or the yellowish portion of the glandula labialis superior.

One of the most natural outcomes of these morphological investigations would lead to an investigation whether the parotid secretion of these solidtoothed snakes is really toxic when it is introduced directly into the blood circulation of different animals, which are susceptible to the action of the parotic secretion (venom) of some poisonous species. This interesting problem attracted the attention of Bertrand and Phisalix (I894), who discovered that the salivary glands of two European species of Tropidonotus secrete a fluid which acts fatally upon guinea-pigs when injected into them.

Still later Alcock and Rogers (1902) examined the poisonous property of the watery extract of the parotid of freshly decapitated specimens of Zamenis mucosus upon rats and mice and of the watery and saline extracts of the parotid and the Harderian glands of Tropidonotus piscator upon the last-named animal. The injection was made subcutaneously. The parotid extract of the Aglyphous snakes used was a viscid mucin, quite different from the thin, opalescent fluid derived from the Opisthoglypha. The violent convulsions that followed the injection of Zamenis extract presented a marked contrast to the characteristic dyspnœic convulsions caused by the Opisthoglyphous snakes, although a sufficient dose killed these small mammalia. The extract of the Harderian gland was without toxic effect.

The poisonous property of the parotid gland, as well as its secretion, of certain harmless, non-groove-toothed snakes, has been established beyond doubt, but there is still much to be done about this problem, especially in regard to the identity of the poisonous principles of these rudimentary forms of the venom glands. A similar investigation of a greater number of nonpoisonous snakes and even of the mammalia is highly desirous.

The passing of snakes from the non-poisonous into the poisonous kinds is a gradual process and is associated with a definite morphological and functional modification of the parts directly concerned. This modification is an acquisition of the poisonous apparatus by grades, namely, the specialization of the supralabial gland into a venomous one, and then the canalization of the maxillary teeth so as to enable them to conduct the venom. These changes are also accompanied by an ascending perfection of these and other accessory apparati. Thus, in one group of snakes there is neither the venom gland nor the poison fang. In a second there is the venom gland of a rudimentary stage, but no venom-conducting tooth. In a third the venom gland attains larger dimensions, but the fang is still primitive, being moderate in size, shallow in groove, and situated inconveniently in the rear. In a fourth group the conditions are more favorable, as the venom gland is better developed, the fang is longer and has a deeper groove or a canal, and its position is in the anterior of the maxilla. The fifth and last group has a well-developed gland and one or more large and strong fangs. The fang is tubular and situated in the anterior part of the peculiarly short space of the erectile maxillary bone. 


\section{CHAPTER IV.}

\section{GEOGRAPHICAL DISTRIBUTION OF VENOMOUS SNAKES.}

New Zealand is entirely free from snakes. Australia and its adjacent islands are free from the Viperidæ - containing neither the Viperinæ nor the Crotalinæ. The American continents are noted for the absence of the true viperine forms, whereas the Crotalinæ, another representative of the Viperidæ family, is fully established throughout temperate and tropical America. The famous rattlesnakes are the most specialized of all the venomous snakes and are exclusively confined to the New World. The total absence of the poisonous Colubridæ from Europe is another remarkable geographical feature, and it is highly interesting to note that the only venomous snakes here belong to the Viperinæ, of which but one genus is represented. In Africa the representatives of the Viperinæ are most numerous, but there are none of the Crotalinæ; of the Colubridæ no Hydrophiinæ are found, while the Elapinæ are fairly numerous.

Asia contains almost every genus of poisonous serpents, except Crotalus. The Elapinæ are well represented by Naja, Bungarus, Hemibungarus, Callophis, and Doliophis, while the Hydrophiinæ are most abundant along the coasts of the tropical regions of Asia. The true vipers are not unknown here, as the Viperinæ are represented by four genera. The crotalines are abundantly represented in Asia, as far as its western neighboring continent Africa, both by Ancistrodon and by Lachesis, better known as Trimeresurus, but, as was stated above, no Crotalus or rattlesnake. Thus Asia may be looked upon as a region where the evolutional balance of various venomous snakes is comparativcly well preserved.

One of the most extraordinary facts is that Australia is an exclusive home of venomous Colubridæ, of which no less than $\mathrm{r} 6$ elapine and 9 marine genera are enumerated; but, as pointed out previously, there is no representative here of the Viperidæ.

Returning to the American continents, the conditions are found to be quite contrary. Here peculiar relations exist between the Crotalinæ and the Colubridæ - both Elapinæ and Hydrophiinæ on one hand, and Crotalinæ and Viperinæ on the other. The prevailing venomous snakes of America belong chiefly to Crotalinæ, and the colubrine and the viperine snakes are thrown into the background. Especially no true vipers exist on this continent. Of the colubrine snakes only one genus is represented, Elaps, ${ }^{1}$ which, although it includes more than 20 species, is in a state of more or less general degradation, as may be judged from its diminutive size and its tendency to burrow.

1 Another genus was described, Micropechis, with only one species, elapoides. 
The predominance of the crotaline snakes is most remarkable. While the genus Ancistrodon is less numerously represented than in Asia, Lachesis is much more in evidence. Moreover, two new genera have made their appearance on the American continent, namely, Crotalus and Sistrurus. Both are characterized by the presence of the "rattles" at the end of the tail.

Of 8 different genera, 4 (Vipera, Echis, Pseudocerastes, and Cerastes) are found in Asia and Africa in common, and Vipera also in Europe, but the rest are characteristic of each continent. It does not follow, however, that these same genera occurring in different continents are represented by the same species. On the contrary, the species of a genus vary according to the prosperity enjoyed by the genus on the particular continent. The members of the genus Vipera have different species-characteristics, depending upon whether they inhabit Africa, Asia, or Europe. Of 4 genera of the subfamily Crotalinæ, Ancistrodon and Lachesis inhabit both Asia and America, but the constituent species of these two genera differ widely according to the continent to which they belong. It is also seen that of 28 genera of the subfamily Elapinæ, only the Naja is met both in Africa and in Asia, and of that genus there is no species common to both continents.

It is noteworthy that even the marine snakes, whose pelagic nature would render almost any artificial geographical boundaries of ocean insignificant, seem to have more or less restricted habitats. Thus, some genera prefer to swim about the coasts of tropical Asia, and especially along the Indian and Malayan coasts and Archipelago, while still others seem to be confined near Sydney. In general, however, the habitat of the marine snakes is highly uncertain and reports of the capture of certain species from unexpected parts of the globe add difficulties to this particular point.

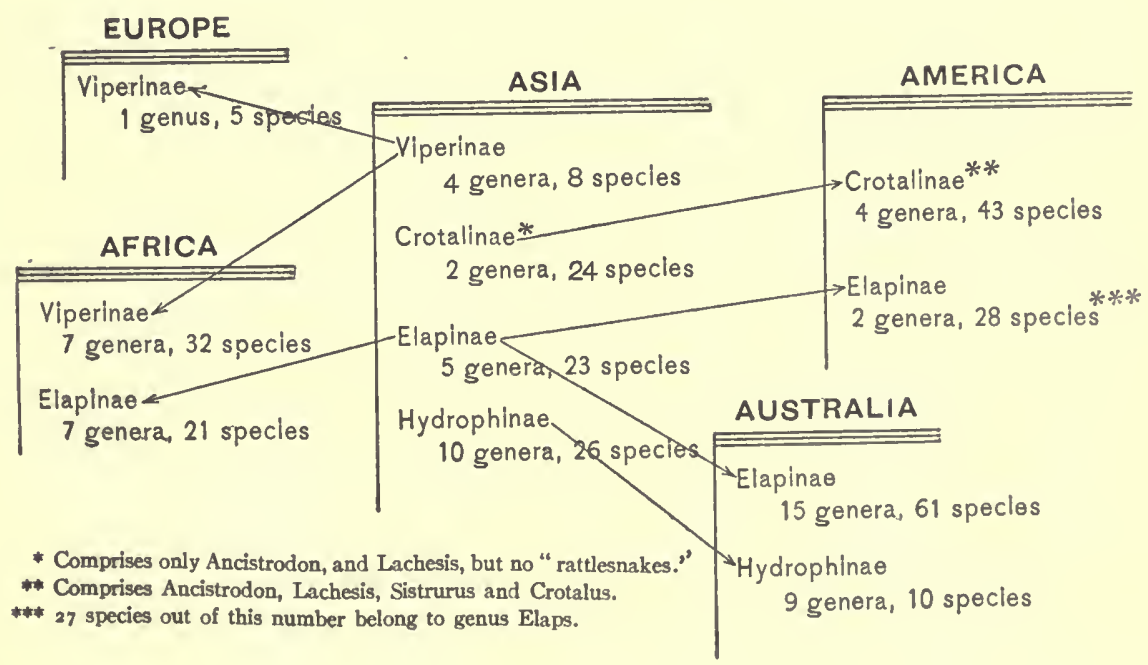




\section{List showing the Geographical Distribution of Venomous Snakes.}

ASIA.

\section{COLUBRIDE. \\ OPISTHOGLYPHA. \\ Dipsadomorphince. \\ Dipsadomorphus trigonatus. cyaneus. \\ kræpelini.}

Cœlopeltis monspessulana.

Psammodynastes pulverulentus.

Elachistodontine.

Elachistodon westermanni.

Homalopsina.

Homalopsis buccata.

Cerberus rhynchops s. Hurria rhynchops.

Hypsirhina plumbea s. Enhydris plumbea.

\section{PROTEROGLYPHA.}

Elapince.

Naja tripudians comprising varieties $N$. tripudians typica, $N$. tripudians cæca, N. tripudians fasciata, N. tripudians sputatrix, N. tripudians leucodira, N. tripudians miolepis.

Naja samarensis.

Naja bungarus s. Ophiophagus elaps s. Hamadryas (king cobra).

Bungarus fasciatus (banded krait).

Bungarus candidus var. cæruleus and multicinctus (common krait).

Bungarus ceylonicus. lividus.

India, Ceylon, Burma, China,

Dutch India, Philippines.

India, Ceylon, Burma, IndoChina, southern China, Dutch India, Borneo.

Hemibungarus colligaster. Southeastcollaris. nigrescens. India, japonicus. Japan, bœttgeri. Philippines.

Callophis gracilis. trimaculatus. maculiceps. macclellandii. bibronii. univirgatus.

Doliophis bivirgatus. intestinalis. bilineatus. philippinus.

Burma, IndoChina, Formosa, southern China.

$\begin{aligned} & \text { intestinalis. } \\ & \text { bilineatus. } \\ & \text { philippinus. }\end{aligned}$
Mansula.

Hydrophiince. Distira ornata. subcincta. cyanocincta. Strait of Malacca, jerdonii. Sea of China,
ASIA. - (Continued.)

Colubride.

PROTEROGLYPHA. Hydrophiina.

Acalyptus peronii. $\left\{\begin{array}{l}\text { Philippines, } \\ \text { Malay } \\ \text { Archipelago. }\end{array}\right.$

Hydrophis obscurus. spiralis. cærulescens. nigrocinctus. elegans. gracilis. cantoris. fasciatus. leptodira.

Tropical

Enhydrina valakadien s. and subbengalensis.

Hydrus platurus s. Pelamis bicolor.

Thalassophis anomalus.

Enhydris curtus. hardwickii.

Platurus laticaudatus s. fischeri. colubrinus. muelleri.

Hydrelaps darwiniensis.

Aipysurus eydouxii. annulatus. lævis.

VIPERIDE.

Proteroglypha (SolenoGLYPHA).

Viperina.

Vipera berus s. Pelias berus.

renardii.

raddii.

lebetina.

russellii s. V. ele-

gans s. Daboia. tropical parts of Indian and Pacific Oceans.

Pseudocerastes persicus..... Persia.

Cerastes cornutus.... Arabia, Palestine.

$\left.\begin{array}{c|l}\text { Echis carinatus s. } \\ \text { Phoorsa. }\end{array}\right\} \begin{aligned} & \text { Arabia, } \\ & \text { Persia, India, } \\ & \text { Beluchistan, } \\ & \text { Afghanistan. }\end{aligned}$

\section{Crotaline.}

Ancistrodon halys. intermedius. blomhoffii.

Ancistrodon blomhoffii brevicaudus. himalayanus. acutus. rhodostoma. hypnale.
Turkestan, Ural Mts., Siberia, Caucasus, Persia, Armenia, western China, India, Ceylon, Himalayas.

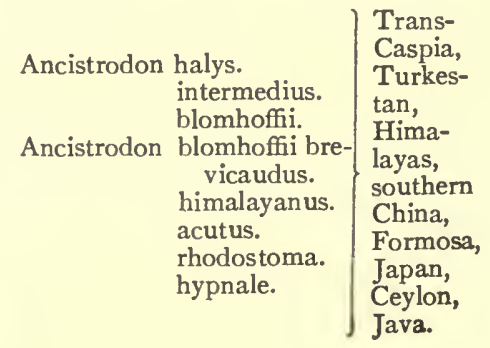


List showing the Geographical Distribution of Venomous Snakes. - (Continued.)

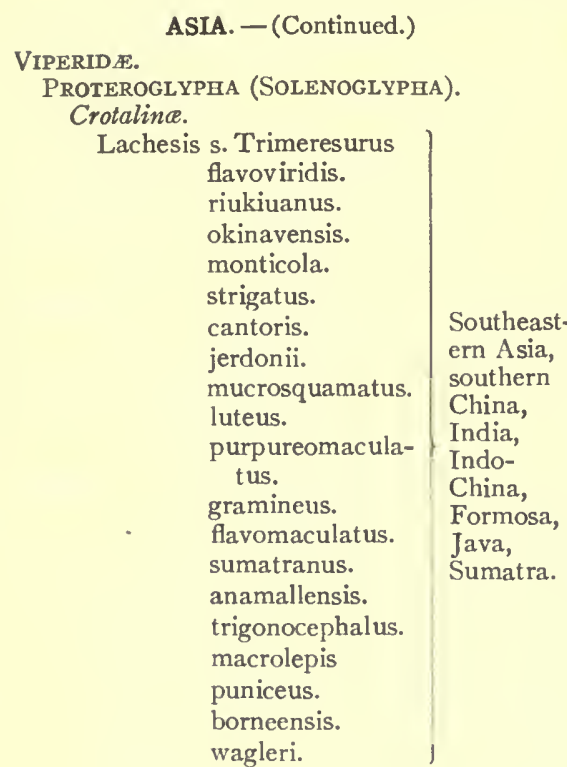

AFRICA.

COLUBRID瓜,

OPISTHOGLYPHA.

Dipsadomorphine.

Macroprotodon cucullat us.

Coelopeltis monspessulana.

Proteroglypha. moilensis.

Elapina.

Naja haje.

flava.

melanoleuca.

nigricollis. anchietæ. goldii.

Egypt, western
and eastern
Africa,
Morocco,
Congo,
Angola.

\begin{tabular}{l|l} 
Sepidon hæmachates. & $\begin{array}{l}\text { Southern } \\
\text { Africa, } \\
\text { Cape of } \\
\text { Good Hope. }\end{array}$
\end{tabular}

Boulengerina stormsi. \} Central

Elapechis guentheri. niger. hessii. decosteri. sundevallii. boulengeri.

$\left.\begin{array}{r|l}\text { Aspidelaps lubricus. } \\ \text { scutatus. }\end{array}\right\} \begin{aligned} & \text { Eastern and } \\ & \text { southern } \\ & \text { Africa, } \\ & \text { Mozambique. }\end{aligned}$

Walterinnesia ægyptia....... Egypt.

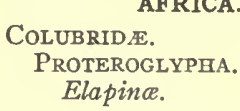

Colubride.

Proteroglypha.

Elapina.

\begin{tabular}{c|l} 
Dendraspis viridis. \\
jamesonii. \\
$\begin{array}{c}\text { angusticeps. } \\
\text { antinorii. }\end{array}$
\end{tabular}$\quad \begin{aligned} & \begin{array}{l}\text { Southern } \\
\text { and central } \\
\text { Africa, } \\
\text { Angola, } \\
\text { Great Lakes, } \\
\text { Congo, } \\
\text { Transval. }\end{array} \\
& \end{aligned}$

VIPERID乎.

Proteroglypha (Solenoglypha).

Viperina.

$\left.\begin{array}{c|l}\text { Causus rhombeatus. } \\ \begin{array}{l}\text { resimus. } \\ \text { defilipii. } \\ \text { lichtensteinii. }\end{array}\end{array}\right\} \begin{aligned} & \text { West Africa, } \\ & \text { Gambia, } \\ & \text { Great Lakes } \\ & \text { Congo, } \\ & \text { Angola, } \\ & \text { Iransvaal. }\end{aligned}$

Vipera latastii. ammodytes. lebetina. superciliaris.

\section{Morocco, Tunisia, Algeria, Egypt, Mozambique.}

Bitis arietans. peringueyi. atropos. inornata. cornuta. caudalis. gabonica (Rhinoceros viper). nasicornis.

Zanzibar, Zambesia, Transvaal, Cape, Congo, Gaboon, Benguela, Angola, Senegal, Niger.

Cerastes cornutus. Eastern Africa, vipera. Sahara.

$\left.\begin{array}{c|l}\text { Echis carinatus (Efa). } \\ \text { coloratus. }\end{array}\right\} \begin{aligned} & \text { Eastern Africa, } \\ & \text { Tchad, Egypt, } \\ & \text { Soudan, } \\ & \text { Somaliland, } \\ & \text { Socotra. }\end{aligned}$

$\left.\begin{array}{c|l}\text { Atheris chlorechis. } \\ \text { squamiger. } \\ \text { ceratophorus. }\end{array}\right\} \begin{aligned} & \text { Tropical } \\ & \text { Africa, Lagos, } \\ & \text { Dahomey, } \\ & \text { Cameroon, } \\ & \text { Gaboon, Congo. }\end{aligned}$

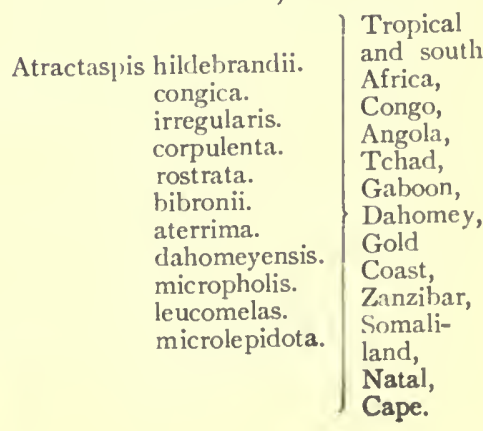


List showing the Geographical Distribution of Venomous Snakes. - (Continued.)

\section{AUSTRALIA AND NEIGHBORING TERRI- TORIES. \\ COLUBRIDE. \\ ProteroglypHA. \\ Elapine. \\ Ogmodon vitianus... Fiji Islands. \\ Glyphodon tristis. $\left\{\begin{array}{l}\text { East Australia, } \\ \text { New Guinea. }\end{array}\right.$}

Pseudelaps muelleri.

squamulosus.

krefftii.

harriettæ.

diadema.

ustralia,

warro. sutherlandii.

Diemenia psammophis.

torquata.

olivacea.

modesta.

textilis (brown

snake).

nuchalis.

Pseudechis porphyriacus cupreus. australis. darwiniensis. papuanus. scutellatus. microlepidotus. ferox.

Denisonia superba. coronata. coronoides. muelleri. frenata. ramsayi. signata. dæmelii. suta.

frontalis.

flagellum.

maculata.

punctata.

gouldii.

nigrescens.

nigrostriata.

carpentariæ.

pallidiceps.

melanura.

par.

woodfordii.

Micropechis ikaheka. New Guinea, elapoides. Solomon Isds.

Hoplocephalus bungaroides or varieg atus (bloodheaded snake).

Hoplocephalus bitorquat us

Hoplocephalus stephensii.

Tropidechis carinata.........Australia.

Notechis scutatus s. Hoplocephalus curtus (tiger snake).

Australia, New

Guinea.

Australia,

New

Guinea.

Australia,

Solomon

Islands,

Australia.

Australia, Tasmania.
AUSTRALIA AND NEIGHBORING TERRITORIES. - (Continued.)

Colubride.

PROTEROGLYPHA.

Elapina.

Brachyaspis curta......... Australia.

Acanthophis antarc- East Australia, ticus (death adder). Molucca,

Elapognathus minor....... Australia.

Rhynchelaps bertholdi. austral is. semifasciatus.

Australia. fasciolatus.

Furina calonota. bimaculata. occipitalis.

Australia:

Tasmania.

VIPERIDE.

Proteroglypha (Solenoglypha).

Viperina.

ydrophiine.

Hydrus platurus. Equatorial and sub-

I Molucca,

Thalassophis anomalus. $\begin{aligned} & \text { Papuasia, } \\ & \text { New }\end{aligned}$ Guinea.

Hydrelaps darwiniensis. Telebes,

Hydrophis elegans. $\begin{aligned} & \text { Tasmania, } \\ & \text { New Caledonia }\end{aligned}$

Distira ornata. cyanocincta.

Enhydris curtus.

Enhydrina valakadien s. bengalensis.

Aipysurus australis.

Platurus muelleri.

EUROPE.

Vipera berus s. Pelias berus. ursinii. aspis. latastii. ammodytes.

France, Italy, Switzerland, Austria-Hungary, Germany, Belgium, Sweden, Norway, Great Britain, Spain, Portugal, Bosnia, Herzegovina, southern Russia, Turkey, Greece.
ColUbRIDE.

OPISTHOGLYPHA.

Dipsadomorphina.

\begin{tabular}{c|l} 
Colopeltis mon- & $\begin{array}{l}\text { Coasts of } \\
\text { Mediterranean }\end{array}$ \\
along Spain, \\
France, Italy \\
(only in Liguri).
\end{tabular}


List showing the Geographical Distribution of Venomous Snakes. - (Continued.)

AMERICA.

Colubrider.

OPISTHOGLYPHA.

Dipsadomorphina.

Trimorphodon lyrophanes. upsilon. vilkinsonii. lambda. tau. collaris.

Sibon septentrionale. yucatanense. annulatum. personatum. rhombiferum. frenatum. nigrofasciatum. pacificum.

Scolecophis æmulus. atrocinctus.

Tantilla coronata. eiseni. nigriceps. gracilis.

Manolepis putnamii.

Conophis.

Coniophanes imperialis. imperialis imperialis. lateritius.

Proteroglypha.

Elapince.

Elaps fulvius (harlequin snake). euryxanthus. marcgravii. heterochilus. surinamensis. gravenhorstii. langsdorfii. buckleyi. anomalus. heterozonus. elegans. annellatus. decoratus. dumerilii. corallinus. hemprichii. tschudii. dissoleucus. psyches. spixii. frontalis. lemniscatus. filiformis. mipartitus. fraseri. mentalis. ancoralis.

Micropechis elapoides.

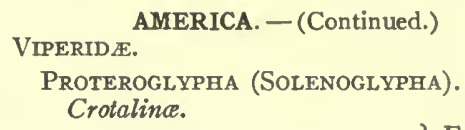

Ancistrodon piscivorus (water-moccasin or cotton-mouth).

Ancistrodon bilineatus.

Ancistrodon contortrix (copperhead).

Eastern

America,

Florida,

Texas,

Mexico,

Guate-

mala.

I achesis mutus (bushmaster).

Lachesis s. Bothrops lanceolatus (Fer de lance or jararacussu).

Lachesis atrox (Labaria). pulcher. microphthalm us. pictus. alternatus. neuwiedii (Bothrops urutu). ammodytoides. xanthogrammus. castelnaudii. nummifer. godmani. lansbergii.

Central

and South America, Martinique, St. Lucia.

Lachesis brachystoma. bilineatus. bicolor. schlegelii. nigroviridis. aurifer.

Central and southern America, Martinique, St. Lucia.

Sistrurus miliarius. catenatus (Massasauga) ravus.

Eastern

America.

east of

Rocky

Mountains,

Crotalus adamanteus s. ? durissus (diamond-back rattlesnake).

Central

America,

Bolivia,

Ecuador,

Peru,

Colombia, Brazil.
Crotalus horridus (banded rattlesnake).

Crotalus confluentus (prairie rattlesnake).

Crotalus atrox var. scutulatus.

Crotalus atrox var. ruber. oregonus. tigris. molossus. cerastes. lepidus. pricei. triseriatus. polystictus. terrificus(dogface rattlesnake). mitchelli (white rattlesnake).
Southern

Canada, British

Columbia, Central America, Guiana, Venezuela, Brazil, Uruguay,

North of

Argentina. 


\section{CHAPTER V.}

\section{POISON APPARATUS OF VENOMOUS SNAKES.}

Venomous snakes in the act of biting inject a poisonous fluid into the object bitten. This fluid is generally known as "venom" and is the product of highly specialized, well-developed glands which show certain phylogenetic relations to supralabial glands and correspond with the mouth-angle glands of birds and the parotid glands of mammals. The fluid is injected into the victim by means of a series of specialized teeth of the maxilla, which differ from ordinary teeth by the presence of a groove throughout the entire front surface of the teeth or of a complete canal from the base to the apex. These specialized teeth, called "venom fangs," are larger than the rest, and are in communication with the venom glands by means of the common ducts of the latter. The end of the excretory ducts does not enter the basal opening of the groove or canal of the poison fang, but opens quite close to the latter. The flowing out of the venom is, however, well prevented by a sheath, which is merely a prolongation or fold of the mucous membrane. Naturally the inoculation itself is accomplished by the complicated motion of numerous muscles, which open the mouth, erect the fangs, and close the mouth. Simultaneous compression of the venom glands by a certain muscular envelopment forces out the glandular secretion through the common duct into the venomconducting fangs, which are in the meantime inserted into the victim.

\section{POISON FANGS.}

The specialized teeth adapted to conduct the secretion of the venom glands into the interior of the tissue of the victim have certain general features common to widely distant families of venomous serpents. They are provided with either a groove or a canal, and are larger in dimension than the rest of the maxillary, palatine, and mandibular teeth. They are situated on the maxillary bones, to which they are firmly ankylosed. The poison fangs are crescent-shaped, with one square, wide end on the base. When in connection with the maxillary bone and ectopterygoid bone (transversum) they resemble a sickle. The base of the fang is, comparatively, very broad and the apex is extremely sharp. In all proteroglyphous snakes the number of active fangs is usually two, arranged side by side. Behind the inner fang are several reserve fangs in developing order, which take the place of the active fang when it is damaged or shed. In one set of proteroglypha the fangs are frontally grooved longitudinally, while in the other set the groove is completely closed into a hollow tube which again opens as a slit near the frontal side of the apex. This latter set is often designated solenoglypha or tubular-fanged. The furrow of the groove is of varying depth, according to the species of the snake. 

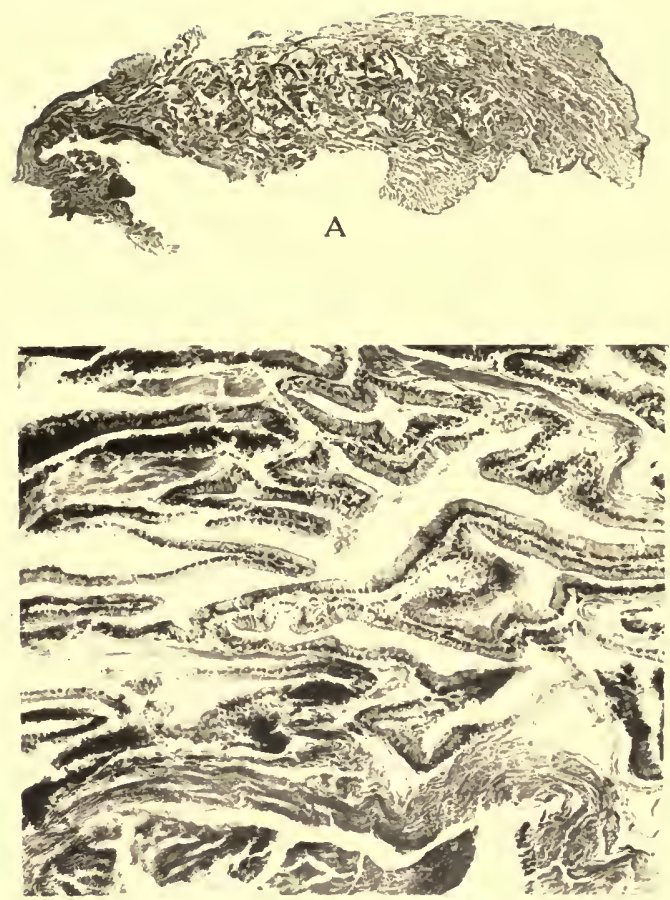

B

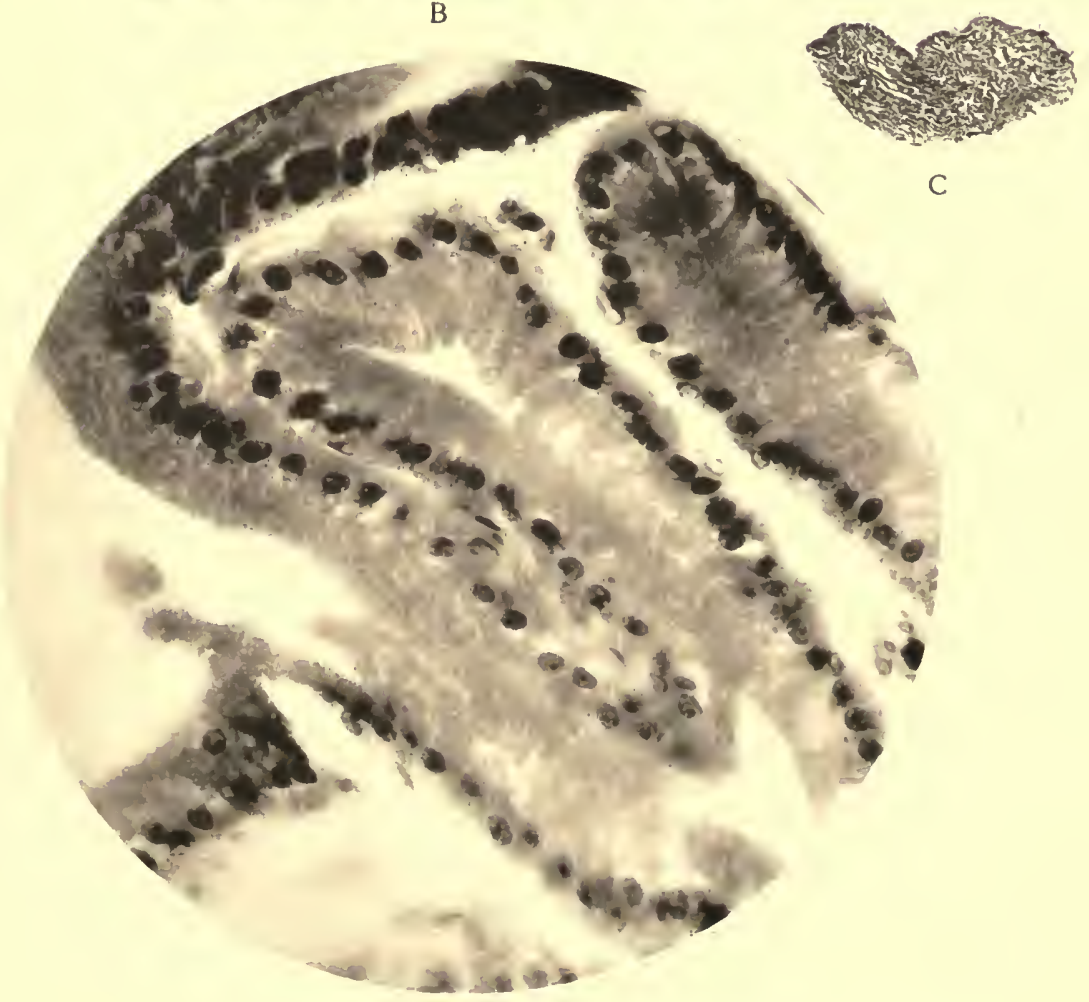

D

Venom gland of Crotalus adamanteus.

A. Longitudinal section. $\times 9$.

B. Cross-section, showing Tubular Raminous Structure. (Note abundant muscle-fibers running into the interacinous spaces.) $\times 100$.

C. Cross-section. $\times 9$.

D. Portion of Tubular Acinus, showing Columnar Epithelial Cells with Nuclei near Base of Cell Body. $\times 1000$. 

In the opisthoglyphous snakes the fangs are short and have usually much shallower furrows than the proteroglypha. The fangs differ greatly in their magnitude according to the snakes. The viperine and crotaline snakes possess the best-developed and longest fangs, while the elapine and hydrophine families have much shorter ones. A fang an inch long is not uncommon in Crotalus and Lachesis. It is hardly necessary to mention that the poison fangs are provided with a regular pulp-cavity which occupies a space just behind the groove or canal separated with a thin septum of dentine and enamel.

The relation of the poison duct to the fang has often been misinterpreted. Niemann ${ }^{1}$ even reproduced a picture in which the poison duct was shown to enter directly into the base-opening of the canal of the fang. But Mitchell as early as I 860 described the real method by which the poison duct communicates with the groove of the poison fang. It is by means of the cavity surrounding the base of the tooth and inclosed by the mucous membrane folds which constitute the proximal portion of the vagina dentis. In Crotalus Mitchell discovered the presence of certain muscular fibrillæ in the mucousmembrane sheath, which apparently serves as a sphincter. This arrangement has the advantage that in the replacement of the fang the connection will not in any way be affected, in spite of the change of the position of a new fang. The sphincter which has been found by Mitchell near the termination of the duct in the Crotalinæ appears to be absent from the proteroglyphous Colubrinæ, while in Hydrophiinæ a non-striated muscle is present near the base of the fang.

\section{POISON GLANDS.}

(Plate 20, A, B, C, D.)

Glandula venenata were not definitely discovered until a correct account was given by Fontana. Schlegel $(\mathrm{I} 828)$ found in many snakes with furrowed posterior teeth a large gland which opens its duct only at the base of this tooth. Duvernoy (I832) then found that a similar gland exists also in numerous suspected snakes. The poison gland of fangless snakes is not exactly equal to the fully developed venom gland of fang-possessing reptiles, but is a mixed gland, consisting of anterior grayish-red portion and posterior grayish-white portion. The latter is provided with only one duct. After the careful studies of Rudolphi, Meckel, and Leydig (I873) it became clear that the posterior portion is of the nature of a serous gland, while the anterior portion is that of a mucous gland. It is noteworthy that a serous gland comes for the first time into existence in these snakes, but not in any class in the inferior evolutional order, which, as in Amphibia, is provided with a mucous gland. In the Mammalia the existence of the serous gland becomes universal.

In the majority of venomous snakes the poison gland occupies a space behind the eve and stretches backwards in length according to the size of the

${ }^{2}$ Niemann, Arch. f. Naturgeschichte, 1892, I. 
gland. Its anatomical position corresponds with that of the parotid gland of the Mammalia, to which its similarity is still further strengthened by the serous character of the secretion. A certain digestive function of the poison gland has been described and is alleged to be essential to digest the prey. The venom gland like the parotid gland has only one excretory duct. Allusion has been made to the fact that the secretion of the poison gland has a double importance to the reptile - to assist digestion and to capture prey.

The dimension ${ }^{1}$ of the poison glands is generally in proportion to the size of the snakes, although some exceptions are observed in certain species. Of the Crotalidæ with the length of about 5 feet the gland attains the size of an almond. The cobra is provided with a somewhat larger gland. The European vipers have much smaller glands, as their size is not very great. It is a curious fact that the genus Doliophis, one of the venomous colubrine genera, is characterized by the possession of a very large, elongated poison gland which extends down one-third of the entire length of the body. It ends in a club form in front of the heart, shifting the latter to the right. Especially Doliophis ${ }^{2}$ intestinalis and Doliophis bivirigatus are noted for their enormous glands. In the visceral region the glands are in one mass and separate from one another near the head in order to supply the poison fang on each side. Similar glands are described by Meyer in Doliophis philippinus, Doliophis nigrotæniatus, and Doliophis flaviceps.

The gland is surrounded by striated muscle fibers which run parallel to its longitudinal axis. According to Meyer and Hoffmann (1890) another duct opens near the exit from a second large gland which lies behind the eye. In Causus rhombealus Reinhardt discovered a poison gland disproportionately large. In a specimen which measured $\mathrm{I} 8$ inches the gland with the duct reached 3 inches. The gland runs down along each side and lies on the ribs and muscles, and is provided with a muscle attached to it.

The poison gland is for the most part a serous gland. A considerable variation is noted in the structure of poison glands throughout Ophidia. In proteroglyphous colubrine snakes the alveoli of the gland are much larger and have a lining epithelium of short columnar cells inclosing a capacious lumen in which secretion is stored. The supporting framework of interalveolar

1S. Weir Mitchell gives the following measurements for the Crotalus adamanteus kept two to eight weeks in captivity:

\begin{tabular}{|c|c|c|c|}
\hline No. & Weight. & Length. & $\begin{array}{l}\text { Weight of gland } \\
\text { (in grains). }\end{array}$ \\
\hline $\begin{array}{l}1 \\
2 \\
3 \\
4 \\
5 \\
6\end{array}$ & $\begin{array}{ll}\text { I } & \text { lb. } 6 \text { oz. } \\
4 & \\
3 & \\
3 & 6 \\
2 & 4 \\
3 & 9\end{array}$ & 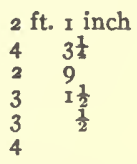 & $\begin{array}{l}7 \frac{1}{2} \text { grains } \\
\text { I } 1 \frac{1}{2} \\
9 \\
9 \frac{1}{3} \\
7 \frac{1}{2} \\
\text { I } 2 \frac{1}{2}\end{array}$ \\
\hline
\end{tabular}

${ }^{2}$ Meyer, the discoverer of this visceral poison gland, used the term Calliophis or Callophis, but Wilhelm Peters (187 ) devised a special generic name Adeniophis for this particular group. Boulenger again employed the third name Doliophis in lieu of Peters's Adeniophis. 
connective tissue varies in amount in different species, but in all cases it is developed to a greater extent in the center of the gland in the region of the forwardly converging ducts. The poison duct, which is longitudinally folded for the greater part of its course, has opening into it, throughout its length, a series of small glands completely surrounding it. These minute lobules are mucous glands and are difficult to stain, and the alveoli and cells have a different structure from the rest of the gland. In Hydrophiinæ the interalveolar connective tissue is extensively developed, most noticeably in Enhydrina hardwickii. Platurus fasciatus is conspicuous for the small size of the external alveoli, especially at the posterior end of the gland. The duct of this group is remarkable for the convoluted course its terminal portion takes. Small lobules are found arranged as in the other Proteroglyphous Colubrinæ. In Platurus fasciatus these glands are reduced almost to single alveoli with a lining epithelium like that of the poison gland itself. But in Distira cyanocincta and Hydrus platurus they are more markedly developed, a few of them in the latter half of the course of the duct becoming mucus-secreting. Towards the termination of the duct the cells of its own lining epithelium also become mucus-secreting. This has been shown to be common in the duct of the parotid and labial glands of the opisthoglyphous Colubrinæ, and it forms a pavement layer in the Crotalinæ.

Thus the Ophidia are the only animals in which a considerable admixture of mucus is present in the parotid secretion, this mucus being derived in all cases from some of the cells of the duct and sometimes from special accessory mucous alveoli. The presence of mucous alveoli in the parotid gland and the conspicuous admixture of mucus in the parotid secretion, more especially of elapine Colubrinæ, may perhaps present an analogy to the condition in the submaxillary glands of many mammalia. They are all restricted closely to the exit of the duct. ${ }^{1}$

Johannes Müller (1830) was, however, the first to recognize the tubular structure of the poison gland and the spongy nature of the inner wall of the tubules. He states also that the glandular tubules stretch continuously from the exit duct to the surface of the organ. According to him the structure of the poison gland of Naja haje is as follows: The connective-tissue capsule of the gland consists of a single layer, but not of double, serous space embracing covers, as is the case of Vipera, while a wide, rather indefinite lymphatic space is present between the poison gland and the upper wall of the oral cavity beneath. Emery (I875) distinguishes two parts in the poison gland of Naja haje. The posterior part is considered as the poison gland proper, the anterior part as belonging to the mucous system, in which all supralabial glands are to be enumerated. In the posterior part the cells near the central zone are cylindrical, while those lining the peripheral zone are flattened epithelia. In the anterior part there are also cylindrical epithelia, but they are somewhat larger and have a much clearer nucleus - not many granular particles around the nucleus - which is always easily seen. In fact, these 
epithelia are identical with those of the supralabial glands, and the anterior part of the poison gland is called the accessory mucous gland. This assumption is supported by the observations that in the epithelia of the anterior part the nucleus is driven near the base of the epithelia, which are spherically swollen. Such appearance is never manifest in the posterior part treated by the same technique. The epithelia of the duct are cylindrical, yet their contents are not so clear and homogeneous, and stain by carmine solution.

The arrangement and ramifications of the glandular tubules are described by Emery and are shown to be more complicated in the posterior than in the anterior part. Emery maintains the presence of ramification of the tubules in the posterior glandular part. In the anterior part there are glandular lobes, whose orifices open into the central secretory way in from five to six regular series. No lobes are found in the posterior part. From behind, a protrusion into the lumen of the secretory way is projected. This protrusion contains a collecting canal from the posterior glandular part and represents the continuation of their central substance.

The structure of the poison gland of Vipera berus, Vipera aspis, and various European vipers has been well studied by Fontana, Rudolphi, Meckel, Joh. Müller, Brandt, de Betta, A. B . Meyer, and Leydig.

The poison gland lies in a fascia-like, pocket-like, extension of ligamentum zygomaticum. The main muscular coat of the gland is furnished by M. masseter, and certain of the fibers are also sent from M. temporalis. The tough, fibrous capsule divides the gland into many main lobes by sending several lamellar foldings within the glandular parenchyma. The tough cover of the poison gland consists of a firm connective tissue which resembles in its texture the ground structure of leather. Beneath this firm capsule the tissue becomes much looser and forms within it a lymphatic space. The connective-tissue framework of the gland retains the same soft, loose character described above, and the gland itself represents a tubular construction.

The poison gland has a triangular form, the front angle of which is drawn into a secretory duct. The gland lies in a firm connective-tissue sheath and through this it is surrounded by muscles from almost all sides. It is so arranged that in every act of biting a compression of the gland, and the subsequent evacuation of the secretion from the poison fang, are brought about. The secretory duct consists of firm, thickly woven, circularly arranged, connective tissue, which contains no muscle fiber. The tough sheath of the poison gland transforms in the interior into a wide-meshed frame, which incloses numerous lymphatic spaces. Beyond this network numerous blades radiate internally and hold many glandular tubules together in groups so as finally to result in so-called granules.

According to the degree of fulness of the secretion, the lumen of the tubules may be quite wide, or the walls may be in contact with each other. The epithelium of the poison gland is low and cylindrical. The protoplasma is more or less strongly granulated, and some coarse granules are seen. The nucleus lies somewhat apart from the base, but never near the apex. In the 
fresh gland the tubules are sometimes filled with the secretion (venom), which appears as clear, transparent particles. The lymphatic space of the secretory duct gradually disappears near the end. Niemann (I892) and Lindemann (1899) observed that the tubular arrangement of the poison gland of Vipera berus is of irregular nature and to be considered as a secondarily modified tubular gland.

While Leydig and Reichel described the epithelia of the poison gland as low and cylindrical, Niemann and Lindemann found them to be cubic. Yet the study of the latter authors revealed the cause of this difference. They found that in the epithelium immediately after the bite the nuclei are dark, stainable, not larger than half the diameter of the basis of cell, and stand slightly apart from the base. The granulation is gradually increased toward the upper part and thickest near the free edge of the epithelium. In a snake which has been kept a long time in captivity and has not bitten for some time the granulation is much lighter and more regularly and evenly distributed throughout the cell-body. The approximate size of the cell remains, however, unchanged.

\section{THE PROCESS OF SECRETION OF VENOM.}

The process of secretion is comparable to that of salivary secretion. In the protoplasma of the epithelium homogeneous droplets appear and render the protoplasma more transparent. Immediately after secretion of the venom the periphery of cells becomes more darkly granulated. ${ }^{1}$

According to a later study of Launoy ${ }^{2}$ ( 1903 ) the process of venom secretion can be divided into two phases: (I) a phase of nuclear elaboration, (2) a phase of cytoplasmic elaboration.

Besides the passive exchanges which take place between nucleus and cytoplasma, the nuclear sphere participates very actively in the secretive process. This participation of nucleus is evident from the following reactions:

(I) By the difference in the stainability of the chromatin grains.

(2) By emission of equal-sized, spherical, well-defined grains, with tinctorial reaction of the internuclear differentiated chromatin, into cytoplasma.

(3) By the exosmosis of the dissolved nuclear substance, which appears in the meanwhile in ergastroplasmic form.

These formations constitute, on the one hand, the grains of "venogene;" on the other, the "ergastroplasmic venogene."

In the venom cell of Vipera aspis and the serous cell of the parotid of Tropidonotus natrix is produced chiefly in a granular form.

After reaching to the perinuclear cytoplasma the venogene grains and ergastroplasmic venogene will at once disappear, if it happens to be during the period of cellular excitement; or will remain for some time, if it is at a period when the cell is saturated with the product. During the cytoplasmic activity the venogene grains and ergastroplasmic venogene disappear.

1 Lindemann.

2 Launoy, Thèse de doctorat ès sciences, Paris, I903, No. II 38 , série A, 454. 
The nuclear and the cytoplasmic elaborations constitute two distinct cytes of secretion. The nuclear elaboration is to furnish the cytoplasma with necessary material for the proper secretory work, while the cytoplasmic cyte is an elaboration, in which not only the basal protoplasma takes part, but also throughout the entire cell, especially the perinuclear cytoplasma.

The venogene grain can be distinguished from the venom grain by its affinity to Unna's blue, safranin, and fuchsin. The venom grain is eosinophilic. It is never secreted in granular form, but always after the intracellular dissolution. In the lumen of the glandular tubules no venogene grain is to be found.

\section{DYNAMICS OF THE FUNCTION OF POISON APPARATUS.}

(Plates 21 and 22.)

The bones which are concerned with the insertion of the poison fang into the victim can be divided into direct and indirect. The direct bone is the supramaxillary, to which the fang firmly ankyloses on the alveolar socket. The supramaxilla is a sort of triangular body and has four facets. The under surface presents a somewhat dull triangle, or rather a pentagonalum, with its apex directed forwards. Here near the apex two sockets are found, in which two acting fangs are usually implanted. The anterior external facet has an irregular surface, and in the crotaline snakes this is eclipsed at the posterior external portion by a spherical excavation - a fossa characteristic of the "pit" vipers. The anterior internal surface is very smooth and oblong. The posterior surface is defective by the presence of a spherical depression, which at the same time excavates the upper half of the anterior external facet. In the posterior surface, just above the fossa, is a smooth articulating surface, which connects this bone with the corresponding articulating surface of the prefrontal (lachrymal) bone.

Near the internal edge of the posterior surface is a small, deep furrow, at the bottom of which are two holes, one communicating with the spherical excavation-pit and the other with the bottom of the alveolar sockets of fangs on the under facet. The border where the under and posterior facets meet forms another articulating line - a narrow, straight line - and is connected with the thin, extended end of the ectopterygoid bone (transversum) by a strong horizontal ligament. This maxillo-ectopterygoid articulation is freely mobile and is one of the most important factors in erecting the fang. The maxilloprefrontal articulation is also of such nature that the maxillary bone is easily rotated and erected. The denomination of different surfaces of the maxillary bone is naturally variable with the positions to which this bone may eventually change, but by the under "surface" is always meant the facet where the dental alveolar sockets are present. This "under surface" becomes the "posterior" when the fangs are horizontally folded with their points directed backwards, and the "posterior surface" will then turn to the "upper."

1 A minute description of the osteology, myology, and the physiological mechanism of the bite of the Crotalus is given by $\mathrm{S}$. Weir Mitchell, Researches upon the venom of the rattlesnake, Smithsonian Contributions to Knowledge, 186r, Washington, D. C. 



\section{Description of Plate 21.}

BONES OF CROTALUS ADAMANTEUS

A. Ventral view of skull. Other bones, right side seen from inside.

I. Premaxillary bone.

2. Prefrontal, or lacrymal, bone.

3. Frontal bone.

4. Post-orbital process.

5. Posterior region of parietal bone.

6. Crest of sphenoid bone.

7. Squamosal bone.

8. Articulating surface of supermaxillary bone (with prefrontal bone, 2).

9. Foramen for entrance of a large branch of trigeminous (into the pit).

I0. Supermaxillary bone.

II. Palatine bóne.

I2. Poison fang.

13. Internal pterygoid bone.

14. External pterygoid bone (so-called transversum).

15. Quadrate bone.

I6. Mandibular bone.

B. Dorsal view of skull. Other bones, right side, seen from outside.

17. Occipital bone.

18. Articulating surface of temporal bone (with squamosal bone, 24).

19. Parietal bone.

20. Frontal bone.

21. Premaxillary bone.

22. Prefrontal, or lacrymal, bone.

23. Post-orbital process.

24. Squamosal bone.

25. Quadrate bone.

26. Mandibular bone.

27. Internal pterygoid bone.

28. External pterygoid bone (or the transversum).

29. Palatine bone.

30. The pit of the supermaxillary bone (the foramen for the nerves is seen in the upper position of the pit).

31. Supermaxillary bone.

32. Poison fang. 


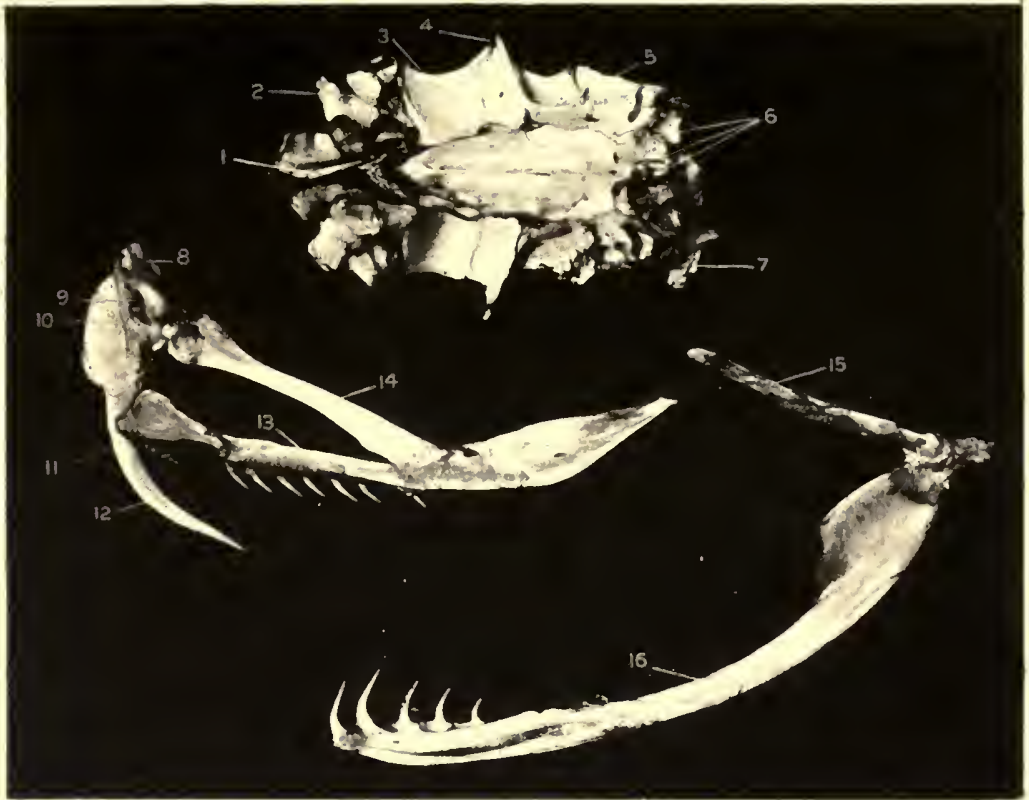

A

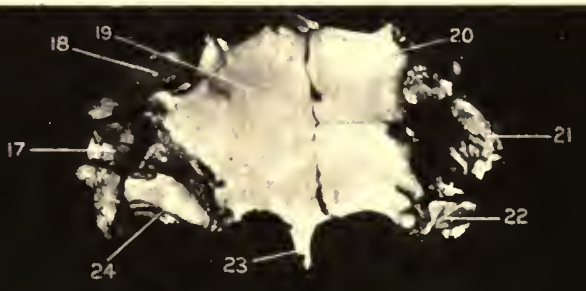

25

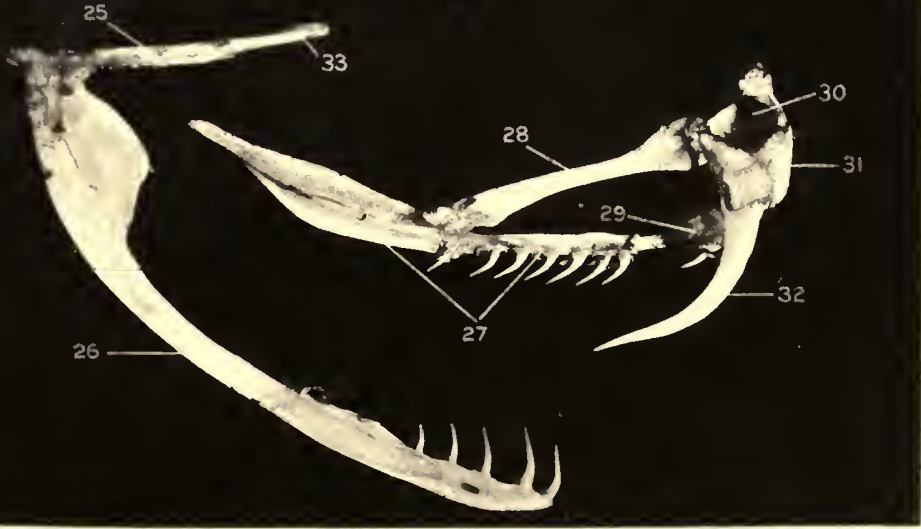

B

Bones of Crotalus adamanteus. 

Among the bones indirectly concerned the ectopterygoid bone and the prefrontal bone are the most important. The ectopterygoid is connected with the maxilla by a broad, strong horizontal ligament at the lower border of the posterior surface of the maxilla, and at its hind end is attached firmly to the upper surface of the endopterygoidal bone near the middle part of the latter. The prefrontal bone is connected with the articulating, small, ovoid surface of the upper corner of the posterior surface of the maxilla. This joint is mobile. The articulation of the prefrontal with the frontal bone admits a certain amount of movement. Thus there are two points on the posterior surface of the maxilla, one at the upper and one at the lower end. Should the ectopterygoid be brought forward by certain muscular movements, it would necessarily result in rotating the maxilla at the maxillo-prefrontal joint and force the maxilla with its fangs to project in a forward direction; hence the erection of the fangs.

The endopterygoid bone is two-thirds anterior straight and one-third posterior slightly turned upwards. In the anterior end it is jointed with the palatal bone, which is short and vertically flattened. The posterior end is loosely connected with the mandibulo-quadrate joint. The ectopterygoid is, as stated above, firmly ankylosed at the upper surface of the middle way of the endopterygoid. The latter has several teeth (solid) under the surface.

Just behind the prefrontal bone (paired) is the frontal bone (paired), and behind the latter the parietal bone (unpaired, but fused at the median line). The frontal bone is slightly depressed in the upper surface (practically a flat roof) and of square shape. On the internal margin it joints with the corresponding part of the other frontal; in the frontal edge it is free, but forms a posterior wall of the nasal cavity. Below it has a large foramen for the olfactory nerve. The premaxillary bone is connected with the median frontal fusion line of two frontal bones by a tiny projection. The lateral edge of the frontal is a slight curve which forms the upper edge of the orbit. Here the bone is very thin and shows the tendency of a vault underneath. At the posterior edge the frontal is jointed with the parietal bone. The parietal bone has a lateral process on each side, near the articulation with the frontal - the posterior orbital process - which forms the posterior upper edge of the orbit. The process leads inwardly to a transverse crest. On the under surface, near the median line, on each side, there is an oval foramen which communicates with the cranial cavity, and which is the optic-nerve path. The parietal bone occupies the largest dimension of the cranium and incloses in it an irregular, oblong cavity for the reception of cerebral and cerebellar contents. On the upper surface it is flat, but on the under surface the median line develops into a sharp, triangular crest enormously elongated, especially toward the posterior part (sphenoidal crest), into a projection. The temporal bones seem to be completely fused with the posterior part of the parietal, and three holes (two larger and one small; the two large ones become one inside) are found near the posterior edge (lateral and inferior surface) of the parietal. Just above them, namely, on the posterior upper surface, 
the squamosal bone is attached with the loose ligament. The squamosal perhaps called mastoid bone by some authors - is a flat, short oblong bone, which attaches to the parietal (or temporal) region with the entire under surface. At its posterior end it joints with the quadrate bone, which, in turn, joints with the condyle process of the mandible. The quadrate is often called zygoma.

It may be stated that the lower maxillary bone of snakes consists of two symmetrical halves, connected by a very strong ligamental band, and that it is capable of a large amount of expansion. The occipital bone can not be distinctly marked out, and this perhaps completely fused with the parietal and temporal bones.

Before entering on the description of the muscles which are concerned in the mechanism of the erection of fangs, biting, and ejaculation of venom, it must be stated here that the venom gland, in the majority of poisonous snakes, occupies the space immediately behind the postorbital process (hence, the posterior edge of the orbit) and the entire lateral region alongside the parietal bone on each side.

The erection of the fang is effected by the contraction of M. sphenopterygoid, ${ }^{1}$ which originates in the crest at the base of cranium and, running backwards and outwards, is inserted fan-like upon the pterygoid plate, which is movable.

The retraction of the fang is effected by the contraction of M. pterygoid externus, ${ }^{2}$ which arises from the tough aponeurosis covering the zygomaticomandibular articulation (or quadrato-mandibular) of the lower jaw, and, running forward below the venom gland, is inserted tendinously into an apophysis of the upper maxillary bone exteriorly to the maxillo-ectopterygoid articulation. While passing below and inside the poison gland M. pterygoid externus sends a strong layer of white fascial tissue out upon the capsule of the gland. Some of its lower fibers are finally inserted directly into the two lips or edges of mucous membrane of the fang.

Another muscle, M. spheno-palatinus, ${ }^{3}$ originates from the raphe of the base of the skull, above the sphenopterygoid and thus nearer the skull, and, running diagonally outwards and backwards, inserts along the inside of the palatal bone. As its fibers cross those of the sphenopterygoid, it has an opposite effect to the latter, and thus assists the depressing action of the pterygoid externus upon the fang.

The opening of the mouth is effected by muscles, such as M. costomandibular and M. vertebro-mandibular, with the help of a muscular layer analogous to M. platysma myoides. The articulation of the jaw is fixed by the double action of the digastricus ${ }^{4}$ and cervical angular muscles.

The closing of the mouth is effected by the temporal muscles. The most

M. pterygo-sphenoid posterior.

2 M. transverso-maxillo-pterygo-mandibularis. This muscle aids in fastening the fang upon the prey attempting to flee.

${ }^{3} \mathrm{M}$. pterygo-sphenoid anterior.

$4 \mathrm{M}$. digastricus is held responsible by many writers for opening the mouth and lowering the mandible. 



\section{Description of Plate 22.}

A. Right side, seen from inside.

I. Spheno-palatine muscle.

2. Spheno-pterygoid muscle.

3. Sphenoid crest.

4. Anterior temporal muscle, mandibular portion.

5. Posterior temporal muscle, mandibular portion.

6. Supermaxillary bone.

7. Mandibular bone.

8. Poison fang.

9. Palatine bone.

Io. Internal pterygoid bone.

I I. External pterygoid bone.

I 2. Parietal bone.

13. Squamosal bone.

I4. Quadrate bone.

I5. Premaxillary bone.

I6. Prefrontal bone.

17. Post-orbital process.

B. Right side, seen from outside.

I. External pterygoid muscle.

2. Posterior portion.

3. Spheno-palatine muscle.

4. Spheno-pterygoid muscle.

5. Posterior temporal muscle, mandibular portion.

6. Anterior temporal muscle, mandibular portion.

7. Supermaxillary bone.

8. Mandibular bone.

9. Pit.

Io. Fang.

I I. Internal pterygoid bone.

I 2. Palatine bone.

I3. Parietal bone.

I4. Post-orbital process.

I5. Prefrontal bone.

I6. Premaxillary bone.

I 7." Quadrate bone.

I8. Squamosal bone.

C. Head of water mocassin (Ancistrodon piscivorus) seen from above. Skin removed except near snout.

I. Poison gland.

2. Ending of the anterior temporal muscle in capsule of poison gland.

3. Mandibular portion of anterior temporal musćle.

4. Attachment of the middle temporal muscle to the tempoparietal region of cranium.

5. Posterior temporal muscle.

6. Internal suspensory ligament of poison gland.

7. Posterior ligament.

8. External pterygoid muscle.

9. Digastric muscle.

Io. Poison fang.

I I. Pit.
I 2. Shield scales.

I3. Eye.

I4. Cervical muscles.

D. Right side, seen from outside.

I. Poison gland.

2. Duct of poison gland.

3. Internal suspensory ligament of gland.

4. Posterior suspensory ligament.

5. Anterior temporal muscle.

6. Insertion of anterior temporal muscle around the poison gland overlapping from behind and ending in the capsule.

7. Posterior temporal muscle, mandibular portion.

8. Posterior temporal muscle, cranial portion.

9. Middle temporal muscle, attachment to the parietal bone. The fibers end in a fan-like, spreading layer over anterior temporal muscle.

Io. External pterygoid muscle.

I I. Origin of the external pterygoid muscle.

I 2. Spheno-palatine muscle.

I3. Digastric muscle.

I4. Supermaxillary bone.

I5. Internal pterygoid bone.

I6. Mandibular bone.

E. Right side, seen from inside.

I. Poison gland.

2. The duct of poison gland.

3. Mandibular portion of the anterior temporal muscle.

4. Upper portion of the anterior temporal muscle enveloping posterior region of gland.

5. Cut edge of the middle temporal muscle.

6. Middle temporal muscle; the upper torn edge is detached from the parietal bone to which it has been inserted. The lower cut edge is originally continuous with the fibers shown in the opposite cut edge through a short piece of the removed portion.

7. Posterior temporal muscle.

8. Upper portion of the posterior temporal muscle.

9. External pterygoid muscle.

го. Its anterior portion.

I I. Spheno-pterygoid muscle.

I 2. Spheno-palatine muscle.

13. Digastic muscle.

14. Internal suspensory ligament.

I5. A portion of posterior ligament of poison fang. 
Noguchi

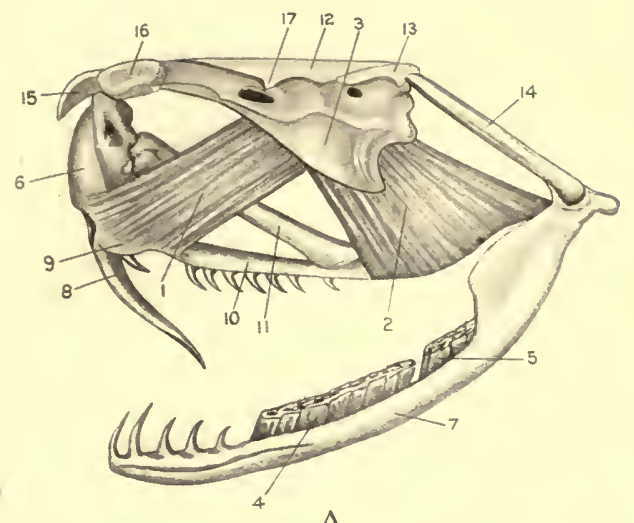

Plate 22
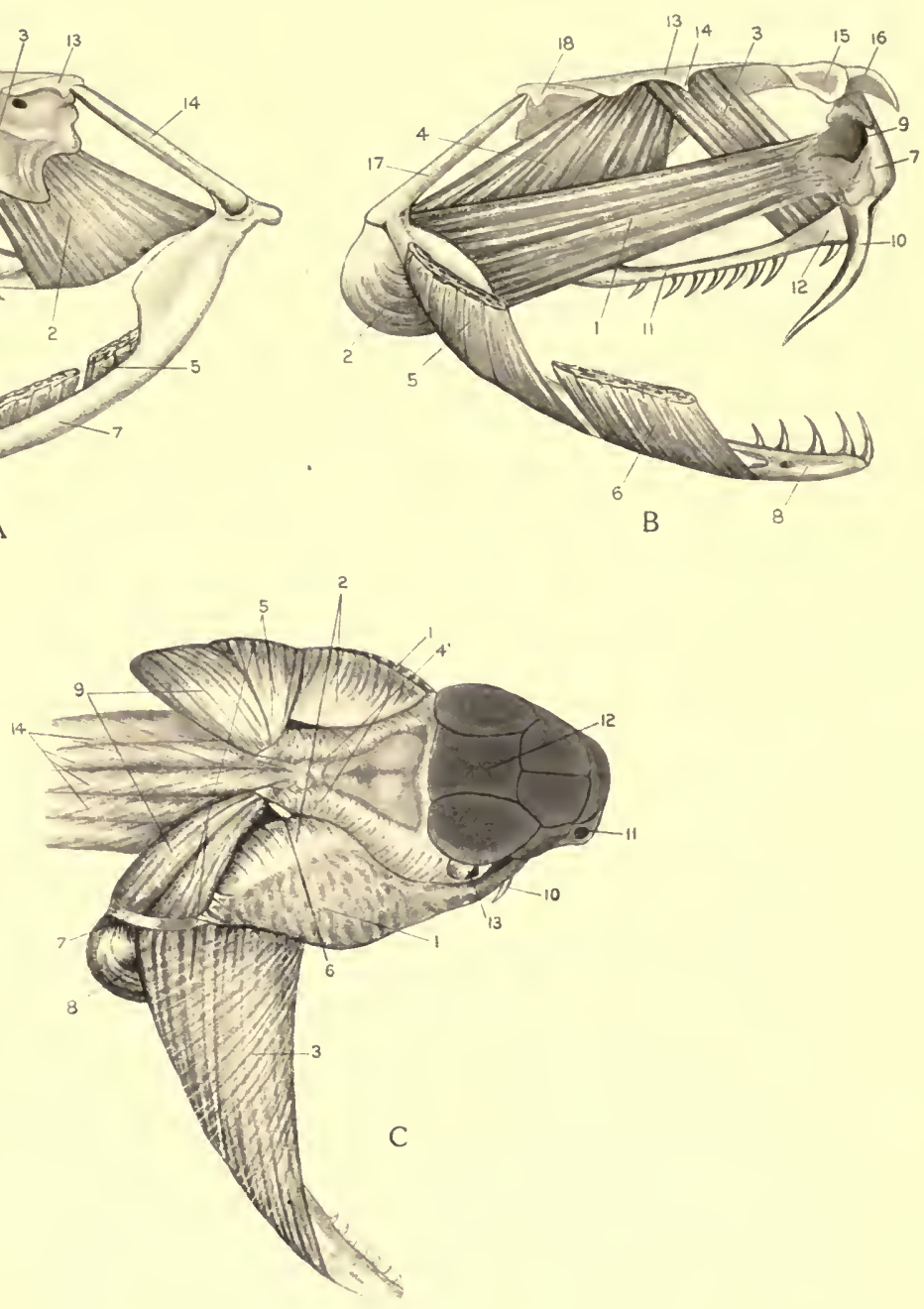

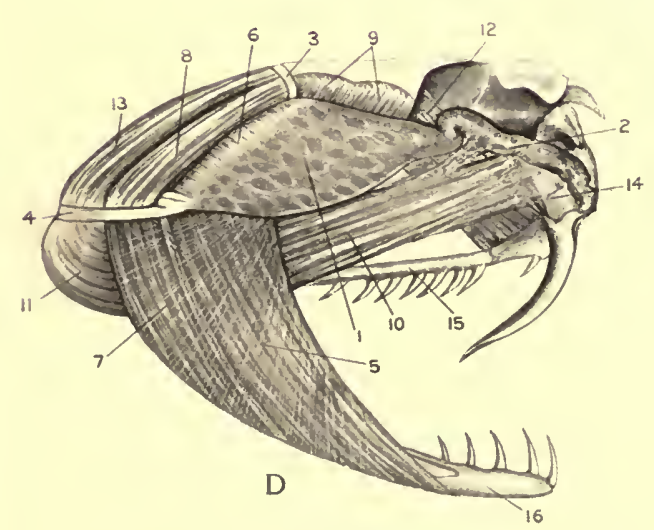

Musculature of the Poison Apparatus, head of Ancistrodon piscivorus.

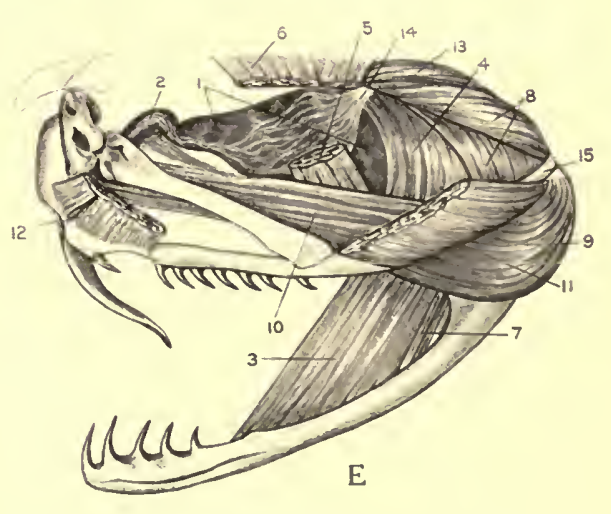




$$
\text { . }
$$


important is the anterior temporal, ${ }^{1}$ which arises from behind the orbit and from the upper two-thirds of the firm fascia of the poison gland. Its fibers run backwards over the gland and descend between it and the middle temporal muscle. In this course the fibers lie posteriorly to the suspensory ligament, and the outer ones, as they fold about the anterior end of the gland, lie in contact with the prolongation of the external lateral articular ligament upon the glandular body. Finally, the muscle winds around the commissure of the lips, and is inserted into the mandible some distance in front of the angle of the lips. The middle and posterior temporal muscles arise chiefly from the temporal fossa and are inserted, one behind the other, into the lower jaw. Their fibers descend nearly vertically and their obvious function is to close the jaw. The function of the anterior temporal muscle is apparently twofold - to exert the pressure upon the poison gland and to aid in shutting the mouth in the meanwhile.

The poison gland of Crotalus occupies the side of the head, behind the eye and beneath the anterior temporal muscle. Its posterior end extends three or four lines beyond the commissure of the lips, while the anterior extremity reaches below and just behind the eye. Thus situated, the gland is in relation with the bony surface behind the eye, with the middle temporal muscle, with nerves which emerge under the suspensory ligament, and with the anterior temporal muscle above and behind where that muscle descends to its insertion. Beneath, the gland is in contact with the external pterygoid muscle, with whose aponeurosis it has peculiar relations. The portion of the gland below the anterior temporal muscle and above the line of the lip is in direct contact with the skin, which is here loosely connected with the areolar tissue.

The ligaments of the poison gland-are firmly connected with the tough, fibrous capsule of the gland, and are really in continuation of the latter. Anteriorly the ligament gradually tapers thin and runs forwards with the duct, constituting a part of its thickness. Posteriorly there is one ligament which attaches firmly upon the fascia of the temporal muscles. Another strong ligament is found to extend from the capsule of the gland to the bony surface beneath the gland. A third attachment of the gland is by means of a fascia which forms a strong expansion upon the external pterygoid muscle and then runs off laterally, to be inserted in the outer capsule of the gland.

THE BITE.

The mechanism of the bite has been studied most exactly and exhaustively by Weir Mitchell, who made observations on the rattlesnakes. The snake prepares itself for striking by raising the head a little above the rest of the body, but not, usually, more than 3 or 4 inches, even in large snakes. The neck and upper end of the trunk are not thrown into complete circle, but lie in two or three abrupt curves across the mass of the coiled body. The

1 M. temporalis anterior of Mitchell may be identical with M. masseter of authors, and his middle temporal muscle with $\mathrm{M}$. temporalis anterior of authors. 
next phase is the forward cast of the body, which is effected by a sudden contraction of the muscles which lie upon the convexity of the bendings formed by the upper part of the snake, so as to abruptly straighten the body and thrust it in a direct line. The projectile range does not exceed a third of its length. The snake can cast itself in every direction - forwards, downwards, or almost directly upwards. At the instant, and while in motion, the jaws are separated widely, and, in order to bring the points of the backwardly curved fangs into a favorable position to penetrate the opposing flesh, this is done to such an extent that an observer standing above the snake can see the white mucous membrane of the mouth as the blow is given. The forward thrust of the body and the opening of the mouth are instantaneously accompanied by the contraction of the spheno-pterygoids of the pterygoid plates, which, through their articulation with the maxilla, bring the fangs to the erect position. The mere act of opening the mouth is not necessarily associated with the erection of the weapon, but, on the contrary, even when the mouth is widely opened, the snake has the most perfect control over the movement of the fang, raising or depressing it at will. At the same moment the cloak-like vagina-dentis is thrust off from the convexity of the fang and is gathered in loose folds at its base. When the erected fangs penetrate the flesh a second series of muscular movements follows. The contraction of the spheno-pterygoid is relaxed and is immediately succeeded by contraction of the pterygoid externus and spheno-palatine. The latter movement, due to the insertion of the posterior apophysis of the maxillary bone and the inside of the palatal bone, respectively, draws the point of the fang violently backwards, so as to drive it more deeply into the flesh.

At this instant occurs a third series of motions which result in the further deepening of the wound and the injection of the venom. The lower jaw is closed upon the bitten part or member. The closure is effected by the posterior, middle, and anterior temporal muscles. The first two tend simply to shut the mouth, but the anterior temporal is so folded about the poison gland that while it draws up the lower jaw, it simultaneously compresses two-thirds of the body of the gland. This force is applied in such manner as to squeeze the venom out of the upper and posterior parts of the gland and drive it forward into the duct. The middle temporal muscle descends from its attachment at the temporal fossa to its thin fan-like insertion over the external surface of the anterior and posterior temporal muscles, passing downwards in a slightly oblique anterior direction along the inner surface of the posterior one-third of the poison gland, and crossing, in part, that portion of the anterior temporal which is wrapping up the anterior twothirds of the gland by a curved course which it takes from the front to the rear, where it ends in the capsule of the gland. Thus, the contraction of this muscle exerts also an important rôle in compressing the gland. The anterior lower part of the gland and a portion of the duct is subjected to the pressure at the same instant, owing to the flat tendinous insertion of a part of the external pterygoid upon the parts in question. 
The whole process - deepening the wound, fixing the prey, and injecting the venom - is the work of an instant, and the next effort of the snake is to disentangle itself from the victim. This step is effected by relaxing the muscles of the neck, so as to leave the head passive, while the continued traction of the muscles of the body pulls upon it and withdraws the fang. The elastic mucus sheath glides over the fang, and the pterygoid externus, again acting, depresses the latter, the snake resuming its posture of defense.

It is not uncommon that in a bite but one fang takes effect. Again, it has often been observed that when the snake in captivity is allowed to bite upon the inner edge of a cup it often uses only one fang. Or, the fangs are used alternately with intervals. It may happen that when the object stands too near the snake the latter miscalculates the distance and the fangs are not in the erect position, hence no penetration. In a contrary instance, the object may be beyond reach of the snake and the biting movements may be performed before the object is struck. In this case the venom is sometimes projected several feet.

The traction of the anterior temporal muscle is associated with the compression of the poison gland, and it becomes rather questionable how in a pacific mood the snake prevents the flow of the venom when it uses this muscle for other than the biting purpose. According to Weir Mitchell this is prevented by two means: the most effectual is the sphincter around the duct, and the other is the mechanical pressure upon the duct while it runs over the frontal angle of the maxillary bone just before it reaches the base of the fang. This mechanical compression is instantaneously removed as soon as the fang is erected. 


\section{CHAPTER VI.}

\section{TOXIC SECRETIONS OF VENOMOUS SNAKES.}

\section{AMOUNTS OF VENOM SECRETED.}

The quantity of venom yielded at one time by a snake, either at a single bite or by squeezing the poison glands, is very variable. It increases, however, in general, in proportion to the size of the snake, although this rule can not be applied to the marine snakes, which secrete an amount that is small in comparison to their size. The continuous failing of health in captivity causes a decrease of venom, both in quantity and in toxicity; especially is this the case where the snakes refuse to take nourishment and are subjected to repeated extractions of venom. While it is very important to determine the exact amounts of venom yielded at a single bite, the data bearing upon this subject are rather unsatisfactory.

Weir Mitchell has noted the difficulty of extracting venom from the rattlesnakes when the latter are resisting forcible manipulation. $\mathrm{He}$ has found that more venom can be extracted when the snakes are put under the effect of an anæsthetic, thus relaxing the muscular resistance. Lamb's careful study of the Indian cobra showed that the amount of venom thrown out voluntarily by a snake is larger than that obtained through forcible compression.

Calmette gives the detailed results of his experiments on two specimens of Naja haje, about 5.5 feet long. During I 20 days in his laboratory one was subjected to 5 and the other to 6 extractions. In the fresh state the total amount of the venom for the first specimen was $0.58 \mathrm{I} \mathrm{gm}$. (per 5 extractions) which weighed $0.174 \mathrm{gm}$. in the dried form. The second snake afforded (on 6 extractions) $0.684 \mathrm{gm}$. fresh venom, which weighed $0.202 \mathrm{gm}$. on drying. Thus the average single amount of venom to be ejaculated by the adult Naja haje is $\frac{0.58 \mathrm{I}+0.684}{5+6}=0.1 \mathrm{I} 5 \mathrm{gm}$. in the fresh state and $\frac{0 . \mathrm{I} 74+0.202}{5+6}$ $=0.033 \mathrm{I} \mathrm{gm}$. in the dried form. He also found that $\mathrm{I} \mathrm{gm}$. of the fresh venom weighed $0.336 \mathrm{gm}$. upon complete desiccation over calcium chloride. With Naja tripudians, Cunningham estimated the amount of a single bite at 0.254 gm. (dried); Lamb at $0.23 \mathrm{I} \mathrm{gm.} \mathrm{(extracted} \mathrm{with} \mathrm{fingers,} \mathrm{dried);} 0.373 \mathrm{gm}$. (by voluntary bite, dried); and Rogers at $0.249 \mathrm{gm}$. (dried).

With Pseudechis porphyriacus, MacGarvie Smith gives the amounts of single bite at $0.1 \mathrm{gm}$. to $0.16 \mathrm{gm}$. in the fresh state and $0.024 \mathrm{gm}$. to $0.046 \mathrm{gm}$. in the dried form.

With Notechis scutatus s. Hoplocephalus curtus the same author gives the amount of venom produced at a single bite at $0.065 \mathrm{gm}$. to $0.15 \mathrm{gm}$. liquid and $0.017 \mathrm{gm}$. to $0.055 \mathrm{gm}$. dried. The dried venom weighed from 9 to 38 per cent of the fresh venom.

Daboia russellii yields on an average 0.15 to $0.25 \mathrm{gm}$. weighed dry (Lamb). 
With Lachesis lanceolatus (fer de lance) Calmette gives $0.320 \mathrm{gm}$. in the fresh and $0.127 \mathrm{gm}$. in the dried form for a single extraction from both glands.

With Crotalus adamanteus, ${ }^{1}$ Flexner and Noguchi put the figures at between $0.179 \mathrm{gm}$. and $0.309 \mathrm{gm}$. in the dried form for a single extractable amount from both glands.

With Crotalus confluentus, Calmette gives $0.370 \mathrm{gm}$. in liquid and $0.105 \mathrm{gm}$. in dried form from a single bite.

With Ancistrodon piscivorus, Flexner and Noguchi estimated 0.I25 gm. to 0.I8 gm. dried as a single extractable dose.

With Ancistrodon contortrix the same authors found the average to be $0.03 \mathrm{gm}$. to $0.06 \mathrm{gm}$. dried.

With two large Egyptian Cerastes specimens Calmette derived 0.I25 gm. ( $0.027 \mathrm{gm}$. in dry) and $0.085 \mathrm{gm}$. (0.019 gm. in dry), respectively.

With Enhydrina, Rogers could extract only 0.0023 gm. to 0.0094 gm. (as dried form) from both glands of the adult specimens.

The loss in weight of venom upon drying has been estimated by various authors. Weir Mitchell and Reichert found it to lie between 25.15 per cent to 27.42 per cent with Crotalus adamanteus, C. atrox, and Ancistrodon piscivorus. Calmette places it at 62 to 80 per cent. C. J. Martin found the loss in weight after drying the Australian venom to be 33 per cent, while Flexner and Noguchi found the solid portion of venom (Crotalus and Ancistrodon) to range from 50 to 70 per cent of the total weight.

\section{TOXICITY OF SNAKE VENOM.}

Irrespective of the modes of action by which the fatal issue of the venom poisoning is brought about, it is possible to determine the approximate minimal lethal dose of each snake venom for a given species of animals by introducing the venom directly into the system of that animal. It may be stated that certain venoms act more powerfully when introduced directly into the blood circulation, while others do not appreciably differ in their final outcome, whether they are given subcutaneously or intravenously. Thus, a much smaller quantity of the venom of Crotalus is effective when injected intravenously than when injected intraperitoneally or subcutaneously, while but little difference is shown with the venom of Cobra in these respects. It is superfluous to emphasize the fact that venoms from different species of snakes differ slightly or widely in their constitution, which is always multiple in nature, and also in their physiological effects. A powerful venom means one which kills or injures the victim by a smaller amount than a weak venom. The cause of these qualitative differences will be treated later in extenso.

The susceptibility of animals to venom is also very variable. Speaking in general, warm-blooded animals are more sensitive to the action of venom than cold-blooded animals. There exists among various species of animals a constant susceptibility peculiar to each group.

In regard to the toxicity of venom we find certain constancy of strength in

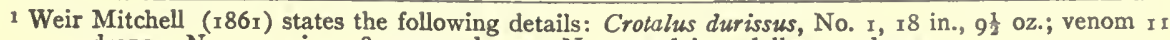
drops. No. 2, 25 in., 18 oz.; 19 drops. No. $3,49 \frac{1}{2}$ in., $3 \frac{1}{8}$ lbs.; 29 drops. 
each species. However, certain exceptions must be expected, as a strict uniformity does not rule out biological phenomena. For these reasons the figures given by different investigators do not quite agree, yet they agree sufficiently to furnish us with the approximate toxicity of each venom.

The minimum lethal doses of the venoms of various species of snake are given in table $I$. The figures indicate the quantities of dried venom in gram per kilogram of the body-weight of the animals. In order to make comparison of the quantities given by different authors in different standards possible, these are reduced to the uniform standard and unit, unless special statement is made to the contrary.

Certain remarkable facts will be noticed by scrutinizing the effects of minimum lethal doses of various venoms upon different classes of animals by different modes of administration. The very high toxicity of the marinesnake venoms, as compared with that exhibited by most of the elapine-snake

TABLE I.

\begin{tabular}{|c|c|c|c|c|}
\hline Species, etc. & $\begin{array}{l}\text { Animal experi- } \\
\text { mented upon. }\end{array}$ & $\begin{array}{l}\text { Nature of } \\
\text { injection. }\end{array}$ & $\begin{array}{l}\text { Amount of venom } \\
\text { administered. }\end{array}$ & Authority. \\
\hline 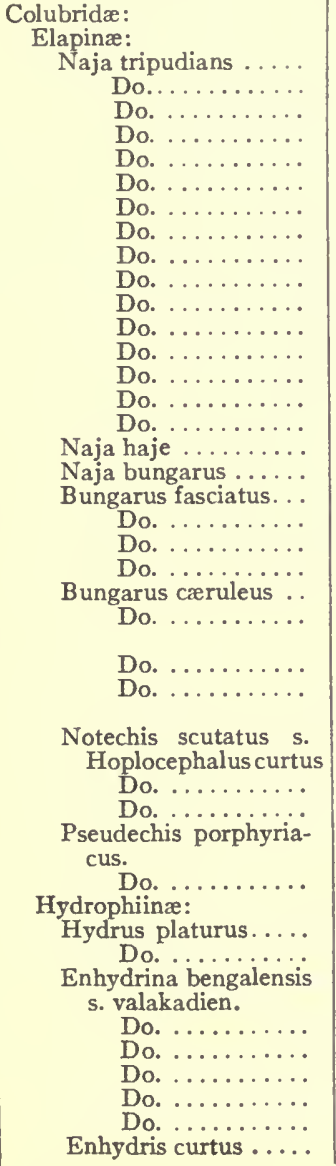 & 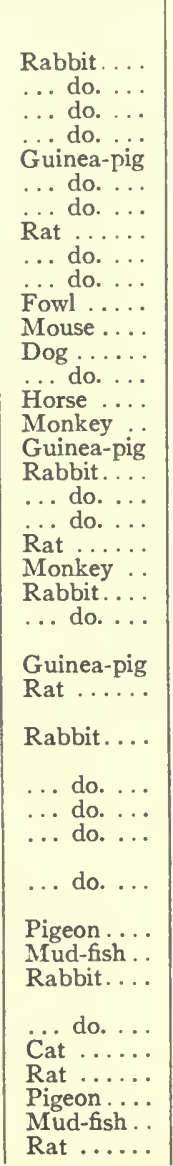 & 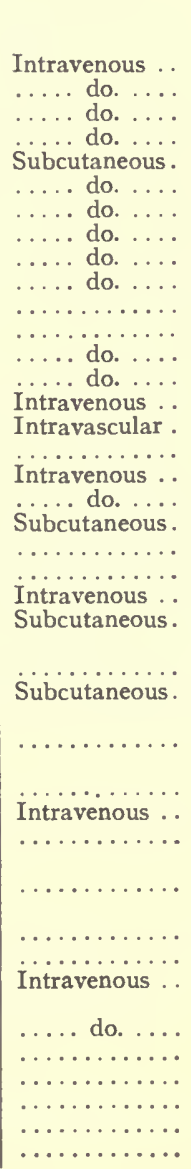 & $\begin{array}{l}0.00025 \text { to } 0.0005 \\
0.00035 \\
0.000245 \\
0.0007 \\
0.0004 \\
0.0005 \\
0.00018 \\
0.0006 \\
0.0004 \text { to } 0.0007 \\
0.0005 \\
0.003 \\
0.00012 \\
0.0005 \\
0.0008 \\
0.0009 \\
0.00025 \\
0.0045 \\
0.00035 \\
0.0007 \\
0.0025 \text { to } 0.003 \\
0.0015 \\
0.003 \\
0.00004 \\
0.00008 \\
0.0009 \\
0.001 \\
0.00025 \\
0.000289 \\
0.00006 \\
0.0005 \\
0.00125 \\
0.000075 \\
0.00025 \\
0.00005 \\
0.00006 \\
0.0002 \\
0.00009 \\
0.00005 \\
0.0005 \\
0.0005 \text { to } 0.0006\end{array}$ & $\begin{array}{l}\text { Calmette. } \\
\text { Lamb. } \\
\text { Fraser. } \\
\text { Elliot. } \\
\text { Calmette. } \\
\text { Noguchi. } \\
\text { Fraser. } \\
\text { Calmette. } \\
\text { Lamb. } \\
\text { Rogers. } \\
\text { Elliot. } \\
\text { Calmette. } \\
\text { Lamb. } \\
\text { Calmette. } \\
\text { Lamb. } \\
\text { Do. } \\
\text { Calmette. } \\
\text { Lamb. } \\
\text { Do. } \\
\text { Do. } \\
\text { Do. } \\
\text { Do. } \\
\text { Do. } \\
\text { Elliot, Sillar, and } \\
\text { Carmichael. } \\
\text { Calmette. } \\
\text { Elliot, Sillar, and } \\
\text { Carmichael. } \\
\text { C. J. Martin. } \\
\text { Calmette. } \\
\text { Tidswell. } \\
\text { C. J. Martin. } \\
\text { Calmette. } \\
\text { Rogers. } \\
\text { Do. } \\
\text { Rogers. } \\
\text { Fraser and Elliot. } \\
\text { Do. } \\
\text { Do. } \\
\text { Rogers. } \\
\text { Do. } \\
\text { Fraser and Elliot. }\end{array}$ \\
\hline
\end{tabular}


TABLE 1. - Continued.

\begin{tabular}{|c|c|c|c|c|}
\hline Species, etc. & $\begin{array}{c}\text { Animal experi- } \\
\text { mented upon. }\end{array}$ & $\begin{array}{l}\text { Nature of } \\
\text { injection. }\end{array}$ & $\begin{array}{l}\text { Amount of venom } \\
\text { administered. }\end{array}$ & Authority. \\
\hline 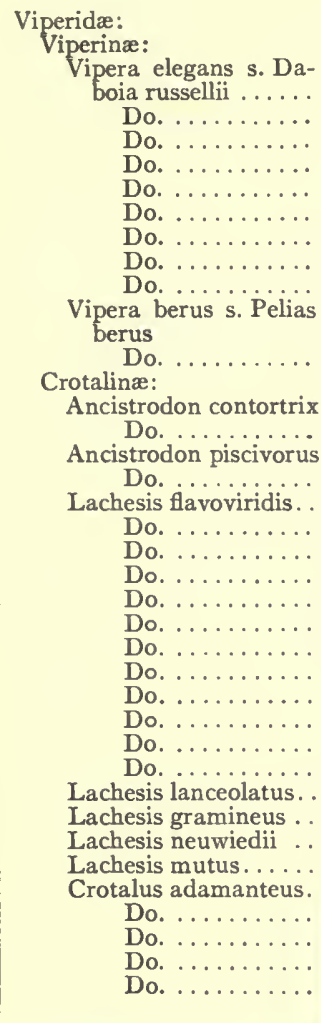 & 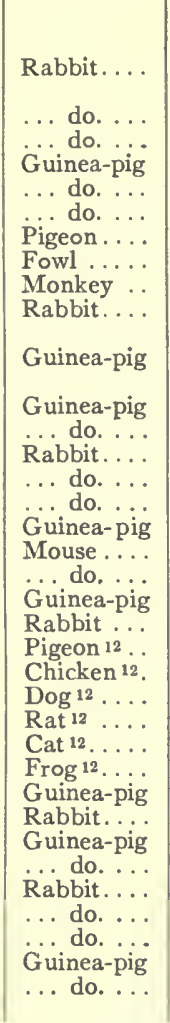 & 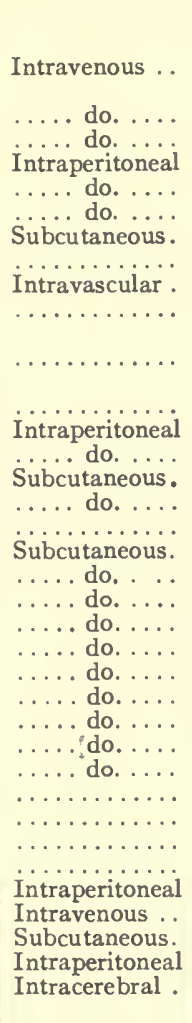 & $\begin{array}{l}0.0001 \text { to } 0.000075 \\
0.00005 \\
0.003 \\
0.0002 \\
0.0015 \\
0.00025 \\
0.0006 \\
0.003 \\
0.001 \text { to } 0.003 \\
0.004 \\
0.0006 \\
0.0225 \\
0.001 \text { to } 0.0012 \\
0.0025 \\
0.01 \text { to } 0.011 \\
0.01 \\
0.02 \\
0.03 \text { to } 0.0005 \\
0.0018 \text { to } 0.0004 \\
0.003 \text { to } 0.0005 \\
0.003 \text { to } 0.0005 \\
0.006 \text { to } 0.001 \\
0.03 \text { to } 0.0005 \\
0.06 \text { to } 0.001 \\
0.18 \text { to } 0.003 \\
0.18 \text { to } 0.003 \\
0.03 \\
0.002 \\
0.03 \\
0.03 \\
0.0004 \\
0.0002 \\
0.005 \\
0.002 \\
0.000125\end{array}$ & $\begin{array}{l}\text { Lamb. } \\
\text { Do. } \\
\text { Elliot. } \\
\text { Lamb. } \\
\text { Calmette. } \\
\text { Noguchi. } \\
\text { Lamb. } \\
\text { Elliot.7 } \\
\text { Lamb. } \\
\text { Calmette. } \\
\text { Do. } \\
\text { Do. } \\
\text { Noguchi. } \\
\text { Do. } \\
\text { Ishizaka. } \\
\text { Calmette.10 } \\
\text { Ishizaka.11 } \\
\text { Kitashima } \\
\text { Do. } \\
\text { Do. } \\
\text { Do. } \\
\text { Do. } \\
\text { Do. } \\
\text { Do. } \\
\text { Do. } \\
\text { Do. } \\
\text { Calmette. }{ }^{13} \\
\text { Lamb. } \\
\text { Calmette. }{ }^{13} \\
\text { Do.13 } \\
\text { Noguchi. } \\
\text { Do. } \\
\text { Do. } \\
\text { Flexner and No- } \\
\text { guchi. }\end{array}$ \\
\hline $\begin{array}{l}20.000003 \text { per } 25 \text { grams. } \\
30.003 \text { per } 600 \text { to } 700 \mathrm{gra} \\
40.0006 \text { per } 600 \text { to } 700, \\
5 \text { Proc. Roy. Soc., } 1904, \\
60.001 \text { per } 600 \text { to } 700 \mathrm{gr} \\
\text { 7 Elliot. An account of } \\
\text { nature and action of } \mathrm{s} \\
\text { Jour., 1900, I, 309, I }\end{array}$ & . & $\begin{aligned} & 12 \text { Th } \\
& \text { we } \\
& \text { fo } \\
& \text { in } \\
& \text { pa } \\
& 130.0\end{aligned}$ & se, but & $\begin{array}{l}\text { produced them } \\
\text { em to be com- } \\
\text { iers. }\end{array}$ \\
\hline
\end{tabular}

venoms, is striking. Then one will quickly notice that viperine as well as crotaline venoms are less fatal than those of the colubrines. The venom of Daboia russellii is, however, an exception to this general rule. Another interesting relation between the action of the colubrine venom and that of the viperine or crotaline venoms is seen in the high resistance offered by Mus against the latter set of venoms. I have often seen instances where the common domestic white rats withstood the intraperitoneal injection of the venoms of Crotalus adamanteus or Ancistrodon piscivorus in a dose of about $0.0 \mathrm{Igm}$.

This refractory characteristic of white rats was first noticed in Copenhagen, where I tried to find out the minimum lethal dose for that particular animal. Previous to that time I never had any reason to suspect such resistance in 
white rats, because in my former experiments (which were not for the purpose of determining the minimum lethal dose) they were easily killed by injecting intraperitoneally the quantities of about $0.0 \mathrm{I} \mathrm{gm}$. of the dried crotalus venom. Whether the Danish rats belonged to a more resistant stock than the American rats, or whether the venom, which was the same collection in both cases, suffered certain elective inactivation during the time of preservation and exposure to different climates - in dried state - within a period of less than one year, I can not state. One thing is clear, however - that the toxicity of the same venom was unchanged for guinea-pigs. The estimation of the minimum lethal dose for a mouse (Ishizaka) again demonstrates that his species is also more resistant to the action of another crotaline (Lachesis) venom. ${ }^{1}$ The horse is extremely sensitive to cobra venom and also to rattlesnake venom. Monkeys are fairly susceptible to the venom of Cobra and of Daboia, though much more so to the former. With the venom of Cobra the degrees of susceptibility of rabbits and that of monkeys are not very far apart, but such is not the case in regard to their susceptibilities to daboia venom.

Concerning the minimum lethal dose of snake venom upon man several authors have given their estimates numerically. Thus, the fatal dose of cobra venom for a man of 60 to 70 kilos has been reckoned by Lamb, from the experiments upon monkeys, to be $0.015 \mathrm{gm}$. to $0.0175 \mathrm{gm}$. Calmette has estimated it to be $0.01 \mathrm{gm}$., while Fraser puts the figure as high as 0.03I gm. Rogers considers $0.0035 \mathrm{gm}$. of the venom of Enhydrina to be surely fatal for a man of 70 kilos. The knowledge of the minimum lethal doses enables us to judge the degree of danger of a given venom. But these numerical indices of toxicity are not sufficient to determine the danger of a given venomous snake. The true viperine snakes - with the exception of certain Asiatic and African species - are least dangerous, because they are small in size and the venom is comparatively non-fatal. The crotaline snakes are very dangerous, because most of them are large in size, some are arboreal and aggressive, swift and hard to detect, and their venom is peculiarly destructive to tissues.

The colubrines, especially the elapine snakes, are the most dreaded, because they usually attain large size, are bold and nocturnal, seek their prey in or around the inhabited districts - even invading houses, and their venom is extremely powerful. Finally, the marine snakes are deadly enough, judged from the powerful venom with which they are provided, yet the nature of their habitat is such as to render them apparently less dreadful to the mass of humanity, their victims consisting mainly of fishermen, especially on the coasts of the tropical Pacific and the Indian Ocean. Thus the size of the snake, the frequency of its occurrence near human presence, and its disposition should form the primary factors, and the strength of the venom the secondary factor, in judging the degree of danger of venomous snakes in general.

\footnotetext{
1 The statement that the larger the species the less the susceptibility to venom seems to be insufficiently borne out by the experimental data. We are not yet in a position to make such generalization, because we do not possess enough systematic materials. At present we have to find out the exact data for every species of animal before we say anything about its susceptibility to a given venom.
} 


\section{MORTALITY CAUSED.}

The mortality from snake bites is naturally greater in those countries where poisonous snakes are more abundant and the conditions of human life favor exposure. According to Fayrer, in 1869 there were II $4 \mathrm{I} 6$ deaths from snake bites in Bengal, Assam, Orissa, Punjab, Oude, and Burma, a district which contains about I I I,000,000 inhabitants, and perhaps almost 20,000 men, i.e., I6 out of every 100,000, are killed each year. In Bengal alone 7,595 men in 1874 , and 8,807 in 1875 , were killed by snakes.

In the years from I 880 to 1887 the yearly average loss of the lives of 19,880 human beings and $2 \mathrm{I}, 4 \mathrm{I} 2$ cattle was reported. In I888, although 578,435 poisonous snakes were destroyed 22,480 human lives were lost, and in 1889 the snakes killed numbered 510,659 and the fatalities to the human race 2I,4I2. These alarmingly high mortality statistics may be attributed partly to the frequent invasions of poisonous snakes into human residence and partly to the powerful venoms they are provided with. Cases are known where venomous snakes have secreted themselves in the bed or in stockings or shoes and fatally bitten the owners. In India the cobra Naja tripudians, though smaller than the king cobra Naja bungarus, is the most dreaded. Of Bungarus, the common krait, B. caruleus, is more dangerous than the other kraits. Daboia russellii and Echis carinata are fatal in their bites.

The bites of Lachesis flavoviridis, better known as Trimeresurus riukiuanus, are fatal in the ratio of slightly over I5 per cent of the entire number of persons bitten. The following figures show the analysis of the results of the bites of Trimeresurus.

TABLE 2.

\begin{tabular}{|c|c|c|c|c|c|c|c|c|}
\hline \multirow{2}{*}{ Year. } & \multicolumn{2}{|c|}{ Bites. } & \multicolumn{2}{|c|}{ Recoveries. } & \multicolumn{2}{|c|}{ Deaths. } & \multicolumn{2}{|c|}{ Crippled. } \\
\hline & M. & F. & M. & F. & M. & F. & M. & F. \\
\hline ז898... & 158 & 53 & I 33 & 46 & 18 & 6 & 7 & I \\
\hline $1899 \ldots$ & 149 & 64 & I $2 \mathrm{I}$ & 53 & 22 & 10 & 3 & I \\
\hline I900... & I 50 & $7 \mathrm{I}$ & I $3 \mathrm{I}$ & 54 & 17 & $\mathrm{I}_{4}$ & 2 & 3 \\
\hline I $901 . .$. & I 48 & 82 & I 30 & 68 & $\begin{array}{l}18 \\
18\end{array}$ & $\begin{array}{l}14 \\
14\end{array}$ & 0 & I \\
\hline $1902 . .$. & I 33 & 48 & II4 & 39 & 14 & 6 & 5 & 3 \\
\hline I903... & I 72 & $7 \mathrm{I}$ & 140 & 57 & 24 & $4 \mathrm{I}$ & I & 7 \\
\hline $1904 \ldots$ & r38 & 53 & 123 & 46 & 12 & 53 & 2 & 3 \\
\hline $1905 . .$. & 182 & 79 & 153 & 63 & 27 & II & 5 & 2 \\
\hline 1906... & 197 & 79 & 164 & 60 & 24 & I7 & 9 & 2 \\
\hline Total .. & 1427 & $60 \mathrm{I}$ & 1209 & 486 & I 76 & 87 & 45 & 22 \\
\hline
\end{tabular}

Thus each year the average number of persons bitten is 225.3 , and 29.2 deaths occur out of this number, making about 15 per cent mortality. If we take the total number of the inhabitants of the islands of Riu Kiu into consideration these figures are by no means small. The total population of the Okinawa prefecture is only 500,000 . The accident statistics will be about 5 per: milli, and the mortality $5^{2.6}$ per 100,000 .

Calmette estimates the mortality from cobra bites at 25 to 45 per cent. Imlach gives 20 per cent mortality, based on 306 cases of Indian snake bites. 
The temperament of different species of poisonous snakes also influences the degree of danger. For example, the comparatively slight mortality from rattlesnakes is often due to insufficient erection of their fangs before the blow is given. According to Weir Mitchell, seven-eighths of all cases of rattlesnake poisoning will recover. On the other hand, Vipera russellii and Bitis arietans, give special pressure to their bites by the violent motion of their entire body.

The deaths caused by the European vipers, chiefly Vipera berus, are few. In nine years (from I 883 to 1892 ) I 4 fatal cases out of 216 bites are reported in Germany, while in Switzerland, in nine years (I877-I886), 7 deaths are reported. The vipers of southern Europe are not so fatal as the common Pelias of the northern countries. Fontana described 2 fatal cases out of 62 , and 80 to 90 deaths have been reported since the time of Fontana; but half of this number were children. According to Viaud-Grand Marais, 44 deaths out of 316 cases occurred in the Vendée and the Département Loire-inférieure, or I4 per cent mortality. Some large animals, such as the horse, ass, and cow, are also fatally poisoned when vipers strike at the nose, lips or tongue. Goats and sheep are said to be more frequently killed by the vipers than cattle.

The depth and locality of the wound are important conditions; the deeper the wound the more dangerous the results. Wounds in the face, especially in the lips and tongue, are more dangerous than in the limbs, while bites upon the fingers or toes are also very dangerous, owing to the fact that the fangs can be driven deeper into the tissue.

The time intervening between the bite and death varies in different venoms. The quickest fatal cases reported are 2 minutes in a crotalus bite (Barton) and 5 minutes in a Javanese snake bite (Kühl). In these cases the venoms were most probably thrown directly into the blood circulation.

As to the time of death after the bite Fayrer gives the following statistics, based on 65 fatal cases of cobra poisoning: 22.96 per cent died less than 2 hours after the bite; 24.53 per cent died between 2 and 6 hours thereafter; 23.05 per cent died between 6 and I 2 hours thereafter; 9.39 per cent died between 12 and 24 hours thereafter; 2 I. IO per cent died after 24 hours.

The bite of the famous Lachesis lanceolatus of Martinique causes death generally after one or two days and very seldom earlier than 6 hours from the time of the bite. With some species of Lachesis death may occur after 2 to 5 , or even as late as Io days. Death from the bite of Crotalus may occur even after I6 days (Home). The viperine bites, excepting certain tropical genera, are not quickly fatal, but cause marked local and general disturbances, which bring about death after days, weeks, or months; but when the venom gets into the circulatory system death may occur more quickly under the symptoms of the sudden loss of consciousness, delirium, tetanus, and trismus.

When death follows after a long period, the anatomical changes, such as hæmorrhage and local necrosis, are always pronounced. Even when patients recover, local paralysis of most diverse parts of body may persist a long time, together with various local manifestations in the portions of the bitten side. Paræsthesia of various kinds, pemphigoid eruptions, and pain are the sequelæ. 


\section{CHAPTER VII.}

\section{PHYSICAL AND CHEMICAL PROPERTIES OF SNAKE VENOM.}

The venom of the snake in the fresh state is a somewhat viscid fluid of a yellowish tint, which varies in intensity from the palest amber (often more or less greenish) to a deep yellow. The specific gravity ranges from I.030 to I.070.' In fresh venom there are floating granular particles, which soon settle down to the bottom of the receptacle. The amount of the suspended particles varies at different times, being more abundant when we squeeze the poison glands forcibly. These particles are whitish and under the microscope are seen to consist of epithelial cells, cellular débris, and some granula. ${ }^{2}$

The reaction of venom to litmus is usually acid, and is alleged to be fainter in the colubrine than in the crotaline venoms. According to Weir Mitchell the reaction of crotalus venom is invariably acid, ${ }^{3}$ and the author has met the same result. In some instances it may be neutral. The taste of venom is described by Mead as acrid or caustic to the tongue, while Fontana simply perceived a benumbing effect on the part on which it was placed, and Jetter confirmed his experience. Weir Mitchell found no such taste or sensation in crotalus venom. Calmette describes venom as having a bitter taste. The peculiar odor, often attached to venom, has its origin in the snake itself.

The amount of yellow pigment in venom is not always the same, as each individual snake has its own intensity, but no color is peculiar to any definite species. It has frequently been observed that one specimen furnishes a deepcolored venom, the other a very pale-colored venom. The amount of yellow pigment is gradually reduced by repeated extraction of venom from a snake which refuses to feed in captivity. No total disappearance has been observed. The author has once seen colorless secretion by a few specimens of banded rattlesnakes (Crotalus horridus) kept in captivity, and thought it a specific characteristic, but later, while collecting venom from another group of specimens belonging to the same species, found it to be quite yellow.

When mixed with water venom diffuses an opalescent tint through it, and, on standing, a considerable amount of whitish deposit settles, consisting of proteins, or protein-like substances, chiefly globulins, mucin, epithelia, and their débris. In a weak neutral salt solution venom produces but little

\footnotetext{
1 Weir Mitchell: Crotalus horridus 1.054; C. alrox 1.077; C. adamanteus 1.06r; Ancislrodon piscivorus 1.032. Wall: cobra 1.058 .

2 These particles, or rather deposit as a whole, are found to be innocuous when freed from the soluble constituents of venom.

3 Weir Mitchell states that the reaction of the mouth of Crotalus is always alkaline, and suggests the possibility of neutralization taking place when the poison accidentally reached the mouth. Mitchell emphasizes the non-volatile nature of the acid, while Calmette makes a contrary statement, as he found the acidity disappears on drying.
} 
turbidity, except the insoluble particles, which are nothing but epithelia, cellular débris, and spherical refractory albuminoid granules.

Venom dries quickly to a solid mass when exposed to an air-current at low temperature (about $35^{\circ} \mathrm{C}$. or even as low as $15^{\circ} \mathrm{C}$.) or placed in a vacuum desiccator over concentrated sulphuric acid or calcium chloride. When dried at a lower temperature, which does not bring about coagulation of the albuminous constituents, venom retains its original hue, slightly intensified through concentration, and presents the appearance of an aggregation of crystals due to the cracking of the dried substances. Dried venom is more brittle than the dried egg-albumin and resembles more the dried serum in this respect. In a cracked condition it consists of small, yellowish, fragile, transparent or translucent particles of varying sizes. Dried venom retains its original solubility in water or weak saline solution for an indefinite length of time, together with its toxicological properties in unaltered strength and quality. It absorbs moisture quite readily and shows strong adhesiveness.

Snake venom in watery or weak saline solution undergoes putrefactive decomposition through multiplication of some bacteria, and gives an unpleasant odor. The toxic properties of the venom disappear from such decomposed solution.

In I860 Weir Mitchell studied the effects of various chemicals upon the crotalus venom, and his results are given in the report of his work in connection with Reichert. Mitchell also studied the effect of boiling upon the activity of the crotalus venom. He found that boiling a solution of the venom, which contained Io to I 2 drops of the venom in 8 c.c. of water, for Io to 15 minutes, produced a dense coagulum and separated out a pearl-colored supernatant fluid. The coagulum was found to be innocuous, while the filtrate was speedily fatal. From the filtrate he precipitated active substances by alcohol; when dried it presented a pale-yellowish tint, and it gave neutral reaction when redissolved in sufficient volume of water. It gave positive reaction to Millon's test and to cupro-potassa test. He designated this substance crotaline. A general qualitative analysis of the rattlesnake venom was summarized as follows, and it may be mentioned that, although he later made slight modifications in regard to the proteid constituents, the facts in general will remain established.

(I) An albuminoid body (crotaline) not coagulable by heat of $100^{\circ} \mathrm{C}$.

(2) An albuminoid compound coagulable at $100^{\circ} \mathrm{C}$.

(3) A coloring matter and an undetermined substance, both soluble in alcohol.

(4) A trace of fatty matter.

(5) Salts (chlorides and phosphates).

According to Mitchell, crotalus venom does not contain any noticeable quantity of potassium sulphocyanide. 


\section{CHEMICAL NATURE OF SNAKE VENOM.}

The venom of snakes is a secretion of a serous (namely, albuminous) gland, which resembles in its phylogeny the parotid of the mammalian class, and is composed of proteins, carbohydrates, salts, water, and certain occasional admixtures of abrased epithelial cells or saprophytic micro-organisms. The percentage of proteid substances, which are the main components of the venom, is between 75 to 50 per cent, although there are certain proportionate fluctuations according to different individuals or species. The amount of fats and mucin is not very large, leaving the remaining percentage to water. The salts found in venom are chlorides and phosphates of calcium, magnesium, and ammonium, and are present only in small quantities.

Our knowledge concerning the chemical nature of venom has passed through many phases of evolution and is constantly moving forward. I shall here attempt to give a brief résumé of the investigations which supply the principal facts upon which our chemical knowledge is based, as well as those which once served to promote our knowledge.

Lucien Bonaparte ( 1843 ) demonstrated that the most active principle of Vipera berus is a protein resembling digestive ferments, and designated it viperine or echidnine. ${ }^{1}$

S. Weir Mitchell and Reichert (I886) made very exhaustive studies upon the venom of poisonous serpents, in which the chemical side of the problem was also ably handled.

According to their analysis there are in venom at least two distinct classes of proteins - one including the globulins and the other the peptones. In distinguishing these two kinds of proteins they refer to the facts that after a thorough dialysis there appears in the dialyzer a large amount of whitish precipitate, which, after being separated from the fluid portion of the venom by means of filtration, is found to belong to the globulin group. The filtrate contains some proteins in solution, as it gave a proteid reaction. This latter protein is found to produce no coagulation by brief boiling; not precipitable by weak or strong mineral acids, or by solutions of ferri-chlorides or cupric sulphate; precipitated, but not coagulated, by absolute alcohol $;{ }^{2}$ and if placed in a dialyzer it is found to be readily dialyzable. Thus, from these general reactions this was placed among the peptones.

As will soon be detailed in tabulated form, the globulins which separated from the venom solution by dialysis are again differentiated into three varieties, all of which agree, however, in general properties in that they are insoluble in distilled water, soluble in weak neutral saline solution, and soluble in dilute acids and alkalies. They become turbid at about $60^{\circ} \mathrm{C}$. and are fully coagulated at a point a little above $70^{\circ} \mathrm{C}$.

The ways of preparing these three globulins are given below. For this

\footnotetext{
1 He precipitated the proteins of the viper's venom with alcohol and found that the precipitate is poisonous when redissolved in water. This differs from Mitchell's method for preparation of crotaline, as the latter was precipitated not from the filtrate of the boiled venom but from the fresh fluid.

No effect upon the cobra peptone.
} 
series they employed the venom of Crotalus adamanteus, Crotalus terrificus, Ancistrodon piscivorus, and of Cobra, but the results recorded here speak only for the globulins of Crotalus adamanteus. They laid special stress upon this, as they did not find the globulins of all venoms to be identical, a fact which agrees very well with the later investigations by certain authors on venoms other than Crotalus adamanteus.

(a) Water-venom globulin: When a sufficient amount of distilled water is added to venom a whitish precipitate occurs which settles to the bottom of the glass, leaving in the course of a few hours a perfectly clear supernatant fluid. If sufficient water has been added at first, the addition of more water to the clear liquid will not cause any further precipitate. The precipitate is this fraction.

(b) Copper-venom globulin: After separating water-venom globulin the filtrate can be gradually precipitated by carefully adding a few drops of a Io per cent solution of copper sulphate. An excess of this reagent causes a complete or a partial re-solution of the precipitate. After standing 24 hours, during which precipitation increases, the deposit is separated by filtration as usual. The filtrate will produce no more precipitate by adding another few drops of cupric sulphate and standing another 24 hours. This fraction did not give any reaction for copper, as tested with ammonia, or ferrocyanide and acetic acid, and was therefore considered not to be a salt of this metal.

(c) Dialysis-venom globulin: The filtrate, after the separation of the two globulins above mentioned, still contains some coagulable proteins (by boiling). The filtrate yields also a considerable amount of precipitate when dialyzed against running water for 24 hours. This is the last fraction of the coagulable proteins of venom. The only proteins still left in the filtrate belong to the non-coagulable proteins and were placed by them among the peptones.

TABle 3.

\begin{tabular}{|c|c|c|c|}
\hline & Water-venom globulin. & Copper-venom globulin. & Dialysis-venom globulin. \\
\hline Sod. chloride ( 0.75 per & Slightly soluble ... & Insoluble.... & Insoluble. \\
\hline $\begin{array}{l}\text { Sod. chloride (ro per } \\
\text { cent). }\end{array}$ & Soluble & do. & Slightly soluble. \\
\hline Carbonic acid (satur.). . & & do. & Soluble. \\
\hline Sod. carbonate........ & $\begin{array}{l}\text { Very soluble; no precipi- } \\
\text { tation by } \mathrm{CO}_{2} \text {. }\end{array}$ & $\begin{array}{l}\text { Very soluble; precipi- } \\
\text { tation by } \mathrm{CO}_{2} \text {. }\end{array}$ & Very soluble. \\
\hline $\begin{array}{l}\text { Hydrochloric acid ( } 0.4 \\
\text { per cent). }\end{array}$ & Very soluble.......... & Very soluble ......... & Do. \\
\hline Metaphosph. acid.. & Insoluble. . . & Insoluble. & Insoluble; yellowish \\
\hline Orthophosph. acid & Soluble & Very soluble . . . . . & Very soluble. \\
\hline Sod. metaphosphate ... & Insoluble.... & Insoluble. . & Do. \\
\hline $\begin{array}{l}\text { Sod. orthophosphate. . } \\
\text { Pot. sulphate. . . . . . }\end{array}$ & $\begin{array}{c}\text { Very soluble... } \\
\text { do........ }\end{array}$ & $\begin{array}{l}\text { Less soluble } \ldots \ldots \ldots \ldots \\
\text { Insoluble. . . . . . . . }\end{array}$ & $\begin{array}{l}\text { Still less soluble. } \\
\text { Insoluble. }\end{array}$ \\
\hline Calc. chloride ........ & do. . . . . . . & Less soluble . . . . . . . & Less soluble. \\
\hline Acetic acid (5 per cent). & do. ..... & Soluble $\ldots \ldots \ldots \ldots$ & Very soluble. \\
\hline Acetic acid (glacial) & & do. & \\
\hline
\end{tabular}

Finally, the venom peptone was prepared by dialysis. Elimination of the coagulable proteins by boiling was unsatisfactory, because it never gave 
clear filtrate, and if the boiling was too prolonged the peptone broke down and gave fine coagula. The following reactions were obtained with this fraction:

TABLE 4 .

No immediate coagulation at a temperature of $100^{\circ} \mathrm{C}$.

Full reactions with the protein color tests. No precipitate with weak or strong nitric acid.

Ferric chloride, no precipitate.

Cupric sulphate, no precipitate.
Mercuric chloride, decided precipitate.

Absolute alcohol, precipitate, redissolved by the addition of water.

Mercuric nitrate, decided precipitate.

Pot. hydrate, precipitated by saturation.

Pot. ferrocyanide in presence of weak acetic acid, a precipitate.

Moccasin peptone resembles the above (crotalus) closely. On the other hand, Mitchell and Reichert met some remarkable properties of a similar preparation obtained from cobra venom. It was not precipitated by mercuric chloride or absolute alcohol. In watery solution all venom peptones produced fine coagula when boiled for a few minutes. After filtration, the filtrate again gave similar fine coagula on boiling, and so the process of boiling, filtering, and reboiling the filtrate went on repeatedly, yet a clear filtrate could not be obtained even after one hour's repetition. Mitchell and Reichert considered this peculiarity to be a decomposition phenomenon of a protein as a result of violent physical force.

The cobra peptone reacted positively to the xantho-proteic, Millon and biuret. There was no precipitate by strong nitric, hydrochloric, or acetic acids, but precipitation resulted by saturated sodic chloride, tannic acid, and basic-lead acetate.

Reverting to the identity of the fractions of coagulable proteins obtained from the different venoms by the same methods, Mitchell and Reichert give comparative lists of their solubility and heat-coagulability. Salt-free suspension of the water-venom globulins of Crotalus terrificus and Cobra, and the copper-venom globulin and dialysis-venom globulin of Crotalus terrificus are recorded as coagulable by heat, while no coagulation or even clearing up is observed by them with the three globulin fractions of Ancistrodon piscivorus.

Except that the water-venom globulin of this latter snake is insoluble in acetic acid (5 per cent or glacial), no remarkable differences are noticeable, and again three fractions behave alike to a certain extent.

Mitchell and Reichert give the following composition of the venom proteins in two crotaline and one elapine snakes:

Crotahus adamanteus:

$0.5 \mathrm{gm}$. dried venom

Ancistrodon piscivorus: $0.3364 \mathrm{gm}$. dried venom

Cobra:

$0.2 \mathrm{gm}$. dried venom
TABLE 5 .

water-venom globulin $0.0495 \mathrm{gm}$. copper-venom globulin $0.0375 \mathrm{gm}$. dialysis-venom globulin $0.0360 \mathrm{gm}$.

$\overline{0.1230 \mathrm{gm} .}=$ globulins.

$0.3770 \mathrm{gm} .=$ peptone (estimated).

water-venom globulin $0.0034 \mathrm{gm}$. copper-venom globulin $0.0182 \mathrm{gm}$. dialysis-venom globulin $0.0047 \mathrm{gm}$.

$0.0263 \mathrm{gm} .=$ globulins 0.3 IOI gm. $=$ peptone (estimated).

water globulin peptone

0.0035

0.1965 (estimated). 
Thus in Crotalus adamanteus 24.6 per cent, in Ancistrodon piscivorus 7.8 per cent, and in Cobra only 1.75 per cent of globulins were found present.

In I886 Norris Wolfenden published some interesting studies upon the constitution of the venom of Naja tripudians and that of Daboia russellii. He first denied the presence of Blyth's cobric acid, which he affirmed to be nothing but calcium sulphate crystals. The bacterial as well as Gautier's alkaloid theory has been completely discarded, the presence of alkaloidal principles in crotalus venom being disproven before this by the MitchellGibbs experiments. Wolfenden first established that the toxic power of cobra venom resides in the protein constituents of the secretion, and is lost when the proteins are removed, and diminished as these are diminished. $\mathrm{He}$ carefully sets up the possibility that the venomous body is something so intimately linked to the proteins that it varies in intensity with the amount of these bodies present and is precipitated, coagulated, or destroyed by all such means as those which precipitate, coagulate, or destroy proteins. By employing the magnesium sulphate precipitation he succeeded in separating three distinct proteins from cobra venom. ${ }^{1}$

Globulin: This was fractionated by saturating the venom solution with $\mathrm{MgSO}_{4}$. It coagulates at $68^{\circ}$ to $75^{\circ} \mathrm{C}$. when in solution in water. It is not, however, a pure globulin, but a mixture of acid albumin and globulin. Wolfenden states that the amount of acid albumin is very small and can be coagulated, when the solution minus the coagulated globulin is heated again with $\mathrm{MgSO}_{4}$. A precipitate is yielded by acid albumin upon the addition of acetic acid and ferrocyanide of potassium. The prolonged dialysis of the

1 Armstrong (quoted by Fayrer in Proc. Roy. Soc. Lond., 1884, 156) has made, in 1873 , the following analysis of cobra venom.

\begin{tabular}{|c|c|c|c|c|c|}
\hline & Crude poison. & $\begin{array}{c}\text { Alcoholic } \\
\text { precipitate. }\end{array}$ & Alcoholic & \multicolumn{2}{|c|}{ Albumin for comparison. } \\
\hline $\begin{array}{l}\text { C. } \ldots \cdots \\
\text { N. } \cdots \cdots \\
\text { H. } \ldots \cdots \\
\text { S. } \ldots \cdots \\
\text { O. } \cdots \cdots \\
\text { P. } \cdots \cdots\end{array}$ & $\begin{array}{c}\text { Per cent. } \\
43 \cdot 5^{6} \\
40.30 \\
\ldots \ldots \\
\ldots \\
\ldots \\
\ldots\end{array}$ & $\begin{array}{c}\text { Per cent. } \\
45 \cdot 76 \\
14.30 \\
6.60 \\
2.5 \\
\ldots \ldots \\
\ldots\end{array}$ & $\begin{array}{c}\text { Per cent. } \\
43.04 \\
12.45 \\
7.0 \\
\ldots \ldots \\
\ldots \ldots\end{array}$ & $\begin{array}{c}\text { Per cent. } \\
53.5 \\
15.7 \\
7.1 \\
\ldots \ldots \\
\ldots \ldots \\
\ldots .\end{array}$ & $\begin{array}{c}\text { Per cent. } \\
53.5 \\
\text { I } 5.5 \\
7.0 \\
1.6 \\
22.0 \\
0.4\end{array}$ \\
\hline
\end{tabular}

Pedler held it possible that the poison is a mixture of albuminous principles with some specific poisons. (Report of Commission on Indian and Australian Snake Poisoning, Calcutta, ${ }_{1874 .)}$ His elementary analysis gives the following figures: $\mathrm{C}_{\mathbf{5}} \mathbf{2 . 8 7}$ per cent, $\mathrm{H} 7 . \mathrm{I}$ per cent, $\mathrm{N} \mathbf{1 7 . 5 ^ { 8 }}$ per cent. Liquid venom contained 27.74 per cent of solid matter and 6.68 per cent ash. Sir Joseph Fayrer and Lauder Brunton compared the action of cobra venom to the alkaloid conin. (Loc. cit., idem.)

Lacerda at first considered the venom to be an organized ferment like bacteria, but later modified this view only to adopt another enzyme theory in which venom is thought to be analogous to the digestive ferment of the pancreas. His discovery that potassium permanganate stops the action of venom came from the idea that oxidation destroys the ferment.

Winter Blyth described a cobric acid as the sole toxic principle of cobra venom. It is not a protein, but microscopic needles crystallized out from the alcoholic filtrate of the venom by means of preliminary precipitation with acetate of lead, and then the removal of the lead with $\mathrm{H}_{2} \mathrm{~S}$ and subsequent evaporation in vacuo. Another method of Blyth is to shake up the alcoholic filtrate with ether, removing the ether, evaporating it off, dissolving in water, passing through a wet filter, and finally evaporating down. (The Analyst, 1877, I, 206.) 
globulin-magnesium precipitate allowed a small trace of albuminous body to diffuse outside the dialyzer, and the latter gave the precipitate with acetic acid and ferrocyanide of potassium, indicating that this was an acid albumin. Judging from this he thought the dialyzable protein of venom could not be a peptone, but an acid albumin.

Serum albumin: A very small quantity precipitable with $\mathrm{Na}_{2} \mathrm{SO}_{4}$ from the magnesium filtrate of venom was obtained, but precipitation required many hours shaking. It coagulated in redissolved condition at between $70^{\circ}$ and $80^{\circ} \mathrm{C}$.

Syntonin: Some fraction was obtained from the filtrate of an aqueous solution of venom previously heated to $98^{\circ} \mathrm{C}$. for 10 to 15 minutes by means of saturated $\mathrm{MgSO}_{4}$, and still more completely by boiling the filtrate with solid $\mathrm{MgSO}_{4}$ in saturation. Usually this frees the venom solution of any protein matter, but there may be some exceptions, which Wolfenden, in that case, thought due to the presence of peptone. He found that the filtrate of the boiled venom solution (in water) is acid and forms coagula by neutralization.

Peptone: Wolfenden employed the method devised by Hofmeister for testing peptone: (I) Cobra venom which had been precipitated by saturation with $\mathrm{MgSO}_{4}$ was treated according to that method. ${ }^{1}$ On addition of the acid phosphotungstate of soda there was produced a slight opalescence. (2) An alcoholic extract of cobra venom was treated with the above method and gave similar opalescence with phosphotungstate of soda. The extract gave undoubted protein reaction. (3) The dialysates (mixed) of cobra venom, after 3 days' dialysis, gave no acid-albumin reaction, but yielded precipitation with Hofmeister's method. Biuret was negative. (4) A portion of cobra venom which was once treated with $\mathrm{MgSO}_{4}$ and $\mathrm{Na}_{2} \mathrm{SO}_{4}$ gave a slight turbidity with the acid phosphotungstate of soda. From these experiments Wolfenden concludes that there are three proteins present constantly in cobra venom, namely, globulin, serum albumin, and syntonin and probably, in traces only, a fourth, peptone.

Similar experimental studies have been extended by Wolfenden to the venom of Daboia russellii. In this series for the separation of globulin he employed precipitation by $\mathrm{MgSO}_{4}, \mathrm{NaCl}$, and $\left(\mathrm{NH}_{4}\right)_{2} \mathrm{SO}_{4}, \mathrm{CO}_{2}$, and dialysis. $\mathrm{He}$ found the globulin to coagulate at $75^{\circ} \mathrm{C}$. The presence of serum albumin was made apparent by precipitation of the magnesium filtrate by $\mathrm{Na}_{2} \mathrm{SO}_{4}$ and the occurrence in the solution of the soda precipitate of an opalescence on boiling, within the range of coagulation temperature of serum albumin $70^{\circ}$ to $80^{\circ} \mathrm{C}$.

\footnotetext{
1 Hofmeister's method is as follows: Treat a solution of albumin with saturated solution of sodic acetate and then add ferric chloride, until of a blood-red color. At this point the addition of the ir on is stopped. Neutralize it with sodium hydrate up to a slight acid reaction. Then boil the fluid for a few minutes, and filter. The colorless filtrate must not give precipitate with ace tic acid and ferrocyanide. Make the filtrate acid with acetic acid and test with an acid solution of phosphotungstate of soda (acidified with acetic acid). The ratio of the filtrate and the reagent is $4: \mathrm{I}$. If any peptone is present there is a flaky precipitate, or a turbidity, on standing for a few minutes. All the albumins except peptone are removed by the ferric acetate. This method is about 50 times more accurate than that of biuret, which can detect only in $1: 2000$.
} 
Albumose and Syntonin: Slow-diffusible proteins are still found in the filtrate of the venom solution heated to $95^{\circ} \mathrm{C}$. Wolfenden believes that they belong either to acid albumin or albumoses, but not to peptone, because they can be removed by ferric acetate. This author expresses the opinion that the substances called peptones by Mitchell and Reichert belong to albumoses.

In 1892 Kanthack ${ }^{1}$ made a thorough examination of the venom of Naja tripudians atrox. He brought out evidences that the chief active principle of cobra venom is albumose; and he gives the following summing up:

(a) The fresh protein precipitate, whether obtained by the addition of absolute alcohol or ammonium sulphate, is amorphous and white, but when dried slowly it forms a translucent colorless mass.

(b) Its solution is colorless or slightly opalescent, and neutral or alkaline to litmus paper.

(c) It is very soluble in water, quite insoluble in alcohol.

(d) It gives a brilliant biuret reaction with caustic potash and a trace of cupric sulphate.

(e) Nitric acid gives a precipitate, soluble on heating and coming down on cooling if the solution is of sufficient concentration. With dilute solution a trace of sodium chloride must be added to cause precipitation.

( $f$ ) Picric acid causes a precipitate, dissolved on heating, but appearing or forming again on cooling.

(g) Boiling produces no physical changes.

(h) Saturation with ammonium sulphate gives a precipitate. Letting the fluid stand for 48 hours and filtering off the precipitate, the clear filtrate gives no biuret reaction, while a solution of the white precipitate reacts beautifully. On adding acetic acid to the filtrate no precipitate is obtained.

(i) Saturation with sodium chloride causes a precipitate. The filtrate gives no biuret reaction, nor a precipitate on the addition of acetic or nitric acid.

(j) The solution gives the ordinary protein reactions, the color with Millon's reagent being less bright, and more of a pinkish-yellowish hue.

From these reactions Kanthack concludes that the substance in question is an albumose, and that only one, a primary albumose, is present. The presence of an alkaloid is denied.

According to Kanthack, cobra venom does not contain any appreciable amount of globulin. The substance described by Weir Mitchell and Reichert as globulin is, according to this author, certain derivatives of the protoalbumose of the same venom.

1 A. A. Kanthack. The nature of cobra poison. Jour. of Physiology, I892, XIII, 272.

In 1892 Martin published a method for separating the albumoses from snake venom. It is as follows: The poison is slightly diluted with sterilized water, and then thrown into a large excess of alcohol, and allowed to stand for a week. The alcohol is separated off and the white precipitate washed with absolute alcohol, dissolved in sterilized distilled water, and once more precipitated by alcohol. The resulting precipitate is allowed to stand under alcohol for a week, then washed with alcohol and dissolved in water, to which a little thymol is added to prevent putrefaction. The solution is found to contain no other proteins than albumose.

Hawkins' method for separating albumose employed by Wolfenden. The solution of cobra venom is saturated with ammonium sulphate and the mixture allowed to stand for several days. 'The white precipitate is dissolved in water and dialyzed until all trace of the salt has disappeared. The solution is then concentrated by dialysis against absolute alcohol, and subsequently poured into a large excess of alcohol and treated as in Martin's method. (Brit. Med. Journ., 1890, July 12.) 
By repeated precipitation by absolute alcohol and redissolution of the precipitate in water, thus excluding the possibility of admixture of globulin, he obtained the protein substance which corresponds to the proto-albumose derived from digestion cleavage. Now, he found that if the solution of the albumose be subjected to the action of higher temperature or the sunlight, there appears in the originally clear solution some precipitate, which is insoluble in distilled water, but soluble in 0.75 per cent sodic chloride solution, from the latter heating, or saturation with $\mathrm{NaCl}$ again throws it down. According to Kanthack this precipitate is a hetero-albumose. The mere dialysis did not uniformly produce precipitate from a solution of native venom, but it did ${ }^{1}$ occasionally. In this case he thinks it to be a hetero-albumose. At times the precipitate derived either from the diffusible proteid of the venom or from the alcohol-treated albumose is partly insoluble in 0.75 per cent sodic chloride solution in contradistinction to a hetero-albumose. This was thought by Kanthack to be a dysalbumose. Prolonged heating of the protoalbumose yields a hetero-albumose and a dysalbumose, which are harmless. It was found that the solution of cobra proto-albumose exposed to the temperature for $\mathrm{x} 2$ hours no longer gives the biuret reaction and is entirely innocuous (and cloudy from the precipitate).

The loss of toxic action by heating the albumose is ascribed to the decomposition of proto-albumose into hetero-albumose and dysalbumose.

C. J. Martin and MacGarvie Smith separated the albumoses of Pseudechis s. Notechis porphyriacus of Australia from the coagulable proteins by filtering the venom solution previously heated to coagulation. The filtrate was then precipitated with a saturated magnesium sulphate (shaken a couple of hours). The precipitate was collected on the filter and washed with the saturated solution of $\mathrm{MgSO}_{4}$. The filtrate was then dialyzed in running distilled water for 24 hours, then concentrated by dialyzing it in absolute alcohol. This last condensed fluid contained certain proteins in solution, and these were found to be a mixture of hetero-albumoses and proto-albumoses with a little of peptones. Sometimes the peptones were absent.

The separation of hetero-albumoses and proto-albumoses was effected by Neumeister's method. The proteins were precipitated with 5 per cent $\mathrm{CuSO}_{4}$ (a few drops), then the deposit was collected and washed with $\mathrm{MgSO}_{4}$, put into distilled water, and then dialyzed during three days. The proteins are thrown down abundantly, and are centrifugalized, clear fluid being pipetted off and then dialyzed in absolute alcohol. Then the residue is finally desiccated at $40^{\circ} \mathrm{C}$. Here the separation is accomplished simply by extracting the dried mass with distilled water, which takes up only proto-albumose, but not hetero-albumose, which is insoluble. The coagulable proteins of this venom consist of albumin and globulin.

Thus the poisonous principles of snake venom have been classed with the toxalbumins, among which several plant poisons, like ricin or abrin, are also enumerated.

\footnotetext{
${ }^{1}$ Kühne never found formation of hetero-albumose out of proto-albumose on dialysis.
} 
Starting from the biological observations made by Flexner and Noguchi, Kyes, under the direction of Ehrlich and partly in association with Sachs, finally made a very important discovery on the hæmolytic constituent of snake venom. Flexner and Noguchi found that venom becomes hæmolytic when there is at the same time the serum of a susceptible species, and thought it to be regular complements of blood serum which activate venom. Calmette discovered that the heated serum contains more activating principles, and all serum becomes, no matter whether originally venom-activating or not, complementary for venom on boiling. From these observations Kyes was led to discover the nature of the venom-activating principles of heated serum. It was found to be lecithin. Later Kyes obtained a definite compound of venom and lecithin, which is hæmolytic by itself. This is called lecithid of venom. His original method of preparing venom-lecithid is given below:

40 c.c. of a I per cent solution of cobra venom in 0.85 per cent $\mathrm{NaCl}$ solution are mixed with 20 c.c. of a 20 per cent chloroform solution of lecithin in a flask of about I 00 c.c. capacity and then shaken in an apparatus for this purpose for about 2 hours. Then the whole mixture is centrifugalized for 45 minutes $-3,600$ revolutions per minute. When the process is successful the watery portion of venom separates sharply from the clear chloroform portion below with a compact, whitish, narrow layer between the two portions. The clear chloroform portion has about I9 c.c. as a rule, and can be easily separated by fine pipette. Then mixing it with 5 volumes of ether, there appears a precipitate which is the lecithid. The unaltered lecithin remains in solution in ether.

As a rule Kyes washed the precipitate with original volume of ether Io to 20 times repeatedly, in order to remove all trace of lecithin from the lecithid. The lecithid can be preserved a long time under ether, without change, or it can be dried carefully, but in the latter case its solubility is observed to undergo change, although its hæmolytic activity remains intact. From I gram of dried cobra venom about 5 grams of dried lecithid has been prepared.

A very important finding is that after the preparation of lecithid, the watery portion lost its hæmolytic property almost completely, while the neurotoxic principle still remained undiminished in the solution. The cobra lecithid is found to be hæmolytic, but not fatal to animals. When injected into a mouse in a quantity which could dissolve 200 c.c. of the blood in vitro it produced only an infiltration of the site of injection. In a rabbit ıo c.c. of a I per cent solution of lecithid caused an extensive infiltration when injected subcutaneously.

The properties of cobra lecithid: The primary product, which is obtained by repeated washing in ether and compressed between filter papers, is insoluble in acetone and ether, but soluble in chloroform, cold alcohol, and warm toluol. From solution in chloroform and alcohol it is precipitated by ether and acetone. Lecithid which still contains some ether, or lecithid rapidly freed from ether by air-current, dissolves in water without cloudiness, and presents a clear, slightly yellowish solution. Its solubility in various lipoid 
solvents distinguishes lecithid from cobra venom on one hand and lecithin on the other.

The curious phenomenon was observed that when a watery solution of the primary lecithid is allowed to stand in the room temperature the solution gradually becomes turbid and separates out whitish precipitate which settles to the bottom. The whitish deposit consists of crystalline, translucent, highly refractory bodies of microscopic dimensions. This modified product is called secondary lecithid. It is almost insoluble in cold water, soluble in warm alcohol, and reappears on cooling. Its solubility in organic solvents is the same as the primary lecithid. The lecithid requires no incubation time for attacking the blood corpuscles. It is thermostabile, while the native cobra venom becomes inactive when heated to $100^{\circ} \mathrm{C}$. for 30 minutes. No biuret reaction is given by the lecithid.

The elementary analysis of pure lecithid of cobra venom has been made by different chemists. ${ }^{1}$

Willstätter and Lüdecke give the following figures:

$\begin{array}{lll}\text { One estimation } & \mathrm{N}=2.73 \text { per cent } & \mathrm{P}=5.76 \text { per cent. } \\ \text { Other estimation } & \mathrm{N}=\mathbf{2 . 8 \text { per cent }} & \mathrm{P}=6.03 \text { per cent. }\end{array}$

The result of von Braun is as follows:

$$
\begin{array}{ll}
\mathrm{N}=2.84 \text { per cent } & \mathrm{P}=5.56 \text { per cent. } \\
\mathrm{H}=10.92 \text { per cent } & \mathrm{C}=59.07 \text { per cent. }
\end{array}
$$

The result obtained by $\mathrm{H}$. Weil is as follows:

$$
\begin{array}{llr}
\mathrm{N}=6.35 \text { per cent } & \mathrm{P}=3.16 \text { per cent } & \mathrm{S}=7.66 \text { per cent. } \\
\mathrm{H}=9.48 \text { per cent } & \mathrm{C}=56.26 \text { per cent } & \mathrm{Ash}=9.29 \text { per cent. }
\end{array}
$$

In this connection Kyes referred to the fact that the percentages of nitrogen and phosphorus of the lecithid closely approach those of monostearyl lecithin and monopalmitin lecithin, which, according to Willstätter and Lüdecke, contains $\mathrm{N}=2.74$ per cent, $\mathrm{P}=6.06$ per cent in the latter, and $\mathrm{N}=2.59$ per cent, $\mathrm{P}=5.73$ per cent in the former.

The lecithids were prepared also from the following venoms:
(I) Lachesis s. Bothrops lanceolatus.
(2) Daboia russellii.
(5) Bungarus fasciatus.
(3) Naja haje.
(4) Bungarus cæruleus (krait).
(6) Lachesis s. Trimeresurus riukiuanus.
(7) L. S. Trimeresurus anamallensis.
(8) Crotalus adamanteus.

Kyes met some irregular results in preparing venom lecithid, and finally found that the acidity which develops and gradually increases during the shaking of the lecithin-chloroform solution and cobra-venom solution was the cause. If the acidity of the mixture be removed by appropriate quantities of alkali, the formation of lecithid goes on again until the acidity reaches the inhibiting degree for the process. After completing this process the alkali is removed from the mixture by means of hydrochloric acid.

Kyes studied the products which arise from the mixture of an insufficient

1 Kyes. Ueber die Lecithide des Schlangengiftes. Biochem. Zeitschrift, 1907, IV, 99. 
lecithin and sufficient cobra venom, shaken as usual. He obtained four preparations:

Substance I. A spontaneous precipitate formed in the watery layer when the latter is separated from chloroform (lecithin solution) by means of I volume ether and two-fifths volume of alcohol. It gives a biuret reaction and many other protein reactions - precipitation by potassic ferrocyanide, acetic acid, nitric acid, tannic acid, picric acid, and alcoholic cadmium chloride solution. Hæmolytically very weak (one-tenth of the original venom), but can be complemented with lecithin.

Substance II. Obtained by first precipitating the watery portion with 5 per cent phenol, then the oily matter which separates out thereby is again precipitated with alcohol. The precipitate has the property of becoming ro times more hæmolytic than the native venom when combined with enough lecithin, but otherwise is almost inactive.

Substance III. Obtained by precipitating the filtrate (of the alcohol-soluble oily fraction, after separation of substance II) with ether. This is gelatinous and water-soluble, has about the same strength as the native venom. Requires lecithin to be active.

Substance IV. Precipitate obtained by treating the filtrate (the soluble portion from which oily matter was removed by phenol) with alcohol.

These bodies are called by Kyes incomplete lecithids, which differ from the complete lecithid in their insolubility in alcohol. Of these four, substance II is neutralizable by antivenin, while some of the incomplete lecithids remain unaffected. Complete lecithid is not reactive to antivenin, but is said to be able to produce anti-serum, which neutralizes lecithid and native venom equally.

Snake venoms are not the only class of bodies which produce hæmolysis in the presence of lecithin.

Pascucci ${ }^{1}$ has shown that ricin becomes hæmolytic when mixed with lecithin. Landsteiner and Jagic ${ }^{2}$ discovered that the colloidal silicic acid, which like ricin is usually only agglutinating, becomes upon the addition of lecithin highly hæmolytic. Landsteiner and Jagic explain this phenomenon as due to the adsorption of lecithin to the corpuscles previously or simultaneously impregnated with the colloidal silicic acid. Naturally they found that lecithin is by itself more or less hæmolytic even without the intermediation of this colloid.

Later, Landsteiner and Jagic ${ }^{3}$ also found that the shaking of the mixture of aqueous solution of colloidal hydrate of iron and choloroform solution of lecithin gives rise to a new compound of these two bodies precipitable from chloroform by a large quantity of ether. This relation is exactly what takes place when venom and lecithin are shaken under the same conditions.

Reiss ${ }^{4}$ states that chloroform solution of lecithin can take up lac and trypsin from aqueous solutions, but these ferments, which apparently had gone over

\footnotetext{
1 Pascucci. Ueber die Wirkung des Ricins auf Lecithin. Hofm. Beitr. zur chem. Physiol. u. Pathol., I906, VII, 457 .

2 Landsteiner and Jagič. Ueber Analogien der Wirkung kolloidaler Kieselsäure mit den Reaktionen der Immunkörper und verwandter Stoffe. Wien. klin. Woch., I904, XVII, 63.

Landsteiner and Jagic. Ueber Reaktionen anorganischer Kolloide und Immunkörperreaktionen. Münch. med. Woch., I904, LI, I I85. Michaelis and Ehrenreich. Die Adsorptionsanalyse der Fermente. Biochem. Zeitschr., 1908, X, $283_{3}$.

- Reiss. Eine Beziehung des Lecithins zu Fermenten. Berl. klin. Woch., r904, XLI, 1185.
} 
to lecithin chloroform, were not precipitated out by adding a large quantity of ether.

Michaelis and Rona ${ }^{1}$ add further knowledge as to the mechanism of lecithid formation. These authors found that chloroform solution of mastix when shaken with aqueous solution of rennet takes up a certain part of this enzyme as chloroform-alcohol solution forms and can equally be precipitated out by means of ether, an exact parallel phenomenon to the process of lecithid preparation of Kyes.

Landsteiner and Jagic and Michaelis and Rona are inclined to regard the phenomenon as of merely physical nature, namely, colloidal reaction.

Kyes, ${ }^{2}$ however, does not consider the physical explanation of Michaelis and Rona of the mastix-rennet phenomenon applicable to the formation of venom lecithid, inasmuch as there is a very great and important difference between these two sets of superficially analogous processes. Venom lecithid does not contain any trace of the original materials from which it has been derived. No evidence of free venom-hæmolytic amboceptors or of native lecithin can be brought out. Its chemical and physical properties are quite different from the original materials. On the other hand, the precipitate of mastix-rennet shows at least that the ferment is intact in all its original characteristics. Here it has been a mere physical process, not comparable with the venom-lecithid formation.

According to von Dungern and $\mathrm{Coca}^{3}$ a very large quantity of oleic acid is separated out during the preparation of cobra lecithid. II c.c. of 20 per cent lecithin solution in chloroform plus 22 c.c. of I per cent cobra venom solution in 0.8 per cent $\mathrm{NaCl}$ solution were shaken 2 hours; 5 times volume of ether; precipitation of lecithid. From $2 \mathrm{gm}$. of lecithin about I.206 gm. lecithid were obtained.

From ro c.c. chloroform solution $0.5642 \mathrm{gm}$. of pure acid oil went into ether. Its acidity agreed with that of oleic acid. $0.5079 \mathrm{gm}$. of this oil was dissolved in absolute alcohol and then determination of acidity was made. It required I6.5 c.c. of $\mathrm{N} / \mathrm{IO} \mathrm{NaOH}$, whereas $0.5079 \mathrm{gm}$. of pure oleic acid took i7.6 c.c. N/ Io NaOH. Baeyer's double bond test with permanganate was positive; lead salt perfectly soluble in ether. In the separated saline solution there was still cobra venom, which, when used in 5 times the original, dissolved the blood in the presence of 0.5 c.c. of 0.05 per cent lecithin just as rapidly as the original I per cent venom solution. The hæmolytic activity of the lecithid was: $0.00002 \mathrm{gm}$. dissolved I c.c. of 5 per cent suspension of $\mathrm{ox}$ corpuscles, but $0.0000 \mathrm{Igm}$. did not act.

A preparation of lecithin purchased from E. Merck they found to contain a large amount of acid (5.5 c.c. N/ Io NaOH to I gm. of lecithin in alcohol, phenolphthalein indicator). With this lecithin hæmolysin was also formed. But the hæmolysin did not precipitate until 40 parts $\mathrm{N} /$ Io $\mathrm{Na}_{2} \mathrm{CO}_{3}$ were added

\footnotetext{
${ }_{1}$ Michaelis and Rona. Ueber die Löslichkeitsverhältnisse von Albumosen und Fermenten mit Hinsicht auf ihre Beziehungen zu Lecithin und Mastix. Biochem. Zeitschr., I907, IV, Ir.

2 Kyes. Bemerkung über die Lecithidbildung. Biochem. Zeitschr., I9o8, VIII, ${ }^{2}$.

${ }^{3}$ v. Dungern and Coca. Ueber Hämolyse durch Schlangengifte. Münch. med. Woch., I907, LIV, 23 I 7.
} 
to I per cent venom solution in saline and then separated with ether and chloroform. A previous addition of alkali was necessary for precipitation of lecithid from chloroform by ether. Acetone also did not precipitate without alkalization. Yet hæmolytic substance was already formed, and evaporation of the fluid in vacuum, washing with acetone and ether (of the residue), gave a large proportion of the pure hæmolytic substance $\left(0.3^{2} \mathrm{gm}\right.$. out of $0.45 \mathrm{gm}$. of lecithin). Its hæmolytic activity was $0.00002 \mathrm{gm}$. per I c.c. 5 per cent suspension of ox corpuscles.

Preservation of these lecithids for a longer period produced reduction in their activity. Immediately after precipitation with ether $0.00002 \mathrm{gm} .=$ complete $0.0000 \mathrm{I} \mathrm{gm.}=$ partial hæmolysis. After a long standing 0.00004 gm. $=$ total and $0.00002 \mathrm{gm}$. partial hæmolysis against I c.c. 5 per cent ox corpuscles.

Heating of I per cent solution for 3 hours at $100^{\circ} \mathrm{C}$. did not cause any appreciable loss of activity, while o.I per cent solution became weakened after 2 hours' boiling.

The lecithid preparations were not poisonous, except in causing swelling of the site of injection.

That the active principle of cobra venom can be prepared in a form free from any proteid substance has been shown by Faust, ${ }^{1}$ who prepared a neurotoxic substance free of nitrogen from Naja tripudians and named it ophiotoxin.

The methods of preparation were as follows:

Ten grams of dried cobra venom were mixed with 500 c.c. of water and allowed to stand over night. The next morning the fluid was filtered and separated from the undissolved portions, which are mainly the epithelia and cellular débris. Combustion of the same leaves a little ash. If the insoluble portion of cobra venom is mixed with hydrochloric acid, a gas evolves which blackens the lead acetate paper and smells of $\mathrm{H}_{2} \mathrm{~S}$.

The clear, light-yellowish filtrate was mixed with a neutral solution of cupric acetate or with a chemically pure (namely, free of iron) solution of copper chloride, and was, after some time, diluted with $\mathrm{KOH}$ or $\mathrm{NaOH}$ solution by dropping, until the fluid showed a weakly or distinctly alkaline reaction. Simultaneously the fluid showed an intense biuret color and threw out a precipitate consisting chiefly of copper oxyhydrate.

In the alkaline reaction, if no further precipitate comes out upon addition of $\mathrm{NaOH}$, the precipitate is separated from the solution by filtration. The filtrate, which is of a deep violet color, throws out another lot of precipitate of the nature of protein or protein-like substances upon addition of a dilute acetic acid. But this fraction was found to be entirely inactive. The filtrate thus obtained was also entirely inactive when tested for its action after removal of the copper salt by dialysis.

The first precipitate was then redissolved in a weak acetic-acid solution, then precipitated again by carefully adding drops of $\mathrm{KOH}$ or $\mathrm{NaOH}$ solution. The precipitate was again obtained, while the fluid once more showed biuret reaction. The precipitate was rapidly filtered after settling. Usually, but not in all cases, the filtrate has still some weak biuret color. If any biuret reaction still occurs, the redissolution in acetic acid solution and reprecipitation with alkalies will have to be repeated.

\footnotetext{
${ }^{1}$ Faust. Ueber das Ophiotoxin aus dem Gifte der ostindischen Brillenschlange. Leipzig, 1907.
} 
MeтHod A: The precipitate was then washed into a flask of suitable size and was shaken thoroughly to obtain a minute suspension. Afterwards a strong current of $\mathrm{H}_{2} \mathrm{~S}$ gas was introduced which split the copper compound of the venom and took away the dark-bluish color of the precipitate. The excess of $\mathrm{H}_{2} \mathrm{~S}$ was then driven off the fluid by a strong air-current. The copper sulphite was next filtered and separated from the clear, biuret-reaction-free filtrate. This last filtrate was able to produce a similar paralytic effect in the frog and respiratory cessation in the rabbit. The solution was weaker than the native venom solution and suggests the possible alteration of the active substance while being treated by alkalies. Copper sulphite did not retain in it any amount of the active principle, because extraction of it by means of 96 per cent alcohol, acetic ether, chloroform, acetone, petroleum ether, or methyl alcohol did not succeed either in a cold or in a hot state.

The filtrate has shown a great tendency to lose its activity, especially when dried. In many instances the dried materials were completely inactive. After drying it becomes less soluble in water, and not at all soluble in the usual organic solvents. In every case it contained no nitrogen. In solution it produced a foam.

METHOD B: This is accomplished by taking up the copper precipitate with alcohol and preserving the same under 96 per cent alcohol for some time in order to get rid of water from the precipitate. Then add alcoholic hydrochloric acid to the supernatant alcohol and shake thoroughly. 'The copper is quickly combined with chlorine and goes into solution in alcohol, while the ophiotoxin remains in a pure state undissolved in the same. Then decant the copper solution and repeatedly wash the precipitated fine flocculence in alcohol, until the washing fluid shows no chlorine in it. Then the precipitate is dissolved in water and tested for its strength. It shows that ophiotoxin is always weaker than the native venom solution. Also that ophiotoxin, which is not found to be protein-molecules, as in the native venom, is easily rendered inactive by various temperatures and alkalies.

As these methods did not give satisfactory results Faust devised the following method based on observations of earlier investigators. In this he utilized the non-coagulable nature of the active principles of cobra venom by higher temperature.

Ten grams of dried cobra venom were dissolved in Ioo c.c. of water and very weakly acidified with acetic acid, then heated I 5 minutes at $90^{\circ}$ to $95^{\circ} \mathrm{C}$. in a waterbath, sodium chloride being added to saturation in the meantime. The greater part of the proteins contained in the native venom is then thrown down as coarse clumps and the fluid is easily filtered. The coagula on the filter was found to be wholly inactive.

In this process magnesium sulphate and ammonium sulphate can not be used, as both of these salts precipitate the main quantity of ophiotoxin along with the proteins. The light-yellowish filtrate is found to be just as active as the original cobra-venom solution. It contains also ophiotoxin and some other substances which give biuret reaction. The color produced by adding cupric sulphate and sodium hydrate, especially on warming, was deep violet, characteristic of albumoses and peptones. The ophiotoxin does not diffuse or dialyze.

Faust dialyzed the above filtrate through membrane until chlorine reaction was no more obtained. If a more prolonged dialysis is made the biuret reacting substance may also disappear, but this is always associated with 
reduction in the strength of ophiotoxin. Now, the entire volume of fluid after dialysis, usually about 800 c.c., was condensed to 50 c.c. In order to remove the biuret-reacting bodies metaphosphoric acid was gradually added, which separated them out. The excess of the acid must be avoided, as this may redissolve some of the precipitate once formed. The reaction may be slightly acid. The precipitate is then separated from the clear fluid by filtration. The filtrate is found to be highly toxic and does not contain nitrogen. The ophiotoxin is insoluble in alcohol and therefore can be precipitated out from the filtrate by adding sufficient alcohol.

Faust found that a weak acid reaction with metaphosphoric acid prevents the inactive modification during the condensation of fluidal volume. Its action seems to be peculiar to this acid, because in the same acidity $\mathrm{H}_{2} \mathrm{SO}_{4}$, $\mathrm{HCl}, \mathrm{HNO}_{3}$, and orthophosphoric acid, as well as tartaric and oxalic acids could not prevent the decomposition of ophiotoxin during evaporation in the air or in vacuo.

This protective property of metaphosphoric acid was also found to be effective in preserving the activity of the ophiotoxin prepared after Method A. Desiccation at $40^{\circ} \mathrm{C}$. did not affect the ophiotoxin if weakly acidified with metaphosphoric acid.

The ophiotoxin in the dried state is a light, somewhat yellowish amorphous powder. Heated on a platinum plate, it first leaves a voluminous carbon, then burns without ash. It contains no nitrogen, phosphorus, or sulphur. Sodium hydrate solution quickly renders it inactive.

Elementary analysis of ophiotoxin by Faust on two preparations agreed very well and gave the following:

\begin{tabular}{|c|c|c|c|}
\hline ved (in & (n). & & \\
\hline $\begin{array}{l}52.01 \text { per cent }(52.11 \\
\text { H } 6.76 \text { per cent }(6.72\end{array}$ & $\begin{array}{r}51.93 \\
6.76\end{array}$ & $\begin{array}{l}52.01) \text {. } \\
6.8 \mathrm{I})\end{array}$ & \\
\hline
\end{tabular}

Faust gives the following simple, empirical formula: $\mathrm{C}_{17} \mathrm{H}_{28} \mathrm{O}_{10}$. The two preparations employed in the foregoing analysis were nearly 5 times more powerful than the original venom, and in spite of the amorphous character he concludes his ophiotoxin to be the pure and single substance.

Ophiotoxin in watery solution reacts weakly acid, but does not act on carbonate of soda. It can be separated out from watery solution by saturating with ammonium sulphate. Sodium chloride and sodium sulphate do not precipitate it. Salts of heavy metals - copper, lead, mercury - throw it out from an alkaline, but not from an acid solution.

Faust states that the ophiotoxin may be an animal glucoside and considers the high content of oxygen to be peculiar to some of the carbohydrate complexes of the molecule. He did not, however, find any substance capable of reducing copper oxide into the oxidule when the ophiotoxin is boiled one hour with concentrated hydrochloric acid. Thus no reducing sugar is formed in the above treatment, showing the difference from the plant glucosides,

Differences from plant sapotoxins are (I) insoluble in alcohol; (2) no reducing carbohydrate ground; (3) a curare-like action on cold-blooded animals 
On the other hand, the ophiotoxin has common properties with the plantsapotoxins, and these are (I) soluble in water and forming froth, but insoluble in ether; (2) difficult resorption from mucous membranes (stomach and intestine); (3) local symptoms after subcutaneous injection, and often formation of an aseptic abscess; (4) hæmolytic action; (5) action upon the nervous system, especially upon the respiratory center; (6) the central action can be produced only when a larger amount is injected subcutaneously, or a small amount directly into the blood; (7) sapotoxins and ophiotoxin are free of nitrogen; (8) they do not dialyze; (9) they are amorphous, colloidal substances and do not crystallize except with difficulty.

Finally Faust laid his theoretical consideration of the pharmacological position of the ophiotoxin bare. He sees that the ophiotoxin resembles quillaja acid, differing from it only by the fact that the former has one atom of hydrogen too little. Another analogy is made with bufotalin, the poisonous secretion of the skin of a toad, in which the ophiotoxin excels the bufotalin in containing twice as many oxygen atoms as the latter. He thinks that both principles have the same carbon frame, but the ophiotoxin has more hydroxyl groups. He sees in this that the former owes its superior activity and lability to the greater number of hydroxyl complexes it contains. He recalls that bufotalin is an oxidization product of bufanin, a cholesterin-like body widely distributed among the amphibia, and that it is not improbable that the ophiotoxin may be an oxidation derivative of another cholesterin-like body which is peculiar to the reptiles. Faust places the ophiotoxin among the sapotoxin group and proposes to term it animal sapotoxin. 


\section{CHAPTER VIII.}

\section{EFFECTS OF VARIOUS PHYSICAL AND CHEMICAL AGENTS UPON SNAKE VENOM.}

This includes the effects of various physical and chemical agents on venom en masse as well as on certain active constituents of venom obtained by chemical processes. As the constituents of different venoms differ both in quantity and quality, the effects of various agents upon them differ accordingly.

\section{EFFECTS OF PHYSICAL AGENTS.}

Effect of desiccation: When allowed to dry at ordinary temperature, all venoms do not suffer a loss in their toxicity. In some viperine or crotaline venoms a slight reduction in their local activity has been observed after desiccation, but never to a great extent.

Effect of preservation: The active principles of snake venom are very stable when kept in a dry state or in a mixture with equal quantity of glycerin. So far as records go, dried crotalus venom after 23 years was just as active as when it was freshly collected (Mitchell), and dried cobra venom preserved for 15 years (Christison) or 16 years (Vollmer) did not show any sign of deterioration of its original strength. On the other hand, when in saline or watery solution, the venom gradually loses its activity. This fact is especially marked with cobra venom, and at body temperature.

Effect of moist heat: The venom of Elapinæ (Naja, Elaps, Bungarus, Hoplocephalus, Pseudechis) can be exposed to the temperature of $100^{\circ} \mathrm{C}$. for a brief period, without reducing its activity to any marked degree. Fayrer and Brunton mention that a 30 -minutes heating of cobra venom at $102^{\circ} \mathrm{C}$. destroys the latter. Wall states that $106^{\circ} \mathrm{C}$. maintained for 30 minutes is sufficient to destroy cobra venom. Kanthack saw cobra venom become harmless after an hour's boiling at $100^{\circ} \mathrm{C}$. Mitchell and Reichert found that the prolonged boiling produced gradual coagulation of the venompeptone and rendered it inert.

The venom of Hydrophiinæ withstands even a brief boiling with impunity. $\mathrm{I} 20^{\circ} \mathrm{C}$. always suffices to cause total inactivation or destruction of all venoms.

The venoms of Viperinæ and Crotalinæ are much more sensitive to the destructive action of heating. The temperature which produces coagulation of the proteins of these venoms destroys the greater part of their poisonous activity. The temperature of $72^{\circ}$ to $75^{\circ} \mathrm{C}$. removes most of the toxicity, while almost complete inactivation is brought about at $80^{\circ}$ to $85^{\circ} \mathrm{C}$. But 
there is still some heat-incoagulable principle left in the heated venom which may cause death when used in a sufficient quantity. ${ }^{1}$

According to Calmette the venoms of Lachesis are the most sensitive to heat and partly lose their toxicity even at $65^{\circ} \mathrm{C}$. Wolfenden mentions that cobra venom coagulates at $70^{\circ}$ to $80^{\circ} \mathrm{C}$. and daboia venom at $65^{\circ}$ to $73^{\circ} \mathrm{C}$.

It may be remarked that the proteins of venoms when once coagulated by heat are entirely non-poisonous, as these can first be freed from the noncoagulable constituents by washing and be injected into animals without producing any symptoms.

From these facts it becomes evident that most of the active principles of the Colubridæ reside in the non-coagulable portion of the venom, while the greater part of the poisonous properties of the Viperidæ venoms are inherent to the coagulable proteins, and this is also confirmed by various evidence.

Effect of dry heat: A prolonged heating of dried venom in a hot-air chamber at $130^{\circ} \mathrm{C}$. does not destroy the activity of the venom.

Dialysis: The venoms of Viperidæ, which mostly contain coagulable proteins as toxic constituents, do not diffuse through dialyzer - either vegetable"or animal membrane, while those of the Colubridæ slowly dialyze through the first, but much more tediously through the latter membrane. It is on account of this property that Weir Mitchell and Reichert classified this noncoagulable, dialyzable principle with "peptone," although it possesses some other qualities as a peptone.

The effect of filtration: The venoms of Colubridæ do not lose their toxicity in any noticeable degree by passing through an ordinary or Martin's gelatinized Chamberland bougie. On the other hand, the venoms of Viperidæ leave all their active principles on the gelatinized bougie, the filtrate in this case being almost or entirely inactive. Madsen and Noguchi found a 50 per cent loss of toxicity in crotalus venom after passing through a usual Chamberland bougie. C. J. Martin ${ }^{2}$ filtered the venom of Pseudechis through the gelatinized bougie under the pressure of 50 atmospheres, and found that the hæmorrhagic principle, similar to the active, coagulable proteins of all viperine or crotaline snakes, remains behind the filter, while the diffusible, non-coagulable protein - albumose-passed into the filtrate. The latter is found to attack the respiratory center. Filtration through animal (but not wood) charcoal retains all of the poisonous matters and the filtrate is innocuous. (Mitchell and Reichert.)

The effect of cold: Lumière and Nicolas ${ }^{3}$ tested the effect of cold produced by evaporating liquid air. The cobra venom employed by them was a I per cent dilution. A portion of it was subjected to the action of liquid air for 24 hours, and another for 9 days at a temperature of $-19 I^{\circ} \mathrm{C}$. Its toxicity remained unaltered after the treatment.

\footnotetext{
1 The venoms of Crotalus adamanteus and Ancistrodon piscivorus are both still active after a brief

2 C. J. Martin. Notes on method of separating colloids from crystalloids by filtration. An explanation of the marked difference in the effects produced by subcutaneous and intravenous injection of the venom of Australian snakes. Roy. Soc. of N. S. Wales, August 5, 1895.

3 Lumière, Aug., and Joseph Nicolas. Province médicale, Sept. 21, rgor.
} 
Light does not have a deteriorating effect on dried venom, but a marked reduction of toxicity is observed when the solution of venom is exposed to the direct sunlight or diffuse daylight during many days. 'The alteration is more marked with the venom of cobra than with the crotalus, and is quicker at $37^{\circ} \mathrm{C}$. than at a lower temperature. The nature of this modification of toxicity will later be discussed in fuller detail.

The action of certain fluorescent aniline dyes upon the venom was studied by Noguchi, who found that the chief toxic principles of cobra venom namely, neurotoxin and hæmatoxin - are more stable than the hæmorrhagic principle of crotalus venom. Besides the deadly principle of daboia venom a fibrin ferment is easily destroyed by eosin or erythrosin in the direct sunlight.

Phisalix passed a continuous electric current through the venom solution and found that the latter becomes destroyed. He attributes this to the formation of a sufficient quantity of chlorated products (chlorates, hydrochlorites, etc.) and ozone from the salts accompanying the venom. An alternating current of high frequency applied to the venom solution, with the view of producing a vaccine, is said to have produced vaccinating substance, but Marmier found that if the rise of temperature be avoided by appropriate apparatus no modification of venom results.

Phisalix found that the emanation of radium attenuates and then destroys the virulence of cobra venom and viper venom. With cobra venom he observed precipitation of proteins and subsequent loss of toxicity. With the venom of the viper he found that the chloroform-water solution of the venom in I : 1000 when exposed to the radium ray gradually becomes attenuated until its action completely disappears.

A series of tubes were exposed to the radium, the first for 6 hours, the second 20 hours, and the third 36 hours. The control unexposed venom solution killed a guinea-pig in ro hours; the first exposed venom in I2 hours; the second in 20 hours, and the third produced no symptom. A second inoculation to the last animal caused a fall of $0.5^{\circ}$ of temperature temporarily. After 4 days, a single minimal lethal dose killed the animal. The solvent of venom exerts a great influence on the effect of radium emanation. If the venom is dissolved in 50 per cent glycerin water the attenuation is still slight after 6 hours' exposure to radium.

\section{EFFECTS OF VARIOUS CHEMICALS.}

The attempt of various investigators to discover an agent which destroys the venom in the tissue or in the organism with the least or no injury to the latter has achieved no great success. However, the results of the researches in this direction have contributed much to our chemical knowledge of venom, and some of the latest chemical studies have had the advantage of these chemical stabilities of venom against various chemical substances. In the following pages the results obtained by various investigators will be given. 
In their fundamental work Mitchell and Reichert made the following observations:

The effects of alcohol: When alcohol is added to fresh venom or to an aqueous solution of venom a copious white precipitate occurs. The precipitate washed repeatedly with further volume of alcohol was fatal when dissolved in distilled water (after drying) and then injected into pigeons. The local effect was always very slight. The filtrate had no marked poisonous effect. A more prolonged treatment (3 days) of the venom with alcohol made the precipitate less soluble in water, but the clear soluble portion was quite toxic. The insoluble particles were easily soluble in dilute acetic acid, and the solution was fatal to pigeons. There was absolutely no local effect and there was no suffusion of blood in the tissue as in the previous experiment. In a pigeon injected with a filtrate (containing much of insoluble fine precipitates) clarified with $\mathrm{NaCl}$ crystals there was intense local effect in the blackening and infiltration of fluid blood. The destructive effect of an acid on the locally active principles of the venom (Crotalus adamanteus) was mentioned. In another series of experiments Mitchell and Reichert found that if there is enough water in alcohol the filtrate carries off a certain amount of the active substances of cobra venom and the injection of the filtrate can cause death. The filtrate became turbid on boiling and gave a decided precipitate with nitric acid.

Dried venom when placed in absolute alcohol for a long time (3 months) does not lose its activity and the alcohol does not dissolve out any of its poisonous constituents.

The effect of caustic alkalies: Mitchell and Reichert examined the action of potassic hydrate upon the venoms of Crotalus adamanteus, Crotalus horri$d u s$, and cobra, and found that the equal weight of this salt rendered the crotalus venom inert, but a much stronger potassic hydrate was required to destroy cobra venom. Very interesting experiments were made as to the relation between the loss of toxicity and coagulation of proteins by heat. They found that coagulation is prevented by dissolving the venom in a subdestructive amount of the alkali before subjecting the venom to the action of heat. This alkalization of venom did not protect the venom from the inactivating action of heat, although no coagulation occurred. The effect of sodic hydrate is the same as the potassic salt. The neutralization of the alkalies brings back the toxic properties of the alkalized venom, although not the original strength.

The effects of ammonia: If used in a sufficiently large quantity some permanent modifications of toxicity occurred, but the effect was not so marked as by the use of potassic or sodic hydrates (Crotalus adamanteus venom being used).

Potassic carbonate: This did not exert any decided effects upon the venom of Crotalus adamanteus.

Nitric acid: The precipitate produced by adding nitric acid to the solution of Crotalus adamanteus venom was found to be inert. The filtrate was also inactive. Thus nitric acid destroys the crotalus venom. 
Muriatic acid: The treatment of Crotalus adamanteus venom with concentrated hydrochloric acid did not destroy its death-dealing principles when tested on pigeon. But no local lesion was observed. Neutralization of acid did not change the result.

Sulphuric acid: The effect on the crotalus venom was not very destructive. Neutralization of acid did not affect the outcome.

Acetic acid: This did not destroy the crotalus venom when mixed with a small quantity of the venom.

Hydrobromic acid: The crotalus venom was destroyed by pure hydrobromic acid, but not entirely by a half-dilution of the same acid. In this series adamanteus and horridus were both used. The action on the cobra venom was very different, as the acid did not destroy this venom so easily as the crotalus venoms.

Tannic acid: Contrary to their expectation, Mitchell and Reichert found this acid to exert comparatively little effect on the venom of Crotalus adamanteus. Cobra venom did not lose its activity after the treatment with tannic acid.

Alum: When added to saturation to the solution of Crotalus horridus venom, it produced precipitate which, when mixed with some water and injected, did not cause death in the quantity of $0.015 \mathrm{gm}$., but was fatal with $0.06 \mathrm{gm}$.

Chlorine water: 0.5 c.c. of chlorine water (fresh) did not destroy the activity of the venom of Crotalus adamanteus.

Bromine: As hydrobromic acid the action of bromine is very marked upon the crotalus and cobra venoms.

Iodine: Produces a dense precipitate, which is non-toxic.

Iodine and potassic iodide: A saturated solution of equal parts of iodine and potassic iodide caused considerable delay of the action of crotalus venom.

Potassic iodide: No effect on crotalus venom.

Potassic bichromate: Almost no effect on crotalus venom.

Potassic permanganate: Crotalus adamanteus dried venom $0.015 \mathrm{gm}$. in 0.5 c.c. was completely destroyed by $0.005 \mathrm{gm}$. of this salt, but not by 0.0038 $\mathrm{gm}$. or less. When the amount of potassic permanganate reaches over 0.015 gm. it produces local slough. The venom of Crotalus horridus and that of Cobra are likewise destroyed by this salt.

Peroxide of hydrogen: This powerful oxidizer did not exert any appreciable destructive effect upon the venom of Crotalus adamanteus.

Silver nitrate: Notwithstanding the powerful action of silver nitrate on albuminoids it was found to have comparatively little effect upon the toxicity of the venom of Crotalus adamanteus when used in equal weights. (Venom $0.015 \mathrm{gm}$. $+\mathrm{AgNO}_{3}$ 0.015 gm. in 3 c.c.) But in a larger quantity the nitrate destroyed the venom completely.

Mercury chloride: Dried crotalus or moccasin venom $0.03 \mathrm{gm} .+$ mercury chloride $0.03 \mathrm{gm}$. in I c.c. produced precipitate. The precipitate after washing in water was injected into pigeons without showing any symptoms. 
Ferrous sulphate: Mitchell and Reichert came to the conclusion that sulphate of iron in equal weights does not destroy the crotalus venom (0.03 gm. each in I c.c. water).

Dialyzed iron: When dialyzed iron is added to a solution of venom all of the proteids are precipitated, and the filtrate is found to give no reactions for proteids with the xanthoproteic or picric acid tests. The precipitate is brown and viscid and insoluble in water, but when injected into the tissue the action of the venom quickly follows. The experiments were made with moccasin venom.

Ferric chloride: Being a powerful precipitant of proteins it quickly produces precipitate of the venom. Io gm. of tincture of chloride of iron or 4 $\mathrm{gm}$. of liquor ferric chloride destroys $0.015 \mathrm{gm}$. crotalus venom in $0.5 \mathrm{c}$.c. of water.

It is also very interesting to see that cobra venom is not markedly affected by chloride of iron, although in some instances some delay in death was observed. Mitchell and Reichert believe that this is due to the fact that the active peptone-like principle of this venom is not affected by this iron preparation.

In summing up their experiments Mitchell and Reichert make some special allusions to the differences in toxic constituents of crotalus and cobra venoms, as shown by them through the action of ferric chloride, and to the comparatively slight destructive effects of different mineral acids. They pointed out the efficient anti-venomous property of bromine. The work of Lacerda on the destructive effect of potassic permanganate upon venom and the claim of Brainerd that iodine exerts destructive influence upon crotalus venom have both been confirmed by these investigators. The destruction of venom by strong alkalies has also been established.

The length of time of contact of these chemicals with venom was very short and the mixtures were made just before the injections.

Similar study was carried on by Kanthack ${ }^{1}$ with cobra venom and its albumoses. He mostly employed fresh venom diluted with thymol to a definite proportion. The standard was such as to make one minim of the mixture able to kill a rabbit in 4 hours, and it was effected by adding 50 to roo volumes of thymol to one volume of cobra venom.

Chlorine water (freshly prepared): Cobra venom was diluted with chlorine water so as to contain the same percentage of venom as the thymol solution. The mixture was allowed to stand for 24 hours and 4 days. At the end of 24 hours I minim still was fatal in 24 hours, while injection of 2 to 3 minims after 4 days' contact had no effect. Thus a prolonged action of chlorine water completely destroys the toxic action of cobra poison.

Trichloride of iodide (Io per cent): 2 c.c. of $\mathrm{ICl}_{3}$ added to 5 minims of the standard venom solution destroyed the action of the latter in 24 hours.

Carbolic acid (ro per cent)': Carbolic acid produces a distinct cloudiness when added to a solution of native poison. After 24 hours the filtrate was

${ }^{1}$ Kanthack. The nature of cobra poison. J. of Physiol., 1892, XIII, 273. 
tested with a delay in its fatal issue. The pure albumose solution is not made turbid by carbolic acid. This fact seems interesting in reference to the precipitate obtained by Kyes with a venom solution after shaking with lecithin. ${ }^{1}$ A dilute solution of venom may be destroyed entirely.

Permanganate of potassium: Brown precipitate is produced and the filtrate gives no biuret reaction. The treated venom is innocuous after a contact of 24 to 48 hours. Nitrate of silver and corrosive sublimate precipitate and destroy the venom when allowed to stand for 24 to 48 hours. Tannic acid precipitates the pure albumose. The filtrate was quite harmless, but the whole mixture was still lethal, though it may be delayed.

The effects of caustic alkalies were studied with the pure albumose and it was found that strong sodic or potassic hydrate destroys the activity very rapidly, but the inactiva venom can be reactivated by removing the alkalies by neutralization with acetic acid. No precipitate occurs before or after neutralization of the alkalized albumose with acetic acid, but the activity of the venom returns on neutralization, provided that the time is within I2 to 24 hours after the addition of alkalies.

It is interesting to notice that Kanthack confirmed the observations of Mitchell and Reichert in the case of cobra venom. If the solution of venom be weak enough, ammonia destroys it altogether.

Acetic acid did not precipitate the albumose and did not destroy or affect its toxicity, even after a long contact. Some other organic acids, citric and lactic acids, had no effect upon the activity of cobra poison or its albumose.

Kanthack experimented on the action of alcohol on cobra venom with special care, as he employed this means of precipitation to obtain his albumose from the venom. Alcohol throws out all of the proteins of the venom and the precipitate reveals the original toxicity when redissolved and injected in animals.

The investigations of Calmette confirm many observations of earlier workers and add some new chemicals to the list.

Carbolic acid in 50 to 1000 , bichloride of mercury in I to 1000 , in acid solution, cupric sulphate, naphthol water, silver nitrate in I to Ioo, do not destroy the toxicity of venom; neither do they retard the onset of toxication if mixed immediately before the injection. The same holds good for chloride of sodium, carbonate and sulphate of sodium, iodide of potash, iodine in gram solution, trichloride of iodine in I to rooo, alcohol, chloroform, ether, and chloride of ethyl.

Ammonium mixed in the ratio of I gm. per $0.001 \mathrm{gm}$. of cobra venom does not alter the action of the latter. The essences of santol, rosemary, cloves, and citron exert no favorable effects in reducing the venomous action.

Quite a number of these substances, especially iodine, ammonia, essences, ether, alcohol, chloroform, cupric sulphate, silver nitrate, and bichloride of mercury form a precipitate soluble in water in excess of the reagents, and the

${ }^{1}$ Kyes. Ueber die Lecithide des Schlangengiftes. Biochem. Zeitschrift, r9o7, IV, 99. 
action of such precipitate is just as strong as the pure venom. Chloride of sodium and sulphate of magnesium in saturation belong to the same group in that respect.

Hydrates of sodium and potash are destructive when used in strong concentration and allowed to act at least for several minutes, but not in dilute condition.

Peroxide of hydrogen, phosphoric acid, sulphuric acid, and hydrochloric acid are inactive on venom in vitro.

Carbonate of sodium or ammonium in I to to does not bring about any reduction of the toxicity of cobra venom when mixed in roo parts of these salts with I part of the venom. Phosphate and sulphate of ammonium form a whitish albuminous precipitate, which is toxic.

Hypersulphate of ammonium does not form precipitate with venom, and the mixture of 20 parts of the salt with I part of the venom does not kill, but this is found to be due partly to the interference of absorption by the salt.

Permanganate of potash ( $\mathrm{I}$ to $\mathrm{I} 0 \mathrm{O}$ ): The solution of this salt when mixed with venom in ratio of ro to I previously to the injection stops the fatal effect of the venom. Even if the venom is first injected intramuscularly and then the solution of potash permanganate ( $\mathrm{I}: \mathrm{IOO}$ ) is immediately injected into the same needle-track the animal never succumbs. But if a short space of time should elapse before the injection of the permanganate solution, toxication takes its normal course. Neither is the effect of venom counteracted in the organism if injected at different parts of the body. This point has long been known from the work of Mitchell.

Bromine water (saturated) and chlorine water were found to be quite efficacious in destroying the venom in the tissue, even after venom has been introduced for Io minutes. It can be used in $\mathrm{I}: 3$ dilution, without any abscess or ulceration, but it is very painful.

Hypobromide of sodium is inactive.

Calmette found that calcium chloride or calcium hyperchlorite in solution of I to I2, from which another dilution with 5 to 6 volumes of water is made, at the moment of use, can be used to destroy the venom in the bitten locality. Chloride of gold in I to roo can be used for the same purpose. All these chlorides and hypochlorites form with venom an insoluble and innocuous precipitate. Their action is, however, a direct one.

Platinum chloride forms a soluble precipitate, and its destructive effect is very slow. Picric acid forms a precipitate, disappearing on heating and reappearing on cooling.

Kaufmann (1889) found that chromic acid removes the toxic constituents of viperine venom, by forming insoluble, innocuous precipitate. Calmette confirms this observation by using I per cent solution, but adds that the acid frequently produces necrosis of the tissue which comes in contact with the acid. 
With the venom of "Lachesis flavoviridis or Trimeresurus riukiuanus Ishizaka gives the following experiments:

Acids: A solution of the venom kept in contact with I per cent acetic acid during 24 hours at $37^{\circ} \mathrm{C}$. loses its hæmorrhagic property. Lactic acid does the same. Hydrochloric acid acts much more strongly and it is sufficient to destroy the venom at room temperature to make the solution somewhat acid, within to to I5 minutes.

The solution of ferrochloride separates (in the presence of sodium acetate, in the cold) the toxic principles and renders the venom inert.

Hydrogen sulphide produces a heavy precipitate, which, when freed from the sulphide by passage of the air, is seen to have been deprived of its poisonous action to a considerable extent.

Acetone separates out all active principles of the venom solution. The precipitate is difficultly soluble in water, but easily in alkalies, and has the activity of the native venom, provided the action of acetone was not too long. The filtrate is, on the other hand, entirely innocent.

Shaking with ether or toluol has no effect on the venom solution, but shaking with petroleum ether or hydrogen sulphide for 5 to io minutes produces thick, white emulsion. The emulsion, when centrifugalized, gives a clear fluid which has all the original powers of the venom. Drying this clear fluid in vacuum reduces its activity to a certain extent.

Shaking the venom solution with chloroform causes emulsion, from which a clear portion is obtained by centrifugalization. After repeating this process we can get a clear solution which has no more hæmorrhagic constituents, but is still neurotoxic and hæmolytic. 


\section{CHAPTER IX.}

\section{THE EFFECTS OF FERMENTS UPON SNAKE VENOM.}

The effects of certain proteolytic enzymes upon toxic constituents of various venoms have been studied by several investigators. The very early experiments of Weir Mitchell on the loss of the poisonous property of crotalus venom as administered by the alimentary canal indicate that the destruction of the toxicity of this venom while passing through the digestive tract of pigeons is due to the action of the proteolytic ferments. His elaborate work on this point is very interesting. Later, he, together with Reichert, states that by digestion in strong artificial gastric juice made from the pig's stomach the toxic power of crotalus venom is completely destroyed.

Fayrer states that the venom of Daboia russellii can pass through the digestive tract without serious disturbance. C. J. Martin found that feeding rats with nearly too times minimal lethal doses (when injected) of the venom of Pseudechis porphyriacus does not cause any symptom during a whole week. The venom can not be recovered from the feces. Calmette, while confirming Martin's experiment, mentions that the venom of Viperidæ may produce in young mammalians inflammation of the mucous membrane of the stomach or intestine. Thus, the venom of Lachesis provokes, when given in sufficient dose, a violent inflammation of the gastric and intestinal mucous membrane, and the animal dies of extensive hæmorrhage in the digestive tract even before any nervous symptom is manifest.

Fraser ${ }^{1}$ observed almost no symptom in feeding a cat with cobra venom, starting with a subminimam lethal dose and increasing gradually to 80 minimal lethal doses in II6 days. In white rats similar tolerance was experienced, 1.000 minimal lethal dose being administered with impunity. In both cases a very feeble antitoxic power developed in the serums of these animals. Fraser ${ }^{2}$ attributes this innocuousness of venom when administered as food to the antivenomous property of the bile of these animals. He tested the bile of Naja haje, the puff adder, rattlesnake, and grass snake, against the venom of Naja haje and Naja tripudians. Naja haje venom 0.000245 per kilo body weight applied to rabbit was fatal. This venom in dose of 0.00025 per kilo was made inert when mixed with $0.000 \mathrm{I} \mathrm{gm.} \mathrm{and} \mathrm{above} \mathrm{of} \mathrm{the}$ bile of the same snake, but required $0.0003 \mathrm{gm}$. and above of rattlesnake bile, or $0.00 \mathrm{I} \mathrm{gm}$. of the bile of puff adder. With grass-snake bile 0.00025

\footnotetext{
1 Fraser. The treatment of snake poisoning with antivenene derived from animals protected against serpents' venom. Brit. Med. Jour, 1895, II, 416 .

2 Fraser. The antivenomous properties of the bile of serpents and other animals. (Brit. Med. Jour., I897, II, 1 25.) In connection with this experiment it may be stated that as early as $1870 \mathrm{~S}$. B. Higgins (of South America) wrote Fayrer about the antivenomous property of the bile of cobra against some of the South American venoms, but the latter did not recognize this property.
} 
gm. of Naja tripudians venom per kilo in rabbit was neutralized by 0.0065 gm. and above.

The poisonous effects of the venom of Naja tripudians were similarly rendered $n i l$ by mixing it with the bile of these venomous snakes, in doses smaller than the non-poisonous kinds. Fraser again states that the bile of the ox can counteract the action of Naja tripudians venom in rabbits if used in sufficient quantities. The strength, however, was found to be about one-seventieth of that possessed by the bile of venomous snakes. It is very interesting to notice that the antivenomous substances are not extractible with alcohol, but go with the precipitate produced by alcohol. Thus, the possibility that this antagonistic property may be due to cholesterin, lecithin, bilc salts, and other lipoidal bodies seems to have been excluded. The alcohol precipitate is soluble in water and consists of proteids and bile pigments. This aqueous solution of the bile precipitate of puff adder in doses of $0.0000 \mathrm{I}, 0.00002,0.000025$, $0.000035 \mathrm{gm}$. per kilo body weight prevented fatal action of $0.00025 \mathrm{gm}$. of the venom of Naja tripudians in white rat. This is rather extraordinary and may be considered to be due to some peculiar ferment-like action of the bile on the venom. Wehrmann ${ }^{1}$ confirmed the antivenomous property of the bile, with ox, eel, and viper. The same author ${ }^{2}$ states that cobra venom loses its toxicity when digested with ptyalin, papain and pancreatin for 24 hours. Pepsin, rennet, and amylase reduced the toxicity of the venom to a slight extent only, while emulsin, sucrase, oxydase of leucocytes, and oxydase of mushrooms were found to be inactive upon the venom.

Kanthack ${ }^{3}$ subjected cobra venom to the action of pancreatin and pepsin and found that 20 minims of cobra venom, the toxicity of which was so great that 2 minims kill a rabbit in 2 to 4 hours, diluted in 8 c.c. of sterilized distilled water and a little pancreatin added to it, and the mixture kept at $40^{\circ} \mathrm{C}$. for 24 hours, became so modified that 4 c.c. of the mixture after the digestion were quite harmless to a rabbit. The digested fluid, after filtration, gave beautiful biuret reaction, and a precipitate with nitric acid, dissolved on heating and reprecipitated on cooling. In another series of experiments he digested 3 minims of a strong solution of venom with pancreatin for 24 hours and injected it into a hen, which died after 4.5 hours. The control died in 45 minutes. The result with the peptic digestion is quite different, and here it delays the effect of the venom albumose only to a slight extent.

The effects of pepsin and papain on the toxicity of cobra, water-moccasin, copperhead, and Crotalus adamanteus venoms have been studied by Flexner and Noguchi, ${ }^{4}$ who employed these means to differentiate various active constituents of these venoms through the resistance offered by the individual constituents to the action of these ferments.

\footnotetext{
1 Wehrmann. Sur les propriétés toxiques et antitoxiques du sang et de la bile des anguilles et des vipères. Ann. Inst. Pasteur, I897, XI, I8ro.

2 Wehrmann. Contribution à l'étude du venin des serpents. Ann. Inst. Pasteur, r 898, XII, 5 ro.

8 Kanthack. Jour. of Physiology, I892, XIII, 273.

1 Flexner and Noguchi. Constitution of snake venom and snake sera. Jour. of Path. and Bacteriology, r903, VIII, 379.
} 
In the presence of 0.8 per cent of hydrochloric acid pepsin destroys within 48 hours all hæmorrhagic and hæmolytic principles of all venoms tested, whereas the hæmorrhagins are destroyed by the acid alone. The hæmolytic substances were destroyed only after the peptic digestion, but not by the acid alone. A slight loss of neurotoxic property was also observed. Speaking of each venom per se it showed that the toxicity of the crotalus venom was almost completely destroyed by treatment with 0.8 per cent $\mathrm{HCl}$ without pepsin, while that of the cobra venom suffered a slight reduction only after the peptic digestion, and those of the ancistrodon venoms became quite weak by the acid-treatment and still weaker by the peptic digestion.

Papain in 0.2 per cent $\mathrm{HCl}$ did not destroy any of the neurotoxic constituents and only slightly reduced the hæmolytic power. 0.2 per cent $\mathrm{HCl}$ was found to cause inactivation of the hæmorrhayic principles of all venoms, and a consequent loss of toxicity of the crotalus venom, but not of cobra and the others. To this particular finding I shall return in a later place. The destructive effect of $\mathrm{HCl}$ in dilute solution upon the crotalus venom has been confirmed by Morgenroth.

The effects of tryptic digestion upon the neurotoxic, hæmolytic, and hæmorrhagic constituents of these venoms were found by Flexner and Noguchi to be far stronger and to destroy the toxicity of all venoms.

Teruuchi ${ }^{1}$ studied the effects of the pancreatic juice and intestinal juice of dog upon the hæmolysin of cobra venom and its compounds with antitoxin and lecithin. The general technique was about as follows: 4 c.c. of 0.005 per cent solution of cobra venom were mixed with I c.c. of the pancreatic juice, then kept $\mathrm{I} 8$ hours at $37^{\circ} \mathrm{C}$. Then the digested fluid was made 8 c.c. with physiological saline solution, making a 0.00025 per cent cobra venom solution. The digestion reduced its action nearly to one-fiftieth of the original strength when tested with 5 per cent goat corpuscles in the presence of I per cent lecithin; the mixture of cobra venom and lecithin being allowed to stand some time before the digestion resists the destructive action of the pancreatic ferments. Pure preparation of cobra lecithid is not affected by the digestion. Teruuchi also discovered that the hæmolysin of cobra venom can be restored from its neutral combination with specific antivenin by the pancreatic digestion. But strangely enough the restored hæmolysin is comparatively much larger in amount than the amount left undestroyed in a control tube during the same length of time. As he also found that the addition of lecithin to the native venom makes the resistance of the latter greater than that without lecithin, it was thought not impossible that the digestion of antivenin liberates enough lecithin to protect the liberated hæmolysin against the pancreatic digestion. It is interesting to learn that the restitution of venom from the neutral mixture with antivenin is hindered by a previous addition of lecithin to the latter.

\footnotetext{
1 Teruuchi. Die Wirkung des Pankreassaftes auf Haemolysine des Cobragiftes und seine Verbindungen mit dem Antitoxin und Lecithin. Hoppe-Seyler's Zeitschr. f. Physiol. Chem., rgo7, LI, 478 .

2 Digestion of lecithin in pancreatic juice reduced its activating power to half the original.
} 


\section{CHAPTER X.}

\section{SYMPTOMS OF VENOM POISONING IN MAN.}

The symptoms produced by the bites of venomous snakes vary according to the families to which they belong. Thus, the symptoms of cobra poisoning differ from those of crotaline or viperine poisonings. Speaking in general, the local manifestation of poisoning is much more pronounced in the latter than in the former cases. This rule is, however, not general, as some members of the colubrine snakes, for example the Australian genera, seem to stand nearer to the Crotalinæ or Viperinæ in their energetic attack on the local tissues. I do not intend here to discuss these differences and their causes, but will simply describe the symptoms observed by various authors in human cases bitten by various groups of venomous serpents.

\section{THE VIPERIDEE.}

\section{CROTALUS POISONING IN MAN. ${ }^{1}$}

Men are more frequently bitten than women. The situation of the wound is usually upon an extremity. The earliest symptom of the snake bite is the pain of the wound, although this is not reported in some cases. Hæmorrhage from the wound is very common, but may depend upon the size of the external opening of the wound inflicted by the fang, or perhaps, also, upon the character of the vessels accidentally penetrated by the fang. The primary local symptoms thus described increase progressively, so that within a period which varies extremely, the swelling and discoloration extend up the bitten limb, accompanied by pain of the most excruciating character. At this time, or after the first few minutes, the increase in the local symptom is probably due to the influence of the destructive action upon the tissue near the wound, to the irritation thus resulting, and to the indirect effect of venom upon local circulation. Thus the extremity becomes larger and more and more discolored until the skin shows every tint of an old bruise. Vesications may appear on the surface, the pain lessens, the local temperature, early diminished, falls still lower, and unless the poison has ceased to act, gangrene ensues, and the tissue becomes necrotic. If, on the other hand, the poison is not present in a dose large enough to insure these effects, the swelling declines and the pain disappears with a celerity which the practitioner or reporter has assumed to be evidence of his own skill or of the utility of his therapeutic means, but which is an essential and most striking feature of crotalus poisoning. The extent of damage brought about by the crotalus bite upon the local 
tissue can not be clearly estimated, as in all cases ligatures, cautery, excision and incision, alone or combined, were freely practised and the resulting damage is not to be ascribed to the effect of the venom alone.

The constitutional symptoms: Crotalus poisoning is followed almost immediately by the general symptoms. It is probable that an interval of several minutes elapses, or the faintness of terror and pain has been mistaken for the constitutional effects of the venom. There are, however, some exceptions in which general manifestations occurred after 20 or 30 minutes. The principal constitutional effect of the venom is a general prostration of the most appalling character. Sometimes within a few minutes, sometimes within one or two hours, this condition of sedation attains its height. The snake strikes and the faintness comes on while the person injured is trying to kill the snake. Or, as in another instance, he walks for some time and suddenly finds his limbs giving way beneath him. The condition of prostration is accompanied by a variety of phenomena. The patient staggers or falls, cold sweats bathe the surface, nausea, vomiting ensues, the pulse becomes quick, rapid, and feeble, the expression anxious, and, in a few cases, the mind slightly affected. But such acute and primary poisoning is not so frequently met with in the case of man, the nearest to this being death in 5.5 hours.

If death does not intervene, the local symptoms soon begin to play a more important rôle, and the swelling and discoloration extend up the limb, and pass on to the trunk, so that when the arm has been wounded, half of the chest and back are seen to be discolored.

Meanwhile, the signs of general poisoning develop, and within a few hours, or a day, the face and other parts become swollen and puffy. At the same time, the general weakness remains well marked, as shown by repeated syncope, the heart quick, feeble, and fluttering, and the respiration labored. In the majority of cases, the slight mental disturbance now passes away and the mind remains clear to the close, whatever the event may be. In other instances, delirium, restlessness, and insomnia are present, but in general the nervous symptoms are confined to slight incoherence and to rare sensory delusions.

No statement is recorded as to the urine. Vomiting was one of the most frequent phenomena. In some cases diarrhoea was observed, once with the stool of a dark bilious character.

Mitchell collected I6 cases, of which 4 were fatal. The earliest death was in 5.5 hours, then 9 and I 8 hours. One case ended after I7 days, but death was not the direct result of poisoning.

The coagulability of the blood was not lost in the case where the victim died in 9 hours, but was completely lost where death occurred in I 8 hours.

In cases of recovery the time required was from I hour(!) to many months, being usually several days. The depression disappeared in two days in one case. Post-mortem autopsies of these fatal cases revealed in some cases congestion of the pia with fluid blood, foamy mucous secretion with bloody tint in trachea and lungs. In some cases bloody serum was found in the 
peritoneal cavity and the mucous membrane of the intestine showed numerous minute red spots, especially in the jejunum. However, such definite anatomical changes were not described in the other two cases.

\section{LACHESIS POISONING IN MAN.}

Local symptoms consist of very severe pain at the point of the bite, and red and then purplish discoloration. The tissues around the bite become infiltrated with serous sanguineous fluid. Severe pain, accompanied by cramps, irradiates toward the root of the limb. The patient complains of unquenchable thirst and dryness of the mouth and throat. The mucous surfaces of the eye, mouth, and genitals congest. These symptoms persist even beyond 24 hours, and there are often hæmorrhages in the mucous membrane of the eye, mouth, stomach, intestine, or bladder, and a more or less violent delirium.

If the amount of the venom is sufficient to cause death, there are, after some hours, stupor, insensibility, then sleepiness, the respiration getting gradually more and more shallow and finally of a stertorous character.

The loss of consciousness seems to be complete, even before coma sets in. After complete cessation of the respiration the heart may beat for about I5 minutes. In some instances death occurs very rapidly, and even before any local manifestation of venom poisoning becomes apparent. This rapid death is usually a result of the extensive coagulation of the blood brought about by the direct inoculation of the venom into the circulation.

\section{DABOIA POISONING IN MAN.}

This viper is one of the most deadly snakes, and next to the cobra probably causes more deaths in India than any other snake. If daboia venom enters directly into the blood circulation violent convulsions rapidly set in and soon end in death. These symptoms are due to a more or less general intravascular thrombosis. When the poison is introduced into the subcutaneous tissues the symptoms may be divided into local and general. Locally severe pain and rapid swelling occur and soon extend up the limb, if the bite is on an extremity. There is often a blood-stained discharge from the wounds. Ecchymose is soon very apparent all round the point of puncture.

The general symptoms are evidenced by marked collapse, thready pulse, cold sweats, nausea, vomiting, dilated pupils insensitive to light, and often complete loss of consciousness. The patient may temporarily recover from these general symptoms, only to fall into a deeper state of collapse than before. Death often takes place soon after the infliction of the bite.

If the general collapse or depression disappears the local symptoms play an important part in the subsequent course of the case. There is a large extravasation of blood with much œedema all round the wounds, and the swelling increases. Extensive local suppuration and sloughing, malignant œdema, and tetanus may supervene and aggravate the symptoms already resulting from the venom. In the meantime, hæmorrhages, often severe, 
may occur from the rectum and other orifices of the body. Albuminuria or hæmorrhage from the kidneys is a constant symptom. Rapid emaciation soon appears and in the prolonged cases a profound anæmia and lethargy set in. There is an absence of paralysis or any symptom which might point to any direct action of the poison on the central nervous system. Death may be delayed for several days; this, however, depends more on the local conditions. Recovery in these cases is not at all uncommon.

\section{ECHIS CARINATA POISONING IN MAN.}

Although the venom of this snake is very active, on account of its small size less mortality results. The symptoms following its bite are similar to daboia poisoning. Local swelling and hæmorrhages are severe. An authentic case was recently reported in St. George Hospital, Bombay, of which Martin and Lamb give a full account. A man was bitten on the temple by an Echis carinata, which was in captivity in the Museum of the Bombay Natural History Society. He came under observation a quarter of an hour after the bite and was then very frightened, as was natural under the circumstances. The whole of the temple, on which two small punctures could be seen, was swollen and ecchymosed, the swelling extending to the side of the face and including the upper and lower eyelids. There was severe pain over the wounds. The blood which exuded from incisions made over the wounds was very liquid and remained unclotted. Vomiting soon began and continued till death. The pulse was very small, feeble, irregular, rapid, and at times could hardly be felt at the wrist. Extreme restlessness and complete insomnia were marked symptoms. The extremities were cold and clammy. The patient remained conscious for many hours; but a short time before death, which took place 25 hours after the bite, he became unconscious and delirious. There were no hæmorrhages from any of the orifices.

\section{VIPERA BERUS POISONING IN MAN.}

The symptoms following the bite of the European viper are similar to those of a small dose of crotalus venom. Local pain follows the bite immediately and the limb soon swells and becomes discolored. Within I to 3 hours entire prostration, accompanied by vomiting and often by diarrhœa, sets in. Cold, clammy sweat is usual. The pulse becomes extremely feeble, and slight dyspnœa and restlessness may be seen. In severe cases, which occur mostly in children, the pulse may become imperceptible and the limbs cold; the patient may pass into coma. In from I2 to 24 hours these severe constitutional symptoms usually pass off; but in the meanwhile the swelling and discoloration spread enormously. The limb becomes phlegmonous and occasionally suppurates. Within a few days recovery usually occurs suddenly, but death may occur from severe depression or from the secondary effect of the suppuration. 


\section{THE COLUBRIDE.}

\section{COBRA POISONING IN MAN.}

The local symptoms are not so pronounced as in the case of the bite of viperine or crotaline snakes. A sensation of burning pain, more or less severe, sets in at the seat of the bite. The spot soon becomes red, tender, and swollen. The constitutional symptoms appear after an interval of about 30 minutes from the time the bite is inflicted; then the patient commences to feel toxicated, sleepy, and weak in the legs; the weakness increases until he is unable to stand. Profuse salivation, paralysis, and swelling of tongue and larynx, with inability to speak or swallow, soon supervene. Nausea and vomiting are of frequent occurrence. The paralysis now becomes more pronounced and the patient is incapable of movement. Respiration ${ }^{\mathbf{1}}$ becomes slower and its excursions diminish. The action of the heart is quickened, but of fair strength. The patient seems to be conscious, but is unable to express himself. Finally respiration ceases, with or without convulsions, and the heart ${ }^{2}$ soon stops. Until respiration ceases the pupil remains contracted and reacts to light. Should the paralytic symptoms gradually disappear the patient recovers rapidly from the poisoning. There are occasional discharges of blood from mucous surfaces, but the urine never contains albumin. ${ }^{3}$

\section{BUNGARUS CFRULEUS POISONING IN MAN.}

The bite of the krait is considered very dangerous, a large percentage of mortality resulting therefrom in India, especially North India.

The symptoms are somewhat similar to those described in cobra bite. There is almost no local swelling or reaction at the place of the bite. In a recent fatal case in India Martin and Lamb enumerate the chief symptoms as paralysis of articulation, embarrassed and stertorous breathing, and semiconsciousness. Death took place about 8 hours after the bite.

\section{THE BITE OF AUSTRALIAN SPECIES OF SNAKES.}

Local swelling and pain are not usually severe. Constitutional symptoms appear in from I 5 minutes to 2 hours. The first symptom is almost invariably faintness and an irresistible desire to sleep. The legs gradually become so weak that the patient becomes unable to stand alone. Alarming symptoms of prostration then supervene, often accompanied by vomiting. The action of the heart becomes extremely feeble, and the pulse thread-like and uncountable; the extremities are cold and the skin blanched. The respiration, after slight preliminary acceleration, becomes shallower from hour to hour as the coma increases. Sensation is blunted, and eventual stimulation of the nerves of special sense ceases to evoke any reaction. The pupil is widely dilated and insensible to light. Death, sometimes preceded by con-

1 Calmette describes an initial acceleration.

2 Calmette states that the heart may be beating even as long as 2 hours after the cessation of respiration.

3 These symptoms are much like those observed in botulismus poisoning. 
vulsion, results from gradual cessation of respiration. The heart may beat for a few seconds after the cessation of respiration. In unusual cases hæmorrhagic extravasation from mucous surfaces occurs and the patient coughs or vomits blood or passes it by the rectum or kidneys. Albuminuria has generally been found and may be accompanied by blood or hæmoglobin in the urine. If the patient survives the coma, recovery is complete and, as a rule, rapid, and without any secondary symptoms.

\section{ELAPS FULVIUS POISONING IN MAN.}

Many fatal cases from the bite of the coral snake have been reported and some of the cases will briefly be stated in order to outline the symptoms experienced with human subjects.

In one case reported by True ${ }^{1}$ the bite was inflicted by a medium-sized Elaps fulvius on the left index finger of a man, who, while handling the snake by grasping it by the neck, was bitten at the moment of releasing the snake. Instead of a quick strike the snake fastened its fangs to the finger and bit hard, closing the lower jaw upon the finger. The closure of the jaws was so firm that it had to be wrenched off, by which operation one of the fangs was broken off in the wound. The first symptom, which appeared immediately after the bite, was a violent pain at the wound. Within one hour the first symptoms of drowsiness and unconsciousness made their appearance, and remained until the morning of the third day. After the period of lethargy and general depression the patient gradually recovered. There was a tendency for the symptoms to reappear periodically. Another patient, ${ }^{2}$ complained of the pain in the bitten $\operatorname{limb}^{3}$ about half an hour after the accident, then deep lethargy and collapse set in and ended the case with death in 18 hours. In still other cases death usually ensued about 24 hours after the bite. It seems that the danger of death from the bite passes away if the victim survives three or four days.

\section{POST-MORTEM EXAMINATION.}

In cases of cobra bite rigor mortis occurs as usual. The subcutaneous tissue of the region of the bite is infiltrated with pinkish fluid and the neighboring vessels are congested. The blood is often fluid, and when examined by the microscope directly after death presents no changes. The brain appears to be normal, but the veins of the pia mater are usually gorged with blood and the ventricles often contain turbid fluid. The lungs are usually congested and the lining membrane of the bronchi is intensely injected. Kidneys are excessively congested.

In cases of death from the bite of the Australian species of snakes the appearances are about the same as those described in the cobra cases. The blood is almost invariably fluid, but may contain a few soft clots. The lungs

\footnotetext{
Fred. W. True. American Naturalist, XVII, $1883,26$.

2 Coe. Scientific American, r89r, LXIV, 401.

8 In most cases pain and a faint reddening of the bitten part are the only local symptoms. Dis-coloration, hæmorrhages and extensive swelling have not been reported.
} 
may be the seat of hæmorrhages. In cases in which hæmorrhages took place from the mucous tracts during life, these surfaces are intensely congested and hæmorrhagic.

Autopsies in cases of death from the viperine snakes present intense hæmorrhage and œdema at the point bitten. If the venom goes into subcutaneous tissue the underlying muscles are frequently disorganized and even diffluent from extravasation of blood. Hæmorrhages may also be found in any of the organs and along the alimentary tract. Kidneys are congested and hæmorrhagic. The blood is fluid.

\section{VARIOUS SYMPTOMS OF SNAKE POISONLNG ENCOUNTERED IN MAN.}

One or other of the following symptoms or conditions is described as having occurred during life or after death (Fayrer):

Local: Pain in the bitten part. Tingling of the bitten part. Burning sensation in the bitten part and up the limb. Loss of feeling in the bitten part and up the limb. Edema in the bitten part and up the limb. Swelling in the bitten part and up the limb. Discolorations blue-black in the bitten part and up the limb. Sloughing of the part bitten. Erysipelatous inflammation of limb or part. Hæmorrhage from the punctures.

General and constitutional: Drowsiness. Thirst. Restlessness. Uneasiness. Rapid or sudden unconsciousness. Foaming at the mouth. Stertor. Coma. Insensibility. Nausea. Vomiting. Vomiting of black fluid (of blood). Swelling of face and body. Fever. Tossing of limbs. Rolling of head. Hurried respiration. Cold, clammy sweats. Saliva running from mouth. Pupils contracted. Pupils dilated, insensible to light. Heart's action weak, fluttering, intermittent. Twitching of diaphragm. Pulse feeble, hæmorrhagic, lost. Anxiety. Despondency. High spirits. Feeling of a glow over the body. Difficulty of articulation. Loss of articulation. Rigidity. Stiffness. Convulsions. Coma. Spasms. Subsultus tendinum. Facial paralysis. Hæmoptysis. Hæmatomesis. Hæmaturia. Hæmorrhage from eyes, nose, mucous membrane of passages, from under thumb and great toe-nails. Loss of voice. Staring. Throbbing headache. Delirium. Peculiar odor in excreta. Dimness of vision. Vertigo. Loss of vision. Oppression of epigastrium. Choleraic, husky voice. Dryness of throat. Feeling of swelling of tongue. Coldness. Froth in lips.

The above descriptions agree mostly with the cobra poisoning.

In the post-mortem examinations Fayrer found recorded:

Blood generally fluid, dark; sometimes clots in the heart or great vessels, dark blood oozing from the mouth. Lungs sometimes pale, sometimes congested, sometimes natural. Heart normal; clots or fluid blood in cavities; cavities stained with dark blood. Abdominal viscera sometimes normal, sometimes congested. Liver and spleen sometimes congested. Kidneys nearly always congested. Cadaveric rigidity present in some, absent in other cases. Abdomen swollen, distended. Body and limbs generally swollen; bitten part discolored; suggillations; effusions of dark sanguinolent serum into areolar tissue. 


\section{CHAPTER XI.}

\section{EXPERIMENTAL VENOM POISONING IN ANIMALS.}

The accurate nature of the actions of venom on organisms can best be studied by introducing the known amounts of venom, either modified or unmodified, into the system by various modes of inoculation under variable conditions. The symptoms observed in human cases can thus be approximately reproduced in certain animals and studied by the aid of different physiological and pharmacological methods. In treating this topic it appears to me to be most convenient to describe the symptoms and afterwards analyze them. I will also describe later the effects of venom upon different organs, body-fluids, tissues, and cells. With the exception of the frog, the experiments made on cold-blooded animals will be given in a subsequent chapter, and those made on warm-blooded animals will be chiefly considered here.

\section{THE VIPERID $Æ$.}

\section{CROTALUS ADAMANTEUS.}

Weir Mitchell found that the effect of the venom of this snake on birds is extremely virulent, and so sudden in some cases that when the dose is large there is hardly time to observe the resulting phenomena. Acute poisoning of pigeons is very common. When pigeons are bitten by Crotalus the symptoms which immediately follow the bite are feebleness and dyspnœa. Convulsions and gasping are always observed. Respiration may cease in a few minutes or sometimes after half an hour. Convulsions may precede the respiratory cessation. Twitching of the muscle near the bitten spot may be seen. The pupil usually remains unaltered, or perhaps slightly contracted. Coagulability of blood seems to be normal. Irritability of the sciatic nerve may continue to exist for nine minutes after death. The heart stops several minutes or longer after the cessation of breathing. The irritability of the muscles is well preserved ten minutes after death. The fang marks are surrounded by circles of extravasated blood. In one instance death took place in 30 seconds, during which time the bird became completely paralyzed.

The chronic form of poisoning was also described by Mitchell. When pigeons are not killed rapidly they may partially recover for some days, during which time local necrosis becomes appalling. Death usually occurs within a few days, or it may result in 12 to 24 hours. The peculiarities of the chronic poisoning are the loss of coagulability of blood, and numerous ecchymoses in internal viscera, serous and mucous membranes, and muscular tissue adjacent to the fang marks. 
In still other series of experiments the venom was directly injected into the pectoral muscle of pigeons, I drop of fresh crotalus venom being used. The time intervening between injection and death was from 15 to 25 minutes. The muscle becomes peculiarly soft and swollen, with extensive extravasation of blood, which makes it very dark. The coagulability was more.or less reduced or completely lost. Where death followed injection instantaneously, the blood was firmly coagulated. Hæmorrhages below serous membranes subpleural, subperitoneal, and subpericardial - are the most frequent and most pronounced. In cases where death does not occur the local tissue may form slough, but a dry atrophy, such as was observed by Mitchell and Reichert in a pigeon, is very rarely caused. I was able to confirm most of the experiments of these authors.

Among the mammals, the rabbit, guinea-pig, cat, dog, rat, mouse, horse, and goat are all susceptible in varying degrees.

A rabbit struck by a rattlesnake may die in one minute. In such case no lesions in the organs are visible. The blood coagulates firmly or extensive thrombosis exists in the large veins and pulmonary artery. In another instance Mitchell describes a case where a rabbit was struck by an exhausted snake, and died 3 days afterwards. In this case bloody feces and albuminuria were observed. A most extensive dissemination of ecchymoses throughout the mucous membranes and nervous system, and accumulation of considerable amounts of bloody serum in the cerebral ventricles and pericardium, were observed. The kidneys were also enlarged and were soaked with dark fluid blood. In cases of death, which occurs in 15 minutes to several hours, prostration, a loss of motor power, jerking respiration, general twitching, feebleness of the heart and pulse and often violent convulsions before death are the chief general symptoms, while the bitten muscle becomes swollen, tender, and soaked with the hæmorrhages. Coagulability may be absent from the blood of these animals. Ecchymoses are very numerous throughout various internal organs and mucous and subserous surfaces. The guineapig, rat, cat, and mouse are affected in similar manner as the rabbit. The horse is also highly sensitive to the action of crotalus venom, as was shown by $\mathrm{McF}$ arland in an attempt to immunize it against this venom. The goat appears more resistant to this venom.

Some experiments made by Mitchell on dogs are extremely instructive. At first the rattlesnake failed to fully insert its fangs into the skin of the dog brought before it, the bite being imperfect or an entire failure. Finally the snake was seized by the neck and forced to bite the dog. Even with this plan many dogs, while suffering general and local disturbances, escaped death. In some cases death ensued several hours after the bite. The usual crotaluspoisoning symptoms ${ }^{1}$ were seen during life, and the autopsies revealed the dark, infiltrated local lesions, but seldom any ecchymoses in internal organs. Serous cavities contained laked fluid in varying quantities. The coagulabil-

1. It is very interesting to notice that after the bite the dogs showed a great thirst and drank water incessantly. This symptom is not uncommon in the Bothrops poisoning in man. 
ity of blood mostly disappeared, and it remained fluid permanently or for some time. The kidneys were often hæmorrhagic and swollen; the bladder sometimes contained bloody urine, and the urine was slightly albuminous. The irritability of sciatic and phrenic nerves was still present after $\mathrm{I} 3$ and 28 minutes respectively. The brain was found mostly congested.

\section{ANCISTRODON.}

The actions of the venoms of American species, Ancistrodon piscivorus and $A$. contortrix, are the same, and are essentially similar to those of the Crotalus on one hand and the Lachesis - including the famous South American Bothrops lanceolatus and Trimeresurus of Japan - on the other hand. As has already been pointed out by Mitchell and Reichert, the venom of the water-moccasin contains more neurotoxic constituent than rattlesnake venom, and consequently the degree of local lesions is comparatively less, but paralytic effects on the respiratory center and motor nerves are stronger. Flexner and Noguchi confirmed these observations.

\section{LACHESIS.}

The actions of the venom of the snakes belonging to this genus are much the same as those of Ancistrodon and still closer to those of the crotalus venoms. In these venoms, as has been already described, the locally destructive principles predominate, in contrast to the venoms of typical colubrine snakes.

Careful study of the action of the venom of Lachesis or Trimeresurus riukiuanus on different animals has been made by Ishizaka, ${ }^{1}$ from which we derive the following:

The mice and rabbits are fairly susceptible to this venom, the former being killed in one hour if $0.003 \mathrm{gm}$. to $0.005 \mathrm{gm}$. be given subcutaneously, while the latter require $0.02 \mathrm{gm}$. to $0.03 \mathrm{gm}$. per kilo body-weight to be fatal in 4 to 6 hours. The visible symptoms in mice are the local swelling, general depression, and dyspnœa. The respiration becomes gradually slower, irregular, shallower, and finally there is a complete standstill, without convulsions in agony. The heart continues to beat for some time after respiratory cessation. The local symptoms appear from io to 15 minutes after injection, and the skin presents violet-dark discoloration and hæmorrhagic œdema. The amount of the venom used is a subminimal lethal dose; the inflammatory hæmorrhagic tissues become necrotic, and after some time the slough is cast off. In rabbits the symptoms are about the same-local swelling, hæmorrhages, dyspnœa, depression, paresis, and slight convulsions before the respiratory cessation. The heart beats some minutes after respiration is stopped. The irritability of the phrenic nerve and other muscular nerves is found to be present. The hæmorrhages are constant symptoms and are always more pronounced in the lower parts of the body, this perhaps being due to the gravity of the venom.

1 Ishizaka. Studien über Habuschlangengift. Zeit. f. experimentelle Path. u. Therapie, 1907, IV, 88. 
The inflammatory hæmorrhagic focus becomes necrotic and may form a crust and be cast off or may be absorbed.

The intravenous administration of the habu venom into rabbit and dog brings about rapid reduction of blood pressure with the frequence and size of pulse almost unaltered. Ishizaka believes that the vasomotor nerve is not paralyzed, as the blood pressure can increase in a later stage of toxication when the artificial respiration is suspended. The irritability of the splanchnic nerve is greatly diminished, but never abolished completely. He also points out that the peripheric vessels are not markedly relaxed. Respiratory frequency is not affected at the beginning, but it lessens gradually and finally disappears. Judging from the presence of the irritability of the phrenic and sciatic nerves after death, the failure of respiration is ascribed to the central paralysis.

By intravenous injection in rabbits and dogs hæmorrhages are produced in internal organs, especially in the pericardium, endocardium, and gastric mucous membrane. In dogs the internal hæmorrhages appear to be more frequent and also present in the lungs, mesenterial membrane, and intestinal tract. On the other hand, administration of the venom per anum did not kill the rabbit when $3.25 \mathrm{gm}$. were given in divided doses, but killed it when a single dose of $0.34 \mathrm{gm}$. was given. In this case there was no hæmorrhage in the mucous membrane, but the histological examination of the kidney showed parenchymatous nephritis.

Under no conditions was Ishizaka able to produce bloody urine or hæmorrhages in the brain, spinal cord, and their membranes, or in the bone marrow.

VIPERA.

Vipera russellii or Daboia is one of the most dreaded snakes in India and its venom is known to cause death with a lightning rapidity when sufficiently injected into the victim. The cause of this quick death has since been discovered to be due to its large content of fibrin ferment capable of producing instantaneous intravascular thrombosis. As to this property of daboia venom and venom in general I will give fuller details in a later chapter. Fayrer and Brunton studied the action of this venom very carefully and the former gives many interesting experiments of the effects of the daboia bite on various kinds of animals. Dogs, cats, and fowls succumbed to a single bite, with the symptoms of pain, swelling, and paralysis of respiratory center. Convulsions were almost constant before death. The blood was found to have lost its coagulability. Horses were allowed to be bitten by Daboia, and these were always killed. Respiration was affected most and seemed to be the cause of death, although always accompanied by general weakness. The blood remained fluid. One experiment with an ox showed that the bite of Daboia fails to kill even if its fangs take effect. There was, however, great swelling and general weakness lasting for a few days.

A more accurate study of this venom has been made by Lamb, who mostly employed monkeys, rabbits, rats, and pigeons. 
Lamb demonstrated that the venom of Daboia russellii, when injected subcutaneously into pigeon, kills the bird in a very short time, from 75 seconds to ro minutes. In these cases the post-mortem examination revealed the constant presence of extensive and solid intravascular clotting in the auricles, and sometimes in the right ventricle of the heart, and in the pulmonary vein and portal system of veins. If the dose exceeded many times a minimal lethal dose it did not change the result much, except that the larger the amount of venom injected the more rapidly the symptoms appeared, and the sooner death took place. The thrombosis was more extensive and more solid than in those cases in which only one minimal lethal dose was given.

The results obtained by intravascular injection of this venom into monkeys do not essentially differ from those obtained in the foregoing cases. Death often took place in a minute after the injection; in such instances there is much gasping, convulsions are constant, and the pupils are dilated. Solid clots are usually seen in the pulmonary vessels, portal veins, superior and inferior venæ cavæ, aorta, and sometimes the right cardiac ventricle. If fluid blood is present it usually remains uncoagulated. The amount of venom given in this series was from $0.00 \mathrm{rgm}$. to $0.0025 \mathrm{gm}$. and the time of death varied from $\mathrm{I}$ to 5 minutes.

In rabbits exactly similar symptoms and final results have been obtained by Lamb, but he observed more pronounced convulsions and gasping. The amount of the venom sufficient to produce fatal intravascular clotting is as small as $0.000075 \mathrm{gm}$. to $0.000 \mathrm{I} \mathrm{gm}$. given intravenously. Death results within 7 to 8 minutes.

Lamb described the chronic form of daboia toxication. In monkeys there are symptoms local and general. Severe hæmorrhages occur around the point of injection, and considerable œdema at the dependent part sets in within a few hours. In some cases the local conditions undergo resolution, but in other cases the parts slough, leaving an irregularly shaped ulcer. In some other cases, rapid gangrenous conditions follow the hæmorrhage and the animal dies of secondary bacterial infection. The general symptoms are a state of depression and lethargy, loss of appetite, clammy skin, considerable cardiac depression, anæmia and in a few severe cases hæmaturia, and bloody discharge from the rectum. Edema may sometimes be observed in penis or scrotum.

Neither convulsion nor paralysis has been observed in these prolonged poisoning cases. When death occurred in 24 to 48 hours after the injection of venom, it was noted that rigor mortis was completely absent. A marked diminution of coagulability is constantly noticed.

All these symptoms are sought by Lamb in the deficiency of coagulability of blood on the toxicated animals. In order to establish the relation between the diminution of coagulability of blood and the degree of illness he examined the coagulability of the blood of a poisoned monkey and found that when the blood recovers its coagulability the symptoms disappear. 
ECHIS.

As with other genera of Viperinæ, the poison of Echis much resembles that of Vipera. The venom of Echis carinata acts very much like that of Daboia russellii and produces a prompt death in dogs, fowls, pigeons, and other smaller laboratory animals. Local symptoms consist of swelling and discoloration of the bitten part. Faintness, staggering, paresis of the limbs, and ante-mortem convulsions are the usual symptoms following the bite of this snake or injection of its venom. The coagulability of the blood taken from the bitten animal after its death from toxication is reported by Fayrer as lost. But this observation need not be regarded as evidence against the presence of extensive thromboses in some veins, because, as was pointed out by Lamb, the fluid blood can be collected from such cases.

\section{THE COLUBRIDÆ.}

The venoms of the snakes belonging to the subfamily Elapinæ are remarkable for their powerful neurotoxic and hæmotoxic effects with only slight local reactions. Especially is this true with the reptiles inhabiting the Asiatic and African continents. The venoms of certain genera of Elapinæ found in Australia also contain considerable of the locally destructive constituents. The symptoms produced by experimental toxications of animals, either through the bite or through injection of the venoms, are described below.

NAJA.

The effects produced by the venoms of various species of Naja are essentially the same and can be stated in the following sentences. The general symptoms of poisoning by cobra venom are depression, faintness, accelerated respiration and exhaustion, lethargy, unconsciousness, nausea, and vomiting. In dogs, guinea-pigs, and rabbits peculiar twitching movements occur, which seem to represent vomiting in them, and occasionally dogs and guinea-pigs actually vomit. Profuse salivation is seen in dogs. As the toxication proceeds, paralysis appears, sometimes affecting the hind legs first and seeming to creep up the body, and sometimes affecting the whole animal at once. There is a loss of coordinating power of the muscles of locomotion. Mild hæmorrhage, a relaxation of the sphincters, and involuntary evacuations, often of a sanguineous or muco-sanguineous character, may precede death, and are generally accompanied by convulsions. In fowls the appearance is one of extreme drowsiness; the head falls forward, rests on the beak, and gradually the bird, no longer able to support itself, crouches, then rolls over on its side. There are frequent startings, as if of sudden awakening from the lethargic state.

BUNGARUS.

The symptoms of toxication by the venom of krait, Bungarus fasciatus, were first accurately observed by Wall, and later confirmed and extended by Lamb. 
Wall divides the experimental cases of toxication with this venom into two classes, acute and chronic. In the acute cases death takes place within 48 to 72 hours after the injection of the venom. There is sometimes a slight swelling at the point of injection. Profuse salivation and vomiting are usual symptoms. Muscular twitching is often observed. The paralysis of respiration is the cause in these cases. There is no extravasation around the site of inoculation and the degree of local swelling is distinctly much milder than in cases of cobra poisoning. The effusion of pinkish fluid is seen in the areolar tissue at the inoculation spot, indicating the destruction of some of the red blood corpuscles. The blood withdrawn from the heart or venæ cavæ of the poisoned animals after death clots firmly on exposure to the air. Wall calls attention to the remarkable difference in the action of the venom of Bungarus fasciatus and that of Naja tripudians in the fact that, with the latter venom, if the animal survives 49 hours after the injection it ultimately recovers. In contrast to this the venom of Bungarus fasciatus, if used in such amounts as not to produce death within 2 to 3 days, brings about a scries of symptoms quite different from those described in the acute cases. In these chronic cases the symptoms begin to manifest themselves in from 2 to I 2 days, and before that period no symptoms ${ }^{1}$ are seen. After this interval of time a diseased condition, more or less active, begins, which, Wall states, invariably ends in death. The main symptoms are the loss of appetite, great depression, and marked diminution in the urinary secretion. Great muscular weakness ${ }^{2}$ is evident, with slight failure of the respiratory functions and an irregular rise of temperature. Purulent discharges from the eyes, nose, and rectum are also observed. There is no tendency to hæmorrhages. Death ensues after a few days' illness. In these chronic cases the coagulability of the blood is found to be impaired.

Lamb found that if a very large amount of the bungarus venom is introduced directly into the circulation of the blood of rabbits death occurs in a few minutes, and post-mortem examination reveals the presence of extensive intravascular thrombosis.

\section{PSEUDECHIS. ${ }^{3}$}

The effects of the venom of Pseudechis porphyriacus, the Australian black snake, are exerted principally on the three most vulnerable points in higher organisms: the blood, the heart, and the respiratory center in the medulla oblongata. Death can result from the alteration produced in any one of these three, and this depends on the concentration with which the venom reaches the circulation. When this concentration attains a certain limit, death may be almost instantaneous, from coagulation of the blood in the vessels terminating the circulation. This happens when small animals are bitten, or when the poison is introduced in adequate quantity directly into

\footnotetext{
${ }_{3}$ Lamb mentions depression and a progressive loss of weight in this period. He used rabbits, rats, and monkeys.

2 Lamb inclines to think that paralysis accompanies this muscular atrophy.

S. J. Martin. On the physiological action of the venom of the Australian black snake (Pseudechis porphyriacus). 1895. Read before the Royal Society of New South Wales.
} 
the circulation. In dogs doses over $0.000 \mathrm{I} \mathrm{gm}$. per kilo body-weight produce extensive intravascular (arterial and venous) thrombosis and death may occur within several minutes. The respiration is seen to continue I or 2 minutes after the heart ceases to beat. When the concentration falls short of that necessary to raise the coagulability of the blood sufficiently to cause thrombosis, the blood shortly afterwards loses its capacity to clot when withdrawn. In this condition any further injection of venom fails to produce thrombosis.

The action of the poison upon the heart and respiratory center is usually simultaneous. But with higher concentration of the venom the heart is more rapidly affected than the respiration, so that by varying the rapidity with which the venom reaches the circulation, the death of an animal may be compassed in any one of three ways: either by clotting the blood in the vessels, cardiac failure, or respiratory paralysis. If animals escape the three possibilities of fatal issue above mentioned, they may succumb to the effects of the pathological changes in the lungs and kidneys. This last danger is, however, not a large one, except with dogs, and the animals usually recover with wonderful rapidity.

Violent convulsions are always observed in cases in which death results from the intravascular thrombosis, and is due to the effect of asphyxia. In cases where death is due to the paralytic action of the venom upon the nervous system, there is first uneasiness, then lethargy, and often vomiting. The lethargy increases and is succeeded by weakness, which first affects the hind quarters. The animal remains quiet, and is disinclined to move. If forced to walk its gait is unsteady and lacks coordination. Later it is quite unable to stand, the pupil becomes dilated and insensitive to light, and breathing is shallow and slower. Reflex action gradually disappears, and the respiration becomes very sluggish and gasping, and ultimately ceases. Death is followed usually, but not always, by a few feeble, convulsive movements.

\section{DISTIRA.}

The symptoms observed in animals after the bite or injections of the venom of the Hydrophiinæ are similar to those of cobra-venom toxication. The local symptom is, however, very slight; and there are no symptoms pointing to any action of the venom upon the coagulability of the plasma or on red corpuscles. Progressive paralysis is accompanied by dyspnœa.

The symptoms produced by the bite of Distira cyanocincta on fowls depend upon the amount of the poison introduced into the system. The bite may kill a fowl within a minute or death may occur after to to 20 minutes, accompanied by paralytic symptoms. The fangs are very minute and often fail to make distinct marks at the spot of the bite, although slight bleeding may sometimes result. Local reaction is entirely negligible. This snake is rather active and may voluntarily bite the animal brought before it. Coagulability of the blood usually remains unaltered from the effect of its bite. The symp- 
toms in dog are mentioned by Fayrer and are well represented in the following example: Distira cyanocincta, 4 feet long, bit a pariah dog twice on the thigh; 40 minutes later the dog was restive, salivated, burrowing its muzzle in the sand. At 45 minutes it was seated, body thrown forward, head down, partially convulsed, salivation increasing; at 50 minutes spasms appeared, with defecation; 55 minutes, involuntary evacuations, respiration slow, tongue hanging out of the mouth, salivation very profuse; an hour after the bite death ensued.

The bite of Distira ornata was seen to be fatal when the snake closed its jaws, with much difficulty, on the comb of a fowl; the symptoms being chiefly of paralytic nature. Fayrer failed to make Distira jerdoni inflict any wound on dogs, the fangs being too small for the skin.

\section{HYDROPHIS.}

Fayrer experimented with a few species of this genus. Thus Hydrophis nigrocincta killed a fowl in 15 minutes, while $H$. chloris, which is probably the same as $H$. fasciatus, caused death after a considerable interval in fowls on which it was forcibly made to close its jaws. The fangs are very minute. On the other hand, Fayrer records one experiment in which the minute fangs of $H$. gracilis could not penetrate the skin of a dog.

\section{ENHYDRINA.}

The bite of Enhydrina valakadien s. bengalensis is fatal when it is induced to bite voluntarily or made to close its jaws on a dog or fowl. Death occurs, however, much slower than in cases of the bite of elapine snakes, which is easily accounted for by the minuteness of the fangs and the torpid and obstinate nature of the sea-snakes.

HYDRUS.

Hydrus platurus (another name of Pelamis bicolor), when quite active is able to inflict a fatal bite on a fowl. No other animals have been tested as to the effects of its bite. The symptoms consist of a series of paralytic reactions. The blood was fluid in one case in a fowl which died about 6 hours after the bite. 


\section{OPISTHOGLYPHOUS COLUBRIDA.}

The characteristics of Opisthoglyphs have already been considered phylogenetically in an earlier chapter of this work and they have been shown to occupy intermediate rank between the harmless and the venomous snakes. In fact, opisthoglyphs are of the lowest order of the poisonous snakes, and are not to be "suspected" as poisonous any longer. Medical practitioners have little practical interest in these snakes, as the accidents from their bite are trifling, with little or no danger to human subjects. But it seems quite proper to record here certain well-known observations made by different herpetologists as to the fatal results of their bites upon some small animals. The observations reproduced here are classic, because it was these that decided in the affirmative the long-standing dispute over the toxicity of these reptiles. The records of the observations are abstracted from the admirable work of Stejneger on "Poisonous Snakes of North America."

Peracca and Deregibus ${ }^{1}$ made special investigations into the possible venomous nature of Calopeltis monspessulana s. lacertinas. Malpolon insignitus. The victims consisted of lizards, frogs, and toads. The snake did not bite voluntarily, and it was necessary to open its mouth and force the animal into its throat; whereupon the snake inserted the venom. The act of biting lasted some moments, and the snake repeated this act several times without allowing its prey to escape. The animals were bitten in the hind leg; in the case of the frog the skin had to be removed from the part to be bitten, as the irritating secretion of the skin appeared to be particularly distasteful to the snake.

The symptoms following the bite are described as (I) the suspension of respiration, which usually occurs in a very few minutes ( $\mathrm{I} 3$ minutes being the maximum in a toad) and may happen suddenly or may be preceded by a gradual sinking, interrupted by a deep-breathing pause; (2) the cessation of reflex movements in the bitten limb, while still persisting for some time in the rest of the body. Irritability of the nerves in the bitten limb soon disappears and general paralysis ensues. Convulsions are rarely seen. The heart continues to beat for a long time, although its strength is much decreased. The muscle around the point of the wound is livid and not excitable. Death ensues generally in half an hour or less.

An interesting but equally convincing observation on the venomous nature of the bite of Trimorphodon biscutatus has been made by Dugès. ${ }^{2}$

One day when I was admiring the snake I saw him seize a Cnemidophorus sexlineatus, at the middle of the body, advancing his jaws so as to bring the corner of the mouth in contact with the body of the lizard; for several moments he chewed (a rare occurrence in a snake) his victim without the latter moving, letting go after having killed it; but at this juncture the saurian was swallowed by another snake (Ophibolus doliatus) which was kept in the same cage, thus preventing me from finishing the observation A few days after, the same Trimorphodon caught

1 Peracca and Deregibus. Giornale della R. Accademia di Medicina di Torino, XXXI, r883, 379.

$2 \mathrm{~A}$. Dugès. La naturaleza (Mexico), I884, VI, 145 . 
another Cnemidophorus by the left arm and chewed several times. At the end of a few minutes the bitten animal died without convulsions, without agitation, as if asleep, a little blood issuing from the wound. (Stejneger.)

On Tarbophis vivax similar experience has been described by Edm. Eiffe.

I offered the half-grown snake a perfectly healthy Lacerta vivipara, which he at once commenced to lap with his tongue and grasped slowly behind the fore legs. The lizard defended itself as best it could and used its teeth well on its enemy. In less than a minute the lizard was almost motionless, the jaws were powerless and the eyes closed; before the expiration of another half minute the lizard died, and was then swallowed.

Still another exhibition of the.poisonous effect of the bite of an opisthoglyph upon a lizard has been reported by Vaillant." The snake in this case was Tragops prasinus Wagler.

A small, living, green lizard was presented to the snake by means of a forceps. The snake seized it across"the neck without descending from the shrubbery among which it lived, and by the play of the jaws drew it back to the corner of the mouth. The lizard tossed and bent about, winding its body and tail around the head of the snake; three minutes later it hung down inert, only the tail still trembling; after a similar space of time convulsions of the whole body occurred again, tying itself around the head, then relapsing without motion, except some spasmodic undulations of the tail; this lasted two minutes, and the animal was then dead.

${ }^{1}$ Léon Vaillant. Mém. Centen. Soc. Philom., r888, Sc. Nat., p. 44. 


\section{CHAPTER XII.}

\section{EFFECT OF SNAKE VENOM UPON THE NERVOUS SYSTEM AND EFFECT OF THE SEQUELÆ UPON THE RESPIRATORY AND CIRCULATORY FUNCTIONS.}

\section{CROTALIN $E$.}

S. Weir Mitchell demonstrated as early as I86I that the toxication of frogs and rabbits by the bite of the rattlesnake quickly stops all motion, voluntary or reflex, within a short time after the bite. In frogs it was found that no reflex acts respond to the stimulation of the sciatic nerves, although the galvanization is followed by the movements of the muscles of the same leg. On the other hand, the electric stimuli to the sciatic nerves, from which the vicious effect of the poison had been excluded by cutting off all of its circulation, produced contraction of the muscles. The loss of the motion was then thought to be caused either by the incapability of the sensory nerves to transmit the stimulus to the nervous centers or by the destruction of the nerve centers themselves. In order to ascertain this point he poisoned a frog to a state of total paralysis, then cut the spinal cord across and thrust a probe up and down. No motion resulted. The irritability of the sciatic nerves when directly tested was found to be nearly perfect. Thus the disappearance of motion seems to have been caused by the paralysis of the spinal cord.

In rabbits it was necessary to keep up the circulation and cardiac activity after the cessation of respiration by means of artificial respiration, which seems to sustain the heart's action for about I2 minutes. During this stage the spinal cord was cut across; no motion resulted. A probe being thrust up and down the spine, feeble quivering of the nearer spinal muscles took place, but the limbs did not move. On dividing the sciatic nerves free motion was observed, and the phrenic trunk was likewise excitable.

In 1886 Weir Mitchell and Reichert made further detailed observations on the effects of Crotalus adamanteus, Ancistrodon piscivorus, and Naja tripudians. Their experiments chiefly concern the effects of the crotaline venoms. In administering a dose of these venoms - just enough to cause acute or subacute poisoning in rabbits - into the jugular vein, they always noticed the increase in the respiration rate, which, however, was quickly followed by a diminution far below the normal. Corneal reflex disappeared before the cessation of respiration, which occurred first. In testing the electric excitability of the respiratory muscles they found them responsive to the stimulus. After exposing the spinal cord the sensory column was 
stimulated, but without response. The motor column was still excitable. The motor nerves were the last to become non-irritable and remained active some time after the irritability of the motor column of the cord had disappeared. They also observed that cutting off the vagus at the neck prevents the occurrence of the primary acceleration of the respiration rate. This they regard to be due to the blockade of stimulus from the peripheral nerves to be transmitted to the nerve center, while the secondary diminution has its cause in the nerve center itself - namely, a paralytic action on this part. Thus they think venom has duplex effects, the irritation of the nerve-ending and depression upon the centers.

Venom globulins, except copper globulin, act similarly to the unmodified venom, but venom peptones cause much less depression of the respiration than the former.

The effects upon the nervous system of the venom of Lachesis flavoviridis s. Trimeresurus riukiuamus, one of the genera belonging to Crotalinæ, have been studied by Ishizaka.

In Rana esculenta $0.0 \mathrm{I} \mathrm{gm.} \mathrm{(subcutaneous)} \mathrm{of} \mathrm{the} \mathrm{dried} \mathrm{venom} \mathrm{causes} \mathrm{death}$ in from Io to 24 hours. The frog soon shows progressive paralysis, although its reflexes, as well as the motor nerves, remain capable of responding to the stimulus for a long time after death. There is no early paralysis of the motor nerve-endings in the striated muscles, and this presents a marked contrast to the effects produced by the venom of Cobra. The frequency of the heartbeat gradually diminishes and is not influenced by atropin. The heart stops in a semi-systolic state. Direct application of a I per cent solution of the venom to an isolated frog's heart brings about momentary changes. The diastolism becomes restricted in width and is soon so stiff that scarcely any blood flows into the relaxed ventricle, while all the peripheral vessels get strongly filled. In this state the cardiac frequency remains unaltered for some time. A frog's heart perfused with Ringer's solution by Williams's apparatus becomes paralyzed within 6 to I 2 minutes when a I per cent venom dissolved in Ringer's solution is allowed to stream through the heart.

In rabbits the venom causes an early cessation of respiration, with the electric irritability of the phrenic nerves and other intramuscular nerves unimpaired. The heart beats some time after the respiration ceases.

A direct inoculation of the venom into the substance of the brain is responded to by acceleration and difficulty of respiration, the increase of reflex actions, and clonic or tonic convulsions. If $0.00 \mathrm{I} \mathrm{gm}$. of the venom is used death may occur in from I to 4 hours, with the cessation of the respiratory function.

In dogs or rabbits an intravenous injection of the venom causes a rapid fall of blood pressure, but the frequency and the size of the pulse remain unaffected. The fall of the blood pressure is not due to the paralysis of the vasomotor center, because the pressure rises again in the later stage when the artificial respiration is suspended. The irritability of the splanchnic nerve is always diminished, but never completely lost. The maintenance of 
the size of pulse in uniformity in spite of the reduced blood pressure seems to exclude the possible occurrence of a paretic state in the peripheral vessels. The sinking of blood pressure is better accounted for by the direct weakening of the cardiac activity. The phrenic and sciatic nerves are still excitable to the electric stimulus after death.

Injection of the venom (o.0or gm. into the sheath of the sciatic nerve) kills a rabbit with typical symptoms, but hæmorrhages spread upwards to the lower third of the medulla along the entire spinal cord, and downwards to the region of the knee. The cord and sciatics are like a dark red string. Small hæmorrhagic foci occur in the interior of the nervous tissue.

\section{VIPERINE.}

Working with the venoms of European vipers, Vipera berus and Vipera ammodytes?, and of Crotalus, Feoktistow found that, even when a complete paralysis of the extremities had occurred, faradization of the peripheral end of a nerve produced perfectly normal contraction of the muscles. Thus he was unable to find any curare-like effect with these venoms. Paresis and then complete paralysis usually affected the hind legs first, gradually ascending to the front limbs. The reflexes disappeared before or after the onset of paralysis. Intravenous injection of strychnine could not reestablish reflex function of the cord, which had lost its reflexes under the effect of the venom. By stimulating the central end of the divided sciatic nerve, even when the hind legs are still in an imperfect paralysis, no movement was obtained in the opposite limb. Dilatation of the pupils is observed in the last stage of venom toxication.

\section{ELAPIN E.}

Of all venoms of the elapine snakes that of Naja tripudians has been most studied. The literature on this particular venom is very extensive, but I will sum up the results in a compact form.

In 1874 Brunton and Fayrer ${ }^{1}$ contributed many important facts to the nature of the action of Indian snake venoms, dealing especially with the venom of Cobra. As already stated in the description of the symptoms of cobra poisoning, the most prominent symptoms of an affection of the nervous system are depression, faintness, lethargy, and in some cases somnolence. There is loss of coordinating power, with paralysis sometimes affecting the hind legs first and creeping over the body, sometimes affecting the whole body at once. Death occurs by failure of the respiration, and is preceded by convulsions. These symptoms were sought by these authors either in the paralysis of the nerve centers or of the peripheral nerves. The occurrence of paralysis before the cessation of respiration might have seemed to exclude the possibility of the second alternative, but careful study demonstrated that, although the motor nerves have their function so much impaired that they no

${ }^{1} \mathrm{~L}$. Brunton and J. Fayrer. On the nature and physiological action of the poison of Naja tripudians and other Indian venomous snakes. Roy. Soc. Proc., 1874, No. 149, 68. 
longer transmit to the muscles of respiration the ordinary stimuli from the medulla, they can still transmit those stronger impulses which proceed from it when greatly stimulated by the increasing venosity of the blood, and which cause the respiratory as well as the other muscles of the body to participate in the general convulsions. Experiments show that the peripheral terminations of the motor nerves are actually paralyzed by cobra venom. Here special attention is drawn to the striking parallelism between the effects produced by cobra venom and those by curare upon the nerve-endings.

Brunton and Fayrer describe also the paralysis of the spinal cord by cobra venom. One of the typical experiments which led these authors to demonstrate the paralysis of motor-nerve endings after the injection of cobra venom was made by protecting one sciatic nerve from the action of the venom (in frog) by means of cutting off all its circulation, and by testing the electric irritability of the protected and unprotected nerves after apparent paralysis. They always found that the side which had been protected from the effects of the venom gave a ready reaction to the stimulus, but that the unprotected sciatic nerve failed to produce contraction of the muscles. Naturally the irritability of the protected sciatic nerve did not react as strongly as the control, but this was easily explained by the fact that the nerve in the former frog was for some time deprived of its blood supply. The direct stimulus to the muscles themselves shows that their excitability was well retained both in protected and in unprotected legs. It was also seen that the longer and nearer the contact of the nerve-endings with a stronger concentration, the more complete is the paralysis of the nerve-endings.

In regard to the effects of cobra venom upon the spinal cord, both on warm-blooded animals and frogs, Brunton and Fayrer concluded that the gray matter is paralyzed, since there is no transmission of painful impulses; but the white sensory columns are little, if at all, affected. The power of the cord to conduct motor impressions from encephalic ganglia appears to be little, if at all affected, until the apparent death of the animal, and they found that, very shortly before respiration ceased, and when ordinary reflex action from the cord was nearly gone, voluntary movements were still made.

According to Brunton and Fayrer the sensory nerves seem to be little, if at all, affected by cobra venom. In contrast to the quick paralysis of the motor nerves of the poisoned limbs the irritability of the sensory nerves is long retained. In an experiment the irritability of the optic nerve and the aural and buccal branches of the trigeminus was seen to be present after the cord had become nearly paralyzed, and in several experiments reflex actions could be induced by irritation of the cornea after voluntary motion and respiration had ceased.

The effects of cobra venom upon secretory nerves have also been mentioned by Brunton and Fayrer, who were uncertain as to the exact mechanism effecting profuse salivation in cobra poisoning in dog. The possibilities were open either to the direct or to the indirect stimulation on the secretory nerves. Judging from the simultaneous occurrence of nausea and vomiting, they were 
inclined to suggest the reflex nature of salivation through irritation of the gastric branches of the vagus. Whatever the primary effects may be, the final result was always a diminution in the secretory function.

In investigating the cause of respiratory failure in cobra poisoning, Brunton and Fayrer called attention to the remarkable fact that the end-plates of the phrenic nerves become completely insensible to the strongest stimuli, while the sciatics and vagus still retain a considerable amount of irritability. Thus, the ultimate arrest of respiration is probably due, in part, to paralysis of the medulla, and, in part, to paralysis of the motor-nerve endings in the respiratory muscles.

In regard to the effects of cobra venom upon the enervation of the circulatory system, Brunton and Fayrer consider this venom to have almost no direct paralytic effects. It is well known that the cause of death in cobra poisoning is usually respiratory failure, with the heart still beating vigorously. But when a concentrated solution of venom is directly introduced into the circulation of frogs the heart stops at once in systole. The same is true when an excised heart of frog is immersed in a strong venom solution. The cessation of the cardiac activity is not of a paralytic, but of a tetanic nature. This cessation of an isolated heart can not be due to the stimulation of the inhibitory center contained within it; for atropin, which paralyzes inhibitory ganglia, does not restore the movements. It is probably not due to the paralysis of motor ganglia, as the heart does not stop in diastole, but in systole, and resists distention by fluid within it. Brunton and Fayrer thought that the most probable cause was the stimulating effects of the venom upon the heart, resulting in the tetanic state of the latter. The inhibitory branches of the vagus are sometimes paralyzed.

In this place it may be mentioned that the capillary circulation is not unaffected, but is greatly increased after the injection of the poison. Judging from the high blood pressure after the heart ceases to beat, the arterioles and capillaries must be much contracted.

Wall reached the conclusion that the principal action of cobra venom on the nervous system consists of an extinction of functions, extending from below upwards, of various nerve centers constituting the cerebro-spinal system, and especially acting on the respiratory center and on those other ganglia allied to it in the medulla, which are in connection with the vagus, the spinal accessory, and hypoglossal nerves; and that it is directly to this destructive action that we have to attribute death in most cases of cobra poisoning. He observed an acceleration of the respiration rate, which does not occur when the vagus is cut before the injection of the venom.

Ragotzi, ${ }^{1}$ going over practically the same field covered by the work of Brunton and Fayrer, found that, if sufficient time elapses from the time of the injection to the manifestation of the action, cobra venom affects and paralyzes the intramuscular endings of the motor nerves. The paralysis of the nerve-

\footnotetext{
${ }^{1}$ Ragotzi. Ueber die Wirkung des Giftes der Naja tripudians. Virchow's Archiv, r89o, CXXII, 201.
} 
endings is found to be much quicker than that of the muscles themselves. In order to produce a fuller effect of the venom upon the musculo-endings he advises the employment of a weak solution or about $0.0000333 \mathrm{gm}$. (or I /30 mg.), $0.00005 \mathrm{gm}$. being a minimal lethal dose, for injection into the dorsal lymph-sac of frogs; too large an amount kills the animal directly from general paralysis without much curare-like action on the nerve endings. He confirms the theory that the phrenic nerves are affected much earlier than other motor nerves.

Ragotzi did not observe acceleration of respiratory frequency at any stage of the poisoning. The inhibitory end-plates of the vagus in the heart were unaffected. In some animals the venom caused a rapid, transient weakening of the heart, which, however, regained its original activity very soon. In the frog, when the venom is given intravenously it arrests the heart in systole at once, and Ragotzi considers this to be due to the direct effect upon the cardiac muscle. In the case of subcutaneous injection, the heart stops in diastole, due, according to this author, to the paralysis of the cardiac ganglia.

Ragotzi emphasized that the spinal cord is not directly affected by cobra venom, and that insensibility of the muscles to the stimuli through the spinal cord is in most cases due to the end-plate paralysis of the motor nerves; or, if there is any paralysis in the cord, it is of a secondary nature, chiefly due to the insufficient blood supply caused by the venom. He recalls the possibility of a fatal hæmorrhage or thrombosis occurring in the regions of the nerve centers when the fresh venom is employed.

Elliot, Sillar, and Carmichael ${ }^{1}$ found the effects of the venom of Bungarus caruleus, the common krait, on the nervous system to consist of paralysis of the respiratory center, curare-like action on the nerve-endings, especially affecting early those of the phrenic nerves, and dilatation of the splanchnic vessels. The vasomotor center is strongly affected. The contraction of arterioles and capillaries is produced, but not in so marked a degree as in the cobra poisoning.

Wall, and later Lamb, ${ }^{2}$ made many important contributions to our knowledge of the behavior of the venom of Bungarus fasciatus (banded krait). In acute cases of poisoning death invariably came through respiratory failure, with very pronounced paralysis of the limbs. In intravenous injection death took place much earlier than in the case of subcutaneous administration of the venom. Lamb is inclined to attribute the cessation of respiration to paralysis of the respiratory center, but no effort has been made to ascertain the extent to which the nerve-endings of certain motor nerves - especially the phrenics - are affected. The changes produced by this venom in the nervous system are chiefly chromatolytic degeneration throughout the entire cerebro-spinal system. I intend to return to this more in detail in a later section.

\footnotetext{
1 Elliot, Sillar, and Carmichael. On the action of the venom of Bungarus caruleus (the common krait). Roy. Soc. Proc., i g04, LXXIV, ro8.

2 Lamb. Some observations on the poison of the banded krait (Bungarus fasciatus). Sci. Mem. by Officers of the Med. and Sanit. Depts. of the Govern. of India, 1904, new series, No. 7 .
} 
The elaborate studies of C. J. Martin ${ }^{1}$ on the physiological actions of the venom of Pseudechis porphyriacus, the Australian black snake, brought out many important facts concerning the action of that particular venom as well as of snake venom in general. The most valuable contribution made therein is the elevation of the significance of intravascular thrombosis in symptomatology in acute venom poisoning to a definite and more prominent position than that hitherto assigned to it. Martin was able to explain the cause of rapid death brought about in a few minutes when a comparatively large dose of the venom is injected in a small animal, by demonstrating the presence of extensive intravascular thrombi in such case. Thus the sudden fall of blood pressure, with violent convulsions and a vigorously beating heart, was excluded from the direct actions of snake venom upon the nervous system. This was later worked out more completely by Martin himself and also by Lamb and others with other kinds of venoms.

In injecting a suitable amount of the venom of Pseudechis Martin obtained the type of toxication in which intravascular thrombosis is no longer a factor, but typical respiratory failure takes place. He was able to show that while the irritability of motor nerves and their termination plates in muscles is still intact, respiration ceases independently also of the effects on circulation. Here the primary paralysis of the respiratory center was conclusive. By giving the venom subcutaneously Martin observed that amplitude and acceleration of the rhythmic rate of respiration increased in the beginning of the poisoning. As Martin observed no influence of division of the vagus on the initiatory acceleration of the respiratory function, he was led to consider the phenomenon as directly due to the stimulus on the respiratory center in the medulla.

In regard to the sensibility of the respiratory and the circulatory systems to the action of the venom, Martin states that usually a stronger concentration has a greater effect upon the heart, and a weaker concentration upon the respiration. With a weak concentration a continued action is necessary to produce marked effect upon the respiratory function. Again, vulnerability of different species of animals to the venom is by no means uniform. Thus dogs are more sensitive to the vascular effects than to the respiratory, while with rabbits the relation is entirely reversed.

Reflex activity of the cord is directly destroyed by the venom, but this is not due to deficient circulation. In animals injected with small amounts of the venom, the initial fall of blood pressure is soon restored to the normal, but the animal is weak and helpless. On examining such an animal the tendon reflexes are feeble or altogether absent; skin and corneal reflexes are abolished, even if the circulation and blood pressure are well kept up.

In frogs the injection of the venom (O.oI $\mathrm{gm}$.) into the dorsal lymph-sacs gradually retards and then stops respiration. In 20 minutes it is absolutely paralyzed and even stimulation of the central and of the divided sciatic nerve

1 C. J. Martin. On the physiological action of the venom of the Australian black snake (Pseudechis porphyriacus). Read before the Royal Society of New South Wales, July 3, r895. 
is unable to produce the slightest reflex response. In this stage the heart may be beating feebly, but the whole circulation is thrombosed. If, however, even thrombosis be excluded from the case by heating the venom before the injection, the result is the same. A series of direct experiments was performed on frogs to demonstrate the paralytic effect of the venom upon the reflex activity of the spinal cord. The method for testing the reflex activity was to dip the foot every 5 minutes into a 4 per cent sulphuric-acid solution, washing off the acid from the foot after each dipping. The venom in a dose of o.or gm. in 5 c.c. was introduced into the dorsal lymph-sacs of the frog, and it was deprived of its fibrin ferment by heating the solution to $85^{\circ} \mathrm{C}$. before use. After envenomization, the brain was destroyed and the animal hung by its lower jaw. The latent period between the application of the stimulus and the response was noticed and the results show that the latent period in control frogs varied from 0.6 to I second during the first hour, but required 3 to 4 seconds when tested the next day. On the other hand, the poisoned frogs gradually lengthened the latent period and finally gave no response within from 20 to 25 minutes after the injection of the venom. The heart in these poisoned frogs ceased to beat after 15 to 20 minutes. In a number of frogs with the hearts excised no response was obtainable after 25 to 30 minutes.

Martin examined the irritability of the terminations of the phrenic nerves and also of the motor nerves of the brachial plexus of rabbits after the injection of the venom of Pseudechis, but found no change in their function of transmitting the impulses to the muscles. On the other hand, he met with some instances in which the contraction of the muscle of the poisoned leg (in frog) was caused by far less stimulus than that of the other leg, a phenomenon not infrequently observed also by some other investigators and accounted for by the suppression of the circulation by the ligature.

\section{HYDROPHIIN Æ.}

The venom of sea snakes is a very powerful one and is unparalleled in any of the land snakes. As already mentioned in the description of symptoms produced by the venom of Hydrophiinæ, its main effects are on the nervous system.

Leonard Rogers ${ }^{1}$ made careful studies on the venom of Enhydrina valakadien, and our present knowledge concerning its physiological action is largely due to his investigations.

In warm-blooded animals (cats and rabbits) there is a primary paralysis of the respiratory center in quickly fatal cases of poisoning. In the more protracted cases of toxication primary failure of respiration is accompanied by a marked rise of blood pressure due to the increasing venosity of the blood. If no artificial respiration is adopted the blood pressure suddenly falls some minutes after the cessation of respiration, but with artificial respiration there

${ }^{1}$ Rogers. On the physiological action of the poison of the Hydrophidx. Roy. Soc. Proc., 1904, LXXII, 305. 
is a gradual diminution, and violent convulsions repeatedly occur. This respiratory convulsion is interpreted by Rogers to be a sign that the respiratory center, which otherwise would fail, is functionally revived by the artificial respiration; hence convulsions. That the paralysis of the respiratory center is not the only cause of asphyxiation, but that paralysis of the endplates of the phrenic nerves takes part in it, is experimentally shown by Rogers both in cold-blooded and in warm-blooded animals. In cats and rabbits, many times the minimal lethal doses were given intravenously, and then the exposed phrenic nerves at the neck were stimulated by an interrupted induced current at intervals of a minute. After the complete cessation of respiration the phrenic nerves were stimulated, but found to be completely paralyzed. Direct stimulation of the diaphragm gave a marked contraction. It was, however, found that the respiration was much reduced in frequency and amplitude several minutes before the weakening of the irritability of the phrenics. It is interesting to notice that the end-plates of the sciatic nerves remained excitable much longer than those of the phrenics, being still reactive at the time of complete cessation of circulation.

Rogers also tested the comparative sensitiveness of the nerve-trunk and nerve-ending to the paralyzing action of the venom. Here, using frogs, he employed the venom in dilution of $\mathrm{I}: 1 \mathrm{O}^{6}$ to $1 \mathrm{IO}^{3}$, subjecting the nerves to its action for I to 5 minutes in strong and up to $I$ hour in weak solution. No deteriorating effects on the irritability of the nerve-trunk were observed, but that of the nerve-ending was totally lost. Even a I per cent solution of the venom of Enhydrina acting for 5 minutes had no effect on the nerve trunk.

In regard to its action on the reflex functions of the spinal cord, Rogers points out that it is slight and altogether secondary in importance to its influence on respiration. He states that the venom of Enhydrina in I : 100 solution has no appreciable effect when applied directly to the frog's heart, whereas a few drops of a I : 1000 solution are quickly fatal when given intravenously. This seems to present a great difference from the venoms of Pseudechis, Naja, and Trimeresurus.

Fraser and Elliot, ${ }^{1}$ working with the venoms of Enhydrina valakadien and Enhydris curtus, mention the occurrence of motor end-plate paralysis in the enhydrina poisoning. They also made direct application of the venom to the region of the respiratory center and found it quickly fatal without affecting the circulatory system at the same time. On application of the venom directly to the exposed hearts (in situ) of mammalia no effect was observed on the vagal cardio-inhibitory center. The vasomotor center is also unaffected by this venom.

1 Fraser and Elliot. Contributions to the study of the action of sea-snake venoms. Roy. Soc. Proc., rgo4, LXXIV, ro4. 


\section{CHAPTER XIII.}

\section{EFFECTS OF SNAKE VENOM UPON THE COAGULABILITY OF THE BLOOD.}

The fluidity of the blood after the bite of certain snakes has been long known. In I 787 Fontana stated that the blood of animals dying of viper bite remained fluid. Brainard ${ }^{1}$ mentions that when death occurred immediately in animals bitten by rattlesnakes, the blood was found at the autopsies to be coagulated, but if some time elapsed before the animal succumbed, the blood remained fluid in the vessels. In I860 Weir Mitchell ${ }^{2}$ confirmed Brainard's observations. Halford observed that the same continued fluidity of the blood followed the injection of some venom of Australian species. Feoktistow ${ }^{3}$ confirmed Fontana's observation on the condition of the blood after injection of the venoms of Vipera ammodytes and Vipera berus.

The continued fluidity of the blood after the bite of the Indian viperine snakes has been frequently noted in past years. Mitchell and Reichert demonstrated the anticoagulating property of the rattlesnake and moccasin venoms directly in vitro.

The increased coagulability of the blood in animals injected with a large amount of viper venom was noticed by Fontana, and nearly one hundred years later also by Heidenschild ${ }^{4}$ on the crotalus venom and by C. J. Martin on the pseudechis venom independently.

In 1893 C. J. Martin ${ }^{5}$ found that 0.00015 gm. per kilo or upwards of the venoms of two Australian snakes, Pseudechis porphyriacus and Notechis scutatus, when introduced into the circulation of dogs, cats, and rabbits, caused intravascular clotting. This action also occurs when the snake discharges a relatively large amount of venom into small animals, as when seizing frogs or mice as prey, but it is not a usual phenomenon of poisoning by these snakes in man. ${ }^{8}$ When the quantity of the venom fails to effect an intravascular coagulation there is always a phase of increased coagulability which lasts but a few minutes, only to be followed by another phase of abnormally diminished coagulability. An intermediate quantity produces thrombosis only in the portal vein, but the blood in the vessels elsewhere

\footnotetext{
1 Brainard. Smithsonian Report. 1854 .

2 Weir Mitchell. Smithsonian Contributions to Knowledge. I 86 r.

Feoktistow. Ueber die Wirkung des Schlangengiftes auf den thierischen Organismus. Mém. d. l'Acad. Imp. d. Sc. d. St.-Pétersbourg. I 888 , XXXVI.

- Heidenschild. Untersuchungen über die Wirkung des Giftes der Brillen- und der Klapperschlange. In aug. Dissert. Dorpat, I886.

${ }^{5} \mathrm{C}$. J. Martin. On some effects upon the blood produced by the injection of the venom of the Australian black snake (Pseudechis porphyriacus). Jour. of Physiol., I 893, XV, 380.

6 An explanation of the marked difference in the effects produced by subcutaneous and intravenous injection of the venom of Australian snakes. Proc. Roy. Soc. N. S. W., 1896.
} 
remains fluid. A very remarkable fact was found by Martin, namely, that if the fluidity of the blood be once produced by injecting a small quantity of the venom no increase of coagulability can again be obtained by giving a second large dose, which would otherwise culminate in an extensive thrombosis. It is very interesting, again, to notice that the plasmas which exhibit only a weak negative phase can be induced to clot by the addition of (I) solution of nucleo-albumin (Wooldridge's tissue fibrinogen); (2) calcium chloride; (3) dilution; (4) passage of $\mathrm{CO}_{2}$; (5) Alexander Schmidt's fibrin ferment. These are most active in the order indicated.

The plasms which have lost all spontaneous coagulability may, however, be made to clot by the following means: (I) addition of a saturated solution of $\mathrm{NaCl}$ up to an equal volume; (2) addition of an equal volume of a saturated $\mathrm{MgSO}_{4}$ solution; (3) addition of acetic acid, until the plasma is just faintly acidulous; (4) similar addition of weak sulphuric, hydrochloric, or phosphoric acids (oxalic acid is ineffectual).

In studying the effect of calcium chloride upon the plasmas of varying stages or degrees of non-coagulability through the effect of the venom, Martin divides the plasmas into three classes:

(I) The cases where only a very moderate negative phase has been produced and the clotting of the shed blood is delayed from 30 minutes to 2 or 3 hours. The addition of a few drops of calcium chloride to a sample of blood drawn from this class causes almost immediate solidification, and if a few cubic centimeters of a I per cent solution of this salt in 0.9 per cent $\mathrm{NaCl}$ be injected into a vein, the coagulability of the blood is raised above the normal, and very frequently the animal dies in a few minutes from extensive thrombosis.

(2) Cases in which the negative phase is more pronounced and the blood which is shed clots only after some hours or days. With this class calcium chloride is without influence upon the extravascular plasma, but raises the coagulability towards the normal.

(3) A very pronounced negative phase in which the blood never clots spontaneously, and in which the addition of saturated solution of sodium chloride, etc., only occasions a very small amount of coagulum. With this class $\mathrm{CaCl}_{2}$ has no effect either when it is injected or added to the plasma in vitro.

In this early investigation Martin drew a parallelism existing between the phenomena produced by venom and those produced by the tissue fibrinogen of Wooldridge, but in Ig05 this analogy was abandoned by him, when he made a further inquiry into the nature of the clotting principle of various venoms in general.

In I90I Lamb ${ }^{1}$ made a remarkable discovery, which has since become quite important in its bearing on the nature of the coagulating property of certain snake venoms on the blood plasma - that the fluid plasma or blood containing I to 2 per cent sodium citrate can be coagulated by adding a small

'Lamb. Indian Med. Gazette, 1901, XXXVI, 443. 
quantity of daboia venom in vitro. This finding threw an entirely different light on the mechanism of coagulation of the blood plasma in venom toxication. The mere decalcification of the blood or blood plasma by means of sodium citrate brings about, as has been long known, a condition of noncoagulability of the blood so treated, and coagulation can easily be effected by simply adding a sufficient amount of calcium chloride to such fluid. Now, Lamb found that the addition of a small amount of daboia venom, in lieu of $\mathrm{CaCl}_{2}$, to such decalcified fluid plasma or blood suffices to produce coagulation. Here neither fibrinogen nor paraglobulin is lacking, but an active fibrin ferment is not present on account of the absence of activating salt, calcium chloride, in the mixture. Thus, the function performed by the venom in bringing about such mixture is that of a preformed fibrin ferment. In just what relation this fibrin ferment stands to that of the blood or protothrombins or thrombogens is not cleared up. But that it is not supplying these proto-enzymes with calcium chloride is evident from the minute quantity required to produce coagulation of the citrate plasmas. In fact, as Martin ${ }^{1}$ found later, no relation to the amount of anticoagulating salts contained in the blood exists.

Lamb's extensive paper appeared in 1903, in which this particular phenomenon has been dealt with on the ground of further experiments.

Lamb and Hanna ${ }^{2}$ found that the rapid death which follows an injection of daboia venom is invariably caused by extensive intravascular thrombosis, but if the amount of the venom injected is not sufficient to effect this change a negative phase of diminished coagulability results, sometimes amounting to complete inhibition of clotting, and that this diminished coagulability is probably an important factor in the production of some of the symptoms which are observed in these cases. $0.000 \mathrm{I} \mathrm{gm}$. of daboia venom per kilo injected intravenously into a rabbit causes extensive intravascular thrombosis, where $0.0004 \mathrm{gm}$. is required for a pigeon, when injected subcutaneously. This thrombosis may be confined, if the quantity of venom injected has not been excessive, to the portal veins, the right heart, and the pulmonary arteries; in these cases the blood collected from the other veins, especially from the left heart, remains unclotted, or clots only after a long interval of time, when the clot is very loose and gelatinous. That it is impossible to produce increased coagulability and thrombosis by injecting any second quantity of the venom after the negative phase of diminished coagulability had once set in agrees with the observations made by Martin on the Australian snake venoms.

Lamb ${ }^{3}$ next tested the coagulating effect of daboia venom upon the citrated whole blood. While I c.c. of the citrate blood I : Ioo required $0.0005 \mathrm{gm}$., the same quantity of the citrate blood I : 50 required $0.002 \mathrm{gm}$. of daboia venom to produce coagulation in less than half an hour. $0.00003 \mathrm{I} 2 \mathrm{gm}$. was

1 C. J. Martin. Observations upon fibrin-ferments in the venoms of snakes and the time-relations of their action. Jour. of Physiol., 1905, XXXII, 207.

2 Lamb and Hanna. Journ. of Path. and Bact., I902, VIII, I.

Lamb. On the action of the venoms of the cobra (Najatripudians) and of the daboia (Daboin russellii) on the red blood corpuscles and on the blood plasma. Sci. Mem. Officers, Med. and San. Depts. Gov. of India, I903, new series, No. 4. 
the smallest amount of venom capable of coagulating I c.c. of the whole blood containing $\mathrm{I}$ : I00 citrate salt.

Although the presence of an excess of the citrate does not prevent the venom from inducing coagulation of the citrate blood, certainly it lessens this power to a certain extent.

The experiment with the citrate and oxalate plasmas obtained free from the blood corpuscles by a process of sedimentation ${ }^{1}$ give similar results. 0.003 to $0.005 \mathrm{gm}$. of daboia venom added to 2 c.c. of the citrate plasma clotted it in less than 3 hours, and 0.0004 to $0.001 \mathrm{gm}$. did so in 20 hours, but $0.0002 \mathrm{gm}$. caused only a slight clot in 20 hours. On the other hand, $0.005 \mathrm{gm}$. of daboia venom added to 2 c.c. of the oxalate plasma produced only a slight coagulum in 20 hours, and the same was true with smaller quantities down to $0.0006 \mathrm{gm}$., but no more effect was obtained when $0.0004 \mathrm{gm}$. was used. If the quantity of the potassium oxalate percentage be reduced by adding an adequate amount of calcium chloride solution to the point where coagulation of the plasma is just prevented from occurring after 20 hours, then $0.005 \mathrm{gm}$. of daboia venom can induce coagulation within ro minutes. This difference is explained by Lamb to be due to the less solubility of the oxalate than the citrate of calcium, and the coagulating effect of daboia venom is more rapid and pronounced with the latter salt.

Hydrocele fluid, either with or without addition of lime solution, could not be coagulated by means of daboia venom; but it quickly clotted when a small amount of oxalate plasma was added.

Lamb expresses the belief that the ultimate cause of this increase of coagulability produced by daboia venom is some obscure interaction between the poison and the nucleo-proteids, or between the poison and fibrin ferment, but not the result of the setting free of normal nucleo-proteids through the destruction of the cells by the poison.

In I904 Noc, ${ }^{2}$ under Calmette, made similar observations on the venoms of different species of Lachesis. He employed the plasmas obtained from the blood of rabbits or horses by first rendering the whole blood incoagulable by adding various salts or leech extract. Of the salts, there were employed, sodium citrate I : Ioo; potassium oxalate 2 : rooo; sodium chloride $4:$ I00; sodium fluoride $3:$ Iooo. The plasma containing one of the above salts coagulated in 15 to 20 minutes when I c.c. was mixed with $0.4 \mathrm{gm}$. to 0.6 c.c. of a 0.5 per cent solution of calcium chloride. Noc found that rapid coagulation is produced when, in the place of calcium chloride solution a small quantity of the venom of Lachesis lanceolatus is added to these plasmas. To I c.c. of the plasma $0.00 \mathrm{I}$ to $0.002 \mathrm{gm}$. of the lachesis venom caused

1 With the flasks containing 50 c.c. of 20 per cent solution of sodium citrate (in 0.75 per cent $\mathrm{NaCl}$ ) on one hand, and 40 c.c. of 5 per cent solution of potassium oxalate (in 0.75 per cent $\mathrm{NaCl}$ ) on the other, one liter of horse blood was drawn into each flask respectively, and then allowed to stand at $14^{\circ} \mathrm{C}$. for $4^{8}$ hours, during which time the corpuscles settled down and clear supernatant fluid or plasma was obtained. In the case of the citrate it contained this salt in $x$ per cent, while in the case of the potassium oxalate 0.2 per cent was the resultant concentration.

2 Noc. Sur quelques propriétés physiologiques des différents venins des serpents. Anns. de l'Inst. Pasteur, rgo4, XVIII, 387 . 
the quickest and firmest coagulation, while the doses above these quantities reduced or annihilated the coagulability. Thus $0.003 \mathrm{gm}$. still produced a loose coagulation, while $0.004 \mathrm{gm}$. doses and upwards (tried up to $0.0 \mathrm{I}$ gm.) did not produce further coagulation.

The venoms of the following snakes possess coagulating power in the order given:

Crotaline: Lachesis lanceolatus (Bothrops), Martinique; L. urutsu (neuwiedii), Brazil; L. jararaca, Brazil; L. jararacussu, Brazil; L. flavoviridis s. Trimeresurus riukiuanus, Japan.

VIPERINe: Vipera russellii (daboia), Burma.

As to the mechanism of the coagulating action of the venom, Noc is inclined to consider it to be a part of activation of the plasmase (or fibrin ferment) by venom. Thus, venom may act something like some organ extracts in bringing the zymogenic form of fibrin ferment (protothrombin or thrombogen) into an active state, although no definite processes are yet known. He does not, however, exclude the possibility that venom contains a veritable fibrin ferment.

The rapidity with which coagulation of the citrate or oxalate blood takes place under the influence of these venoms renders it improbable that the destruction of the red corpuscles has any relation to this phenomenon. At any rate, the venoms of Lachesis do not alter the corpuscles for some time after they are mixed.

Noc also found that the venoms of Naja tripudians, Naja nigricollis, and Bungarus ceruleus were devoid of coagulating property on the whole blood or the plasmas which were rendered incoagulable by these anti-clotting salts or leech extract. This agrees with the negative observations of Lamb with the venoms of Cobra and kraits.

The peculiar phenomenon that a too large amount of lachesis venom, when mixed in vitro, produces incoagulability of the blood is attributed by Noc to the fibrin-dissolving property of the venom. That crotalus venom in a strong concentration in vitro results in the same fluidity of the blood has been shown by S. Weir Mitchell and Reichert.

Martin found that the coagulating property of the Australian snake venoms disappeared after heating to $80^{\circ} \mathrm{C}^{1}$ for half an hour, and Lamb found the same result for daboia venom after heating to $75^{\circ} \mathrm{C}$. during half an hour; finally, Noc, for the lachesis venom, found that there was much weakening at $58^{\circ} \mathrm{C}$., and complete destruction at $80^{\circ} \mathrm{C}$. maintained for the same period in a sealed tube. Noc further found that alcohol precipitates, but does not destroy, the coagulating principle of the lachesis venom.

In I905 Martin ${ }^{2}$ made further contributions to our knowledge of the coagulating constituents of the venoms of Pseudechis porphyriacus, Notechis scutatus, Echis carinata, and Daboia russellii. Of these four venoms that of

\footnotetext{
${ }^{1}$ A weaker solution, viz, o.I per cent, is completely destroyed at $75^{\circ} \mathrm{C}$. for ro to 15 minutes.

$2 \mathrm{C}$. J. Martin. Observations upon fibrin ferments in the venoms of snakes and the time-relation of their action. Jour. of Physiol., 1905, XXXII, 20\%.
} 
Notechis was the strongest, Daboia the weakest, and the other two occupied intermediary positions. Very remarkable is the strength possessed by the notechis venom. Oxalate plasma of dog was mixed with varying quantities of the solution of venom, and the time required for coagulation was noted. The result may briefly be quoted here, as it furnishes us with a more accurate conception of its coagulating potency.

2 c.c. of the plasma were mixed with one drop $=0.017$ c.c. of venom solution of the following strengths, and the mixture placed in a bath at $40^{\circ} \mathrm{C}$.

\begin{tabular}{|c|c|c|c|c|}
\hline 0.1 & per cent $=0.00017$ & gm. Coagulated in less than & & minute. \\
\hline 0.01 & per cent $=0.000017$ & gm. Coagulated in less than & I. 5 & 5 minutes. \\
\hline 0.001 & per cent $=0.00000 I_{7}$ & gm. Coagulated in less than & I5 & minutes. \\
\hline 0.0001 & per cent $=0.00000017$ & gulated in less than & ro & hours. \\
\hline $\begin{array}{l}0.0000 I \\
\text { Control }\end{array}$ & per cent $=0.000000017$ & $\begin{array}{l}\text { gm. Permanently fluid. } \\
\text { Permanently fluid. }\end{array}$ & & \\
\hline
\end{tabular}

The strength of the venoms of Pseudechis and Echis carinata proved to be one-half to two-thirds of that of notechis venom.

Martin states here that the mechanism of coagulation of oxalate or citrate plasmas is independent of the presence of calcium ions, as these venoms clot Io per cent oxalate plasma as rapidly as 0.2 per cent, and the action is the same upon oxalate, citrate, fluoride, and magnesium sulphate plasma, and also upon hydrocele fluid ${ }^{1}$ and solutions of fibrinogen prepared from the horse by the Hammerstein process.

According to Martin, the ferment contained in the venoms does not appear to be used up in the process. After a portion ( 5 c.c.) of plasma is clotted by one drop of o.I per cent solution of the venom, it can be removed and then another portion be added. This will clot. This process can be repeated four or five times, coagulation occurring more and more slowly with each successive addition. The experiment can not be repeated as many times as would be expected from the calculated minimal clotting dose, as presumably each successive crop of fibrin carries away absorbed ferment.

A slow deterioration of clotting power takes place when aqueous solution of the venom is kept at ordinary temperature, and more rapidly if the dilution be greater. The coagulating ferment of the venom dialyzes slightly, and when a 0.0 I per cent solution is filtered through 8 per cent gelatin, ${ }^{2}$ the filtrate possesses about $\frac{1}{2} \frac{1}{0} \overline{0}$ of the ferment power of the original solution.

In a later section I will refer further to the specificity of fibrin ferments contained in the venoms of different species of snakes.

\footnotetext{
${ }^{1}$ Certain discrepancies exist between Martin's observations and those of Lamb in regard to the effect of venom upon hydrocele fluid and also upon the concentrations of oxalate in the plasma. Lamb found no action upon the hydrocele fluid, and much influence was noticed to be exerted by higher concentrations of the oxalate upon the coagulating power of daboia venom.

2 C. J. Martin, Jour. of Physiol., I896, XX, 364 .
} 


\section{ANTICOAGULATING PROPERTY OF SNAKE VENOMS.}

From Fontana's time to the present it has been one of the most remarkable features of venom poisoning that the blood of animals bitten by certain snakes, or of those injected with the venoms of certain species of snakes, temporarily loses its coagulability totally or partially. As has been briefly mentioned in the beginning of this chapter, Fontana determined the fluidity of the blood of animals which died of viper poison; Weir Mitchell and Brainard observed the same fluidity in subacute crotalus poisoning, Fayrer in daboia poisoning, Wall in cobra venom toxication in case of man, and Halford found the same with animals which had received an injection of some Australian snake venoms. The occurrence of the fluidity of the blood of the animals accidentally or experimentally toxicated with these different venoms was nevertheless so inconstant that its nature had been a great puzzle to most of these observers. Weir Mitchell has shown by a direct test-tube experiment that the venom of rattlesnake exerts an anticoagulating effect upon blood shed and allowed to flow into a flask containing rather a large amount of the venom. Martin demonstrated in vivo that an amount of the venoms of Notechis and Pseudechis, insufficient to produce instantaneous thrombosis (positive phase), diminishes or destroys coagulability of the blood for some time to follow (negative phase). Martin's work as a whole received confirmation in the careful investigations of Lamb with daboia venom, but the latter author went into a deeper inquiry as to the nature of the negative phase produced by these Australian as well as Indian snake venoms. The primary question was to ascertain whether the incoagulability brought about by a small amount of daboia venom in the animal body is identical in its mechanism with the diminution of coagulability occasioned by the cobra-venom poisoning.

Cunningham ${ }^{1}$ found that if a sufficient quantity of cobra venom is mixed, outside of the body, with shed blood, coagulation of the latter may be greatly diminished or eventually suppressed in toto.

Kanthack ${ }^{2}$ followed and enlarged Cunningham's observations by his experiments with the normal and immunized bloods. With the latter Kanthack found no inhibitory action of cobra venom on coagulation with the dose which just suffices to suppress clotting of the normal blood. It may be added that the addition of sufficient quantity of antivenomous serum neutralized the discoloring and anticoagulating effects of cobra venom upon the blood in vitro.

Stephens and Myers, ${ }^{3}$ working under Kanthack, confirmed the anticoagulating property of cobra venom on the blood, although they conducted the blood direct from the artery to the test solution, and the results were observed at intervals of varying lengths of time. Their results show that when more than o.or gm. of cobra venom is contained in "I"c.c. and mixed with I c.c. of

\footnotetext{
D. D. Cunningham. Sci. Mem. by Medical Officers in the Army of India, 1895, part 9, 1.

2 Kanthack. System of Medicine, edited by T. Clifford Allbutt, London, I896, I, 570.

8 Stephens and Myers. The action of cobra poison on the blood; a contribution to the study of passive immunity. Jour. of Pathology and Bacteriology, 1898, V, 279.
} 
guinea-pig's blood, the blood becomes black and forms no coagulation, while 0.005 gm. produced a black clot after one hour, and no serum separated when examined the next day. The quantities of $0.0025 \mathrm{gm}$. and 0.00125 gm. in I c.c. of saline solution and mixed with I c.c. of guinea-pig blood retarded coagulation only a few minutes or about ro minutes, and rendered the color of the clot very black, no serum exuding from it the next day. It is interesting to see that throughout the entire experiment, while saline-isotonic solution without venom required 6 minutes for coagulation, the mixtures containing $0.000625 \mathrm{gm} ., 0.000312 \mathrm{gm}$., and $0.00007 \mathrm{gm}$. produced coagulation in 2 minutes and a red-stained serum separated out. The clots in these tubes became semi-fluid the next day. The quantities of 0.000028 $\mathrm{gm}$. and $0.000004 \mathrm{gm}$. allowed the blood to form a bright red clot, from which stained serum was separated out when examined the next day. $0.000002 \mathrm{gm}$. in I c.c. mixed with I c.c. of the blood did not exert any influence in regard to coagulation and subsequent serum exudation, which was exactly the same as with the control.

Using the doses of from 0.0002 to $0.000 \mathrm{I} \mathrm{gm}$. of cobra venom per I c.c. of the blood, they have demonstrated the specific anti-inhibitory property of Calmette's antivenin upon this venom. Their conclusions are:

(I) Cobra venom delays or inhibits the clotting of the blood in vitro.

(2) This inhibitory action is neutralized by antivenomous serum in vitro.

(3) This action of antivenomous serum in vitro is specific.

(4) Antivenomous serum itself, when added to blood, delays clotting.

(5) For a certain dose (0.000I gm.), the measure of the neutralization in vitro, using clotting as a test reaction, is also the measure of the neutralization in corpore for guinea-pigs.

(6) The neutralization of the toxin by its antitoxin, in vitro, is certainly not vital nor cellular, but must be chemical.

Lamb and Hunter were able to show that the injection of a large amount of cobra venom into a vein of rabbit never produces intravascular thrombosis, but causes some deficiency of coagulability of the blood. The diminution of coagulability was found to be more pronounced the larger the amount of venom injected. This fact seems to furnish an easy explanation why Wall, who used a small quantity of the venom, failed to obtain diminished coagulability, while Cunningham, ${ }^{1}$ who killed the animal in a few minutes with a much larger amount of cobra venom, observed the loss of the clotting power of the blood of the animal after its death.

Here a most striking difference in the physiological action of the cobra and daboia venoms is brought to light. The former produces, if employed strong enough, a state of diminished coagulability without producing any increased clotting power, while the latter produces, if in larger quantities, a sudden increase of coagulability, culminating in an instantaneous thrombosis in the

${ }^{1}$ Kanthack and Cunningham both observed that the blood running into a strong solution of cobra venom either remained permanently unclotted, or the clot which formed after considerable delay was soft and gelatinous and no serum exuded. 
blood vessels, and, if only a small fraction of such clotting dose be given, a total or partial loss of coagulability ensues.

The anticoagulating effect of cobra venom upon the whole blood and blood plasma has been demonstrated by Lamb in a quite ingenious manner. The whole blood was made incoagulable by means of I per cent sodium citrate or 0.2 per cent potassium oxalate. Then the quantity of solution of calcium chloride which, when added, brings about coagulation of the citrate or oxalate blood in a few minutes was determined. Now varying amounts of cobra venom were mixed with these incoagulable bloods before adding the lime solution. It was found that even 0.02 to $0.03 \mathrm{gm}$. cobra venom did not produce coagulation when added to I c.c. of the citrate blood. On the contrary, $0.0004 \mathrm{gm}$. of this venom kept I c.c. of the citrate blood unclotted, when the amount of calcium chloride solution sufficient to produce coagulation in I to 3 minutes in the venom-free control citrate blood was added. Distinct inhibiting effect was exerted even by as minute a quantity as $0.0000 \mathrm{I} \mathrm{gm.} \mathrm{of}$ the venom. Lamb mentions that heating cobra venom to $75^{\circ} \mathrm{C}$. for half an hour diminishes its anticoagulating power, but does not destroy it.

With the citrate and oxalate blood plasmas the results obtained were practically the same as with the whole blood. In the case of the citrate plasma $0.00 \mathrm{I} \mathrm{gm}$. of cobra venom prevented coagulation of 2 c.c. of the plasma.

The experiment with hydrocele fluid seems to be of much significance in interpreting the action of cobra venom in bringing about incoagulability of the blood and plasma. As is well known, the hydrocele fluid requires fibrin ferment or at least protothrombin, but not calcium chloride, to become clotted. Lamb found that O.I gm. of the citrate donkey plasma (I per cent) was sufficient to clot 2 c.c. of the hydrocele fluid in 20 minutes. But, when the venom was allowed to act for Io minutes upon the plasma before the addition of the hydrocele fluid, no coagulation took place. The addition of a small quantity of lime solution did not affect this result in any way.

Now, returning to the action of daboia venom as an anticoagulating agent, Lamb could not observe any inhibitory effect upon the whole blood or blood plasma in vitro. The venom of Daboia, like that of Pseudechis, Notechis, and Echis, is a powerful anticoagulating agent when allowed to act in vivo, but not at all in vitro. Every varying subclotting dose, even as small as 0.000000009 gm. has been tried, but on every trial the coagulability increased more or less, without, however, any diminishing effect. Thus the negative phase of coagulability in vivo produced by daboia venom is of an entirely different process from that observed with a large dose of cobra venom both in vivo and in vitro.

Finally an interesting observation was made to ascertain whether the previous addition of a large dose of cobra venom to the citrate plasma would prevent coagulation by a later addition of daboia venom to such mixture. It was found that the presence of a large quantity of cobra venom does not inhibit in the slightest degree the clotting action of daboia venom. In this 
case, it may be mentioned, the cobra venom was allowed to act for 30 minutes upon the plasma before the latter venom was introduced.

Calmette, who in great part confirms the observations already mentioned in this chapter, obtained somewhat different results in regard to a few facts. Thus, in speaking of the simultaneous action of an anticoagulating and a coagulation-inducing venom, he states that the action of each opposite-acting venom is entirely lost by their being mixed together. $0.00 \mathrm{I} \mathrm{gm.} \mathrm{of} \mathrm{lachesis}$ venom can coagulate I c.c. of citrate plasma of rabbit in I minute. But if $0.00 \mathrm{I} \mathrm{gm}$. of the venom of Cobra or of water-moccasin is previously added to the plasma and then $0.00 \mathrm{I} \mathrm{gm}$. of lachesis venom, no coagulation takes place. Such incoagulate mixture clots perfectly if I c.c. of a 0.5 per cent solution of calcium chloride is added.

It was also stated by Calmette that even the most procoagulating venoms prevent coagulation of the blood in vitro when a sufficiently large quantity of these venoms is employed. For example, $0.004 \mathrm{gm}$. of lachesis venom and $0.007 \mathrm{gm}$. of daboia venom prevent coagulation of citrate plasma of rabbit. This phenomenon was explained by the theory that these viperine venoms display a powerful proteolytic action upon coagulated or dissolved fibrin. $\mathrm{He}$ refers also to the fact that even with a weaker coagulating dose the proteolytic action is manifest, for the coagulum once formed is gradually softened and finally dissolved, as is usually seen in an experiment with a cube of eggalbumin in a typtic digestion.

In regard to the anticoagulating property of cobra venom and colubrine venom in general, Calmette states that it is due to destruction of the fibrin ferment by the venom, whereas the viperine venoms are said to attack chiefly fibrin itself. 


\section{CHAPTER XIV.}

\section{NEUROTOXINS OF SNAKE VENOM.}

Through the exhaustive investigations of early physiologists and pathologists, notably of S. Weir Mitchell, Reichert, Fayrer, Brunton, Wall, Ragotzi, C. J. Martin, and Calmette, and of those of more recent date, Kyes, Lamb, Fraser, Elliot, Rogers, Flexner and Noguchi, Stephens, Myers, Noc, and others, it has been established beyond doubt that snake venom contains, besides many other toxins, a definite, independent principle which has a specific destructive action upon the nervous system, the neurotoxin. All evidences brought out either by direct clinical or by experimental observations point to the fact that neurotoxin plays the most important part in producing the death of the victims of venom poisoning. As has already been pointed out elsewhere, the venom fibrin ferment and hæmorrhagin can also be primary factors in producing the fatal issue or venom toxication, yet these are not distributed as widely as the neurotoxin and are present only in certain viperine and a few colubrine snake venoms, in such paramount proportions as to form the principal fatal constituent of these venoms.

The neurotoxin is the chief death-dealing agent of the venoms of all poisonous Colubridæ and is present in these venoms in enormous amounts; the venoms of Viperidæ contain it in comparatively small quantities, while those of the Hydrophidæ are richest of all in this principle. It is noteworthy that the chief toxic principles of the Viperidæ and of a few of elapine Colubridæ consist of blood-clotting ferment and hæmorrhagin, and the neurotoxin is of subordinate importance.

Numerous nervous symptoms produced by the injection of different snake venoms convinced most of the investigators of the presence of neurotic toxins in the venoms. It was perhaps Weir Mitchell who first established the complex nature of snake venom and pointed out that there existed in venom at least two distinct sets of poisonous principles, one acting chiefly upon the nervous system, the other causing extensive local lesions. Fayrer and Brunton paid special attention to the importance of neurotoxins and concluded that the direct cause of death from venom poisoning is the same with all kinds of venoms and is the result of the action of the venom upon the nervous tissues. They thought that the neurotoxins are also present in large quantities in the venoms of Daboia, Pseudechis, Notechis, and Crotalus. Wall ascribed the rapid death from daboia poisoning to the presence of a neurotic principle with special elective action upon the center of convulsion. As will presently be seen, this neurotic theory of Wall on daboia poisoning has been completely overthrown by later investigators, especially by Lamb, who demonstrated 
conclusively that the rapid death with convulsions following the injection of daboia venom is due to the production of extensive intravascular thrombosis. C. J. Martin made similar observations with the venom of Pseudechis porphyriacus, but this author showed that pseudechis venom contains at the same time a considerable amount of the neurotoxin characteristic of all colubrine species. Calmette found that the venoms of Naja produce death by attacking first the nuclei of the accessory and hypoglossary nerves and then the origin of the pneumogastric nerve in the medulla. The symptoms are those of bulbar paralysis. Calmette eliminated from venom its local destructive agents by heating and then separating the coagulable proteids of the venom. The neurotoxin remains almost unabated in its strength in the clear fluid, while the phlogenic principles become inert and are separate from the coagulated proteids. Weir Mitchell has shown that crotalus venom loses all its hæmorrhagic principles by a temperature of about $80^{\circ} \mathrm{C}$. without losing its neurotoxic properties. Kanthack, Wall, Fraser, Wolfenden, Martin, Lamb, Flexner and Noguchi, Noc, and others, all confirmed the thermostabile nature of the neurotoxins.

Besides the high resistance of the neurotoxins to heat, it was also found that they retain their toxic properties after a prolonged treatment with alcohol, while the hæmorrhagic toxins lose all their activity by the same treatment.

Venom neurotoxins reside in a group of proteins which in their physical and chemical reactions fall under the class of albumoses and peptones (Mitchell, Reichert, Kanthack, Martin). They are non-precipitable by dialysis and brief boiling, and pass through a gelatinized porcelain bougie under the pressure of 50 atmospheres (C. J. Martin). The neurotoxic activities of these protein constituents are lost on a prolonged boiling, but their protein reactions remain unaltered by the boiling. This fact clearly indicates that the venom albumoses are not identical with the cleavage products of digestion of proteins called albumoses, but differ from the latter in containing certain radicals capable of attacking the nervous tissues and showing far more lability to the action of high temperature. A complete loss of the neurotropic constituents of the venom albumoses can be brought out only by heating venom solution to $100^{\circ} \mathrm{C}$. for an hour or longer. The more concentrated, the slower is the destruction of the venom solution. Heating to $\mathrm{I} 20^{\circ}$ to $135^{\circ} \mathrm{C}$. invariably destroys the neurotoxins. According to Calmette and Noc, the neurotoxin of the venom of Lachesis lanceolatus is much more sensitive to moist heat and is destroyed at $80^{\circ} \mathrm{C}$.

The neurotoxins are not destroyed when the dried native venom is heated to $135^{\circ} \mathrm{C}$., and they remain also unaltered when subjected to the temperature of $\mathrm{I} 9 \mathrm{I}^{\circ} \mathrm{C}$. below zero. The rays of the sun seem to have marked deteriorating influence upon the neurotoxin when the latter is exposed directly in a solution, but not at all in the dried venom. In the presence of fluorescent dyes the neurotoxin in a solution gradually loses its activity when directly exposed to the sunlight. Electricity in a form of high frequency or of constant current reduces the activity of the neurotoxin of the venom. 
Radium emanation has a similar deteriorating effect upon the neurotoxic principle.

Among the chemical agents which have distinct destructive effects upon the neurotoxins, chlorine, bromine, iodine (as trichloride), potassium permanganate, calcium chloride, calcium hypochlorite, potassium and sodium hydrates, and gold chloride may be mentioned. Silver nitrate, mercury bichloride, iron chloride, copper sulphate, and certain acids like tannic acid or picric acid precipitate the neurotoxic principles together with all other proteins, but they are not sufficient to prevent death when the whole mixture is injected into animals.

Various mineral and organic acids do not destroy the neurotoxin even when used in fairly strong concentration. On the contrary, they are found to exert a certain protective action upon this principle against the effect of high temperature.

The physical and chemical properties of the neurotoxins of venom, as outlined above, show the high stability of these toxins in a very remarkable manner. These marvelously powerful toxin-like substances present an amazing contrast with various toxins of vegetable nature, namely, bacterial toxins and certain toxalbumins, because the latter group shows characteristic high lability against various physical and chemical reagents such as light, heat, acid, and alkali.

As already dealt with in a previous topic, the hæmolysins of venom are also very stable, and it has been almost impossible to separate the hæmolysins and neurotoxins through their physical and chemical properties. These two sets of toxins of venom go hand in hand all through these treatments without losing their coexistence. It is no wonder, therefore, that Cunningham was erroneously led to ascribe all nervous symptoms caused by cobra venom, the venom which contains large amounts of the hæmolysins and neurotoxins, to the primary alteration of the blood.

A series of biological analyses, which affords a far more delicate interpretation of the toxic effects produced by venom, has later brought out numerous evidences that the hæmolysins are quite insignificant in the fatal issue of venom toxication under consideration. Thus there are certain animals, the $\mathrm{ox}$, goat, sheep, etc., which are entirely insusceptible to the hæmolytic toxins, yet highly sensitive to the paralytic effects of the venom; this can only be accounted for by the neurotoxic action of the latter. Even in the cases of animals which show susceptibility to the hæmolysins, death is produced by a minute quantity of venom - scarcely enough to dissolve a small amount of the blood, the loss of which can have no serious sequelix, if any at all. It has been shown time and again that the direct application of venom solution to the fourth ventricle in the medulla quickly produces all nervous symptoms which would follow the administration through any other channels, by the skin, blood vessels, peritoneum, or alimentary canal. Here the changes in the blood corpuscles are excluded from the possible cause of the nervous symptoms, much less of the fatal issue. 
The venoms of Enhydrina and Distira, two marine snakes, contain very little of the hæmolytic principles, but are many times more toxic than that of the most dreaded land snake, the cobra. One minimal lethal dose of the venom of Enhydrina can destroy about $\frac{1}{2} \frac{1}{00}$ part of the blood of the animal injected with this venom. (Rogers.)

The resistance of the hæmolysins is shown to be much weaker than that of the neurotoxins against peptic digestion (Flexner and Noguchi).

So much for the biological isolation of the neurotoxins from the hæmolysins.

The next phase of this subject is of its chemical isolation, which was first accomplished by Kyes and later confirmed by von Dungern and Coca. Kyes succeeded in isolating venom lecithid by shaking an aqueous solution of venom with a chloroform solution of lecithin. The venom lecithid is exclusively hæmolytic, but not at all toxic. On examining the venom solution from which the venom lecithid has been separated by centrifugalization, Kyes found that the original toxicity of cobra venom was left in the aqueous portion in undiminished quantity. ${ }^{1}$ Thus the hæmolytic and neurotoxic principles have been completely separated. The injection of the venom lecithid in a large quantity does not kill the animal. On the other hand, the remaining venom solution is no longer hæmolytic, but still highly neurotoxic. Von Dungern and Coca prepared the lecithid by the same method, but they once found that the venom solution still contained a certain amount of hæmolysins, while another time the removal of hæmolysins was complete.

Morgenroth prepared venom lecithid by a slightly modified method, in which methyl alcohol was substituted for chloroform. This preparation was not only hæmolytic, but also neurotoxic to a certain extent. This apparent difference from the result ascertained by Kyes was later explained by him to be due to the adherence of the neurotoxic principles to the precipitated lecithid. Kyes assumed that weak alcohol contains enough water to hold the neurotoxins in solution, and at the moment of the precipitation of the lecithid with ether the neurotoxins are mechanically carried down.

Faust finally isolated an active substance, the ophiotoxin, from cobra venom by pure chemical processes. ${ }^{2}$

Ophiotoxin is obtained from the non-coagulable, non-dialyzable portion of cobra venom by means of Io per cent metaphosphoric acid, which precipitates all the biuret-giving substances. Now, the filtrate contains only proteinfree active substance of the venom, and by adding alcohol it is precipitated out. It is an amorphous, somewhat yellowish powder, soluble in water, and forms foam by shaking the solution. It is slightly acid, non-dialyzable, and nitrogen-free; it has the formula of $\mathrm{C}_{17} \mathrm{H}_{28} \mathrm{O}_{10}$. According to Faust this substance belongs to the same group as sapotoxins. Its action is nearly 5 times stronger than the native venom, but with a great tendency to become inactive

\footnotetext{
${ }^{1}$ Jacoby made a comparative study of the effects of the isolated neurotoxin and the raw venom of cobra, and found that there is no essential difference in their pharmacological actions on the nervous system. Salkowski-Festschrift, 1904, Berlin.

2 For the details see "Physical and chemical properties of venom," page go.
} 
when in solution. The addition of sodium hydrate to the watery solution of ophiotoxin soon renders it inactive. Unless slight acidity of the solution is maintained by metaphosphoric acid it becomes totally or partially inactive during evaporation. The resistance to heat is not stated, but it appears to be very sensitive, as $40^{\circ} \mathrm{C}$. affects its strength.

The injection of 0.000085 to $0.000 \mathrm{I}$ gm. per kilo body-weight of ophiotoxin into a rabbit causes no appreciable symptoms during 15 to 20 minutes, but afterwards it shows diminished respiration and languidness. The locomotive faculty is gradually troubled, paralysis first attacking the hind legs and quickly extending to the front legs. Dyspnoea and paralysis of the body and legs progress and after 45 to 60 minutes cessation of respiration ensues. The heart beats for some time after this stage is reached. The symptoms produced by intravenous injection are the same as the above. In dog the intravenous injection of ophiotoxin causes about the same symptoms as in rabbit, but the peripheral paralysis is not so pronounced. $0.000 \mathrm{I}$ to $0.000 \mathrm{I} 5 \mathrm{gm}$. per kilo of the body-weight is a minimal dose for dog, when injected intravenously, death ensuing in 45 to 50 minutes.

In frog, when $0.05 \mathrm{mg}$. of ophiotoxin is introduced into vena abdominalis it becomes completely paralyzed in ro minutes, but death takes place after I 2 to 16 hours. With this animal it can be shown that there is, besides the central, also the peripheral paralysis. The irritability of muscles to electric stimuli is not affected in this case.

Subcutaneous administration of ophiotoxin is much less toxic and it requires $3 \mathrm{mg}$. for rabbit and $6 \mathrm{mg}$. for dog per kilo body-weight to get fatal effects, namely, 30 to 40 times larger than the minimal lethal dose by intravenous injection.

The administration of ophiotoxin per os causes only insignificant symptoms, salivation, nausea, vomiting, and diarrhœa being observed in dog, but only slight diarrhœea in rabbit.

Concerning the action of ophiotoxin upon the blood, Faust found that it has a moderate hæmolytic power. Noteworthy is his finding that ophiotoxin attacks the blood corpuscles without the aid of serum or lecithin, whereas the native cobra venom requires these substances for complete hæmolytic process with the corpuscles of ox, goats, or sheep.

Faust thinks it probable that ophiotoxin exists in the venom as an esterlike compound of albumose or peptone, and that in that state it is more stable and more easily absorbed from the tissues.

The action of antivenin upon ophiotoxin has not been mentioned.

Ishizaka employed another method for separating the neurotoxin and hæmolysin of the venom of Lachesis flavoviridis from the hæmorrhagin. He shook the venom solution with chloroform for ro minutes and then the precipitate was removed by centrifugalization. The supernatant fluid was again treated with chloroform and separated from the coagula. This process was repeated several times in succession and he obtained a clear solution. This fluid was still as strongly hæmolytic as the original, but its toxicity was 
reduced to one-tenth of the original; no hæmorrhagin was present. Ishizaka thought that this was due to the removal of hæmorrhagin and that its remaining toxicity was due to the presence of the neurotoxin. This fact is interesting because of the new way of preparing hæmorrhagin-free neurotoxin from the Viperidæ venom. Trypsin destroys the neurotoxin, as well as all other active components of this venom.

For some time controversies existed over the cause of death produced rapidly by the injection of daboia venom into the circulation. Brunton, Fayrer, and Cunningham considered it to be due to the direct action upon the medulla. The symptoms in such a case are restlessness and difficulty in preserving equilibrium, gasping, and labored respiration, followed by violent convulsions and sudden exitus. Lamb and Hanna ${ }^{1}$ however, demonstrated that these symptoms are produced by the formation of extensive intravascular thrombosis. A direct application of the venom solution to the medulla or the injection of such into the spinal canal of monkey did not produce immediate symptoms. A few hours afterward the animal appeared dull, lethargic, and inclined to lie down. These are symptoms which are usually observed in chronic cases when the poison is injected subcutaneously. These symptoms, however, soon passed off and the next day the monkey was all right and no further symptoms developed. The above experiment appears sufficient to exclude the primary neurotoxic nature of this venom in the case of rapid death. In the chronic poisoning local and general symptoms develop, but do not indicate much effect of this venom upon the nervous system, mainly affecting the local tissues and the blood.

TABLE 6.

\begin{tabular}{|c|c|c|}
\hline Species. & Fresh solution. & Heated solution $\left(80^{\circ} \mathrm{C}\right.$.). \\
\hline 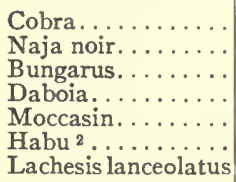 & $\begin{array}{l}0.00005 \text { to } 0.0001 \mathrm{gm} \text {. } \\
0.0004 \mathrm{gm} . \\
0.0004 \mathrm{gm} . \\
0.0008 \mathrm{gm} . \\
0.001 \mathrm{gm} . \\
0.001 \mathrm{gm} . \\
0.005 \text { to } 0.006 \mathrm{gm} \text {. }\end{array}$ & $\begin{array}{l}0.0001 \mathrm{gm} . \\
0.0004 \mathrm{gm} \\
0.0004 \mathrm{gm} . \\
0.001 \mathrm{gm} . \\
0.03 \text { to } 0.05 \text { gm. } \\
\text { Did not kill by } 0.5 \mathrm{gm} \text {. } \\
\text { Ditto. }\end{array}$ \\
\hline
\end{tabular}

Noc determined the toxicity of the venoms of different snakes before and after heating them and demonstrated that the venoms which owe their toxicity to the thermostabile neurotoxins suffer but trifling reduction in toxicity by heating to $80^{\circ} \mathrm{C}$. He separated the coagula by centrifugalization and the clear fluid was used for the test. Table 6 shows the doses of various venoms necessary to kill a mouse within $\mathrm{I} .5$ to 2 hours.

Briot and Massol state that the neurotoxins of cobra venom can easily be absorbed from the mucous membrane of the rectum, and much more easily than by subcutaneous injection.

\footnotetext{
1 Lamb and Hanna. Some observations on the poison of Russell's viper (Daboia russellii). Sci. Mem. Off. Med. San. Dept. Gov. Ind., 1903, No. 3.

3 Ishizaka found that heating this venom to $73^{\circ} \mathrm{C}$. for ${ }_{5}$ minutes reduced its toxicity to one twentyseventh of the original strength.
} 
Calmette and Massol ${ }^{1}$ confirmed the finding of Morgenroth that the neurotoxin can be separated from the neutral mixture of venom and antivenin by means of a weak solution of hydrochloric acid and by almost any acid, mineral or organic. More striking is their finding that the neurotoxic principle of cobra venom can be extracted from the mixture of venom and antivenin by means of 50 per cent alcohol, in which antivenin is insoluble. In fact, Calmette and Massol found that the neurotoxin can be extracted from venom solution by alcohol as high as 86 per cent. They employed findings to show the reversible nature of the compound of venom and antivenin, and I shall later return to this subject in a proper place, when discussing the properties of antivenin.

The neurotoxic principles of snake venom possess specific affinity toward the nerve tissues. Flexner and Noguchi showed that if a few minimal lethal doses of ancistrodon venom be mixed with the mashed brain-substance of susceptible animals the greater portion of the toxicity disappears from the fluid obtained by centrifugalization of such mixture. This fixation of the neurotoxic principles is very pronounced when the emulsion of brain substances is employed, but none or only slightly when the emulsions of other organs are used. Myers, who made a similar experiment before these authors, failed to obtain a positive result.

Calmette lately also found that there is absorption of toxic principles of cobra venom by the brain emulsion.

After the work of Kyes cholesterin is known to possess a certain antihæmolytic property against native cobra venom or lecithid, and the isolation by Faust of a sapotoxin from the cobra venom, and the discovery by Ransom of the antisaponic property of cholesterin, the phenomenon of Flexner and Noguchi, the fixation of the neurotoxin by the nerve tissue, may have to be viewed in a different light. It remains to be seen whether the ophiotoxin of Faust is neutralized by cholesterin or not. In the case of positive outcome, the phenomenon of fixation may simply be due to the action of cholesterin in the brain emulsion. The fixation of tetanus toxin by the brain emulsion, as discovered by Wassermann and Takaki, is no longer a specific phenomenon, but is considered to-day to be the action of cholesterin, protagon, cerebrin, etc. In this regard Noguchi demonstrated that tetanolysin is neutralized by cholesterin, while Landsteiner showed that tetanus toxin is inactivated by protagon. Again, it may be recalled here that Fraser discovered long ago that the bile has antivenomous property against cobra venom.

One of the most important and interesting questions concerning the neurotoxins of snake venoms, both from the practical and the theoretical points of view, is the identity of these principles. It is no wonder that none of the earlier investigators raised this question, because symptomatology does not reveal such delicate differences. All investigations of pre-antitoxin age passed it as granted that the neurotoxic effects of various venoms are pro-

1 Calmette and Massol. Relations entre le venin de cobra et son antitoxine. Ann. Inst. Pasteur, 1907, $\mathrm{XXI}, 929$. 
duced by the same principles. This conception continued to prevail for some time even after the discovery of antitoxins.

While Calmette once made the claim that his antivenin was effective against all venoms, the progress of immunity study did not allow this idea to remain unmodified. Thus C. J. Martin first maintained that Calmette's antivenin, mainly prepared with the cobra venom, is without therapeutic value against the venoms of the Australian snakes. After much controversy Martin agreed with Calmette in that this antivenin has a certain neutralizing effect upon the neurotoxic principles of the Australian snakes, but its ineffectiveness as a therapeutic agent comes from the fact that these Australian venoms owe their toxicity largely to the hæmatoxic (lytic and coagulating) principles against which Calmette's antivenin is without action.

Through the investigations of later workers, especially those of Lamb, even Martin's results have been made an object of some suspicion as to the identity of the neurotoxins contained in the venom of Pseudechis and those contained in the cobra venom.

According to the results obtained by Lamb, the neurotoxins of Pseudechis, Notechis, Bungarus, and Naja are not identical as far as their affinities toward the antivenins are concerned. The antivenin prepared with cobra venom neutralizes only this particular venom, but fails to counteract the neurotoxic effects caused by the other colubrine venoms. Or, the antivenin derived from the animal immunized with the notechis venom has the neutralizing property only for this venom, but not for the others. Similar cross-examinations revealed that the neurotropic toxins of snake venoms are not identical. This question is extremely important in view of the therapeutic application of antivenins in the case of snake bite, and I shall treat this subject in full when I come to deal with immunity in snake venom.

\section{HISTOLOGICAL CHANGES CAUSED BY NEUROTOXINS OF SNAKE VENOM.}

\section{A. Venom NeUrolysis in Vitro.}

The actual histological changes brought about in vivo by the neurotropic toxins of snake venom upon the nervous system have thus far been very carefully demonstrated by the usual section methods. The work of Ewing, Bailey, Kelvington, Lamb, and Hunter sufficiently establishes the relation between the physiological manifestations of the neurotoxins and the anatomical lesions which result from the action of the latter upon the nervous system.

In I903 Flexner and Noguchi ${ }^{1}$ opened a new path through which the destruction of the nerve tissues by venom can be directly observed under the microscope. Their mode of demonstration consisted of exposing the excised ganglia or nerve fibers to the venom solutions of varying concentrations and observing the progress of neurolysis under the microscope. The animals employed were Sycotypus canaliculatus, the periwinkle; Modiola modiolus, a small mussel; and Mactra solidissima, the giant sea-clam. The nerve cells

1 Flexner and Noguchi. On the plurality of cytolysins in snake venom. Jour. of Path. and Bacteriol., I905, X, III. 


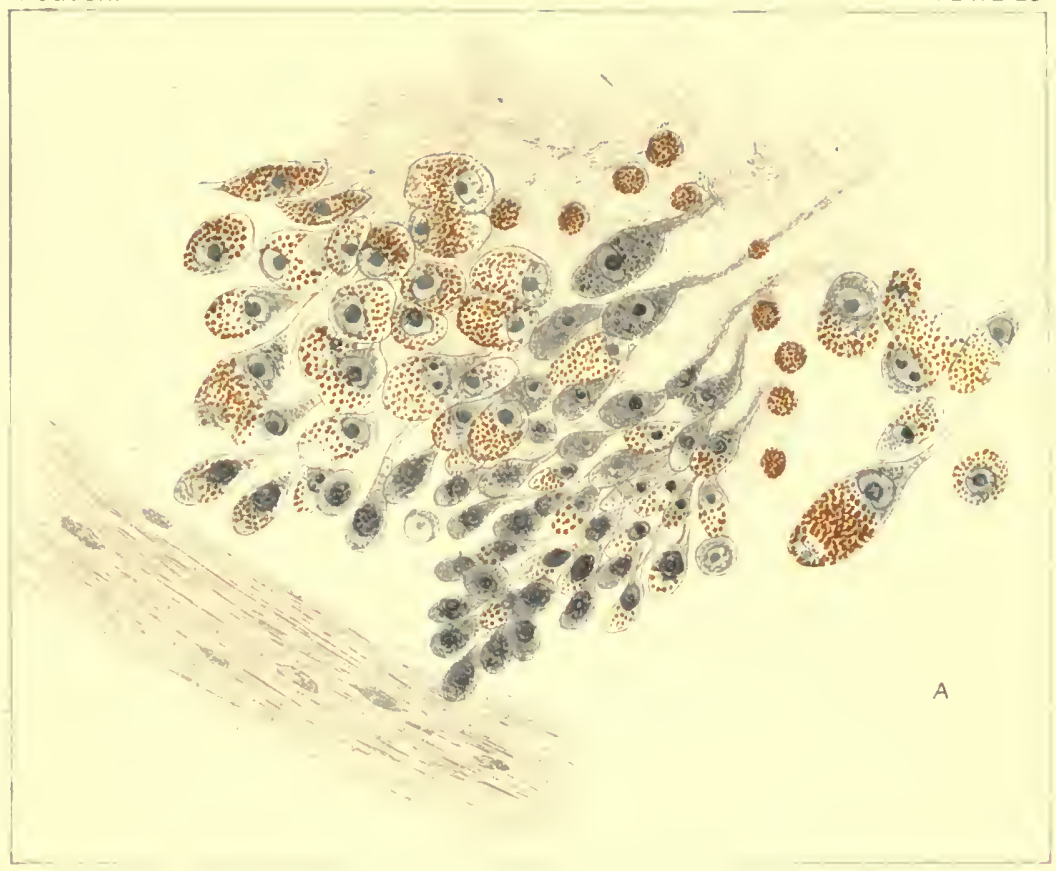

A. Normal Preóesophageal Ganglia of Sycotypus canaliculatus ( 24 hours in sea-water).

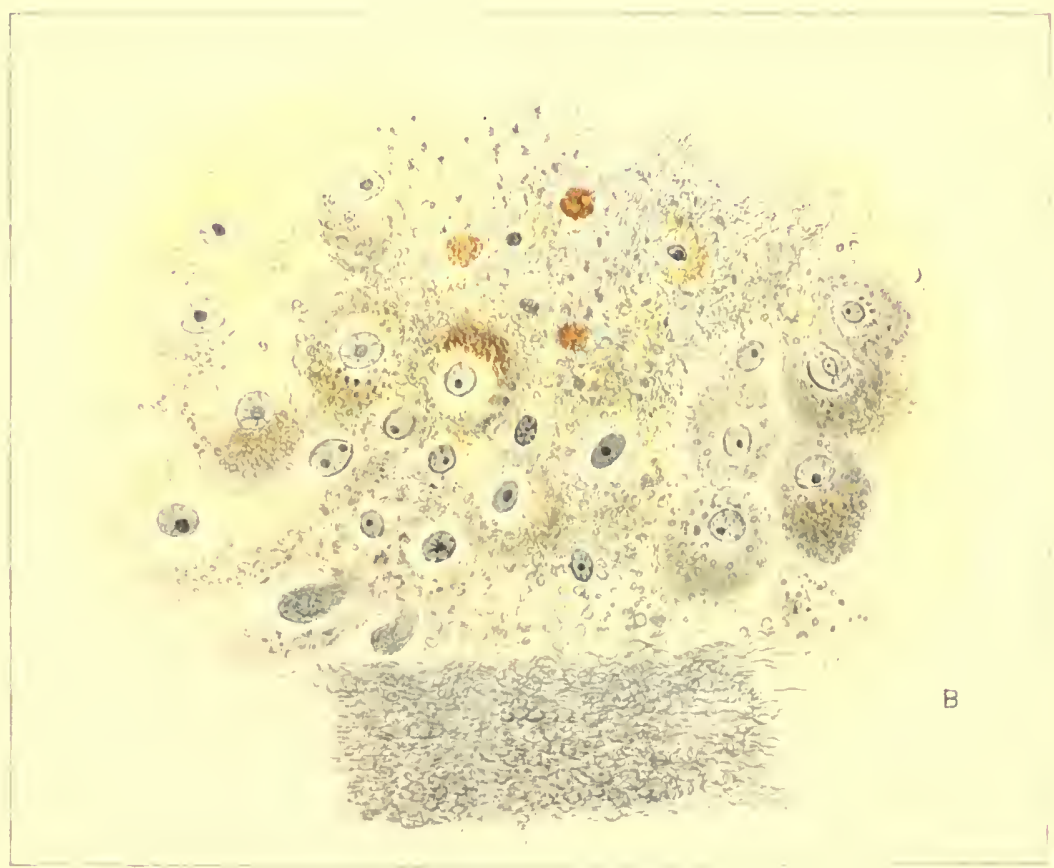

B. The Ganglia acted on by Cobra venom under otherwise same conditions as above. 



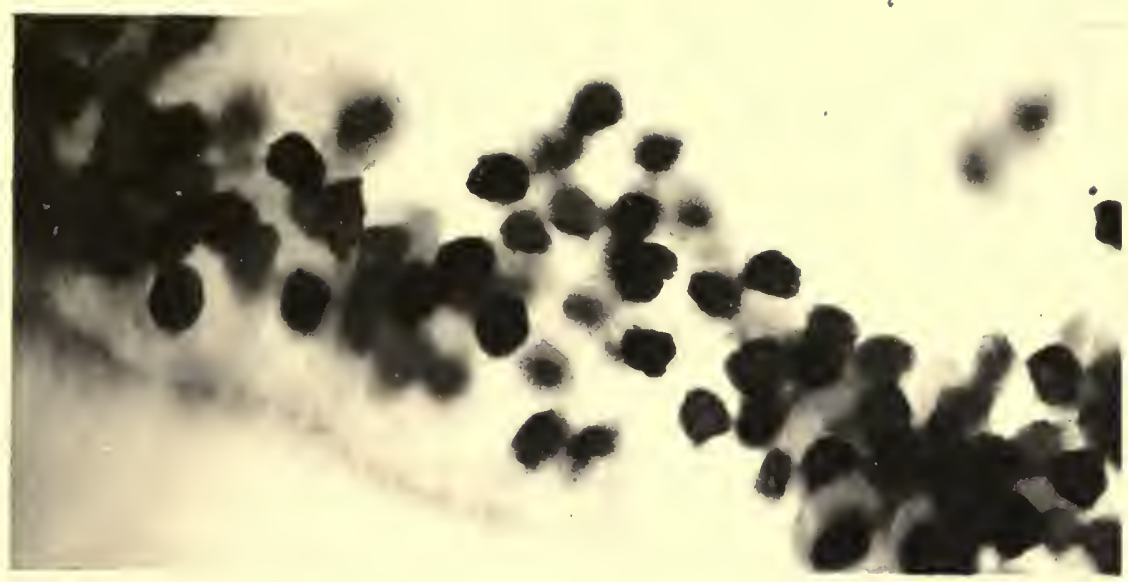

A

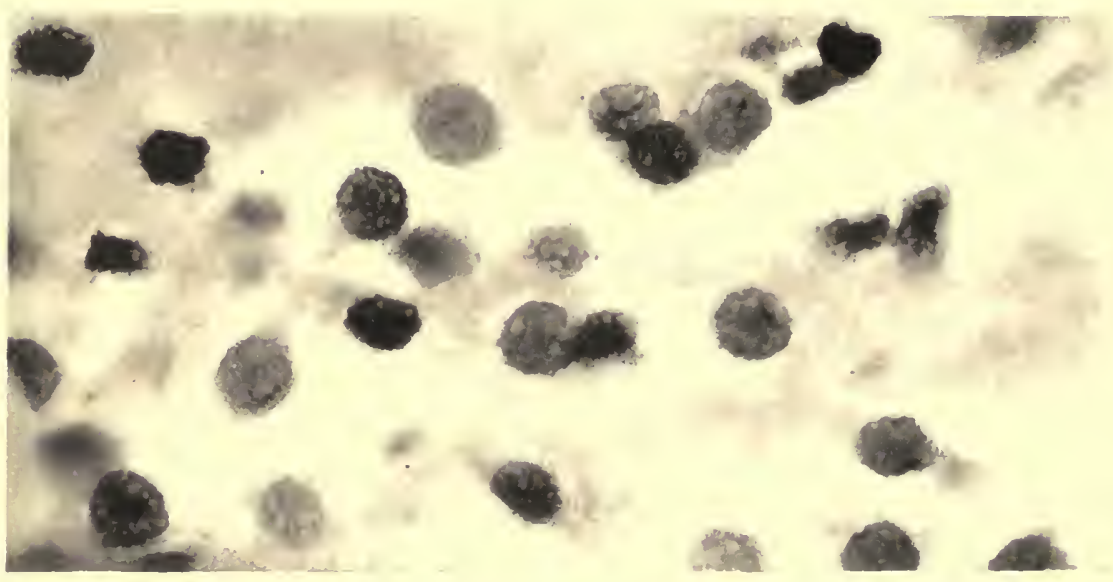

B

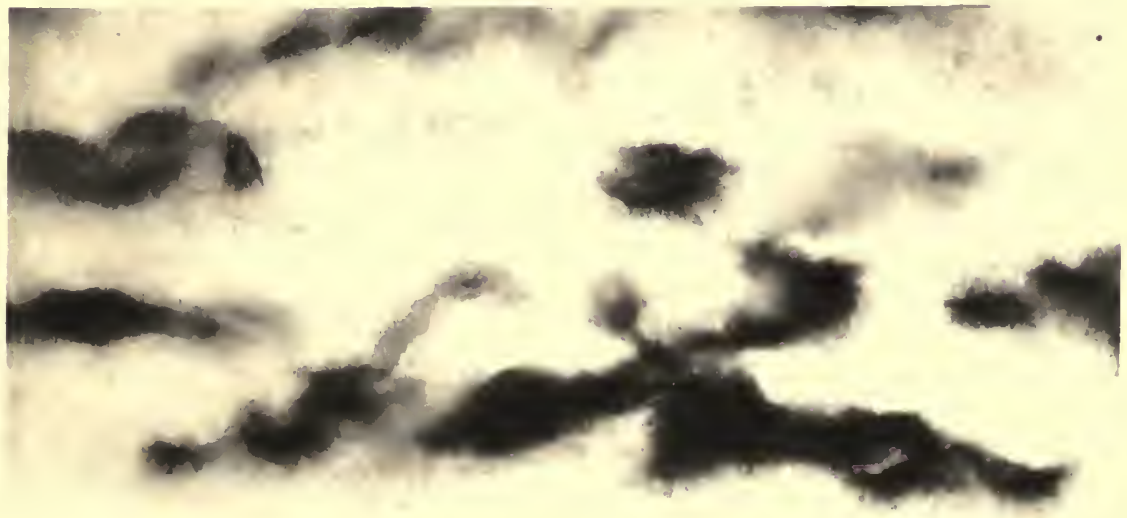

C

A. Medulla oblongata of Rana catesbiana (4 hours in physiol. salt sol.). $\times 500$.

B. The same, kept 2 hours in Cobra venom solution. $\times 500$.

C. The same, kept 4 hours in Moccasin venom solution. $\times 500$.

(Photomicrographs.) 


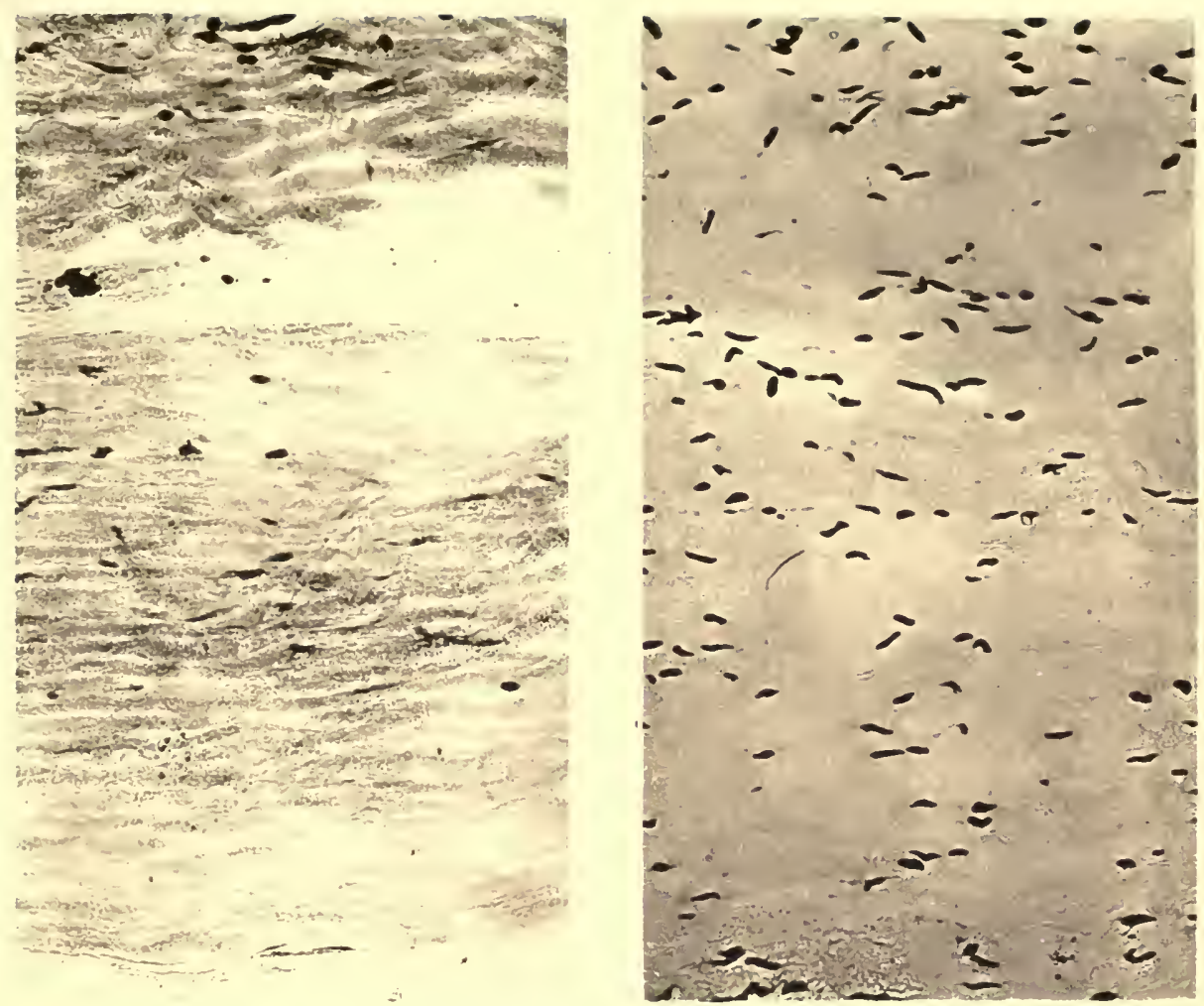

C

A
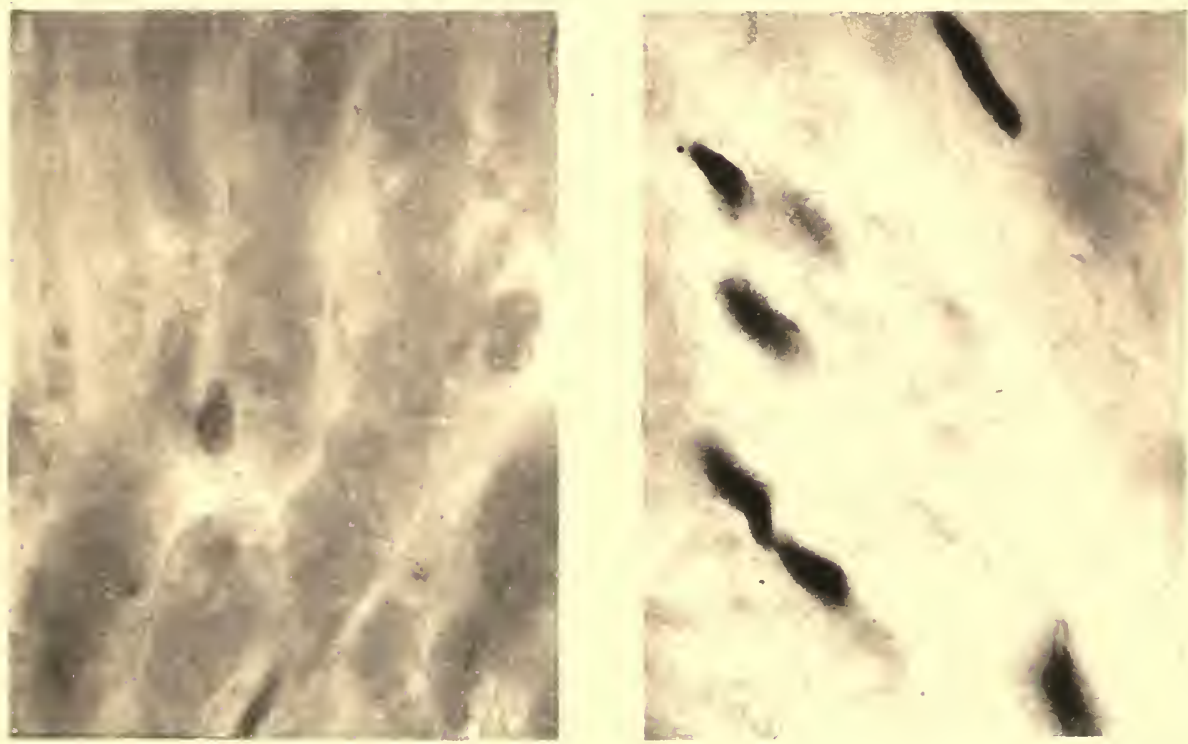

$\mathrm{D}$

B

Nerve Fibers of Rana catesbiana.

A. Normal (low power). B. Normal (high power).

C. Acted on by Cobra venom for 2 hours (low power). D. Acted on by Cobra venom for 2 hours (high power).

(Photomicrographs.) 

employed were those contained in the preœsophageal ganglia. The ganglia having been excised from the living animal, they were carefully and minutely teased in sea water, and then brought under the influence of venom also dissolved in sea water. Observations were made under the microscope at intervals up to 24 hours. Control preparations of the cells suspended in sea water, were examined at corresponding intervals. The temperature was that of the room during the summer months. A brief summary of facts follows.

\section{CELIS OF SYCOTYPUS.}

(Plates 23, 24, 25.)

The controls show two kinds of nerve cells: $(a)$ pigmented and $(b)$ nonpigmented. Between the cells and originating from them numerous fine, non-medullated fibrils occur. The cells are large, reaching $40 \mu$, and are readily observed in unstained preparations. They are oval or elliptical in form, and granular. The pigmented cells contain many highly refractive yellow granules of varying size, which more or less completely obscure the nuclei. The pigment is abundant and granular; there is no diffuse pigment. The non-pigmented cells may equal the first in size and also in number of granules. These granules are markedly uniform in size, round in form, and give a dark grayish hue to the protoplasma, in which they occur in such quantity as to obscure the nuclei. The unpigmented cells are far less numerous than the previous ones. While the first exist in groups, the second tend to appear singly or in small clumps only. The two kinds of cells show marked differences of resistance to venom in solution.

In simple sea water, if protected from evaporation, the nerve cells undergo no appreciable change within 24 hours. After that the cells suffer changes in distinctness of outline, but show no evidence of disintegration for some time.

One per cent cobra venom: Five minutes: The cells are swollen and rendered less distinctly visible. Twenty minutes: Swelling increased; nerve fiber coarsely granular; yellow pigment granules beginning to undergo solution. Sixty minutes: Protoplasma of large pigmented cells very indistinct; pigmented cells disappearing. Twenty-four hours: Almost complete dissolution of the tissue. Here and there some of the large yellow pigment granules have coalesced into globules averaging in size the nucleus of a cell.

One per cent water-moccasin venom: This venom is distinguished in effect from cobra only by its somewhat weaker and slower action. At the end of 24 hours the cell bodies have been dissolved and the pigment liberated, but the latter may still retain the general form of the cell from which it came. Occasionally the granules may be seen to have coalesced, as in the case of cobra-venom solution. The nerve fibers, which are even more resistant to cobra venom than the cell protoplasma, finally vanish entirely.

One percent crotalus venom: This venom is much weaker in action than the other two. Even after contact for 24 hours many of the cells still keep their outlines, and the pigment and many fibrils are still preserved and easily visible. 
The experiments here given confirm previous observations respecting the nerve cells of the mussels and giant sea-clam. The nerve cells of these animals are smaller than those of the periwinkle, and are pigmented; but they are somewhat less satisfactory for study than those of the latter animal. On the other hand, they are somewhat less resistant than the cells of the periwinkle, as is shown by their more rapid disintegration in the controls and correspondingly more rapid neurolysis in venom.

\section{B. Histological Changes of the Nervous System Produced by SNAKE Venom.}

Our knowledge of histological changes produced by various snake venoms upon the peripheral and central nervous system was quite defective until about I900. Many valuable contributions have since been added and to-day we are in a position to corroborate physiological findings by demonstrating gross and minute histological lesions which are accountable for the functional disturbances of the nervous system under the effects of various venoms.

Ewing ${ }^{1}$ found the changes occasioned in the ganglion cells of a rabbit by moccasin venom to be somewhat specific and of extreme grade. Nissl stain showed a general disintegration of the chromatic substance. The outlines of the Nissl bodies were completely obscured; the substance had been deposited in a finely granular form all over the cell body and even in the pericellular lymph space. In the majority of the large stichochromes neither formed bodies nor reticulum could be distinguished. It was evident that the lesions went much deeper than the chromatic substance, affecting the underlying cyto-reticulum, which was granular, disintegrated, and in places completely destroyed. The nuclei were very opaque and the nucleoli often swollen and subdivided. The dendrites were often irregular, shrunken, or detached. These changes constitute a true acute degeneration of the cell, in contradistinction to the simple disturbances of chromatic substance, which may be entirely physiological.

Bailey published his result in the same place. According to him most of the cells of the anterior horn of the spinal gray matter were normal, but a small number presented those modifications in their chromatic elements which probably evidence the early stages of acute degeneration, i. e., ${ }^{\circledR}$ an increase in the granularity of the chromophilic bodies and a fraying out at their edges, with some distinct loss in chromatic substance. The cyto-reticulum is normal. The nucleus may be normal, or there may be an intensification of the surrounding membrane and a thickening of the strands of the nucleoreticulum.

A few cells are found in which there is much greater loss of chromatin, the cell bodies appearing extremely pale and no distinct chromophilic bodies being present.

1 In Gustav Langmann's article "Poisonous snakes and snake poisons." The Medical Record, rgoo, Sept. 15 . 
Kelvington ${ }^{1}$ studied the central nervous system of rabbits killed by subcutaneously injecting varying doses of the venom of Notechis scutatus, the Australian tiger snake. The animals died within from 20 minutes to 36 hours, according to the amounts of the venom given. Death resulted from the paralysis of respiration. There were no signs of inflammation present. Except in the animal which died in 20 minutes after the administration of the poison, the nerve cells exhibited signs of degeneration, which were most marked in those animals which lived the longest (and which received the smaller doses).

The changes consisted in a breaking up of the Nissl granules into a fine, dust-like deposit, which was scattered through the cell. This breaking-up takes place apparently in several stages, smaller masses being formed which subsequently subdivide. The disintegration of chromatic material takes place either throughout the cell or unequally. A dust-like deposit can be traced in the dendrites. The most extreme changes are seen in cells which appear as shadows containing a few fully staining particles. Swelling of the cell-body is not a noticeable feature, and though the nucleus loses its distinctness in outline, it still, as a rule, remains in the center of the cell. The nucleolus is nearly always present.

The position of maximum intensity of the lesions was in the cells about the central canal of the cord, viz, those at the inner side of the bases of the anterior and posterior horns, and especially the small cells in the gray commissure.

In conclusion Kelvington made the following points as to the changes observed in nerve cells after poisoning with notechis venom:

(I) Chromatolysis, the Nissl granules breaking up into dust. Ultimately all stainable substance disappears.

(2) The staining never becomes diffuse.

(3) No swelling of the cell occurs.

(4) The outline of the nucleus is lost, but it retains its central position as a rule. In the very worst cells the nucleus disappears. The nucleolus is usually distinct, though it sometimes appears loose in the cell.

(5) The changes are very unequal in different cells.

(6) The cells around the central canal of the cord show the earliest and most advanced degeneration.

(7) With rapidly fatal doses no microscopic changes occur. Its degree is dependent on the time the animal survives.

(8) Inflammatory and vascular changes are absent.

Since IgO4 Lamb and Hunter ${ }^{2}$ have been studying the histological lesions of the nervous system caused by various venoms of Indian snakes. The

\footnotetext{
1 Kelvington. A preliminary communication on the changes in nerve cells after poisoning with the venom of the Australian tiger snake (Hoplocephalus curtus). Jour. of Physiol., 1902, XXVIII, 426.

2 The Lancet, 1904, I, 20. Op. cit., 1904, II, 518. Op. cit., I904, II, II46; Venom of Bungarus fasciatus (banded krait). Op. cit., I905, II, 886. Op. cit., I906, II, I23I. Action of venoms of different species of poisonous snakes on the nervous system. Op. cit., I907, II, I0I7; Venom of Enhydrina valakadien.
} 
venoms of four different colubrine snakes and one viperine snake had been carefully studied previously. They experimented chiefly on monkeys, usually giving the venom subcutaneously, in order to obtain a longer action of the poison on the nervous system in general.

These two careful investigators found definite signs of chromatolysis at varying stages to be constantly present in the central nervous system of the monkeys injected with these four colubrine venoms - namely, Cobra, Bungarus fasciatus, Bungarus caruleus, and Enhydrina valakadien, but not in the case of daboia-venom toxication. In the case of the venom of Naja tripudians definite histological lesions are demonstrable only when the animal lives longer than two or three hours after the injection of the venom. On the other hand, the venom of Enhydrina may produce within 90 minutes just as pronounced chromatolytic degeneration as in the cases where death does not result until several hours after the injection. The effects of the venom of Bungarus fasciatus are still somewhat different, inasmuch as an incubation period of many hours is required before nervous symptoms appear. Where the symptoms appear within several hours, the animal usually dies within I to 3 days, but should the symptoms appear in 2 to 6 days, the animal dies in a week or longer with the nervous and muscular atrophic symptoms. Lamb calls the first group the acute and the last the chronic poisoning. Cobra venom is never known to produce the latter form of toxication, and therefore it agrees with the acute form of poisoning of bungarus venom.

The intensity and extent of histological lesions observed in all cases of poisoning by these colubrine venoms appear to depend on the period intervening between the time of the injection of venom and the time of death. With the same venom, the longer the interval the more marked are the chromatolytic lesions. In comparing one venom with another the lesions are more pronounced with the kind which kills the animal after a longer duration of toxication. Besides, a certain qualitative difference in activity seems to modify the result, viz, the venom of Enhydrina is not only rapid in action, but also displays a wider affinity for nerve tissues other than the central ganglia.

From their vast materials Lamb and Hunter give a résumé in which all observed lesions are so represented as to enable one to comprehend the processes of chromatolysis and the sphere through which the ganglion cells have to pass under the influence of the neurotropic toxins of snake venom. In the first place, there is a deep and rather diffuse staining of the ganglion cells. In this diffusely stained plasma the Nissl granules are to be seen as deeper-stained bodies, still quite consistent, with rather ill-defined edges. The Nissl bodies next seem to begin to dissolve in the cell plasma, and they suggest the appearance of pieces of metal being acted upon in a strong acid medium. This leads to the next stage, which is still that of diffusely stained cells, but with smaller granules in the plasma. Then the granules and the 
diffuse staining begin to disappear and leave a skeleton cell, with its margin, the reticulum, and nucleus being somewhat deeply stained but very well differentiated. The staining later becomes gradually less intense until we reach the stage in which the cell is little more then a shadow of its former self - the typical "ghost" cell. Vacuoles next appear in the body of the cell and its margin becomes indented as if little pieces had been snipped out. Then portions of the cell disappear altogether and leave little more than a nucleus with the remains of the cell reticulum attached to it. All this time the nucleus, at least in a large proportion of the cells, seems to be little affected otherwise than is shown by a varying intensity of its staining. It remains central, is only exceptionally found at the periphery of the cell, and though it is sometimes lost to view in the diffuse staining of the earlier stages it is almost always to be seen in the later stages of degeneration. Vacuolation is most seen in the pale (ghost-cell) stage, but it is also to be met with in the more deeply stained cells. The connective tissue elements of the gray matter seem to play a somewhat secondary part in this degenerative process. They may be slightly increased in number around the ganglion cell in its earlier stages of chromatolysis, but this increase is not considerable and it is not till vacuolation comes on and the cell begins to break up that they are seen to cluster definitely around the disappearing cell. During this later stage, and sometimes at an earlier stage, they are found indenting the margins and are sometimes inside the body of the cell.

The chromatolytic changes just described appear to be uniformly most advanced in the smaller cortical cells and in the cells of the more central group in the anterior horns of the cord. The larger cortical cells and certain of the cells in the lateral groups of the anterior horns seem to be considerably more resistant to the toxin, for they are slower in showing degeneration, and when it does appear it is hardly ever so extreme as in those other cells. Of the motor nuclei in the pons and medulla the ganglion cells of the third and fifth nuclei were usually affected about equally with those of the cortex and cord. But the seventh, tenth, and twelfth nuclei showed changes less often at a later period, and of a less intensity, than any of the other motor cells in any part of the central nervous system.

In addition to the above description they found that the venom of Enhydrina valakadien, when allowed to act for several hours, produces granular disintegration of myelin and fragmentation of axis-cylinder, thus showing its widespread action on the whole nervous system, not only on ganglion cells, but also on nerve fibers. 


\section{CHAPTER XV.}

\section{HÆEMRRHAGINS OF SNAKE VENOM.}

One of the most alarming symptoms of poisoning in the cases of Crotalus or viper bites is the enormous swelling and profuse extravasation of blood around the wound. Usually these local disturbances set in within 30 minutes and increase steadily in intensity and extent up to 24 hours or even a longer period, when half of the entire body may be swollen and almost blackishpurple in color. The bleeding from the wound often persists a long time. In animals, especially in warm-blooded animals, sanguine extravasation and swelling are equally grave, and even local sloughing ensues. Cold-blooded animals seem to be less susceptible to the hæmorrhagic toxin of venom.

The action of crotalus or water-moccasin venom on the capillary vessels of the omentum or mesentery is very rapid and causes an almost immediate rupture of the endothelial wall of these capillaries, followed by free escape of the blood. This phenomenon can be observed directly under the microscope on the mesentery of frog. If we inject a certain amount of crotalus venom into the peritoneum of animals, the abdominal tension commences to rise in a few minutes and within 30 minutes it is highly distended and becomes difficult to compress. In animals killed with rattlesnake venom after intraperitoneal administration a multiplicity of hæmorrhages appears almost constantly, extending over all the serous membranes, the surface of the visceral organs, the diaphragm, the abdominal muscle-layers, the pericardium, the pleural surfaces, etc. The peritoneal cavity (and pleural cavity in less degree) are filled with bloody exudate.

In certain marine animals occasionally intracranial hæmorrhages and hæmorrhages from the gills are observed. Certain crotaline venoms, such as lachesis venoms, produce severe hæmorrhage in the alimentary tract when administered through the mouth or rectum. In the pigeon the pectoral muscles which receive crotalus venom become thoroughly soaked with the blood and are accompanied by a marked softening.

Now the question arises as to how such extensive and rapid extravasation of the blood is produced. Weir Mitchell and Reichert have rightly pointed out that the hæmorrhages are produced by the venom proteids resembling in their physical and chemical reactions the substances classified under the general name globulin. Thus these authors prepared at least two varieties of globulin, by dialysis precipitation and by copper sulphate precipitation.

Weir Mitchell demonstrated long ago that the hæmorrhagic principles of crotalus venom are non-dialyzable, are destroyed at $75^{\circ}$ or near $80^{\circ} \mathrm{C}$., are precipitable but not destroyed by alcoholic treatment, are easily destroyed by weak acids but not by weak alkalies, and finally are destroyed in the alimentary canal by the action of gastric or pancreatic ferments. The dura- 


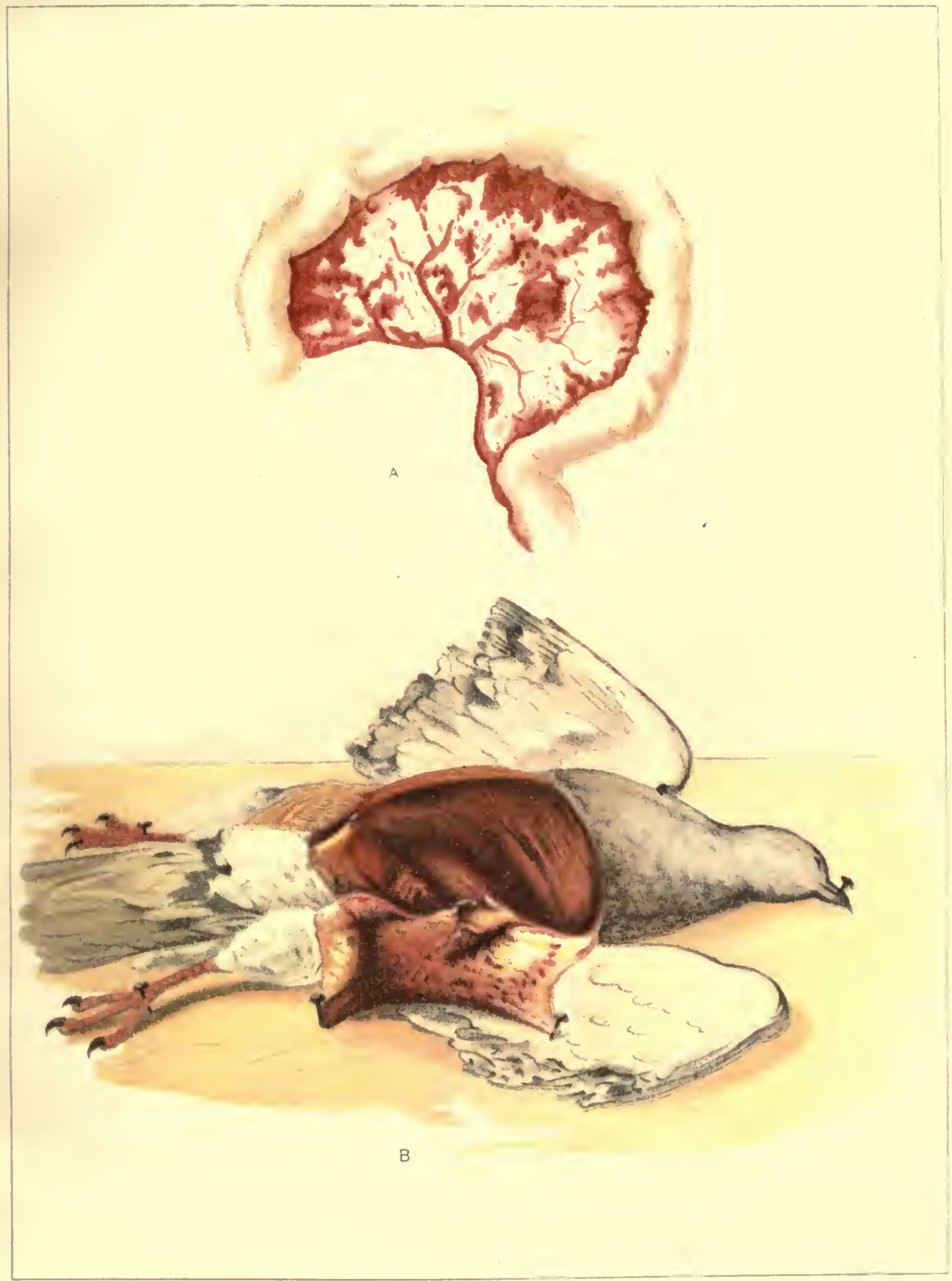

A. Háemorrhages from Capillary and Small Vessels of the mesenterial membrane of Rabbit, under the influence of the venom of Crotalus adamanteus.

B. Hâemorthagic and Softening Effects of the Crotalus adamanteus upon M. pectoralis of Pigeon. 

bility of the hæmorrhagic activity in glycerin or in a dried state has also been shown by this investigator. It is noteworthy that the hæmorrhagic activity of various venoms is parallel with the amount of globulin-like bodies in these venoms.

One can distinguish two distinct local effects produced by various venoms, one hæmorrhagic and the other œdematous. Usually these two effects are present simultaneously and are likely to be confused, but a closer analysis seems to have revealed their independence. Thus Weir Mitchell and Reichert found that the hæmorrhagic effects are the action of the globulins of venom, but the œdematous effects are produced by the dialyzable, peptone-like, proteid fractions. Cobra venom, which is very rich in the peptone-like proteins, causes a marked œdema of the locality of the bite or of the injection of venom, without the characteristic hæmorrhage in the same degree as in the case of viperine or crotaline poisoning. (Plate 26.)

That the venom of vipers is much the same in its general effects as the crotaline venom is recognized by all investigators from the time of Fontana, Mitchell, Fayrer, and Brunton, and for the purpose of avoiding severe local reactions during immunization of animals Calmette employed various chemical and physical agents to eliminate this principle. The clearer and more definite analysis of the hæmorrhagic principles of snake venom was, however, demonstrated by Flexner and Noguchi by their biological methods.

The venom of Crotalus adamanteus is richest in the hæmorrhagic content, and the removal of this principle by means of heating to $75^{\circ} \mathrm{C}$. for 30 minutes deprives this venom of nearly 90 per cent of its toxicity, that is to say, in order to kill an animal with the heated, hæmorrhagin-free venom to to 20 times the minimal lethal dose of the original, unheated venom is required, and the cause of death in the case of the heated crotalus venom is chiefly due to the presence of the thermostabile toxic principle of neurotropic nature. Again, the removal of the neurotoxic principle by means of brain emulsion, which is capable of fixing the neurotropic principle of various venoms, does not materially alter the hæmorrhagic content, and at the same time no diminution in the general toxicity of the crotalus venom takes place. Antivenin which is able to neutralize a large amount of neurotoxins, hæmolysins, and hæmagglutinins, but not hæmorrhagins, is only effective against the fatal effects of certain neurotropic venoms, such as cobra or some ancistrodon venoms, but proves to be totally ineffective against the fatal action of crotalus venom. Inversely, it was found that the antivenin which is strongly antihæmorrhagic, but not antineurotoxic, is without any protective action against the neurotropic venoms, while effective against hæmorrhagic venom.

Before the studies of Flexner and Noguchi there was no distinct demarcation drawn between the hæmolytic and hæmorrhagic processes, and they were described in confusion. But these investigators, by various means, soon cleared away the doubts surrounding the case. On one occasion they found that the antiserum from animals immunized with crotalus serum is markedly antihæmolytic against crotalus venom, but that having no anti-hæmorrhagic 
property it failed to counteract the fatal effects of the venom in vivo. In another instance they found that crotalus venom solution remained almost unaltered in its general toxicity after being kept at $70^{\circ} \mathrm{C}$. for a period of 8 weeks, while that of Cobra had undergone a deterioration down to onetenth of the original activity. The hæmolysins of the crotalus as well as the cobra venom had also undergone a considerable diminution during this period. In testing the hæmorrhagic activity of crotalus venom, it was quickly found that the content in hæmorrhagin was undiminished. In other words, the hæmorrhagins of crotalus venom are remarkably stable in this particular respect, although against high temperature, acids, and other chemical processes, such as oxidation, they are more sensitive to inactive modification. Here the persistence of the hæmorrhagins and the general toxicity in contradistinction to the other toxic principles is clearly demonstrated.

Flexner and Noguchi also demonstrated that the hæmorrhagins of crotalus venom constitute the chief toxic constituents of this venom, by showing the difference which arises from the different modes of introduction into the body. With the neurotropic venoms it matters but little in the final issue whether they are injected into the blood circulation, into the muscular substances, into the serous cavities, or under the skin. Usually death follows more quickly when the venom reaches the central nervous system according to the mode of administration, while the minimal lethal dose remains the same or not very different. On the other hand, if the crotalus venom is injected directly into the brain substance or into the cranial cavity, death is brought about by a small fraction of the minimal lethal dose that is estimated by the subcutaneous administration of the venom. Taking guinea-pigs of 400 grams of body-weight, $0.00 \mathrm{I} \mathrm{gm}$. of crotalus venom, given subcutaneously, kills in about 3 hours, while a smaller dose than this produces extensive swelling, hæmorrhage, and sloughing, but not death. With the same sample of the venom, $0.00005 \mathrm{gm}$. suffices to kill the animals in about 3 hours when injected into the brain. Thus the direct application of crotalus venom to the brain is about 20 times more poisonous than that administered under the skin.

The above experiments clearly point out the difference in the modes of producing fatal effects by cobra venom on one hand and by crotalus venom on the other. Flexner and Noguchi explain this difference on the ground that the neurotoxin, the chief toxic principle of cobra venom, has a specific affinity to the nervous tissue, namely, the ganglion cells of certain parts of the central nervous system, and is not much absorbed or fixed by the other tissues; hence its final effects are nearly the same, irrespective of the mode of injection, although more time is required for the subcutaneous injections than for the intravenous or intracranial administrations. On the other hand, the hæmorrhagin, the chief toxic principle of crotalus venom, has a specific affinity to the endothelial cells composing the wall of the blood and lymph vessels, and when it is introduced at a remote part from the vitally important organ, namely, the brain, it has to travel to the latter in order to produce fatal effects, but as the entire system of the living body is sur- 
rounded and penetrated by a rich supply of blood and lymph vessels the hæmorrhagin seldom invades the central nervous system in a seriously large quantity. Judging from the symptoms only, we readily comprehend that the hæmorrhagin is most energetically absorbed at the spot nearest the place of venom injection. It is only when the venom enters the blood circulation that danger to life is more apparent; otherwise one will find that hæmorrhage will gradually extend wider and wider, but with gradual diminution in its severity, to the remote parts of the body. Naturally a certain portion of the venom necessarily enters the circulation and finally reaches the vitally important region of the brain, and death may follow even the subcutaneous injections, but only after the application of a comparatively large dose.

It is certainly not denied that venom hæmorrhagin may have double functions and that hæmorrhagic effects are only one of the two or more properties it possesses; it may attack certain constituents of the central nervous system as well, but, if it has such action at all, it must be altogether different from that of other neurotropic toxins of venom in general, because its symptoms are entirely different. Moreover, the hæmorrhagic and neurotoxic effects assuming their existence - are produced by the same fraction and disappear at the same time; these are inseparable by our present methods.

In this connection reference may be made to ricin. As is well known, this phytotoxin possesses three functions, hæmagglutinative, hæmorrhagic, and neurotoxic. By pepsin digestion we can destroy agglutinating property, but hæmorrhagic and neurotoxic effects still persist. At present we can not separate the two effects as the work of two distinct substances. Antiricin can neutralize all three properties. It may be that these effects are due to the actions of their correspondingly active principles, and the neutralization by the antiricin is due to the presence of three distinct anti-bodies in the latter. On the other hand, as the antiserum produced with the non-agglutinating digested ricin is able to neutralize the agglutinating function of unmodified ricin, it is not at all improbable that the toxic molecule of the ricin has three different toxophore groups and one common haptophore group; hence the neutralization by antiricin is to combine with and render the common haptophore group inactive. We therefore may consider this point still open to investigation. At all events, Flexner and Noguchi's view, ascribing the chief toxic principle of crotalus venom to hæmorrhagin, must remain unaffected.

Flexner and Noguchi made a quantitative determination of hæmorrhagin in various venoms. For this purpose intraperitoneal injections of venom were employed in guinea-pigs. The lethal dose having been left out of consideration and the animals which survived having been etherized 30 minutes after the inoculation, the existence and degree of hæmorrhage were noted. If, as a standard, I mg. of cobra venom is taken as representing ro minimal hæmorrhagic doses, the same quantities of water-moccasin and copperhead venom would contain Ioo minimal hæmorrhagic doses and of crotalus venom I, minimal hæmorrhagic doses. If the quantity of venom necessary to cause death in a guinea-pig, weighing 300 grams, in 4 hours is injected, there will be 
required respectively, $0.000 \mathrm{I} \mathrm{gm}$. of cobra, equaling I minimal hæmorrhagic dose; $0.2 \mathrm{mg}$. water-moccasin, equaling 20 minimal hæmorrhagic doses; $0.6 \mathrm{mg}$. copperhead, equaling 60 minimal hæmorrhagic doses; and I mg. rattlesnake venom, equaling I,000 minimal hæmorrhagic doses.

The above estimate would amply justify the view of Flexner and Noguchi that the chief toxic constituent of crotalus venom resides in the hæmorrhagin.

Morgenroth has also shown that the hæmorrhagin of crotalus venom is extremely sensitive to the influence of acids. This investigator found that the inactivation of hæmorrhagin can be brought about by a very weak dilution of hydrochloric acid and its action is almost instantaneous. Even if the acid is injected after the venom, provided the venom was promptly followed by the acid injection, no hæmorrhage is produced in the peritoneum of guinea-pigs and consequently no fatality results, even from a large quantity of the venom. I was able to confirm his observation to a large extent.

Flexner and Noguchi had shown, prior to Morgenroth, that the hæmorrhagin is very sensitive to acid treatment. They utilize this mode of modification of hæmorrhagin for immunization, the disagreeable local effects having been easily eliminated without impairing the property of venom to produce antihæmorrhagin in the immunized animals. They considered this phenomenon as an example of toxoid formation of hæmorrhagin in Ehrlich's sense. It is very interesting also to notice that a weak solution of trichloride of iodine produces a similar modification of the hæmorrhagin and can be used for an easy accomplishment of crotalus immunization. Flexner and Noguchi have not made investigations as to the comparative merits of the unmodified and modified venoms in producing antivenins, but, at all events, as the degree of immunity reaches a certain point, the unmodified venom may gradually be substituted, should the modified venom prove in any respect inferior to the unmodified in producing strong antivenin.

Lachesis flavoviridis s. Trimeresurus riukiuanus contains chiefly hæmorrhagin, while hæmolysin, agglutinin, and neurotoxin are present only in trifling quantities. According to Ishizaka, the hæmorrhagin of this venom becomes inactive when shaken with chloroform, or acted upon by hydrogen sulphite, ferric chloride, and acetic or hydrochloric acid.

The removal of hæmorrhagin by heating to $73^{\circ} \mathrm{C}$. diminished its toxicity to one twenty-seventh, while chloroform treatment diminished it to oneseventeenth of its original strength. On the other hand, hæmolytic and neurotoxic effects are not reduced by these treatments.

Ishizaka also found, as Flexner and Noguchi did, that tryptic digestion of the venom completely destroys its toxicity. The modified hæmorrhagin (chloroform, $\mathrm{SH}_{2}$ ) of this venom was capable of producing anti-hæmorrhagin in the animals by repeated injections - this confirming the toxoid formation of hæmorrhagin first described by Flexner and Noguchi.

The same author made an attempt to remove hæmorrhagin by means of endothelial cells of the aorta and richly vasculated organs, but no absorption was observed. 


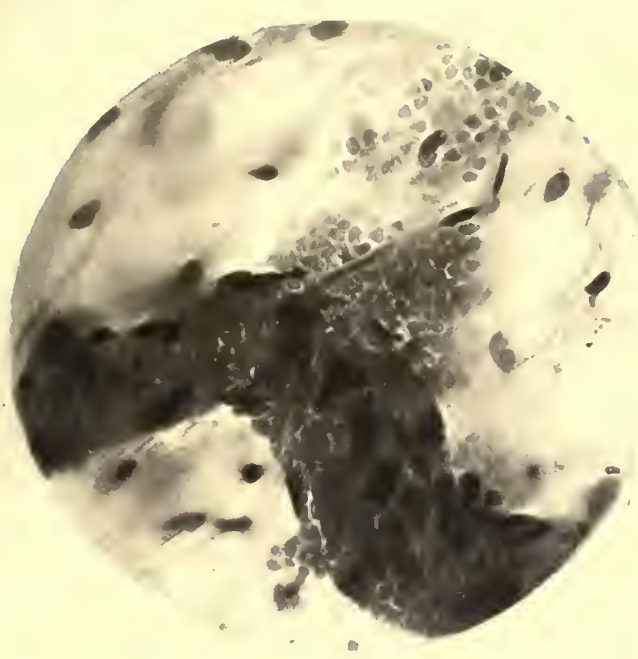

A

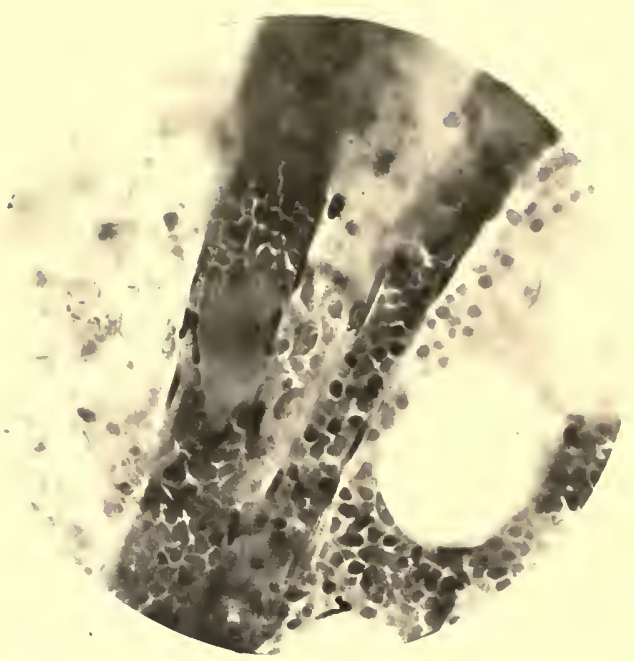

B

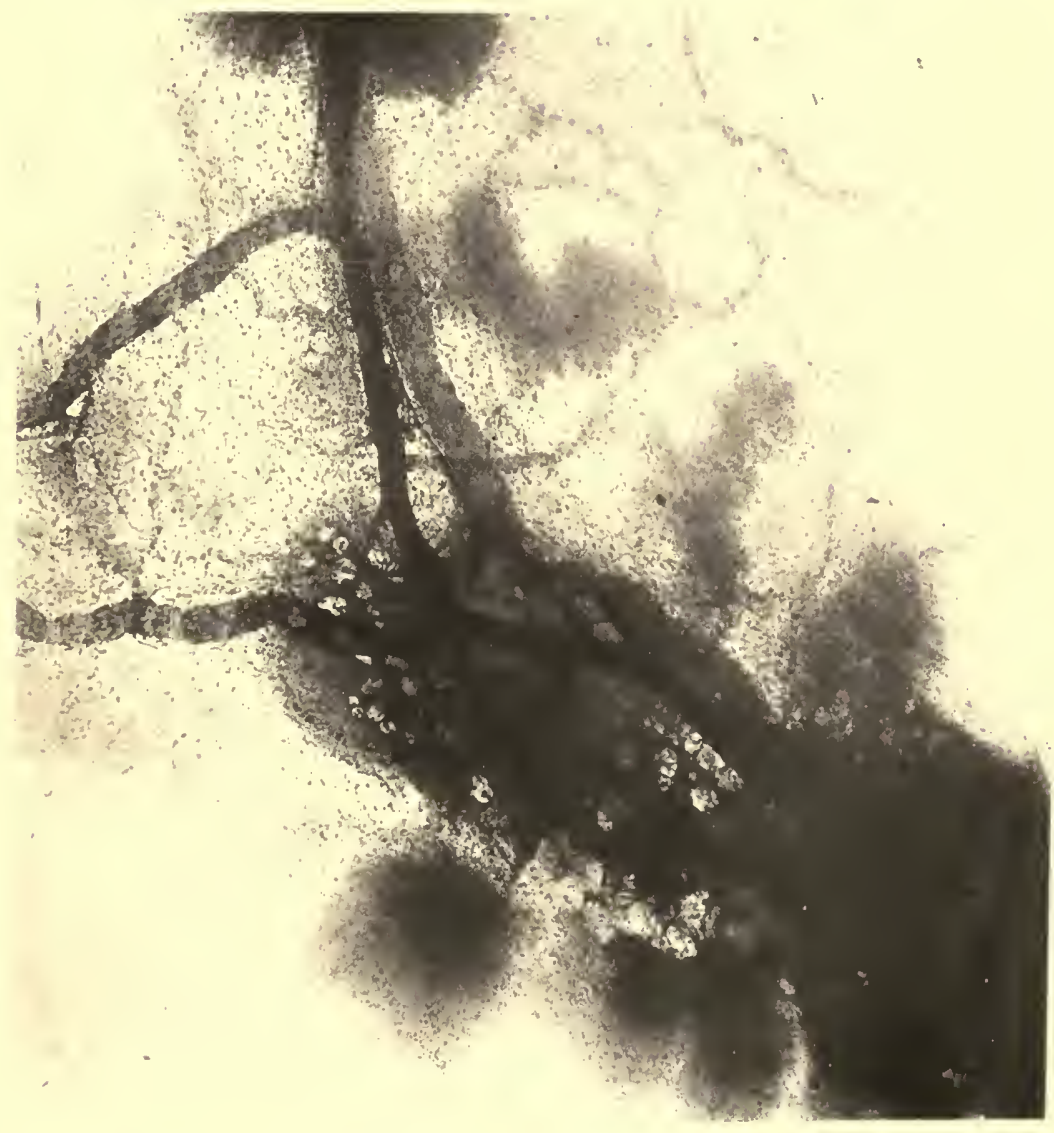

C

A. Hæmorthage caused by venom of Crotalus adamanteus on the mesentery of Guinea-pig Showing one large and two smaller ruptures of Capillary Vessel. Picture shows beginning of hæmorrhage. $\times 1000$.

B. Hæmorrhage caused by venom of Crotalus adamanteus on the mesentery of Rabbit. Showing defect of Capillary Vessel wall caused by disappearance of an Endothelial Cell.

C. Hæmorhage in mesentery caused by Crotalus Venom in Rabbit. $\times 200$. 


\section{HISTOLOGICAL CHANGES CAUSED BY VENOM HEMORRHAGINS.}

In endeavoring to discover the precise mode of the action of hæmorrhagin Flexner and Noguchi have resorted to the mesentery of guinea-pigs and rabbits. The venom (Crotalus adamanteus) was injected into the peritoneal cavity, or, following Weir Mitchell's method, a minute particle of the dried venom was placed on the exposed mesentery. The areas of hæmorrhage, when in thin, transparent membrane, were spread over small bottle-tops, carefully fastened with fine silk, excised, and hardened, usually in Zenker's fluid. The staining was done in hæmatoxylin and eosin. The preparations are transparent and perfectly adapted for the study of the vascular walls. Places showing the smaller, incipient extravasations are suitable for close scrutiny.

The changes in the vascular walls associated with hæmorrhages are clear and unmistakable. The extravasations take place, not by diapedesis, but through actual rents in the walls. The explanation of the rents is of much interest. That they are not simple ruptures seems to be proved by the disappearance, as if through solution, of the parts of the wall at the point of the escape of corpuscles. The solution of continuity is one-sided, and, in some cases, is attended by a displacement of the adjacent endothelial cells, which are pushed outward, away from the vessel, by the force of the escaping blood.

Other phenomena have been noted. Among those of interest is the occurrence of stasis in vessels, attended, usually by hæmorrhage. That the condition is stasis, with the disappearance of the cell-contours, and not agglutination of corpuscles, is shown by the separate statc of the red cells beside the vessels in the rare cases of associated stasis and extravasations. (Plate 27, A, B, C.)

Giant cells occur in the course of the vessels in which venom changes are going on. They are fusion giant cells arising from intravascular leucocytes. From their size they must almost, or completely, block smaller veins in which they form.

The escape of corpuscles is not limited to the red cells. White cells also pass out. Where the latter are noticeable, they are in far greater relative proportion than in the circulating blood. The manner of their escape, namely, by emigration, is easily followed. But especially interesting is the fact that while, in some areas of specimens, the polynuclear cells predominate, in others the mononuclear are chiefly met with.

The escape of corpuscles by dissolution of the walls of the vessels is limited to capillaries and small veins. When acted upon by venom both show irregular bulging of the walls, with which enlargements extravasation is often connected. It is probable that the points of contact with venom, and of injury of the vascular coat, are many, but only in a part of these does the vessel give way entirely.

In conclusion, Flexner and Noguchi made the following statement: "We look upon hæmorrhagin, therefore, in the light of a cytolysin for endothelial cells of blood vessels, the destruction of which is the direct cause of the escape of blood into the surrounding structures." 


\section{CHAPTER XVI.}

\section{VENOM HÆMOLYSIS AND VENOM AGGLUTINATION.}

\section{THE EFFECTS IN VIVO AND IN VITRO.}

Fontana, who observed the loss of coagulability of the blood in cases of death from viper poisoning and the anticoagulating effect of that venom upon the shed blood in vitro, failed to discover any alteration of the corpuscles. Weir Mitchell, who noticed similar effects of crotalus venom in cold-blooded as well as warm-blooded animals, saw no perceptible changes in the cellular elements of the blood, either examined immediately after death or when the blood and venom were mixed in vitro, at least not within any brief period of time, as half an hour. He emphasizes, however, that it is a question open to further study whether or not this direct contact would affect them after a longer time. In his subsequent investigations, once with Reichert and again with Stewart, Mitchell found that the venom of Crotalus destroys blood corpuscles after a long contact in a zone of suitable concentrations of the venom. This observation is very important, as he shows there that a too strong solution of venom again fails to bring about destruction of the corpuscles in vitro, and this phenomenon received confirmation by many later investigators with the venoms of other species of snakes, for example, cobra venom. From the blood of guinea-pig, rendered less coagulable or incoagulable by the crotalus venom, Mitchell obtained beautiful crystals of hæmoglobin which in no way differed from those prepared from the blood of the normal guinea-pig.

Weir Mitchell and Reichert (I886) described a peculiar effect of crotalus venom upon the shape of red corpuscles. Under the influence of the venom the erythrocytes first lose their biconcavity and become spherical, without parting with their pigment. They also exhibit great adhesiveness, arranging themselves into aggregations of various sizes and shapes. The corpuscles comprising these groups sometimes appear to fuse so that their outline can not be determined. (This phenomenon was later confirmed by Flexner and Noguchi, who called it venom-agglutination.) This remarkable condition passes away after a short duration, the corpuscles appearing again in separate spherical form.

The amoboid movements of leucocytes are seen to be quickly suspended in the venom solution.

Fayrer and Brunton (I874) failed to discover any definite alteration of the blood corpuscles when death resulted from cobra venom, except less inclination to form rouleaux and more marked crenation of the corpuscles.

Lacerda (1854), working with a species of Lachesis, probably Lachesis urutsu, mentions crenation of the red corpuscles in chronic poisoning. Some 
are elongated, deformed, or broken up; others present shining points and then break up into minute fragments. Direct contact of the blood with the venom in vitro produces adhesion of the corpuscles, which then lose their normal forms. In a few minutes the dissolution is complete.

Feoktistow (I888), who worked with the venoms of Crotalus and Vipera berus, found that 2 per cent solution of these venoms produced dissolution of the corpuscles after 18 to 24 hours.

Ragotzi (I890) states that the blood corpuscles of mammals injected with cobra venom or directly mixed with it become convex and lose their tendency to form rouleaux. The corpuscles are dissolved after some hours. When a sample of frog's blood is mixed with the venom the corpuscles at once become pale and the stroma invisible. The nuclei remain for some time. The laked blood still shows the oxyhæmoglobin absorption band, but gradually disappears without losing its clear, bright color.

C. J. Martin ( 1893 and 1896 ) made observations on the effects of the venom of Pseudechis porphyriacus upon the blood corpuscles of various animals. The blood of frog was mixed with an equal volume of a 0.7 per cent solution of $\mathrm{NaCl}$ containing $0 . \mathrm{I}$ per cent of venom. The mixture was observed under the microscope. Within a few minutes a disintegration of the corpuscles occurred. The disappearance of the erythrocytes was so complete that at

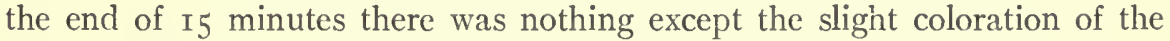
field to distinguish the preparation from one of lymph. The action on the white cells was much slower. At the end of $\mathrm{I}_{5}$ minutes there was no change, but no amoboid movements occurred. Soon nuclei became clearer and then intensely granular, swollen, and finally disappeared. During this time controls were still actively motile. The corpuscles of pigeon were slightly more resistant.

The blood corpuscles of different mammals present remarkable diversity in their power of resisting the destructive effects of the venom, and those of the dog were more sensitive than those of any other animal. With this blood $0.0000 \mathrm{I} \mathrm{gm}$. of the venom was just sufficient to destroy roo c.c. of blood, either in the body or in vitro. The corpuscles of rabbits, cats, guinea-pigs, and white rats, and especially those of man, were much less sensitive to the destructive effect of venom. Martin observed that in dogs hæmoglobin is easily crystallized out from the laked corpuscles, both in vivo and in vitro. The urine nearly always contains such crystals, and in animals which died with suppression of urine two or three days after the injection of the poison, microscopical examination of the kidneys has shown the tubules to be completely blocked with hæmoglobin crystals. Hæmoglobinuria is a frequent symptom with animals other than dogs, except with minimal or subminimal doses.

On examining the blood of animals, immediately subsequent to death from the injection of pseudechis poison, Martin found, except in those cases which succumbed within a few hours after the injection, increase in the number of leucocytes and occasional gathering together of these cells in grape-like 
masses. In dogs injected with pseudechis venom the number of erythrocytes quickly commences to diminish, in some cases to less than half of the original within a few hours. Leucocytopœnia is also striking, as in some instances the number of leucocytes diminished to an almost complete disappearance from the circulation. But after from 30 minutes to 5 hours they reappear almost as numerously as at first. Leucocytopœnia occurs to a trifling extent when the venom is subcutaneously injected. After a few days leucocytosis reaches its height, often 4 or 5 times the normal proportion.

The bile contained hæmoglobin, as Ragotzi found also in the case of cobravenom injection.

Cunningham demonstrated in several experiments that if the blood of an animal which has received a large dose of cobra venom, either intravenously or subcutaneously, be withdrawn from the body after death and allowed to clot, the serum which exudates from the clot is of a red color; also that, if a fowl has been employed, many free nuclei of the red cells are found on examining the blood at death; there has been, in fact, a considerable solution of the bodies of the red cells. Further, he has shown that if the dose of venom injected into a fowl is very large, namely, o.I to $0.3 \mathrm{gm}$., the blood at death contains a great abundance of free nuclei, and the remaining red cells appear deformed; and if the specimen be allowed to stand, at the end of a few hours complete destruction will have taken place.

In I898 Weir Mitchell and Stewart ${ }^{1}$ described the injurious effects exerted by the crotalus venom upon the erythrocytes and leucocytes of the blood of rabbits, snakes, monkeys, and man when mixed outside of the body. The observations were made under the microscope with sealed slide-preparations. Hæmolysis was observed with venom-blood mixtures if the venom is not too concentrated, but not with the blood containing an equal quantity of the fresh venom.

Lamb (IgO3) confirmed the experiments of Cunningham on the destructive action of cobra venom in vivo upon the blood corpuscles of various animals. $\mathrm{He}$ also states the instances in case of man where cell-free sanguineous exudate was found around the point of snake bite. In a donkey receiving slightly over the minimal lethal dose of cobra venom he observed a blood-stained mucous discharge from the rectum.

With daboia venom Lamb made a series of experiments to determine the effects of intravenous and subcutaneous injections of this venom into monkeys, rabbits, pigeons, horses, and donkeys, and obtained results which clearly demonstrate the destructive action of venom upon the corpuscles in vivo. Ante-mortem and post-mortem examinations of the condition of the blood of the venomized animals showed that the serum separated from the loose clots drawn a little before and after death were always stained with free hæmoglobin. If œdema existed around the site of injection of the venom it was red color, but contained no red corpuscles. The urine was dark brown.

1 Weir Mitchell and Stewart. A contribution to the study of the action of the venom of Crotalus adamanteus upon the blood. Trans. Coll. Physicians of Philadelphia, 1897. 3d series, XIX, ro5. 
In the investigations cited in the foregoing pages the primary object was to determine whether snake venoms act destructively upon the cellular elements of the blood, either intra corpore or extra corpore. Although their modes of determining the injurious effects of venom upon the blood corpuscles did not allow earlier investigators to work it out in a quantitative way, enough data were accumulated to conclude the presence of more or less destructive agents in various venoms thus tested. Hæmolysis and also agglutination in certain cases have been clearly demonstrated. In the meanwhile the era of antitoxin and immunity was making rapid progress along all sides of pathology, resulting coincidentally in the preparations of antivenomous serums, first by Calmette, then by Fraser, Lamb, McFarland, Flexner and Noguchi, Brazil, Ishizaka, and Kitashima; and it was natural that antivenomous serum should be drawn into the study of the hæmolytic property of snake venom with brilliant results.

As I will give attention to the immunity questions in later chapters I will not discuss at length the relation between antivenin and venom under the present head, but it is necessary to recognize here the great influence, direct or indirect, exerted by the Ehrlich school on the study of venom hæmolysis. The accurate techniques for determining the strength of toxin and antitoxin in general had been established by Ehrlich and his pupils, and we were thus enabled to distinguish the specific affinity of a given antitoxin to a group of toxins which otherwise would not have been discriminated. Take snake venom, for example: the venoms of different species dissolve the blood corpuscles of a certain animal in a similar fashion, and it would be impossible to distinguish the hæmolytic principle of one venom from that contained in another kind, unless a specific antivenin is used to differentiate them. The same holds good for the toxic constituents other than hæmolysin contained in different snake venoms. No wonder, therefore, that pre-antitoxin investigators were often led to regard the active principles for various sets of cells and tissues as identical in any kind of snake venom. Even after the introduction of antivenin in the study of venom, earlier investigations not unfrequently failed to reveal specificity, and it is evident that this was, to a great extent, due to the lack of pure antitoxins, and also, to a small extent, due to the partial specificity which easily might have evaded differentiation by a less strict quantitative technique of standardization.

The test-tube experimentation with hæmotoxic substances was employed first by Ehrlich in his famous studies on ricin and abrin and their antiserums. Of hæmolytic substances, Madsen, under Ehrlich, introduced a colorimetric measurement for determining the quantity of liberated hæmoglobin in the fluid containing red corpuscles and tetanolysin, thus enabling observation of the intensity of destruction of the corpuscles by the lysin.

The calorimetric estimation of the hæmolytic strength of snake venom was first employed by Myers and Stephen ${ }^{1}$ in their study on cobra venom.

1 Stephens and Myers. Test-tube reactions between cobra poison and its antitoxin. Brit. Med. Jour., 1898, I, 620 . 
These two investigators made the experiments: (I) With a fixed volume of blood mixed with a fixed volume of cobra poison of known strength in a hæmocytometer pipette, and the corpuscles in a given field counted from time to time. (2) Mixing known volumes of blood and poison solutions in small test-tubes and observing in which series of tubes hæmoglobin was dissolved.

Care was taken to have solutions isotonic or slightly hypertonic. It was found that cobra venom has marked hæmolytic powers upon bloods of various kinds of animals as well as man, and that these powers could be checked in the test-tube by the addition of the antivenomous serum. Antivenomous serum, alone, has the power to inhibit the hæmolysis. All other sera tried were without effect. They also found that relationship held good for multiples of these numbers. The proportions varied with different bloods.

In endeavoring to determine whether there might be some relationship between the neutral point in vitro and the protective power of the antivenin in corpore, they found that, for a guinea-pig weighing 250 to $300 \mathrm{gm} ., 0.000 \mathrm{I}$ gm. of cobra venom was the minimal lethal dose, death ensuing in 5 to 8 hours. The hæmolytic action of this poison was neutralized by o.I c.c. of isotonic antivenin, and such a mixture they found was never fatal to animals, but if the hæmolytic action was completely neutralized the guinea-pig might or might not die. When, however, larger quantities of the venom, completely neutralized as regards hæmolysis, were used, they were found to be rapidly fatal on injection, 5 out of 6 animals dying. Thus the investigators conclude that there is no positive connection between the neutralization and the hæmolytic and toxic actions of the venom. Their results are summarized thus:

(I) Cobra poison is strongly hæmolytic in vitro.

(2) This action is neutralized by antivenomous serum, and the action of the latter is specific.

(3) For certain doses (0.000I gm.) the measure of this neutralization in vitro is a neutralization in corpore for guinea-pigs.

(4) This neutralization is chemical, not cellular or vital.

In a subsequent communication ${ }^{1}$ on the same subject, Myers and Stephens state that poison solutions containing from 0.002 to $0.0075 \mathrm{gm}$. in I c.c. hæmolyze blood not at all; at other times, less completely than weaker solutions do. Dog's blood is found to be exceedingly sensitive to the poison, hæmolysis in this animal occurring in very dilute solution - for instance, in the strength of 0.5 c.c. $=0.000009 \mathrm{gm}$. Further, with regard to dog's blood (and the same holds good for frog) it was observed that the hæmolysis was often complete in less than an hour in solutions of various strengths, while in the corresponding tubes for guinea-pig and man hæmolysis was not apparent for three to four hours, though eventually complete.

In continuation of the investigations which he commenced with Myers, Stephens ${ }^{2}$ made another valuable contribution to our knowledge as to the

1 Stephens and Myers. The action of cobra poison on the blood. A contribution to the study of passive immunity. Jour. of Pathol. and Bacteriol., 1898, V, 279.

3 Stephens. On the hæmolytic action of snake toxins and toxic sera. Jour. of Pathology and Bacteriology, I900, VI, 273. 
biological nature of hæmolytic and toxic constituents of snake venoms and certain toxic serums. In this article Stephens confirmed the peculiar antihæmolytic property of cobra venom when employed in a strong concentration, namely, more than $0.0000 \mathrm{I} \mathrm{gm.} \mathrm{in} \mathrm{I} \mathrm{c.c.} \mathrm{He} \mathrm{failed} \mathrm{to} \mathrm{find} \mathrm{the} \mathrm{reason}$ for this non-occurrence of hæmolytic phenomenon in a concentrated venom solution, but at the same time he brought out another puzzling phenomenon with cobra hæmolysis - that the addition of a large quantity of horse serum to such mixture (large quantity of the venom and the blood) induces a rapid and complcte hæmolysis. At that time this was entirely inexplicable, although we to-day understand it and I will later return to this phenomenon.

In testing the neutralizing power of Calmette's antivenin against the hæmolytic principles contained in various snake venoms, Stcphens found that it harl a very slight neutralizing action on the hæmolysins of the venoms of Daboia, Crotalus terrificus, and Pseudechis porphyriacus. Against cobra venom the antivenin neutralized the lytic action of $0.00045 \mathrm{gm}$., or about 4 minimal lethal doses, while the same quantity could neutralize only $0.00003 \mathrm{gm}$. of daboia venom, a quantity far less than the lethal dose. Stephens states that normal or antivenomous serums of horse sometimes produce quite marked and progressive hæmolysis and sometimes an opposite effect. Thus, when antivenin was introduced in a dose insufficient to neutralize cobra venom completely, a much prompter hæmolysis may occur than in the saline venom solution. Here he expresses his uncertainty as to the identity of the hæmolytic principles existing in different venoms.

Stephens's observations on the hæmolytic and toxic effects of the serums of Tropidonotus natrix, python, frog, and eel, as compared with those of venoms, are very interesting. With the tropidonotus scrum he found a certain antihæmolytic action of antivenin, while normal horse serum had none. $\mathrm{He}$ found that a rabbit immunized against the tropidonotus serum to quite a high degree succumbed quickly to a single lethal dose of the scrum of an Australian python, and concluded that the hæmolytic as well as toxic constituents of these two serums can not be identical. While the serum of horse had marked promoting effect upon the cobra as well as daboia venom hæmolysis, an inhibitory effect was found in the serums of the snake.

Stephens filtered a 0.25 per cent solution of cobra venom through a gelatinized bougie, which had previously been used to filter bullock serum, until the filtrate gave no albumin reaction. By repeated filtrations uncler high pressure, the filtrate was tested each time for its hæmolytic and toxic actions. The filtrate was still active after the third passage, but no more after the fourth. A trace of biuret reaction was given with this last filtrate.

In I900 Walter Myers contributed another very exhaustive study on the nature of toxic constituents of cobra venom. From his own experiments, as well as from those of many of his predecessors, notably those of Weir Mitchell and Reichert, he concluded a priori that in the venom of cobra di capello there are present at least two poisonous substances. One of these is hæmolytic, and the other causes death, probably by its action on the respiratory 
center in the medulla oblongata. Myers called the first cobralysin and the second cobranervin. The reasons for their independent existence were first furnished by the experiments of Mitchell and Reichert, ${ }^{1}$ who found that the hæmolytic principles are precipitated and destroyed by heat before the nerve poison is affected. The second reason is deduced from the fact that the fatally acting principles are set free in a considerable amount when multiple doses of cobralysin are completely neutralized by antivenin. ${ }^{2}$ It is only for the minimal lethal dose, or a little over (using guinea-pigs as test animals), that the neutralizations of the two effects run hand in hand. The third reason is that the susceptibility, in vitro, of the red corpuscles of various animals bears no relation to the susceptibility of those animals to subcutaneous inoculation of the venom.

In this series of study Myers adopted Ehrlich's ${ }^{3}$ famous fractionated saturation method ${ }^{4}$ for diphtheria toxin-antitoxin to analyze the combining property of cobralysin for anticobralysin. The selection of suitable blood for estimating the hæmolytic power of cobra was by no means an easy task, for the corpuscles of the most susceptible animals (namely, guinea-pig and dog) were often hæmolyzed by the horse serum alone, rendering the determination of the true action of the venom extremely difficult. The corpuscles of rabbit were more resistant than these two specimens, but much more venom was necessary to obtain enough reaction, and this again made it inconvenient, as the antihæmolytic power of the antivenin he had in hand was so weak that it required I to 2 c.c. to counteract the hæmolytic effect produced by $0.00 \mathrm{I} \mathrm{gm}$. Myers finally came to use human blood, which, when suspended in I c.c. of isotonic (o.8 per cent) saline solution, was hæmolyzed by 0.000003 to $0.000005 \mathrm{gm}$. in 2 hours at $15^{\circ} \mathrm{C}$. It was found that the hæmolytic action of $0.00 \mathrm{I} \mathrm{gm.} \mathrm{of} \mathrm{dried} \mathrm{venom} \mathrm{was} \mathrm{neutralized} \mathrm{by} \mathrm{I.3} \mathrm{c.c.} \mathrm{of} \mathrm{the} \mathrm{antivenin.}$ Theoretically the addition of one-thirteenth of this amount of the serum should neutralize $\frac{0.001}{13} \mathrm{gm}$., and the second fraction again another $\frac{0.001}{13} \mathrm{gm}$. and so forth. But, in reality this was found not to be the case. The first fraction, instead of neutralizing the theoretical portion of the venom $\frac{0.001}{13} \mathrm{gm}$., neutralized $0.00 \mathrm{I} \times 0.8$, leaving only $0.00 \mathrm{I} \times 0.2 \mathrm{gm}$. still in the fluid unneutralized. Speaking of the hæmolytic units, o.ooI gm. contained 2,000 units, but after the addition of 0. I c.c. of the antivenin only 400 units were found to be present in the mixture, whereas it should, theoretically, neutralize only $\frac{2000}{13}=\mathrm{I} 53$ units by this fraction. The addition of 0.2 c.c. of the antivenin left 200 units, 0.4 c.c. 125 units, 0.6 c.c. 58.8 units, 0.8 c.c. 20 units, etc. Finally I.3 c.c. left a dose less than I unit of cobralysin.

These paradoxical phenomena, first seen by Ehrlich and then by Madsen with other toxins, led Myers to assume that cobralysin consists of a set of substances whose toxic effect can not be observed, but have an antitoxin-

1 Weir Mitchell and Reichert. Smithsonian Contrib. Knowl., Washington, 1886.

2 Stephens and Myers. Jour. of Pathol. and Bacteriol., r898, V, 279.

3 Ehrlich. Die Wertbestimmung des Diphtherieheilserums. Klin. Jahrb., r897, VII, 299; and Ueber

die Constitution des Diphtheriegiftes. Deut. med. Wochenschr., 1898, XXXVIII, 597.

4 Madsen. La constitution du poison diphthérique. Ann. Inst. Pasteur, I899, XIII, 568. 
combining property of varying affinity. With this assumption Myers explained these results, and thought that cobra venom contains, besides real intact hæmolysin, a number of toxoids, which are still able to unite with the antitoxin, although their hæmotoxophore side-chains are inert. In some instances he found that the first fraction of the serum neutralized somewhat less than the second. In these cases the presence of prototoxoids was assumed. In fact, according to this hypothesis, the neutralization of a given amount of cobralysin means the neutralization of toxin and toxoids (prototoxoid and deutotoxoid, but not the least reactive epitoxoid); and the amount of any one fraction of the antivenin to combine is always the same (only differing in the toxic expression), which is due to the toxin alone, but not to the toxically inert, antivenin-combining toxoids. At last, Myers tried to determine the reason for the fact that in a venom there can be present toxin and toxoids. He found that when a solution of cobra venom is placed at room temperature (still quicker at $37^{\circ} \mathrm{C}$.) its hæmolytic power becomes rapidly reduced. This reduction in hæmolytic power was not followed by a parallel loss of its combining power with antivenin. In other words, hæmolytic toxoids were formed in such solutions.

\section{THE NEW ERA OF THE STUDY OF VENOM HEMOLYSIS.}

Definite proofs of the existence of hæmolytic and hæmagglutinative substances in different venoms in varying proportions have thus been amply brought about both in corpore and in vitro. In the last few years prior to I900, the investigations assumed a character of quantitative estimation of the hæmolytic principles in various venoms and suggested their specificity as well as their insignificance in the lethal properties of these venoms. The estimate made of their action upon the blood corpuscles was, however, not understood at all. It was Flexner and Noguchi who for the first time found that the active principles of the venom require a second substance to manifest their solvent function upon the blood corpuscles, and this marks the opening of the new era of study of the hæmatoxic actions of the venom.

In I9O2 these investigators discovered that certain venoms do not dissolve the blood corpuscles from which every trace of serum has previously been removed by repeated washings in an isotonic saline solution. But if the separated serum is restored to each of the several kinds of blood corpuscles treated with venom, lysis takes place. They found that the substance or substances of those serums capable of activating the hæmotropic principles of venom have the properties of serum complements, inasmuch as the elective removal of the serum-amboceptors for each kind of the washed corpuscles by absorption in the cold $\left(0^{\circ} \mathrm{C}\right.$.) did not impair their activating property, and heating the serum to $56^{\circ} \mathrm{C}$. for 30 minutes deprived some of the serums of this activating action. Neither did solution of the venomized corpuscles take place at $0^{\circ} \mathrm{C}$. The abolition of the activating property by heating to $56^{\circ} \mathrm{C}$. was observed with the serums of rabbits, guinea-pigs, and Necturus, but seldom with that of dogs. The velocity of the hæmolytic process was 
found to be extremely variable, according to the kind of complement employed. Thus dog's complements produced very rapid solution of the venomized corpuscles, while with those of guinea-pig and rabbit lysis proceeded slowly, taking many hours to complete the reaction. In a second series of experiments Flexner and Noguchi showed that the blood corpuscles of susceptible blood take up the hæmolytic principle of venom by absorption. The supernatant fluid obtained by separating the corpuscles from the venom solution by centrifugalization becomes far less active upon the same kind of cells, but is powerfully active upon the other kinds, to which it gives in turn, by absorption, the hæmolytic bodies electively if each is treated in succession.

From these observations Flexner and Noguchi drew an analogy between the mechanisms of venom hæmolysis and serum hæmolysis: whereas the intermediary bodies in the first are present in venom itself, in the second both the intermediary bodies and the suitable complements are present in the same serum. In Ehrlich's terminology venom contains amboceptors and the serum contains complements. (Plate 28.)

Flexner and Noguchi next mentioned that venom, especially that of Crotalus adamanteus, Ancistrodon piscivorus, and Ancistrodon contortrix, produces agglutination of the washed corpuscles. With the defibrinated blood or the washed corpuscles mixed with suitable activating serum, there is only a momentary agglutination or none, as the cells become quickly dissolved. The more resistant the corpuscles and the stronger the venom solution, the more pronounced and lasting is the phenomenon of agglutination. Venom agglutinins are distinct from venom hæmolysins. The corpuscles agglutinated by ricin are readily dissolved by venom hæmolysins, unless there is a very prolonged action of the former, with more or less delay in liberating hæmoglobin from the firmly conglomerated stroma.

The same authors studied the effects of venom upon leucocytes in vitro. In studying the changes taking place in the leucocytes under the influence of venom a warm stage $\left(37^{\circ} \mathrm{C}\right.$.) was used, the edges of the cover-glasses having first been sealed with vaseline. The leucocytes were obtained from the pleural or peritoneal cavity by injection of chemotoxic substances. The venom solutions varied from to per cent to 0.002 per cent in isotonic saline solution. With cobra venom almost no effect was observed in a solution of 0.002 per cent, whereas 0.002 per cent of rattlesnake venom and 0.005 per cent of moccasin venom caused definite changes.

Only the granular cells showed motility. Weak active solutions are without immediate effect on motion, but begin to manifest an inhibiting action after about an hour, the controls being still motile at the end of 2 hours or longer. After the motility ceases, the cells in general, except the lymphocytes, show increased granulation due to the appearance of coarser and more numerous granules in the protoplasma, the nuclei coincidently becoming more distinct. After 6 hours the majority of the largest granular cells have already disintegrated, the nuclei having been liberated. After 24 hours most of the 


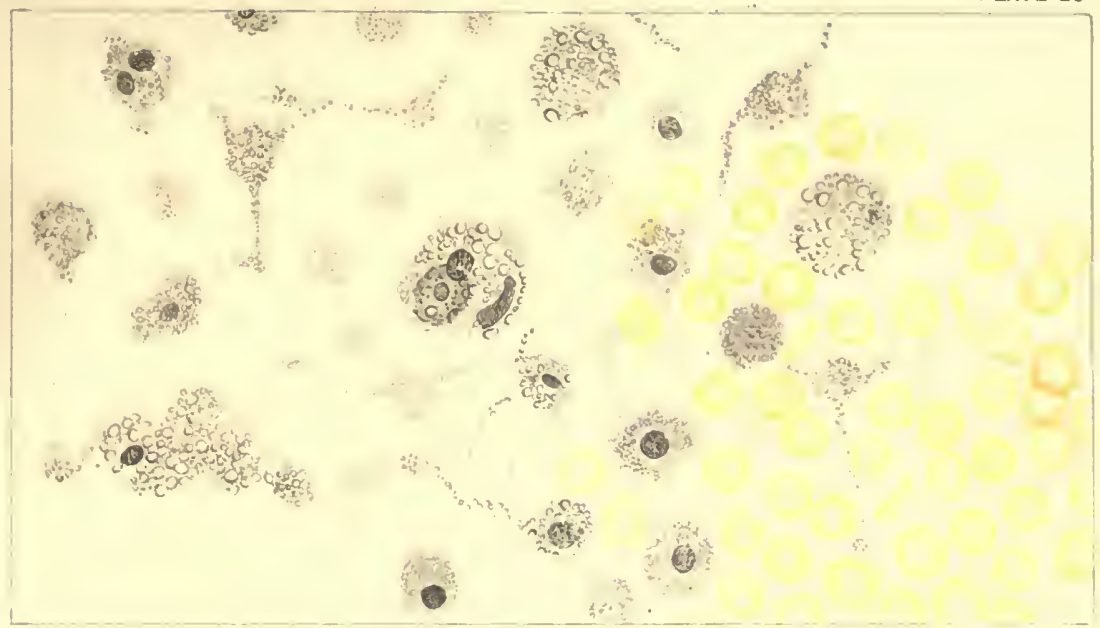

A. Normal rabbit blood; 5 minutes at $37^{\circ} \mathrm{C}$.

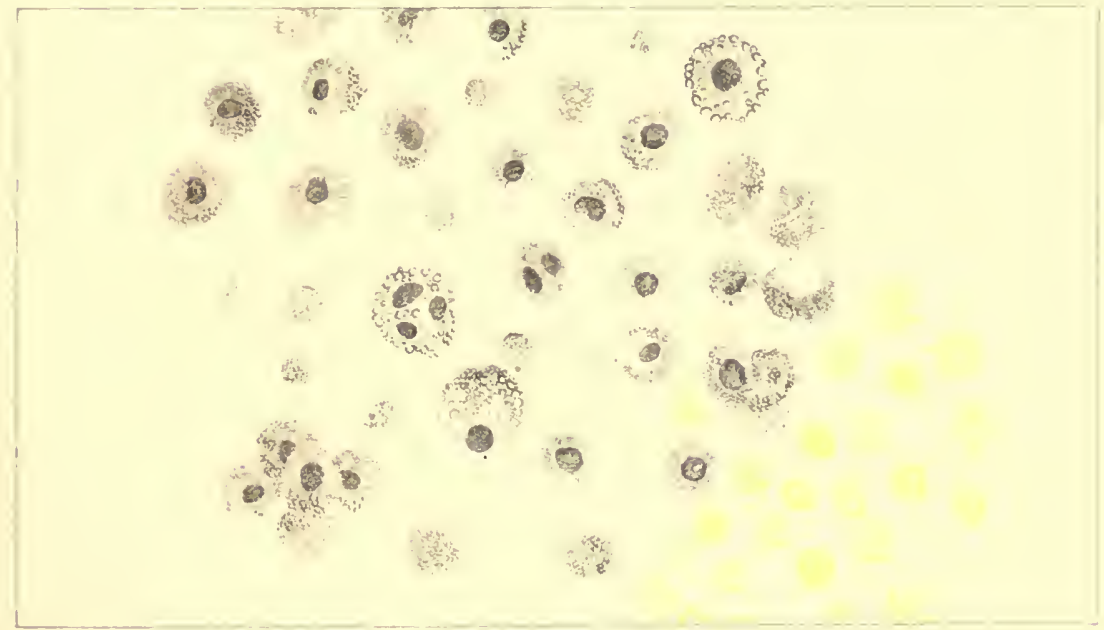

B. Normal; 24 hours in normal saline at $37^{\circ} \mathrm{C}$.

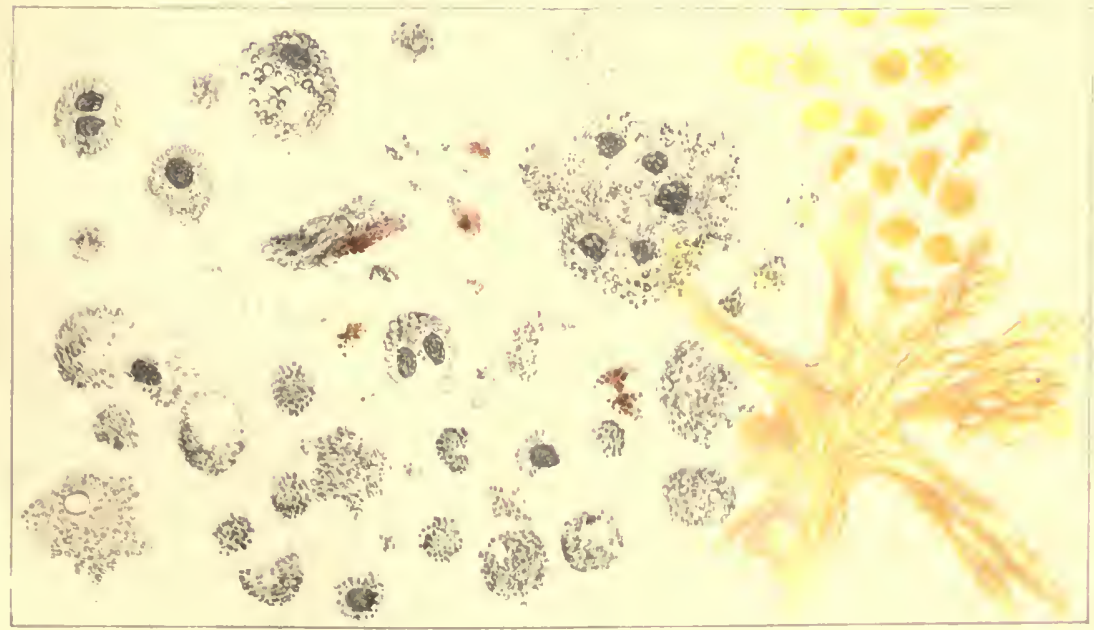

C. Crotalus venom, 0.5 per cent; 6 hours at $37^{\circ} \mathrm{C}$.

Effect on White and Red Corpuscles of Rabbit. (Drawings by Noguchi.) 



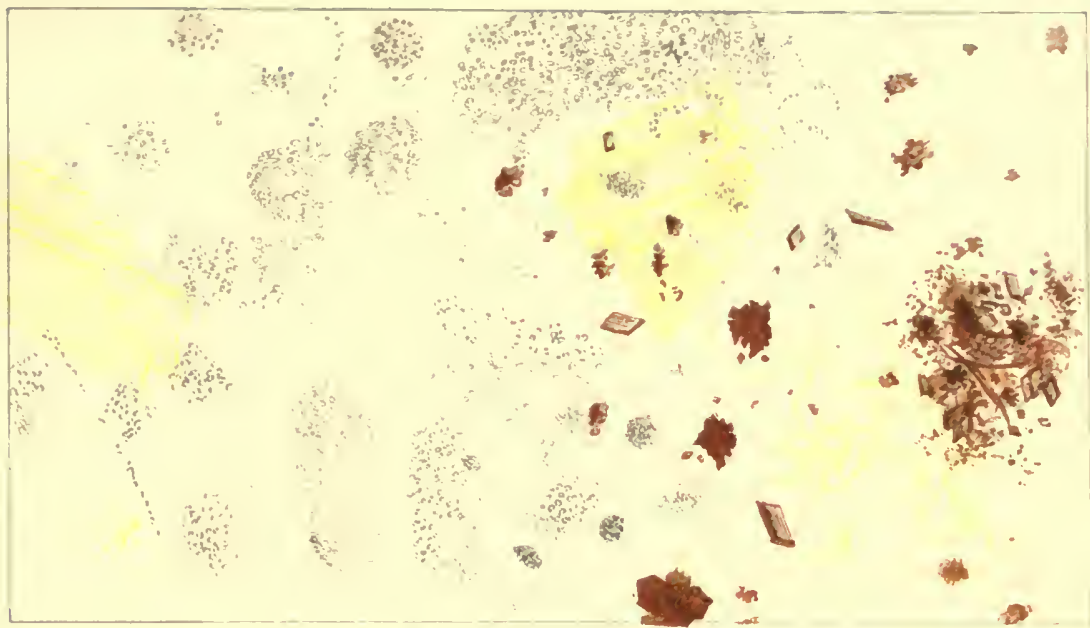

A. Crotalus venom, 0.5 per cent; 24 hours at $37^{\circ} \mathrm{C}$.

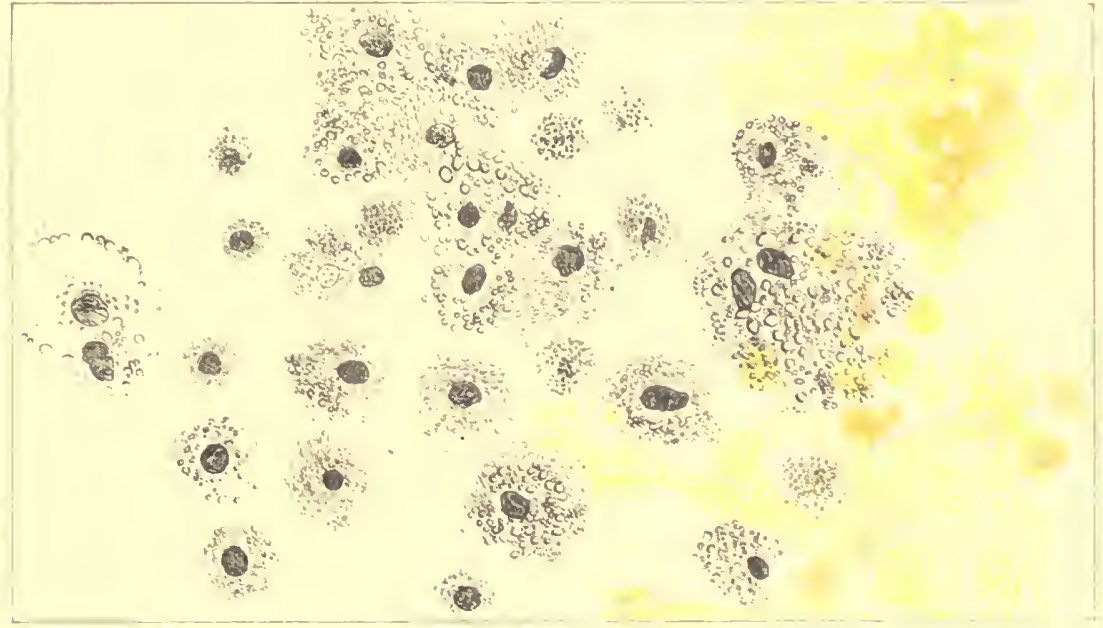

B. Cobra venom, 0.5 per cent; 5 minutes at $37^{\circ} \mathrm{C}$.

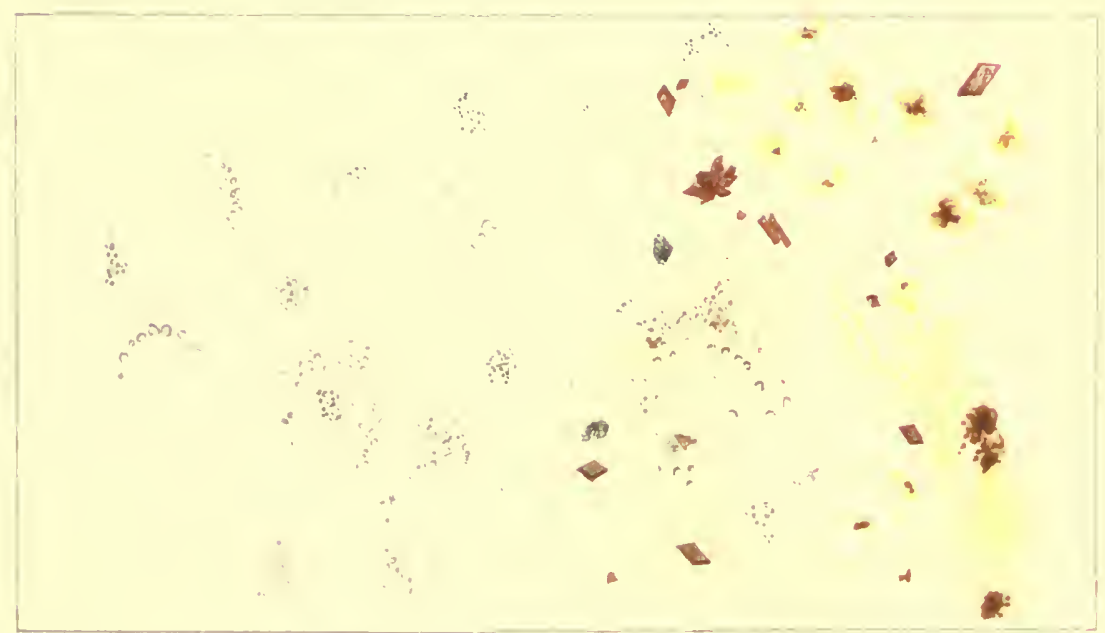

C. Cobra venom, 0.5 per cent; 20 minutes at $37^{\circ} \mathrm{C}$.

Effect on White and Red Corpuscles of Rabbit. (Drawings by Noguchis.) 

medium-sized granular cells have suffered disintegration, while lymphocytes show but slight and inconspicuous changes. Stronger solutions, varying from 0.2 per cent to Io per cent, cause instantaneous cessation of motility and rapid agglutination without distinction of variety of cells. Within 5 to 30 minutes thereafter dissolution sets in, affecting first the largest, then the medium-sized cells, and finally the small lymphocytes.

There are variations in the activities of the several venoms and in the completeness of solution of the cells. Rattlesnake venom is far less active than that of the Cobra. 'Thus in 2 per cent solutions cobra venom causes complete solution in 30 minutes, while that of the rattlesnake requires 2 hours to bring about the same result. (Plate 29.)

The effects upon the washed leucocytes differ from those described in that venom solutions cause agglutination, but with the production of only very little lysis.

The next question to decide was whether the hæmolysins (erythrocytolysins) are identical with the leucocytolysins. The supernatant fluid free from the erythrocytolysins, as obtained by the usual absorption of copperhead venom with the washed corpuscles of rabbits, was allowed to act upon the leucocytes of the same animal. There was no agglutination, but a complete solution of the cells took place within 30 minutes. On the other hand, the parallel experiment in which venom solution was treated with washed leucocytes yielded a fluid still active for defibrinated blood. From these observations they concluded that -

(I) Venom contains principles which are agglutinating and dissolving for leucocytes.

(2) The agglutinating principles may be identical for both white and red cells.

(3) The dissolving principles for leucocytes are distinct from those for erythrocytes.

(4) In order that solution of venomized corpuscles shall occur a complement-containing fluid is required.

(5) The several varieties of white cells of rabbit blood show different susceptibilities to the action of venom.

Calmette made a very important observation in regard to the mechanism of hæmolysis caused by venom. He confirmed the finding of Flexner and Noguchi that venom requires a second substance or substances contained in blood serum in order to accomplish its dissolving action upon the corpuscles. Moreover, he found that the substance or substances of serum concerned in venom hæmolysis differ from ordinary serum alexines in that they do not lose their activating property at $62^{\circ} \mathrm{C}$. At this temperature there may be some diminution of this power, but if heated to $100^{\circ} \mathrm{C}$. the venom-activating action of all serums becomes much more powerful than the unheated serums.

Closely following the work of Flexner and Noguchi on one hand, and that of Calmette on the other, Preston Kyes, under the direction of Ehrlich, made 
a brilliant contribution to our knowledge of the nature of venom hæmolysis. As will be seen below, Kyes, in his first article, confirmed the observations of Flexner and Noguchi as well as those of Calmette and explained at the same time the apparent discrepancies existing between the results obtained by these investigators. He found that there are two kinds of blood corpuscles, according to their susceptibility to the hæmolytic action of snake venom cobra venom being chiefly employed: (I) the corpuscles which undergo hæmolysis by venom without a second substance; (2) the corpuscles which become hæmolyzed only when auxiliary substances (complements, etc.) are present at the same time. The corpuscles of guinea-pigs, dogs, and man were found to be most susceptible, and those of rabbits and horses quite resistant, while those of the ox, sheep, and goat were completely refractory to the cobralysin. I c.c. of 5 per cent suspension of the first-named corpuscles is hæmolyzed by only 0.25 c.c. of 0.01 per cent venom solution, while those of the horse are dissolved by I c.c. of o.I per cent concentration, requiring nearly 40 times more venom than in the case of corpuscles of dogs or guineapigs. Kyes found that the insusceptible kinds of corpuscles can be dissolved by venom if certain suitable fresh serums be introduced. Thus he gives the following combinations as corresponding with the examples of amboceptorcomplement-like phenomenon of venom hæmolysis: Ox corpuscles, guineapig serum; sheep corpuscles, guinea-pig serum; rabbit corpuscles, guinea-pig serum; horse corpuscles, ox serum. The complementing property of guineapig serum is seen to disappear by heating to $5^{\circ} \mathrm{C}$. for 30 minutes. He was also able to confirm that the cobra amboceptors are absorbed by sheep corpuscles at $\circ^{\circ} \mathrm{C}$., even in the presence of guinea-pig serum.

After having confirmed the facts described by Flexner and Noguchi in cer tain particular instances, Kyes now proceeded to clear up the phenomenon why certain kinds of corpuscles are attacked by venom directly. It was found that the susceptible corpuscles contain in thẹir constituents certain substances capable of activating cobra venom. This group of "activators" was called endocomplement and found to be thermolabile. From the ox corpuscles he was able to obtain active endocomplement, notwithstanding these corpuscles are entirely insusceptible to the cobralysin in their integrity. This phenomenon was explained by assuming that the endocomplement of this kind of corpuscles exists in an unavailable state, but becomes accessible after their disintegration, through which process endocomplement was prepared.

Returning to Calmette's phenomenon, namely, the acquisition of venomcomplementing property of various serums, irrespective of whether one was incapable of activating venom in its fresh state or not, after heating to a temperature above $62^{\circ} \mathrm{C}$., Kyes found that heating all kinds of blood serums to $100^{\circ} \mathrm{C}$. invariably renders them activating for cobra venom, and, indeed, more active in this respect than in an unheated native state. Finally Kyes discovered that the thermostabile venom activator of blood serum can be 
extracted with alcohol, and that of the substances extracted with alcohol lecithin alone possessed the property of activating cobra venom in the same manner as a heated serum. The hæmolysis produced by the combined action of cobra venom and lecithin differed from that caused by the combination of cobra venom and certain suitable blood serum (complement) in the former's rapid completion, and also its occurrence even at $0^{\circ} \mathrm{C}$.

Kyes and Sachs went deeper into the search for the closer mechanism of venom hæmolysis produced by certain fresh serum on one hand and lecithin on the other. In order to decide whether the venom-activating property of the fresh serum of guinea-pigs is different from lecithin of that serum, they first employed the fresh serum of guinea-pig to see if in small quantities unable to activate the venom this serum still inhibits the venom-activating action of lecithin. It was found that this serum exerts a powerful anti-lecithin action in a dilution incapable of activating venom, showing that its anti-lecithin component exceeds in amount the venom activator contained in it. In still another experiment the serum of a rabbit immunized against guinea-pig complement was employed. This serum became highly antilecithinic after heating to $56^{\circ} \mathrm{C}$. This lecithin-inhibitory property was saturated with the addition of lecithin, and then its action upon the venom-activating property of fresh serum of guinea-pig was tested. The result shows that this mixture inhibited the latter's venom activation in a very small amount. A third differentiation was made by digesting the fresh serum of guinea-pig with papain, which destroyed the activating power of the former, although it had no effect upon the venom-activating action of lecithin. A fourth differentiation was found in the elective inhibitory action of cholesterin upon the activating property of lecithin, whereas venom-complement hæmolysis is seen to remain unaffected.

Taking up once more the question of the nature of the corpuscular venom activator - their original endocomplement - Kyes and Sachs next sought the seat of the activator in the cells. They quickly found that the stroma is activating, but not the soluble laked fluid of the red corpuscles. By alcoholic extraction the activator was obtained in proteid-free state, and behaved in the same manner as lecithin. Again, as to the activating property of the washed stroma, they state that it corresponds with that of lecithin, as it is not inactivated at $62^{\circ} \mathrm{C}$., is quite active at $0^{\circ} \mathrm{C}$., but inhibited by cholesterin. Thus, no endocomplement longer exists.

The thermolability of the aqueous solution of disintegrated red corpuscles was found to be due to the simultaneous presence of hæmoglobin, which at $62^{\circ} \mathrm{C}$. combines lecithin and renders it inactive in regard to venom hæmolysis. In a series of experiments they showed that lecithin combines with hæmoglobin when heated together in solution to $62^{\circ} \mathrm{C}$.

Kyes and Sachs proceeded further to ascertain the degree of susceptibility of the blood corpuscles of different species of animals to cobra venom, either with the addition of a sufficient amount of lecithin, or in their native state. 
The preparations of lecithins which they employed for venom activation were only slightly hæmolytic, and it required nearly 200 times the amount necessary for the activation of cobra venom. A preparation of kephalin was also capable of venom activation, while sinapin was devoid of this property.

The following table states the results in succinct form:

TABLE 7.

\begin{tabular}{|c|c|c|}
\hline I c.c. 5 per cent suspension. & $\begin{array}{l}\text { With } 0.2 \text { c.c. } 0.025 \text { per } \\
\text { cent lecithin solution. }\end{array}$ & No lecithin. \\
\hline $\begin{aligned} & \text { Blood of } \text { Guinea-pig } \ldots \\
& \text { Ox } \ldots \ldots \ldots \\
& \text { Rabbit. } \\
& \text { Man } \ldots \ldots \ldots \\
& \text { Goat } \ldots \ldots \ldots \\
& \text { Dog } \ldots \ldots \ldots \\
& \text { Horse } \ldots \ldots \ldots \\
& \text { Rat } \ldots \ldots \ldots \\
& \text { Frog } \ldots \ldots \ldots \ldots\end{aligned}$ & 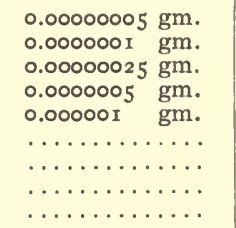 & $\begin{array}{l}0.000025 \mathrm{gm} . \\
\text { Insusceptible. } \\
0.0005 \mathrm{gm} . \\
0.000025 \mathrm{gm} . \\
\text { Insusceptible. } \\
0.000025 \mathrm{gm} . \\
0.001 \mathrm{gm} . \\
0.00025 \mathrm{gm} . \\
0.00001 \mathrm{gm} .\end{array}$ \\
\hline
\end{tabular}

In closing, Kyes and Sachs state that the addition of a small amount of hydrochloric acid to cobra venom increased the resistance of the latter's hæmolytic substance to the temperature of $100^{\circ} \mathrm{C}$. The concentration of this acid was one-eighteenth normal, to prevent quick heat-destruction of the venom, in which almost no diminution of lytic power took place in 30 minutes' boiling, although it was entirely inactive after 2 hours' heating.

Kyes finally succeeded in preparing a new compound which possessed considerable hæmolytic activity from the mixture of an aqueous solution of snake venom and chloroform solution of lecithin. The process of preparation has been described on page 86. This new compound is the venom lecithid and was obtained in a microcrystalline form. Usually it quickly separates out from the aqueous solution and becomes amorphous. It differs in physico-chemical properties from the native venom by its solubility in various organic-fat solvents and in its enormous resistance to high temperature. Its hæmolytic action is almost instantaneous and uninfluenced by low temperature $\left(0^{\circ} \mathrm{C}\right.$.). It is almost non-fatal, although if given subcutaneously in a very large quantity infiltration takes place. It differs from lecithin in its insolubility in ether.

Cholesterin has inhibitory action upon the hæmolytic action upon venom lecithid. It is important, after the shaking of the venom solution with chloroform solution of lecithin, that the aqueous portion of the mixture does not contain any further hæmolytic substance, while the neurotoxic principle remains still in solution.

Besides cobra venom, the venoms of Lachesis lanceolatus, Lachesis anamalensis, Lachesis favoviridis, Crotalus adamanteus, Vipera russellii, Bungarus caruleus, Bungarus fasciatus, and Naja haje were found to form the lecithids.

Flexner and Noguchi ${ }^{1}$ kept up their studies on snake venom and found in the meanwhile that the venoms freshly squeezed out of the poison glands of

1 Flexner and Noguchi. The constitution of snake venom and snake sera. Jour. of Path. and Bacteriol., I903, VIII, 379 . 
various crotaline snakes, Crotalus adamanteus, C. terrificus, C. confluentus, Ancistrodon contortrix, and A. piscivorus, do not contain complements and are inactive without the help of second substances of certain blood serums. They found that even repeated washings fail, with some samples, to prevent subsequent dissolution when mixed with cobra venom. With the corpuscles of dogs the removal of serum had the least influence on the retardation of hæmolysis. In explaining this phenomenon they assumed the presence of intracellular complements in these corpuscles. In fact, Flexner and Noguchi succeeded in extracting intracellular complements from the dog's corpuscles by suspending them in the heated serum over night. If the heated serum is separated next day from the corpuscles by centrifugalizatio, and then tested for its hæmolytic property on washed corpuscles of guinea-pig, there will be more or less marked hæmolysis. The controls with the heated serum of dog or the saline supernatant of the washed corpuscles of dog do not cause any hæmolysis. When the washed corpuscles of dog are repeatedly digested in the heated serum of dog (suspension and washing in several successions) the susceptibility of the digested corpuscles to the hæmolytic action of cobra venom is seen to be far less than that of the corpuscles simply washed repeatedly in isotonic saline solution. This phenomenon is of a dual nature, due sometimes to the removal of intracellular venom activators and then to absorption by the cells of the anticomplementary principle ${ }^{1}$ which has developed in the heated serum of dog.

Flexner and Noguchi then studied the nature of venom-intermediary bodies, ${ }^{2}$ especially in regard to their cytophilic and complementophilic groups. The remarkable feature of venom-intermediary bodies is that they are active with various kinds of foreign blood serums. Those who have worked with normal and immune serum hæmolysins must recognize that the complementophilic groups of the amboceptors of these serums are better fitted with the native complements, hence more active in that combination. In other words, as shown by Ehrlich, Morgenroth, Sachs, Neisser, and Doering, the native serum contains more suitable complements for the homologous amboceptors than the foreign serums. Now, why are venom amboceptors active in the presence of foreign serums? What will be the result when we furnish them with their homologous complements? What will be the relation of venom amboceptors to the native and foreign serum complements?

In this series the venoms employed were fresh and the complements were obtained by allowing the given kind of corpuscles to absorb all specific serum amboceptors for them by the cold method. The complements employed were from the serums of Crotalus adamanteus, Ancistrodon piscivorus, and Pityophis cateniferis. Each complement was tested for its activating value for the hæmolytic amboceptors of cobra, moccasin, copperhead, and rattlesnake venoms. The corpuscles subjected to the action of the combination of snake complement and venom in variable orders were those of the dog and

1 Noguchi. On the thermostabile anticomplementary constituents of the blood. Jour. of Exper. Medicine, 1906, VIII, 726.

2 Intermediary body $=$ Ehrlich's amboceptor and Bordet's substance sensibilisatrice. 
guinea-pig, and had been freed from their native complements by washing. The results obtained are closely in parallel. All four of the venoms become active upon the addition of a suitable quantity of crotalus complement. The hæmolytic process is, however, very much slower than in the cases where the serums homologous to the corpuscles are added. It was found, again, that the velocity of the hæmolytic reaction is increased by using larger quantities of the venom, in combination with the crotalus complement. From this fact Flexner and Noguchi considered it possible to divide the intermediary bodies of venom into two groups, namely, the isocomplementophilic and the heterocomplementophilic. It appears to be remarkable how far the number or amount of the heterocomplementophilic amboceptors exceed the isocomplementophilic in all venoms. From this it at once becomes evident why venom in general is so powerfully destructive when introduced in a heterologous system, while it has almost no effect upon the homologous blood.

The behavior of the complement of Pityophis cateniferis is quite different from the crotalus complement. With none of the venoms here employed did it produce a complete hæmolysis even after a very long period of action. As the controls underwent more or less complete hæmolysis after some hours, especially with cobra venom, the addition of the pine-snake complement is seen to have acted antihæmolytically, at least to a certain extent. There is an indication that the complement of this snake is far less suitable in activating the venom lysins than that of Crotalus adamanteus. In a subsequent series of experiments they found that the crotalus complement can promptly reactivate the crotalus-serum amboceptors (the serum heated to $56^{\circ} \mathrm{C}$.), but only partially those of the pityophis blood, and vice versa.

According to the activability of the venoms by snake complements on one hand, and by heterogeneous complements on the other, Flexner and Noguchi have shown the relative amounts of the isocomplementophilic and heterocomplementophilic intermediary bodies in crotalus, moccasin, copperhead, and cobra venoms. In the case of the corpuscles of guinea-pigs, crotalus venom contained about 7 times as much of the isocomplementophilic as of the heterocomplementophilic intermediary bodies. For the corpuscles of dogs, on the other hand, the hetero-body is present in excess in about the proportion of $\mathrm{I} 2$ to $\mathrm{I}$. With the other venoms the heterocomplementophilic bodies are found to exist in excess in about 60 to roo times. That these figures would differ were the native complements available in each case is indicated by the distinctly weaker action of pine-snake serum upon crotalus venom as compared with its own serum.

Flexner and Noguchi then took up the question of the haptophore groups of the venom-intermediary and serum-intermediary bodies. First the corpuscles of the dog, guinea-pig, and pigeon were subjected to the action of the crotalus serum previously heated to $56^{\circ} \mathrm{C}$. for 30 minutes in order to abate the action of the complement. After contact for a few hours the corpuscles were separated by centrifugalization and washed in 0.85 per cent salt solution. These corpuscles had fixed the intermediary bodies to themselves, as they 
underwent hæmolysis upon introduction of the crotalus complement, but scarcely at all when heterogeneous complements were substituted, which shows that the serum-intermediary bodies in this case required for their lytic function the homologous complement. In other words, the crotalus serumintermediary bodies are isocomplementophilic.

Now, what became of the susceptibility of these serumized cells to the action of venom-intermediary bodies? Are they still able to find the venom-intermediary bodies and produce hæmolysis when a heterogeneous complement is introduced at the same time? Of course, the crotalus complement can not be employed in this test, for the serum amboceptors will grasp the homologous complement and bring about the hæmolysis. The serumized corpuscles have proved to be very resistant to the combined addition of crotalus venom and the serum of guinea-pigs (in the case of corpuscles of the guinea-pigs) or that of dogs (in the case of corpuscles of dogs). In fact, almost no hæmolysis commenced even after many hours' contact, whereas complete hæmolysis proceeded in the normal manner and rapidity with the corpuscles which had not been previously digested in the inactivated crotalus serum. It would appear from this that the receptors of the corpuscles had been saturated with the serum-intermediary bodies of the crotalus serum and became afterwards unable to fix the venom-intermediary bodies; hence there was no hæmolysis in the presence of a heterogeneous complement, which, as already mentioned, is capable of activating the latter set, but not the former set, of the hæmolytic amboceptors. It tends to show that the haptophore groups of the crotalus serum-intermediary bodies and the crotalus venom-intermediary bodies are identical and saturate the same set of receptors in the blood corpuscles. If in the foregoing experiment we replace the crotalus venom with watermoccasin or cobra venoms, the inhibition exerted by digesting the corpuscles in the inactivated crotalus serum becomes far less pronounced than is the case with the first venom. What is the reason for these differences?

It seems most probable that the hæmolytic intermediary bodies in these last two venoms differ from the crotalus intermediary bodies in their structure of haptophore groups and unite with quite other sets of receptors of these corpuscles. Hence the addition of heterocomplementophilic intermediary bodies of cobra or moccasin venoms brings about hæmolysis, although some delay is also noticed here.

A reversion of experimental orders of the above led Flexner and Noguchi to exactly the same conviction, but through another path. The washed corpuscles of dog or guinea-pig can be easily venomized with crotalus or moccasin venom without dissolving them, at least during several hours. Now, after venomization, still better if the venom be left in the mixture, the corpuscles are subjected to the action of the fresh serums of crotalus or pine snake. What actually happens there is that a previous treatment of these corpuscles with these venoms in strong concentrations, or the simultaneous presence of these venoms in large enough doses, interferes with the hæmolytic action of snake venoms. 
If a fairly large amount of the fresh snake serum is added to the washed corpuscles alone, complete hæmolysis will result in a few minutes. But if the same quantity of the serum is added to the venomized corpuscles hæmolysis is always imperfect or complete only after many hours' contact, this especially being more pronounced (inhibited) when moccasin venom is employed. Why is it? It is because the preoccupancy of the receptors of the blood corpuscles by venom-intermediary bodies means the possession of the majority of the receptors by isocomplementophilic intermediary bodies in the case of crotalus venom, but by heterocomplementophilic intermediary bodies in the case of moccasin venom; hence hæmolysis may be complete in the first instance in the presence of the homologous complement, but only little in the second instance on account of the non-availability of the venomintermediary bodies, in this case of the crotalus complement. Even if the moccasin complement be used, hæmolysis proceeds slowly. Again, if, instead of homologous serums, some quick-activating heterogeneous serums should be employed, the venomized corpuscles undergo hæmolysis, the promptness of action being proportionate to the amount of venom, provided a certain limit is not passed beyond which another phenomenon complicates the process of the antihæmolytic action of venom.

Flexner and Noguchi finally resorted to some other methods to identify the haptophore groups of venom-intermediary bodies and serum-intermediary bodies. They found that the anti-serum for crotalus serum was quite antihæmolytic against the crotalus hæmolysin, but less so against moccasin or cobra venoms. Antivenin prepared by Calmette was quite antihæmolytic against crotalus serum. The reason why this antivenin was effective in neutralizing the hæmolytic action of crotalus serum, as well as crotalus venom, may find its explanation in the fact that Calmette immunized his horses with a mixture of several venoms, of which crotalus venom was a component.

Venom hæmolysis was found to proceed uninfluenced by the presence of cholesterin. This fact was later confirmed by Kyes and Sachs, who in case of venom-lecithin hæmolysis found also a marked protection displayed by this substance.

Venom-agglutination occurs with the corpuscles hardened in so per cent formalin in Hayem's solution, but no hæmolysis.

The approximate units of hæmolytic activity of various venoms upon different kinds of defibrinated blood in vitro are given by Flexner and Noguchi in the following table, which also shows the coincidental agglutinative value:

TABLE 8.

\begin{tabular}{|c|c|c|c|c|c|c|}
\hline \multirow{2}{*}{ Venom. } & \multicolumn{3}{|c|}{ Minimal hæmolytic dose in I mg. } & \multicolumn{3}{|c|}{$\begin{array}{c}\text { Minimal } \\
\text { Agglutinative dose in I mg. }\end{array}$} \\
\hline & Man. & Dog. & Guinea-pig. & Man. & Dog. & Guinea-pig. \\
\hline Cobra. & 500 & I I 34 & 378 & 50 & 4 & 20 \\
\hline Water-moccasin & 50 & 500 & 200 & 200 & $230^{\circ}$ & $25^{\circ}$ \\
\hline Copperhead . & 25 & 200 & 100 & 200 & I 25 & 400 \\
\hline Rattlesnake & I & 96 & 8 & 10 & 5 & I 2 \\
\hline
\end{tabular}


The toxoid formation of hæmolytic principles, first observed by Myerswith the cobra venom, has been confirmed by Flexner and Noguchi with the American venoms. They did not find such rapid deterioration as was mentioned by Myers. They found that hydrochloric acid in the concentration of 2 to 3 per cent caused only a slight deterioration of hæmolysins after 48 hours.

Lamb (I903) estimated the hæmolytic value of cobra venom for a number of the bloods of different animals by using the calorimetric measurement in small test-tubes containing a known quantity and the red corpuscles in question. He brought out no specially new point as to its behavior upon the red cells, but he has shown that I per cent solution of cobra venom resists the heating to $73^{\circ} \mathrm{C}$. much better than 0.I per cent solution of the same venom. With unheated venom 0.005 c.c. of the blood suspenderl in 0.5 c.c. isotonic salt solution was dissolved by $0.015 \mathrm{mg}$. The heating of I per cent solution of the venom raised this minimal complete hæmolytic dose to $0.0312 \mathrm{mg}$., while that of $0 . \mathrm{I}$ per cent solution was raised to $0.25 \mathrm{mg}$.

Now, coming to the hæmolytic property of the daboia venom, Lamb found a somewhat singular phenomenon, namely, that this venom, while a powerful destroyer of the red corpuscles in vivo, did not readily dissolve the blood corpuscles when the cells were directly mixed with the venom in a saline solution in vitro. This fact has also been observed by Cunningham and emphasized especially by Stephens and Myers. Lamb found that in order to start hæmolysis of any kind of blood it was necessary to have the toxicity of the saline medium somewhat below the isotoxicity, so as to produce a partial destruction of the corpuscles before the venom is introduced, recollecting also that Stephens and Myers noticed that the addition of the normal horse serum accelerated the hæmolysis with this venom.

Weir Mitchell's phenomenon, namely, non-hæmolysis by too strong a concentration of venom, has also been observed with the daboia venom in vitro. As to the resistance of the hæmolytic principle of the daboia venom, Lamb finds that it differs from that of the cobra venom, as the former loses its activity completely when heated to $73^{\circ} \mathrm{C}$. in a o.I per cent solution, whereas only a certain diminution of power takes place in the latter venom. Another point of difference between these two venoms is the far more powerful hæmolytic action in vivo possessed by the daboia venom.

Noc, working with a large variety of snake venoms, established the fact that the phylogenetic relation between the main families and genera of poisonous snakes is not merely an anatomical and morphological factor, but also a biological factor, for he found that the activity of the hæmolytic principles of their venoms obeys the linear course and rank to which each snake is assigned in the natural system. Noc's experimental data bearing on this point are simple. He determined the length of time required by $\mathrm{I} \mathrm{mg}$. of each venom to hæmolyze completely I c.c. of 5 per cent suspension of the washed corpuscles of horse in 0.9 per cent salt solution in the presence of 0.2 c.c. of the normal horse serum heated previously to $58^{\circ} \mathrm{C}$. It was necessary to add this amount of the heated horse serum to obtain hæmolysis, as 
none of the venoms employed could dissolve the washed corpuscles of horse in a serum-free saline medium. His results are shown in table 9, o.I mg. being administered in each case.

TABlE 9.

\begin{tabular}{|c|c|c|c|}
\hline Name. & $\begin{array}{c}\text { Complete } \\
\text { hæmolysis in }\end{array}$ & Name. & $\begin{array}{c}\text { Complete } \\
\text { hxmolysis in - }\end{array}$ \\
\hline Colubridæ: & & Viperidæ - Continued. & \\
\hline 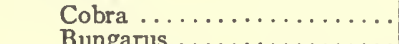 & 5 mins. & Crotalina - & \\
\hline $\begin{array}{l}\text { Bungarus } \ldots \ldots \ldots \ldots \ldots \\
\text { Naja noir } \ldots \ldots\end{array}$ & 10 & Lachesis flavoviridis ...... & 35 mins. \\
\hline $\begin{array}{l}\text { Naja nowr } \ldots \ldots \ldots \ldots \\
\text { Notechis scutatus } . . . \ldots \ldots\end{array}$ & $\begin{array}{l}20 \\
40\end{array}$ & $\begin{array}{l}\text { Ancistrodon piscivorus .... } \\
\text { Ancistrodon contortrix ... }\end{array}$ & \\
\hline Viperidæ: & & Jararacussu. . . . . . . . & 2 hours \\
\hline Viperinæ - & & Jararaca ............... & $2 \frac{1}{2}$ \\
\hline Vipera berus & 60 & Úrutu. . . . . . . . $\ldots \ldots \ldots$ & 3 \\
\hline Vipera russellii. & 30 & Lachesis lanceolatus ...... & 3 \\
\hline
\end{tabular}

In testing the antihæmolytic power of an antitoxin obtained by immunizing an animal against the venoms of Cobra and Bothrops, Noc found that it neutralized the hæmolytic action of I mg. of the venoms of Cobra, Bothrops, Urutu, Bungarus, Jararaca, Naja noir, and Vipera berus, but failed to do so against that of Trimeresurus of Japan (Lachesis flavoviridis). Here he makes the statement that the antihæmolytic power in vitro of a given sample of antivenin is the measure of its antitoxic power in vivo against the same venom.

Notwithstanding Noc's approximate statement in regard to the stronger hæmolytic activities with the elapine venoms, it does not follow that all colubrine snakes are included in this general rule. On the contrary, it is found by Rogers that another large subfamily of Colubridæ, the Hydrophiinæ, contains no appreciable hæmolytic principles in their powerful venoms.

Rogers ${ }^{1}$ studied the hæmolytic action of Enhydrina, Distira cyanocincta, and Distira cantoris upon the bloods of man and pigeon. When these venoms, especially that of Enhydrina, are mixed with the suspension of the blood in the ratio of over I to I,,$\infty$, complete hæmolysis occurs after 24 hours' contact. Cobra venom has about 100 times more hæmolytic power. When the toxicity of these two venoms is compared the enhydrina venom surpasses the cobra venom by ro times (I minimal lethal dose for pigeon $=0.00005 \mathrm{gm}$. for Enhydrina and 0.0005 for Cobra). In still another form of presentation 200 minimal lethal doses of enhydrina venom can dissolve only $\frac{1}{2000}$ part of the blood of the bird, excluding the possible rôle in the fatal issue played by the hæmolytic poison in the enhydrina toxication.

Kyes $^{2}$ (I904) took up the question why none of the kinds of bloods of different species of animals is attacked by the hæmolytic principles of snake venom, in spite of the presence of a nearly equal amount of lecithin in all bloods. Kyes advanced the theory that lecithin in the blood corpuscles of various species does not exist in the same manner, and in some kinds it is

\footnotetext{
${ }^{1}$ Léonard Rogers. On the physiological action of the poison of the Hydrophidx. Proc. Roy. Soc., I003, LXXI, 48r.

2 Kyes. Lecithin und Schlangengifte. Zeitschr. f. physiolog. Chemie, I904, XLI, 273.
} 
easily grasped by the venom, while in others it is not at all available for venom activation. Testing the antihæmolytic power of Calmette's antivenin, he found that it neutralizes the action of the venoms of Bungarus caruleus, Bungarus fasciatus, Naja haje, and Naja tripudians, but not at all that of the venoms of Lachesis lanceolatus, Lachesis flavoviridis, Crotalus, and Vipera russellii. In the absence of serum or lecithin none of the venoms hæmolyzed the bloods of sheep, ox, or rabbit, except that the last kind was dissolved by Naja tripudians. The blood of man was not attacked by the venoms of Lachesis lanceolatus, Lachesis anamalensis, and Crotalus, but by those of the daboia, habu, kraits, and cobras. This article does not contain any substantial evidence that lecithin exists variously in different kinds of bloods.

In 1904 Noguchi ${ }^{1}$ pointed out that the hæmolytic principles contained in the venoms of cobra, rattlesnake, water-moccasin, and daboia are not identical, so far as their affinities to specific antivenins are concerned. Although not in a strict sense, the antivenin derived from an animal immunized against a given venom shows a specific affinity to that venom. In these experiments he employed the antivenin specific for cobra, crotalus, moccasin, and daboia.

$\mathrm{Lamb}^{2}$ (1905) took up the question of the mechanism of venom hæmolysis and contributed many interesting facts. He employed ten different kinds of venoms, comprising Naja tripudians, Naja bungarus, Bungarus caruleus, Bungarus fasciatus, Notechis scutatus, and Enhydrina valakadien of the Colubridæ, and Vipera russellii, Echis carinata, Lachesis gramineus, and Crotalus adamanteus of the Viperidæ. From the action of these venoms upon the washed blood corpuscles of dog, Lamb divides the venoms into two groups according as they have or have not hæmolytic action on these cells without the addition of a free activating agent - lecithin or serum. The first group contains cobra venom and daboia venom, which even in small amount have a complete hæmolyzing effect; the venoms of Bungarus cceruleus and Echis carinata, which have also a complete hæmolyzing action when used in large quantity, and the venom of Notechis scutatus, which has only a slight effect even in comparatively large amount. Group 2, namely, those venoms which have no hæmolytic action on the washed cells of dogs, consists of the poisons of Naja bungarus, Bungarus fasciatus, Enhydrina valakadien, Lachesis gramineus, and Crotalus adamanteus. Testing their hæmolytic value in the presence of the serum of dog or an adequate amount of lecithin developed that, except the venom of Enhydrina valakadien, all these venoms became nearly equally hæmolytic, notwithstanding slight variations may be noticed. $0.0000 \mathrm{rgm}$. was about the average dose which could completely dissolve I c.c. of 5 per cent suspension of the washed dog corpuscles (in 0.85 per cent salt solution) in $\mathrm{r}$ hour at $37^{\circ} \mathrm{C}$. and over night in the ice-chest, when 0.5 c.c. of twofold dilution of dog's serum was added simultaneously. The enhydrina venom never completed hæmolysis even in a dose of $5 \mathrm{mg}$. in the same

\footnotetext{
1 Noguchi. Expériences thérapeutiques avec les antivenins (Crotalus adamanteus et Ancistrodon piscivorus). Ig04.

Lamb. Snake venoms in relation to hæmolysis. Sc. Mem. Off. Med. and San. Dept. Governm. India, 1905, new series, No. I7.
} 
quantity of the blood. From these results Lamb explains why, without addition of suitable serum, hæmolysis was obtained by Kyes and Sachs, who chiefly worked with cobra venom of group I, and not obtained by Flexner and Noguchi, who worked with the venoms belonging to group 2 .

With the same experimental arrangements as the above, but using 0.2 c.c. of o.I per cent lecithin saline suspension as the activator, Lamb demonstrated the variability of the affinities possessed by different venoms toward lecithin. He found that the venoms of Echis carinata, Bungarus fasciatus, and Bungarus caruleus become active on the addition of lecithin in the same degree as on the addition of dog's serum, but lecithin has but slight activating effect upon the venoms of Naja bungarus, Enhydrina valakadien, and Crotalus adamanteus. In this connection it is important to remember that the venoms of Naja bungarus and Crotalus adamanteus are equally or even more hæmolytic when, instead of lecithin, dog's serum is employed as the activator. This phenomenon offers some difficulty in generalizing Kyes's hypothesis that lecithin is solely responsible for the venom-activating property of a blood serum, because pure lecithin is not equivalent, in activating these particular venoms, to a suitable serum.

The washed corpuscles of ox and goat bloods are entirely resistant to all venoms here employed, but become hæmolyzed upon the addition of lecithin with the venoms belonging to group I. On the other hand, lecithin does not appreciably accelerate or activate those venoms falling in group 2. These differences were explained by Lamb as though different venoms have varying affinities to lecithin.

The next question determined by Lamb relates to the fixability of venomintermediary bodies by the blood corpuscles. He tried to impregnate the washed corpuscles of certain suitable kinds of bloods with varying amounts of venoms, say I, 2, 4, 6, 8, 10, and 20 minimal complete hæmolyzing doses. The tests whether the corpuscles absorbed any portion of the venom from the medium after a period of contact were made by examining the fluid separated from the cells (by centrifugalization) for the remaining activity on a fresh lot of the same kind of blood corpuscles with the simultaneous addition of either homologous serum or lecithin, and also by resuspending the sedimented corpuscles in a fresh volume of saline solution and the subsequent introduction of suitable venom activators. In no instance could Lamb demonstrate the fixation of venom by the blood corpuscles. These results, which apparently contradict those obtained by Flexner and Noguchi, are not, in reality, comparable in these instances, as the experimental arrangements in both cases differ so far as the rôles of complements in such mixtures are concerned. As Lamb clearly pointed out, Flexner and Noguchi used the defibrinated blood, whereas Lamb employed the washed cells. There are instances where no fixation of intermediary bodies takes place, unless there is present at the same time suitable complements or complementoids. ${ }^{1}$

1 Bordet and Gay. Sur les relations des sensibilisatrices avec l'alexine. Ann. Inst. Pasteur, 1906, XX, 467. 
Lamb also found the diminution of hæmolysis with much larger doses of venom.

In the meanwhile Noguchi was still pursuing his study on venom hæmolysis and tried to clear up the mechanism of lysis produced by venom in the presence of certain thermostabile chemical substances other than that (lecithin) discovered by Kyes. Noguchi thinks that the hæmolysis caused by venom can in many instances be due to the sensitizing effects of venom on the hæmolytic action of certain substances which are already active by themselves. In other words, venom inflicts upon the blood cells certain injury and renclers them more vulnerable to the solvent action of these substances. Thus in the case of lecithin, a typical venom activator, Noguchi points out that this substance is quite hæmolytic by itself. The hæmolytic power of lecithin is, however, about one-twentieth of what it is when used in the presence of venom. This proportion is not the one which is estimated at the beginning of experiments, but is obtained at the time when the reaction is almost completed. As was shown somewhere else, the velocity of reaction of different chemicals is extremely variable according to the nature of the substance, but the final sum of reaction is not parallel to the velocity of reaction. Now let us take lecithin. This substance does not start to act until many hours after the addition to the blood suspension, but gradually reveals its lytic property in about 3 or 4 hours, and continues to be active until 18 to 24 hours.

On the other hand, the venom lecithin hæmolysis does not require a latent period, but completes the reaction within half an hour or so. If a comparison of the hæmolytic strength of venom lecithin and lecithin alone be taken within the first 5 minutes the proportion would be no lysis with lecithin against the very powerful rapid lysis of venom-lecithin mixture. If an estimate be made after I or 2 hours it would be I to 200-300 or more in favor of the latter. However, this proportion slides gradually to the advantage of lecithin, as the time requisite for its completing reaction gains, until the ratio is about I to 20 after 24 hours.

There is no question as to the formation of a definite new hæmolytic compound (lecithid) in the mixture of venom and lecithin, together with a reduced incubation period of hæmolysis, but it is amazing to see how rapidly this reaction takes place. If a sufficiently large amount of lecithin be added, hæmolysis occurs instantaneously, while an insufficient amount delays the process very markedly, notwithstanding the comparatively large amount of venom.

The rapidity with which lecithin hæmolyzes the blood cells with the airl of venom (cobra) is almost without parallel in the enzymic process - perhaps with the exception of lipase upon neutral fats. Another example of a rapid completion of hæmolytic process is furnished by sodium oleate. This substance is able to hæmolyze about the same amount or slightly more of the blood corpuscles as lecithin or oleic acid, but its reaction is all over within an hour. In this body we see that the zymotoxic (or toxophore) group of the compound is set to a rapid action through the presence of sodium. 
Having found that a certain constant proportion exists between the inherent hæmolytic power of lecithin and the hæmolytic power augmented through the addition of venom, Noguchi undertook a series of studies in which he sought to compare the native hæmolytic power and the hæmolytic power with venom of various groups of substances, in order to ascertain whether certain chemical bodies are or are not able to perform the function of venom activation. The chemicals subjected to this test are numerous and comprise normal fatty acids from formic up to ceratinic, unsaturated mono-carbonic acids containing the higher members, aliphatic acids, unsaturated dicarbonic acids, mineral acids, sodium salts of fatty and acrylic acids, neutral fats, lecithin, neurin, cholin, and some saturated and unsaturated alcohols.

From his experiments Noguchi discovered that the compounds which contain in their molecules a double bond only can become many times more hæmolytic than their native activities upon the addition of venom. Normal fatty, aliphatic, and mineral acids do not act stronger in the venomized corpuscular suspension than without the venom, whereas unsaturated organic acids, especially oleic acid, have their action increased by nearly to to 20 times their inherent strengths. This does not mean that each acid of this particular group has an equal hæmolytic power - which is far from being the case - but simply means that the proportion or ratio is sufficiently constant to rank them with lecithin or kephalin as venom activators. In reality triolein and oleic acid were the only substances worthy of comparison with lecithin in hæmolytic activity, the rest, although maintaining the constant ratio, being far inferior in this respect.

Again coming to the mechanism of venom activation by these simpler fatty compounds - simpler when compared with lecithin - it was noticed that their velocity of reaction was but little affected with the venom, in contradistinction to that with lecithin. It appears from this that the activation caused by these chemicals is essentially different from that brought about by lecithin; nevertheless they are venom activators in a certain sense.

Noguchi further studied the quantitative relation of the requirement of venom and venom activators to produce a definite degree of hæmolysis. Using a uniform amount of venom and variable amounts of activator, he found that the requirement for producing an equal degree of hæmolysis is in proportion to the square root of the amount of venom present in the mixture. In reversing the condition, namely, using a uniform amount of activator and variable amounts of venom, it was found that an increase in activator permits of a reduction in venom approximately in proportion to the square of the amount of activator employed.

The antihæmolytic property of cholesterin against that form of hæmolysis where venom and lecithin are concerned has been found by Kyes. According to Noguchi the action of cholesterin is directed to lecithin, but not to venom. Noguchi prepared a series of hæmolyzing mixtures in which varying amounts of lecithin and venom were so combined as to result in an equivalent hæmolyzer. Cholesterin was added to such mixtures in sufficient amount to 
prevent hæmolysis. To antagonize one complete hæmolyzing mixture the amount of cholesterin was found to vary according to the amount of lecithin which such a mixture contains. The greater the amount of lecithin, the more cholesterin was required to inhibit hæmolysis. No quantitative relation exists between the amount of venom and that of cholesterin. ${ }^{1}$

Noguchi also demonstrates that the addition of methyl alcohol beyond a certain amount (or concentration) finally nullifies the antihæmolytic property of cholesterin, which may indicate that the increase of solubility of cholesterin diminishes its antagonistic action against the mixture of venom and lecithin.

\section{MECHANISM OF VENOM HEMOLYSIS.}

Goebel ${ }^{2}$ discovered that the corpuscles, which are completely refractory to the hæmolytic action of cobra venom in isotonic sodium chloride solution, are promptly dissolved when suspended in isotonic saccharose solution instead of the saline medium.

Pascucci ${ }^{3}$ investigated the action of various hæmolysins, saponin, solanin, tetanolysin, and cobra venom, upon the artificial membrane of lecithincholesterin mixture. It was found that these hæmolysins produced permeability of the membrane for hæmoglobin solution. This alteration was most pronounced when the percentage of cholesterin in the mixture was least. The higher the percentage of cholesterin the less permeability resulted as the effect of these substances.

Morgenroth ${ }^{4}$ confirmed the finding of Kyes and Sachs that the hæmolytic principle of cobra venom is much more resistant to the deteriorating effect of boiling when heated together with a small quantity of hydrochloric acid. He also found that the hæmolysin (as well as neurotoxin) is so modified by this acid that the specific antitoxin now becomes unable to combine with this principle in the acidified medium. Even the neutral mixture of the lysin and antitoxin is split up by the acid into its original components. If the action of the acid has not continued too long the removal of the acid restores to the lysin its original affinity towards antitoxin.

Morgenroth and Pane ${ }^{5}$ followed up the study of the effects of hydrochloric acid upon the hæmolysin of cobra venom. They observed that when cobra venom in an acid medium containing about $\mathrm{N} / 20 \mathrm{HCl}$ is heated for a long time and its hæmolytic power is tested immediately after cooling and neutraliza-

1 Recently Morgenroth made a statement that this experiment was a mistake, on the grounds that cholesterin antagonizes the hæmolytic action of venom lecithid, the ready hæmolysin. To my mind such a criticism is invalid. First of all we must admit that the resultant lecithid is in proportion to the amount of lecithin acted upon by venom. The amoumt of lecithin is the source of lecithid to be formed by the action of venom; hence, if the amount of venom present is sufficient, the quantity of the lecithid produced is directly proportional to lecithin previously present. In other words, the experiment has shown that the inhibitory action of cholesterin is directed against the activated lysin.

2 Goebel. Contribution à l'étude de l'agglutination par le venin de cobra. C. r. de la Soc. Biol., I905. Contribution à l'étude de l'hémolyse par le venin de cobra. Loc. cit., I905.

3 Pascucci. Die Zusammensetzung des Blutscheibenstromas und die Hämolyse. II Mittheil. Die Wirkung von Blutgiften auf Membranen aus Lecithin und Cholesterin. Hofm. Beitr. zur chem. Physiol. und Pathol., I905, VI, 552.

4 Morgenroth. Ueber die Wiedergewinnung von Toxin aus seiner Antitoxinverbindung. Berl. klin.

Woch., I905, XLII, $155^{\circ}$.
5 Morgenroth and Pane. Ueber Beobachtungen reversibler Veränderungen an Toxinen. Biochemische Zeitschrift 1906, I, 354 . 
tion, there is always some reduction in this power. But if the neutralized venom solution be left in the room temperature for a few days and its hæmolytic strength be again measured, it will be found that the venom solution had become once again as strongly hæmolytic as its original native venom solution. On the other hand, the hæmolytic power of cobra venom heated without $\mathrm{HCl}$ remains at its reduced value without regaining its lost strength during the same length of time. Even after a lapse of only 4 hours the return of the hæmolytic strength was often seen to be very complete.

Faust ${ }^{1}$ tested his ophiotoxin for the hæmolytic property and found that this substance has quite marked action upon the washed or unwashed corpuscles of ox, pig, horse, and sheep. Heating to $90^{\circ} \mathrm{C}$. for 15 minutes did not destroy its hæmolytic power.

Ishizaka ${ }^{2}$ studied the hæmatoxic action of the venom of Lachesis flavoviridis and found that the blood of dog is more susceptible to the hæmolytic action than that of cat, rabbit, ox, or rat. 0.05 c.c. of dog's blood promptly dissolved by $0.000002 \mathrm{gm}$. of the venom, while $0.0000002 \mathrm{gm}$. caused only a trace of lysis. Cat's blood is much agglutinated, but only slightly dissolved even in a comparatively large quantity of the venom, while $20 \mathrm{mg}$. of the same failed to hæmolyze any part of the blood of mouse, ox, or rabbit. In these cases more or less agglutination took place. In support of the observations of Flexner and Noguchi, he found with this venom that thorough washing of the corpuscles retards or diminishes hæmolysis to a great extent. With the most susceptible kind of blood, namely, that of dog, Ishizaka found that after 3 to 6 washings the corpuscles become completely insusceptible to the smaller quantities of the venom. He found that lecithin can activate this venom very easily. Cholesterin is found to inhibit hæmolysis caused by the habu venom, but not by combining directly with the latter; this latter fact has been shown by Noguchi in his former studies.

In 1907 Noguchi attempted once more to clear up the questions concerning the susceptibility of the corpuscles of certain kinds of bloods and the nonsusceptibility of those of some other kinds to the hæmolytic action of venom. It appeared to him still quite uncertain why one set of the blood serums is able to activate venom, while the other is not. As to the nature of the thermostabile venom activators of the blood serum, Noguchi agrees with Kyes that it is chiefly lecithin which is capable of venom activation. But some serum contains, besides lecithin, certain thermolabile activators, whose action disappears when heated to $56^{\circ} \mathrm{C}$. for half an hour. There are numerous serums which are devoid of venom-activating property in the fresh state, but these all become invariably activating when heated to the temperature near or above the coagulation point. In these instances there is no doubt that lecithin is liberated by heat and activates venom freely. This, however, does not explain the venom-activating property of the fresh serums; it only suggests that lecithin may exist in one set of serums in a state to be acted upon

${ }_{1}^{1}$ Faust. Ueber das Ophiotoxin aus dem Gift der ostindischen Brillenschlange. Leipzig, I907, I9. 2 Ishizaka. Studien über das Habuschlangengift. Zeitschr. f. experim. Pathol. u. Therapie, I907, IV, 88. 
by venom, while not in the other set. This theory does not readily explain the activating property of a serum which becomes inactive at $56^{\circ} \mathrm{C}$., because if it were lecithin which activates venom, heating would not suppress its activity, as it is found by Noguchi that the acquired activating property of a nonactivating serum through the addition of an adequate quantity of available lecithin is not to be suppressed by a subsequent heating to that temperature. Lecithin is also characterized by its prompt activation, no matter how it is introduced into a serum. As to the quantities of lecithin existing in various kinds of the activating as well as non-activating serums, there are no great differences among them. The same difficulty is encountered in explaining the susceptibility and non-susceptibility of the blood corpuscles of different species of animals. They all contain lecithin in about the same quantities, but venom can not attack them with equal readiness. In the case of dog's corpuscles there is undoubtedly an indication that lecithin is concerned in venom hæmolysis. Again, in the case of serum of that animal the venomactivating property of the fresh serum appears to be caused, at least in part, by the presence of available lecithin. On the other hand, the thermolabile activators contained in the serums of guinea-pig, horse, cat, pig, rabbit, pigeon, hen, goose, and man are distinguished from lecithin by their slow activation. Besides, activation of venom due to lecithin can not be prevented by the addition of calcium chloride, while activation caused by substances which are not of the nature of lecithin is easily removed by this salt. Ether can not remove lecithin from the mixture with serum; hence the activating property of the serum which contains available lecithin remains undiminished after ethereal extraction.

On the other hand, the activators of the second group of serums go over to ether and render the extracted serums no longer activating. Meanwhile the substances extracted with ether can, when transferred to non-activating serum, confer the activating property upon the latter in a marked way. According to Noguchi the second group of activators consist mainly of nonphosphorized fats, fatty acids, and their soluble salts; while in serum these bodies are not hæmolytic, but become quite hæmolytic when venom is introduced. Their mode of activation therefore differs essentially from that caused by combination of venom and lecithin. The activating property of these bodies disappears when mixed with calcium chloride or heated to $56^{\circ} \mathrm{C}$. in the presence of serum components. On mixing non-activating serum with oleic acid or soluble compounds of oleic acid, the former acquires activating power very similar to that possessed by the fresh serums of the second group.

In regard to the variable susceptibility of the washed corpuscles of various kinds of bloods, Noguchi found an existing relation similar to that of activability of the different kinds of blood serums. The water-laked solution or the stroma of the corpuscles of the non-susceptible kind does not contain venom activators, while the reverse is true of the susceptible variety. Of the corpuscular activators there are again two groups - one that of lecithin and the non-phosphorized lipoids. The corpuscles of dog contain both sets, but 
most bloods contain mainly the second group. Ethereal extraction removes from the latter the greater part of the activators, which, when introduced into the non-susceptible variety of corpuscles, make the latter susceptible to the hæmolytic effect of venom. Calcium chloride removes the activating property very effectively, but not that of the first group (dog). In accordance with this finding the defibrinated bloods of the second group are very well protected by the addition of calcium chloride, but this salt fails to protect the blood of the first group. Even the washed corpuscles of the latter group may finally be hæmolyzed by venom in spite of the presence of calcium chloride, demonstrating that lecithin forms at least a part of the activators in these cells. It may be recalled at this place that both from the non-activating serums and from the non-susceptible corpuscles a certain quantity of lecithin is easily extractable with hot alcohol.

It has repeatedly been stated that every serum becomes venom-activating when heated to coagulation and that it matters not whether the serum was originally activating or not. The activating property developing after heating is uninfluenced by calcium chloride and its action is very rapid. There can be no doubt that it is due to the liberation of lecithin by heat. Noguchi found, however, that non-activating serum is here again quite inferior to activating serum in its activating power after heating. In both instances ethereal extraction fails to remove the activator from the clear filtrate which alone is activating. It appears that lecithin exists as a non-coagulable protein compound, comparable to Chabrie's albumin.

Now, taking up the question why lecithin is available for venom activation in dog's serum and not in ox's serum, Noguchi was able to show that lecithin as existing in paired state with serum albumin and serum globulins is entirely inactive in regard to venom activation. It is the same with non-activating or activating serums. But in the activating variety (dog) there exists in the serum a certain protein compound of lecithin capable of venom activation, but not in the non-activating serum. This compound remains in solution when serum globulins are precipitated by dialysis, but can be precipitated by half-saturation with ammonium sulphate. It is perfectly soluble in water, and is not coagulable in neutral alkaline salts solutions upon boiling. Calcium chloride has no inhibiting influence on its venom-activating property and warm alcohol extraction of this protein yields much lecithin, but not with ether. In this place it may be remarked that boiling of fractionated albumin and globulins of ox serum did not produce any striking amount of venom activator. No study has been made to find out why the whole serum produces and the fractionated proteins do not produce venom-activating lecithin compounds on boiling, but the removal of certain salts and lipoids through fractionation may in part account for the difference.

Noguchi is inclined to consider the activation of venom by certain fatty substances, at least in part, as a sort of cumulative action of venom and these chemicals. That venom inflicts upon the washed corpuscles a rather marked injury and renders the latter considerably more subject to all kinds of destruc- 
tive effects of a physical nature has already been shown. But it is not at all improbable that these fatty substances have acted as mordants and enabled the interaction of venom and lecithin compounds of proteins to take place, and hence hæmolysis. At the same time we must not forget that most normal fatty acids can not take the place of acrylic acids as venom activators; that the inherent hæmolytic powers of higher members of the latter acids are nearly to times greater than any other acid, organic or mineral; that lower alcohols, which have quite large lecithin-solving property with but little hæmolytic power, fail to accelerate venom hæmolysis to any marked degree; and finally that mineral as well as organic bases favor slightly if at all the attack of venom on the blood corpuscles. There is one thing which seems to be necessary for the venom-activating property of these acrylic acids and their compounds - that is, the powerful hæmolytic quality. It is still undetermined just how far the lipoid solvent property of these acids and soaps is concerned in their inherent hæmolytic property and also their venom-activating property. The alterations of physical factors, such as the diminution of the osmotic tension of the fluidal media through the introduction of these particular chemical bodies, may play certain important parts in regard to the bursting of the delicate lipoid-like membrane of the blood corpuscles.

Gengou ${ }^{1}$ found that sodium citrate when used in 2.1 per cent solution can stop the hæmolysis caused by cobra venom and suitable blood serum. This antihæmolytic property is, however, removed by adding sufficient calcium chloride to such mixture. The introduction of the latter salt will cause the formation of calcium citrate and sodium chloride, thus removing the inhibiting effect of the soluble citrate from the mixture. Gengou used just enough calcium chloride to remove the citrate soda and did not notice the antihæmolytic property of the lime salt. He employed the laked solution of the washed corpuscles of guinea-pig's blood as a venom activator and obtained a similar result in regard to the antihæmolytic action of sodium citrate.

TABLE IO.

Mixture $=$ (I) Washed corpuscles of ox, I drop. (2) 0.4 per cent cobra-venom solution, 0.2 c.c. (3) Fresh guinea-pig serum in doses indicated in the table. (4) Solutions of respective chemicals in doses to make up the total quantity of the resulting fluid, I c.c. per tube.

\begin{tabular}{|c|c|c|c|}
\hline \multirow{2}{*}{$\begin{array}{l}\text { Amount } \\
\text { of } \\
\text { serum } \\
\text { in c. c. }\end{array}$} & \multicolumn{3}{|c|}{ Hæmolysis produced. } \\
\hline & $\begin{array}{l}\text { Calcium chloride } \\
0.8 \text { per cent solution. }\end{array}$ & $\begin{array}{l}\text { Sodium citrate } \\
\text { a per cent solution. }\end{array}$ & $\begin{array}{l}\text { Sodium chloride } \\
\text { o.9 per cent solution. }\end{array}$ \\
\hline $\begin{array}{l}0.5 \\
0.35 \\
0.25 \\
0.15 \\
0\end{array}$ & $\begin{array}{l}\text { Slight in } 24 \text { hours } \\
\text { None in } 24 \text { hours } \\
\text { None in } 24 \text { hours } \\
\text { None in } 24 \text { hours } \\
\text { None in } 24 \text { hours }\end{array}$ & $\begin{array}{l}\text { Slight in } 24 \text { hours } \\
\text { Trace in } 24 \text { hours } \\
\text { None in } 24 \text { hours } \\
\text { None in } 24 \text { hours } \\
\text { None in } 24 \text { hours }\end{array}$ & $\begin{array}{l}\text { Complete in } 20 \mathrm{~min} \text {. } \\
\text { Complete in } 20 \mathrm{~min} \text {. } \\
\text { Complete in } 40 \mathrm{~min} \text {. } \\
\text { Complete in } 20 \mathrm{~min} \text {. } \\
\text { None. }\end{array}$ \\
\hline
\end{tabular}

Noguchi compared the antihæmolytic powers of sodium citrate and calcium chloride with cobra venom and was able to confirm Gengou's observations.

1 Gengou. Compt. rend. de la Soc. de Biol., 190\%, LXII, 409. 
Both sodium citrate and calcium chloride are very effective antihæmolytic agents against venom. Substituting guinea-pigs' cells for ox corpuscles, the result was the same.

In the next series of experiments the concentrations of these two chemicals were gradually reduced, whereas 0.9 per cent solution of sodium chloride was used as diluent.

TABLE II.

Mixiure $=$ Washed corpuscles of guinea-pig, I drop. 0.4 per cent cobra-venom solution, 0.2 c.c. Fresh guinea-pig serum, 0.35 c.c.

\begin{tabular}{|c|c|c|}
\hline \multirow{2}{*}{$\begin{array}{l}\text { Amounts of } \\
\text { antihæmolytic } \\
\text { salt solutions } \\
\text { added to the } \\
\text { mixture, making } \\
\text { the total } 1.5 \text { c. c. }\end{array}$} & \multicolumn{2}{|c|}{ Hæmolysis produced. } \\
\hline & $\begin{array}{l}\text { Calcium chloride, } \\
\text { o.8 per cent solution. }\end{array}$ & $\begin{array}{l}\text { Sodium citrate, } \\
2 \text { per cent solution. }\end{array}$ \\
\hline I & None .. & None. \\
\hline 0.8 & None ........ & Complete in 2 hours. \\
\hline 0.6 & None ........... & Complete in $60 \mathrm{~min}$. \\
\hline 0.5 & None $\ldots . . . \ldots \ldots$ & Complete in $40 \mathrm{~min}$. \\
\hline 0.4 & None......... & Complete in $25 \mathrm{~min}$. \\
\hline 0.3 & None $\ldots \ldots \ldots \ldots \ldots$ & Complete in $20 \mathrm{~min}$. \\
\hline 0.25 & Complete in 4 hours. & Complete in $15 \mathrm{~min}$. \\
\hline 0.15 & Complete in 2 hours.. & Complete in 15 min. \\
\hline 0.1 & Complete in $30 \mathrm{~min} .$. & Complete in $15 \mathrm{~min}$. \\
\hline$\circ$ & Complete in ro min... & Complete in $10 \mathrm{~min}$. \\
\hline
\end{tabular}

It is noteworthy that calcium chloride has a far stronger antihæmolytic power than sodium citrate and seems to have no relation to the increase of tonicity of the mixture. On the other hand, the concentration of sodium citrate is quite above its isotonicity in effecting the antihæmolytic action of this salt, which is isotonic at a concentration of about 1.76 per cent in the case of guinea-pig corpuscles. 0.8 per cent solution of calcium chloride is here isotonic.

In a third series of experiments the comparative antihæmolytic powers of these two chemicals were tested against different venom activators in the presence of cobra venom.

TABLE I 2.

Washed corpuscles of ox, I drop. 0.4 per cent cobra-venom solution, 0.2 c.c.

\begin{tabular}{|c|c|c|c|}
\hline \multirow{2}{*}{ Activators 0.2 c.c. each. } & \multicolumn{3}{|c|}{ Hæmolysis produced. } \\
\hline & $\begin{array}{l}\text { Calcium chloride } 0.8 \text { per } \\
\text { cent solution I c.c. }\end{array}$ & $\begin{array}{l}\text { Sodium citrate } 2 \text { per cent } \\
\text { solution I c.c. }\end{array}$ & $\begin{array}{l}\text { Sodium chloride } 0.9 \text { per cent } \\
\text { solution I c.c. }\end{array}$ \\
\hline N/rooo lecithin & Complete and prompt & Complete, but with & Complete and prompt. \\
\hline I per cent ovovitellin... & do & do ....... & Do. \\
\hline Heated dog serum ..... & do .. & do & Do. \\
\hline $\begin{array}{l}\text { Fresh guinea-pig serum } \\
\text { N/ rooo sod. oleate .... }\end{array}$ & $\begin{array}{l}\text { None... } \\
\text { do.. }\end{array}$ & $\begin{array}{l}\text { Slight..... } \\
\text { Complete }\end{array}$ & $\begin{array}{l}\text { Complete, but slowly. } \\
\text { Complete and fairly }\end{array}$ \\
\hline $\begin{array}{l}\text { N/rooo neurin oleate } \\
\text { N/rooo ammon. oleate } \\
\text { N/ 100o oleic acid ..... } \\
\text { No activator } \ldots . . . . .\end{array}$ & $\begin{array}{l}\text { do } . . \\
\text { do } . \\
\text { do } . . \\
\text { do } . .\end{array}$ & $\begin{array}{r}\text { do } \text {. } \\
\text { do : } \\
\text { done .. }\end{array}$ & $\begin{array}{l}\text { Do. } \\
\text { Do. } \\
\text { Do. } \\
\text { None. }\end{array}$ \\
\hline
\end{tabular}


From the above table it appears that the antihæmolytic property of sodium citrate is not directed against the same set of activators as that of calcium chloride. Sodium citrate has a certain inhibiting influence upon hæmolysis caused by venom and lecithin, but almost none against the combination hæmolysis of fatty substances and venom. This relation is exactly the reverse with calcium chloride.

Teruuchi ${ }^{1}$ found that cobra hæmolysin and its antitoxin are destroyed by dog's pancreatic juice, activated with the intestinal juice. Cobra lecithid is not affected by this treatment. Through digestion of the neutral mixture of cobralysin and antitoxin by pancreatic juice a portion of the lysin can be restituted. On the other hand, the combination of the mixture of cobralysin and antitoxin with lecithin before digestion seems to prevent the liberation of active lysin under the influence of the pancreatic juice.

Von Dungern and Coca studied the constitution of cobra hæmolysins and found that the washed corpuscles of ox, which are completely insusceptible to the venom, can be dissolved by adding either fresh guinea-pig serum or lecithin. This was first discovered by Flexner and Noguchi and Kyes and Sachs. Von Dungern and Coca investigated whether the cobralysin is absorbed by these corpuscles or not. By allowing the washed ox corpuscles to remain in contact with cobra venom for some hours they found that the cells absorbed a certain portion of cobralysin from the fluid in which they had been suspended. The evidence of absorption was brought out by washing the corpuscles with saline solution, freeing them from cobralysin, and then examining the corpuscles for susceptibility to serum complements and lecithin. If the corpuscles were laden with venom amboceptors, or sensitized with venom sensibilisatrice, hæmolysis would occur on adding complements or lecithin. In fact, they discovered that the venomized corpuscles are easily dissolved by adding guinea-pig complements, but not lecithin. They examined the venom solution, after separation of the corpuscles, for its hæmolytic property, and again demonstrated that it retained all its hæmolysin content by adding lecithin, but lost all its complement-activable hæmolysin. In other words, venom contains two different types of hæmolysins, one resembling typical serum amboceptor, the other quite different from that class of hæmolysins. The latter is active in the presence of lecithin, but not of serum complements, and is not absorbed by the ox corpuscles.

Not knowing the discovery of Noguchi, von Dungern and Coca, independdently of him, found that calcium chloride, barium chloride, and magnesium chloride can prevent hæmolysis caused by venom - especially that calcium chloride is of much greater power than the other two. Like Noguchi, they also observed that their antihæmolytic properties are due to suppression of the activating property of serum complements, without preventing the amboceptors from being absorbed by the corpuscles. Only a slight inhibition can

\footnotetext{
1 Teruuchi. Die Wirkung des Pankreassaftes auf das Hämolysin des Cobragiftes und seine Verbin, dungen mit dem Antitoxin und Lecithin. Hoppe-Seyler's Zeitschr. f. physiol. Chem., 1907* LI, $47^{8}$.
} 
be obtained by these salts against venom-lecithin hæmolysis. Peculiarly enough, barium chloride exceeds the other in its antagonistic action against this form of hæmolysis.

Von Dungern and Coca incidentally refer to the regeneration of the complement once inactivated by barium chloride by means of adding sodium sulphate. This confirms the observations of Noguchi, who studied the same phenomenon with numerous complements and chemicals. ${ }^{1}$ As to the cause of certain inhibitory influence exerted by barium chloride against cobra venom in the presence of lecithin, these investigators ascribe it to the interference of this salt on the formation of lecithid, because the prepared lecithid is as hæmolytic in the barium solution as in the sodium-chloride solution. On the other hand, the prepared lecithid shows less strength in sugar solution ( 9.35 per cent) than in the saline solution ( 0.8 per cent). Formation of cobra lecithid seems to be much easier in the sugar solution than in the saline solution, because certain kinds of blood are easily hæmolyzed in the former, but not at all in the latter medium (Goebel). This phenomenon is interesting, as it presents a reverse relation to the hæmolysis caused by the serum amboceptor and complement.

Von Dungern and Coca studied the nature of cobra lecithid in regard to its bearing on immunity. They prepared lecithids in the usual way, originally given by Kyes. The results of their experiments do not favor the toxin-like view of lecithid. They immunized rabbit with lecithid and obtained antihæmolytic serum. But the antihæmolytic power of the immune serum does not manifest itself until it has been heated to $64^{\circ} \mathrm{C}$., because the normal rabbit serum is found to be almost as strongly antilecithidal as the immune serum in the fresh state. This peculiar phenomenon was first observed and described by Kyes in his studies of immunization against lecithid. Kyes's interpretation was that the normal rabbit serum contains a certain amount of anti-body against lecithid, and its destruction by means of previous heating of the serum to $64^{\circ} \mathrm{C}$. is necessary to make the specific antihæmolytic property of the immune serum appear in a more striking degree.

Von Dungern and Coca gave a very different explanation for this phenomenon on the grounds of their own experiments. They assume that lecithid contains a certain quantity of lecithin-splitting venom-ferment or hæmolysin and the immunization of animals with such mixture causes appearance of anti-body for this minute quantity of venom lysin in its blood serum. The reason why the heated normal serum becomes inactive and the heated immune serum still more or less active against lecithid is that the former furnishes enough liberated lecithin to be acted upon by the native venom contained in the lecithid, hence more hæmolysis than with the fresh normal serum. On the other hand, the immune serum contains, even after heating $\left(64^{\circ} \mathrm{C}\right.$.), a specific anti-body to neutralize the native venom of the lecithid; hence the presence of free lecithin in the heated immune serum is

I Noguchi. Ueber die chemische Inaktivierung und Regeneration der Komplemente. Biochem. Zeitschr., 1907, VI, 327 . 
no longer attacked and rendered lytic by the otherwise active native venom of the lecithid.

At the same time von Dungern and Coca show that a subminimal hæmolytic dose of cobra lecithid becomes a complete hæmolyzing dose if enough of lecithin be added to the mixture, showing that there is still present in the so-called pure lecithid enough lecithin-splitting venom component. On the other hand, the antihæmolytic powers of the heated normal and immune rabbit serums do not differ if they are tested against the lecithid which had been heated to $100^{\circ} \mathrm{C}$. for 3 hours, because here the specific anti-body is not concerned in the reaction. In the case of the heated normal serum the lecithin remains unattacked by the lecithid without the adhering native venom and there will be no more hæmolysis than in the case of the fresh serum.

Von Dungern and Coca do not consider it necessary to assume that cobra lecithid is a chemical compound of venom and lecithin, but entertain the view that the hæmolytic substance is only a split product of lecithin and is contaminated with a minute quantity of native venom component, the latter playing but little part in the hæmolytic activity of the whole lecithid.

From various preparations of ovolecithin they were able to isolate a highly hæmolytic substance with all the physical and biological characteristics of cobra lecithid, except that it did not show evidence of the adherence of native cobra venom, and hence no increase in its lytic power by lecithin addition and no antilysin formation in the animal body. Its hæmolytic activity was about half that of cobra lecithid.

In a subsequent paper ${ }^{1}$ von Dungern and Coca attempted to solve the mechanism of venom hæmolysis induced by adding oleic acid or sodium oleate in subminimal inherent hæmolytic quantities. As already stated, Noguchi, among many other acrylic acids and soaps, found these two chemicals especially suitable for rendering the blood corpuscles hæmolyzable by venom.

Von Dungern and Coca treated the ox corpuscles with cobra-venom solution for I hour ( 20 c.c. 5 per cent corpuscular suspension and 2 c.c. I per cent cobra-venom solution), and then, after separation from the venom, their susceptibility to the hæmolytic action of oleic acid and sodium oleate was tested. The result shows that the degree of hæmolysis is the same whether the corpuscles have been venomized or not. Thus they could find no comparison between the hæmolytic serum complement and these oleic compounds. Then they tried to ascertain if cobra venom can act directly on these chemicals and render them more active, but this was found not to be the case. On the contrary, oleate soap, if allowed to act long, rather diminished than increased the action of cobra venom when there was no blood or lecithin in the mixture. However, if the soap, venom, and lecithin are allowed to remain in contact for a much longer period, the hæmolytic activity of such mixture is rather greater than that of a mixture in which soap is added at the same time as or just before the addition of blood. Oleic acid always exerts an accelerating

1 Von Dungern and Coca. Ueber Hämolyse durch Kombination von Oelsäure oder ölsaures Natrium und Kobragift. Münch. med. Woch., 1908, LV, 105. 
influence, but is not an activation of this acid by venom. Sodium oleate, which is at first somewhat inhibitory, later accelerates the lecithin-splitting process of the venom, and oleic acid favors this reaction under all conditions.

Von Dungern and Coca finally advanced the theory that oleic acid and sodium oleate alter the solubility of cobra-venom components and enable the venom to attack the lecithin of the serum or corpuscles.

\section{ANTIHÆMOLYTIC PROPERTIES OF CHOLESTERIN.}

Abderhalden and Le Count ${ }^{1}$ made an extensive investigation on the mechanism of the antihæmolytic property of cholesterin against venomlecithin hæmolysis. By using various derivative products of cholesterin and also many cleavage and synthetic compounds of proteins they tried to locate the radical upon whose existence the antagonistic property of cholesterin is dependent. They tested a few amino-acids and numerous peptids-dipeptids, tripeptids, and tetrapeptids, peptone Siegfried, etc., but none of these bodies was able to exert the antihæmolytic action. Of cholesterin and its derivates they employed (I) cholesterin from human gall-stone, $\mathrm{C}_{27} \mathrm{H}_{44} \mathrm{O}$; (2) cholesterin from egg-yolk, $\mathrm{C}_{27} \mathrm{H}_{44} \mathrm{O}$; (3) a cholesterin-like body obtained from the radish oil; (4) cholesteryl chloride, $\mathrm{C}_{27} \mathrm{H}_{43} \mathrm{Cl}$; (5) cholesteryl acetate, $\mathrm{C}_{27} \mathrm{H}_{43} \mathrm{OC}_{2} \mathrm{H}_{3} \mathrm{O}$; (6) cholesteryl benzoate, $\mathrm{C}_{27} \mathrm{H}_{43} \mathrm{C}_{6} \mathrm{H}_{5} \mathrm{CO}_{2}$, cholesten, $\mathrm{C}_{27} \mathrm{H}_{44}$; cholesteron, $\mathrm{C}_{27} \mathrm{H}_{44} \mathrm{O}$ (ketone); cholesteron-oxim, $\mathrm{C}_{27} \mathrm{H}_{45} \mathrm{ON}$ (normal oxim of ketone); oxynitrocholesteryl nitrate, $\mathrm{C}_{27} \mathrm{H}_{42} \mathrm{~N}_{2} \mathrm{O}_{6}$; cholesteronol acetate, $\mathrm{C}_{27} \mathrm{H}_{43} \mathrm{O}_{2} \cdot \mathrm{C}_{2} \mathrm{H}_{3} \mathrm{O}$; cholesteronol formiate, $\mathrm{C}_{27} \mathrm{H}_{43} \mathrm{O} \cdot \mathrm{CHO}$; cholestandion, $\mathrm{C}_{27} \mathrm{H}_{42} \mathrm{O}_{2}$; cholestenon diacid, $\mathrm{C}_{27} \mathrm{H}_{42} \mathrm{O}_{5}$ (ketodicarbonic acid); dimethylester of cholestenon diacid, $\mathrm{C}_{27} \mathrm{H}_{48} \mathrm{O}_{5}$ and its sodium salt; chlordicarbonic acid, $\mathrm{C}_{27} \mathrm{H}_{43} \mathrm{ClO}_{4}$; lactone acid, $\mathrm{C}_{27} \mathrm{H}_{40} \mathrm{O}_{5}$.

These substances were first tested for their inherent hæmolytic powers. They all reacted acid when dissolved in a fluid containing methyl alcohol sufficient to hold them in solution. The acidity was neutralized by adding $\mathrm{N} /$ IO $\mathrm{NaOH}$ (indicated by phenolphthalein), the latter solution being prepared by mixing I part of normal $\mathrm{NaOH}$ with 9 parts of methyl alcohol, thus preventing precipitation of the cholesterin and the cholesterin derivatives from the diminution of alcohol percentage during neutralization. The amount of $\mathrm{NaOH}$ required for neutralization was so small that that alone could not produce any marked hæmolysis. Cholesterin from egg-yolk after neutralization became somewhat hæmolytic; the alkali added to it was enough to cause hæmolysis by itself.

The experimental plans were as follows: Cobra venom 0.I c.c. of 0.005 per cent solution uniform. Lecithin 0.I c.c. of 0.05 per cent solution uniform. I c.c. of 5 per cent suspension of the blood corpuscles - horse and goat in an 8 per cent methyl-alcohol, isotonic, salt solution. Then decreasing amounts of the solutions of cholesterins and various derivatives were added.

1 Abderhalden and Le Count. Die Beziehungen zwischen Cholesterin, Lecithin und Cobragift, Tetanus-Toxin, Saponin und Solanin. Zeitschr. f. Pathol. u. Therapie, r905, II, I99. 
The concentration of the cholesterins and their derivatives was usually 0.02 per cent. I c.c. or less of such solution was added to the above combinations.

The results obtained by Abderhalden and Le Count show that cholesterins obtained from gall-stones and egg-yolks displayed marked and about equal antihæmolytic powers, being still able to prevent hæmolysis in doses of 0.15 c.c. and upwards. A cholesterin-like preparation from the radish oil was without this property. Cholesterin showed a slight inhibition when used in dose of I c.c. Cholesteron was entirely inactive in this regard. The chloride, acetate, and benzoate of cholesterin were devoid of antilytic power. Cholesteron-oxim was highly inhibiting, while cholesteron itself was inactive. As to the effect of neutralization of cholesterins with $\mathrm{NaOH}$ they found this property almost unaffected, save the hæmolysis which attends the larger quantities of the neutralized cholesterins, ${ }^{1}$ perhaps due to the dissociable alkali under the circumstances. The rest of the chemicals tested by them were inactive in regard to the venom-lecithin hæmolysis.

From these results Abderhalden and Le Count conclude that the free hydroxyl group is indispensable to the antihæmolytic action of these bodies, and that the double bonds may not be entirely indifferent.

In 1905 Noguchi made a more exhaustive study of the mechanism of Mitchell's phenomenon, or the non-hæmolyzability of the blood corpuscles in a very concentrated venom solution. Mitchell and Stewart observed that in a mixture of blood and fresh venom, in equal parts, the corpuscles, instead of undergoing hæmolysis, were actually preserved from disintegration for a period considerably greater than in the control specimens to which no venom had been added. On the other hand, if the amount of venom employed was less than Io per cent of the mixture, hæmolysis occurred in the usual way. They were led by their experiments to regard the once-dried venom as being a less effective preservative than the fresh secretion, and they noted that, of the corpuscles tested, those of the rattlesnake were most perfectly preserved by crotalus venom. Stephens and Myers, Kyes, Kyes and Sachs, and Lamb encountered the same phenomenon in the course of their studies with cobra, bungarus, and daboia venom. Flexner and Noguchi also confirmed the protective property of crotalus venom upon rabbit corpuscles. It may now be regarded as well established that when the optimum of the hæmolytic action of venom is exceeded, the degree of hæmolysis which it is capable of producing diminishes gradually as the dose of the venom increases. Among the natural biological hæmolysins, venom alone is known to possess this property, but, in the course of a study of bacteriolysis with certain immune sera of high potency, Neisser and Wechsberg observed an inhibition of bactericidal effects when an excess of amboceptors, relative to the complement content, was brought into bacterial suspension.

A similar, although probably distinct, phenomenon has been described by Detre and Sellei in their studies of hæmolysis caused by bichloride of mer-

1 Against tetanolysin the antilytic power was increased by neutralization of cholesterins, while against saponin and solanin it disappeared after neutralization. 
cury. As has been shown by Madsen and Walbum, acids in excess produce non-hæmolyzability of the corpuscles, whereas their weaker concentration causes regular dissolution of the cells.

Kyes and Sachs explain this phenomenon by assuming that an excess of venom amboceptors produces "side-tracking" of lecithin and renders the latter unable to attack the venomized corpuscles. In other words, the hæmolytic amboceptors of the venom are responsible for this phenomenon when used in great excess. They did not, however, produce the evidence that the venom from which all coagulable constituents have been eliminated by a brief boiling, which is insufficient to diminish its hæmolytic power, is still capable of producing this protective phenomenon.

Noguchi analyzed this phenomenon in quite a different manner and reached an entirely different conclusion. He treated the washed corpuscles of horse with varying strengths of different venoms, ranging from a superhæmolytic (or non-hæmolyzable) dose to an optimum hæmolytic dose (this latter concentration is only hæmolytic in the presence of suitable venom activators). When venom is present in more than 5 per cent concentration the hæmolysis of the defibrinated blood of horse is retarded for nearly I 2 hours at $20^{\circ} \mathrm{C}$., causing no lysis within the first 6 hours. But as long as there is a trace of serum constituents in the mixture complete dissolution can not be prevented by any practicable concentration of venom. An equal mixture of the defibrinated blood and 2.5 per cent cobra-venom solution will undergo hæmolysis in I or 2 hours.

It has already been stated that the thoroughly washed corpuscles of horse are not hæmolyzed by venom, no matter what the degree of concentration.

If cobra venom in strengths above 4 per cent be mixed with a corpuscular suspension of 5 per cent, no change may take place in the mixture in many weeks; while with a quantity of venom as small as o.I per cent the cells will disintegrate rather more quickly than in control tubes which are not entirely sterile.

Corpuscles which had been brought into contact with the stronger solutions of venom were tested for resistance to salt solutions of varying toxicity. These tests disclosed the unexpected fact that corpuscles thus highly venomized, and in the presence of an excess of venom, are not hæmolyzable even by water. At the same time their susceptibility to heat is changed. It has been found that the control tubes of blood corpuscles alone are hæmolyzed completely in from I 75 to I 80 minutes when kept at the constant temperature of $53^{\circ} \mathrm{C}$. In the presence of venom of a concentration not exceeding I per cent, complete hæmolysis will take place at this temperature in from 5 to 15 minutes; with a concentration of venom as low as o.oI per cent 30 minutes will be required; with a concentration of Io per cent there is no perceptible change in the corpuscles for the first 20 minutes, after which laking commences. This last laking is not, however, typical. A bright hæmoglobin color does not appear in the fluid, but the cells undergo disintegration, the color of the mixture becomes coffee-like, and in about an hour a turbid pre- 
cipitate of cell particles and venom granules can be discerned under the microscope.

Strong solutions of venom are capable of protecting the corpuscles from destruction by water, but venom solutions below 2 per cent in strength render the cells more sensitive to salt solutions, as measured by the toxicity of the fluid for the corpuscles; and as the strength of the venom descends from this limit the susceptibility, as measured by the degree of toxicity, diminishes.

The next step of inquiry into the mechanism of this phenomenon was taken by Noguchi, who first determined whether the hæmolytic amboceptors of venom have any relation to it. The washed corpuscles of horse were mixed with 10 per cent and 2 per cent solutions of cobra venom and acted upon by the latter for two hours. After this period of contact an excess of horse serum or lecithin was introduced into the mixtures. No hæmolysis took place in the mixture containing Io per cent venom, while complete hæmolysis occurred in the mixture with 2 per cent venom in it. An activator deviation does not exist here.

Another way of demonstrating the non-participation of hæmolysins in this protective phenomenon was brought out by heating the venom to $95^{\circ} \mathrm{C}$. and $100^{\circ} \mathrm{C}$. for a brief period. The venom which had been heated to $95^{\circ} \mathrm{C}$. was a milky fluid with fine precipitate, but it still had both the protective and hæmolytic properties. By separating the coagula by filtration the protective body remains on the filter, while the entire content of hæmolysin reappears in the clear filtrate. When the venom is heated to $100^{\circ} \mathrm{C}$. for 5 minutes it becomes non-protective, but the heated solution contains the greater portion of the hæmolytic principle. Heating to $135^{\circ} \mathrm{C}$. destroys both the hæmolytic and protective properties in toto. That the hæmolytic filtrate of the heated poison exerts a markedly injurious effect on the integrity of washed corpuscles of horse - even in a concentration of Io to 20 per cent of heated venom is also shown by the reduction of their resistance to toxicity. Until a specially injurious agent, which predisposes corpuscles to laking by physical agents, is discovered in venom, Noguchi is inclined to believe that the injurious action of the filtrate is due to venom hæmolysin.

Another interesting fact was brought out in regard to the venom-protection phenomenon. The serum of rattlesnake is highly agglutinative and hæmolytic for corpuscles of horse, and yet it does not protect them in any degree against injurious physical agents. The corpuscles of horse, after a contact of $\mathrm{I} 2$ hours with the inactivated rattlesnake serum in excess, were hæmolyzed by salt solution of 0.45 per cent strength.

The protection afforded by the strong concentration of venom disappears when the corpuscles are washed in salt solution and freed from the venom. Such corpuscles show a greater diminution of their physical resistance than those treated with a weaker venom solution. It is very singular that the protection is closely associated with the presence of the venom.

The venomized corpuscles, which are non-hæmolyzable even in water, are readily hæmolyzed by weak solutions of acid or alkali, and in these cases the 
venomized cells succumb to the latter effects much more easily than the normal corpuscles. Saponin, on the other hand, fails to hæmolyze the venomprotected corpuscles, unless the venom has previously been removed, in which case laking is more prompt in the treated cells than in the untreated cells. The venom renders the corpuscles unhæmolyzable in about 20 minutes.

Noguchi finally proceeded to find out the nature of this protective phenomenon. It was ascertained that the aqueous solution of horse corpuscles does form minute precipitates when mixed with a strong solution of venom. The stroma separated from the water-laked corpuscular solution did not give any appreciable quantity of precipitation. By using an aqueous solution of pure hæmoglobin he discovered that venom produces precipitation with this solution. But in a saline solution at 0.9 per cent the precipitate was of coarser and scantier nature. The weak solutions of acid or alkali promptly dissolve the venom-hæmoglobin precipitate. This seems to explain why acid and alkali hæmolyze the venom-protected corpuscles, while water does not. Globin obtained from the horse hæmoglobin was found to be readily precipitated out by venom from its aqueous, but not saline, solution.

Further, it was found that not every hæmoglobin solution is precipitable by venom. The intracorpuscular contents of horse, rat, and rabbit bloods gave abundant precipitate, while none was obtained with those of dog and guineapig bloods. The solutions of pure hæmoglobin and globin of dog's blood corpuscles did not give precipitation with venom. It may be mentioned here that the corpuscles of dog and guinea-pig are never protected by any high strength of venom, while those of horse, rabbit, and rat become entirely non-hæmolyzable when mixed with strong venom solution.

Noguchi adds that when the serum globulin of horse serum - obtained by dialysis - is suspended in water or weak saline solution, the venom quickly brings down the suspended particles, which, left to themselves, subside very slowly, if at all. Of globulins, pseudoglobulin gave the most abundant precipitation with venom.

The venom-protected corpuscles resist the hæmolytic action of tetanolysin and the destruction by fluorescent aniline dyes when exposed to the sun's rays. 


\section{CHAPTER XVII.}

\section{CYTOLYSINS IN SNAKE VENOM.}

The death-dealing neurotoxins and the hæmorrhagins are most important of all cytolysins contained in snake venom, and the best-studied are the hæmolysins, including the erythrocytolysins and leucocytolysins. Full descriptions of these three groups of cytolysins have already been given elsewhere under separate headings and I shall not repeat them in the present section.

Apart from the neurolysins, hæmorrhagins, and hæmolysins several other cytolysins have been demonstrated in snake venom by Flexner and Noguchi, ${ }^{1}$ and somewhat later by Calmette and Noc. ${ }^{2}$

The results of experiments obtained by Flexner and Noguchi are given in table 13. The venoms employed were those of Cobra, Ancistrodon piscivorus, Crotalus adamanteus, Daboia russellii, and Lachesis flavoviridis.

The animal cells came from a wide range of animals, including warmblooded and cold-blooded species. The former, limited to certain species of mammalia, had served for the study of the effects of venom upon the cells of the liver, kidney, and testes; the latter for that upon the spermatozoa, ova, and nerve cells. The cells were obtained by preparing emulsions of the solid organs and by suspending the expressed spermatozoa or separated ova in appropriate fluids. In the case of warm-blooded animals 0.85 per cent saline solution, and in the case of the marine animals fresh sea-water, were employed. The strength of the emulsions of the cells was approximately 5 per cent of the organs used.

The venom was dissolved in 0.85 per cent saline solution or in sea-water.

The temperature to which mixtures of emulsion and venom were exposed were those of the room or thermostat $\left(37^{\circ} \mathrm{C}\right.$.), depending, usually, on the origin of the cells. Observations of the effects were made (I) in test-tubes with the naked eye and (2) by means of microscopical examination.

\section{EFFECT OF VENOM ON CELLS OF WARM-BLOODED ANIMALS. ${ }^{3}$}

The animals used in these experiments were dog, guinea-pig, rabbit, rat, and sheep. The venoms employed were daboia and crotalus. The experiments given would seem to prove conclusively that venom contains solvents for the parenchymatous cells of several animals, and that considerable differences in activity in this respect occur, according to the source of the venom.

Flexner and Noguchi have also tested other venoms, for example, from the cobra, water-moccasin, and habu, and have found them to possess similar cytolytic properties; but their experiments show that daboia venom contains the most and crotalus venom the least active solvents, the other venoms arranging themselves in the order: water-moccasin, cobra. (Table I3.)

\footnotetext{
1 Flexner and Noguchi. On the plurality of cytolysins in snake venom.

2 Noc. Sur quelques propriétés physiologiques de différents venins de serpents. Ann. Inst. Pasteur, 1904, XVIII, 387.

8 Rabbits' spermatozoa are seen to stop their motion under the influence of crotalus venom. (Weir Mitchell and Reichert.)
} 
TABLE I3.

[Experiment I: Dog's Organs.]

\begin{tabular}{|c|c|c|}
\hline $\begin{array}{l}\text { Cells and } \\
\text { duration. }\end{array}$ & Control. & I per cent daboia venom. \\
\hline $\begin{array}{l}\text { Liver, } \\
3 \text { hours. }\end{array}$ & $\begin{array}{l}\text { Contains separated and } \\
\text { united liver cells; few } \\
\text { free granules and cre- } \\
\text { nated red corpuscles. }\end{array}$ & $\begin{array}{l}\text { Marked agglutination and clearing of fluid; } \\
\text { complete disappearance of cell outlines } \\
\text { and forms. Only ground substance con- } \\
\text { taining numerous refractive granules re- } \\
\text { mains. No nuclei visible. }\end{array}$ \\
\hline $\begin{array}{l}\text { Kidney, } \\
3 \text { hours. }\end{array}$ & $\begin{array}{l}\text { Cells much broken; few } \\
\text { complete cells; many } \\
\text { free nuclei and gran- } \\
\text { ules. Some complete } \\
\text { tubules and glomeruli. }\end{array}$ & $\begin{array}{l}\text { Marked agglutination and clarification of } \\
\text { emulsion; no complete cells visible; ground } \\
\text { substance granular. Glomerular blood } \\
\text { dissolved and cells cleared; nuclei of capil- } \\
\text { laries distinct. }\end{array}$ \\
\hline $\begin{array}{l}\text { Testis, } \\
3 \text { hours. }\end{array}$ & $\begin{array}{l}\text { Testicular cells and sper- } \\
\text { matozoa well pre- } \\
\text { served; few free gran- } \\
\text { ules. }\end{array}$ & $\begin{array}{l}\text { Marked agglutination; complete disappear- } \\
\text { ance of cell-bodies; occasional sperma- } \\
\text { tozoa and refractive granules remain. } \\
\text { Agglutination masses show no preserved } \\
\text { cells. }\end{array}$ \\
\hline
\end{tabular}

I per cent crotalus venom.

Slight agglutination; no solution of cells, but only swelling with indistinctness of cell outlines. Nuclei invisible.

Slight agglutination; granules partly dissolved; individual cells visible; glomerular blood dissolved; capillary walls and nuclei distinct.

Slight agglutination; complete disintegration of testicular cells; large numbers of free nuclei visible; spermatozoa little altered.

[Experiment II: Guinea-pig's Organs.]

Liver, 3 hours.

Kidney, 3 hours.

Testis, 3 hours.
Cells chiefly in smaller and larger groups; nuclei obscured; many granules and crenated red corpuscles.

Cells much broken up; many free granules and nuclei; some red corpuscles and glomeruli.

Testicular cells perfectly preserved; numerous preserved spermatozoa; very few free granules.
Marked agglutination; clearing of fluid; cell protoplasm clear; nuclei distinct. Ground substance in which cell outlines are indistinctly visible show granules and fat.

Marked agglutination and clearing. Nearly complete disappearance of cells and granules; indistinct free nuclei; glomerular blood, capillary walls and nuclei distinct. Marked agglutination; emulsion cleared. Loss of cell outlines and nuclei. Spermatozoa little altered, but entangled in clear ground substance.
Slight agglutination. Only swelling of cells; otherwise unaltered.

Slight agglutination; swelling of cell protoplasm and imperfect solution of granules; nuclei indistinct.

Very slight agglutination; cells have lost refraction; are finely granular and present eroded appearance; $\mathrm{s}$ perm a to $\mathrm{zoa}$ swollen; many free granules.

\section{[Experiment III: Rabbit's Organs.]}

\begin{tabular}{l|c}
$\begin{array}{l}\text { Liver, } \\
3 \text { hours. }\end{array}$ & $\begin{array}{c}\text { Very few free cells; many } \\
\text { small groups of cells; } \\
\text { many red corpuscles. }\end{array}$ \\
$\begin{array}{l}\text { Kidney, } \\
3 \text { hours. }\end{array}$ & $\begin{array}{l}\text { Many complete cells and } \\
\text { tubules; numerous free } \\
\text { granules and red cor- } \\
\text { puscles. }\end{array}$
\end{tabular}

Liver ery few free cells; many small groups of cells;

any complete cells and granules and red corpuscles.
Marked agglutination and clearing; cell clumps show very indistinct outlines; numerous granules; occasional visible nuclei in cells.

Marked agglutination; almost complete disappearance of all cells; few granules remain; nuclei invisible. Whole tubules very indistinct.
Slight agglutination; cells coalesced, but outlines can still be made out; no solution of granules; nuclei invisible.

Moderate agglutination; almost no solution, but granules remain. Cells swollen and granular; nuclei more or less visible.

\section{[Experiment IV: Rat's Organs.]}

Liver, Cells in small groups; 3 hours. many disintegrated cells; free granules, nuclei and red corpuscles.

Kidney, Individual cells and al3 hours. most complete tubules; few free granules and red corpuscles.

Testis, Cells well preserved; nu3 hours. merous spermatozoa; few free granules.
Agglutination; emulsion clear; cells coalesced; outlines gone; granules largely dissolved; nuclei indistinct, but in part free.

Marked agglutination; almost complete disappearance of cells. Complete tubules show indistinctness of outlines and solution of cell granules. Glomeruli cleared.

Marked agglutination; almost complete disappearance of cells; ground substance contains large numbers of twisted spermatozoa.
Slight agglutination; swelling of cells; few outlines remain; granules remain; nuclei invisible.

Slight agglutination; cells swollen, but no solution; granules remain; cells appear eroded.

Marked agglutination; cells granular and eroded, but no solution; nuclei indistinct; spermatozoa preserved.
[Experiment V: Sheep's Organs.]

Liver, Cells in separate state and 3 hours. small groups; outlines sharp and distinct; granules numerous; nuclei usually invisible.

Kidney, Imperfectly separated; 3 hours. cells much broken; some free granules and nuclei; some glomeruli.
No agglutination; cells swollen and granules partially dissolved; nuclei more visible; free granules partially dissolved.

Slight agglutination; almost complete solution of cells, leaving only granules and occasional nuclei; glomeruli cleared; outlines of capillaries and nuclei visible.
Almost unchanged.

Partial solution of cells; many granules and free nuclei remain. Glomeruli partially cleared. 


\section{EFFECT OF VENOM ON CELLS OF COLD-BLOODED ANIMALS.1}

For the purpose of this study Flexner and Noguchi employed three different kinds of cells: $(a)$ nerve cells; $(b)$ spermatozoa; $(c)$ ova.

Nerve cells: In regard to the neurolysis by venom the nerve cells contained in the pre-œsophageal ganglia of Sycotypus canaliculatus, Modiola modiolus, and Mactra solidissima were employed and seen to undergo rapid disintegration under the influence of venom. For the details I refer to the separate heading "venom neurolysis in vitro."

Sperm cells: For the study of venom spermatolysis, the spermatozoa of several different orders of animals - the reptilia, arthropoda, vermes, pisces, and echinodermata - were employed. The method of study consisted in suspending the spermatozoa in sea-water or normal saline solution ( 0.85 per cent), depending upon the nature of the animal. To the uniform milky suspensions the venom in I per cent solution was added. The effects were noted in vitro by the naked eye and under the microscope. Below are two typical experiments given to avoid detailed descriptions for each species:

TABLE I4.

\begin{tabular}{|c|c|c|c|}
\hline \multicolumn{4}{|c|}{ [Experiment I: Spermatozoa of Chrysemys picta (Painted Turtle).] } \\
\hline Control. & Cobra. & Moccasin. & Crotalus. \\
\hline $\begin{array}{l}\text { Spermatozoa ac- } \\
\text { tive; normal } \\
\text { appearance; } 30 \\
\text { minutes. }\end{array}$ & $\begin{array}{l}\text { The milky hue becoming } \\
\text { lighter; motility lost; } \\
\text { many partially dis- } \\
\text { solved. }\end{array}$ & $\begin{array}{l}\text { Suspension becoming clearer, } \\
\text { no motility; swelling of } \\
\text { middle piece especially } \\
\text { marked. }\end{array}$ & $\begin{array}{l}\text { No change; active } \\
\text { motility. }\end{array}$ \\
\hline $\begin{array}{l}\text { Like control; } 2 \\
\text { hours. }\end{array}$ & $\begin{array}{l}\text { Fluid clearing and al- } \\
\text { most without deposit. } \\
\text { Microscopically, frag- } \\
\text { ments only visible. }\end{array}$ & $\begin{array}{l}\text { Moderate agglutination; con- } \\
\text { siderable deposit and much } \\
\text { clearing of the suspension. } \\
\text { Many of the cells dissolved. }\end{array}$ & $\begin{array}{l}\text { No marked change } \\
\text { to naked eye. Mo- } \\
\text { tility present in } \\
\text { some individuals. }\end{array}$ \\
\hline $\begin{array}{l}\text { No motility; ten- } \\
\text { dency of cells } \\
\text { to sink to bot- } \\
\text { tom of test- } \\
\text { tube; } 4 \text { hours. }\end{array}$ & $\begin{array}{l}\text { Fluid almost completely } \\
\text { cleared. All cells } \\
\text { practically dissolved. }\end{array}$ & $\begin{array}{l}\text { Clear fluid, but whitish; ag- } \\
\text { glutinated deposit in which } \\
\text { many of the cells remain in } \\
\text { a swollen condition. }\end{array}$ & $\begin{array}{l}\text { Motility absent; de- } \\
\text { posit of cells; no } \\
\text { agglutination. }\end{array}$ \\
\hline \multicolumn{4}{|c|}{ [Experiment II: Spermatozoa of Tautogolabrus adspersus (Cunner).] } \\
\hline $\begin{array}{l}\text { Very active mo- } \\
\text { tility; } 30 \mathrm{~min}- \\
\text { utes. }\end{array}$ & $\begin{array}{l}\text { Motility gone in } 5 \text { min- } \\
\text { utes; beginning in ro } \\
\text { minutes to clear; no } \\
\text { agglutination. }\end{array}$ & $\begin{array}{l}\text { Clearing in } 30 \text { minutes owing } \\
\text { to marked agglutination; } \\
\text { deposit forming. }\end{array}$ & $\begin{array}{l}\text { Slight agglutination; } \\
\text { motility much re- } \\
\text { duced. }\end{array}$ \\
\hline $\begin{array}{l}\text { Very active mo- } \\
\text { tility; I hour. }\end{array}$ & Solution complete. & Deposit undergoing solution. & $\begin{array}{l}\text { Very slight motility } \\
\text { remains. }\end{array}$ \\
\hline $\begin{array}{l}\text { Very active mo- } \\
\text { tility; } 2 \text { hours. }\end{array}$ & Solution complete. & Only débris remains. & $\begin{array}{l}\text { Motility gone; little } \\
\text { if any solution. }\end{array}$ \\
\hline
\end{tabular}

These two experiments will suffice to show the rapid action of cobra and the weaker effect of water-moccasin and crotalus renom in causing spermatolysis. The effect of crotalus venom is, indeed, but slightly injurious, producing, as it does, agglutination, but almost no solution of the cells.

1 Mitchell and Reichert observed that the crotalus venom causes the cilia of pharyngeal epithelia to cease their motions, but those of the tunic of oysters remained unaffected. 
Other kinds of spermatozoa which are acted upon in much the same manner as the two examples given are those of the following orders and species:

Pisces: Fundulus heteroclitus (minnow), Cyprinus carpio (German carp.)

Arthropoda: Homarus americanus (lobster), Eupagurus longicarpus (small hermit-crab), Eupagurus pollicaris (large hermit-crab), Limulus polyphemus (horse-shoe crab), Libinia (spider-crab).

Vermes: Cirratulus grandis, Lepidonotus squamatus (scale-worm), Lumbriconereis opalina, Nereis virens (clam-worm).

Echinodermata: Asteria vulgaris (star-fish), Arbacia punctulata (purple sea-urchin).

The following kinds of spermatozoa are found to be wholly refractory to the effect of venom, even cobra: Phascolosoma among the vermes, and Pentacta frondosa (sea-cucumber) among the echinodermata.

Egg cells: For the study of ovolysis the egg cells of several orders of coldblooded animals were employed: pisces, arthropoda, vermes, and echinodermata. Not all of these cells are affected equally, and some are not acted on at all. In some instances pigmented ova, under the influence of venom, give up their pigment, which is diffused along with other interior contents into the surrounding medium, tinting this so as to suggest the liberation of hæmoglobin from red blood-corpuscles by venom and other hæmolytic substances.

Table I 5 illustrates the changes in unfertilized eggs brought about by venom.

The experiments prove the susceptibility to venom cytolysis of certain ova of cold-blooded animals. Of the ova tested, those of Limulus and Nereis failed to show distinct changes leading to more or less complete dissolution. Among other susceptible ova are those of Phascolosoma and Cirratulus, with which may be mentioned the fact of the insusceptibility of sperm cells of the former worm under the same conditions of venom treatment. (Plates 30 and 3r.)

TABLE I 5 .

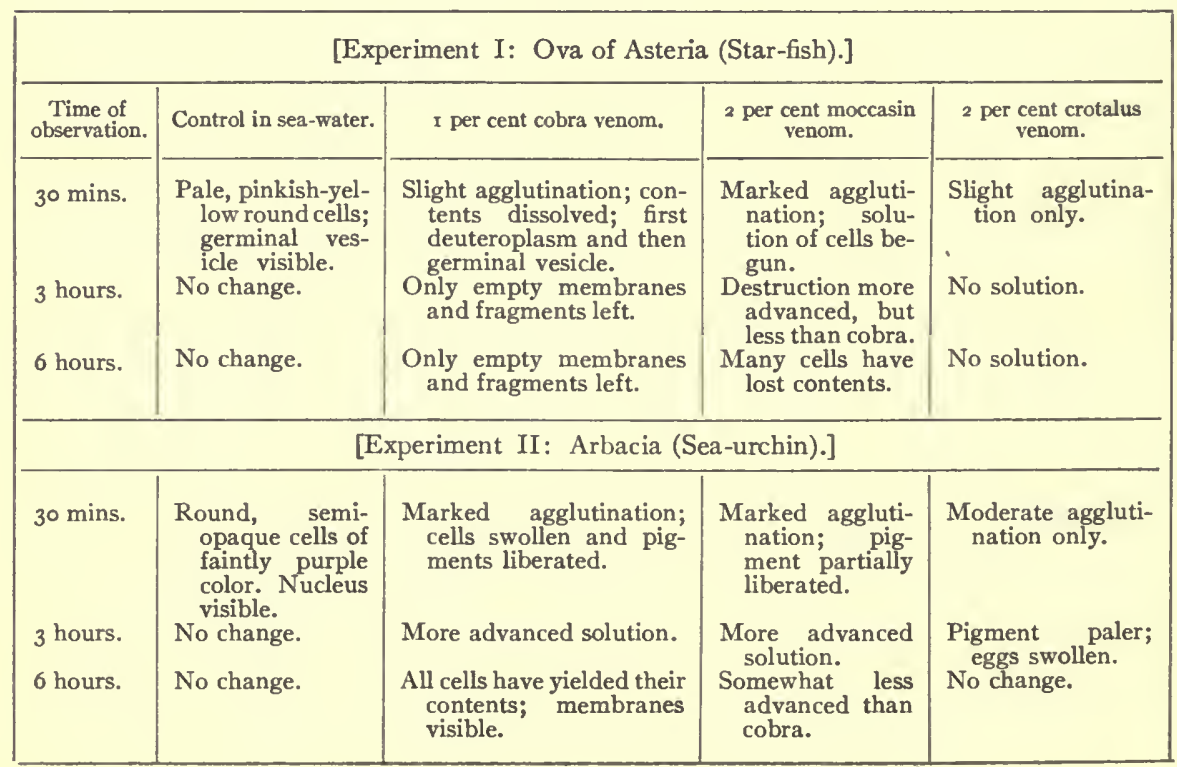




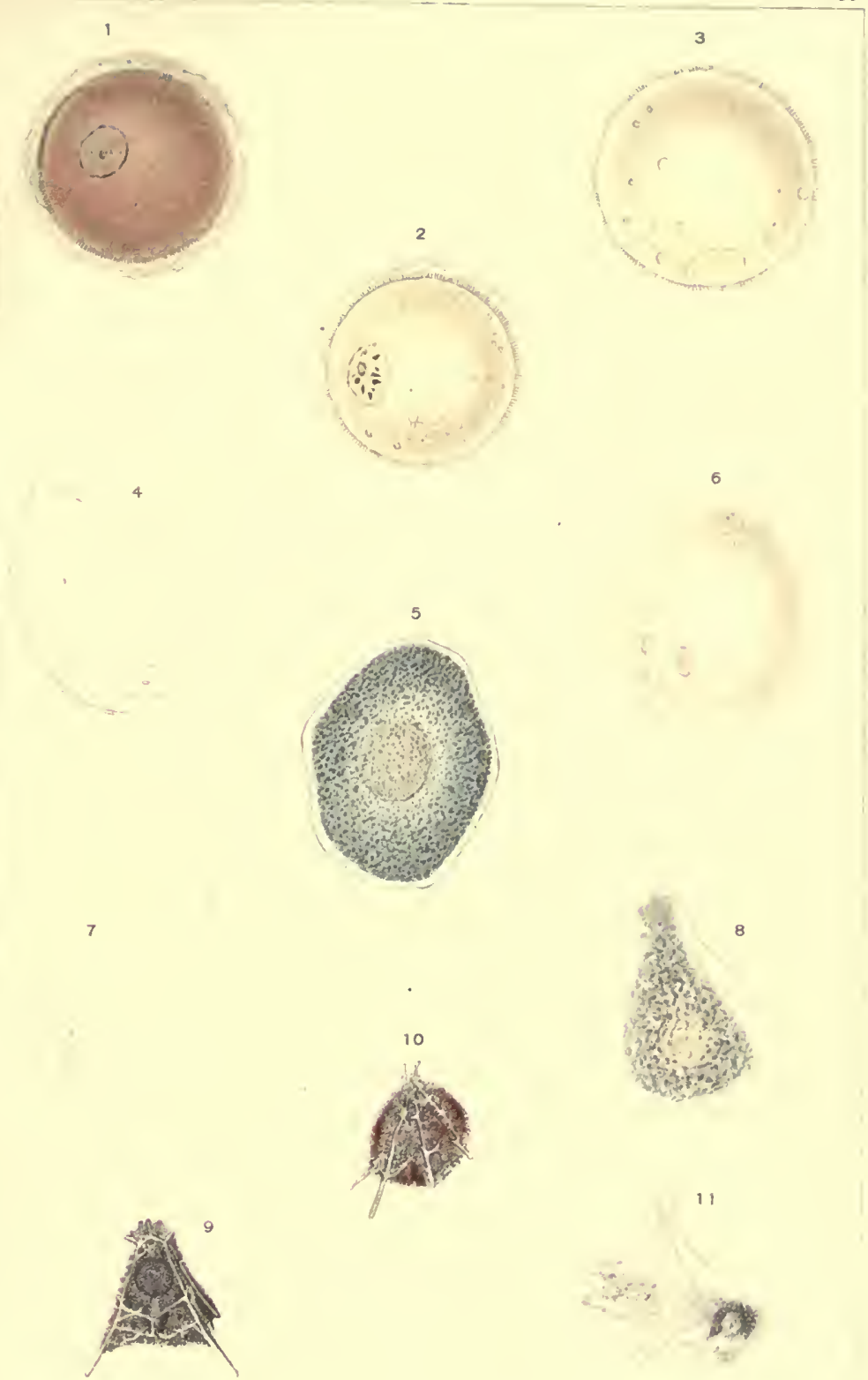

1 to 4. Eggs of Arbacia punctulata. 1. Normal. 2 to 4, Different stages of Ovolysis caused by 1 per cent Cobra venom in sea-water.

5 to 8 . Eggs of Lepidonatus squamatus. $\quad 5$, Normal. 6 and 7, Different stages of Ovolysis caused by I per cent Cobra and 2 per cent Crotalus venom, showing no real Ovolysis, but peculiar Retraction of Deutoplasm.

9 to 11. Pluteus stage of Arbacia punctulata. 9. Normal, active pluteus. 10, Pluteus under the effect of 2 per cent Cobra venom. 11, Disintegration under the effect of same venom.

(Drawings by Noguchi.) 



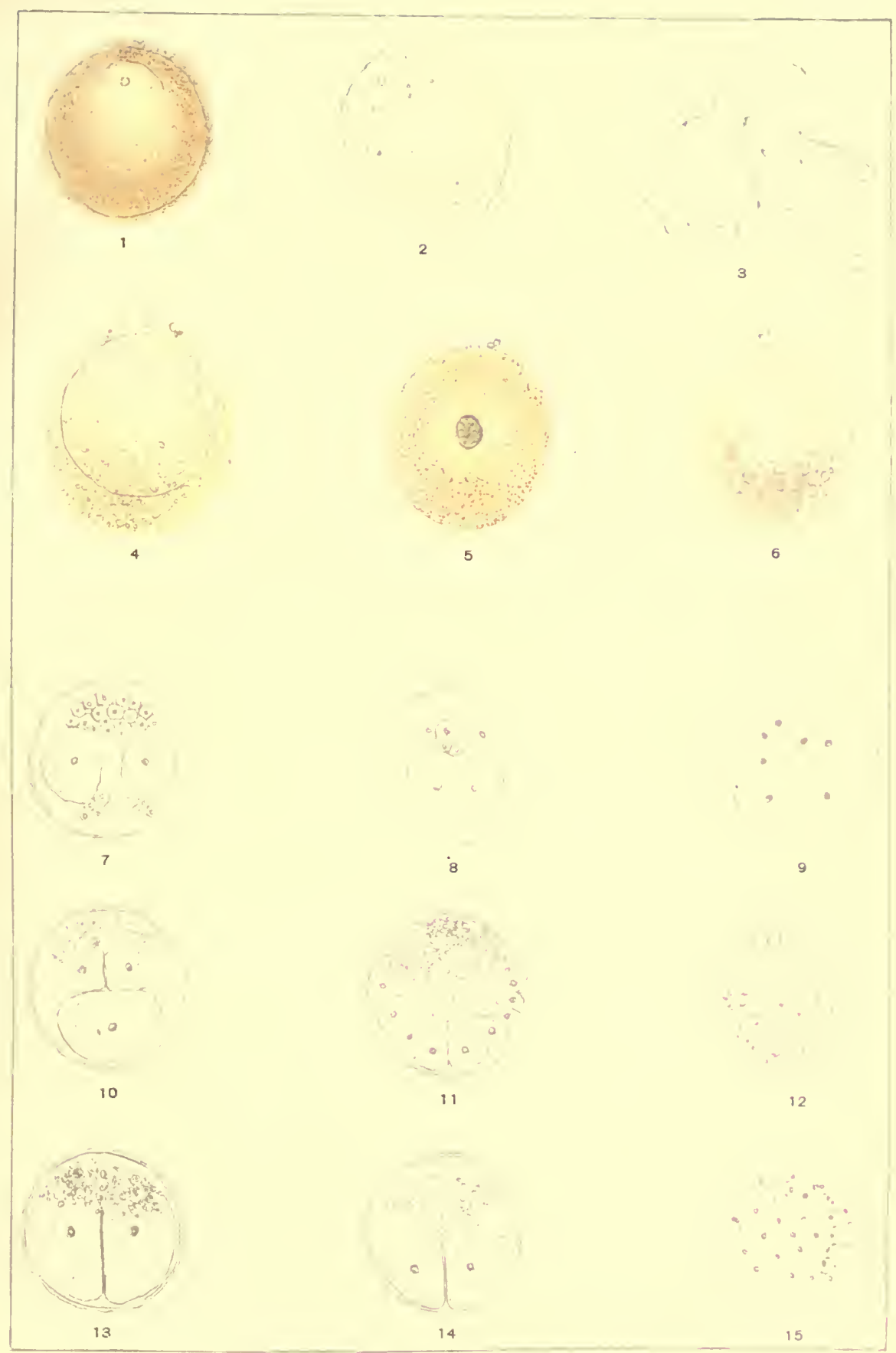

\section{Ovolysis-Eggs of Asteria vulgaris.}

1, Normal unfertilized egg. 2, Action of 1 per cent Cobra or 2 per cent Moccasin venom. 3. Result of complete Ovolysis by these venoms in 6 hours. 4. Action of 2 per cent Crotalus venom in 6 hours. 5, Normal egg with polar body formation. 6, Ovolysis by venom. 7 to 15. Ovolytic effects of venom upon fertilized eggs. 
- 
TABLE I5.-Continued.

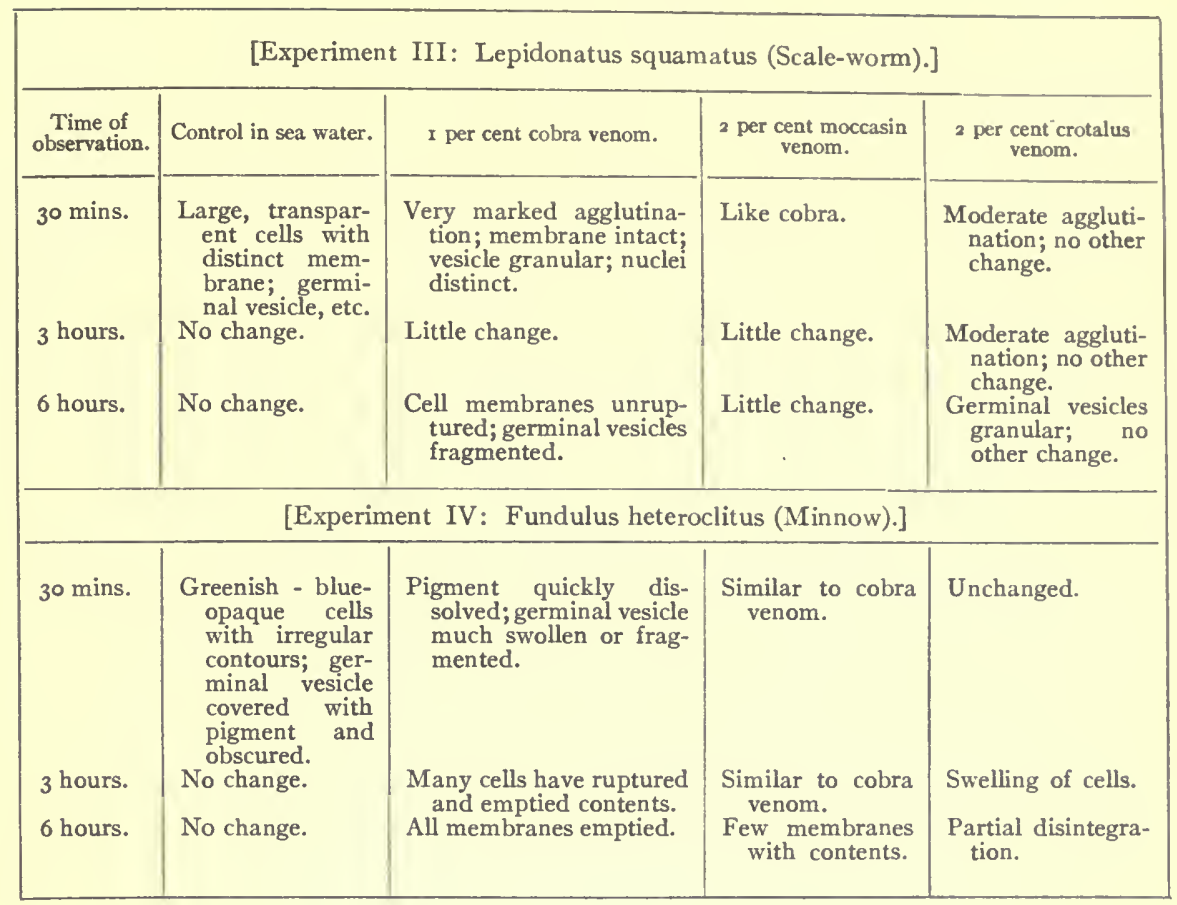

Flexner and Noguchi next determined the action of venom upon the fertilized ova of Fundulus, Arbacia, and Asteria. Observations upon these cells were conducted under two sets of conditions: $(a)$ fertilization was attempted in venom solutions, and $(b)$ venom in solution was added to the fertilized eggs at different periods of segmentation. The following facts appeared:

\section{Fundulus ova:}

(I) Venom in strong solution (5 per cent cobra) dissolves the fertilized ova, but in weaker solution only delays segmentation.

(2) After fertilization and beginning segmentation weak solutions of venom do not prevent further segmentation.

(3) Brief treatment with weak venom solutions of the segnenting ova up to the time of the morula stage causes only delayed development.

(4) Brief treatment of the embryos with weak solutions at about the period of formation of the brain and optic vesicles ( 36 hours) causes malformation and delays the hatching.

(5) More advanced embryos are more resistant, but finally may succumb to venom poisoning.

\section{Arbacia and Asteria ova:}

(I) Strong solutions ( 5 per cent cobra) of venom prevent fertilization, but weak solutions permit its occurrence.

(2) Strong solutions of venom delay segmentation, while weak solutions cause imperfect and irregular segmentation.

(3) Brief treatment with weak venom solution accelerates the blastula formation, while the plutei are killed by strong solutions of venom. 
Flexner and Noguchi found that the cytolytic principles of snake venom are still active after moist heating to $85^{\circ} \mathrm{C}$. for 30 minutes and are not destroyed by moist heat at a temperature of $100^{\circ} \mathrm{C}$. maintained for $\mathrm{I}_{5}$ minutes. Dry heating for 2 hours at $140^{\circ} \mathrm{C}$. suffices to diminish, but not to abolish, the activity of daboia venom.

The mechanism of venom cytolysis was also studied. They found that previous heating of susceptible somatic cells and nerve cells to $55^{\circ} \mathrm{C}$. for 30 minutes renders the cells almost insusceptible to the solvent action of venom, although agglutination and some granulation of the cells may occur. Addition of fresh serum or fresh body fluid to the mixture of the heated cells and venom causes a certain amount of dissolution and disintegration, which are never so strong as in the case of unheated cells. Repeated washings of the fresh cells in sea-water or saline solution do not suffice to prevent or even delay considerable solution of the cells by venom. They also pointed out that the cytolysis can not be due to the action of proteolytic ferment of venom, for the latter directly attacks the gelatin and is completely destroyed by $80^{\circ} \mathrm{C}$.

In an extensive series of experiments these investigators were able to show that venom contains a number of cytolysins, each having a special preference for one given group of cells. They also consider that cytolysins of one group attack their corresponding cells with varying severity according to the source of the cells, which fact they regard as due to the differences in the receptor apparatus of similar cells in different species of animals.

Since the appearance of the above work of Flexner and Noguchi, the important discovery by Kyes of the interaction between venom and lecithin has appeared and makes it probable that the mechanism of venom cytolysis, especially the dissolution of egg cells, may have some resemblance to the venom-lecithin hæmolysis. As is shown by Jacques Loeb and others, the membrane of ova seems to be of a lipoidal nature and the deutoplasma contains a considerable amount of lecithin. There may be, at least in part, certain relation between the lecithinophilic property and the ovolytic processes in this case. Loeb and others have shown that artificial parthenogenesis can be accomplished by the combined effects of fat-solvent or fatty acids and changes in the toxicity of the medium in which the ova are placed - in the presence of oxygen. I have made an attempt to produce a similar phenomenon by substituting fat-solvents with weak venom solutions, but so far without definite result. It is significant that Flexner and Noguchi observed the accelerating influence of weak venom solution upon blastula formation.

In this connection the interesting observations of Feré ${ }^{1}$ on the influence of venom upon the evolution of chicken embryos must not be overlooked. This biologist introduced the venom of viper (in dose of $0.00005 \mathrm{gm}$. per egg) into the egg-white and found that 83 out of roo toxicated eggs presented various anomalies of development when opened and examined 72 hours after the inoculation.

1 Féré. Evolution de l'embryon de poule. Influence de l'introduction du venin dans l'albumen de l'œuf de poule. C. R. de la Soc. Biol., i 896 . IIme Série, 8. 


\section{CYTOLYTIC ACTION OF SNAKE VENOM ON MICRO-ORGANISMS.}

Flexner and Noguchi ${ }^{1}$ first stated that snake venom produces on $B$. anthracis, B. coli, and B. typhi rapid involutions, degeneration, and plasmolysis when it is mixed with nutrient media. Cobra venom was the strongest and crotalus venom the feeblest, while ancistrodon and daboia venoms were intermediate. (Plate 32.)

Somewhat later Calmette and $\mathrm{Noc}^{2}$ found that I per cent cobra venom quickly dissolves Vibrio cholera and asporogenous strain or young culture of B. anthracis. Staphylococcus aureus, B. diphtherie, and young B. subtilis were equally affected, while $B$. pestis, $B$. coli, and $B$. typhi were more resistant; and $B$. pyocyaneus, and $B$. prodigiosus were almost unaffected. $B$. tuberculosus proved totally insusceptible. The removal of the bacteriolytic substance for one kind means the same for the rest, showing the non-specific nature of this particular principle of venom.

Calmette's antivenin effectively stops the bacteriolytic action of cobra venom. The reappearance of this property out of the neutral mixture of venom and antivenin does not occur when heated to $80^{\circ} \mathrm{C}$. The bacteriolytic property disappears when heated to above $85^{\circ} \mathrm{C}$. for 30 minutes; hence it is not due to the proteolytic property of venom, which disappears at $80^{\circ} \mathrm{C}$.

Trypanosomes are also dissolved by I per cent cobra venom in 30 minutes. ${ }^{3}$

1 Flexner and Noguchi. Snake venom in relation to hæmolysis, bacteriolysis, and toxicity. Jour. Exp. Med., 1902, VI, 294. Foot-note.

2 Noc. Ann. Inst. Pasteur, I905, XIX, 209.

3 Calmette. Les venins. 1907 , Paris. Goebel. Ann. Soc. Med. de Gand, r905. 


\section{CHAPTER XVIII.}

\section{HISTOLOGICAL CHANGES PRODUCED BY SNAKE VENOM ON VARIOUS ORGANS AND TISSUES.}

Before presenting the facts derived from the elaborate and extensive studies of various investigators concerning the histological alterations produced by snake venom, a general review of the nature of these changes may be permitted at this place.

As we shall presently see, the histological changes, which were demonstrable with the practicable methods of our past and present histological status, fall into two great groups. The first group is the fatty degeneration of the protoplasma of the diverse kinds of cells, and the other comprises the changes designated necrosis. The question quickly arises whether both are the action of the same principles or the actions of specific agents for each group of alteration. In view of the recent development in the biochemical investigations of the active principles contained in snake venom and other similar cellular toxins, it appears that the latter hypothesis conforms to the observed facts. The lipolytic properties of snake venom-especially the liberation of fatty acids from phosphorized and non-phosphorized fats by certain ferment-like principles of venom - render it probable that fatty degeneration is the result of the cytolysis of such agents. It is partly due to the EhrlichKyes phenomenon (or formation of lecithids and liberation of free fatty acids) and to the Neuberg-Rosenberg phenomenon (or the splitting of neutral fats), both being liable to take place in media as rich in lecithin and fats as the cell protoplasma. Considering the potency which a minute quantity of venom circulating in the venomized body possesses, it is again reasonable that in the production of fatty degeneration lecithin-splitting plays the foremost part.

The necrotic changes I consider due to the specific phenomena peculiar to each group of somatic as well as nervous tissues, and brought about by the action of specific cytolysins in the sense of Flexner and Noguchi, namely: there exists between the cells and the active principles a special affinity, if not specific. The relation between fatty degeneration and the necrotic alterations of these cells is not quite clear, inasmuch as various fatty and lipoid substances display marked destructive effects on various cellular elements. It may be true, at least in part, that the necrotic processes are caused secondarily by the primary fatty degeneration. On the other hand, there are many evidences that point in the opposite direction. Fatty degeneration may be entirely absent from the cells showing marked disorganization of their constituents. Equally we may assume that fatty degeneration may be produced secondarily by the cessation of the normal oxidating function of the cells, through specific toxins of venom. In deciding this point the results which I 


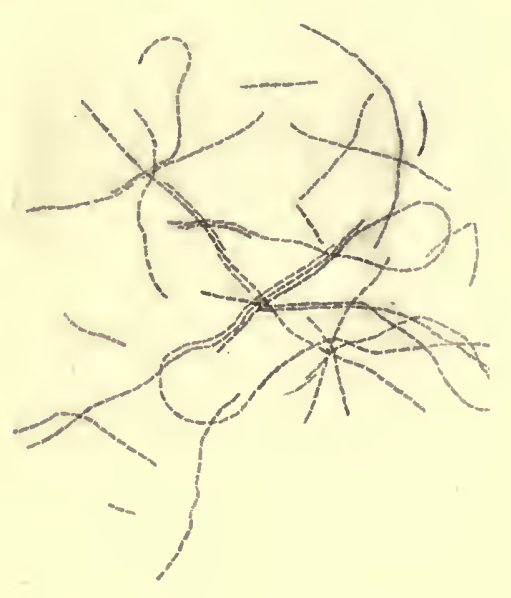

A

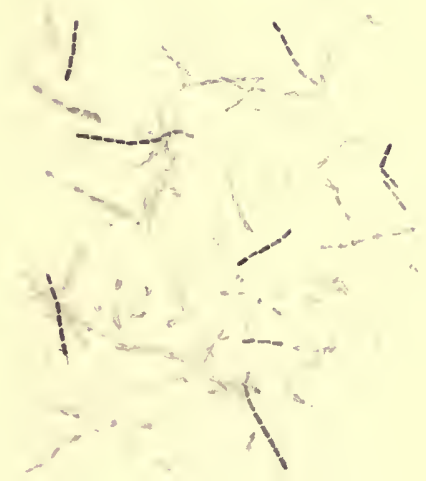

C

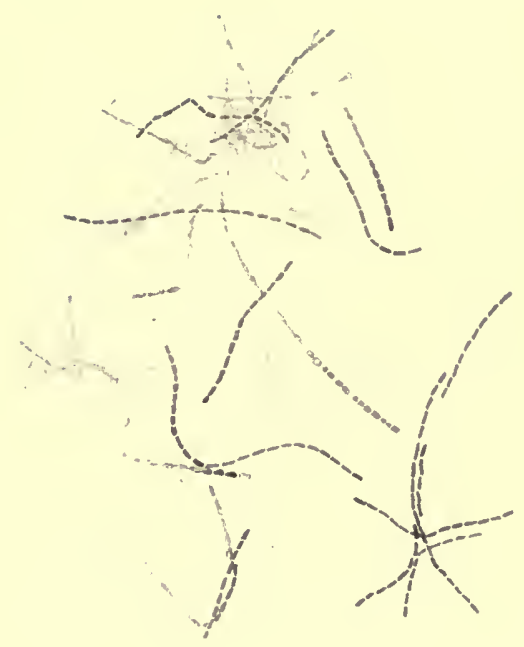

B

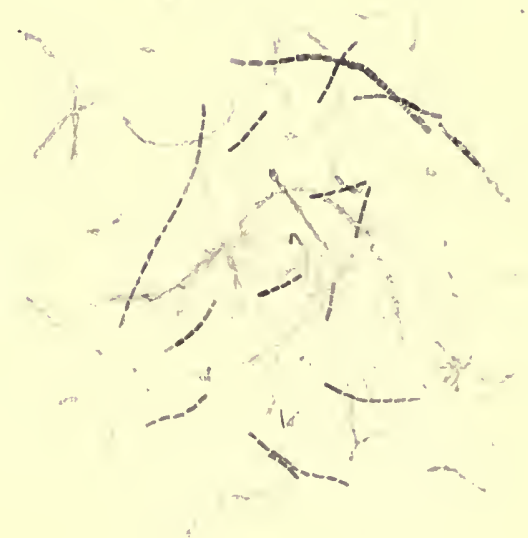

D

A, Young Agar Culture of B. anthracis.

B, C, and D, Young Cultures of B. anthracis on Venomized Agars.

(Drawings by Noguchi.) 

obtained through studies on the effects of various venoms upon the excised tissues in vitro have a certain weight. In this case the vital processes have no parts.

Our present knowledge of the pathological histology of venom toxication is derived from the investigations of S. Weir Mitchell and Reichert, ${ }^{1}$ Hindale, ${ }^{2}$ Karlinski, ${ }^{3}$ C. J. Martin ${ }^{4}$ Nowak, ${ }^{5}$ Ewing and Bailey, ${ }^{6}$ Kelvington, ${ }^{7}$ Lamb and Hunter, ${ }^{8}$ Hovius, ${ }^{9}$ Zeliony, ${ }^{10}$ Flexner and Noguchi, ${ }^{11}$ Jousset ${ }^{12}$ and that of the writer added in the present work.

The histological changes produced by the neurotoxins and hæmorrhagins, owing to tixir direct importance in the fatal effects of the venoms they contain, have been dealt with in detail in the separate sections, and these will not be repeated here.

The solvent actions of snake venom upon various sets of cells in the fresh state must properly fall under the present heading and the phenomena can be compared with the changes demonstrated in the sections as stained specimens, but the writer has given the former a special space, on account of the unique manner of study by which Flexner and Noguchi worked.

\section{ACTION OF SNAKE VENOM UPON THE LIVER.}

This organ is especially susceptible to the action of venom. In the case of rapid death the protoplasma of hepatic cells is turbid and granular, and the granules take stains well along the periphery, but not in the interior of the cell. In the case of slower death, namely, prolonged toxication with venom, the protoplasma heaps up to certain parts of the cell and forms vacuoles of indefinite contour. One part of the protoplasma is necrotized and destroyed. Here the nuclei undergo certain alterations. Their contour is well marked and sharp, but the chromatin in the interior presents granular fragmentation, and the entire nucleus takes basic dyes faintly, due to the diffusion of dissolved chromatin substance into the nuclear fluid.

When the protoplasma of hepatic cells undergoes further changes its chromatin mass of nuclei diminishes and gradually loses the property to take up stains, and finally the entire cell contains a small quantity of granules without the nucleus.

1 Weir Mitchell and Reichert. I886, Washington.

${ }^{2}$ Hindale. Medical News, 1884 , XIIV, 454.

Karlinski. Zur Pathologie des Schlangenbisses. Fortschritt der Medicin, r89o, VIII, 6 I 7.

4 C. J. Martin. On the physiological action of the venom of the Australian black snake (Pseudechis porphyriacus). Proc. Roy. Soc. of N. S. Wales, 1895.

- Nowak. Etude expérimentale des altérations histologiques produites dans l'organisme par les venins des serpents venimeux et des scorpions. Ann. Inst. Pasteur, I 898, XII, 360 .

- Ewing and Bailey. Appendix to Gustav Langmann's "Poisonous snakes and snake poison." Med. Record, 1900, LVIII, 401 .

7 Kelvington. A preliminary communication on the changes in nerve cells after poisoning with the venom of the Australian tiger snake (Hoplocephalus curtus). Jour. of Physiol., 1902, XXVIII, 426.

8 Lamb and Hunter. See under "Neurotoxins."

Vailant Hovius. Thèse Bordeaux, 1902.

10 Zeliony. Path.-histolog. Veränderungen der querstreiften Muskeln an der Infektionsstelle des Schlangengiftes. Virchow's Arch. f. path. Anat. und Physiol., 1905, CLXXIX, 36.

11 Flexner and Noguchi. The constitution of snake venom and snake sera. Jour. of Path. and Bacteriol., I908, VIII, 379.

12 Jousset. Lésions produites par les venins de serpents. Art. Med., Paris, 1899, LXXXVII, 358. 
In certain cases there is extensive lesion of fatty degeneration and in parts numerous small foci of total destruction of hepatic tissue. The liver of the dog is very sensitive and the microscopic structure of parenchyma may sometimes be completely destroyed. There is no lobular disposition to be further distinguished; the trabecules are broken up and only confused agglomeration of the cells in the extravasated blood can be made out.

With the animals which lived a long time after venomization there are also some changes in the biliary tract. The epithelial cells are subjected to fatty degeneration. In dog and other small mammals there are infiltrations of mononuclear cells between the epithelia of the biliary canalicules. The latter may sometimes be tumefied, swollen, or vacuolated. Thus the histological changes of the liver are fatty degeneration, necrosis, and the infiltration of lymphocytes in the biliary tract.

\section{ACTION OF SNAKE VENOM UPON THE KIDNEY.}

This organ is also very susceptible to the action of venom. The glomerula are affected in their three parts. The blood-vessels in the cortex are static and their walls are sometimes ruptured, causing the escape of blood into the capsular cavity. The capsular cavity is filled up with granular exudate. The epithelial coat of Bowmann's capsule is bulged and the nucleus stains badly.

In the tubule contorts the cellular lesions present a great analogy to those of the liver. There are granulations and vacuolation, and the nucleus becomes diffuse. Their lumen is filled with the necrotic cell débris. Similar obliterations occur in the Henle loops.

In the straight tubes and collecting tubes the epithelia are sometimes detached in blocks. Some of these canals are obliterated with granular cylinders or by the swelling of the epithelial cells.

The vessels in the renal parenchyma are always distended and sometimes ruptured, resulting in small foci of interstitial hæmorrhage. It is not uncommon for the extravasated blood to destroy the parenchyma.

In case of pseudechis poisoning there are frequently radial hæmorrhages in the cortex, acute necrosis of epithelium lining the convoluted tubes. The hæmoglobin from the disintegrated corpuscles exhibits an abnormal tendency to crystallize, and this sometimes happens in the tubules of the kidney to such an extent as to block the greater number.

\section{ACTION OF SNAKE VENOM UPON THE LUNGS.}

In the lungs venom produces numerous small impacts, around which are seen capillaries much dilated and the pulmonary vesicules are rendered very small.

\section{ACTION OF SNAKE VENOM UPON THE SPLEEN.}

Nowak observed only a slight degree of fatty degeneration in the spleen in those cases where the lesions in the liver and kidney were very advanced and extensive. 


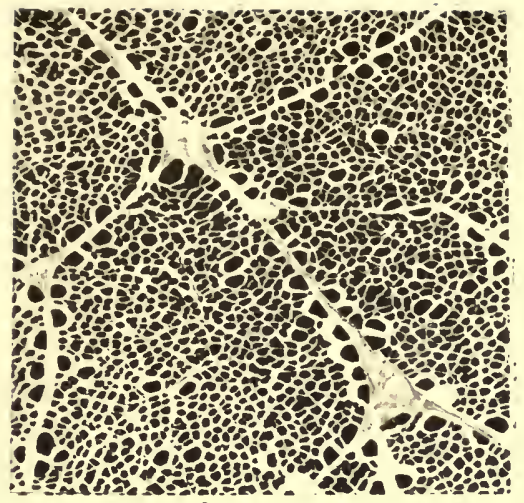

A

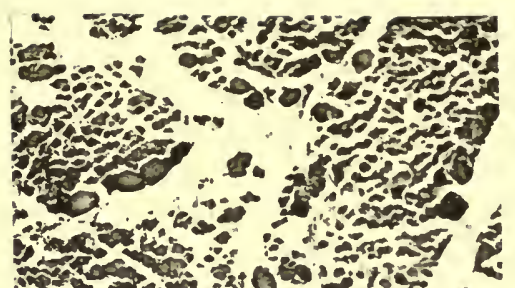

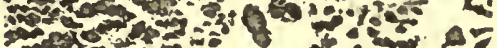

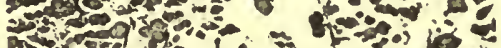

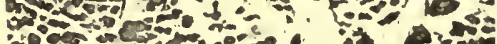

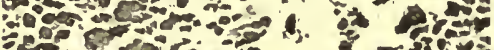
20.

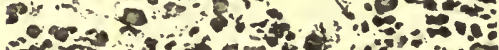
For
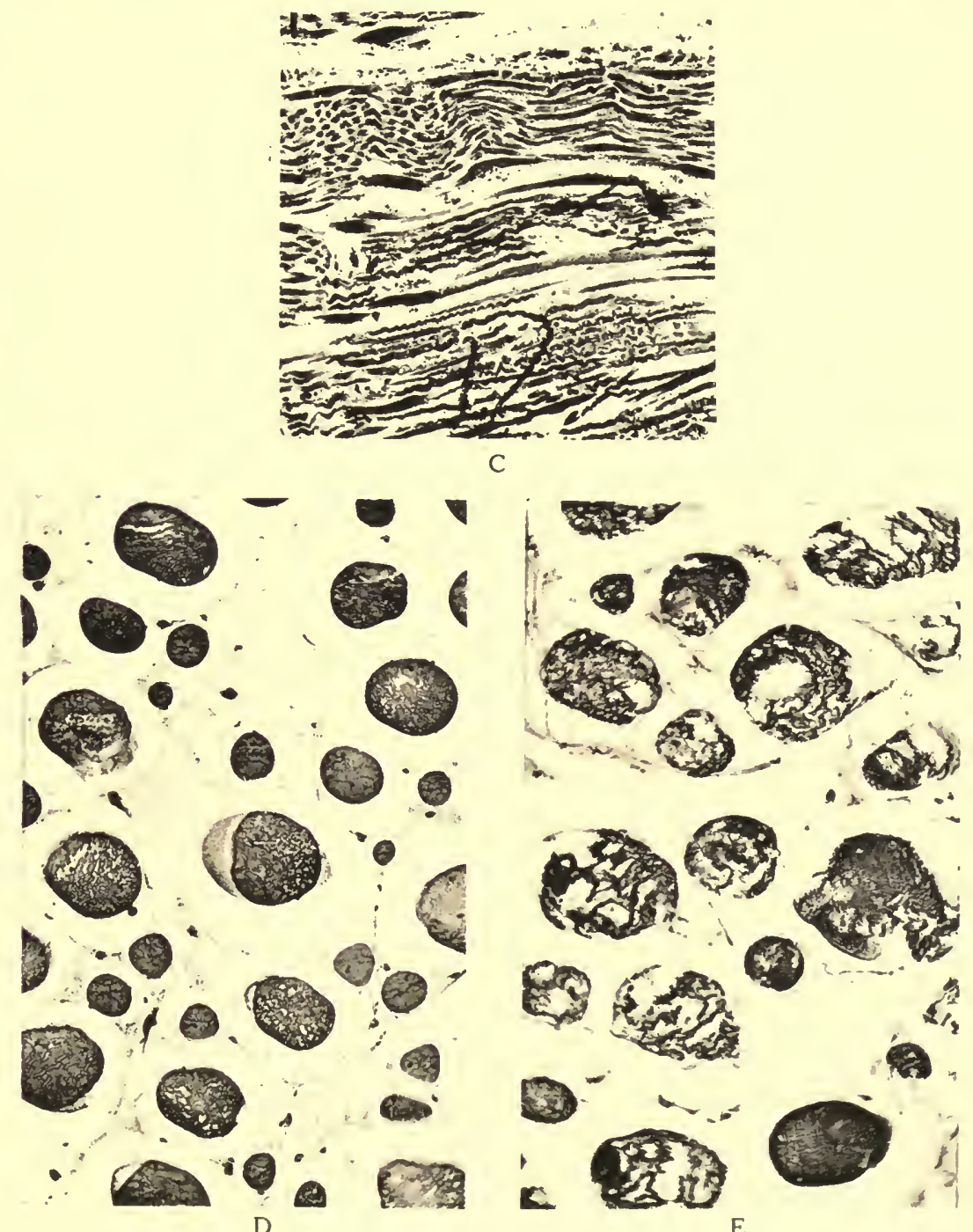

A. Cross-section of Pectoral Muscle of Normal Pigeon. B, Cross-section of Pectoral Muscle of Pigeon which died from effect of venom of Crotalus adamanteus. C, Longitudinal section of Pectoral Muscle of Pigeon which died of Crotalus venom poisoning. D, Cross-section of Normal Muscle of thigh of Frog. E, Cross-section of Venomized Muscle of thigh of Frog. (Photomicrographs.) 


\section{-}


ACTION OF SNAKE VENOM UPON THE HEART.

Sometimes there are small hæmorrhages in the periphery, but seldom in the substance. The muscular fibers present a slight fatty degeneration only in cases where extensive histological alterations are seen in the liver and kidneys.

ACTION OF SNAKE VENOM UPON THE MUSCLES.

The muscular fibers become necrotic within 30 minutes after the injection. The venomized tissue is infused with a certain amount of albuminous mass rich in fibrine and the extravasated blood. After some hours there appears a number of polymorphic leucocytes between the degenerated muscular fascia. These leucocytes steadily increase in number and in one or two days reach the maximum. The muscular nuclei undergo alterations and become elongated or angular, giving an aspect of myoblast-sarcoblasts. In the protoplasma of myoblasts particles of destroyed muscle and fatty globules are frequently seen.

In the accompanying plate both the longitudinal and cross-sections of venomized muscles are shown. Striated muscles are affected in a manner suggesting a partial dissolution of muscular substance. (Plate 33.) 


\section{CHAPTER XIX.}

\section{FERMENTS IN SNAKE VENOM.}

Apart from the cytolysins, of which detailed accounts have already been given elsewhere, snake venom betrays by its actions the presence of four distinct classes of ferment-like substances. These are the fibrin ferment, proteolytic, diastatic, and lipolytic enzymes in the biochemical sense. The amounts of these bodies in different kinds of snake venom are variable, one predominating the other according to the nature of the venom; nor are the amounts of these four constituents the same in a given kind of venom.

That venom contains powerful fibrin ferments in the classical sense, and that they form the most important part of the toxicity of certain viperine, crotaline, and colubrine snake venoms, has already been fully related and will not be repeated here.

Just how much the other three ferments participate in the toxic effects of snake venom is, however, open to further investigation. It appears to be fairly certain that the neurotoxic, hæmolytic, hæmorrhagic, hæmagglutinative, as well as other dissolving effects on various groups of cells - liver, kidney, testis, ova, spermatozoa, leucocytes -- are not due to the action of the proteolytic ferment considered under this heading.

The lipolytic ferments may appear in some respect to have something to do with the hæmolytic and hæmagglutinative actions of venom, but judging from their comparatively feeble power in splitting lecithin or neutral fats they can not be the same principles responsible for the powerful hæmolysis which certain venoms produce. If we assume the formation of hæmolytic lecithid by the action of venom upon lecithin to be due to a ferment-like action of venom hæmolysins, this is different from all other known ferments in their stabilty to temperature and reactions. Unfortunately we are not yet in possession of accurate data concerning the thermal and chemical stabilities of venom lipases described by Neuberg and Rosenberg, and can not make any definite statement as to the relation between these two sets of principles.

The proteolytic action and anticoagulating property of venom are declared to be due to the same principle by Calmette and Noc, while the softening effects of venom upon muscle are ascribed by Flexner and Noguchi to the similar enzyme of venom. Venom produces a marked degeneration of various bacteria, as first described by Flexner and Noguchi and extended by Noc, but we may not be justified in attributing this action solely to the proteolytic action of venom.

Before assigning to the three ferments here considered their proper positions among factors constituting general and separate toxicities of venom, 
we still have a long way to travel through the most complex and misleading paths of study. I propose, therefore, to record only the facts already obtained by various investigators up to the present moment.

\section{PROTEOLYTIC ACTION OF SNAKE VENOM.}

Flexner and Noguchi, with a view to finding a suitable explanation of the softening effect of venom upon muscle, described so fully and graphically by Mitchell and Reichert, carried out a series of experiments for determining whether or not venom contains a proteolytic ferment. As the softening of muscle takes place quickly, within 30 minutes to a few hours, the operation of bacteria can be excluded. Several proteid substances were exposed to venom in sterile saline solutions, prepared by passing the dissolved venom through the Chamberland filter. In some experiments the solution was kept under a layer of toluol. Gelatin in ro per cent solution was mixed with crotalus and cobra venom in solutions containing ro $\mathrm{mg}$. of dried venom. Cobra venom brought about complete liquefaction in two days, crotalus in I6 hours. Fibrin heated to coagulation $\left(60^{\circ}\right.$ to $62^{\circ} \mathrm{C}$.) is not attacked by venom; coagulated egg-albumin is also unaffected. On the other hand, raw fibrin obtained from dog, rabbit, and guinea-pig is easily and more rapidly fragmented by venom than in the control tubes. Venoms heated to $75^{\circ} \mathrm{C}$. for 30 minutes lose their liquefying property. The addition of Calmette antivenin does not influence the result.

Muscle in thin slices was taken from the pigeon and guinea-pig; 2 per cent solution of venom (cobra, crotalus, water-moccasin) was filtered through the Chamberland bougie. To one set of tubes the muscle was added; to another set, muscle plus the sterile serum of the animal; while in a third the muscle minus venom was placed. The control tubes showed no change to the naked eye after 6 hours' contact. The temperature was $36^{\circ} \mathrm{C}$. In the other tubes changes were noticed in 2 hours. At this period the muscle was opaque, swollen, and of a grayish color, and the fibers were separated. In 3 hours the swelling and separation of the fibers had increased, and by shaking the tubes the slices of muscle could be easily broken up. In 6 hours disintegration was complete.

Crotalus serum is without liquefying action upon gelatin.

Flexner and Noguchi concluded, therefore, that venom contains a body capable of modifying protein, and upon this the softening effect of muscle tissue in corpore doubtless depends.

Delezenne ${ }^{1}$ has established the existence in venoms of a kinase analogous to the kinase of leucocytic origin and to enterokinase. The venom alone does not attack the heat-coagulated egg-albumin, but it confers upon the inactive pancreatic juice an intense digestive power. The venom of Lachesis is shown to be the richest in kinase. It digests gelatin completely and after the latter is subjected to the action of this venom it becomes incapable of solidification.

1 Delezenne. Sur l'action kinatique des venins. C. R. Ac. des Sc., rgo2, CXXXV, 329. 
Launoy ${ }^{1}$ demonstrated that the dissolved albuminoid substances (casein, serum-albumin of ox blood) are disintegrated by cobra and viper venom, but the modified molecule remains in solution after the addition of formal and it is no longer precipitable by acetic acid. The hydrolysis never descends to the peptone stage, but only to the formation of albumoses, which give biuret reaction. The same author ${ }^{2}$ mentions the presence in cobra venom of a precipitant for soluble ferments. Coagulated proteins and fibrins are not attacked by the filtered solutions of cobra or scorpion venom. No tyrosinase was found in these venoms.

Noc, ${ }^{3}$ under Calmette, has made a very interesting series of experiments on the proteolytic property of different venoms upon fibrin and gelatin. $\mathrm{He}$ obtained, with the fibrins of horse and rabbit bloods exposed to the action of venoms at $37^{\circ} \mathrm{C}$. under toluol, the following results:

TABLE I6.

I c.c. solution of venom of -

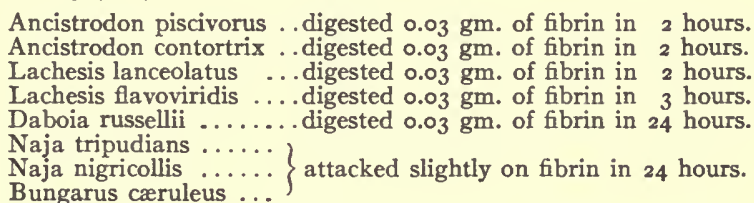

With gelatin he obtained similar results. 20 per cent gelatin +0.2 per cent thymol and $0.00 \mathrm{I}$ gm. of each venom were thoroughly mixed and kept at $37^{\circ} \mathrm{C}$. At the end of the observations the tubes were put in water at $15^{\circ} \mathrm{C}$. All tubes with $0.00 \mathrm{Igm}$. of venom remained liquid.

At the same time Noc also studied the anticoagulating property of these venoms upon blood in vitro and found that there is a perfect parallelism between the proteolytic and anticoagulating properties of these venoms, concluding that the latter phenomenon is the effect of the proteolytic substance of venom upon the fibrin. These two properties are destroyed at the same time when the venom is heated to $80^{\circ} \mathrm{C}$. during 30 minutes in sealed tubes.

It may be stated here that the citrated plasm, which coagulates on the addition of calcium chloride in 15 minutes, becomes incoagulable when acted upon by $0.00 \mathrm{I} \mathrm{gm}$. of the venom of Ancistrodon piscivorus, $0.003 \mathrm{gm}$. of Ancistrodon contortrix, $0.004 \mathrm{gm}$. of Lachesis lanceolatus, $0.006 \mathrm{gm}$. of Vipera russellii, and $0.00 \mathrm{I} \mathrm{gm.} \mathrm{of} \mathrm{Naja} \mathrm{tripudians.} \mathrm{Noc} \mathrm{observes} \mathrm{that} \mathrm{Calmette's}$ antivenin has no neutralizing power for the proteolytic principle of venom, as was already mentioned by Flexner and Noguchi.

Calmette ${ }^{4}$ states that the serum obtained from animals immunized with the venoms of Viperidæ, filtered through the Chamberland bougie, but unheated, can effectively neutralize the dissolving action of venom on gelatin and fibrin.

${ }^{1}$ Launoy. Sur l'action protéolytique des venins. C. R. Ac. des Sc., 1902, CXXXV, 401.

2 Launoy. Thèse doct. ès sc. Paris, 1903, No. II 38.

${ }^{3}$ Noc. Sur quelques propriétés physiologiques des différents venins de serpents. Ann. Inst. Pasteur, 1904, XVIII, 387 .

4 Calmette. Les venins. 1907, Paris. 


\section{DIASTATIC ACTIONS OF SNAKE VENOM.}

In 1884 Lacerda $^{1}$ made a series of observations, ascribing to venom the power of emulsifying fats and coagulating milk, but not of saccharifying starch. His experiments did not exclude possible bacterial contamination and are considered not conclusive as to the interpretation he thus offered.

In I894 Wehrmann, ${ }^{2}$ under Calmette, and then Launoy, ${ }^{3}$ repeated this study, and found that venom does not hydrolyze starch or inulin; but that saccharose is slightly inverted by the venom of cobra and of viper. Venom does not modify glucosides - amygdalin, coniferin, salicin, arbutin, and digitalin; hence it does not contain emulsin. According to Launoy cobra venom has no catalytic action, neither positive nor negative, upon soluble ferments: emulsin, amylase, and pancreatin. It exerts a slight inhibitory action upon pepsin.

On the other hand, Delezenne ${ }^{4}$ has shown that venom contains a kinase and activates the inactive pancreatic juice, enabling the latter energetically to hydrolyze albumin. This investigator found that 0.0005 to $0.00 \mathrm{Igm}$. of lachesis venom added to I c.c. of pancreatic juice can completely digest $0.5 \mathrm{gm}$. of albumin within Io to I 2 hours. Even 0.0002 to $0.0001 \mathrm{gm}$. and sometimes only $0.0000 \mathrm{I} 25 \mathrm{gm}$. were sufficient to digest the same quantity of albumin, although 24 hours, 48 hours, and 72 hours were respectively required to complete its action. Cobra venom was found to be less active, requiring 0.0005 to $0.000 \mathrm{I}$ gm., and the pelias venom requires about 5 times as much to obtain the same effect. Delezenne found that this kinetic property of venom disappears when heated to $100^{\circ} \mathrm{C}$. for $\mathrm{I}_{5}$ minutes.

\section{LIPOLYTIC ACTION OF SNAKE VENOM.}

According to Neuberg and Rosenberg ${ }^{5}$ snake venom has a feeble lipolytic power on lecithin, olive oil, and castor oil, and this action is accelerated by the addition of manganese sulphate. The proof for the existence of such ferment in venom requires a strict quantitative work, because the materials used for this test have more or less inherent acidity, especially the lipoids. Scrutinizing the work of these investigators, we find that the reaction, as the lipolytic action of snake venom on neutral fats is so weak that the increase in the degree of acidity after splitting, does not exceed one-tenth of that already present before the venom has acted. On the other hand, the increase in acidity is much more pronounced when the activator $\left(\mathrm{MnSO}_{4}\right)$ is used and may amount to one-third the original acidity. The splitting of lecithin is much more easily accomplished by venom and the increase in acidity may amount to nearly 5 times the original in the case of cobra venom and 2 times in the case of water-moccasin venom. The lipolytic action of crotalus venom on lecithin was not stated by these investigators.

1 Lacerda. Leçons sur le venin des serpents du Brasil. I884.

2 Wehrmann. Ann. Inst. Pasteur, I 898 , XII, 5 Io.

${ }^{8}$ Launoy. Thèse, Paris, 1903. loc. cit.

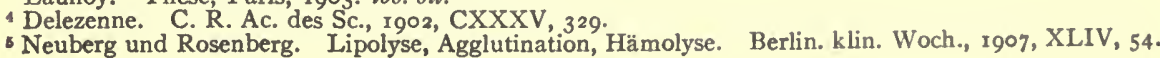


A summary of the results of Neuberg and Rosenberg's experiments:

TABLE 17.

\begin{tabular}{|c|c|c|c|c|}
\hline & $\begin{array}{l}\text { Acidity } \\
\text { before } \\
\text { splitting. }\end{array}$ & $\begin{array}{l}\text { Acidity } \\
\text { after } \\
\text { splitting. }\end{array}$ & $\begin{array}{l}\text { Alcohol } \\
\text { added for } \\
\text { titration. }\end{array}$ & $\begin{array}{l}\text { Increase in } \\
\text { acidity after } \\
\text { splitting. }\end{array}$ \\
\hline 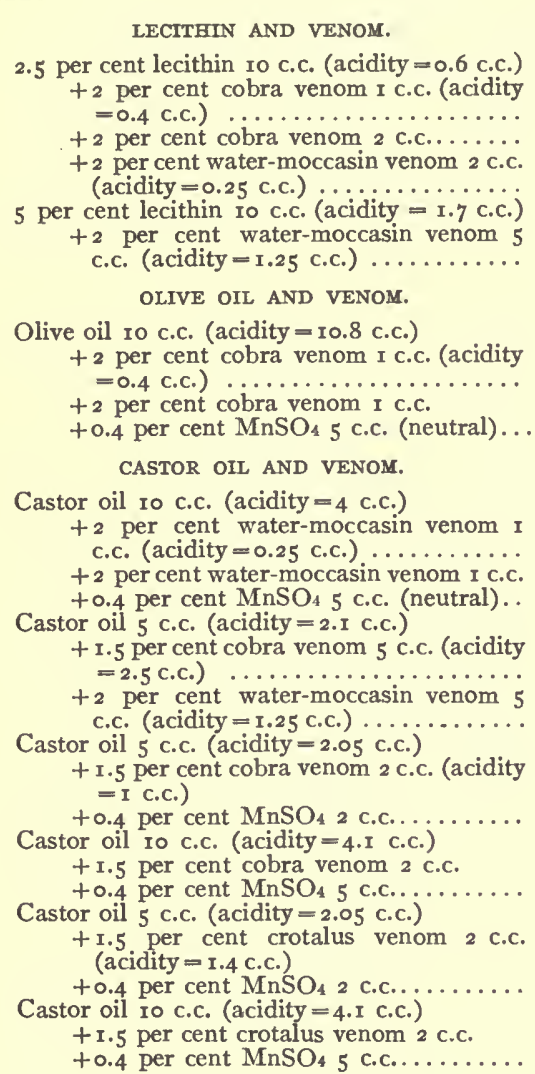 & $\begin{array}{c}\text { N/ıо KOH } \\
\text { c.c. } \\
\text { I.० } \\
\text { I. } 4 \\
\text { I.० }\end{array}$ & \begin{tabular}{|c|}
$\mathrm{N} /$ го KOH \\
c.c. \\
6.3 \\
20.5 \\
6.7
\end{tabular} & $\begin{array}{c}\mathrm{N} / \text { I० KOH } \\
\text { c.c. } \\
\ldots \ldots \ldots \ldots \\
\ldots \ldots \ldots \ldots \\
\ldots \ldots \ldots \ldots\end{array}$ & $\begin{array}{c}\text { N/ro KOH } \\
\text { c.c. } \\
5.3 \\
19.1 \\
5.6\end{array}$ \\
\hline
\end{tabular}

From table I7 the participation of venom lipase in typical venom-hæmolysis seems to be excluded.

According to the same authors, ricin, and crotin in much less degree, possess a similar fat-splitting property, somewhat stronger even than crotalus venom. Bee venom also seems to have a certain lipolytic power.

It is most desirable to investigate the thermal and chemical resistances of the lipolytic ferments of snake venom and other toxins in order to elucidate their importance as factors in the general toxicity of these substances. 


\section{CHAPTER XX.}

\section{ANTIBACTERICIDAL PROPERTIES OF SNAKE VENOM.}

S. Weir Mitchell has repeatedly pointed out the danger of a secondary bacterial infection in the subject which survives the primary fatal effects of snake venom, and also of the rapid decomposition of cadavers dead of venom toxication. He perceived that there must be a definite alteration produced by venom in the preservative properties of the tissues, but did not establish this point on an experimental basis.

In 1893 William H. Welch, together with C. B. Ewing, ${ }^{1}$ finally discovered that rattlesnake venom has the property of annihilating the bactericidal power of the blood. A rabbit was fatally poisoned with venom and just after its death the blood was collected from the large veins. Control blood was obtained from a healthy rabbit. The bactericidal power was tested by introducing into the serums obtained from those bloods, cultures of the anthrax bacillus and of cholera bacillus. It was found that while normal serum destroyed thousands of the respective bacilli, the venomized serum had lost this power. It is supposed that the rapid decomposition of the bodies of those who die of snake poisoning, as well as the extensive suppuration from which they suffer, may depend upon this cause.

An exhaustive study of the same phenomena was next made by Flexner and Noguchi, ${ }^{2}$ and the results are briefly mentioned below. The animals employed were the dog, rabbit, and Necturus; the venoms belonged to the cobra, moccasin, copperhead, and rattlesnake, and the bacteria were B. typhi, $B$. coli, and B. anthracis. The method consisted in -

(I) Introducing venom into the animal and drawing the blood from the femoral artery into sterile Nuttall bulbs.

(2) Permitting the blood from the normal animal to enter Nuttall bulbs in which the venom solution was contained.

(3) Admixture of the venom in sterile solution (heated for 4 days to $56^{\circ}$ to $60^{\circ} \mathrm{C}$., 30 minutes each time) with separated serum.

The bactericidal effects of the normal serums were first established. Rabbit serum is highly destructive for B. typhi and B. anthracis and least for B. coli. Dog serum is highly destructive for B. typhi. Necturus serum is also very destructive for $B$. typh $i$ and $B$. coli, but without marked effects on $B$. anthracis.

(I) Serum venomized in vivo: Cobra venom was most active. Blood from rabbits which had received o.or gm., taken 57 minutes after injection -

1 Welch and Ewing. The action of rattlesnake venom upon the bactericidal properties of the blood. Trans. of the First Pan-American Medical Congress, Washington, 1893, I, 354.

2 Flexner and Noguchi. Snake venom in relation to hæmolysis, bacteriolysis, and toxicity. Jour. of Exper. Medicine, 1902, VI, 277. 
moribund state - showed great loss of bactericidal properties. The three kinds of bacteria multiplied in this serum very freely, while all were completely destroyed except (in a few experiments) $B$. coli, which showed considerable diminution until after 6 hours, when increase began. In another series, $0.03 \mathrm{gm}$. of crotalus venom was injected into the blood of animals, taken after 45 minutes; full serum was used for inoculation of bacteria; practically the same result as in the previous series was obtained.

(2) Blood mixed with venom in vitro: In this series rabbits only were employed. The venom solutions were placed in Nuttall bulbs and the blood from the femoral artery was permitted to stream into them. In each experiment $0.006 \mathrm{gm}$. of venom were mixed with 20 to 30 c.c. of the blood. Coagulation was very slow or completely inhibited, and the serum was obtained when necessary by centrifugalization. It invariably contained hæmoglobin. The results all show that the bactericidal power of the venomized blood is completely abolished. This series of experiments may be open to the criticism that the increased nutritive value of the serum because of the hæmoglobin present may have been the cause of the effects noted; as a control, therefore, peptone was added to the serum in the proportion of $0.006 \mathrm{gm}$. of peptone to 20 c.c. of serum. From this experiment it follows that improvement in nutritive value reduced bactericidal effect, but in far less amount than is noted in the parallel case of venom. That the nutritive change is unimportant is shown by the first series of experiments, in which the poisoning was done in vivo, and also by the following experiments in which venom was added directly to the separated serum.

(3) Direct addition of venom to the serum in vitro: In this series serums of normal rabbits and dogs were employed. To I c.c. of rabbit serum $0.00 \mathrm{I} \mathrm{gm}$. of crotalus venom, and to I c.c. of dog serum $0.006 \mathrm{gm}$. copperhead venom were added. The results were the abolition of the germicidal powers of these serums. In order to determine the least quantity of venom required to remove the bactericidal properties of the serum varying quantities of copperhead venom were employed. Dog serum was chosen with B. typhosus. In each case I c.c. of serum was used. Table I8 gives one of these experiments, and the number of bacteria grown on one plate is shown.

TABLE I8.

[Experiment XXXII (a): I c.c. dog serum and varying amounts of copperhead venom.]

\begin{tabular}{|c|c|c|c|c|c|}
\hline \multirow{2}{*}{$\begin{array}{l}\text { Time of contact } \\
\text { before plating out. }\end{array}$} & \multicolumn{5}{|c|}{ Amount of copperhead venom employed. } \\
\hline & $0.0005 \mathrm{gm}$. & $0.0002 \mathrm{gm}$. & $0.000 \mathrm{gm}$. & $0.00005 \mathrm{gm}$. & $0.00002 \mathrm{gm}$. \\
\hline $\begin{array}{r}\text { Immediately. } \\
\text { I hour. ..... } \\
3 \text { hours .... } \\
6 \text { hours } . . . \\
24 \text { hours } . . .\end{array}$ & $\begin{array}{l}5,970 \\
6,240 \\
12,810 \\
\text { Innumerable } \\
\ldots \ldots \ldots \ldots \ldots\end{array}$ & $\begin{array}{l}3,070 \\
3,960 \\
\text { 10,000 } \\
\text { I00,000 } \\
\text { Innumerable }\end{array}$ & $\begin{array}{l}4,290 \\
1,830 \\
6,730 \\
\text { I3,140 } \\
\text { Innumerable }\end{array}$ & $\begin{array}{r}4,940 \\
2,620 \\
1,350 \\
172 \\
10,000\end{array}$ & $\begin{array}{r}3,350 \\
920 \\
593 \\
15 \\
0\end{array}$ \\
\hline
\end{tabular}


From this it may be concluded that the specimen of venom employed by Flexner and Noguchi destroyed the bactericidal properties of dog serum against $B$. typhosus when added in the proportion of $0.00005 \mathrm{gm}$. of venom to I c.c. of serum, and that $0.00002 \mathrm{gm}$. in the same quantity of serum was practically without action.

Flexner and Noguchi found that $0.000 \mathrm{I}$ to $0.0006 \mathrm{gm}$. of copperhead venom added to I c.c. of Necturus serum removed only a part of its bactericidal properties against $B$. coli and $B$. typhosus, but its inaction was very remarkable in contrast to the other serums they employed. It may be remarked that Necturus is highly refractory to venom. An animal weighing $250 \mathrm{gm}$. received without ill effect $0.05 \mathrm{gm}$. venom, equivalent to I60 minimal lethal doses for the guinea-pig of equal weight.

The effect of heat upon venom in relation to its action upon the bactericidal properties is of interest. For this purpose cobra, water-moccasin, copperhead, and rattlesnake venoms were studied. Temperatures varying from $75^{\circ}$ to $90^{\circ} \mathrm{C}$. were employed, and the heated venoms were mixed with the streaming blood in Nuttall bulbs and with the separated serum. The venom was kept at the lower temperature $\left(75^{\circ} \mathrm{C}\right.$.) for 30 minutes and at the higher temperature $\left(90^{\circ} \mathrm{C}\right.$.) for $\mathrm{I}_{5}$ minutes. The heated venom acts just as the unheated, except in the case of crotalus venom, the effect of which is somewhat diminished at the higher temperature $\left(90^{\circ} \mathrm{C}\right.$.).

Finally, Flexner and Noguchi attributed the antibactericidal properties of various venoms to the fixation or inactivation of bacteriolytic complements, but not to any perceptible alterations on the part of intermediary bodies (amboceptors) of these serums.

In $1905 \mathrm{Noc}^{1}$ made interesting obsiervations concerning the anticomplementary property of cobra venom. He found that the bacteriolytic actions of the fresh serums of the rabbit, horse, guinea-pig, rat, and man are completely annihilated by this venom, which is due to the fixation of complements by venom. He employed hæmolytic reaction to demonstrate the absence of complements from the venomized serum. Normal rat serum is hæmolytic upon the corpuscles of horse blood, and this was used as the test reaction. He prepared 6 different combinations:

\section{TABLE I9.}

(1) Normal rat serum 0.5 c.c.

(2) Normal rat serum 0.5 c.c. $+0.0005 \mathrm{gm}$. cobra venom, after is min. I c.c. antivenin.

(3) Normal rat serum 0.5 c.c. $+0.001 \mathrm{gm}$. cobra venom, after $15 \mathrm{~min} .2$ c.c. antivenin.

(4) Cobra venom $0.001 \mathrm{gm}$.

(5) Antivenin I c.c.

(6) Normal rat serum 0.5 c.c. + I c.c. antivenin.

Then 2 drops of defibrinated horse blood were introduced into each tube and incubated at $37^{\circ} \mathrm{C}$.

The results: Complete hæmolysis in a few minutes in (I) and (6). In (4) hæmolysis completed in I hour, but no hæmolysis in (2) and (3), showing that 0.5 and $0.00 \mathrm{Igm}$. of cobra venom completely destroyed alexine in I5

1 Noc. Ann. Inst. Pasteur, Igo5, XIX, 209. 
minutes; the venom itself was neutralized by antivenin after it had already done its destructive work on alexine. Calmette and Noc regarded this as the complement-fixation by venom amboceptor.

In I908 Morgenroth and Kaya ${ }^{1}$ found that the complement of guinea-pig serum is destroyed by cobra venom after several hours' contact at $37^{\circ} \mathrm{C}$. or room temperature, but not so much at $0^{\circ} \mathrm{C}$. Such serum is unable to activate cobra venom for hæmolyzing the corpuscles of goat blood, although simultaneous admixture of the serum, cobra venom, and the corpuscles results in the completion of hæmolysis. Coincidentally the complementary function of the serum for the anti-goat hæmolytic amboceptor (from immunized rabbit) is seen to have been diminished considerably. These authors consider the destruction of the complement in this case to be due to the action of certain ferment-like bodies present in the venom. They found that this anticomplementary function of cobra is lost on boiling.

It is not at all improbable that the disappearance of the complement is due to the action of proteolytic ferment already described by Flexner and Noguchi and by Noc, although nothing definite can be said about the mechanism.

1 Morgenroth and Kaya. Ueber eine komplementzerstörende Wirkung des Kobragiftes. Biochem. Zeitschrift, I908, VIII, 378 . 


\section{CHAPTER XXI.}

\section{TOXICITY OF THE TISSUES OF VENOMOUS SNAKES.}

Flexner and Noguchi ${ }^{1}$ determined the relative toxicity of the tissues of Crotalus adamanteus and found that it greatly depends upon the amount of blood contained in the organs. The fresh tissues obtained from snakes bled to death were injected intraperitoneally, in the form of sterile emulsions, into guinea-pigs weighing about $300 \mathrm{gm}$. each. The results, as shown in table 20 , are of interest, but do not, however, represent pure experiments, in that with each injection more or less of the blood was introduced. On account of the high degree of toxicity possessed by the blood, the organs in general were seen to exert injurious effects. The symptoms noted agree with those of crotalus-serum poisoning, in keeping with which the organs containing the most blood after death are found to be the most toxic. Of somewhat special interest are the poisonous properties exhibited by the eggcontents.

TABLE 20.

\begin{tabular}{|c|c|c|}
\hline Organs. & $\begin{array}{l}\text { Quantity } \\
\text { in grams. }\end{array}$ & Result. \\
\hline Spinal cord & 2 & Ill; recovered. \\
\hline Spleen ..... & 2 & Death in 2 hours; moderate hæmorrhage. \\
\hline Liver & 2 & Death in 5 hours; slight hæmorrhage. \\
\hline Kidney. . & 2 & Ill; recovered. \\
\hline Adrenal .... & I & Ill; recovered. \\
\hline Egg & 2 & Death in 4 hours; no hæmorrhage. \\
\hline Muscle. & 2 & Ill; recovered. \\
\hline Testis . . & 2 & Ill; recovered. \\
\hline Pancreas & I.2 & Ill; recovered. \\
\hline
\end{tabular}

The cause of death in the case of crotalus-egg injection may be due to the action of the neurotoxin.

Phisalix ${ }^{2}$ also found that the egg of Vipera berus presents toxic effect similar to that described by Flexner and Noguchi with the crotalus egg.

\footnotetext{
1 Flexner and Noguchi. Constitution of snake venom and snake sera. Jour. of Path. and Bacteriol.,

${ }_{2}^{1}$ Phisalix. 'C. R. Soc. Biol., 1905, LVII, 15.
} 


\section{CHAPTER XXII.}

\section{EFFECTS OF SNAKE VENOM ON MUCOUS, CONJUNCTIVAL, AND SEROUS MEMBRANES AND THE ALIMENTARY TRACT.}

Weir Mitchell has shown that crotalus venom can be ingested by the pigeon, one of the most susceptible animals to this venom, with impunity, and no poisonous principle is recoverable from the excreta of the pigeon. Naturally this may depend upon two possibilities: the non-absorption of the venom through the buccal mucous membrane and the destructive action of the gastric and intestinal ferments.

Mitchell and Reichert applied venom directly to the gastric membrane under laparotomy and found no visible changes produced by a few hours' contact. This they ascribed to the non-absorption of the venom by unbroken mucous membrane. Here they did not pay attention to the inactivating action of hydrochloric acid - even in a very dilute concentration - upon the hæmorrhagin of the venom; hence their conclusion regarding this particular phenomenon may require some modification.

The recent investigation of Ishizaka on the production of active immunity through oral administration of lachesis venom lends color to the occurrence of the absorption of that venom from the intestinal canal. ${ }^{1}$

Lacerda, Calmette, and C. J. Martin state that the venoms of Lachesis lanceolatus and Pseudechis may cause intense inflammation and hæmorrhagic changes in the alimentary tract when sufficient quantities of these venoms are given by the mouth. If the dosage be sufficiently large death usually follows their administration, with the usual venom-poisoning symptoms.

With the venom of cobra alimentary administration gives somewhat different results from those obtained in the case of crotaline venoms. Brunton and Fayrer observed that fatal effect is produced in animals when cobra venom is given from the digestive tract by feeding.

Fraser points out that absorption of cobra venom from the stomach is very slight. In rats and cats nearly 1,000 times the subcutaneous lethal dose was given without fatal effect. As a result of such administration of venom the serum of these animals was found to contain a certain amount of antitoxin.

Calmette failed to confirm Fraser's experiments, as he always found the venom to act fatally when given by the mouth in large dosage.

Kanthack fully confirms Fraser's observations that immunity can be secured by feeding the venom to animals.

Briot and Massol have seen that cobra venom is more rapidly absorbed from the rectum of animals than from the areolar tissue of the skin. The

1 The absorbtion of foreign proteins through the alimentary tract has been recently demonstrated by Rosenau and Anderson by anaphylactic phenomena. 
symptoms produced by the rectal administration of cobra venom are exactly the same as in the cases of other modes of inoculation.

When we consider the effects of digestive ferments on the toxic principles of cobra venom, the results obtained by various observers, though seemingly contradictory in a few instances, are uniformly equal in their demonstrative values.

Gastric digestion has but little effect upon the neurotoxin, while the tryptic digestion exerts far greater destructive influence upon this chief principle of cobra venom. Thus, should the ferments be prevented from their action on venom under certain circumstances there would be greater absorption of the more intact neurotoxin from the alimentary tract than under reverse circumstances. It is not surprising that in some instances death followed, while in other cases the animal survived the alimentary administration of the venom. Similarly we ought to expect a varying degree of antivenin formation.

The rapid fatal issue which follows the rectal administration of venom only confirms the occurrence of the fermentative destruction of venom in the upper parts of the alimentary canal and the ready absorption of venom from the lower region (rectum) without profound modification.

The action of snake venom upon the conjunctiva and cornea has also been studied by various investigators.

Brunton and Fayrer found that cobra venom produces slight congestion of the membrane and sometimes was even absorbed in sufficient quantity to kill the animal.

Weir Mitchell and Reichert observed that crotalus venom produces on the conjunctiva, in a few minutes, ecchymatous and odematous changes and rapidly closes the eyelids. In one case, in a rabbit, death occurred in 5 hours from the conjunctival application of venom. Cat's eye reacts similarly to that of the rabbit. They found, however, that the cornea remained quite transparent.

The author once met with an accident during one of the manipulations to extract venom from a rattlesnake. A minute particle of venom sprinkled from a fang entered my left eye. Within 20 seconds an intense pain set in and forced me to close the eye in an instant. I ran to a sink nearby and washed the eye in running water for fully Io minutes. The sharp pain persisted for about 2 hours, during which both lids were so swollen as to close the eye completely. After 4 hours the pain gradually decreased and I felt some nausea and light headache. The next morning the swelling and other symptoms disappeared, leaving several ecchymoses on the conjunctiva.

Calmette states that cobra venom induces a purulent inflammation of the conjunctiva of the rabbit, comparable to that caused by abrin. This property disappears from the venom heated to $80^{\circ} \mathrm{C}$.

The action of crotalus venom upon various serous surfaces has been studied by Mitchell and Reichert, and is described as consisting of the rapid rupture of small capillaries (hæmorrhage) and the simultaneous absorption of the 
venom. The intraperitoneal injections of various venoms are followed by a rapid absorption of the latter, although less rapidly than from the pleural cavity or blood-vessels. The absorption is slowest when venom is injected subcutaneously.

According to Briot and Massol the absorption of cobra venom from the rectum is somewhat quicker than from the abdominal cavity. 


\section{CHAPTER XXIII.}

\section{ARTIFICIAL IMMUNIZATION.}

\section{ACTIVE IMMUNITY - PROPHYLACTIC INOCULATION.}

The principle of active immunity against certain contagious diseases, such as Jenner's vaccination and Pasteur's antirabid inoculation, has long been known to medicine. The attempt, however, to produce a state of increased resistance to a more rapidly acting poison through the same procedure was not made until many years after Pasteur's brilliant discovery. This was done first by Henry Sewall with the venom of Sistrurus catenatus (or Crotalophorus tergeminus) upon pigeons. In I886 to I887 this investigator ${ }^{1}$ conducted a series of experiments in which he successfully produced active immunity against this venom in pigeons by means of repeated injections of non-fatal doses at varying intervals of time between each injection. Pigeons are known to be highly sensitive to the fatal effect of crotalus venom. Sewall carefully estimated the minimal fatal dose of the venom and then after a period of many months of "prophylactic injections" several pigeons, which withstood the immunization, were tested for their resistance to the action of the venom. It was found that some pigeons showed no symptoms when injected with even ro minimal lethal doses, whereas the control birds succumbed in several hours with the usual paralytic symptoms. Sewall also observed that the immunity gradually declined in the absence of fresh injections of the venom, and that even 5 months after the last injection the birds may still show quite marked resistance. Sewall's work antedates by a couple of years the renowned discovery of Behring and Kitasato of the diphtheria antitoxin.

Kaufmann ${ }^{2}$ also recognized that immunity to viperine venom could be secured by repeated sublethal injections.

The importance of the subject of immunity and immunization to venom now became evident, and the work of Phisalix and Bertrand directly bridges the gap between active immunity and passive immunity in snake venom. In 1894 these investigators ${ }^{3}$ found that it was possible to immunize guinea-pigs to the action of serpent's venom. The reduction of the toxicity of venom by heat was interpreted by them as due to the conversion of the poisonous principle of venom into the vaccinating principle. Only a portion of the venom undergoes this change, however, enough remaining

\footnotetext{
1 Henry Sewall. Experiments on the preventive inoculation of rattlesnake venom. Jour. of Physiol., I887, VIII, 203.

${ }^{2}$ Kaufmann. Les Vipères de France, morsures, traitements. Paris, I893.

3 Phisalix and Bertrand. Vaccination et accoutumance du cobaye contre le venin de vipère. Atti d. Cong. Med. internaz., Roma, 1894, II, Pat. gen. ed Anat. patol., 200. Atténuation du venin de vipère par la chaleur et vaccination du cobaye contre le venin. Compt. rend. d. l'Acad. d. Sci. Paris, 1894, CXVIII, 285.
} 
unchanged to cause the typical poisoning if large doses are given. From their experiments they conclude that venoms contain two distinct principles, one of inflammatory action, comparable to certain diastase, for which they suggest the name echidnase; the other of general action, actively impressing the nervous system and described as echidnotoxin. They found that after guinea-pigs were injected with heated venom they could resist a minimal fatal dose of venom. This protection they ascribe to the echidnase.

Phisalix and Bertrand, and simultaneously Calmette, transferred the stage of active immunity to the more important stage of passive immunity - or the era of antivenins, and this will be treated in full under "passive immunity."

It may be stated in this connection that for some time neither Kanthack ${ }^{1}$ nor Calmette ${ }^{2}$ could perceive any increase in resistance to venom after treating the animals with non-lethal doses. The first-named investigator employed both the venom and blood of cobra for the injections, but without favorable protective result.

Fraser ${ }^{3}$ made some very interesting observations on the production of immunity by administering the venom through the alimentary tract. $\mathrm{He}$ immunized a cat by gradual administration of venom per os, until it could take I gram at a dose, this being equivalent to 80 minimal lethal doses calculated from subcutaneous injection. Eight days after the large dose mentioned it was injected with I.5 times the subcutaneous dose without harm. The cat was pregnant, and on the fifty-fourth day of the administration gave birth to kittens, which continued to suck the immunized mother. On the fifty-seventh day after birth one of the kittens was given two minimal lethal doses of the venom and showed scarcely any symptoms. Another, on the sixty-ninth day after birth, received three minimal lethal doses, but died.

According to Fraser little venom is absorbed from the stomach. To a series of white rats he administered by the mouth, Io, 20,40, 200, 300,600, and $\mathrm{I}, \infty 00$ times the subcutaneous fatal dose, but all remained well except for slight drowsiness. The rat which received the I,000 fatal doses was 8 days afterward given two fatal doses subcutaneously, was sick in consequence, but recovered.

Kanthack ${ }^{4}$ was able to confirm Fraser's statement that animals can be immunized by alimentary administration of venom.

Phisalix and Bertrand ${ }^{5}$ state that the injection of heated $\left(68^{\circ} \mathrm{C}\right.$.) serums of viper and adder into the peritoneal cavity of guinea-pigs confers after 24 hours the power to resist the effect of one fatal dose of venom. 0.25 c.c. of the heated serum was sufficient for that purpose; the blood of adders had a similar, but less intense, protective power.

1 Kanthack. The nature of cobra poison. Jour. of Physiol., 1892, XIII, 272.

2 Calmette. Le venin de Naja tripudians. Ann. de l'Inst. Pasteur, I892, VI, I6o.

3 Fraser. The treatment of snake poisoning with antivenin derived from animals protected against serpent's venom. Brit. Med. Jour., I 895, II, 4 I6.

4 Kanthack. Report on snake venom in its prophylactic relation with poisons of the same and other sorts. Rep. Med. Off. Loc. Gov. Bd., I895-6, Lond., 1897, 235-266.

${ }^{5}$ Phisalix and Bertrand. Sur l'emploi du sang de vipère et de couleuvre comme substance antivenimeuse. Compt. rend. de l. Soc. d. Biol., 1895, ro série, II, 75 I. 
Phisalix ${ }^{1}$ altered the venom of viper by alternating currents of high frequency and found the modified venom to act as a protective vaccine.

Phisalix and Bertrand next succeeded in separating the toxic and the immunizing principles of the venom of viper by passing a I $: 5, \infty 00$ solution through the porcelain filter. Toxicity was almost completely absent from the filtrate, but the echidno-vaccine was still contained in it, as the injection of the filtrate into guinea-pigs rendered the animals refractory to the effects of two minimal lethal doses of fresh unfiltered venom given 48 hours later.

Calmette, ${ }^{2}$ later, dissented from the above statement, as he found that filtration simply reduced the toxicity of venom to two-fifths of its original power, but if proteins were removed by heat-coagulation before the filtration, practically all passed through. The vaccination reported by Phisalix and Bertrand he looks upon as merely an early stage of the usual form of experimental immunity.

\section{PASSIVE IMMUNITY - ANTIVENINS.}

Since the successful therapeutic application of the diphtheria antitoxin the future of the problem of immunity has assumed quite a new aspect. The discovery of Behring and Kitasato, that the protective principle developed in the animal successfully immunized against a particular toxin can be transmitted into a normal animal and confer upon the latter the power to resist the otherwise lethal action of the toxin in question has now been brought into the study of venom immunity. Naturally the basis of such possibility in venom is dependent on whether or not the animals can be made actively immune by the sublethal inoculation of venom. This has been established affirmatively by Sewall, Kaufmann, Phisalix, and Bertrand in their preventive inoculation, either with unmodified or heated venoms.

The first observation upon the antitoxic property of the blood of animals immunized to venom was made by Phisalix and Bertrand. ${ }^{3}$ They found that when guinea-pigs were killed 48 hours after vaccination with the echidnovaccine, their serum or defibrinated blood mixed with the venom and injected into the peritoneal cavity of other guinea-pigs enabled them perfectly to resist the action of the venom.

In the meanwhile Calmette commenced to install the results of his famous series of studies bearing on the production of antivenin, with such progress that he finally succeeded in introducing the antivenin to preventive and therapeutic applications in the treatment of snake bite. $\mathrm{He}^{4}$ first employed the usual laboratory animals, such as rabbits and guinea-pigs, to immunize with cobra venom.

\footnotetext{
1 Phisalix. Atténuation du venin de vipère par les courants à haute fréquence; nouvelle méthode de vaccination contre le venin. Compt. rend. d. I. Soc. d. Biol., I806, io série, III, 233.

' Calmette. Serpents' venom and antivenomous serum. Brit. Med. Jour., r896, II, 1025.

- Phisalix and Bertrand. Sur la propriété antitoxique du sang des animaux vaccinés contre le venin de vipère. Compt. rend. d. PAcad. d. Sci., Paris, 1894, CXVIII, 356.

${ }^{4}$ Calmette. L'immunisation artificielle des animaux contre le venin des serpents, et la thérapeutique expérimentale des morsures venimeuses. Compt. rend. d. l. Soc. d. Biol., 1894, ro série, I, I20.
} 
The principles of immunization Calmette resorted to were:

(I) Accustoming the animal to frequently repeated, gradually increased doses of diluted venom.

(2) The administration of a fatal dose of venom, followed by immediate curative therapeutic treatment with chloride of calcium or gold.

(3) The administration of repeated increasing doses of venom mixed with the chloride of calcium or gold.

Of these three methods he preferred the first. The serums obtained from the immunized animals showed preventive as well as curative effects in animal experiments.

Somewhat later Calmette ${ }^{1}$ added to the above facts that the antitoxic property of his antivenin was equally effective in counteracting the action of all kinds of snake venoms, namely, those of vipers, Notechis scutatus and Pseudechis porphyriacus, as well as that of cobra, with which it was prepared. This statement, and also another, that the immunity can be developed by repeated injections of weak solutions of alkaline hypochlorites without the venom, have since undergone a complete modification through more careful and extended investigations by later workers on this subject, and to-day the question of specificity of antivenin may be considered as settled against this assertion. To this point I shall return at length.

As his study progressed Calmette ${ }^{2}$ at last found another method of immunization, namely, by injecting animals with gradually increasing doses of venom modified by heat. He pointed out that the temperature of $75^{\circ} \mathrm{C}$. inactivates all the local irritant and œdema-producing principles without affecting the activity and the immunizing quality of the venom. After 48 hours the animals readily endure a fatal dose of venom and at the end of a month have quite a high immunity. At this time Calmette was still uncertain of the therapeutic value of the antivenin for the treatment of snake bite.

$\mathrm{He}^{3}$ next prepared the antivenin by immunizing two asses to venom (cobra) previously heated. The first received $0.0022 \mathrm{gm}$. within a period of 97 days and another $0.0016 \mathrm{gm}$. within 76 days. The serum of the first was of such antitoxic value that 0.5 c.c. neutralized $0.00 \mathrm{Igm}$. of the venom; 4 c.c. of the serum injected 4 hours before the venom protected against 2 minimal lethal doses. If one inoculated a rabbit with enough venom to kill a control rabbit in 3 hours, and an hour subsequently administered 4 to 5 c.c. of the serum, the animal recovered. The later the therapeutic serum is administered, however, the less certain is recovery to take place, so that Calmette in his experiments placed $\mathrm{I} \frac{1}{2}$ hours as the limit of certain cure. He observed that the local action of the highly irritative venoms of Crotalus, Lachesis cerastes, and $L$. trigonocephalus is always present when these venoms are injected into the immunized animals.

\footnotetext{
${ }^{1}$ Calmette. Propriétés du sérum des animaux immunisés contre le venin des serpents, thérapeutique de l'envenimation. Compt. rend. d. l'Acad. d. Sci., Paris, 1894, CXVIII, 720 ; Atti XI. Cong. Med. internaz., Roma, I894, II, Patol. gen. ed Anat. patol., Iog.

${ }^{2}$ Calmette. Contribution à l'étude du venin des serpents. Ann. l'Inst. Pasteur, I894, VIII, 275.

${ }^{3}$ Calmette. Ibid., 1895 , IX, 225.
} 
Here Calmette records that the venom of Scorpio afer, $0.00005 \mathrm{gm}$. of which killed white mice in 2 hours and also a guinea-pig weighing $500 \mathrm{gm}$. in due time, was neutralized by the antivenin. $0.00 \mathrm{I} \mathrm{gm}$. of the scorpion venom mixed with 3 c.c. of the antivenin failed to kill guinea-pigs, though the control animal died. Guinea-pigs immunized to the venom of French vipers were able to resist the effects of the scorpion venom.

Calmette inoculated a large cobra upon several occasions with I 2 to 20 and 24 c.c. of his antivenin and found that its blood, which should have been fatal for guinea-pigs in doses of 0.5 c.c., had lost all its toxicity. He thought this due to neutralization of the toxic principles of the blood by the antivenin and assumed that the toxicity of the blood of venomous snakes is identical with that of the venom.

In this paper Calmette further attempted to show. that the immune serums obtained by immunizing animals with venom and abrin are effective against each other's antigen. But this statement received little experimental corroboration afterwards. It was about this time that the biological or cellular theory of immunity of the French school was fighting hard against the chemical theory of the German school. Therefore, it is no wonder that Calmette expressed himself in favor of the vital view of the process of passive immunity.

Fraser $^{1}$ (1895) announced the results of his immunization experiments with venom, showing that a rabbit had tolerated 50 minimal lethal doses of cobra venom by means of gradually increasing doses of the venom. Then his more important and extensive work ${ }^{2}$ appeared, in which, after having determined the minimal lethal dose of cobra venom for different animals and that of various venoms for rabbits, he recognized the neutralizing property of the serum of the immunized animal against venom, when the two are mixed in vitro. The immunization was performed, for the most part, with subcutaneous injections of venom, though he also produced immunity in cats by gastric administration. Fraser gives a series of protective inoculations against $\mathrm{I}, 2,3$, and 4 lethal doses of venom:

Series I: One minimal lethal dose of venom, with $0.5,0.25,0.1,0.05$, $0.02,0.01,0.005,0.004$ c.c. of antivenomous serum respectively. All these animals survived. When, however, the dose of serum was reduced to less than 0.0025 c.c., they died.

Series 2: Two minimal lethal doses of venom, with $0.75,0.7$, and o.6 c.c. of antivenin were followed by recovery, but 0.5 c.c. was insufficient to effect recovery.

Series 3: Three minimal lethal doses of venom, with I.5, and I c.c. of antivenin were followed by recovery, but 0.8 c.c. did not save the animal.

Series 4: Four minimal lethal doses of venom mixed with 2 c.c. of antivenin were followed by death.

Fraser found that when the venom and antivenin were given in opposite sides of the body, one immediately following the other, doses of $\mathrm{I}, 2$, and 3 c.c.

1 Fraser. Trans. of the Medico-Chir. Soc. of Edinburgh, I895, XIV, 212.

2 Fraser. The rendering of animals immune against the venom of cobra and other serpents, and on the antidotal properties of the blood serum of the immunized animals. Brit. Med. Jour., I895, I, 1309 . 
of serum failed to protect, but 2.5 and 3 c.c. saved the animal; 4 c.c. of the serum per kilo body-weight was able to save the animal, when given 30 minutes before, from a little more than the minimal lethal dose of venom. It was also shown that $I .5$ and 0.8 c.c. of antivenin injected 30 minutes after a lethal dose will save the animal, and that 5 c.c. will save it from twice the lethal dose.

Fraser found, as Calmette had done, that the antivenin made by using cobra venom was efficacious against various kinds of venoms. In regulating the dose of antivenin he urges that the dose be calculated by using cats and not herbivorous animals, which are so highly susceptible. He ${ }^{1}$ believes that the difference in the degree of susceptibility to venom of carnivorous and herbivorous animals is much dependent on the diet. Thus after feeding white rats on meat for seven weeks he found that their resistance to venom was greatly raised. In the same article Fraser recommended that the antivenin be injected into the bitten part before the ligature is removed. The dose of antivenin for use in medicine for man was fixed by him at 20 c.c., although this standard was abandoned by him a little later.

Fraser, ${ }^{2}$ after dealing with the possibility of producing immunity in human subjects by administering venom per os, entered a rather pessimistic warning by stating that the estimated dosage of antivenin is such as to make it scarcely practicable in human therapeutics. He recommended 350 c.c. as the quantity necessary to cure a man of I 70 pounds. In a subsequent paper he once more laid bare his view as to the possible therapeutic value of antivenin. Calculated from his experimental data he believes that about 300 c.c., at least, of the serum would have to be injected in order to save a man from a single lethal dose of venom. He expressed fear that this enormous quantity of the antivenin would render its clinical application almost impracticable.

Fraser ${ }^{3}$ points out a very important fact concerning the venom-antivenin reaction, viz., that when I.3 c.c. of antivenin per kilo body-weight is mixed in vitro with 5 minimal lethal doses of venom, and the mixture allowed to stand 5 to ro minutes, death follows its injection into animals, though when the mixture is allowed to stand 20 minutes or longer the animal recovers. This he thinks proves the chemical nature of the reaction. He denies the probability that leucocytes are active in protecting the venomized body against the venom, being stimulated by the antivenin. He thinks the theory of vital nature untenable, and expresses his belief that protection or immunity is chiefly due to the accumulation in the blood of an antidotal substance, and that this substance originates, at least in part, from the venom itself and is normally a constituent of the venom.

Encouraged by the favorable results of his experimental serum therapy on small animals with the antivenin obtained from various laboratory animals,

\footnotetext{
1 Fraser. The treatment of snake poisoning with antivenin derived from animals protected against serpents' venom. Brit. Med. Jour., I895, II, 4 I 6.

2 Fraser. Address on immunization against serpents 'venom and the treatment of snake bite with antivenene. Brit. Med. Jour., I896, I, 957.

${ }^{8}$ Fraser. The limitations of the antidotal power of antivenene. Brit. Med. Jour., r896, II, 910.
} 
and also from two asses, Calmette next made a most important stride in the antivenin treatment of human beings in snake poisoning. Whatever errors he may have made as to the interpretation of the mechanism of passive immunity and the specificity of antivenin, medical science owes to Calmette ${ }^{1}$ much of the development and achievement of this particular phase of venom immunity.

In $1895-1896$ he had immunized a number of horses against venom by the usual processes. He started with small, gradually increasing doses of the solution of cobra venom mixed with small, gradually decreasing quantities of $\mathrm{I}: 60$ solution of calcium chloride, injected subcutaneously, with an interval of 4 or 5 days between each injection. In general, after 2 months' immunization the horses became able to bear a dose of pure venom which could kill roo kilograms of rabbit. After reaching this stage the horses showed less and less local reaction to the injection and their serum attained a considerable degree of antivenomous power. Not less than six months was necessary before the serum could be of sufficient potency for therapeutic purposes. Therefore a longer time is required for venom immunization than for diphtheria toxin. Even after a large number of injections the local œdema followed each inoculation and persisted for many days. The horses became uneasy and lost their appetite, their respiration was accelerated and inspiratory, they perspired abundantly, but had no fever. These symptoms usually disappeared in 2 or 3 days. If the injection was too frequently repeated the horse had nephritis, hæmaturia, and eventually succumbed. The choice of venom was of some importance and Calmette employed the venom of Cobra because it is the most active of all venoms and has less local effect than the other venoms, such as the venom of Pseudechis of Australia.

Calmette mentions that the phylogenetic principles of various venoms of Viperidæ are by no means identical, because sometimes intense hæmolysis occurs, while at others simply a white œdema follows the injection of this group of venoms. These local poisons are completely destroyed by $75^{\circ} \mathrm{C}$. or a small quantity of calcium chloride. When the immunization of the animal advanced pretty high in regard to the cobra venom, Calmette injected various kinds of venoms of other species, thus avoiding the violent sloughing, hæmorrhage, or œdema which would have followed if these venoms had been given without the preliminary immunization with cobra venom. When the animal became able to stand the injection of a dose of venom fatal to 500 kilograms of rabbit, he judged the immunization to be complete enough.

The standardization of the antivenomous power of Calmette was made on rabbit, whereas an antivenin capable of neutralizing or preventing the effect of I minimal lethal dose per I.000 gm. of rabbit by the dose of o.I c.c. of the antivenin was expressed in numerical value of I0.000. This means that I c.c. of such serum can neutralize the minimal lethal dose of venom for $10.000 \mathrm{gm}$. of rabbit. Calmette believed that a serum possessing ro.000 antivenomous

1 Calmette. Le venin des serpents. Physiologie de l'envenimation, traitement des morsures venimeuses par le sérum des animaux vaccinés. Soc. d'édit. scientif., Paris, 1896. 
units is sufficiently strong for therapeutic purposes. The antivenin prepared by Calmette had power equaling 20.000 units. Since 1895 Calmette has been sending out his antivenin to various laboratories in India, Cochin China, and Australia for trial in cases of snake bite. The antivenin is in bottles containing Io c.c. each. The warning is given not to use it after the lapse of one year from date of preparation, as its antitoxic power gradually diminishes with age.

It may be stated that Calmette employed in his immunization of horses the following venoms: Cobra di capello (Naja tripudians), Trimeresurus (Lachesis), Naja haje, Cerastes, Crotalus, Bothrops (Lachesis lanceolatus), Pseudechis, Hoplocephalus (Notechis), and different species of European vipers. The proportions of these venoms varied, but the venom of Naja tripudians was most used.

Some cases of snake bite successfully treated with Calmette's antivenin are recorded, the reports having been made by Hankin and Lepinay in Asia.

In July, I896, Calmette ${ }^{1}$ read a paper concerning the treatment of animals poisoned with snake venom, by the injection of antivenomous serum, before the laboratories of the conjoint board of the Royal College of Physicians and Surgeons of London. It was accompanied by a series of experiments demonstrating the preventive and curative properties of his antivenin against the fatal poisoning of rabbits with cobra venom. Among others he made a suggestion as to the method for testing accurately and promptly the strength of the antivenomous serum. A standard solution of type venom must be placed at the diposal of the appointed experts. The toxic unit of this solution will be based upon the quantity of venom necessary to kill a rabbit of 2 kilograms in 20 minutes by intravenous injection in the marginal vein of the ear; the above quantity corresponding on the average to $0.002 \mathrm{gm}$. of cobra venom, weighed dried, and $0.004 \mathrm{gm}$. of crotalus venom. An antivenomous serum, to be sufficiently active for therapeutic use, must be a preservative in a mini$\mathrm{mal}$ lethal dose of 2 c.c. on intravenous injection of the toxic unit of venom. The preventive inoculation must be made I 5 minutes only before the injection of the venom. The testing of the serum is thus effected in less than 30 minutes.

Calmette and Delarde ${ }^{2}$ state that immunity against venom can be produced in cold-blooded animals by repeated injections of subminimal lethal doses, but it may not necessarily be followed by the appearance in the blood of the antivenomous principle in these animals, for example, in the frog.

Calmette ${ }^{3}$ published the details of his demonstrations of experimental serum therapy of animals poisoned with venom, as shown in London, before the Royal College of Physicians and Surgeons. He injected 6 rabbits (weight I. 45 o to 1.770 grams) with 3 c.c. of antivenin intravenously. After 5 hours a

1 Calmette. The treatment of animals poisoned with venom by the injection of antivenomous serum. Lancet, I 896 , II, 449 .

2 Calmette and Delarde. Sur les toxines non-microbiennes et le mécanisme de l'immunité par les sérums antitoxiques. Ann. Inst. Pasteur, $1896, \mathrm{X}, 675$.

${ }^{3}$ Calmette. Sur le venin des serpents. Ibid., I897, XI, 214. 
dose of venom capable of killing a rabbit in about 20 minutes was injected into each of them, and into 2 control rabbits at the same time. The controls died in $\mathrm{I} 6$ and $\mathrm{I} 7$ minutes after the injection, respectively, while the 6 animals which had received the antivenin beforehand showed no symptoms of toxication. In the second series 8 rabbits received simultaneously equal doses of venom, sufficient to kill them within 2 hours. These venomized rabbits were then divided into four sets. To the first two animals 3 c.c. of antivenin were given intravenously 30 minutes after the injection of venom. To the second set the same quantity of antivenin was administered after I hour. One of the third set expired at the moment when, after 90 minutes, an attempt was made to inject the antivenin; while the other, though seriously ill, was successfully treated with 5 c.c. of the serum. The fourth set was left untreated and they both died in roo minutes and ro5 minutes, respectively.

Calmette showed that the effect of the same dose of venom administered into the marginal vein of the ear of a rabbit can be neutralized by the injection of 3 c.c. of antivenin into the marginal vein of the opposite side, 2 and 5 minutes after the injection of venom. The rabbits treated with antivenin before and after the injection of venom, in both series of experiments, all survive. The venom employed was a mixture of the venom of Naja tripudians and that of Bungarus caruleus.

Calmette gives his standard of antitoxic units and emphasizes the variation of susceptibility of diverse animals to venom. Thus the quantity of the antivenin necessary to save a more susceptible species from I minimal lethal dose is larger than for the less sensitive species. Calmette employed rabbit for the test-animal.

The duration of acquired immunity against venom is longer with the animal which received a larger dose at the last injection. Rabbit inured to I minimal lethal dose was still resistant in 2 months, while with guinea-pig it was only one month. A rabbit immunized to stand one single dose of $0.006 \mathrm{gm}$. (I $20 \mathrm{minimal}$ lethal doses) when tested 8 months after the last inoculation was not killed by injection of thrice the dose which kills the control in 20 minutes.

The duration of passive immunity secured by injecting antivenin is usually not over 2 to 4 days. A dose of 20 c.c. of antivenin administered to a normal rabbit protects it from a dose of venom, intravenously given, capable of killing the control in $I_{5}$ to 20 minutes, only for a period of 7 days. The daily injection of antivenin during two weeks may give the rabbit immunity which lasts for 20 to 25 days. ${ }^{1}$ Transmission of immunity against venom is seen to occur from a female guinea-pig to the offspring, but never from the male.

In the following I shall briefly record, chronologically, the work of different investigators in regard to the production of antivenins for different kinds of

1 In his paper Calmette discusses the nature of the toxic principles of different venoms, showing that the neurotoxins resist heating to $75^{\circ}$ to $80^{\circ} \mathrm{C}$., while the local poisonous substances are made inactive. He expresses his view of the unitary nature of the neurotoxins of various venoms. 
snake venom, but a fuller consideration of their results will be made under the separate heading, the specificity of antivenins.

McFarland (I900-I90I) undertook the immunization of horses with the mixed venoms of crotalus, ancistrodon, cerastes, etc., and obtained a serum which had a marked antivenomous power against various kinds of venom.

In 1902 Tidswell ${ }^{1}$ prepared a pure antivenin for Notechis scutatus venom by immunizing horses with gradually increasing doses of unmodified venom of Notechis. This antivenin showed a marked protective power against the venom used in the preparation, but not for the other Australian venoms, such as that of Pseudechis or the death adder.

In 1903 Flexner and Noguchi ${ }^{2}$ produced several antivenins for crotalus venom, modified either with weak hydrochloric acid or iodine trichloride solution. The crotalus antivenin thus produced was able to neutralize the effects of unmodified crotalus venom, but had almost no action against the other venoms.

In 1904 Noguchi prepared in goats two pure antivenins, one for Crotalus adamanteus and the other for Ancistrodon piscivorus. Both had marked specific antitoxic powers.

In $1904 \mathrm{Lamb}^{3}$ produced a highly antitoxic immune serum in horses by injections of pure cobra venom. This antivenin was found to be highly specific for the same venom. $\mathrm{He}^{4}$ then succeeded in producing a pure antivenin for unmodified daboia venom and found it to be specific.

In 1905 Brazil ${ }^{5}$ prepared pure antivenins for the venoms of Lachesis lanceolatus and Crotalus terrificus. Both were highly specific.

In 1907 Ishizaka ${ }^{6}$ produced pure antivenin with the venom of Lachesis flavoviridis in rabbits. He was able to immunize successfully, if not highly, to the effects of unmodified venom by repeated, gradually increasing doses of modified venom solutions. The modifications were by (I) chloroform shaking; (2) glacial acetic acid; (3) hydrogen sulphite; (4) temperature of $60^{\circ}$ to $68^{\circ} \mathrm{C}$. The rectal administration of the native venom led to an appearance of antitoxin in the body of the animal, while the alimentary introduction per os failed to do so. The actions of the antivenin are found to be highly specific.

In the same year Kitashima ${ }^{7}$ produced antivenin for the venom of Lachesis flavoviridis in larger animals (goat, ox, and horse).

1 Tidswell. Australian Med. Gazette, 1902, XXI, I77.

2 Flexner and Noguchi. Production and properties of anticrotalus venin. Jour. of Med. Research, 1904, n. s., VI, 363 .

a Lamb. Specificity of antivenomous sera. Sci. Mem. Off. Med. Sanit. Depts. Govern. Ind., I904, n. s., No. 10.

${ }^{4}$ Lamb. The specificity of antivenomous sera, with special reference to a serum prepared with the venom of Daboia russellii. Sci. Mem. Off. Med. Sanit. Depts. Govern. Ind., I905, n. s., No. 16.

${ }^{5}$ Brazil. L'intoxication d'origine ophidienne, Paris, 1905.

- Ishizaka. Studien über Habuschlangengift. Zeitschr. f. exper. Path. und Therapie, 1907, IV, 88.

7 Kitashima. On "Habu" venom and its serum therapy. The Philippine Jour. of Science, I907, III, Section B, I5 1 . 


\section{CHAPTER XXIV.}

\section{SPECIFICITY AND THERAPEUTIC VALUES OF ANTIVENINS.}

\section{SPECIFICITY OF ANTIVENINS AS A WHOLE.}

Calmette at one time held that the neutralizing property of an antivenin is not quite specific, and that a number of immune serums produced by certain plant toxalbumins or bacterial toxins can equally counteract the effects of snake venom, but the experimental evidences brought out by many investigators now seem to contradict this view. The investigations of Stephens and Myers seem conclusive on this point. They ${ }^{1}$ first studied the effect of Calmette's antivenin upon the hæmolytic power of cobra venom and found that hæmolysis can be completely prevented by adding enough antivenin, and that the relation holds good for a multiple of doses. This antihæmolytic property was found to be specific to the antivenin. They also studied the relation between the antihæmolytic and the antitoxic powers of the antivenin and found that with only $x$ minimal lethal dose the neutralization went hand in hand for both principles, but with multiple doses a mixture hæmolytically neutral still proved fatal.

In a subsequent paper ${ }^{2}$ the same authors extended their study on the specific protective action of antivenin, the anticlotting power of cobra venom being used as a test-reaction. They arrived at the same conclusions as in their previous experiments on hæmolysis, namely, that the anticlotting power of cobra venom can be neutralized by the antivenin and that this neutralization is specific. They state that the neutralization of the anticlotting and that of the toxic power of cobra venom run parallel as long as only one minimal lethal dose is used, but this ratio does not hold good in multiple doses of venom in regard to its lethal effects in vivo.

\section{SPECIFICITY OF ANTIVENINS DUE TO DIFFERENCES IN THE CHARACTER- ISTIC TOXIC PRINCIPLES OF THE VENOM OF EACH SPECIES.}

The fatal effects of various kinds of snake venoms are by no means due to one toxic principle, but are produced by different sets of toxins which vary according to the kind of venom. Thus in the venoms of Naja, Bungarus, and all of the Hydrophiinæ death is produced through the neurotoxins present in these venoms in dominating proportions. On the other hand, the venoms of Viperinæ, namely, those of Daboia or Echis, cause instantaneous death by

\footnotetext{
1 Stephens and Myers. Test-tube reactions between cobra poison and its antitoxin. Brit. Med. Jour., I898, I, 620 .

Stephens and Myers. The action of cobra poison on the blood, a contribution to the study of passive immunity. Jour. of Path. and Bacter., r898, V, 279.
} 
producing intravascular thrombosis. One group of Crotalinæ can cause death by similar toxic principles, while another contains more neurotoxins. The species of Ancistrodon belong to the latter group, and Lachesis to the former. The venom of Crotalus owes its fatal effects to the locally acting principles, the hæmorrhagins, which may also be injurious to the vascular system throughout the entire body of the victim. The colubrine snakes inhabiting Australia possess a venom which contains considerable of both neurotoxins and thrombic ferments and can cause death by either of these. Besides, the hæmolytic toxins of Daboia and Notechis appear to play an important part in chronic toxications with these venoms.

The above brief presentation of the complex nature of the toxic principles of various venoms is introduced here in order to enable one to form a general conception on toxicity before describing how our present knowledge of the specificity of antivenins has gradually developed.

The first investigator who observed the inefficiency of Calmette's antivenin against the venom of other species was C. J. Martin, who made tests of the neutralizing power of the antivenin against the venom of Pseudechis and found that it had a very feeble protective action. In order to discover the cause of this failure Martin tested the antivenin against the two separate toxic principles which constitute the venom of Pseudechis.

Martin, ${ }^{1}$ some time previously, succeeded in separating these two principles, either by heating the venom solution to $80^{\circ} \mathrm{C}$. or by filtering through the gelatinized porcelain bougie under 50 atmospheric pressures. The heatresistant, non-coagulable portion of the venom is filterable through the bougie and has neurotoxic action, while the heat-coagulable, non-filterable component has hæmotoxic action and also affects the heart. At that time Martin was unaware of the independent existence of fibrin ferment and failed to allude to this as such, but ascribed this thrombose-production to the extensive destruction of the red corpuscles by hæmotoxin. Therefore, as he himself corrected his former view, the principle which he earlier called hæmotoxin must be understood as the fibrin ferment. As the result of his experiments on animals Martin ${ }^{2}$ pointed out that Calmette's antivenin can protect the animal from the lethal effect of the filterable toxin (neurotoxin), but not at all from that of the unfilterable toxin (hæmotoxin, fibrin ferment). This explains why the unmodified venom, which contains both principles in considerable amounts, is not affected by Calmette's serum.

Meanwhile Kanthack ${ }^{3}$ was working on a similar problem and brought out the fact that Calmette's antivenin failed to protect animals from the fatal effects of comparatively small doses of daboia venom, and concluded that the action of antivenin is highly specific for the production.

1 C. J. Martin. Proc. Roy. Soc. New South Wales, Aug. 5, 1896.

2 C. J. Martin. Concerning the curative power of antivenomous serum on animals inoculated with Australian snake's venom. Intercolon. Med. Jour., r897, II, 527, 537.

${ }^{3} \mathrm{Kanthack}$. Report on snake venom in its prophylactic relation with poisons of the same and other sorts. Rep. Med. Off. Loc. Govern. Bd., 1895-96, London, 1897, 235. 
Stephens ${ }^{1}$ then brought out the very important fact that the hæmolytic principles of various kinds of venoms are not identical as far as their affinity to Calmette's antivenin is concerned. He showed that, while the hæmolytic toxin of cobra venom is easily neutralized by this antivenin, those of daboia or crotalus venoms remain almost unneutralized by the same. He concludes:

(I) That antitoxic sera can act upon toxins other than, but allied to, those used in the preparation of the serum.

(2) That the hæmolytic constituents of snake toxins, and hence snake toxins as a class, are not identical.

(3) That against a minimal lethal dose of daboia venom 0.5 c.c. of Calmette's antivenin has very little action.

(4) That the antihæmolytic properties of antivenomous sera must be increased, in order to afford any efficient protective serum, e.g., against pseudechis toxin or daboia toxin.

Myers ${ }^{2}$ found that cobra venom contained two principles, which he terms cobralysin and cobranervin. The cobralysin, which is the hæmolytic substance, is destroyed by heat, the cobranervin remaining unaltered. Cobralysin can be neutralized by antivenin, the cobranervin remaining free. It is only in minimal fatal dose that the neutralization of both goes together. With multiples of the minimal fatal dose, a non-hæmolytic mixture of venom and antivenin may rapidly kill a guinea-pig.

The susceptibility of the erythrocytes to the action of the cobralysin in vitro bears no relationship to the susceptibility of the animal to subcutaneous toxication by the venom. In the lethal properties of the venom the cobralysin plays an insignificant part. Toxoids rapidly form in dilute solutions of venom, these toxoids seeming to be specific.

McFarland immunized horses to unmodified crotalus venom mixed with several other kinds of venoms and obtained an antivenin which was equally effective against the venoms of Crotalus adamanteus, Ancistrodon contortrix, Naja tripudians, and Cerastes. It was able to counteract only the neurotoxins, but not local irritative principles. This experiment neither negatives nor proves the question of the specificity of antivenins, as it was prepared with mixed venoms.

On the other hand, Flexner and Noguchi ${ }^{3}$ produced an antivenin for crotalus venom by injecting venom modified by hydrochloric acid or trichloride of iodine and found that the antivenin had a neutralizing action upon the hæmorrhagins; also that Calmette's antivenin has only a feeble protective action against crotalus venom, as it has no anti-hæmorrhagic power.

In 1904 Jacoby made a series of experiments with the hæmolysin-free cobra venom in regard to its relation to the native unmodified venom. The material which he employed was the aqueous solution of cobra venom, from

\footnotetext{
1 Stephens. On the hæmolytic action of snake-toxin and snake sera. Jour. of Path. and Bact., 1899-1900, VI, 273.

2 Myers. On the interaction of toxin and antitoxin; illustrated by the reaction between cobralysin and its antitoxin. Jour. of Path. and Bact., 1899-1900, 415.

${ }^{3}$ Flexner and Noguchi. Production and properties of anti-crotalus venin. Jour. of Med. Research, I 904 , n. s., VI, 363 .
} 
which every trace of hæmolysin had been removed by Kyes's method for the isolation of venom lecithid. It was found that this modified venom solution was highly toxic, especially upon the nervous system. In various pharmacological tests it was identical with the raw venom as far as its lethal properties are concerned. Thus it was chiefly the neurotoxin which was contained in that hæmolysin-free solution of cobra venom which was hence called the neurotoxin. Jacoby ${ }^{1}$ found, however, a very important difference between the neurotoxin and the raw cobra venom, when he attempted to neutralize the former with Calmette's antivenin. The antivenin was protective against the raw venom, but not at all against the isolated neurotoxin. This incapability of Calmette's antivenin to neutralize the neurotoxin was ascribed to a possible modification of the molecule during the isolation from hæmolysin, and a parallel was drawn between this and that observed by Kyes with the isolated cobra lecithid. On the other hand, Jacoby succeeded in producing immunity in rabbits against the isolated neurotoxin and found that the serum of the immunized animals had neutralizing properties for the neurotoxin as well as the raw cobra venom. This singular phenomenon was also observed by Kyes with his hæmolytic lecithid.

\section{SPECIFICITY OF ANTIVENINS DUE TO DIFFERENCES IN INDIVIDUAL CYTOTROPIC TOXINS OF VENOMS OF DIFFERENT SPECIES.}

In the past few years the question of venom immunity has become rather far-reaching. Since the establishment of the facts that the action of antivenin is specific and that an antivenin may be incapable of neutralizing one set of toxins, while the other set may be completely counteracted, attention has been given to whether or not one particular toxin is common to the venoms of different species. We have already seen that all venoms of Elapinæ and Hydrophiinæ contain one type toxin destructive to the nervous system. Is the neurotoxin contained in the venom of Naja tripudians identical with that present in Bungarus or Enhydrina? The venoms of vipers and of certain Australian Colubrinæ are known to contain fibrin ferment, but is the fibrin ferment of the venom of Daboia identical with that of Echis or Pseudechis or Notechis? The crotaline venoms contain a considerable amount of hæmorrhagin, but is that principle contained in Crotalus identical with that of $A n$ cistrodon? The same inquiry arises also as to the hæmolysin and other cytotoxins contained in different kinds of venoms.

This question of the specificity of various individual type toxins is of the utmost importance both from practical and theoretical standpoints. To those familiar with the almost fabulous discriminative immunity reactions of living organisms to a countless variety of toxins and albuminoid bodies, it may not appear extraordinary that the neurotoxins, hæmolysins, fibrin ferments, hæmorrhagins, and still other cytotoxins of the venom of one species should differ from the similar principles of other species of snakes. Never-

1 Jacoby. Ueber die Wirkung des Kobragiftes auf das Nervensystem. Beitr. z. wissensch. Medicin und Chemie. Festschrift zu Ehren des 60. Geburtstages von Ernst Salowski. Berlin, 1904, 200. 
theless it was some time before accurate differentiation of these toxins could be realized. At present we are still far from being in a position to analyze the exact cause of this individual difference in these seemingly identical cytotoxins. Specificity, as we understand it from the immunity reactions, is still an unknown factor and, beyond perceiving the fact as it is, we have no right to infer an absolute difference. In fact, it is not at all improbable that specificity is nothing but the expression of the variable surroundings amidst which venom toxins coincidentally exist.

The work of Faust demonstrated the probability that venom toxins exist in a native state as ester-like compounds of proteins. If this assumption is correct the venom immunity reactions would correspond to the protein immunity reactions, to which the well-known precipitation and complementdeviation phenomena properly belong. Again, it is remarkable that immunity reactions are obtainable only when antigens of colloidal character are injected. This consideration may not be out of place here, bcause we may in the future be able to modify the toxin molecules in such manner that they become nontoxic without altering the radicals responsible for the production of antitoxins, as was done by Flexner and Noguchi with the hæmorrhagins - toxoid formation in Ehrlich's sense.

In the following pages I will detail some of the more important investigations concerning the specificity of different type toxins of venoms.

In 1899 Stephens observed that Calmette's antivenin could neutralize the hæmolytic principle of cobra venom, but failed to do so when tested against the hæmolysins contained in daboia venom and crotalus venom. He therefore suggested that the hæmolysins of different venoms, hence snake toxins, as a class, are not identical with each other. Having had no pure antivenins he could not pursue this particular point farther.

The more accurate determination of this species specificity of venom cytotoxins calls for the employment of pure antivenins, that is to say, antivenins produced by injecting pure venoms of different species. With such antivenins we can determine whether the antivenin produced with venom A can neutralize venom B or C. Inversely, the action of venom A can be tested with the antivenins produced with venom $\mathrm{B}$ or $\mathrm{C}$, and so on.

Up to the present time eight pure antivenins have been produced, namely: (I) Daboia antivenin (Lamb); (2) Crotalus adamanteus antivenin (Flexner and Noguchi); (3) Crotalus terrificus antivenin (Brazil); (4) Ancistrodon piscivorus antivenin (Noguchi); (5) Lachesis lanceolatus antivenin (Brazil); (6) Lachesis flavoviridis antivenin (Kitashima, Ishizaka); (7) Notechis scutatus antivenin (Tidswell); (8) Cobra antivenin (Lamb).

The work of Lamb has been most extensive and systematic and has contributed much to our knowledge concerning this particular phase of venom immunity, while the results obtained by other investigators have assisted in settling the question of individual specificity of type toxins. For the sake of clearness and brevity the results of their investigations are presented in tables $2 \mathrm{I}$ and 22. 
TABLE 21. - Daboia antivenin. ${ }^{1}$

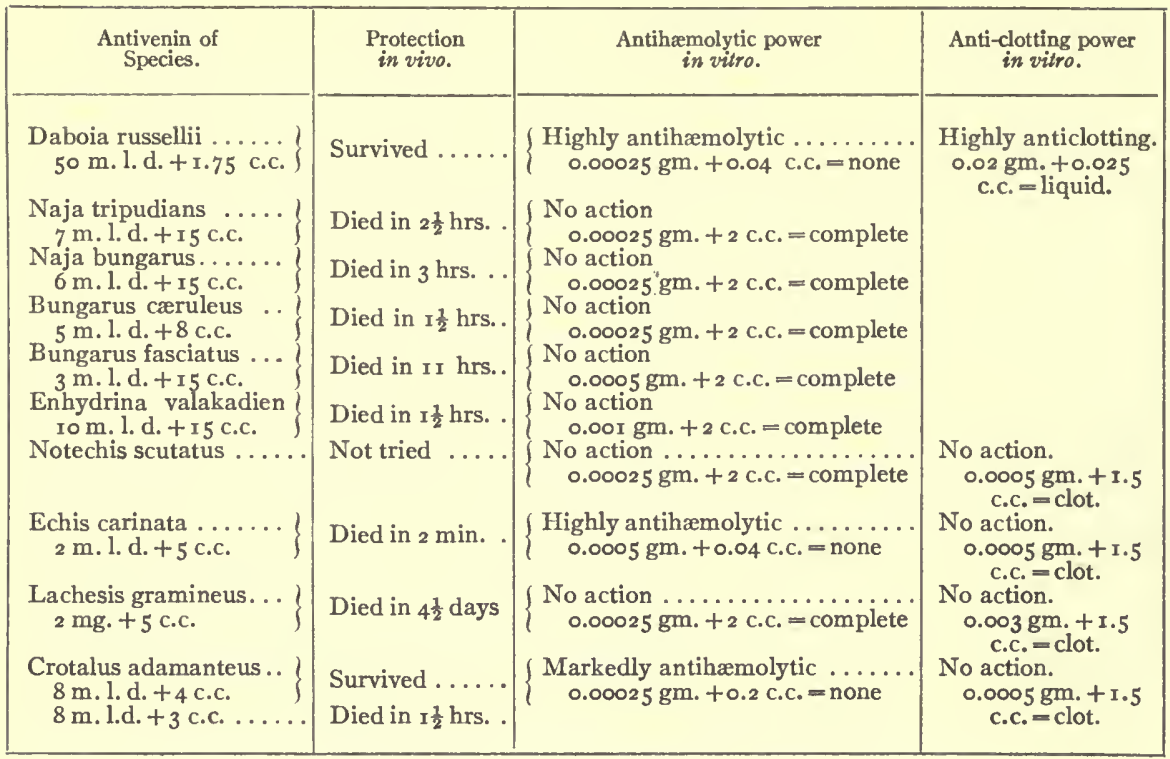

TABLE 22. - Notechis scutatus antivenin.2

\begin{tabular}{|c|c|c|c|}
\hline $\begin{array}{l}\text { Antivenin of } \\
\text { Species. }\end{array}$ & $\begin{array}{l}\text { Protection } \\
\text { in vivo. }\end{array}$ & $\begin{array}{l}\text { Antihæmolytic power } \\
\text { in vitro. }\end{array}$ & $\begin{array}{l}\text { Anticlotting power } \\
\text { in vitro. }\end{array}$ \\
\hline Notechis scutatus ... & & Rather feeble.$\ldots \ldots \ldots \ldots \ldots$ & $\left\{\begin{array}{l}\text { Highly anticlotting } \\
0.0 \text { I }_{\text {I }} \text { gm. }+0.06 \\
\text { c.c. = liquid. }\end{array}\right.$ \\
\hline $\begin{array}{l}\text { Naja tripudians } \ldots . . . \\
\text { Io m.1.d. + 5 c.c. }\end{array}$ & Died in $\mathbf{I} \frac{1}{2} \mathrm{hrs}$. & More, but rather feeble........ & \\
\hline $\begin{array}{l}\text { Naja bungarus. ...... } \\
2 \mathrm{mg} .+4 \text { c.c. }\end{array}$ & Died in $3 \frac{1}{2}$ hrs. . & Slight . & \\
\hline $\begin{array}{l}\text { Bungarus cæruleus } \ldots \\
\text { o.4 mg. }+4 \text { c.c. }\end{array}$ & Died in $47 \mathrm{~min}$. & No action... & \\
\hline $\begin{array}{c}\text { Bungarus fasciatus } . . .\} \\
6 \text { m.l. d. }+5 \text { c.c. }\end{array}$ & Died in ro $\mathrm{min}$. & No action .. & \\
\hline $\begin{array}{l}\text { Enhydrina valakadien } \\
\text { o. } 5 \mathrm{mg} \text {. }+4 \text { c.c. }\end{array}$ & Died in $56 \mathrm{~min}$. & Quite marked . & \\
\hline $\left.\begin{array}{c}3 \text { thrombos. d. }+5 \text { cc. } \\
\text { Sub-thrombos. d. }+ \\
4 \text { c.c. }\end{array}\right\}$ & $\begin{array}{l}\text { Died in } 1 \frac{1}{2} \mathrm{~min} . \\
\text { Died in } 18 \mathrm{hrs} .\end{array}$ & No action . & \\
\hline $\begin{array}{l}\text { Echis carinata ...... } \\
\quad 0.5 \mathrm{mg} .+4 \text { c.c. }\end{array}$ & Died in 2 min. . & Quite marked ... & No action. \\
\hline $\begin{array}{l}\text { Lachesis gramineus. .. } \\
\quad 2 \mathrm{mg} .+3 \text { c.c. }\end{array}$ & Died in $6 \mathrm{~min}$. & No action & No action. \\
\hline $\begin{array}{l}\text { Crotalus adamanteus . } \\
0.5 \mathrm{mg} .+4 \text { c.c. }\end{array}$ & Died in 6 hrs. .. & No action ...... & No action. \\
\hline
\end{tabular}

According to Tidswell ${ }^{3}$ the antivenin which he prepared with pure venom of Notechis scutatus was able to neutralize this particular venom (o.4 c.c.

1 Lamb. The specificity of antivenomous sera, with special reference to a serum prepared with the venom of Daboia russellii. Sci. Mem. Off. Med. Sanit. Depts. Govern. Ind., I905, n. S., No. I6. ${ }^{2}$ Lamb. Specificity of antivenomous sera. Sci. Mem. Off. Med. Sanit. Dept. Gov. Ind., I903, n. s. No. 5. Ibid. Second communication. Op. cit., 1904, n.s., No. ro.

3 Tidswell. Preliminary note on the serum-therapy of snake-bite. Australian Medical Gazette, 1902, XXI, I77. 
neutralized $0.00059 \mathrm{gm}$.$) , but completely failed to neutralize the poisons of$ brown and black snakes and also that of the death adder.

TABLE 23. - Cobra antivenin. ${ }^{1}$

\begin{tabular}{|c|c|c|c|}
\hline $\begin{array}{l}\text { Antivenin of } \\
\text { Species. }\end{array}$ & $\begin{array}{l}\text { Protection } \\
\text { in vivo. }\end{array}$ & $\begin{array}{l}\text { Antihæmolytic power } \\
\text { in vitro. }\end{array}$ & $\begin{array}{l}\text { Anticlotting power } \\
\text { in vitro. }\end{array}$ \\
\hline 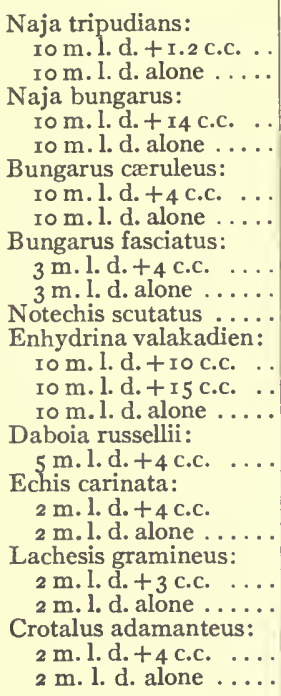 & 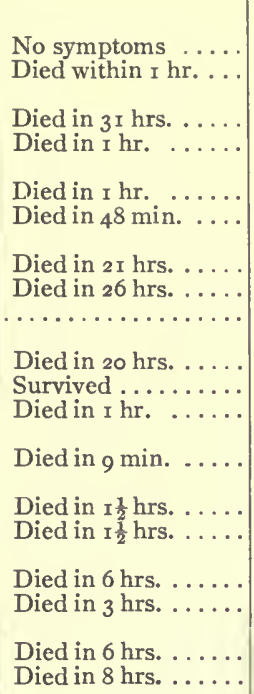 & 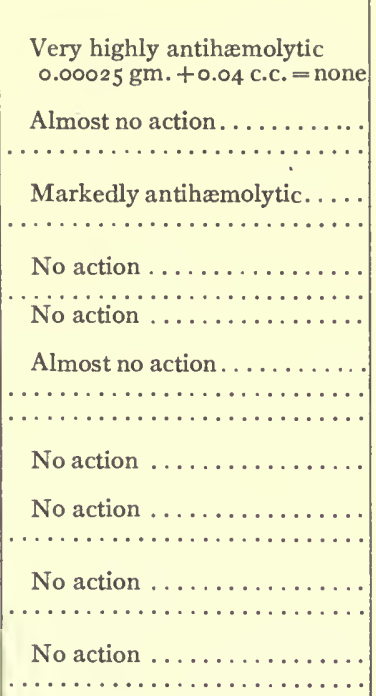 & $\begin{array}{l}\text { No action. } \\
\text { No action. }\end{array}$ \\
\hline
\end{tabular}

The anticoagulating property of cobra venom is effectively stopped, but that of Naja bungarus is decreased little or not at all.

\section{CROTALUS ADAMANTEUS ANTIVENIN.}

Flexner and Noguchi ${ }^{2}$ succeeded in producing pure crotalus antivenins in rabbit and dog by means of certain modified solutions of the crotalus venom. The strength of one of the preparations was such that I c.c. of it neutralized I I minimal lethal doses of unmodified crotalus venom. With this antivenin they tested its protective action against the venoms of cobra, daboia, and water-moccasin. They found that 2 c.c. of this serum had no antitoxic action whatever against only one lethal dose of these first two, but possessed some against the last-named venom. Two minimal lethal doses of the moccasin venom were thus made non-fatal with I c.c. of the serum. They noticed, however, that the hæmorrhagin of this venom remained but little neutralized, while the antivenin was very effective in removing the hæmorrhagic action from the crotalus venom. From this fact Flexner and Noguchi were led to assume that a multiplicity of hæmorrhagins occur in the venoms of different species of snakes.

1 Lamb. Specificity of antivenomous sera. Second communication. Sci. Mem. Off. Med. Sanit. Dept. Govern. Ind., r904, n. S., No. Io.

2 Flexner and Noguchi. Production and properties of anticrotalus venin. Jour. of Med. Research, I 904 , n. s., VI, 363 . 
In a later work Noguchi ${ }^{1}$ prepared a pure crotalus antivenin with unmodified venom and used it to determine the specificity of antivenin in regard to toxicity in vivo and hæmolysis in vitro. The results are as shown in table 24 .

TABLE 24.

\begin{tabular}{|c|c|c|}
\hline Antivenin of Species. & Protection in vivo. & $\begin{array}{l}\text { Antihæmolytic power } \\
\text { in vitro. }\end{array}$ \\
\hline $\begin{array}{l}\text { Crotalus adamanteus: } \\
12 \mathrm{~m} .1 \text {. d. }+2.5 \text { c.c. . . }\end{array}$ & Survived (no hæmorrhage)... & $\begin{array}{l}\text { I c.c. neutralized - } \\
\text { ro } \mathrm{m} . \mathrm{h} . \mathrm{d} \text {. }\end{array}$ \\
\hline $\begin{array}{l}\text { Ancistrodon piscivorus: } \\
1 \mathrm{~m} . \mathrm{l} . \mathrm{d} .+2.5 \text { c.c. ...... }\end{array}$ & Survived ... & 1.33 \\
\hline $2 \mathrm{~m} .1 . \mathrm{d} .+2.5$ c.c. ..... & Died (hæmorrhage). . & \\
\hline $\begin{array}{l}\text { Naja tripudians: } \\
\text { I m. l. d. + 2.5 c.c. }\end{array}$ & Died . & 0.75 \\
\hline Daboia russellii...... & 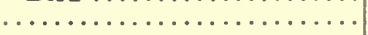 & 1.5 \\
\hline Lachesis flavoviridis. & $\ldots \ldots \ldots$ & 2.25 \\
\hline
\end{tabular}

\section{CROTALUS TERRIFICUS ANTIVENIN.}

Brazil $^{2}$ immunized mules and horses with the venom of Crotalus terrificus, or cascavel of Brazil. This antivenin neutralizes the toxic action of the same venom as well as that of Lachesis jararacussu, but not that of Lachesis lanceolatus, L. alternatus, and L. neuwiedii.

\section{ANCISTRODON PISCIVORUS ANTIVENIN.}

Noguchi ${ }^{3}$ obtained pure antivenin for water-moccasin venom by treating goat with modified venom followed by injections of unmodified venom. As the supply of venom was insufficient he was unable to raise immunity to any high degree. The antivenin which he got was, however, sufficiently strong to determine the point in question. The results may be summarized in table 25 .

TABLE 25 .

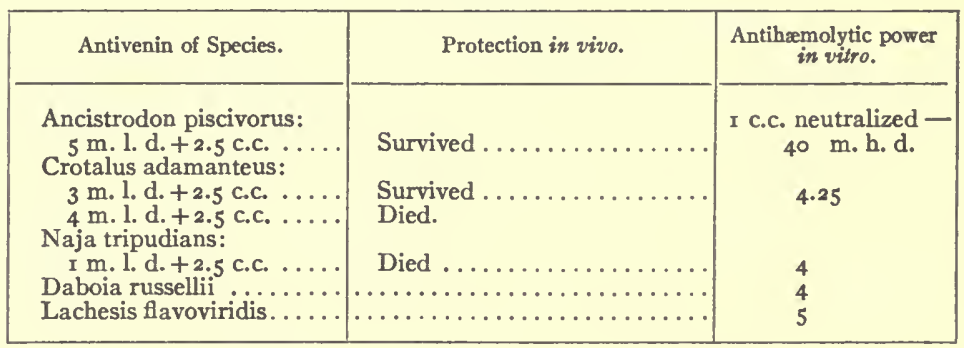

\section{LACHESIS LANCEOLATUS ANTIVENIN.*}

The antivenin prepared by Brazil by immunizing animals with the venom of Lachesis lanceolatus has proved to be very effective against this venom and also those of Lachesis alternatus and L. neuwiedii, but not at all so against

1 Noguchi. Therapeutic experiments with anticrotalus and antimoccasin sera. Jour. of Exp. Med., 1906, VIII, 614.

2 Brazil. Contribution à l'étude de l'intoxication d'origine ophidienne. Paris, r9o5.

3 Noguchi. Therapeutic experiments with anticrotalus and antimoccasin sera. Jour. of Exp. Med.

1906, VIII, 6r4.

- Brazil. Loc. cit. 
the crotalus venom. On the other hand, anticrotalus serum was quite antitoxic both against the crotalus and the jararacussu venoms.

\section{LACHESIS FLAVOVIRTIS ANTIVENIN. ${ }^{1}$}

This was first prepared in large animals by Kitashima at the Institute for Infectious Diseases at Tokio, but a more detailed work on this venom and its immunization was performed by Ishizaka. This investigator immunized a number of rabbits with the venom modified with chloroform, glacial acetic acid, hydrogen sulphite, at temperatures ranging from $60^{\circ}$ to $68^{\circ} \mathrm{C}$. His modification was aimed at the removal of the hæmorrhagin without at the same time destroying the immunizing properties of this particular principle - as Flexner and Noguchi have done with the American crotaline venoms. In this manner he was able to obtain antivenins which very effectively neutralized the hæmorrhagic toxin of the unmodified venom. Thus the work of Flexner and Noguchi on the production of hæmorrhagin toxoids is confirmed and extended. The hæmorrhagin of the same venom was easily neutralized, but that of viper's venom was neutralized only slightly or not at all, showing the difference in the hæmorrhagins of different species.

Against the general toxicity of habu venom this antivenin was quite effective, but not at all or only slightly against the venom of viper.

\section{CALMETTE'S ANTIVENIN.}

According to Lamb 5 c.c. of this serum failed to neutralize $0.002 \mathrm{gm}$. $=$ 3 minimal lethal doses of Bungarus fasciatus venom and $0.00005 \mathrm{gm} .=\mathrm{I}$ minimal lethal dose of Echis carinata venom. The same author has also shown its inefficacy in combating the fatal effect of Daboia russellii venom. It is superfluous to detail here the controversies between C. J. Martin and Calmette about the neutralizing properties of this serum against certain Australian colubrine species. It seems that the experiments carried out by Tidswell supported Martin's old argument.

Noguchi also found Calmette's antivenin inefficacious in neutralizing the fatal effects of Crotalus adamanteus and Ancistrodon piscivorus.

Brazil concludes that Calmette's antivenin has no neutralizing effects against the venoms of Lachesis lanceolatus and Crotalus.

\section{THERAPEUTIC VALUE OF ANTIVENINS.}

The therapeutic value of antivenins is influenced by several factors. First, it depends on whether or not an antivenin can neutralize venom after symptoms of toxication have already developed. At least, it ought to be able to neutralize venom even after the lapse of several hours, provided death does not ensue within that period. With the venoms which kill the victim within several minutes through the production of intravascular thrombosis, antivenin may be of but little practical value; but in the case of bites of Colubridæ and most Crotalidæ death usually comes after several hours or later, seldom

1 Ishizaka. Studien über das Habuschlangengift. Zeitschr. f. exper. Path. und Therapie, 1907, IV, 88. Also, Kitashima. The Philippine Jour. of Science. I907, III, Section B, I 5 I. 
within a few hours. Some of the elapine venoms (such as that of Bungarus) act rather slowly and afford opportunities to employ specific antivenin with reasonable expectation of success.

The strength of the neutralizing power of an antivenin, as tested by mixing the serum with the venom before injection into the susceptible animals, is of course no measure of what the same serum can do when injected into the animal already inoculated with venom. But from results obtained by Calmette, Fraser, Martin, Noguchi, and others it is evident that antivenins are able to save the venomized animals by a later administration of a sufficient amount of the serums. The amount of antivenin necessary to neutralize the lethal effects of venom increases with the time which elapses after the injection of venom, and after a certain stage of toxication it is no longer possible to prevent death, even with a large quantity of the serum.

According to Calmette, his antivenin was able to cure the animal as late as 90 minutes before the time of assured death, provided the venom (cobra) be injected subcutaneously and the antivenin intravenously.

Fraser has shown that when the venom and antivenin are injected simultaneously at the same spot the quantity of the latter required is much smaller than when they are injected at opposite sides of the body. He also states that delay in the administration of the serum necessitates the increase of its quantity to save the animal from the same amount of venom. The quantity of antivenin required to neutralize a definite amount of venom was about 1,000 times more when injected separately at different parts of the body than that required for neutralization of the same quantity of venom in vitro. ${ }^{1}$

C. J. Martin ${ }^{2}$ then pointed out that absorption of antivenin follows its subcutaneous injection very slowly. About the same quantity of antivenin necessary to neutralize venom in vitro is capable of doing so when the former is injected into the circulation and the latter subcutaneously. At least to or 20 times this quantity is required when they are both placed simultaneously under the skin, but in different parts of the body.

Noguchi's ${ }^{3}$ recent investigations on the therapeutic value of the antivenins of Crotalus and Ancistrodon brought out quite different facts from those mentioned in the previous work. He demonstrated that these two antivenins, especially that of Crotalus, can save the animals even from a moribund condition, as long as they are able to stand on their feet. When 2 minimal lethal doses of venom are injected collapse occurs usually after $3 \frac{1}{2}$ hours and death takes place about I5 minutes later. If, even at a very critical moment, enough antivenin be injected, the animal quickly recovers, without any general symptoms, after I or 2 days. When the venom is injected intraperitoneally extensive and profuse hæmorrhage takes place and the abdominal

\footnotetext{
1 Fraser. Nature, 1896, 594.

2 C. J. Martin. Advisability of administering curative serum by intravenous injection. Intercolon. Med. Jour. of Australasia, I897, II, 537. Ibid., I898. III, 7I3. Also C. J. Martin and W. B. Halliburton. Further observations concerning the relation of the toxin and antitoxin of snake venom. Proc. Roy. Soc. Lond., 1899, LXIV, 88.

\& Noguchi. Expériences thérapeutiques avec les antivenins (Crolalus adamanteus et Ancistrodon piscivorus). Oversigt over det danske Videnskabernes Selskabs Forhandlinger, I906, 269.
} 
tension becomes very high, but the subsequent administration, also intraperitoneally, of an adequate amount of antivenin stops further distension and accelerates resorption of the sanguine exudate very promptly. The quantity of antivenin had to be increased the more the injection was delayed.

The comparatively favorable results of experimental antivenin therapy against the crotalus and moccasin venoms are no doubt to be ascribed to the differences in the chief toxic principles of these American snake venoms and of the Indian cobra venoms. At least the absorption of the hæmorrhagins, the chief toxins of the former, is much slower than the neurotoxins of the latter; hence there is more chance for the antivenin to act directly and in higher concentration.

From these observations it would appear that antivenins, at least crotaline antivenins, possess excellent neutralizing quality.

The second factor which affects the therapeutic value of antivenins is the conditions with which we have to deal in the practical cases of snake bite. This is an unknown factor, namely, the quantity of venom injected into the victim during the bite. It may happen that the snake injects the maximal quantity of its venom, or it may inject only a small quantity. It is the first hypothetical case that we ought to expect in practice.

I have given the maximal quantities of venom per single bite for various kinds of venomous snakes in a separate topic and shall avoid repetition here, and take up only three representatives of subfamilies, Elapinæ, Crotalinæ, and Viperinæ, for the discussion (table 26).

TABLE 26 ,

Naja tripudians (cobra) yields about $\ldots \ldots \ldots \ldots \ldots . .2$ to $0.35 \mathrm{gm}$. (dried).

Crotalus adamanteus (rattlesnake) yields about....... 0.2 to $0.3 \mathrm{gm}$. (dried).

Daboia russellii (chain viper) yields about .......... 0.15 to $0.25 \mathrm{gm}$. (dried).

Now the question arises as to the quantity of antivenins necessary to neutralize the above doses when mixed directly in vitro. Of course the quantity of antivenins depends upon the antitoxic units contained in them.

According to Martin and $\mathrm{Lamb}^{1}$ the cobra antivenin, prepared at the Pasteur Institute in India, requires I c.c. to neutralize $0.00 \mathrm{I} \mathrm{gm}$. of dried cobra venom, while Calmette's antivenin takes 2 c.c. for the same amount of venom.

Of preparations of crotalus antivenins prepared by Flexner and Noguchi, 0.5 c.c. neutralized $0.00 \mathrm{rgm}$. of dried crotalus venom.

Of the daboia antivenin, prepared by Lamb, I c.c. is required to neutralize $0.00 \mathrm{I} \mathrm{gm}$. of the dried venom.

From these figures we can immediately calculate the amount of each antivenin necessary to neutralize in vitro the maximal quantities of venoms liable to be injected by the respective snakes into their victims.

But here comes another consideration, namely, the maximal amount of each venom which a man can resist. Calculated from the experiments made upon monkeys the minimal lethal doses for cobra venom are placed by Lamb

${ }^{1}$ C. J. Martin and Lamb. Snake bite. Allbutt System of Medicine, 1907, II, London. 
at somewhere from 0.015 to $0.02 \mathrm{gm}$., and for daboia venom at $0.06 \mathrm{gm}$. Although no estimates of the toxicity of the venom of Crotalus adamanteus have been made on monkeys, the minimal lethal doses of this venom determined on rabbits, guinea-pigs, and rats by subcutaneous administration are Io to 20 times larger than those of Naja tripudians, also determined on the same species of animals in the same manner. It is therefore a fair approximation to place the minimal lethal dose of crotalus venom for a man at 0.I5 to $0.3 \mathrm{gm}$. Of course the local disturbances caused by even much smaller doses of this venom would be extremely grave, if not fatal. This estimate appears to be in harmony with the statistics of mortality in man, as Weir Mitchell recorded only I death out of 8 cases of rattlesnake bite.

Now returning to the dosage of antivenins, we need only to neutralize the quantity of venom which would be beyond what a man could tolerate without death. Thus in the case of cobra bite one has to neutralize nearly 0.200 to $0.35 \circ \mathrm{gm}$., which means the quantity of the present cobra antivenin approximating $35^{\circ}$ c.c.

In the case of daboia bite at least $0.1 \mathrm{gm}$. of the venom would be in excess of the reasonable tolerance of a man, and hence it would be necessary to inject Ioo c.c. of the daboia antivenin at once.

In the case of crotalus bite the fatal issue may or may not follow in an adult, but about 0.05 to $0 . \mathrm{I} \mathrm{gm}$. may be injected in excess of toleration. The present antivenin, which is still in course of preparation and is expected to exceed all previous preparations in its antitoxic units - for we now possess a sufficient supply of the venom, which we never had before - will require 25 to 50 c.c. to prevent death. The dosage of the crotalus antivenin is still an undetermined factor, but we may confidently expect a preparation at least many times more powerful than those obtained with insufficient injections of the venom.

With crotalus venom another important fact must not be neglected. It is the local disturbances of the site and whole surrounding region of the bite. I believe, however, that by the prompt and appropriate application of the crotalus antivenin, which contains much antihæmorrhagin, this will also be treated effectively.

Taking up the cases of cobra and daboia poisonings, we have seen that in order to prevent death in man at least 350 c.c. of the cobra antivenin and Ioo c.c. of the daboia antivenin must be immediately injected intravenously, ${ }^{1}$ because the above dose is calculated from the neutralizing powers in vitro. Should the symptoms be already manifest the quantities of these antivenins must accordingly be many times increased. Again, if the serum be administered subcutaneously the dosage must be increased ro to 20 times, and this would mean the injection of 3,500 to 7,000 c.c. of the cobra antivenin at once!

\footnotetext{
1 Martin once made a statement that the quantity of antivenin sufficient to neutralize a given amount of venom mixed in vitro can neutralize the same quantity of venom in vivo, if the latter be injected subcutaneously and the former intravenously. But Martin and Lamb in their joint article state that ro to 20 times the quantity of antivenin must be injected intravenously in order to effect neutralization of the same amount of venom as in the case of test-tube mixture.
} 
Notwithstanding the pessimistic calculations of Martin and Lamb, Calmette still adheres to his well-known optimistic views. He recommends the injection of Io c.c. of his antivenin when the symptoms are not yet manifest, but 30 c.c. must be injected subcutaneously if the patient should come under treatment after some delay or the snake should prove to be a cobra or a bungarus. Where symptoms of toxication are already present Io to 20 c.c. of the antivenin must be given intravenously.

The third factor, which equally lessens the possibilities of the practical application of antivenin treatment of snake poisoning, lies in the difficulty of obtaining sufficient venom for immunizing large animals. In order to promote the degree of immunity to a much higher standard than hitherto accomplished, enormous quantities of venom would be required. To obtain Io grams of dried cobra or daboia venom is by no means easy, but to accumulate many kilograms of such material appears to be impracticable. In fact Lamb, who had every encouragement and support from the British government and no doubt was best situated to undertake such work, confesses his discouragement about the future of serum therapy for bites of Indian snakes.

Again, in every case of snake bite we have to inject the specific antivenin only, and no other. It is rather difficult to identify the nature of the snake from the description of the victim. Even when the snake is identified, it may happen that it is too small, though deadly, to furnish enough venom for preparing its specific antivenin, and in such an instance there will be no available antivenin.

Although the future of antivenin therapy may appear hopelessly gloomy, yet the problem of antivenins has its bright side. The circumstances which control the amount of the venom injected by a snake are extremely variable. Not every snake bite ends disastrously. Only those which occur under circumstances very favorable to the snake prove fatal. Under some conditions only superficial scratches of the fangs may be inflicted. Between these two extremes there must be a series of variations in which the excessive amounts (beyond the dose which a man can bear) vary from a mere fraction of $0.00 \mathrm{I} \mathrm{gm.}$ up to those doses which would require 50 or soo c.c. of the present antivenins to neutralize and to prevent death. I conceive, therefore, that injections of specific antivenins are of a great benefit in cases of snake-poisoning. It would be necessary to employ the maximum practicable dose of antivenin in every instance, no matter what quantity of the venom might have been injected by the snake.

In America the future of antivenin therapy of snake bites is of a more optimistic nature. The average fatality from the bite of the more common American venomous snakes is extremely low and the occurrence of the accident is comparatively rare. The collection of venoms is not as difficult as in India, for Crotalus and Ancistrodon yield rather large amounts of venom. At the Rockefeller Institute stronger antivenins for crotalus and moccasin venoms are now being prepared. 


\section{CHAPTER XXV.}

\section{INTERACTIONS BETWEEN VENOM AND ANTIVENIN.}

\section{ESTABLISHMENT OF THE CHEMICAL NATURE OF THE VENOM-ANTIVENIN REACTION.}

The poisonous constituents of snake venom have one of the most important peculiarities of the class of substances known as toxins, namely, they stimulate in the body of susceptible animals the formation of specific anti-bodies when introduced into the latter in sublethal quantities. This was proven by Sewall even before the discovery of Behring and Kitasato of the antitoxin for diphtheria, and fully confirmed and extended by Phisalix, Bertrand, Calmette, Fraser, and many other later investigators. Thus the fact that animals immunized with snake venom acquire a higher resistance to the effects of the same venom, and that this acquired immunity can easily be transmitted to a normal animal through the introduction of the blood serum of the immunized animal, has been proven beyond doubt. But what is the cause of such protection? Is it due to the formation of new substances in the body of the immunized animal, capable of neutralizing the toxic substances of the venom, or is it due to a mere physiological tolerance of the vulnerable cells to the noxious effects of the poison?

Sewall's experiments fail to decide this point, but the work of Calmette and Fraser has already shown that this is not a mere toleration on the part of cells, but is due to the acquisition of a new property by the blood serum perhaps including also certain other body fluids - as the result of artificial immunization, namely, the antivenomous property. In other words, the antitoxin has developed in the immunized animal. Thus the protection afforded by active as well as passive immunities is the work of antitoxin. To this every investigator in this field agrees.

The next question, which has a broader bearing upon the mechanism of antitoxin immunity in general, is whether the counteracting property of antitoxin against toxin is effected directly or indirectly through the cooperation of cellular elements of the animal to be protected.

By the first hypothesis venom is directly acted upon by the antivenin without the aid of vital process of the cells, like an acid upon a base. By the second hypothesis the antitoxin renders the susceptible cells less sensitive to the toxin without attacking the toxin directly. The former is known in immunity as the chemical theory, while the latter view is the cellular or vital theory.

A clear-cut decision on this point has for a long time been almost impossible, as there were no means of separating toxin and antitoxin from the mixture of both, once made outside the body. All toxins and antitoxins lose their activi- 
ties at about the same degree of temperature, both being destroyed somewhere about $75^{\circ} \mathrm{C}$. or even lower. Separation through filtration is equally unavailable, as they appear to have about the same molecular size. Chemical destruction of one or the other has so far been unsuccessful, both being easily inactivated by such treatment. Notwithstanding all these difficulties, Ehrlich, Behring, Kitasato, Madsen, and others have held the chemical theory, while Metchnikoff and Roux and their adherents have maintained the vital theory. It is therefore quite natural that the vital theory has shown a marked tendency to disprove the specific nature of an antitoxin, inasmuch as diverse reagents may eventually produce similar effects upon the cells and raise their resistance to a certain toxin or infectious virus. On the other hand, the chemical theory has been restricted to the phenomena concerning toxins and antitoxins, but not the form-elements like bacterial infection in the narrow sense, and hence to a more strict specificity of the reaction.

To decide the mechanism of toxin-antitoxin reaction Calmette drew the reaction between venom and antivenin into the discussion. Venom offers a great advantage over the more labile toxins for settling this dispute, because its toxic principles are remarkably resistant both to high temperature and to many chemical reagents, by which antivenin is easily destroyed or inactivated. In 1895 Calmette ${ }^{1}$ demonstrated that in the mixture of venom and antivenin the former remains unaffected by the latter and both are present side by side. Mixtures of venom and antivenin were so prepared as to be neutral or harmless for rabbits. Part of the mixture was at once injected into an animal and did no harm. The other portion was heated to $68^{\circ} \mathrm{C}$., by which the antivenomous serum was destroyed by coagulation, then injected into a rabbit, which died. From this experiment it is concluded that the antivenin does not destroy the venom in vitro, as the heat, which affects the serum but not the venom, was able to effect the separation of the two, which it could scarcely have done had the reaction been chemical.

Fraser ${ }^{2}$ then showed that when I.3 c.c. of his antivenin per kilo is mixed in vitro with 5 minimal lethal doses of cobra venom and the mixture allowed to stand 5 to Io minutes, death follows its injection into animals, though when the mixture is allowed to stand 20 minutes or longer the animal recovers. This he thinks proves the chemical nature of the reaction. He denies the probability that leucocytes are active in protecting the venomized body against the poison, being stimulated by the antivenin, and he concludes that the theory of vital stimulation is equally untenable.

Calmette and Délarde ${ }^{3}$ insisted upon the vital process of immunity and refused to accept the chemical explanation. They quote some instances where the antitoxin function does not exist in spite of a high degree of acquired immunity against certain toxins. Certain immune serums exert non-specific

1 Calmette. Contribution à l'étude des venins. Ann. Inst. Pasteur, 1895, IX, 225.

${ }^{2}$ Fraser. The limitation of the antidotal power of antivenene. Brit. Med. Jour., i 896, II, gro.

${ }^{3}$ Calmette and Delarde. Sur les toxins non-microbines et le mécanisme de l'immunité par les sérums antitoxiques. Ann. Inst. Pasteur, 1896, X, 675. 
protection against venom and vice versa. The serums of animals naturally refractory to the toxins rarely possess antitoxic properties against these toxins. They took these facts as in favor of the vital theory.

A little later C. J. Martin and Cherry ${ }^{1}$ demonstrated the chemical nature of the reaction of venom and antivenin by means of filtration. They prepared the mixture of venom and antivenin in neutral proportion and allowed it to stand for a certain time at $37^{\circ} \mathrm{C}$., after which it was filtered through a porcelain bougie covered with gelatin. The filtrate was harmless, showing that the venom, which should have passed through, had been previously destroyed.

The same authors ${ }^{2}$ also showed that if the neutral mixture of venom and antivenin is heated within Io minutes after its mixing the venom is present still undestroyed by the antivenin, as the heated mixture is quite lethal. On the other hand, the toxic action of venom does not reappear if the mixture is heated after 20 minutes or later. These experiments are regarded as conclusive for the chemical nature of the interaction of venom and antivenin, which has lately been accepted by Calmette. ${ }^{3}$

Stephens and Myers ${ }^{4}$ studied the effects of antivenin upon the hæmolytic, anticoagulating, and toxic properties of cobra venom and showed that the neutralization of the first two biological properties of the venom can be effected in vitro, looking upon this phenomenon as conclusively chemical.

\section{REGENERATION OF VENOM AND ANTIVENIN FROM THEIR NEUTRAL COMBINATION.}

In I905 and I906 Morgenroth made some interesting observations concerning the interaction of venom and antivenin. $\mathrm{He}^{5}$ first showed that the neutral mixture of cobra venom and antivenin has no power to enter combination with lecithin to form hæmolytic lecithid, but if a small amount of the normal solution of hydrochloric acid is added to such mixture the lecithid is formed. Then he ${ }^{\boldsymbol{B}}$ demonstráted another important phenomenon. If a small amount of hydrochloric acid is added to the neutral mixture of venom and antivenin, there appears after heating the whole to $100^{\circ} \mathrm{C}$. for 30 minutes, in the heated fluid at least half of the amount of the neurotoxin originally introduced. The failure of total regeneration of the neurotoxin is ascribed by him to the irreparable modification of the toxin molecule under the action of its antitoxin.

In the first instance, hydrochloric acid modified the hæmolytic amboceptor so as to prevent combination with antitoxin, but still permitting union with lecithin. Lecithid, which is formed by subsequent addition of lecithin to the

${ }^{1}$ C. J. Martin and Cherry. The nature of the antagonism between toxins and antitoxins. Brit. Med. Jour., I 898 , II, I I 20.

2 C. J. Martin and Cherry. Proc. Roy. Soc., 1898, LXIII, 420 . C. J. Martin. Relation of the toxin and antitoxin of snake venom. Proc. Roy. Soc., I899, LXIV, 88.

${ }^{3}$ Calmette. Les venins. Paris, $1907,766$.

${ }^{4}$ Stephens and Myers. Test-tube reactions between cobra toxin and its antitoxin. Brit. Med. Jour., I898, II, 627, and also: The action of cobra poison on the blood, a contribution to the study of passive immunity. Jour. of Path. and Bact., 1898, V, 279.

${ }^{5}$ Morgenroth. Ueber die Wiedergewinnung von Toxin aus seiner Antitoxinverbindung. Berl. klin. Woch., I905, XLII, 1550 .

- Morgenroth. Weitere Beiträge z. Kenntnis der Schlangengifte und ihrer Antitoxinen. Arbeiten aus dem patholog. Institut zu Berlin, 1906, 437. 
acidified mixture, does not combine with the antivenin produced with native venom; therefore, Morgenroth has succeeded in regaining the antivenin out of the mixture of venom and antivenin once completely neutral.

Calmette and Massol ${ }^{1}$ next studied the question of the regeneration of venom from the neutral venom-antivenin mixture, not only by the method of Morgenroth, but also by using alcohols. Their investigations on this subject are very instructive and throw much light on the nature of the interaction of venom and antivenin. The principal facts obtained by them may be briefly summarized in the following:

(I) The atoxic compound of cobra venom and its antivenin has entirely different properties from those of its components.

(2) The toxic substance of cobra venom is soluble in liquids containing 50 to 80 per cent alcohol. On the other hand, in the presence of antivenin, the venom begins to become insoluble in 50 per cent alcohol and is almost completely insoluble in 64 per cent. The antivenin by itself is insoluble in alcohol, and after a short time of contact is destroyed by this reagent.

(3) The antivenin, in the presence of venom, ceases to be destroyed by ethyl alcohol, even in 80 per cent concentration, and remains active in the presence of this reagent. The same holds good for other precipitants, such as methyl alcohol, propylic alcohol, acetic ether, and acetone. The sulphates of ammonia and magnesium precipitate the venom-antivenin compound without dissociating the two.

(4) The toxic substance of cobra venom is not coagulated by heating it to $76^{\circ}$ to $80^{\circ} \mathrm{C}$.

(5) The antivenin is destroyed by the temperature of $68^{\circ} \mathrm{C}$. But when mixed with venom it becomes thermostabile up to $75^{\circ} \mathrm{C}$. At this temperature (at least the serum which they studied) the atoxic compound of venom plus antivenin is partially dissociated, and the venom accordingly goes in solution. That which remains in combination is insoluble. This phenomenon occurs as well at $80^{\circ} \mathrm{C}$.

(6) In the presence of the majority of the mineral or organic acids (of which sulphuric, formic, oxalic, acetic, butyric, succinic, tartaric, citric, maleic, lactic, and boric acids have been tested), and under the influence of the temperature of $72^{\circ} \mathrm{C}$., the antivenin composing the atoxic compound venom and antivenin regains its thermolability and the venom is set free. The venom is not destroyed by antivenin and it can be recovered almost completely by this treatment. Boric, succinic, and butyric acids are ineffective.

(7) In the presence of 50 per cent ethyl alcohol and free mineral or organic acids, the atoxic compound of venom and antivenin can be dissociated at the laboratory temperature. The antivenin, after 1o to 15 minutes, is so little modified that, at least in part, it can reconstitute the original atoxic compound of venom and antivenin. The venom is not destroyed by the antivenin and one can recover it almost all quantitatively. Thus the atoxic

1 Calmette and Massol. Relations entre le venin de cobra et son antitoxine. Ann. Inst. Pasteur, 1907, XXI, 929. 
compound of serum and venom possesses entirely different properties from those of its components.

The theory of dissociable combination of toxin and antitoxin must therefore be admitted.

Teruuchi ${ }^{1}$ studied the effects of pancreatic digestion upon the neutral compound of cobra venom and antivenin. For the test reaction he used the hæmolytic action in the presence of an adequate quantity of lecithin as activator. He first found that the hæmolytic power of the venom and the antihæmolytic power of the antivenin are largely destroyed by the pancreatic ferment, but the activating property of lecithin and the hæmolytic power of lecithid are not at all affected.

Then he prepared a neutral mixture of venom and antivenin, which, after 2 hours at room temperature, and 48 hours further on ice, was subjected to the digestion. The result showed that about one-tenth of the original hæmolytic strength was recovered through the digestion, the liberated amount being somewhat larger than one would expect from the digestion of pure solution of venom under the same conditions. This may be due to the fact that the serum proteins of antivenin have been attacked more readily than cobra venom and the destructive action of the ferment on the latter is somewhat restrained.

The restitution of hæmolytic principle by the pancreatic digestion of the neutral mixture of venom and antivenin did not take place when lecithin had previously been added to the mixture and allowed to stand 48 hours on ice.

\section{THE EHRLICH-MADSEN PARTIAL SATURATION PHENOMENON IN VENOM-ANTIVENIN REACTION.}

Strictly quantitative experiments aiming at gaining a more profound insight into the mode of interaction between snake venom and its antivenin were first made by Walter Myers. He employed the partial saturation method of Ehrlich and Madsen, originally introduced for the study of the constitution of diphtheria toxin and tetanolysin. Myers used the hæmolytic power of cobra venom as the test-reaction. The mixtures of venom and antivenin were allowed to stand at laboratory temperature for 2 hours before testing their action on blood. In order to neutralize $0.00 \mathrm{I} \mathrm{gm}$. of this venom for hæmolysis I.3 c.c. of antivenin were required. The results obtained from the partial neutralization showed that when one-thirteenth of the serum is necessary to neutralize the cobralysin, the minimal hæmolyzing dose rises from $0.000005 \mathrm{gm}$. to $0.000025 \mathrm{gm}$., a quantity 5 times as great. The venom, in other words, has lost four-fifths of its toxic action. On adding 0.2 c.c. of serum or two-thirteenths of the serum necessary for complete neutralization the minimal hæmolyzing dose rises to $0.00005 \mathrm{gm}$., or nine-tenths of its hæmolytic power has disappeared.

\footnotetext{
1 Teruuchi. Die Wirkung des Pankreassaftes auf das Hämolysin des Cobragiftes und seine Verbindungen mit dem Antitoxin und Lecithin. Hoppe-Seyler's Zeitschrift f. Physiol. Chemie, I 907 , LI, 478.
} 
The rise of the minimal hæmolyzing doses through the fractions of the serum necessary for complete neutralization was as follows:

TABLE 27.

$0.001 \mathrm{gm}$. venom alone $\ldots \ldots \ldots \ldots \ldots .0 .000005 \mathrm{gm}$.

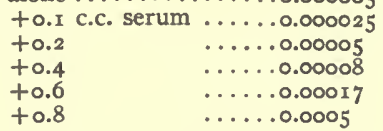

In another way the above results can be summarized as follows:

○.00I gm. of venom contains $10,000 \div 5=2,000$ minimal hæmolyzing doses. With o.I c.c. of serum necessary for a complete neutralization it now contains $10,000 \div 25=400$ minimal hæmolyzing doseș. If we arbitrarily call the number of combining equivalents in $0.00 \mathrm{I}$ gm. of venom $\mathbf{I} 30$, the above fraction neutralized I,600 minimal hæmolyzing doses per ro equivalents. On the theory of simple neutralization we should have neutralized $2,000 \div \mathrm{I} 3=$ I 53 minimal hæmolyzing doses. Myers gives the following calculations:

TABLE 28.

\begin{tabular}{|c|c|c|c|c|}
\hline & $\begin{array}{l}\text { M. h. d. still } \\
\text { left. }\end{array}$ & Difference. & $\begin{array}{l}\text { Combining } \\
\text { equivalents. }\end{array}$ & $\begin{array}{l}\text { M. h. d. removed } \\
\text { by I equivalent. }\end{array}$ \\
\hline Venom alone & 2000 & & & \\
\hline $\begin{array}{l}\text { +o.I c.c. serum. } \\
+0.2\end{array}$ & 400. & $\begin{array}{r}1600 \\
200\end{array}$ & $\begin{array}{l}\text { 10 } \\
\text { 10 }\end{array}$ & $\begin{array}{r}160 \\
20\end{array}$ \\
\hline+0.4 & 125 & 75 & 20 & 3.75 \\
\hline $\begin{array}{l}+0.6 \\
+0.8\end{array}$ & $5^{88.8}$ & $\begin{array}{l}66.2 \\
38.8\end{array}$ & 20 & $3 \cdot 3$ \\
\hline & & & 20 & \\
\hline
\end{tabular}

It will be seen at once that the interaction of the cobralysin and its antilysin is very different from that of a single neutralization, say of a strong acid by a strong base. If we explain this reaction according to the toxoid theory of Ehrlich, as was done by Myers, the results may be represented as in figure I.

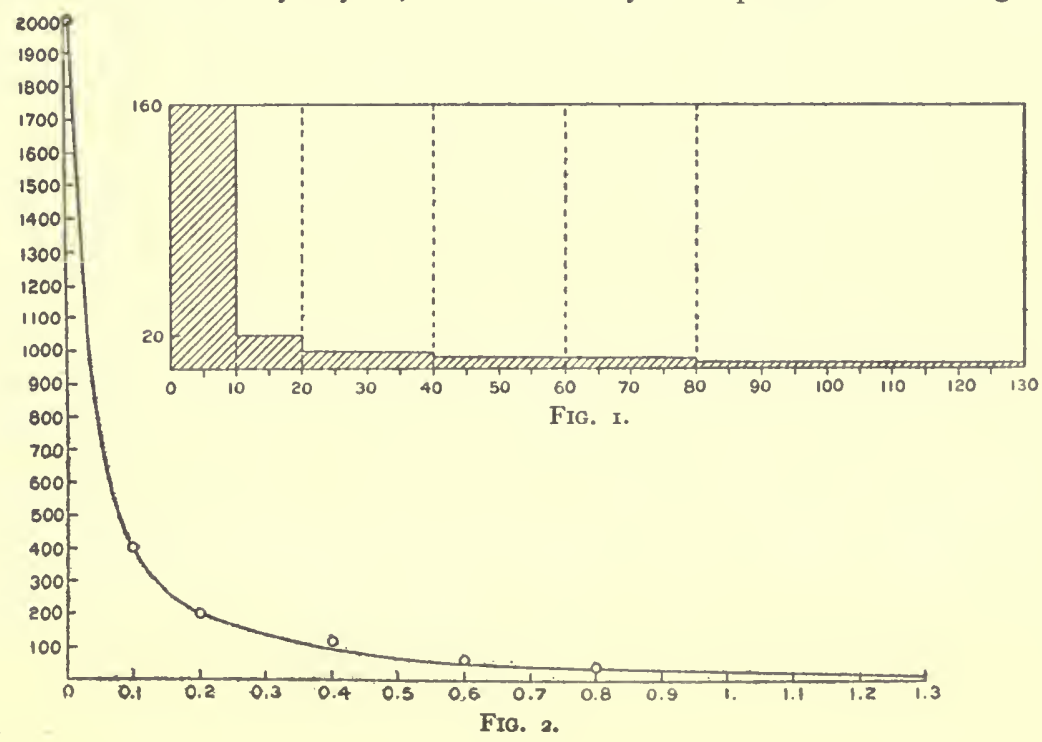


But if we interpret the results according to the physico-chemical theory of Arrhenius and Madsen the graphic expression will be somewhat different (fig. 2).

With another sample of cobra venom Myers obtained somewhat different results from the first sample. $0.00 \mathrm{Igm}$. of this venom contained $10,000 \div 7$ $=\mathrm{r}, 428$ minimal hæmolyzing doses and was neutralized by 0.7 c.c. of the antivenin. His results were as shown in table 29 and figures 3 and 4 .

TABLE 29.

\begin{tabular}{|c|c|c|c|c|}
\hline & $\begin{array}{l}\text { M. h. d. still } \\
\text { present. }\end{array}$ & Difference. & $\begin{array}{l}\text { Combining } \\
\text { equivalents. }\end{array}$ & $\begin{array}{l}\text { M. h. d. removed } \\
\text { by I equivalent. }\end{array}$ \\
\hline Venom alone & 1428 & & & \\
\hline + 0.05 c.c. serum & 1000 & 428 & I0 & 85.6 \\
\hline$+0 . I^{2}$ & $333 \cdot 3$ & 666 & Io & 33 \\
\hline+0.2 & 166.6 & I66 & 20 & I6 \\
\hline+0.4 & 40 & I 26 & 40 & 6 \\
\hline
\end{tabular}

Figures $\mathrm{I}$ and 3 are presented by Myers as directly showing the constitution of the venoms employed in his experiments. Theoretically the first venom contained a very large amount of toxoids of an equal or a weaker affinity to antitoxin than the toxin itself; hence the neutralization of the toxin was first to be effected, leaving, however, a comparatively small number of hæmolytic units unneutralized, or only slowly neutralized, for the subsequent Io fractions out of the entire $\mathrm{I}_{3}$ of the serum. This is assumed to be due either to the interference with the neutralization of the lysin by the presence of an overwhelming quantity of toxoids or to the presence of small quantities of toxins of weaker affinities (syntoxin and epitoxin). Should we have to accept this explanation, a most remarkable fact about the antitoxin develops, namely, the antitoxin has to neutralize many times more toxoids than the toxin itself before the mixture is made neutral, or, at least, harmless.

Take the above experiments. We have seen that the first one-thirteenth of the serum neutralized I,600 minimal hæmolyzing doses, and that this neutralization was visible through the reaction of hæmolysis. The second one-thirteenth has neutralized 200 minimal hæmolyzing doses, and the third 75 minimal hæmolyzing doses, etc. If we assume that each fraction can neutralize $\mathrm{I}, 600$ of haptophore groups either in the form of toxin or in the form of toxoids, I. 3 c.c. of the antivenin must have neutralized at least $\mathrm{I}_{3}$ times that much, namely, I,600 $\times \mathrm{I}_{3}=20,800$ haptins, before rendering $0.00 \mathrm{I} \mathrm{gm}$. of the venom neutral. Analyzing this number, it becomes evident that r.3 c.c. of serum neutralized 2,000 lytic haptins and r8,800 non-lytic haptins (toxoids), the latter being 9.4 times more than the former.

With the second venom we have similar facts, except that there were present in that sample 17,192 non-lytic haptins against $\mathrm{I}, 428$ lytic haptin units. Of the non-lytic haptin units 47.4 were of prototoxoid and entered combination with the first fraction of antitoxin along with the toxin. 
Again, a remark may be made here as to the anti-haptin units contained in the antivenin employed in the above two experiments. In the first experiment I.3 c.c. of antivenin neutralized about 20,800 units, making I 60 per 0.1 c.c., while in the second 0.7 c.c. neutralized I8,620 units, making 266 per o.I c.c. of the serum. As these estimates are made with invisible factors (toxoids) we are at a loss how to fix the cause of this difference. If we assume that in the first venom there was also toxoid, although not shown in the spectrum, of an affinity equal to the toxin it would be easy to account for this difference. In this case we must assume that the amount of uncalculated toxoids was the difference.
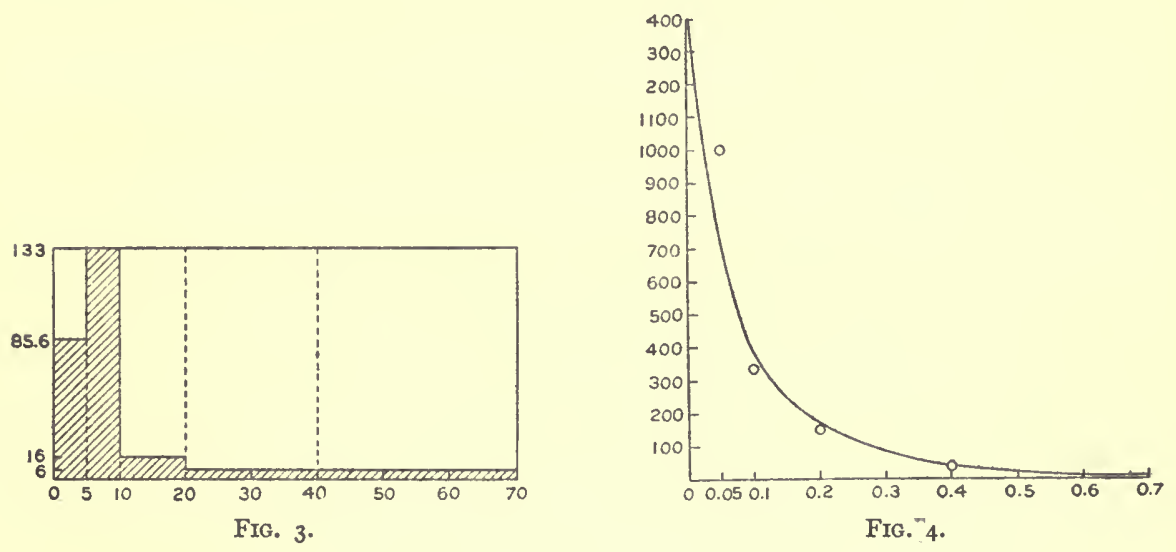

If we exclude toxoids from the reaction between venom and antivenin, we can make a direct comparison of the neutralized hæmolyzing units per o.I c.c. of antitoxin in both series. In the first series o.I c.c. neutralized $2,000 \div \mathrm{I} 3=$ I 53 minimal hæmolyzing doses, and in the second $\mathrm{I}, 428 \div 7=204$ minimal hæmolyzing doses. This shows that the antitoxin used in the second series had about I.5 times more strength than that in the first. The comparison made in the other way, namely, including toxoids, shows also about the same ratio, as in the second series the serum was I.4 times stronger. It is not improbable that the antivenins employed in these two series were not of the same strength.

Myers then proceeded to examine whether or not the deteriorated solutions of cobra venom have lost their hæmolytic as well as their combining powers. The venom solutions were of 0.2 per cent and were made in an 0.8 per cent salt solution. One of the most striking facts brought out by him is that when the venom solution of the said strength was kept at $35^{\circ} \mathrm{C}$. for 6 hours its strength dropped from 2,000 to 333 , in 12 hours from 2,000 to 250 minimal hæmolyzing doses per milligram. On the other hand, their combining property for antivenin remained practically unaltered. If there was any diminution in this power it was only trifling. 
Table 30 and figures 5 and 6 show one of Myers's experiments with the same venom used in the first series, but kept at $35^{\circ} \mathrm{C}$. for I 2 hours.

TABLE 30.

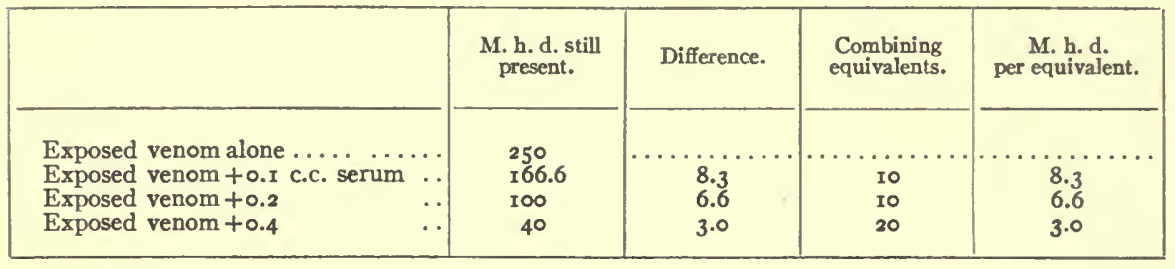

While inclining very markedly to the toxoid theory of Ehrlich, Myers has, nevertheless, pointed out the possible reversibility of the reaction between toxin and antitoxin.

fi: Somewhat later the relation between the toxic and hæmolytic powers and the corresponding antitoxins of cobra venom was investigated by Flexner
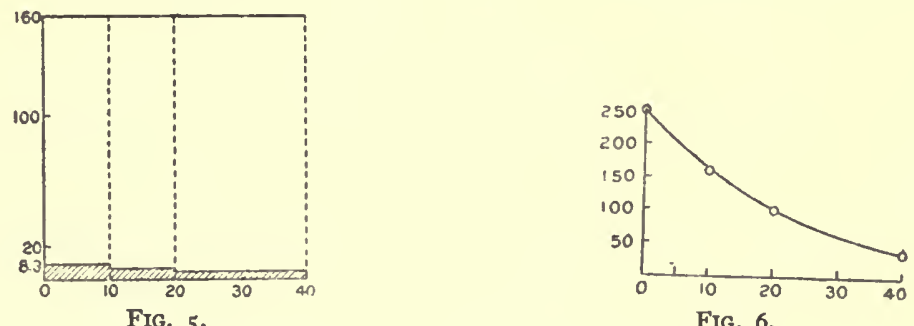

FIg. 6.

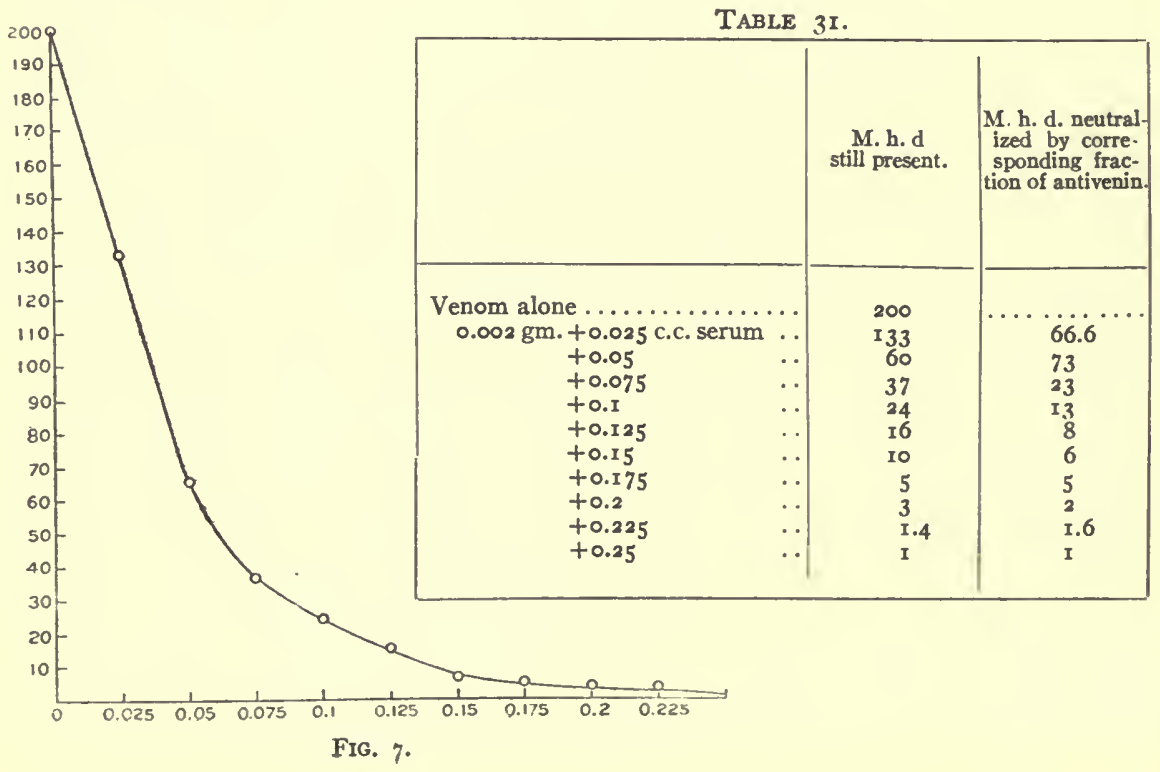


and Noguchi, ${ }^{1}$ who confirmed the results obtained by Myers with cobralysin and then extended this sort of observation to the neurotoxin of the same venom. The cobra venom which they worked with contained I,00o minimal hæmolyzing doses in $0.001 \mathrm{gm}$. for the test volume of defibrinated guinea-pig or dog's blood ( $\mathrm{I}$ c.c. of 5 per cent suspension in 0.85 per cent $\mathrm{NaCl}$ ). The antivenin was that of Calmette. First the fresh solution of venom was neutralized with antivenin. $0.002 \mathrm{gm}$. were completely neutralized by 2.25 c.c. of the serum. By partial neutralization the results shown in table $3 \mathrm{I}$ and figure 7 were obtained.

They then subjected the venom solution to the influences of room temperature and of $37^{\circ} \mathrm{C}$. for a period of I9 days, under aseptic conditions. These solutions showed very marked diminution in their hæmolytic action. The neutralization with antivenin gave the results shown in table $3^{2}$ and figure 8.

TABLE 32.

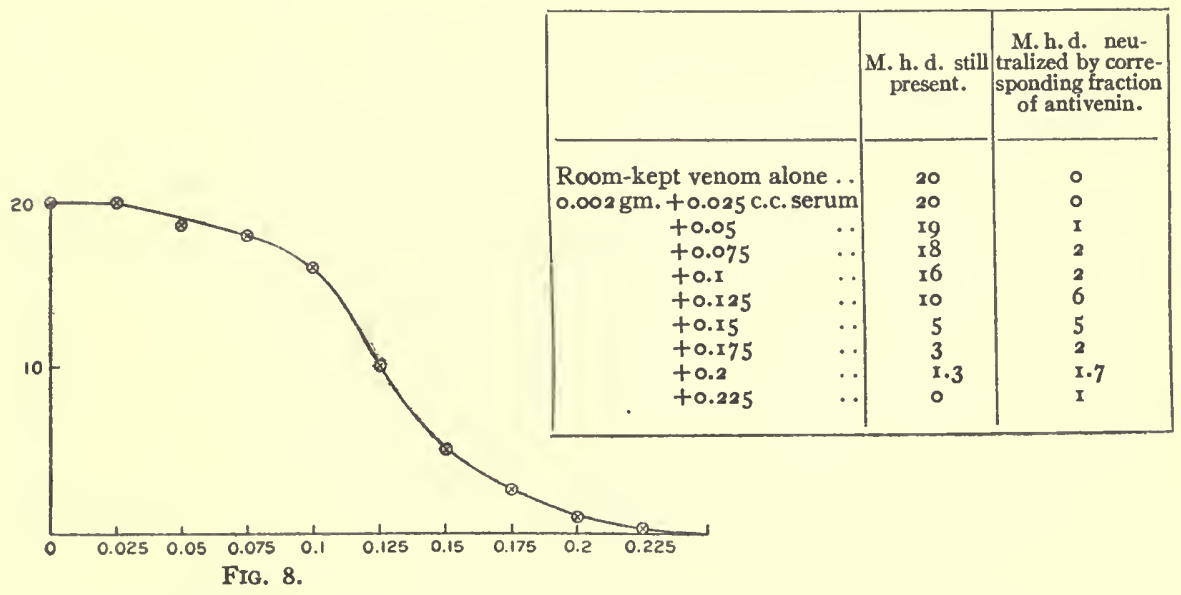

The neutralization of the venom solution kept at $37^{\circ} \mathrm{C}$. for I9 days showed the results given in table 33 and figure 9.

TABLE 33 .

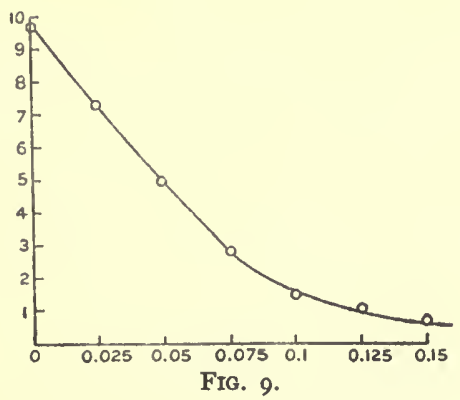

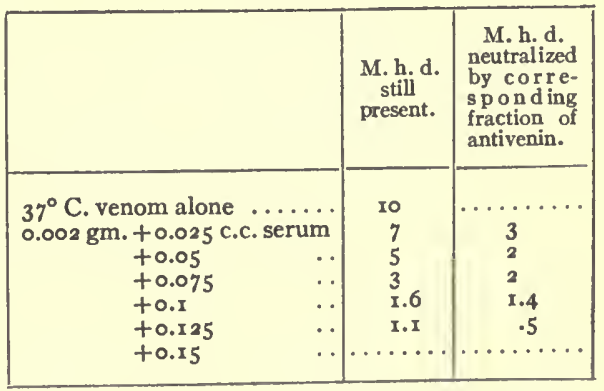

1 Flexner and Noguchi. Constitution of snake venom and snake sera. Jour. of Path. and Bacteriol., I903, VIII, 279. 
Following the above experiments Flexner and Noguchi proceeded to determine whether or not the reduction in toxicity of cobra venom through deterioration in fluid is accompanied by a reduction in its antivenin-combining power. The sterile venom solution was kept for I9 days at room and thermostat temperature, as in the foregoing experiments. They found that the solution in the fresh state was able to kill a guinea-pig of about $300 \mathrm{gm}$. by $0.000 \mathrm{I} \mathrm{gm}$. of venom. $0.0004 \mathrm{gm}$. of the venom became non-lethal when injected into the guinea-pig after being mixed with 0.4 to 0.5 c.c. outside the body.

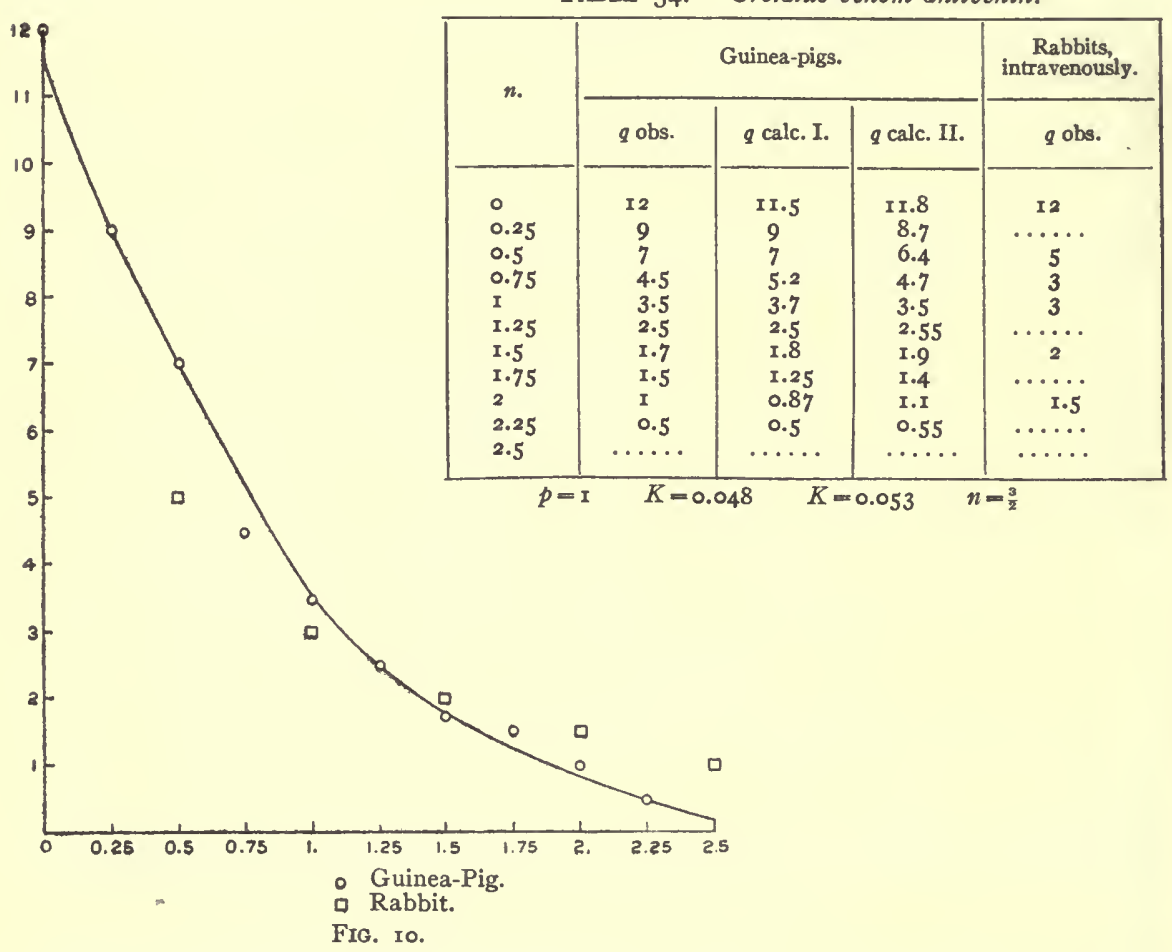

The same venom solution, after standing at room temperature for 9 days, became so weakened that $0.0004 \mathrm{gm}$. (instead of $0.000 \mathrm{Igm}$. of the original) was required to kill a guinea-pig of the same weight. To neutralize $0.004 \mathrm{gm}$. of this solution (weight being expressed in calculating back to the dried venom), namely, I minimal lethal dose, 0.3 c.c. of the antivenin was necessary.

The deterioration of toxicity was much greater at $37^{\circ} \mathrm{C}$. kept I9 days and it was found to require $0.00 \mathrm{I} \mathrm{gm}$. to kill the same test animal. Thus the reduction was from Io minimal lethal doses to I minimal lethal dose per milligram. For complete neutralization of $0.004 \mathrm{gm} .=4$ minimal lethal doses of this modified venom 0.8 c.c. of antivenin were necessary.

The two experiments outlined above demonstrate that the deterioration of cobra venom neurotoxin with age and higher (even at $20^{\circ} \mathrm{C}$.) temperature is 
much more marked than the combining property of the venom, although both undergo certain inactive modifications.

In 1903-04 Madsen and Noguchi carried out a large series of experiments on the partial-neutralization phenomenon of different venoms and their specific antivenins, with specific reference to the hæmolysis and toxicity.

\section{CROTALUS-VENOM ANTIVENIN.}

Guinea-pigs were used as test animals; the mixtures were injected intraperitoneally. The venom had the toxicity of $0.0005 \mathrm{gm}$. = I minimal lethal dose for guinea-pigs (weight 300 grams) given intraperitoneally. $0.006 \mathrm{gm}$. was the amount of venom used for the experiment; 2.25 c.c. of the antivenin (specific) made this amount non-lethal. 'Two hours' standing at $37^{\circ} \mathrm{C}$. was always allowed to the mixtures before injection into the animals. The results are given in table 34 . Under $n$ are indicated the quantities

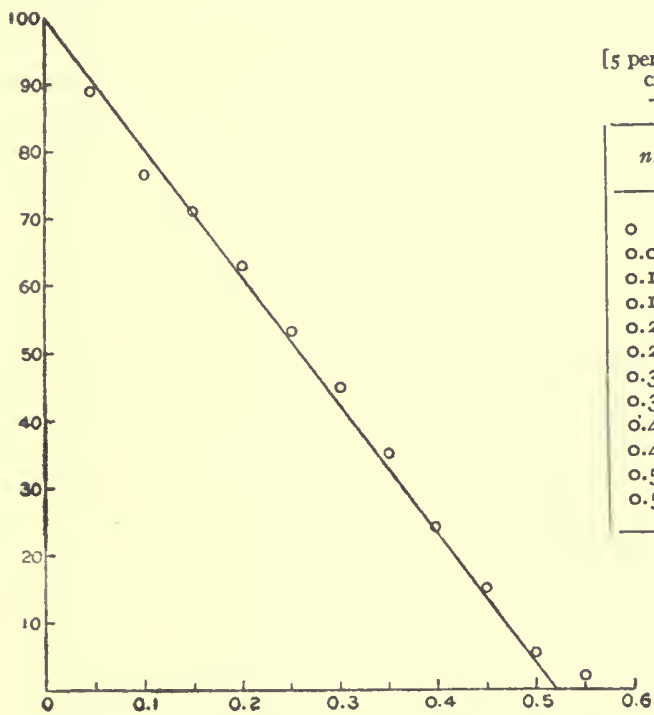

Frg. rr. - Crotalolysin antilysin. Dog's blood.

TABLE 35 .

5 per cent suspension of dog's blood; $x$ c.c. of 0.05 per cent crotalus venom solution $+n$ c.c. of crotalusa antivenin $+\mathrm{I}-n$ c.c. 0.9 per cent $\mathrm{NaCl}$ solution.]

\begin{tabular}{|c|c|c|c|c|c|}
\hline$n$. & I. & II. & III. & $q$ obs. & $q$ calc. \\
\hline 0 & 0.02 & 0.016 & 0.006 & 100 & roo \\
\hline 0.05 & 0.023 & 0.018 & 0.0065 & 89 & 90.5 \\
\hline 0.1 & 0.026 & 0.02 & 0.0078 & 77.4 & 81 \\
\hline 0.15 & 0.028 & 0.023 & 0.0085 & 70.6 & 72 \\
\hline 0.2 & 0.03 & 0.025 & 0.01 & 63.5 & 62.5 \\
\hline 0.25 & 0.033 & 0.029 & 0.0125 & 54.4 & 53 \\
\hline 0.3 & $0.03^{85}$ & 0.035 & 0.015 & 45.9 & 44 \\
\hline 0.35 & 0.052 & 0.043 & 0.019 & 35.8 & 34.5 \\
\hline 0.4 & 0.078 & 0.065 & 0.026 & 24.4 & 25 \\
\hline 0.45 & 0.11 & 0.098 & 0.047 & 15.8 & 16 \\
\hline 0.5 & 0.275 & 0.24 & 0.12 & 6.8 & 6.5 \\
\hline 0.55 & $1.5^{\circ}$ & I.I 5 & 0.35 & 1.5 & ○ \\
\hline
\end{tabular}

of antivenin added to a constant dose of venom, $0.006 \mathrm{gm}$., and under " $q$ observed," the observed toxicity. These observed values, after allowing for errors in experiment, can be expressed by the same formula which represents the combinations of toxins and antitoxins of other substances.

$$
\frac{\text { Free toxin }}{\text { volume }} \cdot \frac{\text { Free antitoxin }}{\text { volume }}=K \text {. Toxin-antitoxin }
$$

In this case:

$$
\frac{\mathrm{I}}{q_{0}}\left[n-\frac{\mathrm{I}}{q} \cdot p-\left(\frac{\mathrm{I}}{q}-\frac{\mathrm{I}}{q_{0}}\right)\right]=K\left(\frac{\mathrm{I}}{q}-\frac{\mathrm{I}}{q_{0}}\right)^{\frac{3}{2}}
$$
$\frac{I}{q}$ represents the quantity of antitoxin equivalent to an amount of toxin used, and $K$ the constant of dissociation. 
With $p=\mathrm{I}$ and $K=0.048 \mathrm{gm}$., they found the value of $q$, shown under " $q$ calc. I." Figure Io shows the results graphically. The tracing is the calculated values of " $q$," while the circle shows the observed values. It will be noted, therefore, that the values derived from the experiments mentioned above can be expressed according to the simple formula

$$
-\frac{d q}{d n}=K q
$$

With rabbits and a constant dose of venom, $0.006 \mathrm{gm}$., they obtained the results shown in the last column of table 34 .

The neutralization of the hæmolytic component of crotalus venom by its specific antitoxin gave the results (in grams) shown in table 35 and figure II.

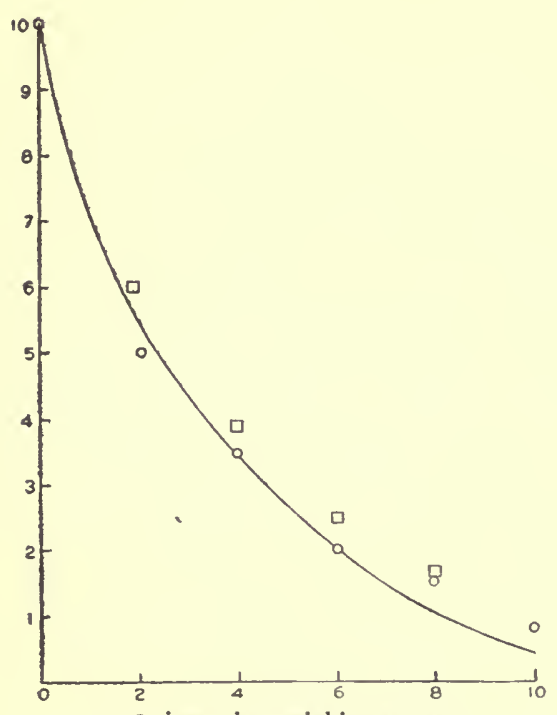

- Quinea-pigs weighing $450 \mathrm{gm}$.

D. Guinea-pigs:weighing $370 \mathrm{gm}$.

FIG. 12. - Intraperitoneal injection.

\begin{tabular}{|c|c|c|}
\hline$n$. & q. & g. \\
\hline ० & Io & II \\
\hline I & ....... & 7 \\
\hline 2 & 5 & 4 \\
\hline 3 & $\ldots \ldots$ & 1.5 \\
\hline $\begin{array}{l}4 \\
6\end{array}$ & $\begin{array}{l}3.5 \\
2\end{array}$ & $\begin{array}{l}\mathrm{I} \\
\ldots\end{array}$ \\
\hline 8 & 1.7 & $\ldots$. \\
\hline 10 & I & \\
\hline
\end{tabular}

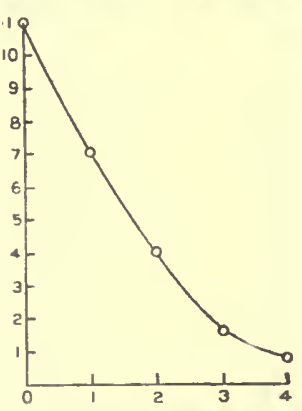

FIG. I3. - Guinea-pigs weighing $250^{\circ}-1 \mathrm{gm}$. Subcutaneous injection.

\section{COBRA-VENOM ANTIVENIN.}

$0.0005 \mathrm{gm}$. of this venom was I minimal lethal dose for guinea-pigs of about $500 \mathrm{gm}$. The antivenin used for this purpose was very weak and took about Io c.c. to neutralize $0.003 \mathrm{gm}$. of the venom. To $0.0028 \mathrm{gm}$. of the venom were added the amounts of antivenin indicated under $n$. The mixtures were, as usual, incubated for 2 hours at $36^{\circ} \mathrm{C}$.; then the fractions of each mixture were injected intraperitoneally into guinea-pigs. Two series were undertaken with this antivenin, one with guinea-pigs of 370 and the other with those of 450 grams. The second series gave the estimate recorded in the first column $q_{0}$ of table 36 . 
With another preparation of Calmette antivenin, much more powerful, and 4 c.c. of which neutralized $0.003 \mathrm{gm}$. of the venom, the results shown in the third column of table 36 were obtained.

Figure I2 shows the results of experiments with the first antivenin and Figure $I_{3}$ those of the second antivenin.

The results of partial neutralization of cobra hæmolysin by the antivenin are as follows: For the test 8 c.c. of I per cent suspension of washed horse corpuscles (each liter containing 8 c.c. of o.or $n$ lecithin) in each tube were used. The test dose of venom was I c.c. of o.I per cent cobra venom. Two preparations of antivenin were used (table 37 and fig. 14).

TABLE 37.

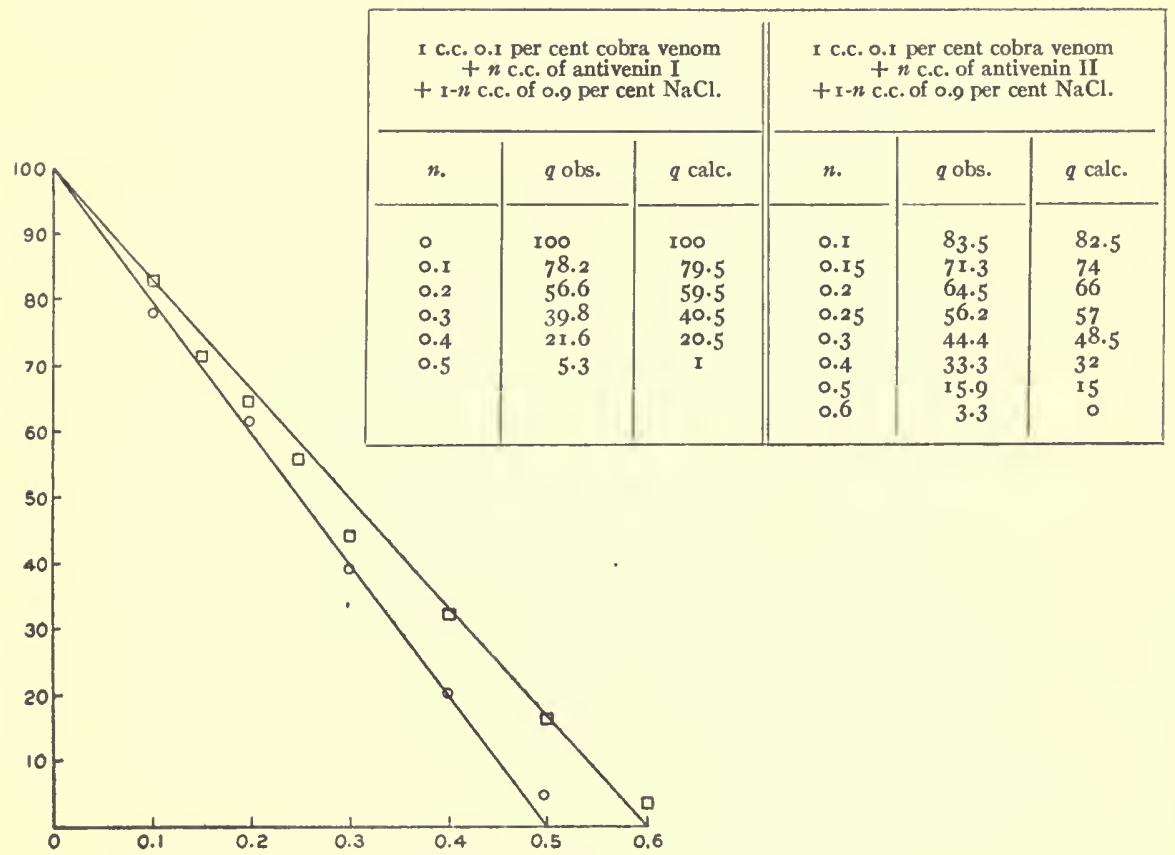

- Neutralization with antivenin I.

Neutralization with antivenin II.

FrG. r4. - Cobralysin antilysin. Horse blood with lecithin.

WATER-MOCCASIN-VENOM ANTIVENIN.

With this venom the partial neutralization with its specific antivenin gave a singular result. When 2 c.c. of the antivenin were added to to minimal lethal doses of the venom (0.012 gm.) the mixture contained about 6 minimal lethal doses, but with 8 , Iо, 20, and 40 c.c. there was no complete neutralization. Madsen and Noguchi left this phenomenon to a later investigation, not having enough material for further work at that time.

The neutralization of the hæmolytic component of water-moccasin venom with the specific antivenin gave the following results: 8 c.c. 5 per cent suspension of dog blood in 0.9 per cent $\mathrm{NaCl}$ were used for the test reaction. 
" $q$ calc." were calculated on the hypothesis that $\mathrm{I}$ c.c. of antivenin is equivalent to I.2 c.c. of the venom solution and that $K=0$. In this case the deviation of the calculated values with the increase of antivenin is much greater than in the cases of crotalus and cobralysins.

From these observations Madsen and Noguchi point out that the neutralization of the toxic principles of cobra, moccasin, and crotalus venoms by their specific antivenin shows analogy with the results obtained by Madsen, Arrhenius, and Walbum with many other toxins and antitoxins, and can be interpreted according to the view held by Arrhenius and Madsen. With the hæmolytic components of these venoms the neutralization shows almost a straight line and there is only slight dissociation.

The results obtained by $\mathrm{Kyes}^{1}$ regarding the neutralization of cobralysin by antilysin show also that the reaction between these two bodies is very strong and gives a straight line. Criticizing the results obtained by Myers and by Flexner and Noguchi, who found a marked curve indicative either of

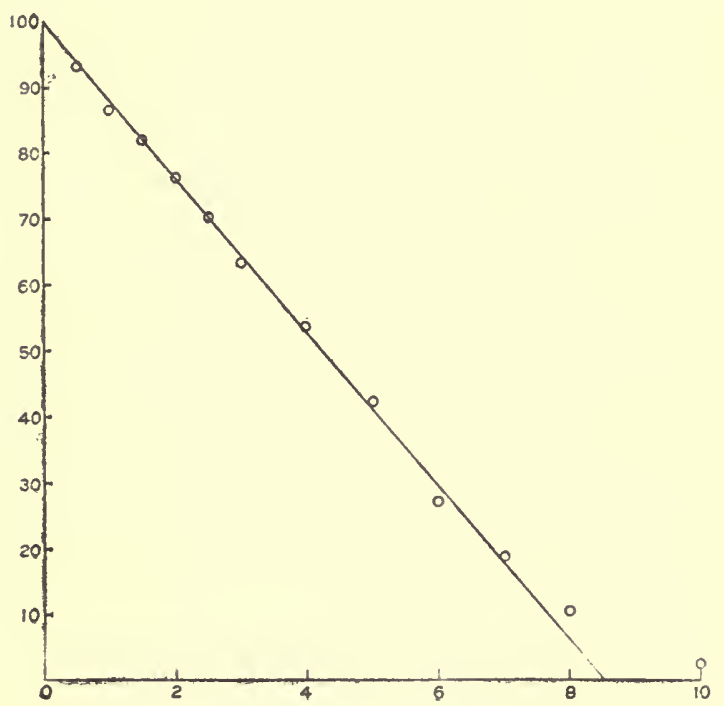

TABLE 38.

I c.c. 0.05 per cent solution of moccasin venom $+n$ c.c. of antivenin $+I-n$ c.c. of I per cent $\mathrm{NaCl}$ solution.

FIG. I 5. - Ancistrodonolysin-antilysin. Dog's blood.

\begin{tabular}{|l|c|r|}
\hline \multicolumn{1}{|c|}{$n}$. & $q$ obs. & $q$ calc. \\
\cline { 1 - 3 } 0 & & \\
0.05 & I00 & I00 \\
0.1 & 93 & 94 \\
0.15 & 87 & 88 \\
0.2 & 82 & 82 \\
0.25 & 77 & 76 \\
0.3 & 70 & 70 \\
0.4 & 63 & 64 \\
0.5 & 53 & 52 \\
0.6 & 42 & 40 \\
0.7 & 26 & 28 \\
0.8 & 17 & 16 \\
I & 10.5 & 4 \\
& 2 & 0 \\
\hline
\end{tabular}

the presence of toxoids in Ehrlich's sense or of the strong dissociation in Arrhenius and Madsen, Kyes points out the importance of the presence of sufficient amount of activators (lecithin) in order to obtain the real expression of the reaction. With a defective supply of venom activator it would be natural to obtain a false result. Kyes proves his claim by a very interesting series of experiments in which the amount of activator was used in variable proportions. In the case of sufficient supply of activator he obtained a straight, and in the defective supply of activator a curved, neutralization line.

${ }^{1}$ Kyes. Cobragift und Antitoxin. Berl. klin. Woch., I904, XLI, 494. 


\section{CHAPTER XXVI.}

\section{PRECIPITIN-REACTION WITH SNAKE VENOM.}

That a comparatively specific precipitating substance is developed in the serum of animals through repeated injections of the serums of alien species or various other proteid substances was first shown by Bordet and then carefully worked out in detail by Nuttall, Uhlenhuth, Wassermann and Schütze, Myers, Linossier and Lemoine, and others. The precipitation reaction has been shown to be highly specific, but not absolutely so. Besides the specific precipitins for numerous kinds of serums of different species, including human serum, precipitins for such proteids as casein of milk, the albumins occurring pathologically in the urine, crystallized egg albumin, pure serum globulin from sheep and from bullock, Witte's peptone, and muscle have also been produced by various investigators.

Nuttall observed that the reaction is more intense when the host animal and the animal furnishing the serum for injection are widely distant. Myers found that precipitin prepared with egg albumin does not precipitate other proteids, such as the serum globulins obtained from the sheep or bullock, and Witte's peptone. Uhlenhuth and Wassermann and Schütze have worked out the specific nature of the precipitin for human blood and applied this reaction to identify the source of a given unknown blood for the medicolegal purpose. Quite recently this reaction has been recommended by Wassermann to detect the adulteration of sausages with certain meats legally prohibited from sale as human diet. According to Noguchi precipitins can be produced even in certain invertebrate animals, such as crustacea.

In 1902 Lamb $^{1}$ first studied the precipitin formation with snake venom and employed this reaction to distinguish between the proteids of different snake venoms. He prepared an immune serum in rabbit with pure cobra venom and obtained a markedly precipitating serum when mixed with the homologous venom (cobra). He tested its precipitating property, 3 or 2 parts of the serum being mixed with I part of venom solution, varying in strength from 0.I per cent to $0.000 \mathrm{I}$ per cent, and observed the amount of precipitate formed after I8 to 24 hours. I per cent venom solution was not suitable for the test, as this concentration produced more or less precipitate even with nornal rabbit serum.

Among the results obtained by Lamb special interest is attached to the facts that daboia venom behaved in almost every respect the same as cobra venom: precipitate was formed practically in the same quantity. Secondly, the heated venom solutions $\left(75^{\circ} \mathrm{C}\right.$. $)$ of these two venoms - heat-coagulated proteids being removed by filtration - gave just as much precipitate as the

1 Lamb. On the precipitin of cobra venom: a mean of distinguishing between the proteids of different snake poisons. Lancet, I902, II, 43 I. 
unheated venom solutions did. Heating of the immune serum to $55^{\circ} \mathrm{C}$. for 30 minutes did not affect its precipitating quality and quantity. The reaction appeared with the dilutions down to $0.00 \mathrm{I}$ per cent, but not with 0.000 I per cent.

The precipitin tests made with the venoms of Bungarus fasciatus, Notechis scutatus, and Echis carinata were all negative, namely, no precipitate was formed with these venoms.

The above experiments of Lamb clearly point out that the proteids of two entirely different snake venoms, both from the physiological and zoological standpoints, can eventually be identical; hence these proteids can have no relation to the real toxic components of these venoms. While a venom of a colubrine snake (cobra) and that of a viperine snake (daboia) may have similar proteids, it does not follow that all viperine venoms are similar in this regard. On the other hand,Lamb found that the venoms of two colubrine snakes (Bungarus fasciatus and Notechis scutatus) did not contain any proteids which could react with the cobra anti-serum. Echis carinata, a viper, also has no corresponding proteids with those existing in the venoms of cobra and daboia.

In a subsequent communication Lamb ${ }^{1}$ extended the precipitin test to various venoms representing practically the entire class of Ophidia. The immune serum used as the precipitin was prepared in rabbit by repeated injections of pure unheated cobra venom. With this cobra anti-serum he obtained the following results:

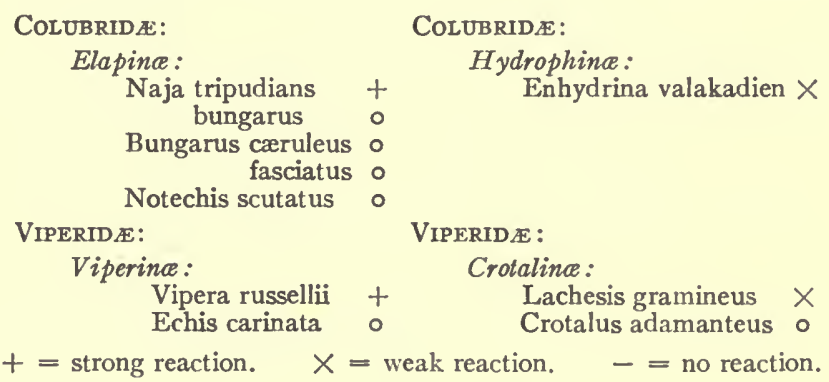

From the foregoing table it becomes evident that the precipitin-reaction bears no relation to the zoological classification of snake, but is of the most irregular nature. Neither does it seem to have any relation to the physiological or toxicological constitution of the snake venom.

Lamb also brought out the fact that the antitoxic value of antivenin has no relation to the precipitin content of the serum. Three antivenins of high strength have been found to possess almost no precipitating property. He sought the reason for this non-occurrence of precipitation in the species of the animals, holding that asses and horses are unsuitable for the precipitin production. 
In the meanwhile, Flexner and Noguchi ${ }^{1}$ were engaged with the study of precipitin formation with different venoms. They made the following statement regarding this particular phenomenon. Precipitins are formed from venom along with or independent of the immunizing principles for venom. There is no relation between the degree of protection afforded by and the amount of precipitin present in the immune serum. Precipitins may arise in treated animals even when the modified venoms are incapable of provoking the production of immunizing substances. Precipitins for different venoms - crotalus, cobra, and daboia - are highly, although not absolutely, specific. Below is a concise statement of their work on the venom precipitins.

TABLE 39 .

\begin{tabular}{|c|c|c|c|c|c|c|}
\hline \multirow{2}{*}{ Antiserum. } & \multirow{2}{*}{ No. } & \multirow{2}{*}{ Animal. } & \multirow{2}{*}{$\begin{array}{c}\text { Degree } \\
\text { of } \\
\text { protectiveness. }\end{array}$} & \multicolumn{3}{|c|}{ Precipitation. } \\
\hline & & & & Crotalus venom. & Cobra venom. & $\begin{array}{l}\text { Daboia } \\
\text { venom. }\end{array}$ \\
\hline $\begin{array}{l}\text { Crotalus } \\
\text { Do. } \\
\text { Do. } \\
\text { Do. } \\
\text { Do. } \\
\text { Do. } \\
\text { Cobra } \\
\text { Daboia }\end{array}$ & $\begin{array}{l}1 \\
2 \\
3 \\
4 \\
5 \\
6 \\
7 \\
8\end{array}$ & $\begin{array}{l}\text { Rabbit } \\
\text { Rabbit } \\
\text { Dog } \\
\text { Rabbit } \\
\text { Rabbit } \\
\text { Rabbit } \\
\text { Rabbit } \\
\text { Rabbit }\end{array}$ & $\begin{array}{l}\text { Feebly } \\
\text { Feebly } \\
\text { Feebly } \\
\text { Strongly } \\
\text { Not at all } \\
\text { Strongly } \\
\text { Not at all } \\
\text { Not at all }\end{array}$ & $\begin{array}{l}\text { Moderate } \\
\text { Copious } \\
\text { Slight } \\
\text { Moderate } \\
\text { Copious } \\
\text { Copious } \\
\text { None } \\
\text { None }\end{array}$ & $\begin{array}{l}\text { None } \\
\text { None } \\
\text { None } \\
\text { None } \\
\text { None } \\
\text { None } \\
\text { Moderate } \\
\text { None }\end{array}$ & $\begin{array}{l}\text { None } \\
\text { None } \\
\text { None } \\
\text { None } \\
\text { None } \\
\text { None } \\
\text { None } \\
\text { Slight }\end{array}$ \\
\hline
\end{tabular}

The immune serums I, 2, 3, 4 were prepared with the venom modified with weak hydrochloric acid; 5 with hydrochloric acid and pepsin; $6,7,8$ with weak solution of trichloride of iodine. The test was made in testtubes, each containing 0.5 c.c. of the immune serum and 0.5 c.c. of 0.5 per cent venom solution.

Ishizaka ${ }^{2}$ found that while the pure antivenin of Lachesis flavoviridis produces a copious precipitate with that venom, it produces only a slight precipitate or none at all with the venom of viper.

\footnotetext{
1 Flexner and Noguchi. Production and properties of anticrotalus venin. Jour. of Med. Research, r904, n. S., VI, 363 .

2 Ishizaka. Studien über Habuschlangengift. Zeitschr. f. exper. Path. u. Therapie, 1907, IV, 88.
} 


\section{CHAPTER XXVII.}

\section{NATURAL IMMUNITY. \\ EFFECTS OF VENOM UPON SNAKES.}

The experimental data bearing on this question are more or less conflicting, but one fact has been established beyond any doubt, namely, that venomous snakes are not absolutely immune to the action of their own and alien venoms, though their susceptibility - subject to more or less fluctuation - is far less than that of the majority of innocuous snakes and saurians. The determinations of the effects of venom were carried out in two ways: one allowing the snake to bite either itself or other snakes; the other (which is more accurate and reliable) injecting the venom into the subject on which its effects were to be tested.

Fontan ${ }^{1}$ in his biting experiments failed to produce death on vipers by the bite of the same species. Claude Bernard ${ }^{2}$ has, however, found that vipers succumb to the bite of vipers within 3 days.

In I86I Weir Mitchell made a series of experiments as to the effect of crotalus bite on the same species. His experiments are somewhat unique in their arrangement, as he tested the action of this venom upon the same snake from which it was taken, or by letting a snake bite itself at a spot denuded of its skin. In the biting method he obtained 3 positive results out of 4 experiments. In two of these cases death occurred in ro days, and in another it took place in I4 days. By the injection method all three rattlers succumbed to their own venom. The first, receiving Io drops of its fresh venom, died in 36 hours; the second, receiving 8 drops, died in 67 hours; the last was killed in 7 days with 7 drops of its venom injected. The autopsies showed softening of the sites of the bite or injection, but not much alteration could be observed in the internal organs. Mitchell quotes the self-biting experiments made by Burnett on Crotalus, in which death usually followed the bite in a few minutes!

Russell, Fayrer, ${ }^{3}$ and Waddell, ${ }^{4}$ working on the Indian venomous snakes, have obtained more negative results. In the majority of cases the snakes remained almost unaffected, or at least survived a large quantity of their own or alien venoms introduced either by the biting or by the injection methods. There are, however, a few instances where a venomous snake was killed by another species of venomous snake within a few days after the bite. Fayrer studied Cobra, Bungarus, Echis, and Daboia in this regard. Waddell, like Russell, obtained negative results.

${ }^{1}$ Fontana. Abhandlung über das Viperngift, 1787 , Berlin.

2 Claude Bernard. Leçons sur l'effet des substances toxiques, 1857 .

3 Fayrer. The Thanatophidia of India. I874.

- Waddell. Are venomous snakes antitoxic? An inquiry into the effect 'of serpents' venom upon the serpents themselves. Sci. Mem. Off. Arm. India, I889, IV, 47. 
The action of snake venom, especially that of Cobra, is quite powerful upon different species of non-poisonous snakes. The bite of Cobra was fatal within 30 minutes to several hours to the following snakes: Passerita mycterizans (green whip-snake), Tropidonotus quincunciatus (grass-snake), Dendrophis picta (tree-snake), and Dryophis (green tree-snake). Ptyas mucosus is much more resistant to cobra venom and often escapes death from several successive bites. If death occurs it usually comes over 24 hours after the infliction of the venomous bite.

\section{EXPLANATION OF THE MECHANISM OF NATURAL IMMUNITY.}

On what does the relatively high natural immunity of venomous snakes depend? Why are the venomous species of snakes more resistant to venom than their innocuous congeners, and why do the latter possess a greater resistance than various mammals and birds? Bearing on these interesting questions numerous experiments were performed.

The work of Leydig, Phisalix and Bertrand, Jourdain, and other anatomists and physiologists established in the non-venomous snakes the existence of poison-secreting glands and made the differences in the non-venomous and venomous snakes appear as a matter of grade in the evolutional phase. (See Phylogeny of snakes.) The physiological analogies between the venomous and innocuous species have been shown by the toxic properties of the parotid glands of the latter to be somewhat comparable to the poisonous action of venom (Alcock and Rogers). Again, the poisonous properties of the blood serum of various poisonous snakes, as well as those of the innocuous kinds, came to light, and it was shown that these serums are rather powerfully poisonous, being strongest in the serum of the snake with the most active venom.

These facts have formed the basis on which Phisalix and Bertrand built their theory that the non-susceptibility of snakes, especially of the venomous species, to venom is due to the constant internal secretion of venom.

In I893 Phisalix and Bertrand ${ }^{1}$ studied the relation of the poisonous properties of the blood of viper and its venom, and concluded that they are identical in their physiological actions. The source of the toxic principle in the blood was sought in the constant absorption of the venom.

Calmette $^{2}$ found that the blood of Cobra is highly toxic for the rabbit.

The fact that certain non-venomous snakes sometimes enjoy a comparatively high immunity to venom demands explanation. Phisalix and Bertrand ${ }^{3}$ investigated this point carefully and have shown that while adders have no venom apparatus by which it is possible to produce a poisonous wound, the secretion of the parotid glands resembles venom in the effects it produces when artificially introduced into animals. Extracts of the various organs

\footnotetext{
I Phisalix and Bertrand. Toxicité du sang de la vipère. C. R. Soc. Biol., r893, ro ser., V, 997; and C. R. Ac. Sci., 1893, CXVII, rog9.

2 Calmette. Sur la toxicité du sang de cobra capel. C. R. Soc. Biol., 1894, ro ser., I, Ir.

a Phisalix and Bertrand. Sur la présence de glandes venimeuses chez les couleuvres, et la toxicité du sang de ces animaux. C. R. Soc. Biol., r894, ro ser., I, 8. C. R. Acad. Sci., r894, CXIII, 7.
} 
were used experimentally, but only those of the major maxillary glands were found to possess the poisonous action described. The blood of these snakes was also found to be poisonous, and from it a precipitate was secured which behaves exactly like the active principle secured from the blood of vipers.

As a logical consequence it should follow that the removal of the poison gland must also remove the toxic properties of the blood of venomous snakes. An experiment of this sort is by no means easy to perform. Phisalix and Bertrand ${ }^{1}$ have, however, carried out this experiment on 46 vipers. The poison glands were removed from one-half of them. After I68 days from the ablation of the glands the blood was taken from the heart under the influence of chloroform and tested for its toxicity. All guinea-pigs survived, while the blood from the control vipers was highly poisonous and killed the animals.

The same authors ${ }^{2}$ went further in this inquiry and finally found that the infection of the blood of viper or adder heated to $68^{\circ}$ causes no symptoms in guinea-pigs, but confers upon the latter an increase in resistance to the toxic effect of viper's venom. This phenomenon was considered by them to be analogous to the protection conferred by the injection of the attenuated viper's venom.

Calmette ${ }^{3}$ found that the bloods of Cobra, Naja tripudians and Naja haje, Crotalus, and Cerastes are highly toxic upon guinea-pigs, but instead of accepting the hypothesis of Phisalix and Bertrand he considers the active principles of the blood and venom of venomous snakes to be different. The toxicity of the blood disappears on heating to $68^{\circ} \mathrm{C}$., while the venom retains its activity at this temperature. The repeated injection of the sublethal quantities of snake blood produces an immunity not only against the same blood but also against the venom. From this Calmette infers that the toxicity of the blood is due to the presence of a forerunner of venom from which the latter is produced through the process of secretion of venomous glands.

The later study of Flexner and Noguchi ${ }^{4}$ shows that the blood serums of Crotalus and Ancistrodon are highly toxic upon guinea-pigs, while that of the innocuous pine snake (Pityophis catenifers) is less so. Taking up the hæmolysis as the test reaction these authors found that the antiserums of Crotalus and Pityophis serums have neutralizing properties upon the hæmolysins contained in these serums as well as in the case of the venoms of Cobra, Ancistrodon, and Crotalus. They have, however, noticed that the antihæmolytic actions of these inmune serums are quite specific and display more protection against the serums with which they were produced. The neutralization of toxicity of these two snake serums (Crotalus and Pityophis) by their respective antiserums was also found to be highly specific. Without definite conclusion as to whether the venom is the cause of the toxicity

1 Phisalix and Bertrand. Sur les effets de l'ablation des glandes à venin chez la vipère. C. R. Soc. Biol., 1894, ro ser., I, 747. C. R. Acad. Sci., 1894, CXIX, 919.

2 Phisalix and Bertrand. 'Sur l'emploi du sang de vipère et de couleuvre comme substances antivenimeuses. C. R. Soc. Biol., I895, ro ser., II, 751. C. R. Acad. Sci., 1895, CXXI, 754 .

Calmette. Le venin des serpents. I896, Paris.

4 Flezner and Noguchi. Constitution of snake venom and snake sera. Jour. of Path. and Bacteriol. I903, VIII, 379 . 
of the blood or the toxic elements of the blood are the source of venom, Flexner and Noguchi distinguished the differences in these two sets of active principles by their capability to unite with or to be activated by their homologous and heterogeneous complements. According to these authors venom lysins are capable of being activated by isocomplements as well as heterocomplements, while the amboceptors of the snake serums are active only in the presence of their own complements. This explains why the snake serum loses its toxicity when heated to $56^{\circ} \mathrm{C}$. or above; here the inactivation is due to the disappearance of suitable activators - isocomplements in this case. At present our knowledge concerning the venom activators is so enlarged that the so-called heterocomplements, in Flexner and Noguchi's sense, comprise lecithin, certain fatty substances, and also serum complements.

It becomes probable that Calmette's view on the relation of blood toxicity and venom toxicity was a proper one.

Stephens ${ }^{1}$ and Noc found that Calmette's antivenin neutralizes the hæmolytic principle of snake serums, especially that of Cobra.

Theoretically considered, natural immunity must be regarded as the expression of combination of many factors. It is seldom that the blood of an animal refractory to the effect of a toxin contains a definite anti-substance comparable to the product of artificial immunization known as immune body or antitoxin. In the cases of poisons, such as saponin and other glucosids, the blood may contain a definite substance (like cholesterin) capable of direct neutralization, but in other cases - such as certain alkaloids - toleration through the repeated introduction of these bodies into an animal body may be attained without inducing the formation of any definite anti-body. In still other cases, normal serums often contain substances similar to real antitoxins, as in horse serum for tetanus toxin.

Again to-day we find very instructive instances of another set of phenomena pointing to the cellular and vital processes of immunity, either natural or acquired - namely, the rôles of phagocytosis advocated so long by Metchnikoff and his collaborators. In this instance the substances called opsonins by Wright and cytotropic substances by Neufeld must be regarded as the cause of natural as well as acquired immunity.

Still other examples of natural immunity are the cases of chicken against tetanus, and hen and tortoise against abrin. There are no antitoxic properties in these bloods. This may be due to the absence of suitable receptors in the sense of Ehrlich's side-chain theory.

In considering the nature of natural immunity in snakes against their own and alien venoms, we must take the above factors into account before we can reach a conclusion. I am inclined to think that the phenomenon is the expression of not one single circumstance, but of several circumstances here enumerated. The lack of suitable receptors especially seems to be playing a dominant part.

${ }^{1}$ Stephens. On the hæmolytic action of snake toxins and snake sera. Jour. of Path. and Bacteriol., I900, VI, 273. 


\section{NATURAL IMMUNITY OF CERTAIN ANIMALS FROM SNAKE VENOM.}

It has been a popular belief that certain warm-blooded animals are immune to the bites of poisonous snakes. Of the mammals the mongoose (Herpestes ichneumon), hedgehog (Erinaceus europaus) and hog (Sus); and of the birds the Ajaja, Cancroma, Botaurus, and Mycteria, known under the names of culebrero and guacabo in Colombia, are alleged to resist the effects of venom.

Three experiments made by Fayrer on the mongoose show that this animal is not immune to the venom of Cobra, but is less sensitive than other warmblooded animals. The quick movements of this animal and its thick hair seem to protect it from being bitten by the Cobra. One of Fayrer's descriptions of the experiments is quoted below:

A mongoose and a full-sized cobra were put into a large wire cage at I p.m. The snake struck at the mongoose and they grappled each other frequently, and apparently the mongoose must have been bitten, as the snake held on to it about the neck or head.

At $I^{\mathrm{h}}{ } 5^{\mathrm{m}}$ p.m. there was no effect on the mongoose; both it and the snake were much excited and angry, the snake hissing violently.

$2^{\mathrm{h}} 3 \mathrm{O}^{\mathrm{m}}$ p.m. no effect on the mongoose. The snake is bitten about the neck, and shows the bleeding wounds.

$2^{\mathrm{b}} 5 \mathrm{I}^{\mathrm{m}}$ p.m. They occasionally attack each other, but the mongoose jumps over the snake and tries to avoid it.

Next day at noon both were well; the snake frequently struck at the mongoose, but did not appear to injure it; both seemed very savage, but the mongoose would not bite the snake; he jumped over it.

There had been two cobras in the cage with the mongoose during the night, both equally fierce and striking at each other and the mongoose; but the latter was not poisoned. He was rather severely scratched on the head by the cobra. But on being bitten in the thigh by the same cobra, when both were taken out of the cage the mongoose succumbed to the poison and died very soon.

According to Calmette ${ }^{1}$ the blood serum of the mongoose is devoid of any antivenomous properties against the venom of Cobra, although death may be slightly delayed. He injected into three normal mongooses the doses of cobra venom respectively corresponding to 4,6 , and 8 minimal lethal doses for the rabbit. The first showed no symptoms; the second was ill for two days, but recovered; the third mongoose died in $\mathrm{I} 2$ hours. Thus the immunity of the mongoose is relative only.

Flexner and Noguchi ${ }^{2}$ found that the defibrinated blood of the mongoose from Jamaica was not hæmolyzed by crotalus and ancistrodon venoms in the concentrations from 20 per cent to 0.05 per cent. The addition of an adequate amount of the crotalus serum to not too high concentrations of these venoms produced a rapid dissolution of the mongoose corpuscles, while the concentrations above 0.5 per cent of the venoms again progressively diminished the amount of hæmolysis in the presence of a uniform quantity of the

1 Calmette. Les venins. I907, Paris.

2 Flexner and Noguchi. Constitution of snake venom and snake sera. Jour. of Path. and Bacteriol., I903, VIII, 379 . 
crotalus serum. Unlike the venom, the crotalus serum is highly hæmolytic upon the mongoose corpuscles.

Lewin ${ }^{1}$ and Phisalix and Bertrand ${ }^{2}$ made numerous experiments on the immunity of the hedgehog against the venom of Vipera berus. It is known that the hedgehog chases the viper and eats it very eagerly. The spinous coat of the animal protects it from being bitten by the snake and the animal is very skilful in catching the reptile at vulnerable parts of the body. Should the snake succeed in biting the hedgehog, the latter seldom dies. The inoculation of about 40 minimal lethal doses for guinea-pig of this venom into the hedgehog is required to kill. Whether or not the resistance of this animal is due to the presence of an antitoxic substance in the blood has been studied by Phisalix and Bertrand, who state that the serum of this animal heated to $58^{\circ} \mathrm{C}$. in order to deprive it of its inherent toxicity for the guineapig can, when mixed with 2 minimal lethal doses of the viper poison in quantities of 8 c.c. of the serum, protect the guinea-pig from the fatal effects of venom.

In regard to the natural immunity of hogs, which is popularly credited in the Mississippi Valley, it is still unconfirmed experimentally. Calmette ${ }^{3}$ found the pig to resist more cobra venom than dogs (speaking proportionally), but its serum contained no antivenomous properties. Along the valleys of the lower Mississippi it is said that the hog swallows young crotalus with evident liking.

Concerning the grallics of Colombia, the culebrero and guacabo, nothing definite is known, except that these birds hunt young snakes for their prey. Probably they are relatively immune to the bite of poisonous snakes, partly because they understand how to kill the snake, and partly, perhaps, because they are less sensitive to the effect of the venom itself.

1 Lewin. Beitr. z. Lehre von der natürl. Immunität. Deutsch. med. Woch., r898, XXIV, 629.

2 Phisalix and Bertrand. Recherches sur l'immunité du hérisson contre le venin de vipère. C. R. Soc. Biol., I895, Io ser. II, 639. Ibid. Bull. de Muséum d'Histoire natur., I895, I, 294; op. cit., II, I0o.

8 Calmette. Les venins, r907, Paris. 


\section{CHAPTER XXVIII.}

\section{EFFECTS OF SNAKE VENOM UPON THE BLOOD OF COLD- BLOODED ANIMALS, AND UPON THE NERVE CELLS, NERVE FIBERS, OVA, AND SPERMATOZOA.}

Fontana, ${ }^{1}$ as early as 1787 , performed experiments on the effects of the venom of viper on vipers, two innocuous snakes, one salamander, turtles, and leeches, and found that none of these cold-blooded animals die of viper poisoning. On the other hand, he found certain fish and frogs to be susceptible to the viper's venom, death following the bite after a much longer time than in the cases of warm-blooded animals.

In I860-186I S. Weir Mitchell ${ }^{2}$ made a careful study of the effects of crotalus venom upon frogs, and observed two kinds of venom poisoning - an acute or rapid and a chronic or slow poisoning. He pointed out the relatively greater resistance of frogs to the venom.

For physiological and pharmacological experiments with various kinds of venom on isolated organs, the frog has been nearly always employed by investigators, and it would be superfluous to give any further description of the effects which venom produces on this animal.

Brunton and Fayrer ${ }^{3}$ also made a few experiments on cold-blooded animals. Two fishes, Ophiocephalus marulius and a carp, succumbed to the cobra venom. Cobra venom seems to destroy the irritability of snails.

According to Rogers, the venom of marine snakes, as compared with that of land snakes, acts more powerfully upon marine animals than upon the warm-blooded animals, although the absolute susceptibility of these two orders of animals to the first venom is greater in the case of the warm-blooded animals.

A more systematic study of the effects of snake venom on cold-blooded animals has been recently made by Noguchi. The results obtained by him were first issued as Publication No. I2 of the Carnegie Institution of Washington, and are quoted in the following pages $(27 \mathrm{I}-280)$.

1 Fontana. Abhandlung über das Viperngift. 1787 , Berlin.

2 Weir Mitchell. Physiology and toxicology of the venom of the rattlesnake. Smithsonian Contr. to Knowledge, $186 \mathrm{r}$, Washington.

8 Brunton and Fayrer. On the nature and physiological action of the poison of Naja tripudians and other Indian venomous snakes. Proc. Roy. Soc., 1874, 68. 


\section{THE ACTION OF SNAKE VENOM UPON COLD-BLOODED ANIMALS.}

Since the writings of Fontana, Weir Mitchell alone seems to have concerned himself with the study of the action of snake venom upon cold-blooded animals. Having studied and described the action of rattlesnake venom upon frogs and upon Crotalus itself, he intended, as appears from a paragraph in his earlier paper on venom, to extend his observations to a wider class of animals. Thus he writes:

"It was my intention to examine, in the next place, the effects of the venom upon leeches, fish, eels, and crustacean animals, but for some reasons, which it is needless to relate, I was obliged to postpone these observations until some future occasion." 1

The following orders of animals were tested against venom: Reptilia, Amphibia, Pisces, Insecta, Crustacea, Vermes, Mollusca, Echinodermata.

Several kinds of venom were employed: cobra, water-moccasin, and rattlesnake. All had been previously dried, and hence they were dissolved, before injection, in sterile sea-water or normal saline solution, according as they were to be introduced into fresh or salt water animals. The mode of injection varied with the animal species employed: in higher forms the peritoneum was selected, in lower forms the body cavities or water vascular system. Some of the vermes gave unsatisfactory results in respect to the dosage because of strong muscular contraction produced by the needle puncture and the presence of septa throughout the body. It was almost impossible to calculate the exact amount of venom introduced into these animals.

Each experiment was accompanied by at least two control animals maintained under precisely the same external conditions. In every case in which the cause of death was doubtful the experiment was repeated. In general, it may be stated that the animals used in the experiments stood the necessary handling and captivity without serious drawbacks. But in a few instances the degree of sensitiveness to these procedures was found to be very great. Thus, in the case of several kinds of small fish, e.g., pollack, silver-side, pipe-fish, this sensitiveness was so great that they did not survive beyond 24 hours in captivity. Animals surviving the injections were, as a rule, killed at the end of the experiment and examined for local and general lesions.

The results of the study are given in tabulated form. In reviewing the tables, one is impressed with the wide degree of susceptibility to snake venom exhibited by cold-blooded animals. On analyzing the effects produced, it becomes quickly evident that cobra venom exerts little if any local action, although it is the most toxic of all venoms employed. Crotalus venom, on the other hand, while exhibiting the least general toxicity, displays the greatest local action. Water-moccasin venom occupies an intermediate position in this regard.

The chief local effect produced by rattlesnake and water-moccasin venoms is the escape of red blood corpuscles from the vessel; only rarely is macroscopic necrosis of tissue visible. This production of hæmorrhage is, however, not restricted to the site of injection of the venom, but in some animals generalized hæmorrhages also take place. This latter effect was noticed chiefly in fishes, from which the blood may escape in such large quantity from the gills as to color the sea-water. In other instances, hæmorrhages into the skin occur, and I have noticed during life, in the dog-fish poisoned by crotalus venom, the occurrence of intracranial hæmorrhage. Only one species of fish - the puffer - was wholly insusceptible to the locally irritating principles of venom; it succumbed, however, to the general toxic effects of all the venoms.

It would appear as if the chief toxic effects of crotalus and moccasin venoms are the outcome of their local action, and yet the general toxic constituents which

1 Researches upon the venom of rattlesnake, with an investigation on the anatomy and physiology of the organs concerned. Smithsonian Miscellaneous Collections, vol. XII, Washington, $186 \mathrm{r}$. 
they contain can not be without marked action in some cases. These venoms may, therefore, cause death either through a destructive local action or through the operation of the neurotoxin upon the central nervous system.

In the case of cobra venom, the toxic action must be ascribed to neurotoxin. There the local effects are almost nil, while the respiratory disturbances are very apparent. The poisoned animals suffer from dyspnœa and from motor paralysis. Among fishes cobra venom causes rapid loss of equilibrium, so that the venomized animal swims with a rotary motion until it becomes too weak to struggle further. Crotalus and moccasin venoms cause far less disturbance of equilibration, while, on the other hand, their action at the beginning is likely to be irritative; the animal dashes about furiously without exhibiting evidence of a marked loss of balance.

Speaking generally, cobra venom is most toxic and crotalus venom least toxic for cold-blooded animals. Moreover, this rule applies to the different classes as well as to the various species of animals employed. In other words, cold-blooded animals are more highly susceptible to the toxic action of neurotoxin than to that of hæmorrhagin. ${ }^{1} \quad$ Crotalus venom is effective chiefly in those instances in which the local lesions are marked; while in instances in which it acts independently of the local lesions a far larger dose, in keeping with its small proportional content of neurotoxin, is required to produce fatal results.

Snakes and frogs succumb easily to cobra venom, but they are relatively insusceptible to crotalus and moccasin venoms. They would seem to be entirely resistant to the action of hæmorrhagin. Turtles are more susceptible to all venoms than the foregoing animals, and fishes exceed turtles in this respect. The grasshopper succumbs only to large doses of venom. Among the crustaceans the horseshoe crab is almost insusceptible, and other species of crabs are only moderately susceptible to venom poisoning. The lobster is only moderately resistant.

Excepting the earthworm, all the worms with which I experimented showed a low degree of susceptibility. While the first will die in toto if injected with venom, the others show at times general effects, but they suffer only partial necrosis, from which they finally recover. After separation of the dead parts the worms seem to have been entirely restored. On the injection of Phascolosoma with an enormous dose of venom I have seen the muscular contractibility of the injected part disappear for a period of a week or longer, but in the end it was recovered. If necrosis occurred a slough was formed and was finally cast off.

Upon echinodermata venoms produce little effect. The sea-urchin succumbed to all the venoms, while star-fish and sea-cucumbers were not perceptibly affected.

The general toxicity of venoms upon the adult organism, as compared to their special effects which are produced upon the embryological elements ${ }^{2}$ of the same species, is of considerable interest. The ova or spermatozoa of some vermes and echinodermata are easily dissolved or fragmented by venoms, while the adults of corresponding species are almost entirely insusceptible to them. On the other hand, the reverse is possible. Thus the eggs of Fundulus - a fish - are comparatively insusceptible to venoms, as they can be fertilized in sea-water containing rather a large amount of venoms and development of the fertilized ova progresses in the normal way, but the adults are found to be highly susceptible to the same kind of venoms.

A close examination as to the relation existing between the general toxicity and the hæmatoxic power ${ }^{3}$ of venoms upon cold-blooded animals adds further interesting as well as important facts to the understanding of the nature of the action of snake venom in vivo.

1 Flexner and Noguchi. The constitution of snake venom and snake sera. Journal of Pathology and Bacteriology, 1903 , VIII, 396.

2 Flexner and Noguchi. On the plurality of cytolysins in snake venom. Univ. of Penna. Medical Bulletin, 1903, July-August.

Noguchi. The effects of venom upon the blood of cold-blooded animals. Univ. of Penna. Medical Bulletin, 1903, July-August. 


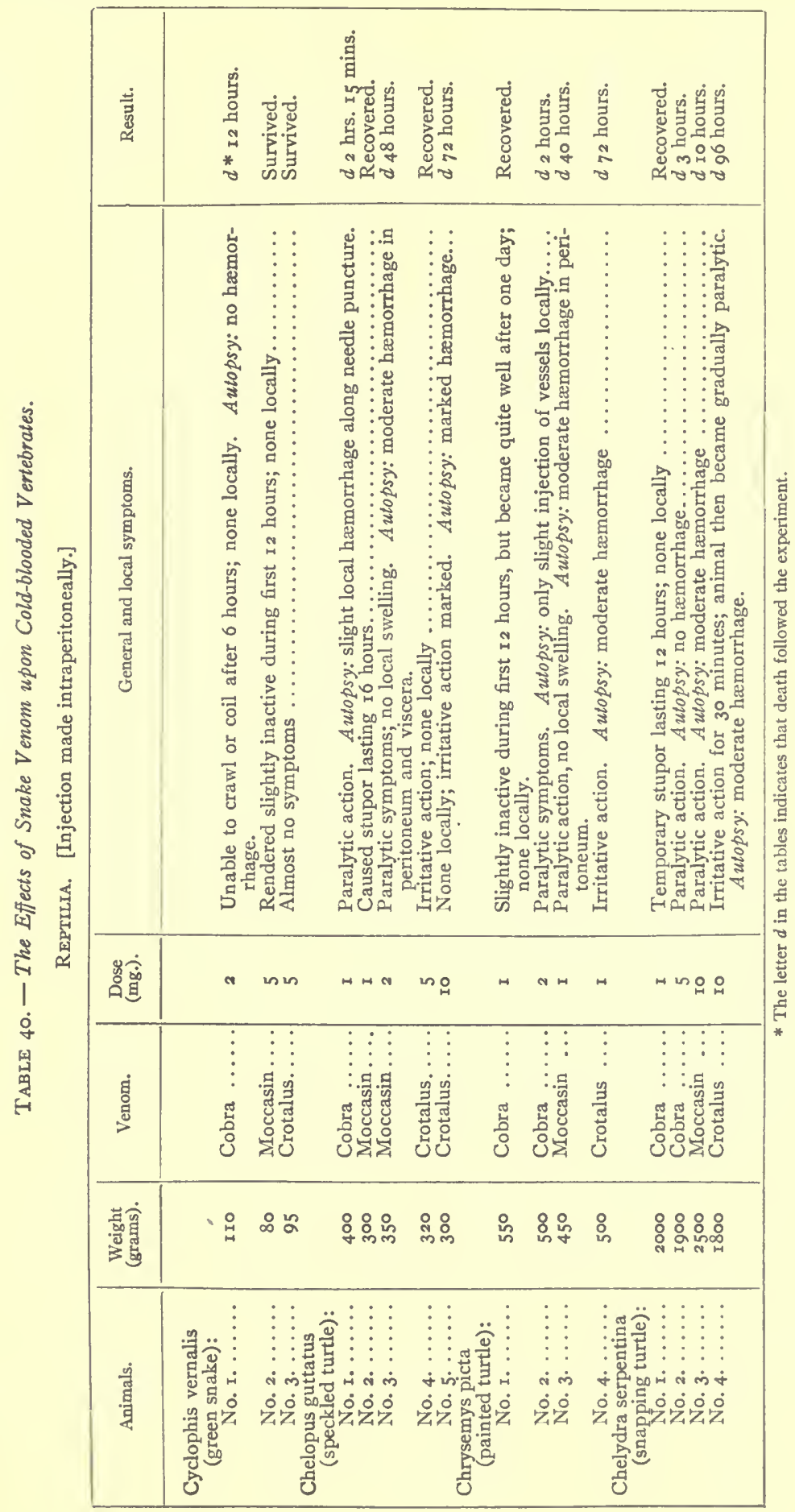




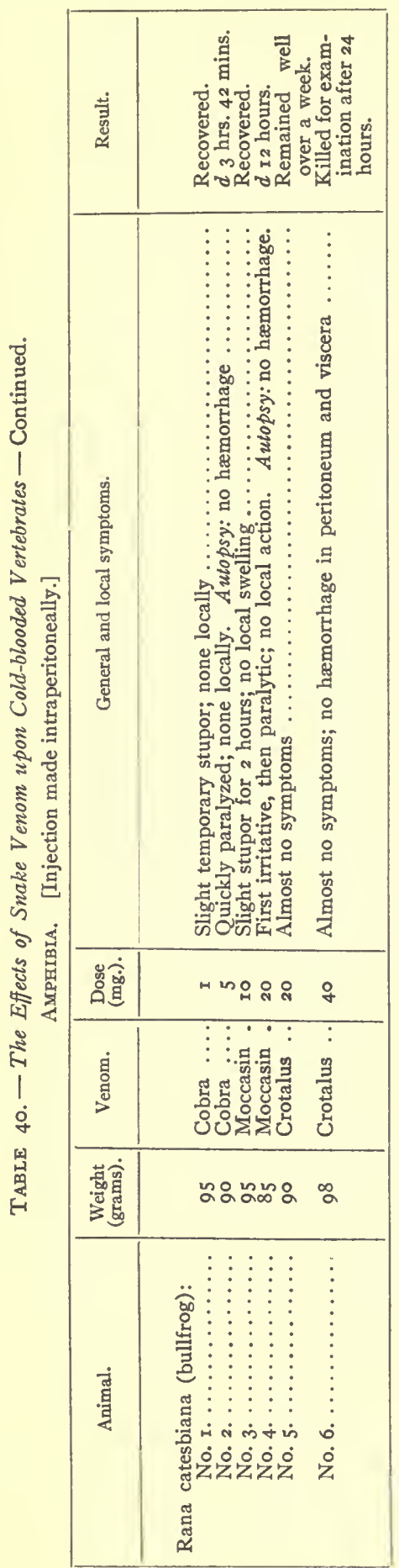

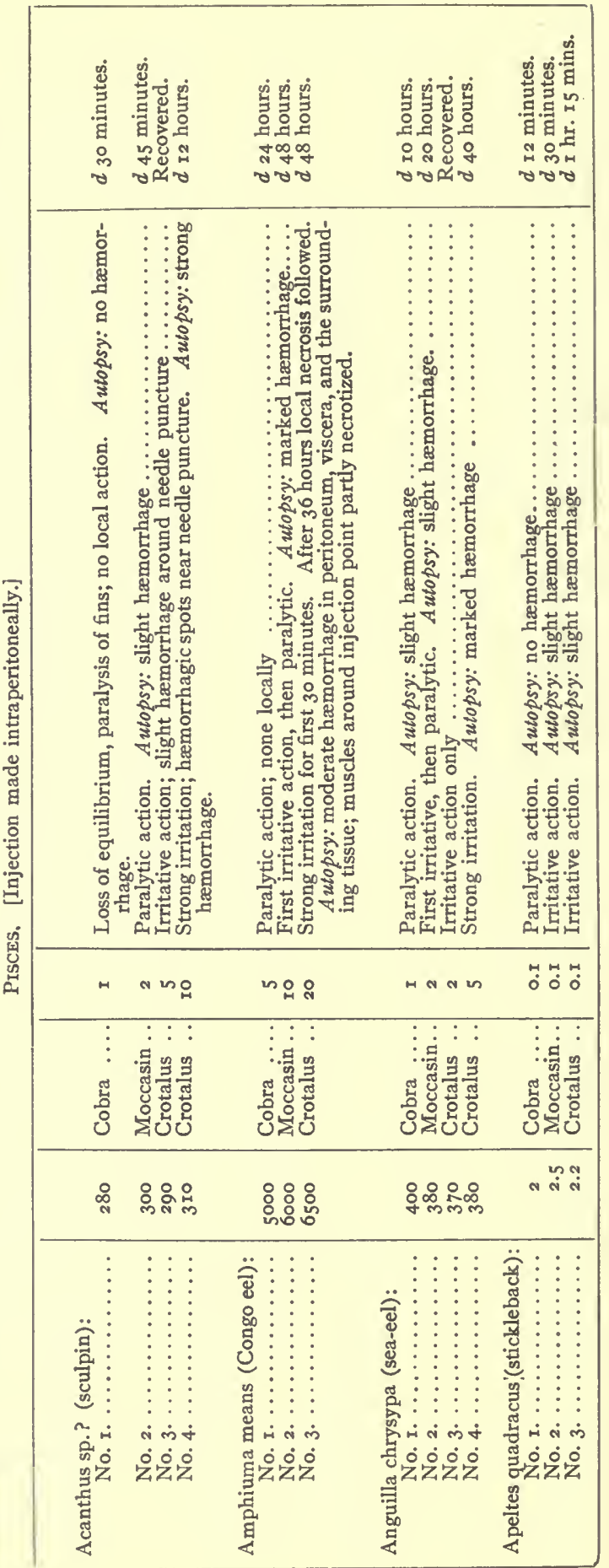




\begin{tabular}{|c|c|c|c|c|c|c|c|c|}
\hline 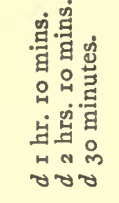 & 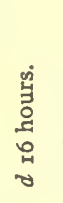 & $\begin{array}{l}\text { : } \\
\text { 今े } \\
\text { i } \\
\text { in } \\
0\end{array}$ & 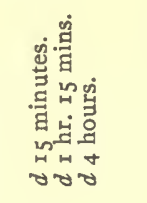 & 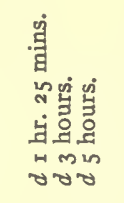 & 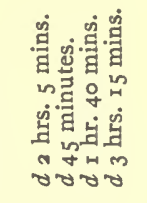 & 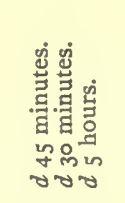 & 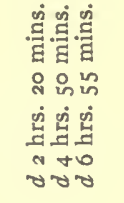 & 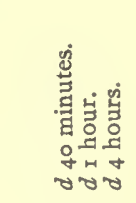 \\
\hline 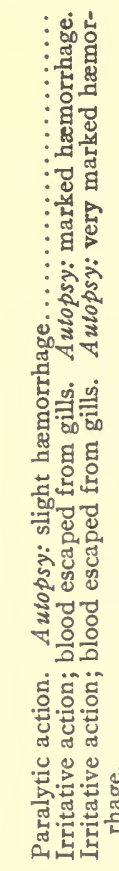 & 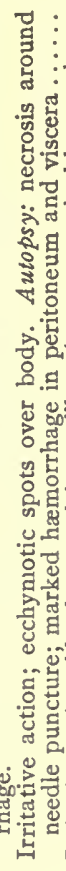 & & 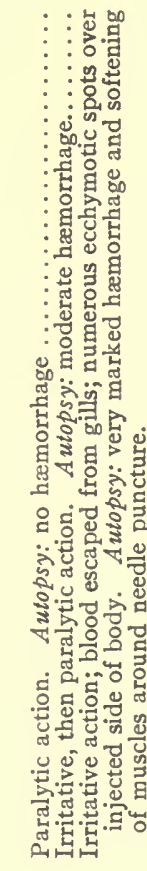 & 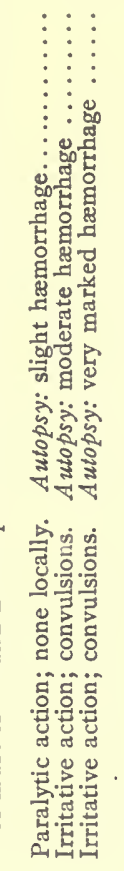 & 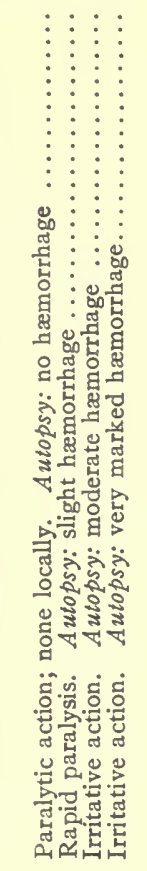 & 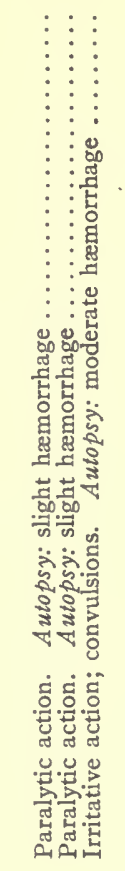 & 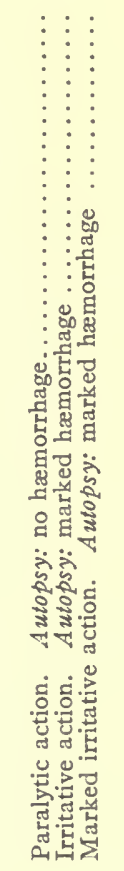 & 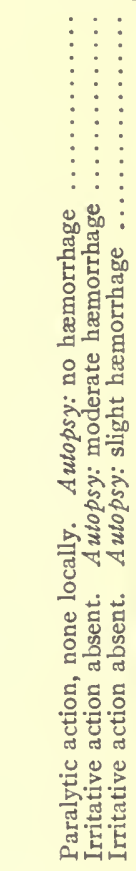 \\
\hline H w in & $H$ & in & HH & MHA & HNO & แ & HW & MH \\
\hline 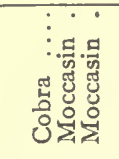 & 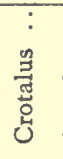 & 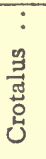 & 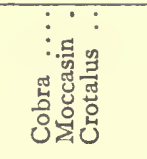 & 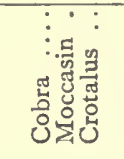 & 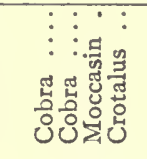 & 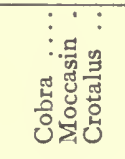 & 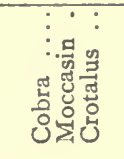 & 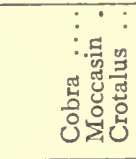 \\
\hline ঃ융 & $\stackrel{\infty}{\infty}$ & $\stackrel{\circ}{\circ}$ & 욕욱 & 업: & 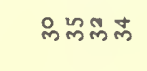 & ํํํำ & 옴욤욤 & 옇웜웅 \\
\hline 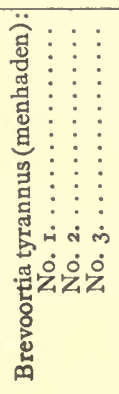 & $\begin{array}{c}\vdots \\
\vdots \\
j \\
\vdots \\
\dot{z}\end{array}$ & $\begin{array}{l}\vdots \\
\vdots \\
\dot{0} \\
\dot{2}\end{array}$ & 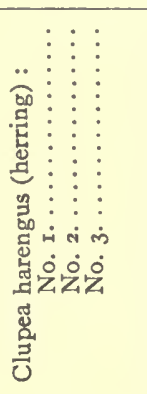 & 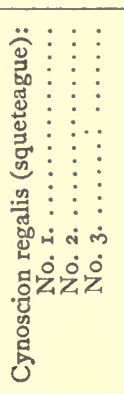 & 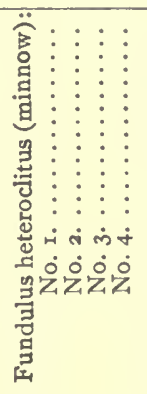 & 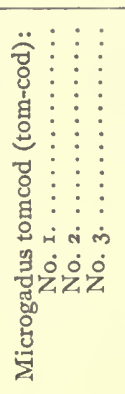 & 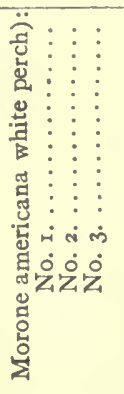 & 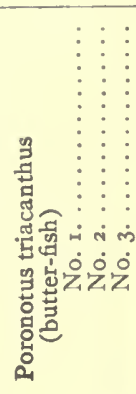 \\
\hline
\end{tabular}




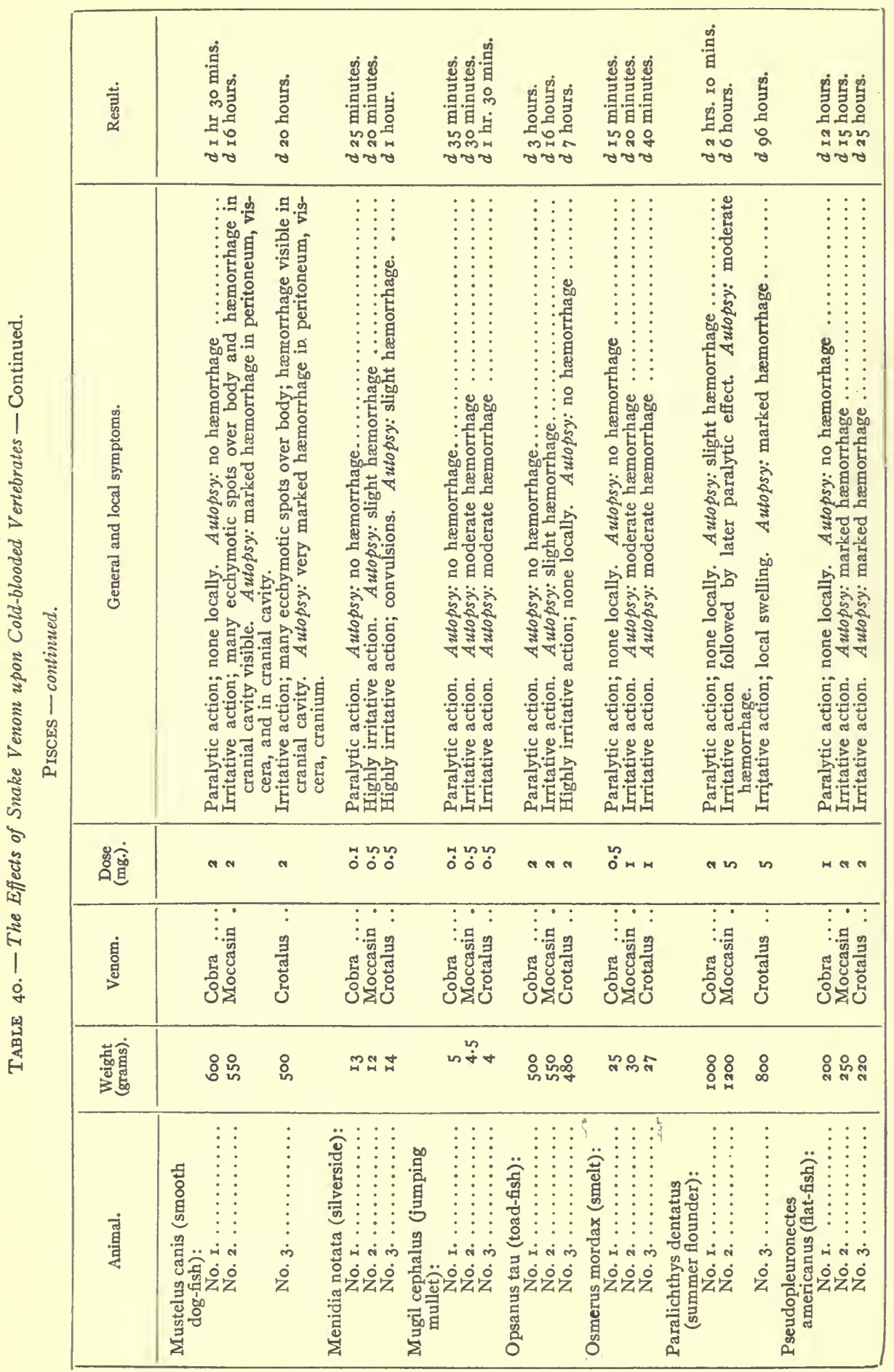


THE ACTION OF SNAKE VENOM UPON COLD-BLOODED ANIMALS

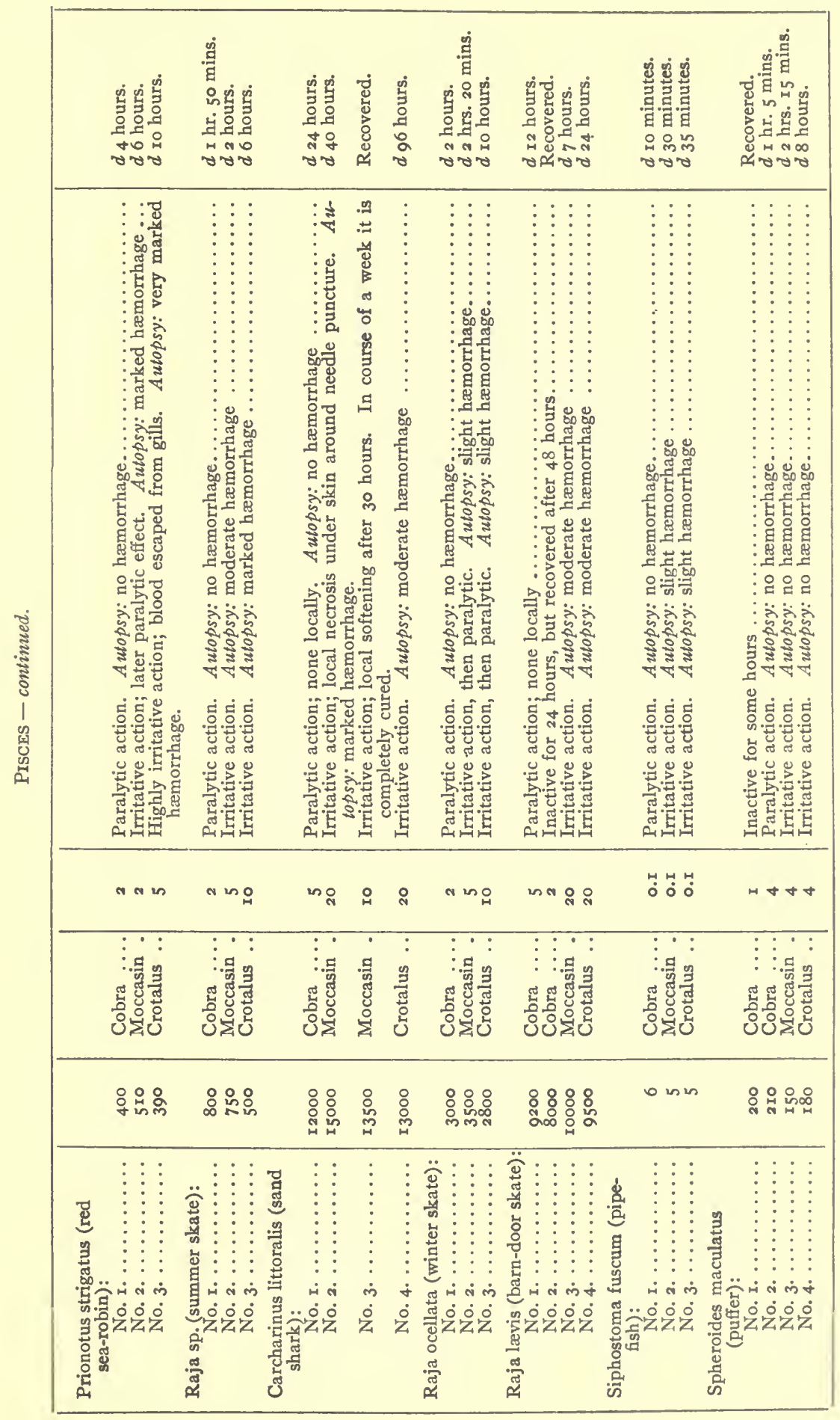



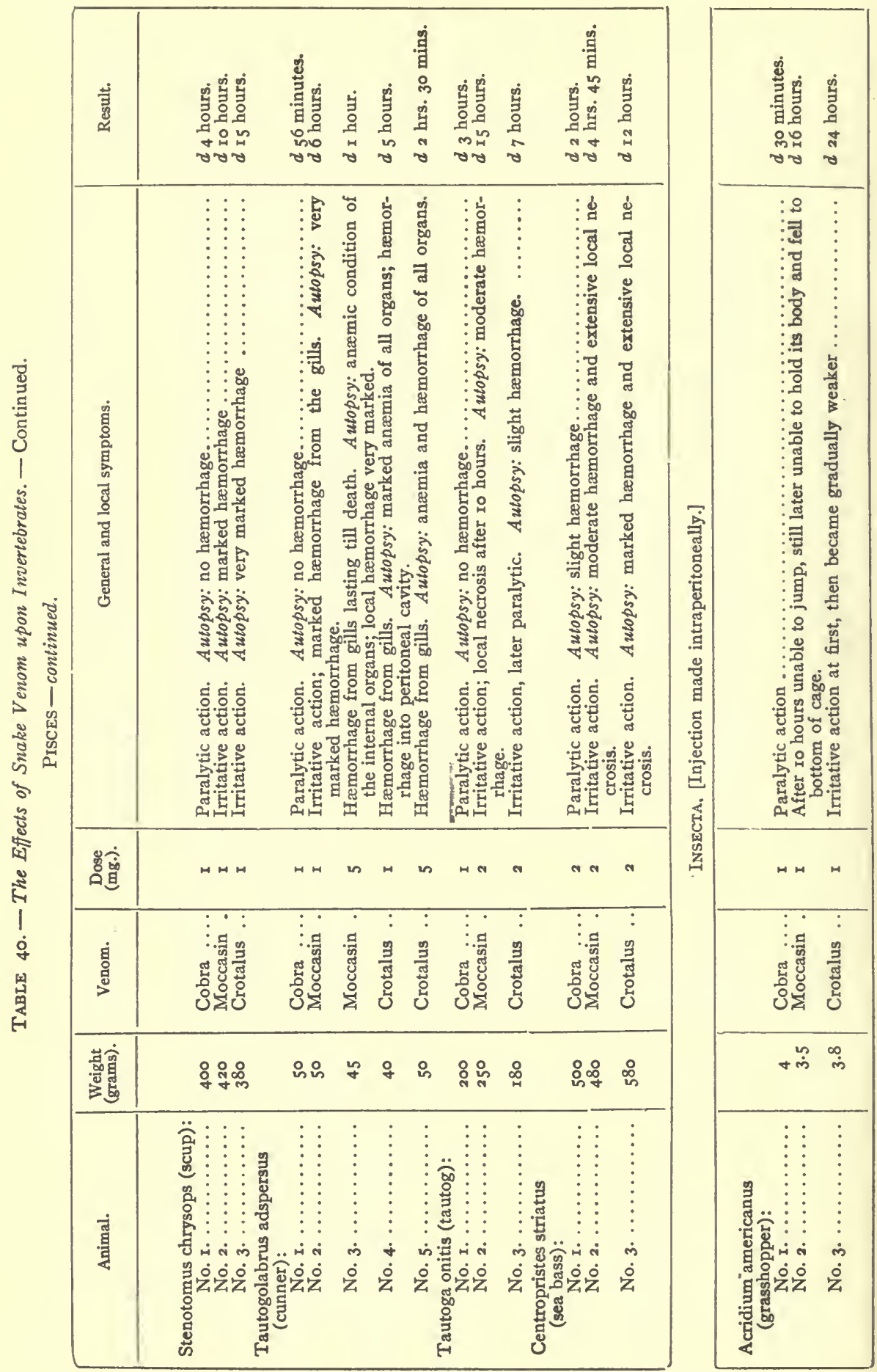


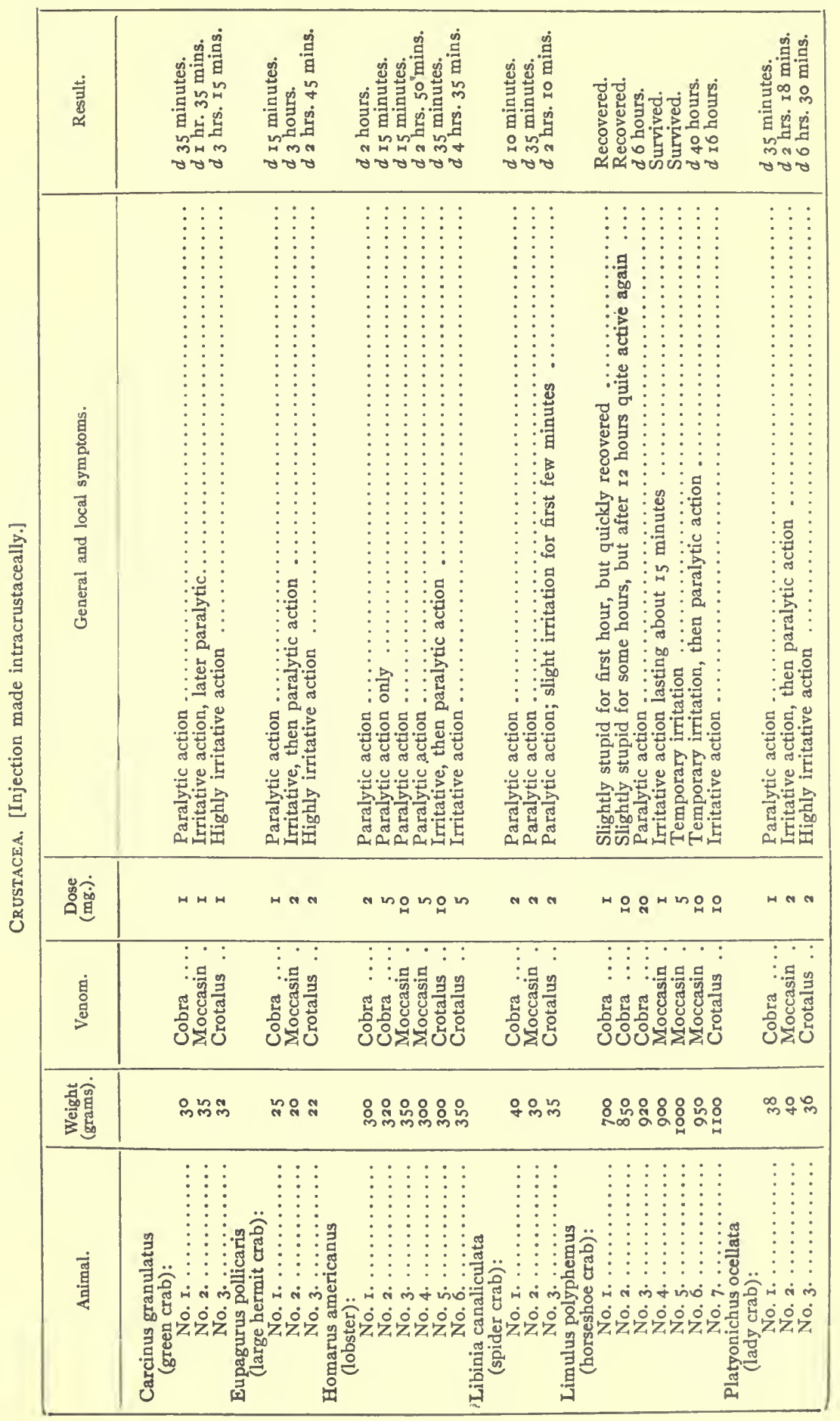




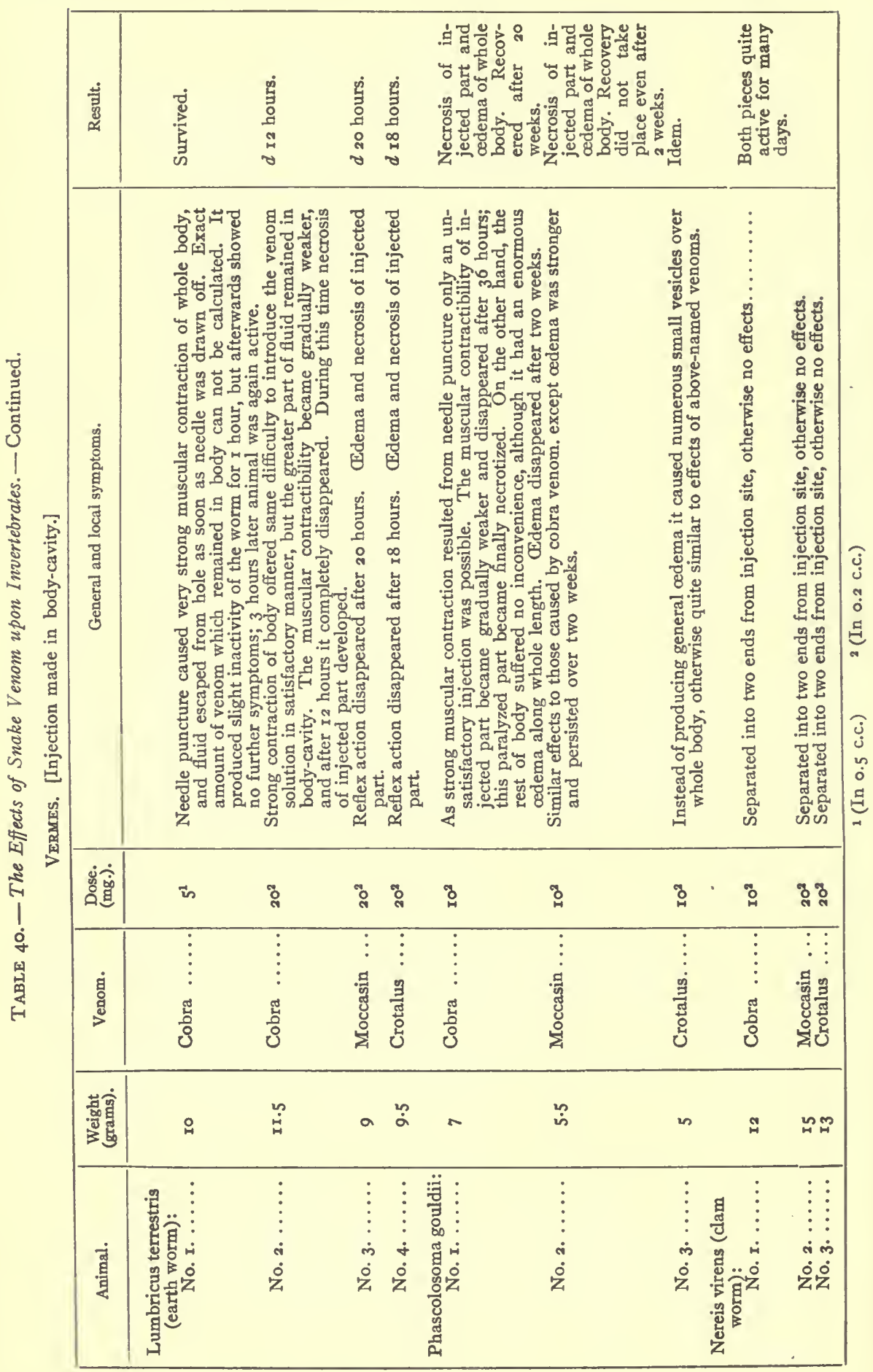



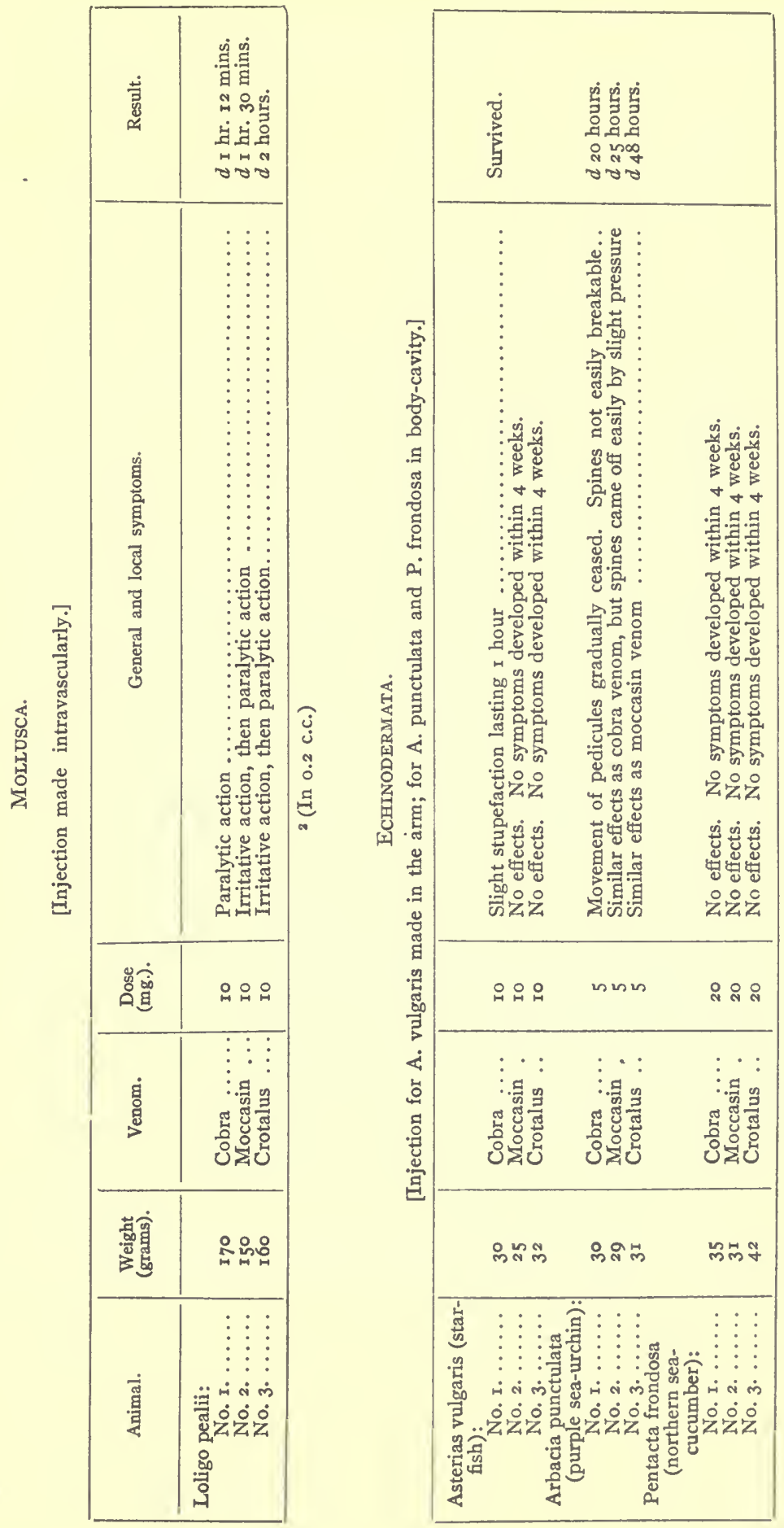


\section{THE EFFECTS OF VENOM UPON THE BLOOD CORPUSCLES OF COLD- BLOODED ANIMALS.}

The following article is reprinted from the University of Pennsylvania Medical Bulletin, July-August, I903:

In the course of experiments upon hæmolysis carried out during the past summer at the Marine Biological Laboratory, Woods Holl, I took advantage of the opportunity to study the agglutinative and lytic action of venom upon the blood corpuscles of a wide series of cold-blooded animals. The study is of sufficient interest, I think, to warrant presenting the results in a tabulated form. (See table $4 \mathrm{I}$.)

The blood was obtained from animals belonging to the classes of reptilia, amphibia, pisces, insecta, crustacea, vermes, mollusca, and echinodermata.

The dried venoms were dissolved either in 0.9 per cent or 2 per cent saline solution immediately before conducting the experiments; the venoms employed were cobra, water-moccasin, and rattlesnake; the blood was used in 5 per cent suspension; the temperature was that of the room, and varied between $20^{\circ}$ and $30^{\circ} \mathrm{C}$.

In order to determine the minimum hæmolytic, leucolytic, or agglutinative quantity (dose) of venom, the reactions were noted at a fixed interval. Thus, for hæmolysis and leucolysis, after I2 hours; for agglutination, after 4 hours of contact.

While solution of the erythrocytes can be readily observed in test-tube reactions, leucolysis can be determined only by direct microscopic examination. In general, there is no difficulty in distinguishing leucolysis and leuco-agglutination; but in some instances the act of defibrination causes considerable alteration of the white corpuscles, and these cells exhibit a tendency to undergo spontaneous agglomeration. When the result was mistakable it was indicated by the use of the term "doubtful."

The action of venom upon washed corpuscles was also studied, and it was determined that hæmolysis occurred not at all with water-moccasin and rattlesnake venom, while with the cobra venom a delayed solution would set in. This result with cobra venom recalled the similar one which Professor Flexner ${ }^{1}$ and I had met with in our studies of cobra-venom hæmolysis in warm-blooded animals, and is now sufficiently explained on the basis of the existence of intracorpuscular complements as observed by us and by Kyes, ${ }^{2}$ and of Kyes's important researches on lecithin in relation to its action as complement to cobra-venom amboceptor.

The heat liability of venom agglutinins for the blood cells of cold-blooded animals was found to vary between $68^{\circ} \mathrm{C}$. and $72^{\circ} \mathrm{C}$. for an exposure of 30 minutes. The temperature of $100^{\circ} \mathrm{C}$. maintained for 30 minutes abolishes largely the hæmolytic power of venom over these corpuscles. Crotalus venom proved most susceptible, as its activity is greatly reduced at $90^{\circ} \mathrm{C}$. in 30 minutes.

\footnotetext{
1 Flexner and Noguchi. The constitution of snake venom and snake sera. Univ. of Penna. Medical Bulletin, I902, XV, 345; Journal of Pathology and Bacteriology, 1903, VIII, 379.

2 Kyes. Ueber die Wirkungsweise des Cobragiftes. Berliner klin. Wochenschrift, I002, 886, 918. Kyes and Sachs: Zur Kenntniss der Cobragift activirenden Substanzen. Berliner klin. Wochenschrift, I903, XLI, $21,57,82$.
} 
TABLE $4 \mathrm{I}$.

\begin{tabular}{|c|c|c|c|c|c|c|c|}
\hline \multirow[b]{2}{*}{ Name. } & \multicolumn{2}{|c|}{ Cobra venom. } & \multicolumn{2}{|c|}{$\begin{array}{l}\text { Water-moccasin } \\
\text { venom. }\end{array}$} & \multicolumn{2}{|c|}{$\begin{array}{c}\text { Crotalus ada- } \\
\text { manteus venom. }\end{array}$} & \multirow[b]{2}{*}{ Remarks. } \\
\hline & $\begin{array}{c}\text { Mini- } \\
\text { mum } \\
\text { hæmo- } \\
\text { lytic } \\
\text { dose. }\end{array}$ & $\begin{array}{l}\text { Mini- } \\
\text { mum } \\
\text { agglu- } \\
\text { tina- } \\
\text { tive } \\
\text { dose. }\end{array}$ & $\begin{array}{c}\text { Mini- } \\
\text { mum } \\
\text { hamo- } \\
\text { lytic } \\
\text { dose. }\end{array}$ & $\begin{array}{c}\text { Mini- } \\
\text { mum } \\
\text { aggluti- } \\
\text { native } \\
\text { dose. }\end{array}$ & $\begin{array}{c}\text { Mini- } \\
\text { mum } \\
\text { hamo- } \\
\text { lytic } \\
\text { dose. }\end{array}$ & $\begin{array}{c}\text { Mini- } \\
\text { mum } \\
\text { agglu- } \\
\text { tina- } \\
\text { tive } \\
\text { dose. }\end{array}$ & \\
\hline & P.ct. & P.ct. & P.ct. & P.ct. & P.ct. & P.ct. & \\
\hline $\begin{array}{l}\text { Bascanium constrictor (black snake) } \ldots \ldots \\
\text { Cyclophis vernalis (green snake) } \ldots . . . \ldots .\end{array}$ & 0.005 & 0.1 & 0.1 & 0.05 & & o & Typical \\
\hline $\begin{array}{l}\text { Cyclophis vernalis (green snake) } \ldots \ldots \ldots \\
\text { Aromochelys odorata (musk turtle) } \ldots \ldots \ldots\end{array}$ & 0.01 & 0.1 & 0.2 & 0.02 & $\circ$ & $\circ$ & laking of \\
\hline $\begin{array}{l}\text { Aromochelys odorata (musk turtle) } \ldots \ldots \ldots \\
\text { Chelopus guttatus (speckled turtle) } \ldots \ldots \ldots\end{array}$ & 0.005 & 0.2 & 0.2 & $0.0 \mathrm{I}$ & $\circ$ & I & erythro- \\
\hline $\begin{array}{l}\text { Chelopus guttatus (speckled turtle) } \\
\text { Chrysemys picta (painted turtle) }\end{array}$ & 0.005 & 0.2 & 0.1 & 0.002 & $\circ$ & 0.5 & cytes. \\
\hline $\begin{array}{l}\text { Chrysemys picta (painted turtle) } \ldots \ldots \ldots \\
\text { Chelydra serpentina (snapping turtle) ..... }\end{array}$ & $\begin{array}{l}0.002 \\
0.002\end{array}$ & 0.1 & 0.05 & 0.005 & $\circ$ & 0.5 & Do. \\
\hline $\begin{array}{l}\text { Chelydra serpentina (snapping turtle) ..... } \\
\text { Emys meleagris (Blanding's tortoise)..... }\end{array}$ & $\begin{array}{l}0.002 \\
0.005\end{array}$ & 0.2 & 0.02 & 0.01 & o & 0.5 & Do. \\
\hline $\begin{array}{l}\text { Emys meleagris (Blanding s tortoise) ........ } \\
\text { Rana sp. ? (leopard frog) .............. }\end{array}$ & $\begin{array}{l}0.005 \\
0.02\end{array}$ & 0.1 & 0.2 & 0.05 & $\circ$ & 0.5 & Do. \\
\hline $\begin{array}{l}\text { Rana sp. } \\
\text { Rana catesbiana (bullfrog) } \ldots \ldots\end{array}$ & $\begin{array}{l}0.02 \\
0.1\end{array}$ & 0.2 & 0.5 & 0.02 & 0.4 & I & Do. \\
\hline Acanthus sp. ? (sculpin) $\ldots \ldots$ & $\begin{array}{l}0.1 \\
0.005\end{array}$ & 0.5 & 0.5 & 0.01 & $\circ$ & $\circ$ & Do. \\
\hline Amphiuma means (Congo ecl) $\ldots$... & $\begin{array}{l}0.005 \\
0.005\end{array}$ & 0.1 & 0.02 & 0.1 & 0.05 & 0.5 & Do. \\
\hline Anguilla chrysypa (eel) .......... & $\begin{array}{l}0.005 \\
0.005\end{array}$ & $\begin{array}{l}0.2 \\
0.05\end{array}$ & $\begin{array}{l}0.02 \\
0.01\end{array}$ & $\begin{array}{l}0.1 \\
0.02\end{array}$ & $\stackrel{0}{0.1}$ & $\begin{array}{l}\mathbf{I} \\
2\end{array}$ & $\begin{array}{l}\text { Do. } \\
\text { Do. }\end{array}$ \\
\hline Apeltes quadracus (stickleback) & 0.01 & 0.2 & 0.02 & 0.2 & 0.12 & 0 & $\begin{array}{l}\text { Do. } \\
\text { Do. }\end{array}$ \\
\hline Brevoortia tyrannus (menhaden) .......... & 0.005 & 0.5 & 0.005 & 0.1 & 0.02 & 0.4 & Do. \\
\hline Clupea harengus (herring) . ........... & 0.02 & 0.5 & 0.01 & 0.05 & 0.02 & 0.5 & Do. \\
\hline Cynoscion regalis (squeteague) & 0.05 & $\mathbf{I}$ & 0.08 & 0.1 & $\circ$ & $\circ$ & Do. \\
\hline Fundulus heteroclitus (common minnow). . & 0.05 & 0 & 0.2 & 0.5 & 0.4 & $I$ & Do. \\
\hline Microgadus tomcod (tom-cod) .......... & 0.001 & o & 2 & 0 & 0.1 & o & Do. \\
\hline Morone americanus (white perch) ........ & & o & $\circ$ & $\circ$ & $\circ$ & $\circ$ & Do. \\
\hline Murænoides gunnella (butter-fish) $\ldots . .$. & 0.002 & 0.1 & 0.005 & 0.01 & 0.01 & $\circ$ & Do. \\
\hline Mustelus canis (smooth dog-fish) ... & 0.01 & 0.2 & 0.005 & 0.1 & $\circ$ & I & Do. \\
\hline Carcharinus littoralis (sand shark) .. & 0.5 & I & 0.8 & I & o & $\circ$ & Do. \\
\hline Opsanus tau (toad-fish) $\ldots \ldots \ldots \ldots \ldots$ & 0.05 & 0 & $\circ$ & $\circ$ & $\circ$ & $\circ$ & Do. \\
\hline Osmerus mordax (smelt) $\ldots \ldots \ldots \ldots \ldots$ & 0.02 & 0.5 & 0.2 & 0.2 & 0.4 & $\circ$ & Do. \\
\hline Paralichthys dentatus (summer flounder) .. & 0.002 & 0.2 & 0.008 & 0.1 & 0.02 & 2 & Do. \\
\hline Pleuronectus americanus (flat-fish) ....... & 0.001 & 0.2 & 0.02 & 0.05 & $\circ$ & I & Do. \\
\hline Prionotus strigatus (red sea-robin) $\quad \ldots \ldots$ & 0.001 & 0.2 & 0.002 & 0.02 & $\circ$ & 2 & Do. \\
\hline Pterophryne histrio (summer skate) ...... & 0.02 & 0.4 & 0.002 & 0.2 & 0.4 & $\circ$ & Do. \\
\hline 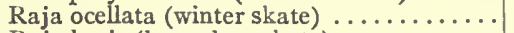 & 0.01 & 0.5 & 0.02 & 0.1 & 0 & $\mathbf{I}$ & Do. \\
\hline Raja lævis (barn-door skate)............ & 0.0001 & 0.5 & 0.05 & 0.2 & 0.5 & $\mathbf{I}$ & Do. \\
\hline Pomatomus saltatrix (blue-tish) ......... & 0.002 & 0.5 & 0.004 & 0.2 & 0.02 & o & Do. \\
\hline 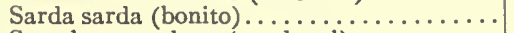 & 0.01 & I & 0.5 & 0.5 & $\circ$ & I & Do. \\
\hline Scomber scombrus (mackerel) $\ldots \ldots \ldots \ldots$ & 0.02 & I & 0.6 & 0.5 & $\circ$ & o & Do. \\
\hline Siphostoma fuscum (pipe-fish) . ........ & 0.02 & $\mathbf{I}$ & 0.1 & 0.5 & 0.2 & $\circ$ & Do. \\
\hline Spheroides maculatus (puffer) .......... & $\circ$ & 4 & 0 & 0.2 & $\circ$ & $\circ$ & Do. \\
\hline Stenotomus chrysops (scup)............. & 0.2 & 0.5 & 0.001 & 0.1 & 0.01 & I & Do. \\
\hline Tautogolabrus adspersus (cunner) ...... & 0.05 & $\mathbf{I}$ & 0.002 & 0.2 & 0.02 & 2 & Do. \\
\hline 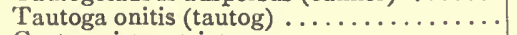 & 0.05 & I & 0.2 & 0.1 & 0.5 & $\circ$ & Do. \\
\hline Centropristes striatus . . . . . . . . . . . & 0.08 & 2 & 0.5 & 0.3 & I & 2 & Do. \\
\hline Pollachius virens (pollock) .......... & 0.2 & 0.5 & 0.5 & 0.2 & 0.5 & 2 & Do. \\
\hline 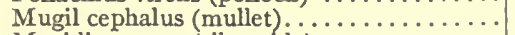 & 0.001 & 2 & 0.0005 & 0.2 & 0.02 & $\circ$ & Do. \\
\hline Menidia notata (silverside) ........... & 0.02 & 0 & 0.05 & 2 & 0.2 & $\circ$ & Do. \\
\hline Acridium americanus (grasshopper) .. & 0.05 & 2 & 2 & I & 5 & $\circ$ & No ery- \\
\hline Carcinus granulatus (green crab) $\ldots .$. & 0.05 & I & 0.1 & 2 & 0.5 & $\circ$ & throcy- \\
\hline Eupagurus longicarpus (small hermit crab) & 0.05 & I & 0.1 & I & 4 & $\circ$ & tes; leu- \\
\hline Eupagurus pollicaris (large hermit crab) ... & 0.05 & I & 0.1 & I & 4 & o & colysis \\
\hline Homarus americanus (lobster) ........ & 0.4 & 2 & 0.3 & 0.2 & 0.6 & 3 & only. \\
\hline Libinia canaliculata (spider crab) . . & 0.2 & I & 0.8 & 0.5 & 2 & 0 & Do. \\
\hline Limulus polyphemus (horseshoe crab) .. & 0.02 & I & 0.02 & 0.02 & 0.1 & 2 & Do. \\
\hline Platonychus ocellatus (lady crab) ........ & $0 . \mathrm{I}$ & ? & 0.4 & ? & ○ & o & Do. \\
\hline Lumbricus terrestris (earth worm) ....... & 10 & $\circ$ & 0 & $\circ$ & $\circ$ & $\circ$ & Do. \\
\hline Amphitrite ornata $\ldots \ldots \ldots \ldots \ldots \ldots \ldots$ & 5 & 0 & Io & o & o & $\circ$ & Do. \\
\hline Cirratulus grandis..$\ldots \ldots \ldots \ldots \ldots$ & 0.04 & $\circ$ & 0.5 & $\circ$ & I & $\circ$ & Do. \\
\hline 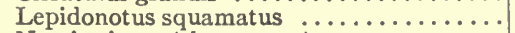 & 6 & $\circ$ & 10 & $\circ$ & $\circ$ & $\circ$ & Do. \\
\hline Nereis virens (clam worm) $\ldots \ldots \ldots \ldots$ & 5 & $\circ$ & 10 & $\circ$ & $\circ$ & $\circ$ & Do. \\
\hline Phasolosoma gouldii $\ldots \ldots \ldots \ldots \ldots \ldots$ & 5 & ○ & 0 & $\circ$ & $\circ$ & $\circ$ & Do. \\
\hline Ensatella americana (razor clam) ....... & 0.1 & $\mathbf{I}$ & 5 & 0.1 & 0 & $\circ$ & Do. \\
\hline Loligo pealii. . ..................... & 0.05 & 2 & O.I & 0.5 & 0.5 & $\circ$ & Do. \\
\hline Mactra solidissima (sea clam) ...... & 0.5 & I & 0.3 & 0.2 & $\circ$ & $\circ$ & Do. \\
\hline Modiola modiolus (mussel) $\ldots \ldots \ldots \ldots$ & 0.5 & ? & 3 & 2 & $\circ$ & $\circ$ & Do. \\
\hline Sycotypus canaliculatus (whelk, periwinkle) & 0.1 & $\mathbf{I}$ & 0.5 & 0.5 & 5 & $\circ$ & Do. \\
\hline Asteria vulgaris (common star-fish)... & 2 & ○ & 5 & 2 & 。 & o & Do. \\
\hline Arbacia punctulata (purple sea-urchin) . . & 0.005 & 2 & 0.02 & I & 0.5 & $\circ$ & Do. \\
\hline Pentacta frondosa (northern sea-cucumber) & & $?$ & 5 & $?$ & $\circ$ & $\circ$ & Do. \\
\hline
\end{tabular}




\section{SUMMARY.}

I. The lytic principles of venom for blood corpuscles are active over a wider group of animals than the agglutinative principles.

2. The more distant, as a rule, the animal groups are from the vertebrates the less the susceptibility of their blood corpuscles to venom lysins and agglutinins.

3. In one instance only-that of Sphenoides maculatus-did the blood corpuscles prove wholly insusceptible to the action of venom. This animal is, however, susceptible to the toxic action of venom, although crotalus venom produces death without causing hæmorrhage. According, therefore, to the view of the constitution of venom held by Professor Flexner and myself, this animal is subject chiefly to the action of the neurotoxic constituent of venom.

4. Cobra venom contains the largest and crotalus venom the smallest number of hæmolytic units, while moccasin venom contains the largest number of agglutinative units for these bloods.

5. The mechanism of venom lysis in these animals is identical with that in warm-blooded animals. Complements are therefore present in all vertebrates and many, at least, invertebrate species.

6. The heat liability of the venom agglutinins and hæmolysins for coldblooded animals agrees closely with that for warm-blooded animals.

\section{EFFECTS OF SNAKE VENOMS ON THE NERVE TISSUES, OVA, AND SPERMATOZOA.}

The marked cytolytic properties of various snake venoms upon the nerve tissues, ova, and spermatozoa have already been described in detail under the heading cytolysins in snake venom and neurolysis in vitro, and I shall not repeat at this place. It suffices to say that the individual groups of these cells are affected by various venoms in various manners, depending upon the source of the materials. 


\section{CHAPTER XXIX.}

\section{EFFECTS OF`SNAKE VENOM UPON PLANTS AND THE PROCESS OF GERMINATION OF SEEDS.}

Under the heading "Cytolytic action of snake venom upon micro-organisms" the energetic destructive action of various venoms upon unicellular plants (bacteria) has already been described. Now it is of some interest to find out whether venom has any influence on the vital processes of multicellular plants. The literature on this subject is rather meager and there are only a few experiments to be referred to here.

In I854 B. J. Gilman ${ }^{1}$ inoculated several small but vigorous and perfectly healthy vegetables with the point of a lancet well charged with venom. The next day they were withered and dead. No control was made, nor were the size of the plants and the amount of venom employed stated.

In the same year Salisbury ${ }^{2}$ experimented with the venom of Crotalus adamanteus upon four young shoots of the lilac (Syringa vulgaris), a small horse-chestnut of one year's growth (Esculus hippocastamum), a corn plant (Zea may's), a sunflower plant (Helianthus annuus), and a wild cucumber vine.

Without testing the toxicity of the venom on animals, he introduced the venom into the plant, just beneath the inner bark, with the aid of the point of a pen-knife. The quantity of venom was that which adhered to the point of the instrument. No visible effect from the poison was perceptible until about 6 hours after it had been inoculated. At this time, the leares above the wound, in each case, began to wilt. The bark in the vicinity of the incision exhibited scarcely a perceptible change. 96 hours after the operations nearly all the leaf-blades in each of the plants, above the wounded part, were wilted and apparently quite dead. On the fifth day the petioles and bark above the incisions began to lose their freshness, and on the sixth day they were considerably withered. On the tenth day they began to show slight signs of recovery. On the fifteenth day new but sickly-appearing leaves began to show themselves on the lilacs, and the other plants began to show slight signs of recovery in the same way. Neither of the plants was entirely deprived of life. The edges and apices of the leaves were the parts first attacked. There was no effect on the leaves below the point of inoculation, and those on the side upon which the venom was inserted were the first to suffer.

\footnotetext{
i Quoted by Mitchell.

$2 \mathrm{~J}$. H. Salisbury. Influence of the poison of the northern rattlesnake (Crotolus durissus) on plants. Jour. of Med., 1854, XIII, 337.
} 
Weir Mitchell ${ }^{1}$ made a similar experiment in 1859 and obtained results which tend to show that the effects observed by Salisbury were caused by the mechanical injuries from the insertion of the instrument. He experimented first with active crotalus venom on four young shoots of Tradescantia, a very succulent and tender trailing plant. Each of the shoots was split half-way through, and about a third of a grain of dry, pulverized venom was dropped into the opening, which was then allowed to close on the poison. Next the plants were well watered and a drop or two allowed to fall on the line of incision. Four controls were made without venom. During a week no result was obtained. After that period two of the unvenomed shoots and one of the poisoned became sickly and gradually lost most of their leaves within the ensuing fortnight.

In his second series of experiments Mitchell employed (I) a young shoot of common bean; (2) a long flower or budding flower-stalk of medicinal colchicum, C. autumnale; (3) three branches of geranium, growing on a large and healthy plant; (4) a small succulent garden weed; (5) a young dahlia. The venom was freshly collected and had been tested for its potency on animals. The mode of introducing the venom varied according to the kind of plant, but it was accurate and reliable, the quantity of venom being one or two drops. Unfortunately some of the plants had no controls. The period of observation was three weeks, but neither in the bean, colchicum, or geranium did the leaves die or the plants suffer in any way. Mitchell, however, reserved any definite conclusion as to the effect of venom on higher plants in general.

One of the most interesting experiments is the inhibiting influence of crotalus venom upon germination of seeds of certain plants. Mitchell placed a number of the seeds of canary and mignonette in venom solution (I or 0.5 drop of fresh venom to 8 drops of water) and in plain water. None of the seeds in the venom solution germinated, while germination took place in plain water under otherwise similar circumstances.

C. Darwin ${ }^{2}$ observed that $0.015 \mathrm{gm}$. of cobra venom dissolved in 8 c.c. of water acted powerfully on Drosera. A minute drop on a small pin's head acted energetically on several glands, more powerfully than the fresh poison from a viper's fang. Three leaves were immersed in 90 minims of the solution; the tentacles soon became inflated and the glands quite white, as if they had been placed in boiling water. After 8 hours' immersion they were taken out and placed in a fresh lot of water, and after about 48 hours re-expanded, showing that they were by no means dead.

1 Weir Mitchell. Smithsonian Contr. to Knowledge, I86r, Washington, D. C.

2 Quoted by Brunton and Fayrer. Proc. Roy. Soc., 1875, 273. 


\section{CHAPTER XXX.}

\section{THE TREATMENT OF SNAKE BITE.}

\section{NON-SPECIFIC TREATMENT - IMMEDIATE LIGATURE AND DISSECTION.}

In order to prevent the absorption of the venom a ligature should immediately be placed on the limb above the point bitten. It must be applied where there is only one bone and not on the forearm or lower leg, and must be tight. A stout India-rubber band is very suitable for this purpose, but in ordinary circumstances only part of the clothing would be available and answer quite well, a stick being passed under the ligature and twisted.

The value of the ligature differs according to the nature of the venom. Should the venom contain fibrin ferment, as in Daboia, Echis carinata, Notechis scutatus, and Pseudechis porphyriacus, the benefit of the ligature is very great. In these cases the ligature prevents the absorption of the venom and brings about intravascular thrombosis throughout the peripheral vessels into which the venom enters. There is then no further absorption of venom into the circulation, and upon the removal of the ligature no general venomtoxication follows. Martin established this interesting and important fact upon animals.

On the other hand, the ligature has no more advantage in most colubrine venom-poisoning than to prevent the absorption of the venom mechanically. As soon as the ligature is removed the usual venom poisoning sets in, and the ligature can never be left for longer than 30 minutes without danger, lest the entire limb undergo gangrenous mortification. In that case, the destruction of the venom deposited locally must promptly be commenced by means of certain chemical agents, such as potassium permanganate, chlorides of gold and calcium, and others.

There is another way of preventing the absorption of the venom, that is, dissection of the bitten locality. Wall recommends careful and deep dissection with the knife of all parts likely to contain the poison. The dissection must be free in all directions, especially so in the direction of the lymphatics and venous return. In the case of the fingers, hand, and such parts it should be carried clear down to the bone. After this free and careful dissection the wound should be freely washed out with a strong solution of potash permanganate.

Martin and Lamb call attention to the danger which would arise from the injection of chloride of gold or chloride calcium, as these solutions are liable to attack the least resistant tissues instead of following the venom, and would produce a nasty slough. These authors believe that the washing of the punctures with any reagent is futile and that the application of any destructive agent to an incision through wounds is almost useless, because the exact site of the venom deposited is extremely difficult to strike in this way.

To suck the wounds is absolutely useless. 


\section{LOCAL TREATMENT.}

Local treatment of the place of the snake bite is of great importance and should never be neglected, no matter whether the therapeutic agent be a nonspecific or a specific. The retardation of the venom by means of a timely ligature above the point of the wound is first to be resorted to, and immediately afterwards the fang punctures must be freely and widely incised in order to facilitate the closer contact of a chosen reagent with the venom in situ. Meanwhile, the solution of the antidotal reagent is to be injected intramuscularly in such manner that the solution will besiege the venom in the spot, and any attempt of the latter to escape and be absorbed into the system will necessarily meet with the destructive reagent. Of course certain reagents - non-specific as they are - are much more promptly diffusible than the venom and have a better chance to reach the venom even when the former are injected somewhat distantly from the wound. Notwithstanding numerous experiments, we are to-day in a position to choose for the local treatment only certain reagents which are comparatively less destructive to the tissues than others. In the following I describe some whose usefulness has been fairly established. The chemicals which destroy venom are numerous, but most of them can not be used for local treatment on account of their injurious action on the tissues themselves.

As to the local treatment with specific agents, namely, the specific antivenins, it must be remembered that certain snake venoms, such as the viperine and crotaline, are enormously destructive to the local tissues, and it is but rational to inject the antivenin at and around the point of the wound. This does not mean that the intravenous injection of the antivenin can be neglected; on the contrary, the injections should be made both intravenously as well as locally. Even in the case of colubrine poisoning local treatment with the antivenin must be resorted to, especially when the case comes under treatment soon after the incident. Naturally here the intravenous injection deserves the primary attention.

It would be of great value to use non-specific and specific agents in combination, should the patient come early under observation. In such case the non-specific chemicals must be applied closer to the bitten place and the antivenin should be applied somewhat distantly from the point of the injection of the solution of the non-specifics, in order to avoid the destructive action of the chemical upon the antivenin. Here it is understood that the antivenin is also to be given intravenously.

\section{POTASSIUM PERMANGANATE.}

Early in I860 S. Weir Mitchell made thorough studies on the effect of various chemicals upon the toxic properties of rattlesnake venom and found numerous agents capable of depriving the venom of its fatal activity. The first experiments on the use of permanganate of potash as an antidote were, however, made by Fayrer ${ }^{1}$ in 1869 , both by local application. and by intravenous injections, but without satisfactory results.

1 Fayrer. The Thanatophidia of India, 1872, p. 95. London. 
Winter Blyth ${ }^{1}$ showed that cobra venom becomes innocuous when it is mixed with potassium permanganate in vitro.

Couty and Lacerda,${ }^{2}$ in I88I, made a number of experiments upon the effect of permanganate of potash on snake venom (Lachesis) and found that this substance not only destroyed the lethal action of the venom when mixed with it in vitro, but also preserved life when a I per cent solution was injected into the tissues close to the place where the venom had been previously injected, and also where venom and antidote were injected directly into the vein.

Vincent Richards, also in I88I, similarly showed that the cobra venom is destroyed by permanganate of potash in vitro, so that death does not follow the injection of the mixture. But after the development of the poisoning symptoms no beneficial effect was to be had from the injection of this chemical.

In 1902 Brunton devised an instrument by which the bitten person himself can at once apply potassium permanganate to the place of snake bite. The instrument consists of two principal parts, one for opening the wound by incision and the other for holding a quantity of crystals of potassium permanganate. The first is a fine steel lancet and the latter is a hollow excavation in the opposite end of the wooden handle, to which the lancet is also fastened at the other end. Each of these main parts of the instrument is covered with a wooden cap.

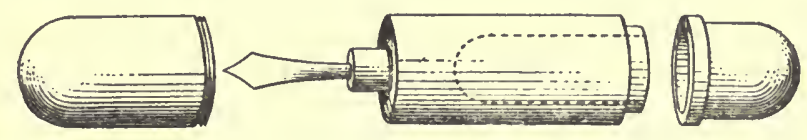

FIG. 16.

In an emergency the limb on which the bite occurred must be ligated with a tight bandage and the puncture of the fangs must be at once opened by free incision, when the crystals of the permanganate are to be applied - a few drops of saliva for facilitating its solution may be used - to the wound, and rubbed in it thoroughly.

\section{Experimental Merit of the Treatment: ${ }^{3}$}

Leonard Rogers made a series of very instructive and thorough experiments to determine if potassium permanganate can nullify the toxic effects of various kinds of snake venom on certain animals and thus prevent deatl. A ligature was simultaneously applied to the bitten limb. Rogers summarizes his results as follows: The venoms tested were these of Cobra, Daboia russellii, Crotalus terrificus (the pit viper), African puff adder, Bungarus

\footnotetext{
1 Winter Blyth. The poison of cobra. The Analyst, 1877, 204,

2 Couty and Lacerda. C. R. Acad. Sci., I881, XCII, 465. Also, Lacerda. C. R. Acad. Sci., I882, XCIII, 466: O veneno ophidico e seus antidotos. Rio de Janeiro, 1881 .

3 Brunton, Fayrer, and Rogers. Experiments on a method of preventing death from snake bite capable of common and easy practical application. Proc. Roy. Soc., London, 1904, LXXIII, 323.
} 
fasciatus, and Enhydrina valakadien. In the case of each to or more lethal doses were neutralized by very small quantities of permanganate in solution (Io per cent), and in most of them 20 lethal doses were readily rendered harmless. This salt will neutralize about its own weight of the venom and is effective against every class of snake venom.

After the injection of the venom the ligature is to be applied to the limb for 30 seconds to ro minutes, the release occurring in from 2 to 3.5 minutes.

The results with rabbits were very encouraging, but better results were obtained with the experiments on cats.

\section{Practical Merit of the Treatment :}

The practical value of the potassium permanganate treatment on human subjects may be very great. Rogers ${ }^{1}$ has already reported ${ }^{7} 7$ cases of snake bite in India in which this local treatment has been resorted to. The results recorded by him show that only 2 out of 17 cases ended fatally. In these cases nothing definite about the quantities of venom injected by the snakes could be learned, hence no conclusion can be drawn as to the absolute efficacy of potassium permanganate. It seems, however, that this salt has done much in averting death, as evidenced by the small mortality of cases thus treated in comparison with the deaths usually following the bites of these deadly Indian serpents where this treatment is not used.

The table given by Rogers presents many interesting facts and it is given here for those interested in scrutinizing various points concerning the cases of snake bite in human subjects (table 42 ).

TABLE 42.

\begin{tabular}{|c|c|c|c|c|c|c|c|}
\hline Sex. & Age. & Snake. & $\begin{array}{l}\text { Fang } \\
\text { marks. }\end{array}$ & Site of bite. & $\begin{array}{c}\text { Time of } \\
\text { treatment. }\end{array}$ & Time bitten. & Result. \\
\hline $\begin{array}{l}\text { Male } \\
\text { Male } \\
\text { Female } \\
\text { Female } \\
\text { Male } \\
\text { Male } \\
\text { Female } \\
\text { Male } \\
\text { Female } \\
\text { Female } \\
\text { Male } \\
\text { Female }\end{array}$ & $\begin{array}{l}\text { Ad. } \\
30 \\
40 \\
\text { Ad. } \\
\text { Ad. } \\
\text { Ad. } \\
\text { Ad. } \\
\text { Ad } \\
35 \\
\text { Ch. } \\
\text { Ad. } \\
\text { Ad. }\end{array}$ & $\begin{array}{l}\text { Daboia }{ }^{1} \\
\text { Cobra } 1 \\
\text { Cobra }^{1} \\
\text { Daboia } 1 \\
\text { Daboia } 1 \\
\text { Daboia } 1 \\
\text { Daboia } 1 \\
\text { Daboia } 1 \\
\text { Cobra (seen) }{ }^{2} \\
\text { ? } 2 \\
? 2 \\
? 2\end{array}$ & $\begin{array}{r}? 6 \\
2 \\
\ldots \\
2 \\
2 \\
\cdots \\
2 \\
2 \\
2 \\
1 \\
2 \\
\ldots\end{array}$ & $\begin{array}{l}\text { Arm } \\
\text { Foot } \\
\text { Forearm } \\
\text { Foot } \\
\text { Toe } \\
\text { ? } \\
\text { Foot } \\
\text { Foot } \\
\text { Finger } \\
\text { Finger } \\
\text { Foot }\end{array}$ & $\begin{array}{l}\text { At once } \\
30 \mathrm{mins} \\
\text { I } \mathrm{hrs} . \\
30 \text { mins. } \\
45 \text { mins. } \\
\text { At once } \\
4 \mathrm{hrs} \text {. } \\
\text { I hr. } \\
30 \text { mins. } \\
\text { At once } \\
\text { Soon } \\
9 \text { hrs. }\end{array}$ & $\begin{array}{l}\text { Day } \\
\text { Evening } \\
\text { Midnight } \\
\text { Morning } \\
\text { O.M. } \\
\text { Day } \\
\text { ? } \\
\text { Afternoon } \\
\text { Io A.M. } \\
\text { Noon } \\
\text { ro P.M. } \\
\text { 3 A.M. }\end{array}$ & $\begin{array}{c}\text { Recovered. } \\
\text { Do. } \\
\text { Died. } \\
\text { Recovered. } \\
\text { Do. } \\
\text { Do. } \\
\text { Do. } \\
\text { Do. } \\
\text { Do. } \\
\text { Do. } \\
\text { Do. } \\
\text { Died. }\end{array}$ \\
\hline
\end{tabular}

1 Killed and identified.

2 Snake not killed.

Several cases of snake bites have lately been successfully treated by the same method, but I deem it superfluous to record them at this place.

\footnotetext{
1 Rogers. Five cases of snake bite successfully treated by the local application of permanganate of potash. Indian Med. Gazette, I905, XL, 4I. Twelve cases of snake bite treated by incision and application of permanganate of potash with ten recoveries. Indian Med. Gazette, I905, XL, 369 .
} 


\section{CHLORIDE OF GOLD, HYPOCHLORITES OF ALKALIES AND CHLORIDE OF CALCIUM.}

As energetic destroyers of snake venom in loco, chloride of gold, hypochlorites of alkalies, and chloride of calcium have been recommended by Calmette ${ }^{1}$ for local treatment of snake bites. If promptly injected I per cent solution of chloride of gold and hypochlorites of alkalies can destroy the activity of various snake venoms and save the animals from death. These reagents have the advantage over many other venom-destroying chemicals of being less caustic on the tissues into which they are injected. ${ }^{2}$

Chloride of calcium, freshly dissolved in a ratio of $2 \mathrm{gm}$. per Ioo c.c. of water, and having the titration of 90 c.c. of gaseous chlorine per $100 \mathrm{gm}$., is most highly recommended by Calmette. Owing to the easy diffusibility of chlorine gas to a considerable distance from the spot of injection the venom is quickly destroyed by the lime solution, even after absorption commences.

The simultaneous application of an elastic ligature is also recommended.

Certain acids seem to have more or less pronounced destructive action upon snake venom. Kaufmann ${ }^{3}$ recommends the local application of chromic acid - in I per cent solution - for the purpose of postponing the lethal effect of venom. The local irritating properties are completely destroyed by this reagent, but not the toxic properties.

The early work of Weir Mitchell also indicates the destructive action of certain acids upon the hæmorrhagic principles of crotalus venom, although he did not recommend the acid as a practical means of combating the effects of the venom.

Recently Morgenroth found that guinea-pigs which had received some lethal doses of crotalus venom into the peritoneum can be saved from death by prompt injection of dilute hydrochloric acid. I was able to confirm this phenomenon. But how much benefit can be derived from the acid treatment in the subcutaneous venom-poisoning remains to be seen.

\section{GENERAL MEDICAMENTATION.}

Fayrer and Brunton recommended the administration of strychnine as a means of prolonging the life of the bitten person. This notion is derived from their experiments on the beneficial effect of artificial respiration on snake poisoning, when strychnine, as a cardiac and respiratory stimulant, was thus introduced. Feoktistow as well as Aron failed to discover any curative influence either by the artificial respiration or the injection of strychnine. Aron also tested the effect of atropin and caffein without obtaining any beneficial result. Feoktistow thinks that the use of strychnine and caffein should be forbidden because of the danger of increasing hæmorrhage through the rise

\footnotetext{
1 Calmette. Contribution à l'étude du venin des serpents. Ann. Institut Pasteur, 1894, VIII, 275; also, Les venins. Paris, 1907.

${ }_{2}$ Martin and Lamb state the danger of slough from the injections of these chemicals.

3 Kaufmann. Sur le venin de vipère. Bull. Soc. Centr. de Méd. vet. Par., 1889, n. s., VI, I87. C. R. Soc. Biol., 1894, 10 ser., I, I13.
} 
of blood pressure. In America some cases were reported where strychnine and brandy had been given with success, although no therapeutic value of this substance could be confirmed in these cases. According to Elliot, strychnine has no stimulating action upon the cases where the patients are in an aphasic state.

Raston Huxtable ${ }^{1}$ collected 426 cases of snake bite, of which II 3 were treated with strychnine, with I5 cases of death, a mortality of I8.2 per cent, while 313 without strychnine resulted in 13 cases of death, the mortality being only 2.4 per cent.

Although Fontana rejected it as quite worthless, ammonia enjoyed much reputation as an antidote against snake bite for many years without, however, any definite experimental verification. The strongest advocate of ammonia as an antidote against venom poisoning was Halford, who recommended the injection of 1o to 40 drops (diluted with 2 to 3 parts of water) of ammonia into the vein in all cases of snake bite. Yet the injection of ammonia is by no means harmless, but is often followed by serious complications, such as phlebitis, perivascular necrosis, etc. Experimentally ammonia is entirely powerless to delay the usual course of toxication with venom. There may still be certain physicians who adhere to this worthless traditional ammonia treatment, but its practice should be discontinued.

Alcohol, in the forms of wine, whisky, and brandy, has been freely administered by physicians, perhaps partly encouraged by the popular belief ascribing certain cases of recoveries of snake bite to their use, although there is no solid foundation whatever for this notion. Certain investigators recommended the use of alcoholic beverages with the supposition that the absorbed venom is partly secreted from the stomach and this can be precipitated by the alcohol before its reabsorption. But, as we all now know from experiment, alcohol precipitates but does not impair the toxic properties of the venom, hence alcohol administered per os can have no value as an antidote. Indeed, it was shown long ago by Mitchell and Reichert that in animal experimentation, at least, alcohol has a distinctly injurious influence and quickens death from venom-toxication. It is, therefore, not advisable to prescribe whisky or brandy in the cases of snake poisoning. It is certainly harmful to give alcohol in any excessive quantity.

Certain diaphoretics, e.g., Folia jaborandi and philocaspin, have also been recommended with the view of eliminating venom, but in reality such would be of no avail. In some cases, where alcohol was given, stomach-irrigation was practised with the hope of removing the precipitated venom.

In the case of violent excitement, potassium bromide, morphia, and other narcotics have often been used.

Rogers recommends the administration of adrenalin chloride in the case of bites from Daboia and those snakes the poisons of which have a marked paralytic action on the vasomotor center.

${ }^{1}$ Huxtable. Transaction of Third Intercolonial Congress, 1892, 152 . 


\section{CERTAIN ALLEGED ANTIDOTES FOR SNAKE POISONING.}

It would be purposeless to enumerate at this place all snake remedies, popularly credited as such, and I shall describe only a limited number of the antidotes most frequently referred to. None of these are warranted as to their antidotal value.

The best known, guaco or huaco, also known as herba de cobra or yerba capitana, is a syntherea with strong aromatic perfume and is found in Colombia and other parts of tropical South America. Its proper name is Mikania guaco Humb. et Bonnpl. Its leaves are well decocted and administered internally as well as locally. It is also inoculated for prophylactic purposes against snake bite. Chambers failed to obtain any protective action of guaco against the venom of Vipera arietans on rabbits. Another reputed plant remedy is Simaba cedron, the nuts of which are also believed by the South American natives to be antidotal. In the West Indies, the roots of Dorstenia contrayerva and Chicocecca anguifuga are also reputed to be valuable as antidotes.

In North America the roots of Aristolochia serpentaria and Polygala senega or Euphorbia prostrata, the swallow-root of Arizona, are often used internally and externally in the case of rattlesnake bite.

Among the East Indian vegetables the roots of Ophiorohiza mungos and many varieties of Aristolochia, and the wood of Strychnos colubrina and Ophioxylon, are the best known.

Olive oil and sugar-cane juice are also employed. Ruta graveolens and Dictamnus albus are popularly supposed in Europe to be antidotal, but in reality are not at all so when experimentally tested. Various ethereal oils, namely the essences of camilla, peppermint, thyamin, and baldria, are equally inactive.

Among certain composite antidotes Bibron's antidote and Tanjora pills may be mentioned. 'The former consists of potassium iodide, mercuric chloride, and bromine water, while the latter contains chiefly arsenic acid. Mitchell found Bibron's antidote worthless, while Fayrer did not discover any efficacy in the Tanjora pills.

Psychic treatment is also in practice among the East Indians (though they believe it a real antidote), in the form of snake stones. The snake stone is obtained from the stomach (?) of cobra and is the concrement known as bezoare. The round concretion of cinerated acorn and a dark achatstone are also among the Indian snake stones. These are applied locally to the place of the bite. The cinerated acorn or achatstone may absorb some of the venom, but never any considerable amount. Thus, the snake stones can have no real curative value except certain psychic effect upon the superstitious natives. 'The alleged cases of successful treatment of snake bite with snake stones must have been cases which would have recovered without the stone treatment. 


\section{SPECIFIC TREATMENT.}

The most rational treatment of snake poisoning is by specific antivenins. That the action of antivenin is highly specific has been related under the chapters concerning antivenin. The therapeutic value of antivenin is also discussed at length, and we may duly hope that in the near future specific antivenins of higher potency for the most deadly venoms will be produced and placed in the hands of practitioners in the countries where accidents and death from venomous serpents are frequent.

Up to the present time a polyvalent antivenin is not sufficiently strong to be of much practical use, and it would be necessary to employ various monovalent specific antivenins for the cases indicated. There are, at the least, several available antivenins for practical purposes, as follows: Cobra antivenin, Daboia antivenin (issued from the Pasteur Institute, India), Notechis antivenin (Tidswell, Australia), Lachesis antivenin (Brazil,) Crotalus antivenin and Moccasin antivenin (Rockefeller Institute, New York). A seventh is another Lachesis antivenin (Trimeresurus antivenin) and may be gotten from the Institute for Infectious Diseases, Tokio.

Besides these monovalent antivenins there is a polyvalent antivenin prepared by Calmette at the Pasteur Institute, Lille, although its action is more pronounced against cobra venom than the other venoms.

As Martin and Lamb rightly pointed out, the antitoxic powers of all these antivenins are still feeble and are far from being satisfactory for practical purposes. But, as I have stated elsewhere, the amounts of venom introduced into the body by the bite are extremely variable, and death may occur in certain instances as the result of a small excess over the quantity which by itself is insufficient to be fatal. Here antivenins are of immense service in averting death by neutralizing that excess. The excess may again be very variable, but there must be a range of doses by which the antivenins, however feeble they may be, can prevent the venom from reaching the vital organs of the organism. Remembering that the antivenins are the only agents that can neutralize the venom after the absorption of the latter into the general system, we are amply justified in injecting as large a dose of antivenin as practicable in every case of snake bite and, indeed, no practitioner would be justified in hesitating to use this specific agent freely simply because of the comparatively low antitoxic value which our present preparations of antivenins possess.

To my mind there can be no room for the slightest doubt as to the great service that antivenin has rendered towards saving the unfortunate victims of snake poisoning from certain death. In many instances the cases of recovery might have been due to the shortage of amount of venom introduced, but equally as many cases must have been due to the removal of the excess of the venom by the use of antivenin. The cases of death in spite of the injection of antivenin are the instances where the excess of the venom has been more than the employed dose of antivenin could neutralize. 
For these obvious reasons I earnestly caution practitioners not to view the future of the antivenin therapy of snake bite in a gloomy light. All therapeutic experiments on animals point to the high curative property of antivenins, and this is especially marked in the cases of crotalus antivenin and ancistrodon antivenin.

Enough has been said to uphold the practical value of antivenins, and it now remains to give the rules for administering these specific antidotes:

(I) The injection should be made as soon after the bite as possible.

(2) The injections should be made both intravenously and locally. In the latter the intramuscular as well as subcutaneous injections should be made somewhat distant from the incised wounds of the fang punctures. Here I per cent solution of potassium permanganate should be injected at and around the point of the bite, and the antivenin introduced somewhat remote from the chemical.

(3) With the present preparations of antivenins a quantity, at least, of roo c.c. should be injected into the vein and also as much into the bitten limb or parts of the body as will be absorbed by the tissues. The injections there may be made not at one spot, but at several places surrounding the entire circumference, for example, of the limb involved.

Where specific antivenins are employed general medicamentation becomes entirely superfluous and any excessive use of alcohol is decidedly objectionable.

A decidedly favorable report has recently been made by Kitashima on the antivenin treatment of Habu poisoning in man. Antihabu serum has been tried upon a number of cases in Anami, Oshima, and Riu kiu since 1905. In most cases the serum has been gratuitously distributed among the practitioners of the islands. The neutralizing power of the antivenin was such as 1o c.c. of it will render o.I gram ${ }^{1}$ (dry weight) of the habu venom completely inactive when mixed in vitro and allowed to act during 30 minutes at $37^{\circ} \mathrm{C}$. At present 40 c.c. of this antivenin are put in a bottle as a curative dose for one case. In a chronic case, twice or more is used. The injection is made near the bite, which is incised slightly, washed and dressed in the usual manner. II 5 cases were treated with the antivenin, of whom 5 died, making a death rate of 4.2 per cent. One patient was brought in 3 hours after the bite and died in a few minutes after receiving the antivenin. Kitashima states that if the antivenin is given immediately after the bite, swelling only makes its appearance, with only the slightest phenomena of toxication. In ordinary cases general symptoms, such as vomiting, colic, and pain soon disappear. Pain at the site of the bite also decreases in 2 to 3 hours and the swelling subsides after serum treatment.

In the future when I c.c. of antivenin may become so active as to neutralize, for example, $0.0 \mathrm{Igm}$. of venom or even more, the incision or dissection may be abandoned and the non-specific venom-destroyers, such as permanganate of potash and certain chlorides, may also become superfluous.

\footnotetext{
A habu discharges, under natural circumstances, 0.3 to 0.5 c.c. of venom, equaling about 0.1 gram
} of the dried venom. 
Of course, these measures - incision, dissection, and chemical destruction of venom - are chiefly for instant use and are easily practised by the person bitten, so that their value remains almost unaffected by the improvement of the antivenins.

In conclusion, it may once more be emphasized that the ligature must always be placed immediately after the bite. 


\section{BIBLIOGRAPHY.}

Abderhalden (E.) and Le Count (E. R.) Die Beziehungen zwischen Cholesterin, Lecithin und Cobragift, Tetanusgift, Saponin und Solanin. Zeitschr. f. exp. Path. und Therapie, 1905, II, I99-2I 5 .

À Beckett (W.) Injection of ammonia in snake poisoning. Austral. M. J., I868, XIII, 390392.

Albertoni (P.) Sull' azione del veleno della vipera. Sperimentale, I879, XLIV, I42-I 53.

Alcock (A.) and Rogers (L.) On the toxic properties of the saliva of certain "non-poisonous" colubrines. Proc. Roy. Soc. Lond., I902, LXX, 446-454.

Alt (K.) Ueber die Ausscheidung des Schlangengiftes durch den Magen. Münch. med. Wochenschr., I892, XXXIX, 724-728.

Andrews (0. W.) On the preparation and use of Calmette's antivenene. Brit. Med. Jour., I 899, II, 660.

Arrhénius (Svante) Hämolytische Versuche. Biochem. Zeitschrift, I908, XI, I6r.

Auché (B.) Note sur un cas de foyers nécrotiques du foie dans l'envenimation. Journal de méd. de Bordeaux, 1903, XXXIII, 69-7 I.

Badaloni (G.) Sul valore del permanganato di potassa quale antidoto del veleno dei serpenti (ofidi). Bull. d. sc. med. di Bologna, I 882 , 6. S., IX, 5-I9.

Baker (T. E.) Treatment of snake bites. India J. M. and Phys. Sc., I 836 , n. S., I, 493.

Bancroft (T. L.) Some further observations on the physiological action of snake venom, together with a reference to the strychnine cure of snake bite. Australian Med. Gaz., I894, XIII, 228-230.

Bang (Ivar) Kobragift und Hämolyse. I. Bioch. Zeitschrift, I908, XI, 52 I-537.

Baron. Des serpents à sonnettes, de leur morsure, des effets qu'elle produit et des moyens d'y remédier. Clin. d. hôp. et de la ville, $1827, I, N o .57,2-4$.

Barrett (J. W.) The action of snake venom on the blood. Lancet, I 894 , II, 347 .

Bartlett (C. R.) Curious habit of the African cobra (Naja haje). Conjunctivitis from snake poison. Jour. Roy. Arm. Med. Corps, I904, III, 360.

Berncastle (J.) Australian snake bites, their treatment and cure. Melbourne, I868, 3 I p. I $2^{\circ}$. - On the distinction between the harmless and venomous snakes of Australia. Austral. M. Gaz., I8 70, II, 2 I.

Bertholdo. La sieraterapia nella morsicatura di serpenti velenosi. Corriere san., Milano, I $898, \mathrm{IX}, 516$

Binz (C.) Ueber indisches Schlangengift. Sitzungsber. d. Nied.-rhein. Ges. f. Nat.- u Heilk. zu Bonn, I882, IV, I69-I7I.

Bland (W.) Bites of the venomous snakes of Australia. Austral. M. J., I861, VI, I-6.

Blyth (A. W.) Poison of the cobra de capello. Analyst, London, 1877, I, 204.

Bories (E.) Rattlesnake poisoning treated by potassium permanganate. Polyclinic, Phila., I $883, \mathrm{I}, 57$.
Boulenger (G. A.) Catalogue of snakes in the British Museum, London, $1893-96.3$ v. $8^{\circ}$.

Brazil (Vital) A serumtherapie do ophidismo em relação á distribuição geographica das serpentes. Revista medica de S. Paulo, I 907 , $\mathrm{X}, 196$.

___ Das globulinas e serinas dos seruns antitoxicos. Idem, I907, X, 368 .

Dosagem do valor anti-toxico dos seruns anti-peçonhentos. Idem, I907, X, 457.

- Serum anti-ophidico. Brazil-med., Rio de Jan., I903, XVII, 384 .

Contribution à l'étude de l'intoxication d'origine ophidienne. Paris, A. Maloine, I 905.26 p. $8^{\circ}$.

Breton (P.) Case of the fatal effects of the bite of a venomous snake. Tr. M. and Phys. Soc., Calcutta, $1825, I, 55-58$.

Briot (A.) Sur l'existence d'un kinase dans le venin de la vive (Trachinus graco). C. $R$. Soc. biol., I904, LVI, I II 3-III4.

Brunton (T. L.) Remarks on snake venom and its antidotes. British Medical Journal, I89r, I, $I-3$.

Brunton (T. L.) and Fayrer (J.) On the nature and physiological action of the poison of Naja tripudians and other Indian venomous snakes. Part I. Proc. Roy. Soc. Lond., I872-3, XXI, 358-374; I873-4, XXII, 68-r33. Rep. on san. improv. in India, $1872-3$, London, 1873 , 275-283. Part II. Rep. on san. improv. in India, $1873-4$, London, $1874,332-362$.

On the nature and physiological action of the Crotalus poison as compared with that of Naja tripudians and other Indian venomous snakes; also, investigations into the nature of the influence of $\mathrm{Naja}$ and Crotalus poison on ciliary and amoboid action, and on vallisneria, and on the influence of inspiration of pure oxygen on poisoned animals. Proc. Roy. Soc. Lond., I $874-5$, XXIII, 26 I-278.

Note on the effect of various substances in destroying the activity of cobra poison. Proc. Roy. Soc. Lond., I878, XXVII, 465-474.

and Rogers (L.) A method of preventing death from snake bite, capable of common and easy practical application. Indian Med. Gazette, I904, XXXIX, 327-333.

Calmette (A.) Etude expérimentale du venin de Naja tripudians. Ann. Institut Pasteur, I892, VI, I60-I 83 .

L'immunisation artificielle des animaux contre le venin des serpents, et la thérapeutique expérimentale des norsures venimeuses. C. R. Soc. biol., I 894 , 10. sér., I, I 20- I 26.

- Sur la toxicité clu sang de cobra capel, C. R. Soc. biol., 1894, Io. sér., I, I I-I 2 .

Propriétés du sérum des animaux immunisés contre le venin des serpents, et thérapeutique de l'envenimation. C. R. Acad. sci., 1894, CXVIII, 720-722; Atti d. xi. Cong. med. internaz., Roma, I894, II, Patol. gen. ed anat. patol., 109. 
Calmette (A.) Contribution à l'étude du venin des serpents. Ann. Institut Pasteur, I 894, VIII, 275.

Contribution à l'étude des venins. Ann. Institut Pasteur, 1895, IX, 225.

The treatment of animals poisoned with snake venom, by the injection of antivenomous serum. British Medical Journal, 1896; Lancet, i 896 , II, $449-450$.

- Le venin des serpents; physiologie de l'envenimation; traitement des morsures venimeuses par le sérum des animaux vaccinés. Paris, 1896.72 p. $8^{\circ}$.

Serpents' venom and antivenornous serum. British Medical Journal, I896, II, 1025.

- Sur le venin des serpents et sur l'emploi du sérum antivenimeux dans la thérapeutique des morsures venimeuses chez l'homme et chez les animaux. Ann. Institut Pasteur, I897, XI, 2 I 4.

_- Sur le mécanisme de l'immunisation contre le venin. Ann. Institut Pasteur, 1898 , XII, 343-347; Presse médicale, I898, I, I9I; Ann. d'hygiène et de méd. colon., Paris, I 898 , I, I 29

On curative power of the antivenomous serum. British Medical Journal, I 898, I, 1253; Intercolonial Medical Journal of Australasia, I 898 , III, I 92.

- Les sérums antivenimeux polyvalents; mesure de leur activité. C. R. Acad. sci., 1904, CXXXVIII, 1079-1082.

- Sur l'action hémolytique du venin de cobra. C. R. Acad. sci., 1902, CXXXIV, 1446-I 447 .

and Délarde Sur les toxines non-microbiennes et le mécanisme de l'immunité par les sérums antitoxiques. Ann. Institut Pasteur, I $896, \mathrm{X}, 675$.

- and Massol (L.) Relations entre le venin de cobra et son antitoxine. Ann. Institut Pasteur, I907, XXI, 929-945.

Choudhroi (L.N.) Report of a genuine case of viper bite in a dog treated with permanganate of potash; recovery. Indian Med. Gazette, $1905, \mathrm{XL}, 400$.

Cloitre (J.) Note sur le serpent de corail en Nouvelle Calédonie. Ann. d'hyg. et de méd. colon., I905, VIII, I $3 I^{-1} 34$.

Cope (E. D.) The crocodilians, lizards, and snakes of North America. Rep. U. S. Nat. Museum, I898, I 53-I 294. Washington, I 900.

Cunningham (D. D.) The physiological action of snake venom. Sci. Mem. Medical Officers of the Army of India, I895, IX, 1 .

Cuvier (G.) Leçons d'anatomie comparée. 2. éd. Paris, $1835^{-46 .} 8$ v. $8^{\circ}$.

Ditmars (R. L.) The reptiles of the vicinity of New York City. Amer. Mus. of Natur. Iist. Amer. Museum Journal, I 905, V, 93-140. The reptile book. New York, Doubleday, Page \& Co., I907. xxxii, 472 p. $4^{\circ}$.

Dubois (R.) Sur le venin de la glande à pourpre des murex. C. R. Soc. biol., r $903, \mathrm{LV}, 8 \mathrm{r}$.

Dugès (Ant.) Recherches anatomiques et physiologiques sur la déglutition dans les reptiles. Ann. des sc, natur., I827, XII, 337-395.

Dungern (E. von) and Coca (A.F.) Ueber Hämolyse durch Schlangengift. Münch. med. Woch., 1907, LIV, 2317-2321.

U Ueber Fämolyse durch . Combinationen von ölsaurem Natrium, Ölsäure, Kieselsäure und Serum. Berlin. klin. Woch., I 908 .

Ueber Hämolyse durch Kombinationen von Oelsäure oder ölsaurem Natrium und Kobragift. Münch. med. Woch., rgo8.
Dungern (E. von) and Coca (A. F.) Ueber Hämolyse durch Schlangengift. II. Biochem. Zeitschrift, I908, XII, 407 .

Diirigen (B.) Deutschland's Amphibien und Reptilien. Magdeburg, 1897. viii, 676 p. $8^{\circ}$.

Duvernoy (G. L.) Mémoire sur les caractères tirés de l'anatomie pour distinguer les serpens venimeux des serpens non-venimeux. Annal. des sc. natur., $1832, \mathrm{XXVI}, \mathrm{I}_{3}-160$

Elliot (R. H.) An account of some researches into the nature and action of snake venom. British Med. Jour., 1900. I, 309, I 146; II, 2 I 7 . - On the value of the serums of the Russell's viper and the cobra as antidotes to the venoms of those snakes. Indian Med. Gazette, rgo I, March and April.

Abstract of a contribution to the study of the action of Indian cobra poison. Lancet, 1904, I, 7 I5-7I 6.

A contribution to the study of the action of Indian cobra poison. Proc. Roy. Soc. Lond., 1904, LXXIII, 183-190.

- Sillar (W. C.) and Carmichael (G. S.) On the action of the venom of Bungarus cœruleus. Lancet, I904, II, I42; Proc. Roy. Soc. Lond., I904, LXXIV, ro8-rog.

Emery (C.) Ueber den feineren Bau der Giftdrüse der Naja haje. Arch. f. mikroskop. Anat., I $875, \mathrm{XI}, 561-568$.

Eteson (A.) The snake-stone. Indian M. Gaz., Calcutta, I876, XI, 309-313.

Ewing (C. B.) The action of rattlesnake venom upon the bactericidal power of the blood serum. Medical Record, I894, XLV, 663-665.

Faneau-Delacour (É.) Mémoire sur la morsure des ophidiens. Ann. de la méd. phys., Paris, I 833, XXIII, 273; 399.

Faust (E. S.) Ueber das Ophiotoxin aus dem Gifte der ostindischen Brillenschlange, Cobra di capello (Naja tripudians). Leipzig, 1907. 24 p.

_ـ_ Die tierischen Gifte. Braunschweig, 1906. xiv, 248 p. $8^{\circ}$

Fayrer (J.) Experiments on the influence of snake poison and on the injection of liquor ammonix into the venous circulation as an antidote. Indian M. Gaz., I869, IV, I 29-132.

Experiments on the influence of snake poison and on the injection of certain fluids into the venous circulation, as antidotes, and on the application of the ligature and actual cautery. Indian M. Gaz., I869, IV, I 53-1 56.

Deaths from snake bites; a trial condensed from the session's report. Indian $\mathbf{M}$. Gaz., I869, IV, I 56.

Experiments on the influence of the poison of the cobra, the daboia, and the bungarus, and of certain methods of treatment. Indian M. Gaz., 1869, IV, 177 .

Experiments on the influence of snake poison, and the use of certain reputed antidotes; and the effects of excision, etc. Indian M. Gaz., 1869, IV, $201,225$.

- Experiments on the influence of snake poison on the blood of animals. Indian M. Gaz., I869, IV, 249.

Experiments on the influence of snake poison. Indian M. Gaz., 1868, III, 169, 193, 217,$241 ; 1869, I V, 3$.

On the action of the cobra poison. Edinb. Med. J., I868-9, XIV, 522-529, 915923, 996-I0Ir; 1869-70, XV, 236-248, 334$339,417-430,620-624,805-821,994-1003$, 1099-1 108; 1870-71, XVI, 48-58, 135-147, $237^{-2} 50,320-340,423-436,623-633,715^{-}$ 723, I101-I106. 
Fayrer (J.) Experiments on the influence of certain reputed antidotes for snake poison. Indian M. Gaz., Calcutta, I869, IV, 25. Experinents on snake poison. Indian Med. Gaz., I $870, \mathrm{~V}$, I I9, I40, I 58, I82, I 98 , 219, 240; I87 I, VI, 3, 24 .

Notes on deaths from snake bite in the Burdwan division. Indian Ann. M. Sc., Calcutta, I870-71, XIV, I63-I75.

- On the influence of the poison of Bungarus cœruleus or krait. Indian M. Gaz., $1870, \mathrm{~V}, \mathrm{1} 8 \mathrm{I}$.

On the immediate treatment of persons bitten by venomous snakes. Indian $\mathbf{M}$. Gaz., I 87 I, VI, 26.

- Another antidote for snake poison. Indian M. Gaz., 1871 , VI, I 74 .

Treatment of snake poisoning by artificial respiration. Indian M. Gaz., I872, VII, 218.

Experiments on the poison of the rattlesnake. Med. Times and Gaz., Lond., I873, I, 37 I.

Experiments on cobra poison and on a reputed antidote. Indian M. Gaz., I873, VIII, 6.

Snake poisoning in India. Med. Times and Gaz., I873, II, 249-25I, 492-493.

The Thanatophidia of India. 2d edition.

J. \& A. Churchill. London, 1874 . xi, I $7^{8}$ p. $\mathrm{F}^{\circ}$. The ammonia treatment of snake poisoning. Med. Times and Gaz., I 874, I, 601-602. The venomous snakes of India and the mortality caused by them. British Medical Journal, 1892, 620 .

Feoktistow (A. E.) Eine vorläufige Mittheilung über die Wirkung des Schlangengiftes auf den thierischen Organismus. Mém. d, l'Acad. imp. d. sc. de St.-Pétersbourg, I 888, 7. s., XXXVI, No. $4,22 \mathrm{p}, 4^{\circ}$.

Ferozdin Mohroof. Poisonous snakes and Calmette's serum; a successful case. Indian M. Gaz., 1904, XXXIX, 20.

Fitzgerald (F. G.) Notes of an unusual case of snake-bite. Jour. Roy. Arm. Med. Corps, I904, III, 422 .

Fletcher (R.) A study of some recent experiments in serpent venom. Am. J. M. Sc., I883, n. s., LXXXVI, I3I-I 46.

Flexner (Simon) and Noguchi (Hideyo) Snake venom in relation to hæmolysis, bacteriolysis, and toxicity. Journal of Experimental Medicine, I902, VI, 277-301; Univ. of Penn. Med. Bulletin, 1901-02, XIV, $43^{8-448 . ~}$

The constitution of snake venom and snake sera. Journal of Pathology and Bacteriology, I903, VIII, 379-410; Univ. of Penn. Med. Bulletin, I902-3, XV, 345-362. snake venom. On the plurality of cytolysins in Bacteriology, I905, X, I I I-1 24; Univ. of Penn. Med. Bulletin, I903-4, XVI, I6 $3^{-}$ I 7 I.

erties of anticrotalus venin. Journal of Medical Research, Ig04, n. s., XI, 363-376.

Francis (C. R.) On snake poison. Ind. M. Gaz., 1868, III, I 25.

Frank (B.) Chlor gegen Viperngift. Wochenschr. f. d. ges. Heilk., I $847,527-532$.

Fraser (T. R.) The rendering of animals immune against the venom of the cobra and other serpents, and on the antidotal properties of the blood serum of the immunized animals. British Med. Journal, r 895, I, I 309; Transl. in Gior. d. Accad. di med. di Torino, 1895 , 4. ser., I, 66r -664 .
Fraser (T.R.) The treatment of snake poisoning with antivenene derived from animals protected against serpents' venom. British Med. Journal, I 895 , II, 4 I6.

Address on immunization against serpents' venom and the treatment of snake bites with antivenene. British Med. Journal, 1896, I, 957 .

The limitations of the antidotal power of antivenene. British Med. Journal, I896, II, 9ro.

Bemerkung über die antitoxischen Eigenschaften der Galle der Schlangen und anderer Thiere. Wien. mediz. Blätter, I897, $\mathrm{XX}, 48 \mathrm{I}, 498$.

- The antivenomous properties of the bile of serpents and other animals. British Med. Journal, I897, I, I25; Indian Medical Record, I897, XIII, I47, I52, 39; Indian Lancet, I $898, \mathrm{~L}, \mathrm{I}$.

A note on the antivenomous qualities of the bile of serpents and other animals. British Medical Journal, I 897, II, 595.

Further note on bile as antidote to venom and disease toxins. British Medical Journal, I 898 , II, 627 .

[Professor Fraser shows a rabbit immunized against cobra poison]. Trans. Med. Chir. Soc., Edinburgh, I895, XIV, $212-$ 215 .

and Elliot (R. H.) Contributions to the study of the action of sea-snake venoms. Proc. Roy. Soc. Lond., I904, LXXIV, 104I08.

Fuhr (R. W.) Spitting snakes. J. Roy. Arm. Med. Corps, I905, IV, 540.

Gautier (A.) Sur le venin du Naja tripudians (Cobra capello) de l'Inde. Bull. Acad. de méd., Paris, I88I, 2. s., X, 947-958.

Geare (R. I.) Venomous serpents. Sci. Amer. N. Y., I903, LXXXVIII, I I8, I37, I54, I 76 ; Suppl., N. Y., 1903, LV, $22747^{-22748 .}$

Gerrard (J.) Snake poison and its alleged antidotes. Austral. M. Gaz., I870, II, 27.

Gistl (J.) Schlangen des Alterthums; ihr Gift und dessen Gegenmittel. Med. Centr.-Ztg., Berl., I $832, I, 529,545,56 \mathrm{I}$.

Gœbel (O.) Contribution à l'étude de l'agglutination par le venin de cobra. C. $\mathbf{R}$. Soc. biol., I905, LVIII, 420-42I.

- Contribution à l'étude de l'hémolyse par le venin de cobra. C. R. Soc. biol., I905, LVIII, 422-423.

Action du venin de cobra sur les trypanosomes. Ann. Soc. méd. de Gand, r9o5, LXXXV, I48-I5I.

Grandy (C. R.) Report of a case of rattlesnake bite. Virginia Med. Semi-Month., I902-3, VIII, 515-5I7.

Grant (W. T.) The rattlesnake's poison and its remedies. Georgia M. Companion, I87 I, I, 457-459.

Gratier (Marcel) La vipère en thérapeutique. [Thèse.] Paris, Igo3. 9i p. $8^{\circ}$.

Guyon (C.) Morsure du céraste ou vipère cornue. Gaz. méd. de Paris, I862, 3. sér., XVII, $7 \mathrm{I}-73$.

Halford (G. B.) On the condition of the blood after death from snake bite, as a probable clue to the further study of zymotic diseases, and of cholera especially. Melbourne, I867. 24 p. $8^{\circ}$.

24 P. 8 . the blood after death from snake bite. Brit. M. J., I 867 , II, 563 . 
Halford (G. B.) On the injection of ammonia into the circulation. Melbourne [I860] I4 p. $8^{\circ}$. - The treatment of snake bite in Victoria. Austral. M. J., I870, XV, I6I-I 76 .

Tabular list of cases of snake bite treated by the injection of liquor ammonix. Austral. M. J., I $870, \mathrm{XV}, 5$.

Du traitement des morsures de serpents venimeux par les injections intra-veineuses d'ammoniaque. Bull. gén. de thérap., Paris, I 874, LXXXVII, 258-27I.

On the effects of the injection of ammonia into the veins in cases of snake poisoning. Austral. M. J., I875, XX, 66-I 35 .

Thoughts, observations and experiments on the action of snake venom on the blood. British Med. Journal, r 894 , II, I 252.

Hallowell (E.) Remarks on the bites of venomous serpents, with cases. Tr. Coll. Phys. Phila., I 869-7o, II, 220.

Hanna (W.) and Lamb (G.) A case of cobrapoisoning treated with Calmette's antivenine. Lancet, I goI, I, 25-26.

Hardison (W. H.) Ammonia in the treatment of bites of poisonous reptiles and insects. Louisville M. News, I880, IX, 270.

Hardy (H.) Spitting snakes. J. Roy. Arm. Med. Corps, I 905 , IV, I 20.

Harlan (R.) Experiments made on the poison of the rattlesnake; in which the powers of the Hieraceum venosum, as a specific, were tested; together with some anatomical observations on this animal. Tr. Am. Phil. Soc., Phila., I828, n. s., III, 300-314.

Harwood (E.) Iodine, an antidote to the poison of the rattlesnake. Northwest. M. and S. J., Chicago, $1854-5$, n. s., XI, I 87 .

Haynes (J. R.) Experiments in animal poisons, Crotalus horridus (rattlesnake). Cincinnat. M. Advance, $1879, \mathrm{VI}, 481-487$.

Haynesworth. Some account of the success of the plant called jestisweed, in curing the disease induced by the bite of the rattlesnake, and other venomous serpents. Phila. M. and Phys. J., I808, III, 57-6r

Heinzel (L.) Zur Pathologie und Therapie der Vergiftung durch Vipernbiss. Wochenbl. d. Ztschr. d. k. k. Ges. der Aerzte in Wien, 1866, XXII, I69, I81, I93, 205, 217,229 , 240.

Heusinger. Ueber die Wirkungen des Klapperschlangenbisses. Mag. f. d. ges. Heilk., Berlin, I 822 , XII, $443-448$.

Hoffmann (C. K.) Reptilien. I 879-90. 3 v. $8^{\circ}$. (Bronn, H. G. Klassen und Ordnungen des (Tierreiches. Bd. VI, Abt. 3.)

Hopkins (W. K.) Alcohol as a remedy for the poison of the rattlesnake. Northwest. M. and S. J., Chicago, 1852-3, IX, 389-39r.

Hunter (A.) Notes on precipitins for snake venoms and snake sera. Proc. Physiol. Soc. Lond., 1905 , May 2o, p. Ixi

Hunter (W. K.) The histological appearance of the nervous system in krait and cobra poisoning. Glisgow Med. Jour., I $903, \mathrm{LIX}, 8 \mathrm{I}-08$.

Imlach (C. J. F.) Mortality from snake bites in the province of Sind; from oflicial records, with a special report on the snake season of 1854 . Tr. M. and P'hys. Soc. Bombay, I $855^{-6}$, n. s., III, 80-I 30 .

Ingalls (W.) Bite of a moccasin snake. Boston M. and S. J., $1842-3$, XXVII, 170 .

Irwin (B. J. D.) Notes on Euphorbia prostrata as an antidote to the poison of the rattlesnake. Am. J. M. Sc., Phila., I86r, n. s., XLI, 89-9I.
Ishizaka ( $\mathrm{T}$.) Studien über das Habuschlangengift. Zeitschr. f. exper. Path. u. Therapie, I907, IV, 88-II7.

Jackson (M. H.) Rattlesnake bites. South. Pract., Nashville, I879, I, 259.

Jackson (S.) Remarks on the bites of venomous serpents, with cases. Tr. Coll. Phys. Phila., $1850-53$, n. s., I, 409-4II.

Jacoby (M.) Ueber die Wirkung des Kobragiftes auf das Nervensystem. Beiträge $\mathbf{z}$. wissensch. Med. u. Chem. Festschr. Ernst Salkowski. Berlin, 1904, 199-204.

Jacolot (A. A.M.) Die Curados de Culebras, oder Impfung zum Schutze gegen den Biss giftiger Schlangen; ein auf authentischer Forschung in Mexico basierter Originalbericht. Wien. med. Woch., 1867, 731-733, 747-749.

Jenkins (G. W.) Observations on the pathology and treatment of bite of the rattlesnake. Tr. Wisconsin M. Soc., Milwaukee, 1878 , XII, 63-65.

Jordan (D. S.) Manual of the vertebrate animals in the northern United States. Chicago, I 899.397 p. $8^{\circ}$.

Jourdain (S.) Quelques observations à propos du venin des serpents. C. R. Acad. sc., I 894, CXVIII, 207-208.

Jousset (P.) Lésions produites par les venins de serpents. Arc. méd., Paris, I 899, LXXXVII, $35^{8}$.

- and Lefas. Action des venins par la voie stomacale. C. R. Soc. biol., I904, LVII, 472473 .

Kanthack (A. A.) Report on snake venom in its prophylactic relation with poisons of the same and other sorts. Rep. Med Off. Local Gov. Bd., I 895-6, London, I897, 235-266.

On the nature of cobra poison. Jour. of Physiology, 1892, XIII, 272.

Kathariner (Ludwig) Ueber den Verdauungskanal und die Wirbelzähne von Dasypeltis scabra Wagler. Zool. Jahrb., I 898, Äbt. f. Anat. u. Ontog., XI, 50I-518.

Kaufmann (M.) I.es vipères de France; morsures; traitements. Paris, I893. vi, I8o p. $8^{\circ}$.

Le traitement des morsures de serpent; lettre de M. Kaufmann. Revue scientifique, I $890, \mathrm{XLV}$, I 80-I 8 I.

Sur le venin de vipère.

C. R. Soc. biol., I 894 IO. sér., I, II 3 - II 5 .

Kelly (Howard A.) The recognition of the poisonous serpents of North America. Bull. Johns Hopkins Hospital, r899, X, 2 I 7.

Kelvington (Basil) A preliminary communication on the changes in the nerve cells after poisoning with the venom of the Australian tiger snake (Hoplocephalus curtus). Jour. of Physiology, 1902, XXVIII, 426.

Kenyon ( $\tilde{F}$. C.) The action of the venom of the Australian black-snake. American Naturalist, I 897, XXI, $245^{-248}$.

Kesteven (W. B.) Is arsenic eating prophylactic against the effects of bites of venomous reptiles? Brit. M. J., 1858 , 174 .

King (E. P.) Bite of a copperhead successfully treated by indigo. Annalist, N. Y., $1847-8$, II, 229.

Kitashima (T.) On "Habu" venom and its serum therapy. Philippine Journal of Science. B, Medical Sciences, I 908 , III, I $5 \mathrm{I}-\mathrm{I} 64$.

Kleinschmidt (C. H. A.) Case of bite by a copperhead snake. Tr. M. Soc. Dist. Columbia, I 875 , II, $54-56$

Kline (L. B.) Case of septic poisoning caused by the bite of a copperhead. M. and S. Reporter, Phila., I868, XIX, 326-327. 
Knox (R.) On the treatment of wounds inflicted by poisonous snakes. Lancet, I839-40, I, 199-203.

Koeppen. Verletzung des Hodensacks durch einen Schlangenbiss und freiwillige Castration. Wchnschr. f. d. ges. Heilk., Berlin, 1836,221 .

Kunkler (G. A.) On the bite of a copper snake. Med. Counselor, Columbus, $1855, \mathrm{I},{ }_{48} \mathrm{I}_{-4} 8_{3}$.

Kyes (P.) Ueber die Wirkungsweise des Cobragiftes. Berl. klin. Woch., rgo2, XXXIX, 886,918 .

- Ueber die Isolierung von SchlangengiftLecithiden. Berlin. klin. Woch., I903, XL, 956-959; 982-984.

Cobragift und Antitoxin. Berl. klin. Woch., I904, XLI, 494-497.

Lecithin und Schlangengifte. Zeitschr.f. physiol. Chem., I904, XLI, 273-277.

Bemerkungen über die Lecithidbildung. Biochem. Zeitschr., I908, VIII, 42.

- and Sachs (H.) Zur Kenntniss der Cobragift activirenden Substanzen. Berl. klin. Woch., 1903, XL, $2 \mathrm{I}-23,57,82$.

Labesse (P.) Les pierres à serpents. Anjou méd., Angers, I905, XII, 56-62.

Lacerda (J. B. de) Venin des serpents. C. R. Acad. sc., Paris, I878, LXXXVII, I093I095.

O permanganato de potassa como anti doto da peçonha das cobras. União med., Rio de Jan., I88I, I, 514, 56 I.

- Sur-le permanganate de potasse comme antidote du venin de serpent. C. R. Acad. sc., I88I, LXXXIII, 466- 468 .

A acção do alcool e do chloral sobre o veneno ophidico. Uniāo med., Rio de Jan., I 882, II, 76-83, I09-I I 6 .

Lacombe (A.) Bites of rattle and other poisonous snakes treated in Venezuela. Boston M. and S. J., I85I, XLIV, 289-292.

Lallemant (C.) Erpétologie de l'Algérie. Gaz. méd. de l'Algérie, I866, XI, I9, 3I, 47, 64, $8 \mathrm{I}, 99, \mathrm{I} 28$.

Lamb (George) On the action of snake venom on the coagulability of the blood. Indian Med. Gaz., I 901 , XXXVI, 443-447.

- On the precipitin of cobra venom. Lancet, I902, II, 43I-435; I904, I, 9I6-92 I.

- Snake venoms; their physiological action and antidote. Glasgow Med. Journal, I903, LIX, $8 \mathrm{I}-98$.

- On the serum therapeutics of cases of snake bite. Lancet, I904, II, I 273-I 277 .

- On the action of the venoms of the cobra (Naja tripudians) and of the daboia ( $\mathrm{Da}$ boia russellii) on the red blood corpuscles and on the blood plasma. Sci. Mem. Off. Med. Sanit. Dept. Gov. India, n. s., No. 4, 1903. 45 p. $4^{\circ}$

Specificity of antivenomous sera. Sci. Mem. Off. Med. Sanit. Dept. Gov. India, n. s., No. 5 , 1903 . I 4 p. $4^{\circ}$.

- Some observations on the poison of the banded krait (Bungarus fasciatus). Sci. Mem. Off. Med. Sanit. Dept. Gov. India, n. s., No. $7,1904.3^{2}$ p. $8^{\circ}$.

- Specificity of antivenomous sera (second communication). Sci. Mem. Off. Med. Sanit. Dept. Gov. India, n. s., No. IO, 1904. 25 p. $8^{\circ}$

- The specificity of antivenomous sera with special reference to a serum prepared with the venom of Daboia russellii. Sci. Mem. Off. Med. Sanit. Dept. Gov. India, n. s., No. I6, 1905. 18 p. $4^{\circ}$.
Lamb (George) Snake venoms in relation to hrmolysis. Sci. Mem. Off. Med. Sanit. Dept. Gov. India, n. s., No. I7, I905. I 5 p. $8^{\circ}$.

and Hanna (W.) Standardisation of Calmette's antivenomous serum with pure cobra venom; the deterioration of this serum through keeping in India. Sci. Mem. Off. Med. Sanit. Dept. Gov. India, n. s., No. I, I902. I 9 p. $8^{\circ}$.

- Some observations on the poison of Russell's viper (Daboia russellii). Sci. Mem. Off. Med. Sanit. Dept. Gov. India, n. s., No. 3, I903. (2) 39 p. F.

and Hunter (W. K.) Action of venom of different species of poisonous snakes on the nervous system. Lancet, I904, I, 20-22; II, 518-52I, I I 46-II49; I 905, II, $88_{3}-88_{5}$; I906, I, I 23 I-I 233; 1907, II, IOI7-1019.

Landerer (X.) Des moyens usités en Orient pour se garantir des serpents et de se guérir de leurs morsures. Écho méd., Neuchâtel, I86I, $\mathrm{V}, 49^{8}$.

Langmann (Gustav) Poisonous snakes and snake poison. The Medical Record, I900, LVIII, $401-409$.

Launoy (L.) Contribution à l'étude des phénomènes nucléaires de la sécrétion (cellules à venin, cellules à enzyme). Paris, I903. 226 p., 2 pl. $8^{\circ}$.

Leydig (F. von) Ueber Organe eines sechsten Sinnes. Nova Acta Acad. Leop.-Carol., Frankfurt a. M., I868, XXXIV, 24. - Zur Kenntniss der Sinnesorgane der Schlangen. Arch. f. mikrosk. Anat., $187 \mathrm{I}-2$, VIII, 3 I $7-357$.

- Die in Deutschland lebenden Arten der Saurier. Tübingen, 1872 . vii, 262 p. $4^{\circ}$.

_-_- Ueber die einheimischen Schlangen. Zool. u. anat. Bemerkungen. Abh. d. Senckenb. naturf. Ges., I $88_{3}-84$, XIII, I 67.

- Ueber die Kopfdrüsen einheimischer Ophidier. Arch. f. mikrosk. Anat., I873, IX, $598-65^{2}$.

Lindsley $(\mathrm{H}$.) Alcohol as a remedy for the poison of the rattlesnake. Stethoscope and Virg. M. Gaz., Richmond, I 852, II, 540-54 I.

McFarland (Joseph) Some studies of venoms and antivenenes. Proc. Amer. Med. Assoc., I9or; Proc. Path. Soc. Phila., I9oo; Proc. Soc. Amer. Bacteriologists, I900.

- Some investigations upon antivenene. Jour. Am. Med. Ass., I901, XXXVII, r 597I60I. - The progress of knowledge concerning venom and antivenene. A synoptical review of the literature of the past fifteen years. Phila. Med. Jour., 1902, IX, 329$332 ; 369-372 ; 403-407 ; 450^{-457} ; 49^{2-499}$.

McReddie (G. D.) A case of snake bite; treatment with permanganate of potash. Inclian M. Gaz., 1882, XVII, 267.

Madsen (Th.) and Noguchi (H.) Toxines et antitoxines; l'influence dle la température sur la vitesse de réaction. (II.) Oversigt over det $\mathrm{Kgl}$. Danske Videnskabernes Selskabs Forhandlinger, I904, No. 6, 447-456.

___ _._. Venins-antivenins (Crotalus adamanteus, Naja tripudians, Ancistrodon piscivorus). Oversigt over det Kgl. Danske Videnskabernes Selskabs Forhandlinger, I906, No. 4, 233-268.

Snake venoms and antivenins. Journal of Experimental Medicine, rgo7, IX, is -50 . 
Madsen (Th.), Noguchi (H.), and Walbum (L.) The influence of temperature upon the rate of reaction (hæmolysis, agglutination and precipitation). Journal of Experimental Medicine, 1906, VIII, $337-364$.

_ _ - Toxines et antitoxines; l'influence de la température sur la vitesse de réaction. I. Oversigt over det Kgl. Danske Videnskabernes Selskabs Forhandlinger, I9०4, No. 6, $425-446$.

Martin (C. J.) On the physiological action of the venom of the Australian black snake (Pseudechis porphyriacus). Roy. Soc. N. S. Wales. J. and Proc., I895, XXIX, $146-277$.

An explanation of the marked difference in the effects produced by subcutaneous and intravenous injection of the venom of Australian snakes. Roy. Soc. N. S. Wales. J. and Proc., I896, XXX, I $50-157$.

___ On some effects upon the blood produced by the injection of the venom of the Australian black snake (Pseudechis porphyriacus). Jour. of Physiology, I893, XV, 380.

- Snakes, snake poisons and snake bites. Hermes Med. Supplement. J. Sydney Univ. Med. Soc., 1895 , Dec. 4.

- Advisability of administering curative serum by intravenous injection. Intercolonial Medical Journal of Australasia, I897, II, 537 ; 1898 , III, 7 I 3 .

Concerning the curative power of antivenomous serum on animals inoculated with Australian snakes' venom. Intercolonial Medical Journal, 1897, II, 527.

_ - The curative value of Calmette's serum in the treatment of inoculation with the poisons of Australian snakes. British Medical Journal, 1898, II, I805; Intercolonial Med. Journal of Australasia, I898, III, I97.

—__ Observations upon fibrin-ferments in the venoms of snakes and the time-relations of their action. Journal of Physiology, 1905, XXXII, 207-215.

The contribution of experiments with snake venom to the development of our knowledge of immunity. British Med. Jour., I904, II, 574.

and Cherry. The nature of the antagonism between toxins and antitoxins. British Medical Journal, I8g8, II, I I 20.

and Halliburton (W. D.) Further observations concerning the relation of the toxin and antitoxin of snake venom. Proc. Roy. Soc. London, 1898-99, LXIV, 88-94.

__ a a d Lamb (G.) Snake poison and snake bite. Allbutt (T.C.) and Rollerston (H.D.): System of Medicine, I907, II, pt. II, 783 .

- and Smith (J. McG.) The venom of the Australian black snake (Pseudechis porphyriacus). Journal and Proceedings of Roy. Soc. of New South Wales, I892, XXVI, 240264.

Meckel (J. F.) Ueber die Kopfdrüsen der Schlangen. Arch. f. Anat. u. Physiol., 1826, XI, II3.

Meirelles (E.) Envenenamento ophidico e a sôrotherapia. Gaz. clin. S. Paulo, I904, II, 429434. Brazil-Med., Rio de Jan., I904, XVIII, 439.

Menger (R.) Moccasin bite treated with adrenalin chloride. Texas Med. Jour., I904-5, $\mathrm{XX}, 263-266$.

Meyer (A. B.) Ueber den Giftapparat der Schlangen, insbesondere über den der Gattung Callophis Gray. Monatsber. der Akad. d. Wiss. zu Berlin, 1869, 193-215.
Meyer (A. B.) Die Giftdrüsen bei der Gattung Adeniophis Pet. Sitzungsber. der Berlin. Akad d. Wiss., 1886 , No. 36, 61 I-6 14 .

Mills (T. W.) Snake venoms from chemicophysiological point of view. (No original work.) Journal of Com. Medicine and Surgery, 1887, VIII, $3^{8-43}$.

Minz (A.) Ueber Toxolecithide. Biochem. Zeitschrift, I908, IX, 357 .

Mitchell (A.) Bite of the diamond rattlesnake (Crotalus adamanteus). Boston M. and S. J., 1873 , LXXXIX, 331-333.

Mitchell (S. Weir) On the treatment of rattlesnake bites, with experimental criticisms upon the various remedies now in use. N. Am. M. Chir. Rev., Phila., 186r, V, 269-310.

Experimental contributions to the toxicology of rattlesnake venom. N.Y. Med. J., I $867-8$, VI, 289-322.

The venom of serpents. Med. Times and Gaz., London, 1869, I, 137.

Observations on poisoning with rattlesnake venom. Am. J. M. Sc., Phila., 187o, n. s., LIX, 317-323.

Remarks upon some recent investigations of the venom of serpents. Lancet, I883, II, 94 .

and Reichert (E. T.) Preliminary reports on the venom of serpents. Med. News, Phila., I 883 , XLII, $469-47^{2}$.

- Researches upon the venoms of poisonous serpents. Smithsonian Contributions to Knowledge, I 886 , XXVI, No. 647 . ix, 186 p. pl. $F^{\circ}$.

Bibliography: p. I 59-1 79 .

and Stewart. A contribution to the study of the action of the venom of the Crotalus adamanteus upon the blood. Trans. College of Physicians, Philadelphia, 1897, 3d ser., XIX, I05.

Moeller. Allahabad Pioneer.

Moreau de Jonnès (A.) Monographie du trigonocéphale des Antilles, ou grande vipère ferde-lance de la Martinique. J. de méd. chir., Paris, I816, XXXVI, 326-365.

Morgenroth (J.) Ueber die Wiedergewinnung von Toxin aus seiner Antitoxinverbindung. Berlin. klin. Woch., 1905, XLII, 1550-1554.

and Carpi (U.) Ueber ein Toxolecithid des Bienengiftes. Berl. klin. Wochenschrift, I906, XLIII, 1424.

Ueber Toxolecithide. Biochem. Zeitschrift, I 907 , IV, $248-26 \%$.

Miller (Johannes) De glandularum secernentium structura penitiori earumque prima formatione in homine atque animalibus. Leipzig, I830. 131 p. I 7 pl. Fo.

Myers (W.) Cobra poison in relation to Wassermann's new theory of immunity. Lancet, I 898, II, 23-24.

On the interaction of toxin and antitoxin; illustrated by the reaction between cobralysine and its antitoxin. Journal of Pathology and Bacteriology, 1899-I900, VI, 4I5-

${ }^{434}$ ' The neutralization of the hæmolytic poison of cobra venom (Cobralysin) by antivenomous serum. British Medical Journal, 1900, I, 3 I 8 . The standardization of antivenomous serum. Lancet, 1900, I, I433-1434.

Neidhard (C.) Crotalus horridus; its analogy to yellow fever, malignant, bilious, and remittent fevers. 2 d ed. W. Radde, New York, 1868. xvi, $9-87$ p. $8^{\circ}$. 
Nicholson (E.) On some popular errors regarding Indian snakes. Madras Month. J. M. Sc., I 870 , II, 350-358.

Statistics of deaths from snake bite. Brit. Med. J., I 883 , II, 448.

Nicolle (C.) and Catouillard (G.) Sur le venin d'un scorpion commun de Tunisie (Heterometrus maurus). C. R. Soc. biol., I905, LVIII, I00I02.

Action du sérum antivenimeux sur le venin de Heterometrus maurus. C. R. Soc. biol., I905, LVIII, $231-233$.

Niemann (F.) Beitr. zur Morphologie und Physiologie der Oberlippendrüsen einiger Ophidier. Phil. Diss. Bern. Berlin, 1892. Arch. f. Naturgesch., I 892 , I, 262-286.

Noguchi (Hideyo). The effects of venom upon the blood corpuscles of cold-blooded animals. Univ. of Penn. Medical Bulletin, I903, XVI, I 82 .

The action of snake venom upon coldblooded animals. Carnegie Institution of Washington Publication No. I 2, I904. I 6 p. $8^{\circ}$.

A study of the protective action of snake venom upon blood corpuscles. Journal of Experimental Medicine, I905, VII, IOI-222.

- On certain thermostabile venom activators. Journal of Experimental Medicine, I906, VIII, 87-102.

_- Expériences thérapeutiques avec les antivenins (Crotalus adamanteus et Ancistrodon piscivorus). Oversigt over det $\mathrm{Kgl}$. Danske Videnskabernes Selskabs Forhandlinger, I 906, No. $4,269^{-280}$.

Therapeutic experiments with anticrotalus and antimoccasin sera. Journal of Experimental Medicine, I906, VIII, $6_{14}-624$.

The photodynamic action of eosin and erythrosin upon snake venom. Journal of Experimental Medicine, Igo6, VIII, $25^{2-26}$.

___ On extracellular and intracellular venom activators of the blood, with especial reference to lecithin and fatty acids and their compounds. Journal of Experimental Medicine, I907, IX, 436-454.

Ueber gewisse chemische Komplementsubstanzen. Biochem. Zeitschrift, I907, VI, $327-359$.

Noc (F.) Propriétés bactériolytiques, et anticytasiques du venin de cobra. Ann. Institut Pasteur, 1905, XIX, 209-223.

__- Sur quelques propriétés physiologiques des différents venins de serpents. Ann. Institut Pasteur, I 904, XVIII, 387-406.

Nowak (J.) Etude expérimentale des altérations histologiques produites dans l'organisme par les venins des serpents venimeux et des scorpions. Ann. Institut. Pasteur, I 898, XII, $369-384$.

Odier (R.) Les progrès récents de la médecine. Le sérum antivenimeux. Biblioth. Univ. Lausanne, r904, XXXIII, 94-102.

Ogle (W.) Loss of speech from the bite of venomous snakes. St. George's IIosp. Rep., London, I868, III, $167-176$.

Ott (I.) Rattlesnake virus; its relation to alcohol, ammonia, and digitalis. Arch. Med., N. Y., I882, VII, I 34-I4 I.

The physiological action of the venom of the copperhead snake. Virginia M. Month., Richmond, I882-3, IX, 629-634.

Pasquier (H.) Du prognostic et du traitement de l'envenimation ophidienne. Thèse. Paris, I883. $60 \mathrm{p} .4^{\circ}$.
Passano (P. A.) Etudes historiques, théoriques et pratiques sur quelques points relatifs aux morsures des serpents venimeux. Thèse. Montpelier, I880. I Io p. $4^{\circ}$.

Paul (J. L.) and Shortt (J.) Cases of snake bite. Med. Times and Gaz., London, 1873, II, $214-216$.

Peracca (M. G.) and Deregibus (C.) Esperienze fatte sul veleno del Colopeltis insignitus, Giorn. d. r. Accad. di Med. di Torino, 1883 . ser., XXXI, 379-383.

Peyrot. Kérato-conjonctivite par projection de venin. Ann. d'hyg. et de méd. colon., I904, VII, I07-I I0.

Phisalix (C.) Antagonisne physiologique des glandes labiales supérieures et des glandes venimeuses chez la vipère et la couleuvre; la sécrétion des premières vaccins contre le venin des seconds. C. R. Soc. biol., 1896 , ıo. sér., III, $963-965$.

Atténuation du venin de vipère par les courants à haute fréquence; nouvelle métliode de vaccination contre le venin. C. R. Soc. biol., I896, 10. sér., III, 233-234.

Propriétés immunisantes du sérum d'anguille contre le venin de vipère. C. R. Acad. sci., 1896, CXXIII, 1305-1308; C. R. Soc. biol., i 896, 1o. sér., III, I I 28-i i 30 .

Venins et animaux venimeux dans la série animale. Revue scientifique, 4. sér., VIII, 97I04; 195-20I; 329-335.

Propriétés immunisantes du venin de salamandre du Japon vis-à-vis du venin de vipère. C. R. Soc. biol., 1897, 10. sér., IV, 822-823.

La cholestérine et les sels biliaires, vaccins chimiques du venin de vipère. C. $R$. Acad. sci., I 897, CXXV, 1053-1055.

- Antagonisme entre le venin des Vespidæ et celui de la vipère; le premier vaccine contre le second. C. R. Soc. biol., I897, Io. sér., IV, 103I-ro33; C. R. Acad. sci., I897, CXXV, 977-979.

- La propriété préventive du sérum antivenimeux résulte d'une réaction de l'organisme; c'est donc en réalité une propriété vaccinante. C. R. Soc. biol., 1898, ro. sér., $\mathrm{V}, 253-256$.

- Les sucs de champignons vaccinent contre le venin de vipère. C. R. Soc. biol., 1898 , Io. sér., V, I I 5 I-II 53 .

_- La tyrosine vaccin chimique du venin de vipère. C. R. Acad. sci., 1898, CXXVI, $43^{-}$ 433 ; C. R. Soc. biol., I898, Io. sér., V, I53I 55 .

${ }^{155^{\circ}}$ Venins et coagulabilité du sang.

C. $R$. Soc. biol., I899, II. Sér., I, $834^{-835}$.

Relations entre le venin de vipère, la peytone et l'extrait de sangsue au point de vue de leur influence sur la coagulabilité du sang. C. R. Soc. biol., I899, I r. sér., I, 865867 .

Sur la coagulation du sang chez la vipère. C. R. Soc. biol., I899, I1. sér., I, S8I882.

- Nouvelles observations sur l'échidnase.

C. R. Soc. biol., I899, I I. sér., I, 658-66o.

Recherches sur les causes de l'immunité naturelle des vipères et des couleuvres. C. R. Acad. sci., 1903, CXXXVII, 270-272; C. R. Soc. biol., 1903, LV, $1082-1085$.

- Influence des radiations du radium sur la toxicité du venin de vipère. C. R. Acad. sci., t904, CXXXVIII, 526; C. R. Soc. biol., 1904, LVI, 327-328. 
Phisalix (C.) Sur un nouveau caractère distinctif entre le venin des vipéridés et celui des cobridés. C. R. Soc. biol., I904, LVII, 486-488. - Sur la présence du venin dans les oufs de vipère. C. R. Soc. biol., I 905 , I.IX, I 5 I 7 ; C. R. Acad. sci., I905, CXL, I719-172I. Influence de l'émanation dú radium sur la toxicité des venins. C. R. Acad. sci., 1905, CXL, 600-602; C. R. Soc. biol., I905, LVIII', 366-368.

- and Bertrand (G.) Toxicité du sang de la vipère. C. R. Soc. biol., I 893, 9. sér., V, 997-999; C. R. Ac. sci., 1893, CXVII, 1099-1102.

- Sur la présence des glandes venimeuses chez les couleuvres et la toxicité du sang de ces animaux. C. R. Acad. sci., I894, CXVIII, 76-79.

Sur la propriété antitoxique du sang des animaux vaccinés contre le venin de vipère. C. R. Acad. sci., 1894, CXVIII, 356-358; C. R. Soc. biol. I 894 , ro sér. I, I I I-I I3; Semaine Médicale, I894.

Atténuation du venin de vipère par la chaleur et vaccination du cobaye contre ce venin. C. R. Acad. sci., 1894, CXVIII, 288291.

Vaccination et accoutumance du cobaye contre le venin de vipère. Atti $d$. xI. Cong. med. internaz. Roma, I 894, II, Patol. gen. ed anat. patol., $274^{-277}$.

Sur la présence de glandes venimeuses chez les couleuvres, et la toxicité du sang de ces animaux. C. R. Soc. biol., I894, Io. sér., I, 8-II.

Sur les effets de l'ablation des glandes venimeuses chez la vipère. Arch. de physiol. norm. et path. Paris, I 89,5, 5 . sér., VII, roo-Io6. Also abstract in C. R. Acad. sci., I894, CXIX, 919-92I; C. R. Soc. biol., I 894, 1о. sér., I, 747-749.

- Sur l'emploi et le mode d'action du chlorure de chaux contre la morsure des serpents venimeux. C. R. Acad. sci., I895, CXX, 1296-1 298; C. R. Soc. biol., I895, 10. sér., II, $443^{-445}$.

- Recherches sur l'immunité du hérisson contre le venin de vipère. C. R. Soc. biol., I895, Io. sér., II, 639-64I.

- Sur l'emploi du sang de vipère et de couleuvre comme substance antivenimeuse. C. R. Acad. sci., I895, CXXI, 745747 ; C. R. Soc. biol., I895, Io. sér., II, $75^{1-}$ 753 .

Action du filtre de porcelaine sur le venin de vipère, séparation des substances toxiques et des substances vaccinantes. C R. Acad. sci., I896, CXXII, I439-1442; C. R. Soc. biol., I896, тo. sér., III, 656$65^{8}$.

and Charrin (A.) Action du venin de vipère sur le névraxe. Paraplégie spasmodique. C. R. Soc. biol., 1898, ro. sér., V, 96-98. and Claude (H.) Lésions du système nerveux dans un cas d'intoxication expérimentale par le venin de vipère. C. R. Soc. biol., 1898, го. sér., V, 31 7-320.

Piffard (H. G.) Periodical vesicular eruption following the bite of a rattlesnake. Med. Rec., N. Y., $1875, \mathrm{X}, 62-63$.

Ralph (T. S.) Observations on the action of snake poison on the blood. Austral. M. J., I 867 , XII, 353-36r.

Rangel Pestana (B.) Notas sobre a acção hemolytica dos venenos de diversas especies de cobras brasileiras. Revista medica de $\mathrm{S}$. Paulo, I908, XI, 436.
Ranvier (L.) Traité technique d'histologie. 2. édit. Paris, I889. 871 p. $8^{\circ}$.

Redi (F.) Lettera sopra alcune opposizione fatte alle sue osservazioni intorno alle vipere. Firenze, 1685 . 31 p. $4^{\circ}$.

- Osservazioni intorno alle vipere. Firenze, I664. 91 (4) p. $4^{\circ}$.

Reichel (Paul) Beitrag zur Morphologie der Mundhöhlendrüsen der Wirbeltiere. Morphol. Jahrb., I882, VIII, I-72.

Remedios Monteiro (J.) Do permanganato de potassa contra o veneno das cobras. Gaz. med. da Bahia, I88I-2, 2. s., IV, I97I99.

Report of the Commission appointed to investigate the influence of artificial respiration, intravenous injection of ammonia, etc., in Indian and Australian snake poisoning. Indian Ann. M. Sc., Calcutta, 1875, XVII, I 1 I-25 2, 4 pl. (app.) No. I-3, pp. i-xcviii.

Report of the special comnittee on the subject of snake poisoning. Austral. M. J., 1877, XXI, I04, I 5 I, I 84.

Return showing the number of deaths from snake bites, in the year 1869 , in the Province of Bengal. Indian M. Gaz., I87o, V, (suppl.) $\mathrm{I}-4$.

Richards (V.) Experiments on snake poison. Ind. Ann. M. Sc., I870-71, XIV, I77202.

Snake poisoning antidotes. The 'nature of snake poison and its action on the blood. Ind. Ann. M. Sc., I872-3, XV, I63-1 76 .

- Experiments with strychnine as an antidote to snake poison. Med. Times and Gaz., Lond., I874, I, 595-597.

- Further experiments with permanganate of potash, liq. potassæ, and iodine in cobra poisoning. Ind. M. Gaz., I882, XVII, r99202.

Notes on Dr. Wall's monograph on cobra and daboia poisons. Ind. M. Gaz., I882, XVII, 239; 259 .

Permanganate of potash and liq. potasse in snake poisoning. Lancet, I882, I, ro97.

Report on the snake-bite cases which occurred in Bengal, Behar, Orissa, Assam, Cachar, etc., during the year 1873-4. Ind. M. Gaz., I876, XI, 96-100.

Rogers (L.) On the physiological action of the poison of the Hydrophidæ. Proc. Roy. Soc. Lond., 1902-3, LXXI, 481-496; LXXII, 305 .

On the physiological action and antidotes of colubrine and viperine snake venoms. Proc. Roy. Soc. Lond, I903, LXXII, 419423; Lancet, I904, I, 349-355.

Physiological action and antidotes of colubrine and viperine snake venoms. Lond., I904. 68 p. $4^{\circ}$.

The treatment of snake-bites. Jour. Tropic. Med., Lond., I904, VII, 252.

Five cases of snake-bite successfully treated by the local application of permanganate of potash. Indian Med. Gazette, 1905, XL, 4I.

Twelve cases of snake-bite treated by incision and application of permanganate of potash, with ten recoveries. Indian Med. Gazette, I905, XL, 369-371.

Rosén (N.) Ueber die Kaumuskeln der Schlangen und ihre Bedeutung bei der Entleerung der Giftdrüse. Zool. Anz., I 904, XXVIII, I-7.

Rousseau (L. F. E.) Expériences faites avec le venin d'un serpent à sonnettes (Crotalus horridus). J. hebd. d. méd., Paris, 1828, I, 29I-296. 
Roy (G. C.) Remarks on the action of snake poison on the blood. Indian M. Gaz., 1877, XII, 3I5-3I7.

Rudek (E.) Ueber und gegen das Gift der Schlange und Fliege. Berlin, 1887.21 p. $12^{\circ}$.

Rudolphi (K. A.) Grundriss der Physiologie. Berlin, $1821-1828.2$ v. $8^{\circ}$.

Rufz de Lavison (E.) Enquête sur le serpent de la Martinique. Francęméd. et pharm., Paris, I $860, \mathrm{VII}, 8 \mathrm{I}$.

Sachs (H.) Tierische Toxine als hämolytische Gifte. Biochem. Centralblatt, I 9o6, IV.

- Die Hämolysine und die cytotoxischen Sera. Ein Rückblick auf neuere Ergebnisse der Immunitätsforschung. Lubarsch-Ostertag. Ergebnisse d. allg. path. u. path. anat., Wiesbaden, 1907, XI, 515-644.

- Antigene tierisches Ursprunges. Kraus (R.) und Levaditi (C.) Handb. der Technik und Methodik der Immunitätsforschung, I907, I. Bd., Chapter XII, 244.

St. John (J. H.) On the poison of the rattlesnake. Lond. Med. Reposit., I8 27 , XXVIII, 445 .

Salisbury (J. H.) Influence of the poison of the northern rattlesnake (Crotalus durissus) on plants. Proc. Amer. Ass. Adv. Sc., I85I, Washington, I 852, VI, 336-337.

Schlegel (H.) Untersuchung der Speicheldrüsen bei den Schlangen mit gefurchten Zähnen, in Vergleich mit denen der Giftlosen und Giftigen. Nova Acta Acad. Leop.-Car. Nat. Cur., 1828, XIV, i, I45-154.

- Essai sur la physionomie des serpens. Amsterdam, I 837.2 v. $8^{\circ}$

Scott (J.) The influence of cobra venom on the proteid metabolism. Proc. Roy. Soc. Lond., 1905, LXXVI, B, I66-I78.

Semple and Lamb. The neutralizing power of Calmette's antivenomous serum; its value in the treatment of snake bite. British Med. Journal, I899, I, 78I.

Sewall (H.) Experiments on the preventive inoculation of rattlesnake venom. Journal of Physiology, I887, VIII, 203-2Io.

Short (R. T.) Case of a lad, aged I7, who had been bitten by an average-sized prairie rattlesnake (Crotalus massacagua). Med. Arch. St. Iouis, I869, III, 564.

Shortt (J.) Experiments with snake poison. Madras Month. J. M. Sc., I87o, I, 2 14, 275. Review of cases of snake bite. Madras Month. J. M. Sc., I 87 I, III, 8I-0I.

Stannius (H.) Wirbeltiere. In Siebold-Stannius, Lehrbuch der vergleichenden Anatomie. Part II. Berlin, I 845-46.

Stejneger (L.) The poisonous snakes of North America. U. S. National Museum. Ann. rept. for 1893 , p. $337-487$. Washington, 1895 .

_ - Herpetology of Japan and adjacent territory. U. S. National Museum, Bull. 58, I907. $\mathrm{xx}, 577$ p. $8^{\circ}$.

Stephens (T. W. W.) On the hæmolytic action of snake toxins and toxic sera. Journal of Pathology and Bacteriology, I899-1900, VI, 273.

- 2 and Myers (W.) Test-tube reactions between cobra poison and its antitoxin. British Medical Journal, I $898, I, 620$.

The action of cobra poison on the blood; a contribution to the study of passive immunity. Journal of Pathology and Bacteriology, I 898, V, 279.

Stockbridge (W.) Snakes and snake bites at the Southwest. Boston M. and S. J., I843, XXIX, $40-43$.
Teruuchi (Y.) Die Wirkung des Pankreassaftes auf das Hämolysin des Cobragiftes und seine Verbindungen mit dem Antitoxin und Lecithin. Zeitschr. f. physiol. Chemie, I907, LI, $478-487$.

Thierry de Maugras (C. H.) Notice sur la vipère à cornes. Rec. de mém. de méd., chir., mil., Paris, 1847 , 2. S., III, $324-330$.

Tidswell (F.) Preliminary note on the serumtherapy of snake-bite. Australian Medical Gazette, I902, XXI, I 77-r 81.

Tiedemann (Fr.) Ueber die Speicheldrüsen der Schlangen. Denkschr. d. Akad. d. Wiss. zu München, I8r3, mathem.-phys. Kl., 253o. Also, Reprinted from the above. I8r4.

Tissière (L. T.) De la vipère cornue (bicorne) du sud de l'Algérie. Gaz. méd. de l'Algérie, I858, III, I İ, 4 I, 86, I०4.

Tomes (C. S.) On the development and succession of the poison fangs of snakes. Phil. 'Tr., Lond., 1876, CLXVI, pt. 2, 377-385.

On the structure and development of the teeth of ophidia. Phil. Tr., Lond., I 875 , CLXV, pt. I, 297-302.

Tsurusaki (H.) Zur Kenntnis der komplexen Hämolysine. Biochem. Zeitschrift, I908, X, 345.

Viaud-Grand-Marais (A.) De la léthalité de la morsure des vipères. Gaz. d. hôp., Paris, I 868, XLI, 245, $25^{8}$.

- Description de la maladie produite par l'inoculation du venin de la vipère. Gaz. d. hôp., Paris, I869, XLII, I90, 2 10.

Quelques plantes américaines employées contre les morsures des serpents venimeux. Rev. méd. franç. et étrang., Paris, I 874, I, $362-37 \mathrm{I}$.

- Note sur le vichamaroundou, les pilules de Tanjore, les pierres à serpents et quelques végétaux employés dans les Indes contre les morsures envenimées. J. de méd. de l'ouest, Nantes, I879, 2. s., XIII, 30-40.

____ Note sur l'envenimation ophidienne étudiée dans les différents groupes de serpents. J. de méd. de l'ouest, Nantes, I880, XIV, 3455 .

5erpents venimeux. Dict. encycl. d. sc. méd., Paris, r 881, 3. S., IX, 387 .

Vollmer (E.) Ueber die Wirkung des Brillenschlangengiftes. Arch. für experim. Pathologie und Pharmacologie, I892-3, XXXI, I-I 4 .

Waddell (L. A.) Are venomous snakes autotoxic? An inquiry into the effect of serpents' venom upon the serpents themselves. Sci. Mem. Medical Officers of the Army in India, I 889, Publication IV, $47-72$.

Watkins-Pitchford (H.) and Watkins-Pitchford (W.) On Indian snake-stone. British Med. Jour., I90.4, I, 438.

Wall (A. J.) Report on the physiological effects of the poisons of the Naja tripudians and the Daboia russellii. Rep. on san. meas. in India, I 876-7, London, I 878, 229-249.

_- On the differences in the physiological effects produced by the poisons of certain species of Indian venomous snakes. Proc. Roy. Soc. Lond., I88r, XXXII, 333-362.

Wehrmann. Sur les propriétés toxiques et antitoxiques rlu sang et de la bile des anguilles et des vipères. Ann. Institut Pasteur, I 897, $\mathrm{XI}, 8$ ro.

Welch (William H.) and Ewing (C. B.) The action of rattlesnake venom upon the bactericidal properties of the blood. Transactions of the First Pan-American Medical Congress, Washington, I893, I, 354-355. 


\section{VENOMOUS SNAKES AND THE PHENOMENA OF THEIR VENOMS}

West (G. S.) On the buccal glands and teeth of certain poisonous snakes. Proc. Zool. Soc. Lond., I895, pt. $4,4 \mathrm{I} 2$.

On the histology of the salivary, buccal and Harderian glands of the Colubridx, with notes on their tooth-succession and the relationships of the poison-duct. J. of Linn. Soc. Zool., I 898, XXVI, 517-526.

Wiedersheim (R.) Die Kopfdrüsen der geschwänzten Amphibien und die Glandula intermaxillaris der Anuren. Zeitschr. f. wiss. Zool., I876, XXVII, r-50.

Wilson (W. H.) The physiological action of scorpion venom. Proc. Physiol. Soc. Lond., I904, p. xlviii.
Wilson (W. H.) The immunity of certain desert mammals to scorpion venom. Proc. Physiol. Soc. Lond., rgo4, p. 1-lii.

- On the venom of scorpions. Rec. Egypt. Gov. Sch. Med., Cairo, I 904, II, 7-44. Wolfenden (R.N.) On the nature and action of the venoms of poisonous snakes. Journal of Physiology, I 886, VII, 327-364.

Wolff. Folgen von Schlangenbissen. Arch. f. med. Erfahr., Berlin, I82 I, II, 42-44.

woods (F. H.) Five cases of snake bite. N. S. IV. M. Gaz., Sydney, I873-4, IV, I $29^{-1} 32$.

Woodward (B.) Iodine as a remedy in rattlesnake bite. Northwest. M. and S. J., Chicago, r856, XIII, 6r. 


\section{INDEX.}

Absorption of venom from serous and $\mathrm{mu}^{\text {P }}$

cous membranes .............221, 222

Acalyptus .................... 27 peronii................ 27

antarcticus ............... 22

Acetone, effect on venom............... 102

Acids, effects on snake venom ........... $9^{8}$

Acrylic acids............... I89, I84

Adrenalin, in treatment of snake bite .... $29^{2}$

Africa, venomous snakes of . .......... 53

Aglypha ................... I

Aglyphodonta................. 46

Aipysurus .................... 29 australis $\ldots \ldots \ldots \ldots \ldots \ldots \ldots \ldots, 29$

Albumoses of venom $\ldots \ldots \ldots \ldots \ldots \ldots \ldots 8_{4}, 8_{5}$ Alcohol, alleged value in treatment of snake bite................ 292

effects on snake venom ........ 79

Alimentary tract, effects of snake venom on

$220-222$

Alluaudina ..................

Alum, effects on snake venom........... $9_{8}$

Amblycephalidæ, definition of $\ldots \ldots \ldots \ldots{ }_{2}$

Amblyodipsas....................... Io

Ammonia, alleged value in treatment of snake

bite ............... 292

effects on snake venom ....... 97

Ammonium, carbonate of, effects on snake venom ................ IOI effect on snake venom....... roo

Amphibia, effects of snake venom upon..... 274 mucous glands of oral cavity ... 47

Amplorhinus ................... ${ }_{6}^{47}$

Ancistrodon ..................... 35

acutus $\ldots \ldots \ldots \ldots \ldots \ldots \ldots, 37$

bilineatus ............. ${ }_{36}$

blomhoffii ............ 37

brevicaudus ...... 37

contortrix ........... 36 amount of venom secreted $\ldots \ldots \ldots$. 7 I

halys ................ 36

himalayanus $\ldots \ldots \ldots \ldots \ldots \ldots .37$

hypnale $\ldots \ldots \ldots \ldots \ldots \ldots \ldots, 37$

intermedius $\ldots \ldots \ldots \ldots \ldots \ldots \quad 37$

piscivorus $\ldots \ldots \ldots \ldots \ldots \ldots .35$

amount of venom secreted $\ldots \ldots \ldots$.

effect of venom upon the nervous system I 24

venom of ........ 73

poisoning, experimental ........ I I 5

rhodostoma ............ 37

Angiostomata

Anguis fragilis, glands of $\ldots \ldots \ldots \ldots \ldots \ldots \ldots . \quad 47$

Animals, natural immunity from snake

venom ....................... 268

Antibactericidal properties of snake venom.

$215-218$

Anticoagulating property, effect of antivenins on. $238-239$ effect of heat upon I I I $^{2}$ of Daboia venom. I4 I Echis ....... I 4 I
Anticoagulating property, negative phase PAGE. of ........ I 34

Notechis ...... I I I

Pseudechis .... I 41

snake venoms.. r 33 ,

Antihæmolytic properties of cholesterin. I $\begin{array}{r}\text { I } 39^{-1}, 12 \\ 78\end{array}$ I 84,185, I 86, I 94 Antihæmolytic properties of cholesterin de-

rivatives................. 194

Antihremolytic properties of excessive

amount of venom.........179, 195-198

Antiricin ..................... 159

Antivenin of Ancistrodon piscivorus . . . . . . 240

Calmette's ................24

Cobra .................

Crotalus adamanteus ......... 239

Crotalus terrificus ............ 240

Crotalus venom........... 257

Daboia ................. 238

Lachesis flavoviridis ......... 24I

Lachesis lanceolatus ........... 240

Notechis scutatus ........... 238

water-moccasin venom ....... 259

and venom regenerated from their neutral combination. . . . . . 248

Antivenins .................225-24 data as to the effective dosage

of $\ldots \ldots \ldots \ldots \ldots \ldots \ldots \ldots \ldots \ldots \ldots$ difficulty of obtaining strong..... 245 duration of effects after injection $23 \mathrm{I}$ effect of alcohol........... 249 heating........... 249

effects in relation to time elapsed 242 interactions between venoms and

246-260 modes of administration of.... 295 specific treatment of snake bites

with ...........294-296

specificity of ............234-245

therapeutic value of . . . . . 2.4 $1-245$

Anura, mucous glands of oral cavity..... 47

Aparallactus .................... Io

Apostolepis .................. I0

Aristolochia serpentaria, used for snake bite. 293

Artificial immunization ........223-232, 246

Asia, venomous snakes of $\ldots \ldots \ldots \ldots \ldots .53$

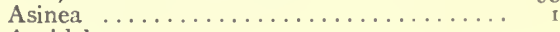

Aspidelaps $\ldots \ldots \ldots \ldots \ldots \ldots \ldots \ldots \ldots \ldots \ldots \ldots \ldots$ I 7

lubricus $\ldots \ldots \ldots \ldots \ldots \ldots \ldots$ I 7

scutatus................ 17

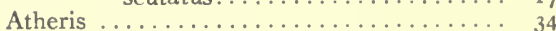

ceratophorus $\ldots \ldots \ldots \ldots \ldots \ldots \ldots .6 \ldots$

chlorechis .............. 34

squamiger $\ldots \ldots \ldots \ldots \ldots \ldots \ldots \ldots \ldots \ldots$

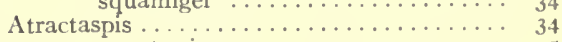

aterrima $\ldots \ldots \ldots \ldots \ldots \ldots \ldots, 35$

bibronii $\ldots \ldots \ldots \ldots \ldots \ldots \ldots, 35$

congica ............... 34

corpulenta ............. 34

dahomeyensis $\ldots \ldots \ldots \ldots \ldots \ldots, 35$

hildebrandii ............. 34

irregularis ............. 34

leucomelas ............. 35

microlepidota ........... 35 
Atractaspis micropholis . . . . . . . . $\quad 35$ rostrata 34

Australia, exclusive home of Colubrida..... free from Viperidæ......... 52

Bacillus anthracis ...........205, 215 coli ...........205, $215,216,217$

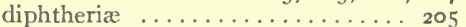
pyocyaneus ................. 205

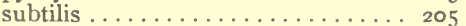
tuberculosus .............. 205 typhi ...............205, 2 I 5 Barium chloride, antihemolytic property of. I9 I Bengal, mortality from snake bites in ..... 75 Bibron's antidote, used for snake bite..... 293

Bile, antivenomous properties of........103-104

Bite of Australian species of snakes........ I ro snake, mechanism of ........67-69

Bitis

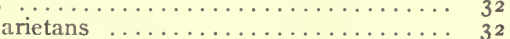
mortality caused by $\ldots \ldots \ldots \ldots, 7^{6}$

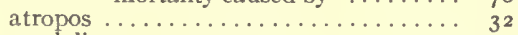

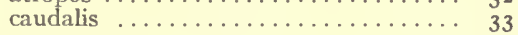

cornuta ................. 32

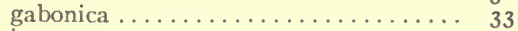

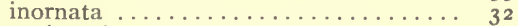

nasicornis ................. 33

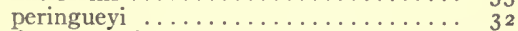

Blood corpuscles, protective property of

venom on ................... 195-198

Blood pressure, in venom toxication....... I 25

Boida, definition of ..............

Boiginze ...................... 4

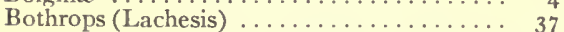

Boulenger on systematic position of venom-

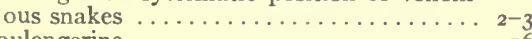

Boulengerina ................ I 6

Boulengerina stormsi ............. I 6

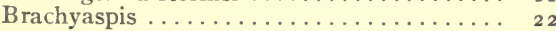

curta ............. 22

Brachyophis $\ldots \ldots \ldots \ldots \ldots \ldots \ldots \ldots \ldots \ldots \ldots \ldots$ Io

Brandy .................... 292

Bromine, effects on snake venom ........ 98 water, effects on snake venom .... ro r

Bungarus ......................... I4 caruleus, effect of venom of, upon nervous system ...... I 29 effects upon coagulability of the blood ...... I37 mortality caused by.... 75 poisoning in $\operatorname{man} . . . .$. I IO candidus s. cæruleus......... I 14 fasciatus ................. I 4 effects of venom of, upon nervous system...... I 29 mortality ca used by $\ldots \ldots \ldots \ldots .75$ poisoning, experimental ....... I 18

Caffein, effect on venom toxication........ 29 I

Calanelaps ................... Io Calcium chloride, antihæmolytic property of. I 88- I90

Calliophis effect on...... 34, I 35, I $_{3} 6$

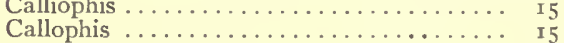

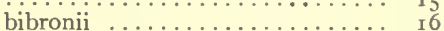
gracilis $\ldots \ldots \ldots \ldots \ldots \ldots \ldots \ldots$ I 5 macclellandii ............. I5 maculiceps $\ldots \ldots \ldots \ldots \ldots \ldots$ I 5 trimaculatus ............ I univirgatus .............. I6

Calmette's antivenin .......... I50, I67, 241 Carbolic acid, effect on snake venom....99, roo Catodonta ........................ I Caustic alkalies, effects on snake venon.... 97

Causidæ .................. 3

PAGE.

Causus . . . . . . . . . . . . . 3 I

defilipii ........................ 32

lichtensteinii ........................ 32

resimus . . . . . . . . . . . 32

rhombeatus.............. 31

poison glands of...... 60

Cells of sycotypus. . . . . . . . . . . I 5 I

Cerastes .................... 33

a mount of venom secreted...... 71

cornutus ............... 33

vipera $\ldots \ldots \ldots \ldots \ldots \ldots \ldots \ldots \ldots \ldots$

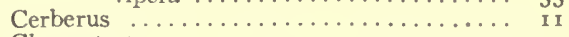

Chamætortus ................. 5

Chelonia, mucous glands of oral cavity .... 47

Chemical effects of snake venom ........ 96

nature of snake venom........ 79

the venom-antivenin re-

action .............246

properties of snake venom .....77-93

Chicken egg, effect of venom on evolution of embryo .................... 204

Chicocecca anguifuga, used for snake bite . . 293

Chloride of calcium, experiment with . . . . 226 gold, experiment with........ 226 water, effects on snake venom

99 , roI

Chlorine water, effects on snake venom ..98, ro

Chloroform, effect on venom......... I02

Cholesterin ................... I49, I 74 antihamolytic properties of .. 194-198 effects on venom hamolysis.... I 74 , I $78, \mathbf{1} 84, \mathbf{I} 85$, I 86

Cholin .................... 184

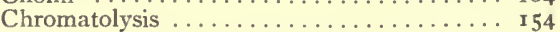

Chrysopelea ................... ro

Coagulability of blood, increased and dimin-

ished $\ldots \ldots \ldots \ldots \ldots \ldots \ldots \ldots \ldots \ldots \ldots \ldots$

Coagulating property, counteracted by anti-

coagulating property............ I42

Coagulating property, effect of antivenoms on

$23^{8}, 239$

Coagulating property of Daboia venom, effect

of cobra venom on ............ I4I, I42

Coagulating property of venoms, comparative

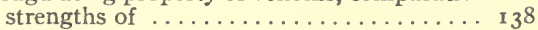

Coagulation, intravascular............ 133

Cobra, effect of venom of, upon the nervous

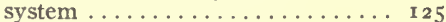

chemical analysis ........... 87

digestibility by trypsin........... I05

lecithid ...................... 86

poisoning in man ............ I 10

preparation properties........ 86-87

venom antivenin $\ldots \ldots \ldots \ldots \ldots \ldots \ldots$
Cobralysin

absorbability by blood corpuscles I9 I

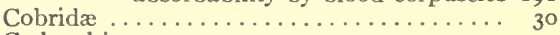

Colopeltis $\ldots \ldots \ldots \ldots \ldots \ldots$

lacertina, venomous nature of bite

of .............. 122

moilensis ................ 7

monspessulana ............ 7

venomous nature of

bite of........ 1 22

Cold-blooded animals, effect of snake venom upon......270-284

effect of snake venom Cold, effect on snake venom of .... 201-204

Coluber æsculapii .............. 50 flavescens ................ 50 viridiflavus var, carbonarius..... 50

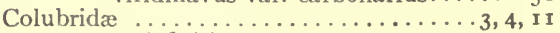
definition of $\ldots \ldots \ldots \ldots \ldots \ldots,{ }_{2}$

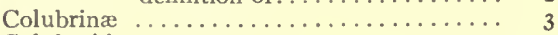

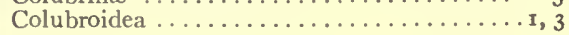


Complement, chemical inactivation and reactivation of .......... 192 destruction of, by venom...... 218 disappearance of activating property by heating....... I 72 in venom hæmolysis .. I 70, I 7 I, 175

Coniophanes.................... imperialis ............ 9 imperialis imperialis ....... I0 imperialis proterops........ I0 lateritius ............. Io

Conjunctival nembranes, effects of snake venom on ...............2 20-222

Conophis................... 9

Cope on systematic position of venomous snakes ..................... 3 Copper-venom globulin ............ so Corneal reflex................ 124, 130 Coronella lævis.................49, 50 Coryphodon korros ............... 50 Crocodilia, mucous glands of oral cavity.... 47 Crotalidæ ..................... Crotalinæ ..................... 35 effect of venom upon nervous system................. I 24

Crotalus . . . . . . . . adamanteus .............. 43 amount of venom secreted $\ldots \ldots \ldots \ldots$ i I effects of venom of... 124 hæmorrhagic content of ............. I57 poisoning, experimental $\ldots \ldots \ldots \ldots \ldots$ I $I_{3}$ venom of ........ $7 \mathrm{I}$ atrox ................... 44 anount of venom secreted .. 7 I var. ruber ........... 44 var. scutulatus ......... 44 cerastes $\ldots \ldots \ldots \ldots \ldots \ldots \ldots . \ldots \ldots 45$ confluentus $\ldots \ldots \ldots \ldots \ldots \ldots$. 44 amount of venom secreted .............

effect of venom of, upon nervous

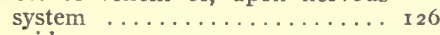
horridus ............... 43 lepidus $\ldots \ldots \ldots \ldots \ldots \ldots \ldots \ldots, 45$ mitchelli ............... 45 molossus ............... 45 mortality caused by $\ldots \ldots \ldots \ldots \quad 76$ oregonus .............. 44 poisoning in $\operatorname{man} \ldots \ldots \ldots \ldots \ldots$ 106 polystictus .............. 45 pricei ................. 45 terrificus $\ldots \ldots \ldots \ldots \ldots \ldots \ldots 43,45$ tigris ................. 45 triseriatus .............. 45

venom antivenin .......... 257

Crustacea, effects of snake venom upon.... 279

Cytolysins, effects of heating on......... 204 effects of, on cells of warmblooded animals......... I99-200

effects on cells of cold-blooded animals .............. 23 I in snake venom .........199-205 mechanism of .............. 204 mode of study of . . . . . . . . 199 plurality of ..............204 Cytolytic action of snake venom on microorganisms.......... 205

Cytolytic action of snake venom on nerve cells..................... $20 \mathrm{I}$ Cytoilitic action of snake venom on ova

Cytolytic action of snake venom on sperma$202-203$ tozoa .................201-202
Daboia, anticoagulating properties of ties of venom of 141 poisoning in man.......... 108,135 russellii, effects of, upon the coagu-

lability of the blood..... 137 amount of venom secreted . 70 mortality caused by ...... 75

Daspeltis scaber................. 50

Dendraspis .................. I angusticeps $\ldots \ldots \ldots \ldots \ldots \ldots$ I8 antinorii $\ldots \ldots \ldots \ldots \ldots \ldots, 18$ jamesonii ................ 18 viridis $\ldots \ldots \ldots \ldots \ldots \ldots \ldots$ I 7

Denisonia ..................... 19 carpentariæ ............. $2 I$ coronata ............... 20 coronoides $\ldots \ldots \ldots \ldots \ldots \ldots, 20$ flagellum $\ldots \ldots \ldots \ldots \ldots \ldots \ldots, 20$ frenata $\ldots \ldots \ldots \ldots \ldots \ldots \ldots \ldots \ldots$ 20 gouldii ............... 20 maculata ............... 20 melamura .............. 21 nuelleri ................ nigrescens.............. 2 I nigrostriata ............. $2 \mathrm{I}$

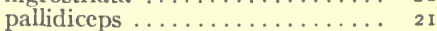
par $\ldots \ldots \ldots \ldots \ldots \ldots \ldots \ldots, 21$ punctata .............. 20 superba............... 20 woodfordii $\ldots \ldots \ldots \ldots \ldots \ldots \ldots$ 2 I

Desiccation, effect on snake venom....... 94

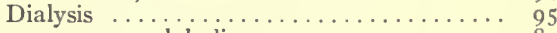
venom globulin $\ldots \ldots \ldots \ldots \ldots \ldots \ldots$ so Dialyzability of venom constituents ..... 79 fibrin ferment ..... $3_{3}^{8}$

Dialyzed iron, effects on snake venom..... 99

Diaphoretics, in treatment of snake bite.... 292

Diastatic actions of snake venom ........ 2 I 3

Dictamnus albus, used for snake bite...... 293

Diemenia ....................... 19

Dipsadinæ ................... 4

Dipsadoboa .................... 5

Dipsadomorphinæ ............... 4

Dipsadomorphus ............... 5 cyaneus $\ldots \ldots \ldots \ldots \ldots \ldots, 5$ kræpelini ............ 5 trigonatus........... 5

Dispholidus ................... I0

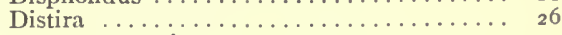
cyanocincta ............... 27 poison glands of ...... 61 jerdonii ................... 27 ornata ..................... 26 poisoning, experimental......... I 20 subcincta ............... 27

Distribution of venomous snakes $\ldots \ldots \cdot 5^{2-57}$ Ditypophis ................... 6

Dog, effect of ophiotoxin on .......... 147

Dogs, experiments as to effect of snake

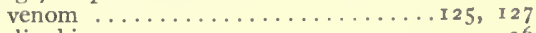

Doliophis

bilineatus ......................... 16

bivirgatus ..................

intestinalis .............. 16

philippinus ............... 16

sp., poison glands of . ........ 60

Dorstenia contrayerva, used for snake bite.. 293 Dromophis . . . . . . . . . . . 6 Dryophiops.................... Io

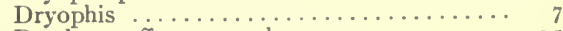
Dry heat, effect on snake venom......... 95

Echidnase .................. 224 Echinodermata, effects of snake venom upon 281 Echidnotoxin .................. 224

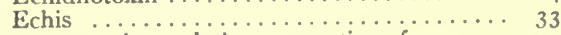
anticoagulating properties of ...... I4 I 
Echis carinata venom, effects of, upon coagulability of the blood....137, 138 mortality caused by ...... 75 poisoning in $\operatorname{man} . \ldots \ldots \ldots$ I09

carinatus................. 34

coloratus $\ldots \ldots \ldots \ldots \ldots \ldots \ldots \ldots, 34$

poisoning, experimental .......... II

Effects of snake venom on plants and the process of germination of seeds .... 285, 286

Effects of snake venom upon the nervous system and effect of the sequelæ upon the respiratory and circulatory functions ... I 24-1 26

Effects of various physical and chemical agents upon snake venom .........94-102

Ehrlich-Madsen partial saturation phenomenon in venom-antivenin reaction....... $25^{\circ}$

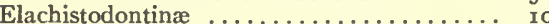

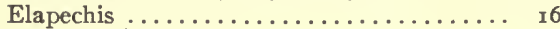

boulengeri $\ldots \ldots \ldots \ldots \ldots \ldots \ldots$ I 7 decosteri ............... I

guentheri.............. I

hessii ................ I7

niger ................ I7

sundevallii ............... I 7

Elaphis æsculapii ................. 49

virgatus $\ldots \ldots \ldots \ldots \ldots \ldots \ldots \ldots$ so

Elapidæ................... I I

Elapinæ ................... I, II, 47 effect of venom of, upon nervous system................. I 26

Elapognathus $\ldots \ldots \ldots \ldots \ldots \ldots \ldots \ldots \ldots \ldots \ldots$ minor................. 23

Elapomoius....................... 10

Elapomorphus ................ 10

Elapops.$\ldots \ldots \ldots \ldots \ldots \ldots \ldots \ldots \ldots \ldots$ 10

Elapotinus ......................... 10

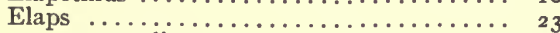

ancoralis $\ldots \ldots \ldots \ldots \ldots \ldots \ldots \ldots \ldots 2_{26}$

annellatus ................. 25

anomalus $\ldots \ldots \ldots \ldots \ldots \ldots \ldots{ }_{25}$

buckleyi .................. 25

corallinus ................ 25

decoratus .................... 25

dissoleucus................. 25

dumerilii ................... 25

elegans ........................ 25

euryxanthus .................. 24

filiformis ................ 26

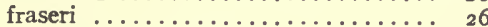

frontalis $\ldots \ldots \ldots \ldots \ldots \ldots \ldots \ldots{ }^{25}$

fulvius $\ldots \ldots \ldots \ldots \ldots \ldots \ldots \ldots \ldots \ldots \ldots, 24$ poisoning in man ........ II I

gravenhorstii .............. 24

hemprichii $\ldots \ldots \ldots \ldots \ldots \ldots \ldots \ldots \ldots \ldots{ }_{25}$

heterochilus ............... 24

heterozonus ................ 25

langsdorfii ................ 24

lemniscatus ................ 25

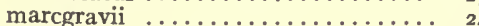

mentalis .................... ${ }_{26} 6$

mipartitus ..................... ${ }_{26} 6$

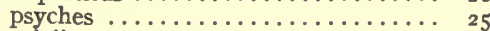

spixii......................... ${ }_{25}^{25}$

surinamensis ............... 24

tschudii ................... 25

Electricity, effect upon neurotoxins of snake

venom ..................... I44

Endocomplement...................

Enhydrina .................. ${ }_{28}$ amount of venom secreted..... 71 bengalensis $\ldots \ldots \ldots \ldots \ldots \ldots{ }_{28}$ hardwickii, poison glands of .... 6I poisoning, experimental ....... I 2 I valakadien ............... 28 effects of venom of $I_{3}{ }_{1}, I_{3}$
Enhydrina valakadien, effect of venom upon

Enhydris $\ldots \ldots \ldots \ldots \ldots \ldots \ldots \ldots \ldots \ldots{ }^{28}$ curtus $\ldots \ldots \ldots \ldots \ldots \ldots \ldots \ldots 29$ effects of venom of ....... $13^{2}$

Epanodonta ..................... I

Erythrocytolysin $\ldots \ldots \ldots \ldots \ldots \ldots \ldots \ldots$ I $7 \mathbf{1}$

Eteiropsas................. 5

Euphorbia prostrata, used for snake bite... 293

Europe, venomous snakes of . ......... 53

Eurystomata.................. I

Experimental venom-poisoning in animals.

I $13^{-1} 23$

Fangs, poison. ................... $5^{8-59}$

Faust's preparation of ophiotoxin........90-91

Ferments, effects on snake venom.......103-105 in snake venom...........210-214

Ferric chloride, effects on snake venom.... 99

Ferrous sulphate, effects on snake venom... 99

Fibrin, fate of, after coagulation........ $13^{8}$ ferment ............... 34 , 2 Io in venom .................. 135, 137

Filtration, effect on snake venom........ 95

Fish, effects of snake venom upon.....274-278

Frogs, effect of ophiotoxin on.......... 147 experiments as to effects of snake

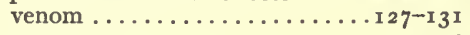

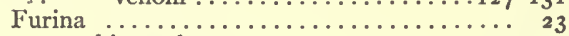

bimaculata............... 23

calonota ............... 23

occipitalis.............. 23

Gastric juice, effect on venom.......... 103

Geodipsas .......................

Geographical distribution of venomous

snakes $\ldots \ldots \ldots \ldots \ldots \ldots \ldots \ldots \ldots 5^{2-57}$

Glands, lingual ................ 47

mucous $\ldots \ldots \ldots \ldots \ldots \ldots \ldots \ldots, 47$

palatine ................ 47

parotid ................ 47

poison................... $59-63$

serous $\ldots \ldots \ldots \ldots \ldots \ldots \ldots \ldots, 47$

sublingual ............... 47

supralabial $\ldots \ldots \ldots \ldots \ldots \ldots \ldots \ldots, 47$

Glandula, angularis oris $\ldots \ldots \ldots \ldots \ldots \ldots, 48$

labilis superior............ 48

maxillaris, superior ........... 48

Glauconiidæ, definition of .......... 2

Globin .......................... 19

Globulin $\ldots \ldots \ldots \ldots \ldots \ldots \ldots \ldots \ldots \ldots \ldots \ldots \ldots \ldots \ldots{ }_{82}$

Glyphodon .................. I8 tristis $\ldots \ldots \ldots \ldots \ldots \ldots \ldots \ldots$ I8

Glyphodonta ................. I

Guaco, used for snake bite........... 293

Hæmoglobin ................... 198

Hæmolysins, absorbability of .......... I81 effect of antivenins on.168, 238-239 of snake venom.........145, 167 phyogenetic relation of ....... 179 toxoid formation of . ....... 169, 179

Hæmolysis, by snake sera............. 167 in cold-blooded animals ...282-284 mechanism of ............. 185 venom ............... $16_{2}$

Hæmorrhages, caused by venom........... 156 Hæmorrhagins, biological isolation of ....... 157 comparative quantities in different venoms........ $59^{-1} 60$ effect of acids on ......... I6o histological changes caused by............... I6I intracerebral administration of $\ldots \ldots \ldots \ldots \ldots \ldots \ldots \ldots \ldots$ of snake venom........ $156-161$ 
Hæmorrhagins, physical and chemical PAgE. erties ........... I56-1 57 toxoid formation of ...... I60

Heart, effect of direct application of venom on .................. I 32 histological changes caused by venom 209

Hemibungars .................. I4 boettgeri ................. I5 collaris .............. I4 colligaster. . . . . . japonicus............ 15 nigrescens $\ldots \ldots \ldots \ldots \ldots$ r 5

Herba de cobra, used for snake bite........ 293

Herpetodryas carinatus ............ 50

Himantodes ..................... 5

Hipistes ................... II

hydrinus $\ldots \ldots \ldots \ldots \ldots \ldots$ II

Histological changes caused by venom hæmorrhagins ................ I6 I

Histological changes of nervous system produced by snake venom............ $\mathbf{1 5}^{2}$

Histological changes produced by venom on various organs and tissues........206-200

Hologerrhum ................... 5

Homalopsinæ ................ Io

Homalopsis................... ro buccata ............. II

Hoplocephalus .............. 2 I bitorquatus ............. 2 I bungaroides $\mathrm{s}$. variegatus... 2 I curtus, amount of venom secreted ............. 70 stephensii ........... 2 I

Hydrates of sodium and potash, effects on snake venom

Hydrelaps .

darwiniensis ............. 28

Hydrobromic acid, effects on snake venom. . $9^{8}$ Hydrocalam us .................. Io Hydrochloric acid, effects on snake venom... ror Hydrogen sulphide, effect on venom ...... I02 Hydrophidæ $\ldots \ldots \ldots \ldots \ldots \ldots \ldots \ldots \ldots . \ldots \ldots$

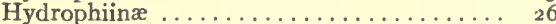
effect of venom of, upon nervous system.......... I 3 I

Hydrophis ...................... cantoris .................. 28 corulescens ............. 27 elegans ................... 27 fasciatus ...................... ${ }_{28}$ gracilis ................ 27 leptodira $\ldots \ldots \ldots \ldots \ldots \ldots \ldots, 28$ nigrocinctus ............. 27 obscurus s. stricticollis ....... 27 poisoning, experimental ........ I 2 I spiralis $\ldots \ldots \ldots \ldots \ldots \ldots \ldots, 27$

Hydrus .................... ${ }_{28}^{27}$ platurus, poison glands of ....... s. Pelamis bicolor ...... 28 poisoning, experimental ......... I 2 I

Hypobromide of sodium, effects on snake venom ................ I

Hypsirhina ..................... I

Ialtris

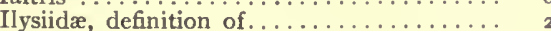

Immunity, active, against venom . . . 223-225 natural ............264-269 passive...............225-24I produced by feeding........ 228

Immunization against venom, principles of. . 226 artificial ..........223-232 by feeding ........... 228

Inoculation, prophylactic, against venom.... 223 Insects, effects of snake venom upon ...... $27^{8}$
Iodine, and potassic iodide, effects on snake venom................. $9^{8}$ Interactions between venom and antivenin..

Intravascular thrombosis $\quad 246-260$ .... I 30

Kephalin ................. ${ }^{84}$ Kidney, histological changes caused by venom ....................... 208 Kyes's preparation of venom lecithids ...... 87

Lachesis .................... 37 alternatus ............... 38 ammodytoides ............ 38 anamallensis............. $4 \mathrm{I}$

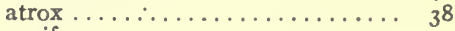
aurifer $\ldots \ldots \ldots \ldots \ldots \ldots \ldots \ldots . \ldots \ldots$ bicolor ................ 39

bilineatus $\ldots \ldots \ldots \ldots \ldots \ldots \ldots \ldots . \ldots \ldots$ borneensis...............

brachystoma............. 39

cantoris ............... 40

castelnaudii .............. $3^{8}$

flavomaculatus ........... 40

flavoviridis .............. 40

effect of venom of, upon the nervous system .. I 25 mortality caused by ... 75

godmani .................... $3^{8}$

gramineus $\ldots \ldots \ldots \ldots \ldots \ldots \ldots, 40$

jerdonii ................ 40

lanceolatus $\ldots \ldots \ldots \ldots \ldots \ldots \ldots .37$ amount of venom secreted........... 7 I effects of, upon the coagulability of the blood ............ ${ }_{3} 6$ mortality caused by ... ${ }_{76}$

lansbergii ................. 39

lateralis $\ldots \ldots \ldots \ldots \ldots \ldots \ldots . \ldots 39$

luteus ................... 40

macrolepis ............. 4 I

microphthaImus.............. $3^{8}$

monticola ................ 39

mucrosquamatus ........... 40

mutus .................... $3_{38}^{8}$

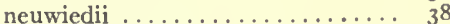

nigroviridis $\ldots \ldots \ldots \ldots \ldots \ldots \ldots \ldots . \ldots \ldots$

nummifer ............... 38

okinavensis $\ldots \ldots \ldots \ldots \ldots \ldots \ldots 39$

pictus $\ldots \ldots \ldots \ldots \ldots \ldots \ldots \ldots \ldots 3^{8}$

poisoning, experimental ........ II5

in $\operatorname{man} . \ldots \ldots \ldots \ldots$ ro 8

pulcher .................. $3^{8}$

puniceus ............... 4 I

purpureomaculatus $\ldots \ldots \ldots \ldots \ldots, 40$

schlegelii ................. 39

strigatus ................ 40

sumatranus............. 4 I

trigonocephalus ............. 4 I

undulatus ................. 39

wagleri $\ldots \ldots \ldots \ldots \ldots \ldots \ldots \ldots{ }_{4}$

xanthogrammus ............ $3^{8}$

Lactic acid .................. ro2

Langaha ...................... 5

Lecithid, alleged presence in ordinary lecithin

preparation ............. 89

effect of heating on ......... 192, 193

hæmolytic properties of $\ldots \ldots \ldots$ I 74

in relation to immunity ........ $19^{2}$

physico-chemical phenomena re-

sembling...............88-89

preparation and properties of $\ldots 86-87$

toxicity of . . . . . . . . . . . 174 
Lecithin, activating proverty for hæmolysin PAGE. antagonistic property of cholesterin

83,191

on

hæmolytic action on blood cor-

puscles................ I8 protein compound of ......... I88

Leech extract, effect on venomized plasma. . 136

Leucocytolysin ................ I 7 I

Ligature, as a means of preventing absorp-

tion of venom .................. 287

Liophis merremii $\ldots \ldots \ldots \ldots \ldots \ldots . \ldots 5^{\circ}$

Lipase, in venom ............... 213

Lipoids ................... I 87

Lipolytic ferment in snake venom ........ 213

Liver, histological changes caused by venom. 207

Lungs, histological changes caused by venom 208

Lycodryas .................... 5

Lycognathus........................ 6

Macrelaps $\ldots \ldots \ldots \ldots \ldots \ldots \ldots \ldots$ Io

Macroprotodon .................

Macrostomata .....................

Magnesium chloride, antihæmolytic property

of .................. I9

Malpolon insignitus, venomous nature of bite

of .................... I 22

Manmalia, mucous glands of oral cavity ... 47

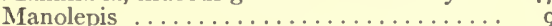
putnamii $\ldots \ldots \ldots \ldots \ldots \ldots \ldots \ldots \ldots$

Massasauga ...................................

venom .................... ${ }_{2} 6_{5}$

Mercury chloride, effects on snake venom...

Micrelaps .................... 10

Micro-organisms, effects of venom on..... 205

Micropechis ..................... 2 II

elapoides $\ldots \ldots \ldots \ldots \ldots \ldots$ 2I

ikaheka ........... 2 I

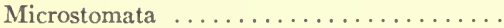

Mimophis ................... 6

Minimal lethal dose, of various snake

venoms $\ldots \ldots \ldots \ldots \ldots \ldots \ldots \ldots \ldots \ldots \ldots \ldots \ldots \ldots+73$

Miodon $\ldots \ldots \ldots \ldots \ldots \ldots \ldots \ldots \ldots \ldots \ldots$ I0

Mitchell's phenomenon ............... I

mechanism of ..... I95

Moist heat, effect on snake venom....... 94

Mollusca, effects of snake venom upon.....28 $28 \mathrm{I}$

Mongoose, immune to venom of cobra.... 268

Morphólogy of venomous snakes. . . . . . 4 45

Mortality caused by snake venom.......75 76

Motor end-plate .............. I 29, I32 nerve, effect of venom upon ...... I 26-127

Mucous membranes, effects of snake venom on ....................220-222

Muriatic acid, effects on snake venom...... $9^{8}$

Muscles, histological changes caused by

venom ......................200

Myology, head of poisonous snake....66, 67

Naja ..................... I 2 anchietæ $\ldots \ldots \ldots \ldots \ldots \ldots \ldots \ldots$ I3 bungarus, mortality caused by ...... 75 $\begin{array}{ll}\text { s. Ophiophagus elaps } & \text { s. } \\ \text { Hamadryas } \ldots \ldots \ldots \ldots & \text { I2 }\end{array}$

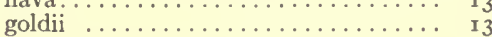

haje $\ldots \ldots \ldots \ldots \ldots \ldots \ldots \ldots$ I amount of venom secreted...... 70 poison glands of ............ 6 I melanoleuca ................ I3 nigricollis

effects of, upon the coagulability of the blood........ I 37 poisoning, experimental .......... I 18

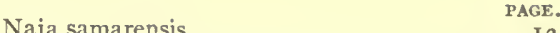
tripudians $\ldots \ldots \ldots \ldots \ldots \ldots \ldots \ldots$ I2 amount of venom secreted. 70 effect of venom of, upon the nervous system.... I 24, I 26 effects of, upon the coagulability of the blood ...... I 37 mortality caused by...... 75 Najidæ .....................

Narcotics in treatment of snake bite...... 292

Natrix torquatus ................ 49

Natural immunity from snake venom ...264-269 Nerve cells, changes produced by Notechis

venom ............... I53 effects of snake venom upon. 201,270 endings, paralysis of . I $127,128,129,132$ fibers, effects of snake venom upon $270-284$ trunk ................... 132 Nervous system, effect of snake venom

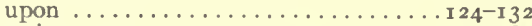

Neurin..................... I 84

Neurotoxins of snake venom ......... I43 ${ }^{-1} 55$

New Zealand, free from snakes......... 52

Nitric acid, effects on snake venom....... 97

Notechis ................... 22 anticoagulating properties of venom of .................... I4I scutatus, amount of venom secreted 70 effects of, upon the coagulability of the blood...

133,137

s. Hoplocephalus curtus..

Nucleo-albumin, effects on coagulability of venomized plasma .............. 134

Ogmius $\ldots \ldots \ldots \ldots \ldots \ldots \ldots \ldots$ 10

Ogmodon $\ldots \ldots \ldots \ldots \ldots \ldots \ldots \ldots \ldots \ldots \ldots$ 18

vitianus............... I8

Oleic acid, as venom activator........... hæmolytic action of . .......... 183 splitting of, during lecithid formation .............. 89

Olive oil, used for snake bite............ 293

Ophiorohiza mungos, used for snake bite... 293

Ophiotoxin, chemical formula of ....... 92 hæmolytic power of ........ I86 pharmacological position of ...92-93 pharmacological properties of. 146,147 preparation of ..........90 9 9 properties of ................

Ophiozylon, used for snake bite ........ 293 Opisthoglypha ....................... 46 effects of venoms of . . . . . 122

Opoterdonta ................. I Ova, effects of snake venom upon..... 202-203,

$270-284$

Oxybelis $\ldots \ldots \ldots \ldots \ldots \ldots \ldots \ldots \ldots \ldots$
Oxyrhopus $\ldots \ldots \ldots \ldots \ldots \ldots$

Pancreatic digestion, on venom neurotoxin,

hæmolysin, hæmorrhagin ........... I05

Pancreatin, effect on venom........... I04

Papain.......................... 105

Paraglobulin................... 135

Pelias berus $\ldots \ldots \ldots \ldots \ldots \ldots \ldots \ldots \ldots .3^{\circ}$

Pepsin, effect on various toxic constituents of venoms............... I05 effect on venom ...............

Peptic digestion .................. I05

Peptone ....................... $8_{3}$ Permanganate of potash, effects on snake venom .................. IoI

Permanganate of potassium, effects on snake venom ...................... I00

Peropoda ................... I 
Peroxide of hydrogen, effects on snake venom $\ldots \ldots \ldots \ldots \ldots \ldots \ldots \ldots \ldots$. 8 , IOI

Philodryas . ................ 6

Phosphoric acid, effects on snake venom.... IO I

Photodynamic substances, effects of ...... 96

Phrenic nerve .......... I28, I 29, I 31 , I 32

Phylogeny of venomous snakes.........46-5I

Physical properties of snake venom..... 77-93

Pisces, mucous glands of oral cavity...... 47

Plants, effects of snake venom upon....285, 286

Plasma, citrate ............... 35 , I 37

Platurus xalate.............. I 36 , 137

colubrinus..............

fasciatus, poison glands of ....... 6 6

laticaudatus s. fischeri......... 29 muelleri................. 29

Platycerca ................... 3

Poison apparatus of snakes $\ldots \ldots \cdot 46-51,58-69$ dynamics of function of. .64-67 duct $\ldots \ldots \ldots \ldots \ldots \ldots \ldots \ldots, 59$ fangs $\ldots \ldots \ldots \ldots \ldots \ldots \ldots \ldots \ldots \ldots \ldots \ldots \ldots \ldots \ldots \ldots+55^{8}-59$

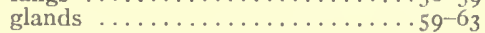

Polemon ................. 10

Polygala senega, used for snake bite...... 293

Post-morten examination after snake-poison-

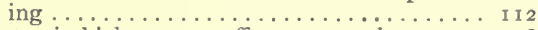

Potassic bichromate, effects on snake venom 98 carbonate, effects on snake venom . 97 iodide, effects on snake venom.... 98 permanganate, effects on snake venom................ 98

Potassium permanganate used for snake bite 287,290

Precipitability of various venom constituents. 81 Precipitin-reaction with snake venom . . . 261-263 Preservation, effect on snake venom....... 94 Proteolytic ferment, in venom.......204, 2 II Proteroglypha .................... I I , 46 Protothrombin ................ I 37 Psammodynastes pulverulentus.............

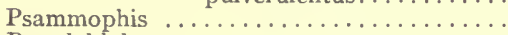

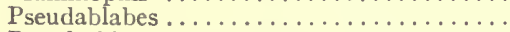

Pseudechis anticoagulating properties of venom of ............. I 41 cupreus $\ldots \ldots \ldots \ldots \ldots \ldots \ldots$ I9 ferox ............... I9 poisoning, experimental ........ I I porphyriacus ........... I9 porphyriacus, amount of venom

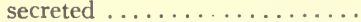
porphyriacus, effects of, upon the coagulability of the blood .133, 137 porphyriacus, effects of venom of upon the nervous system ...... I 30

Pseudocerastes .................. 33 persicus ............. 33

Pseudelaps ..................... I8 viadema $\ldots \ldots \ldots \ldots \ldots \ldots$ I9

harrietta $\ldots \ldots \ldots \ldots \ldots \ldots \ldots$ I8 krefftii ................ I8 mulleri ............... I8 squamulosus.............. 18 sutherlandii ............. 19 warro................ rg

Pseudoglobulin .................. 198 Psychic treatment, used for snake bite..... 293

Ptyas korros.................. 50 Pupils, effect of venom upon............ 126 Pythonodipsas .................. 6

Rabbits, effects of ophiotoxin on......... 147 experimients as to effect of snake venom ...........124, 1 25, 131
Rattlesnake, banded

black-tailed..... .43

diamond back ........... 43

dog-faced $\ldots \ldots \ldots \ldots \ldots \ldots, 45$

green............... 45

horned .............. 45 .

mountain diamond $\ldots \ldots \ldots \ldots \quad 44$

Pacific ............... 44

prairie $\ldots \ldots \ldots \ldots \ldots \ldots \ldots, 44$

red diamond ........... 44

southern pigmy .......... 4 I

tiger ............... 45

western diamond $\ldots \ldots \ldots \ldots, 44$

white............... 45

Regeneration of venom and antivenin from neutral combinations.............. 248

Reptilia, mucous glands of oral cavity ..... 47

Respiration, artificial, in venom toxication.. 29 I rate of, in venomized subjects $\ldots \ldots \ldots 125,126,128,129$

Respiratory center .... I 28, I 29, I 30, I $31, I_{32}$

Rhamphiophis ................ 6

Rhinobothryum .................. 5

Rhinocalamus .................. I0

Rhinhoplocephalus $\ldots \ldots \ldots \ldots \ldots \ldots \ldots \ldots, 22$

bicolor $\ldots \ldots \ldots \cdots \cdots \cdots{ }^{22}$

Rhinostoma .................. 6

Rhynchelaps................... ${ }^{23}$

australis $\ldots \ldots \ldots \ldots \ldots \ldots 23$

bertholdi ............. 23

fasciolatus ............. 23

semifasciatus............ 23

Ricin ...................... I 59

Rinachis scalaris ....................... 49

Ruta graveolens, used for snake bite...... 293

Salts of snake venom............. 78

Sauria, mucous glands of oral cavity ..... 47

Sciatic nerve ............... 124, 127

Scolecophis ................... 8 æmulus.............. 8 atrocinctus $\ldots \ldots \ldots \ldots \ldots \ldots$. 9

Scorpio afer .................... 227

Sea-snakes, venom of . ............ 131

Seeds, effects of snake venom upon gcrmina-

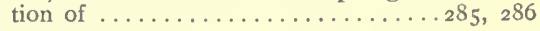

Sensory nerves...................... 127

Sepedon .................... I 3

Serum, activating properties of, on venom hæmolysis $\ldots \ldots \ldots \ldots \ldots \ldots$ I 70 , I 7 I

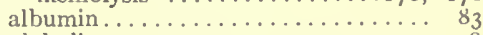
globulin ....................... 198

Serous membranes, effects of snake venom

on .......................220-222

Sibon $\ldots \ldots \ldots \ldots \ldots \ldots$

annulatum $\ldots \ldots \ldots \ldots \ldots \ldots \ldots, 8$

frenatum $\ldots \ldots \ldots \ldots \ldots \ldots \ldots \ldots, 8$

nigrofasciatun $\ldots \ldots \ldots \ldots \ldots \ldots, 8$

pacificum $\ldots \ldots \ldots \ldots \ldots \ldots \ldots \ldots \ldots \ldots$

personatum ............... 8

rhombiferum ............... 8

septentrionale................. s

yucatanense ............... 8

Silver nitrate, effects on snake venoin..... 98

Simaba cedron, used for snake bite....... 293

Sistrurus ................... 41 catenatus................ $4^{\mathrm{I}}$ var. edwardii........ 42

miliarius ................ $4^{1}$

ravus $\ldots \ldots \ldots \ldots \ldots \ldots \ldots \ldots, \quad 42$

Snake bite, general medicamentation...... $29 \mathrm{I}$ immediate ligature and dissection 287 local treatment ............. 288 mechanism of ..........6.6.69 treatment of ...........28 $87_{7-296}$ 
Snake bite poisoning, certain alleged anti-

dotes for ................ 293 stones, used for snake bite. . . . . . . 293 venom, action upon heart ........ 209 kidney ........ 208 liver ......... 207 lungs ........ 208 muscles .......200 spleen........20 208 amount secreted $\ldots \ldots \ldots \ldots$ 70 antibactericidal properties of

$215^{-218}$

cytolysins in ......... $199-205$

description of . . .......79-80

diastatic actions of . ....... 213 effect of, on cells of cold-

blooded animals .....20I-204 effect of, on cells of warm-

blooded animals ........199-200 effect of, on coagulability of

blood............... I 33 effect on nervous system . I 24-I $3^{2}$ ferments in . . . . . . . 210-214 hæmolysins of .......... I45 histological changes produced on various organs and tissues

206-209 neurotoxins of ........... $143^{-1} 55$ physical and chemical prop-

erties of ..........77-93 precipitin-reaction with $.261-263$ proteolytic action of ....... 2 II toxicity of $\ldots \ldots \ldots \ldots \ldots+77^{-76}$

Snakes, effects of snake venom upon ...... 264 Sodium, carbonate of, effects on snake venom Ior citrate ............. r 35, I 36 antihæmolytic property.. I89, I90 fluoride, effect on venomized plasma $\quad 3^{6}$

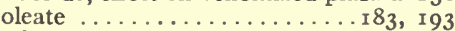

Solenoglypha .............. I, II, 46 Solubility of various protein constituents of venom ..................... 80

Specificity of antivenins . . . . . . . 233-245 Spermatozoa, effects of snake venom upon..20r-

$202,270-284$

Spinal cord, paralysis, in venom toxication.. I 27 , I $30,131,3^{2}$

Spleen, histological change in, caused by venom ...................... 208 Staphylococcus aureus ................ 205 Stenophis $\ldots \ldots \ldots \ldots \ldots \ldots \ldots \ldots \ldots \ldots$. 5

Stenorhina .................. Io

Strychnine, value of, as an antidote to venom

toxication ................ 29 I-292

Strychnos colubrina, used for snake bite... 293

Sugar-cane, used for snake bite . . . . . . 293

Sulphuric acid, effects on snake venom...98, ror Sun, effects upon neurotoxin of snake venom. I 44 Supervenomization of blood corpuscles ..... I95 Swallow-root, used for snake bite........ 293

Sycotypus, cells of............... I5I

Symptoms, venom poisoning in man..... 106-I I 2

Syntonin ..................... $8_{3}, 84$

Systematic position of venomous snakes.... I- 3

Tachymenis .................. 6

Tanjora pills, used for snake bite....... 293

Tannic acid, effects on snake venom...... 98

Tantilla ...................... 9 coronata .............. 9 eiseni .................. 9 gracilis ................ 9 nigriceps .................

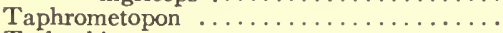
Tarbophis venomous nature of bite of. 123 Thalassophis ................. 28 anomalus $\ldots \ldots \ldots \ldots \ldots \ldots, 28$

Thamnodynastes ............... 6

Thanatophidia............... I

Thelotornis ................... I0

Therapeutic values of antivenins $\ldots \ldots \ldots 233^{-245}$

Thrombogen ................... I37

Thrombosis, intravascular.......... I35, 144

Tomodon .................... 6

Tortricina ................. I

Toxalbumins ................. 85

Toxic secretions of venomous snakes..... $70-76$

Toxicity of snake venom............7 $7^{1-76}$ tissues of venonious snakes..... 219

Toxoid, hæmolysin ................ I 79 hæmorrhagin ............ I60

Tragops prasinus, venomous nature of bite

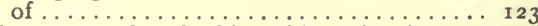

Treatment of snake bite with antivenins. $294^{-296}$

Trichloride of iodide, effects on snake venom 99

Trigonocephalus ................... 37

Trimeresurus ................... 37

riukiuanus, effect of venom of, upon the nervous system.... I 25 riukiuanus, mortality caused by 75

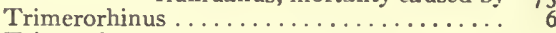

Trimorphodon ................

biscutatus, venomous nature

of bite of . . . . . . 122 collaris ............... 8 lambda $\ldots \ldots \ldots \ldots \ldots \ldots, 8$ lyrophanes ........... 8 tau ................. 8 upsilon .................. 8 vilkinsonii .......... 8

Tropidechis ...................... 22 carinata.............. 22

Tropidonotus natrix $\ldots \ldots \ldots \ldots \ldots \ldots \ldots, 4,49$ piscator ............. 51 subminiatus .......... 49 tesselatus ............ 50 torquatus ............ 49 viperinus $\ldots \ldots \ldots \ldots \ldots \ldots, 49$

Trypanurgos ................. 49 Trypanosomes, effects of venom ........ 205 Trypsin ....................... 105 Typhlopidæ, definition of ............

Urodelia, mucous glands of oral cavity .... 47 Uropeltidæ, definition of . . ............

Vagus $\ldots \ldots \ldots \ldots \ldots \ldots$ I 25, I 28 , I 29, I 30 Vasomotor center ............. I 24, I 25, I 32

Venom activators................... $83^{-189}$ agglutination......... $162-198,282-284$ albumin ................. 82 and antivenin regenerated from their neutral combination........... 248 cytolysis, mechanism of . . . . . . 204 ferments .............. $210-214$ rôles of, in venom toxication 2 IO

globulins $\ldots \ldots \ldots \ldots \ldots \ldots \ldots$ o, 82 hæmolysis, amboceptor nature of .... I 70 effect of antivenin ...... 168 injurious effects on blood corpuscles ......... I 89 protective property of acids on ........... 185 toxoid formation of ...... 169

hæmolysis ............. $6_{2}-198$ among cold-blooded animals..........282, 284 in saccharose solution.... 185 mechanism of ....... $185-194$ new era of study of..... I69 
Venom kinase

.

lecithid.................. 146

lipase ................. 21

neurolysis in vitro ........... 150

peptones $\ldots \ldots \ldots \ldots \ldots \ldots \ldots .6 \ldots \ldots$ poisoning in animals, experimental . .

I $13-123$

man, symptoms of. . . 106-11 2 process of secretion of .........6. $63-64$ proteolytic, anticoagulating property of .............. 212 ferment ............ 21 properties of $\ldots \ldots \ldots 2$ I I-2 I 2

Venomous snakes, geographical distribution

of $\ldots \ldots \cdots \cdots \cdots 5^{2-57}$

of American continents . $5^{2}$ phylogeny of .......46-5x toxic secretions of .... . 70-76 systematic position of ... $\mathrm{x}-3$ toxicity of tissues of . . . 219

Venoms, secretion of $\ldots \ldots \ldots \ldots \ldots \ldots \ldots 6_{3}$

Vibrio choleræ .....................205

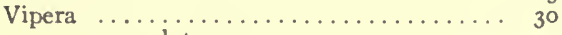

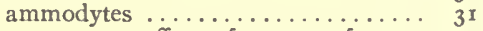

effect of venom of, upon

nervous system....... I 26 effects of, upon ccagu-

lability of blood..... 133

Vipera aspis ............................. berus, effect of venom of, upon the
nervous system.......... I 26 effects of, upon the coagulability of the blood ........ 133 mortality caused by ....... 76 poisoning in $\operatorname{man} \ldots \ldots \ldots \ldots$ rog
Vipern berus, PAGE.

berus $\ldots \ldots \ldots \ldots \ldots 30$

latastii.................. 3 I

lebetina $\ldots \ldots \ldots \ldots \ldots \ldots \ldots \ldots 3^{1}$

poisoning, experimental.......... I 6

radii ....................... 31

renardii $\ldots \ldots \ldots \ldots \ldots \ldots \ldots \ldots \ldots \ldots \ldots 3^{1}$

russellii ................. 3r mortality caused by ......... ${ }_{76}^{31}$

sp., poison glands of. .........6. $6 \mathrm{r}-63$

superciliaris $\ldots \ldots \ldots \ldots \ldots \ldots \ldots 3^{\mathrm{r}}$ ursinii ................. 30

Viperidæ .................. 29

definition of $\ldots \ldots \ldots \ldots \ldots \ldots \ldots, 2$

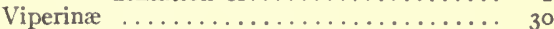
effect of venom of, upon nervous system $\ldots \ldots \ldots \ldots \ldots \ldots \ldots$ I 26

Walterinnesia $\ldots \ldots \ldots \ldots \ldots \ldots \ldots \ldots \ldots$ r 7 ægyptia ........... 17

Warm-blooded animals, effect of snake venom

on cells of ................. 199-200 Water-moccasin venom antivenin ....... 259

Water venom globulin ............. 80

Whisky .................... 292

Wooldridge's tissue fibrinogen ........... r 34

Worms, effects of snake venom upon ...... 280

Xenocalamus ................... ro

Xenopeltidæ, definition of $\ldots \ldots \ldots \ldots \ldots \ldots{ }_{2}$

Xenopholis ..................... ro

Yerba capitana, used for snake bite...... 293

Zamenis mucosus $\ldots \ldots \ldots \ldots \ldots \ldots \ldots$ 5r 







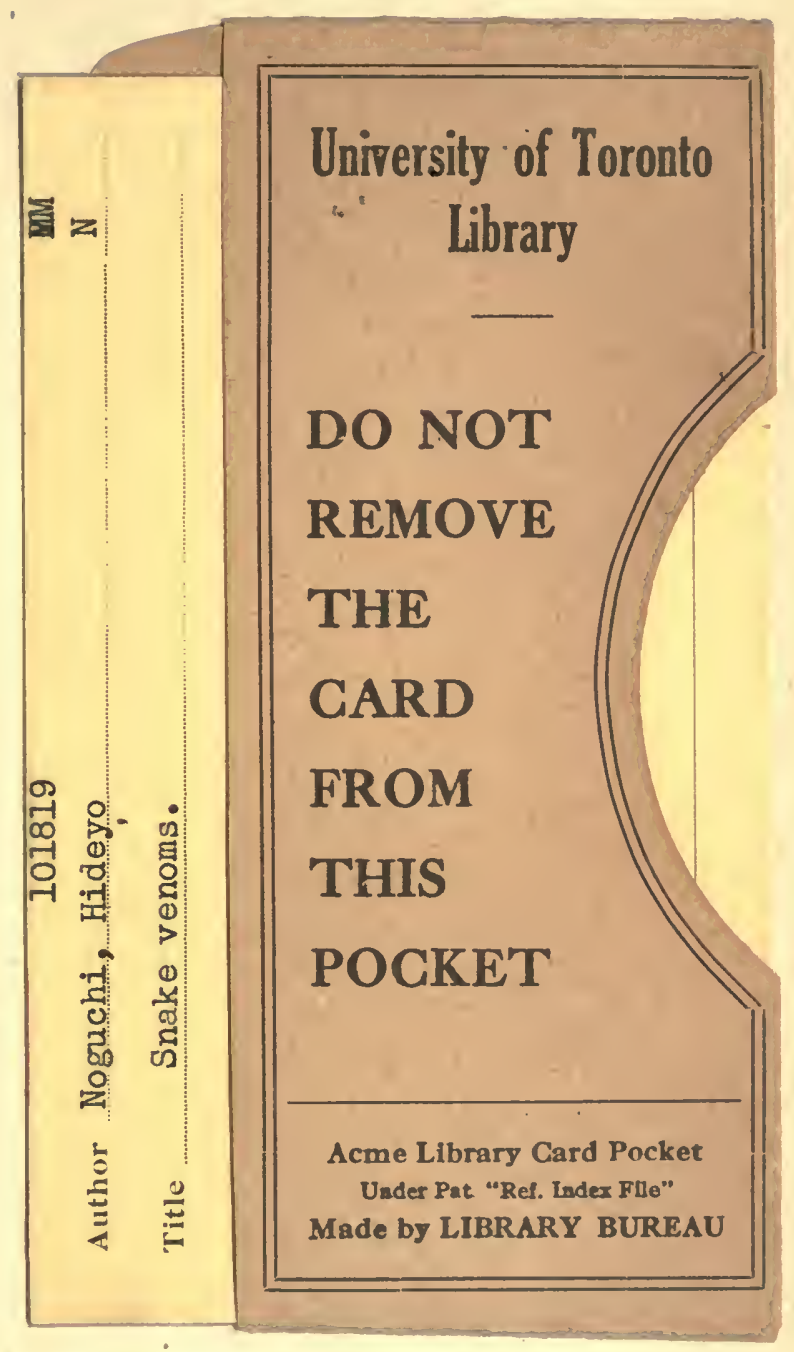


